Research Material/ Material de Investigación: "Ejecutoria original del pleito seguido por el licenciado don Cristóbal Vaca de Castro, sobre los 21 capítulos que le puso el fi scal Villalobos, sobre la versación que tubo en el gobierno del Perú. Año 1545"

Transcripción de: Álvaro M. Espinoza de la Borda y Deysi A. Zambrano Flores

\title{
Consultas paleográficas:
}

Hélène Roy y María Luisa García Valverde

Documento localizado y copiado por Mariusz Ziólkowski, por cortesía del Archivo de la Abadía del Sacromonte de Granada.

Los integrantes del grupo de investigación agradecen al Personal del Archivo y en particular al Archivero, el P. Juan Sánchez Ocaña por su ayuda en la realización del Proyecto.

Published online:/ Publicado online:

http://estudioslatinoamericanos.pl/index.php/estudios/article/view/Cristobal VacadeCastroEjecutoria/ResearchMateriallMainText

Doi: https://doi.org/10.36447/Estudios2019.v39.researchmaterial1

Estudios Latinoamericanos is a journal published by the Polish Society for Latin American Studies (Polskie Towarzystwo Studiów Latynoamerykanistycznych).

The Polish Society for Latin American Studies is scholarly organization established to facilitate research on Latin America and to encourage and promote scientific and cultural cooperation between Poland and Latin America.

Estudios Latinoamericanos, revista publicada por la Sociedad Polaca de Estudios Latinoamericanos (Polskie Towarzystwo Studiów Latynoamerykanistycznych).

Sociedad Polaca de Estudios Latinoamericanos es una asociación científica fundada con el fin de desarrollar investigaciones científicas sobre América Latina y participar en la cooperación científica y cultural entre las sociedades de Polonia y América Latina. 


\section{EXECUTORIA ORIGINAL DEL PLEYTO} SEGUIDO POR EL LICENCIADO DON CRISTÓBAL VACA DE CASTRO, SOBRE LOS 21 CAPÍTULOS QUE LE PUSO EL FISCAL VILLALOBOS, SOBRE LA VERSACIÓN QUE TUBO EN EL GOVIERNO DEL PERÚ = AÑOS DE 1545. 
/ 1 r. / Don Felipe. Por la gracia de Dios Rey de Castilla / de León, de Aragón, de Ynglaterra y Francia de las / dos Secilias, de Jerusalem, de Navarra, de Granada, de / Toledo, de Valencia, de Galizia, de Mallorcas, de Sevilla / de Cerdeña, de Córdova, de Córcega, de Murcia, de Jaén, de los $\mathrm{Al}$ /garves, de Algezira, de Gibraltar, de las yslas de Canaria, de las / Yndias, yslas e tierra firme del mar océano, Conde de Barce / lona, Señor de Vizcaya e de Molina, Duque de Atenas e / de Neo patria, Archiduque de Austria, Duque de Borgoña e / de Brabante, e Mylan, Conde de Flandes, e de Tirol, etcétera, / al nuestro justicia mayor, e a los del nuestro Consejo, presydentes / e oydores de las nuestras audiencias, alcaldes de la nuestra casa e corte / y chancillerías e a todos los corregidores, asistente gobernado / res y alcaldes y otros juezes e justicias qualesquier de to / das las ciudades, villas e lugares de los nuestros Reynos / e Señoríos y de las nuestras Yndias, yslas y tierra firme / del mar océano y a vos los nuestros oficiales de la Casa de / la Contratación de las Yndias que residís en la ciudad de / Sevilla y a cada uno de vos en vuestra juredición, a quien / esta nuestra carta executoria fuere mostrada o su traslado / signado de escribano público sacado con autoridad de justicia / en manera que haga fe, salud e gracia sepades que pleito / se trató ante los del nuestro Consejo Real de las Yndias en / tre el nuestro fiscal en el dicho Consejo de la una parte y el licenciado / Cristóbal Vaca de Castro del nuestro Consejo y nuestro Gobernador e / capitán general que fue de las provincias del Perú de la otra, / el qual fue sobre razón que el licenciado Villalobos / nuestro fiscal presentó en el nuestro Consejo Real de las Yndias dos / peticiones y acusaciones de veinte y un capítulos con / tra el dicho licenciado Vaca de Castro, la una en veinte e / nueve días del mes de junio del año pasado de mill e quinientos / e quarenta y cinco, y la otra en veinte días del mes de julio / del dicho año diciendo que en el tiempo que fue nuestro gober / nador en las dichas provincias del Perú avía ecedido en / algunas cosas en el dicho cargo y especialmente por el primer / capítulo de las dichas acusaciones, dixo que no pudiendo / llevar cargados los indios y debiendo castigar a los que hiziesen //

/ 1 v. / lo contrario el dicho licenciado Vaca de Castro los avía llebado / cargados como a bestias más de ciento dellos con sus ropas e / hazienda e de sus criados más de trecientas leguas, sin darles cosa / alguna de que avían rescivido gran daño y muchos muerte, y / por el segundo capítulo dixo que debiendo poner en cabeza nuestra / todos los yndios vacos o que vacasen no lo avía hecho an / tes los abía puesto en su cabeza y él e sus criados avían / llevado los frutos dellos en coantía demás de cien mil caste / llanos que heran los indios siguientes, los del marqués Pi / zarro e sus hijos que heran las ciudades de Truxillo y los / Reyes, y otros en la ciudad del Cuzco, y los que tenían Diego Mén / dez y Pedro Oñate y Juan Vázquez de Osuna e don Diego de / Almagro y Hernando Pizarro y en Arequipa otros muchos y / la provincia de los Carangas con color que heran de Diego de / Aller y otros muchos en las Charcas y en Guánuco y Chacha / poyas y los de Juan de Baldibieso y los del Obispo del / Cuzco y otros muchos lo qual todo hera obligado a nos lo / boluer e restituir, y por el tercero capítulo dixo que / estando probeido por hordenanzas que ninguno pudiese / vender en aquella tierra carnero ni oveja ni cordero sino / fuese el obligado a dar carne por peso en la dicha carni / sería el dicho licenciado Vaca de Castro lo hazía así guar / dar a todos y ponya estanco en ello y en el mayz e otros / mantenimientos y provisiones proybiendo que ninguno / lo contratase sino él solo y un criado suyo en su nombre / que se llamaua Gaspar Gil en lo qual avía ynteresado otros / cien mil castellanos los quales hera obligado a nos los res / tituyr, y por el quarto capítulo dixo que estando el dicho / licenciado Vaca de Castro en la ciudad de los Reyes para yr / a la provincia de Xauxa avía rescivido de los nuestros oficiales / en ropa y dineros para pagar la gente en quantía de se / senta mil ducados y avía retenydo en su poder mucha parte / dello sin lo pagar a 
los soldados y avía puesto tienda / de la dicha ropa en la ciudad de los Reyes, y en el Cuzco / por dos criados suyos que se llamaban Gudiel y Mexía / en lo qual avía interesado más de otros cien mil caste / llanos y hera obligado a nos los restituyr, e por el quinto //

/ 2 r. / capítulo dixo que el dicho licenciado Vaca de Castro avía hecho / dar al capitán Peranzures de nuestra hazienda real cinco mil / castellanos quando venía a estos Reynos los quales hera o / bligado a volver, y por el sexto capítulo dixo que estando / probeydo que no se hechasen indios a las minas e abiendo él / de mandar que se guardase ansí no lo avía hecho antes a / vía mandado hechar mucha cantidad de indios a las mynas / especialmente a las de la provincia de Calabaya [sic] y a otras muchas / minas donde murieron muchos yndios e sacaron más de / cien mil castellanos y no les avía pagado los jornales e / por ello avía incurrido en las penas en que incurrían / los que hechavan yndios a las minas y pidió e suplicó / fuese condenado el dicho licenciado Vaca de Castro en todo lo que avía sacado y en los jornales de los dichos yndios y / en la pena de la ley, y por el séptimo capítulo dixo que / el dicho licenciado Vaca de Castro avía tomado de nuestra / hazienda real en oro y plata, piedras y otras cosas más / de ciento y cinquenta mil castellanos y no avía dado / quenta dellos, y por el otabo capítulo dixo que el / dicho licenciado Vaca de Castro por defraudar nuestro patrimonio / real no avía manifestado lo que avía sacado de / las minas ny lo que avía avido de los réditos de los / indios por no pagar el quinto que sería más de cinquen / ta mil castellanos y para mejor defraudar el dicho / quinto avía hecho que un platero hiziese dos marcas / y las avía tenido en su casa e poder, más de quatro días / y aunque los nuestros oficiales le avían dicho que no a / vía de aver más de una marca e que la metiese en el arca / de las tres llaves no lo avía querido hazer antes / las avía tenido en su poder y después de hecho lo / que avía querido y marcado el oro, avía hecho llamar / a los oficiales y al platero y remachar la una y / meter la otra en la dicha arca y que se presumía aver / marcado su oro en los dichos días y aver cometido el / dicho delito por aver cometido otros, y por el no / beno capítulo dixo que el dicho licenciado Vaca de Castro / avía enviado de las dichas provincias e del Perú a //

/ 2 v. / estos Reynos más de ducientos mil castellanos escon / didamente con muchas personas en especial con Alonso de / Villalobos e Diego de Aller los quales después de averlo / traído se avían vuelto al Perú y con Fray Francisco / Martínez y el capitán Peranzures y Francisco Becerra / e Juan de Carranza e Juan de Ruiloba, su criado el qual / diz que traya más de sesenta mil castellanos y se bino / a juntar con el dicho licenciado Vaca de Castro en la ysla / de Cuba cuando venía a estos reynos y allí los a / vía tomado al dicho Ruiloba e juntado con lo que él / traya e a todas las personas con quien avía enviado / el dicho oro les avía mandado que no lo registrasen / en su nombre sino en el dellos y ansí se avía hecho / por encubrirlo todo lo qual avía perdido con el quatro / tanto conforme a las hordenanzas, e por el dézimo / capítulo dixo que estando probeído por hordenan / zas que ningún oro ny piedras ny plata ni otras cosas / que vienen de las Yndias se desembarcasen, sino en la / dicha ciudad de Sevilla y se manyfieste todo ante los dichos / oficiales, el dicho licenciado Vaca de Castro avía fle / tado una carabela en la dicha ysla de Cuba y la avía / enviado a Portugal con mucha cantidad de oro con / un criado suyo que se llamava Arguello y lo abía es / condido en el dicho reyno de Portugal e ansí mismo / el dicho licenciado Vaca de Castro vinyendo de la dicha / ysla de Cuba en conserva de la flota, se abía derrotado a la ysla de los Azores con toda su hazienda e de allí / a Portugal donde lo abía escondido sin traerlo a / la dicha ciudad de Sevilla por lo qual avía incurrido / en perdimiento de todo ello con el quatro tanto, / y por el onzeno capítulo dixo que no enbargante que / en tierra firme e avía notificado una provisión / nuestra al 
dicho licenciado Vaca de Castro para que fuese a / hazer residencia, no lo avía hecho ny enviado para ello / persona con su poder, antes se avía venido huyendo con / tinuando su derrota a la dicha ysla de los Azores y no / públicamente sino por lugares y caminos escondidos, //

/ 3 r. / e por el dozeno capítulo dixo que el dicho licenciado Vaca de / Castro no avía cumplido más cédulas reales que le fue / ron dadas cerca del buen tratamiento de los yndios y que no / les consintiese cargar ny hechar a las mynas y tasa de los / tributos lo qual avía hecho por su propio interés por / cargar él los indios y echarlos a las minas y llevarles los / tributos que avía llevado, e por el trezeno capítulo dixo / que aviéndole sido mandado por cédula nuestra y instrucción / que tuviese especial cuidado de nuestra hazienda real e / tomase las quentas della no lo avía hecho, antes avía / tomado y ocupado mucho de la dicha nuestra hazienda real e / aunque le avía sido noteficada la dicha nuestra cédula / en tierra firme, no abía vuelto ny enviado a hazer re / sidencia ny tampoco se avía ocupado en las otras cosas / que le fueron encomendadas, e por el catorzeno capítulo di / xo que debiéndose de ocupar en cumplir las provisiones e / instrucciones que por nos le fueron dadas se abía ocupado / en cosas suyas particulares en el granjear de las mynas / y cobrar para sí nuestros tributos y en rescatar los yndios / y en el trato de vender por sí sólo e por sus criados todos / los mantenimientos y ropa y con esto avía dexado de / cobrar para nuestra cámara los bienes de los culpados en / la muerte de don Francisco Pizarro y enbiar al nuestro Consejo los / autos y sentencias dello para que acá se cobrasen los bienes de / los tales culpados en lo qual nuestra cámara avía recibido de / daño más de docientos mil castellanos en los quales pidió / fuese condenado el dicho licenciado Baca de Castro y que a / su costa se hiziesen las diligencias necesarias, y por el / quinze capítulo dixo que abiendo de hazer sus autos / deligencias con Diego de Almagro y sus secazes avía apartado con quarenta / de a caballo recogidos para guarda de su persona e se a / bía puesto detrás de un cerro aunque se agrabiaba la / gente por sacallos aquellos caballos recogidos y le di / xeron que no lo hiziese y por ello estuvo en punto de per / derse la batalla, y por el diez y seis capítulo dixo //

/ 3 v. / el dicho licenciado Vaca de Castro avía dilatado la prisión al / dicho don Diego de Almagro cinco o seis meses por gozar de los / frutos de sus indios y avía estado a punto de soltarse / tenyendo postas para yrse a Mango Ynga que estaba alzado / y tornar e rehazerse y lo mismo avía hecho con Diego / Méndez dilatándole la prisión por gozar de sus yndios / hasta que se fue que hera uno de los más culpados, e / por el capítulo diez y siete dixo que sabiendo que nos / ynbiábamos visorrey y audiencia con hordenanzas que no se / encomendasen indios y que ningún gobernador tuviese / encomiendas de indios a personas que no avían si / do conquistadores ni servido a nos sino heran sus / criados amigos y parientes y personas de quien esperaba / favor e ynteres e de dineros, y por el capítulo diez / e ocho dixo que el dicho licenciado Vaca de Castro a / vía rescivido presentes en mucha cantidad de dinero / oro, plata, joyas e otras cosas por dar repartimientos / gobernaciones y capitanías e otros oficios y por desimu / lar con otros culpados y porque no quitase indios a / otros y otras causas lo qual hera más de cien mil / castellanos y avía tomado de lo devido a nos más de / ciento y cinquenta mil, y por el capítulo diez e nueve dixo / que sabiendo del visorrey y audiencia que iva e de las / hordenanzas que llebavan el dicho licenciado Vaca de Castro / avía hecho juntar los pueblos del Perú persuadién / doles que no obedeciesen las dichas hordenanzas y por su / causa e consejo se avía lebantado la tierra y subzedido / las disenciones pasadas en lo qual avíamos perdido / más de un millón y hera obligado a lo pagar, y por el / veynte capítulo dixo que como hombre culpado en las / tomas de nuestra hazienda real y de particulares y en o / tras culpas ynbiaba 
dádivas de oro y de otras cosas / a los del dicho nuestro Consejo de las Yndias y a sus mujeres / y a otras personas favorecidas y por dar color a sus delitos a / vía enviado poder para recusar a los del nuestro Consejo //

/ 4 r. / oydores de la nuestra audiencia de quien no estuviese seguro / que le avía de favorecer, y por el capitulo veinte y uno / dixo que el dicho licenciado Vaca de Castro por ser más aprobe / chado de nuestra hazienda real y de los repartimientos de yndios / y porque no fuésemos avisados de sus culpas y excesos a / vía tenido mucho tiempo los nabíos detenidos en los puertos / de que avíamos muy desservido y los tratantes e / maestres de naos danificados en más de cien mil castellanos / en lo qual pedía fuese condenado por ende que nos suplicaba / mandásemos proceder contra el dicho licenciado Vaca de Castro y / sus bienes y contra todas las otras personas que pareciesen / culpados en lo susodicho y condenarlos en las penas en que / incurrieron y executarlas en sus personas e bienes e / sobre todo pedía complimiento de justicias y que mandásemos / tomar su confisión al dicho licenciado Vaca de Castro con / forme a la ley de la partida e hizo presentación de ciertas yn / formaciones y escrituras y de un testimonio firmado / de Alonso Pérez Granillo escribano de la nao nombrada San / tiago y de ciertas cartas mesibas de ciertos pueblos del / Perú a nos escriptas en que nos significaban los servicios / del dicho Vaca de Castro y entre ellas una de la Villa de la Plata, / otra de la de San Juan de la Vitoria e otra de la Villa de A / requipa el tenor del dicho testimonio y cartas mysibas / son como se siguen. [Al margen: testimonio] A todos los señores que la presente / vieren que nuestro Señor salve y guarde de mal, yo Alonso Pérez / Granillo escribano de la nao que Dios salve nonbrada San / tiago de ques maestre Alonso Morillo doy fee como en un / día martes a veinte y siete de mayo de este presente año / de mil y quinientos y quarenta y cinco años el dicho maestre / Alonso Morillo en presencia de my el dicho escribano y de los / testigos de yuso escriptos estando en la ciudad de la ysla / de la Tercera pidió y requirió al licenciado Vaca de Castro pa / sajero que venía en la dicha su nao que por quanto el dicho licenciado se avía desenbarcado sin su licencia ny consentimyento por / el dicho maestre estar enfermo que el dicho licenciado se enbar / case porque él estaba presto para hazerse a la vela e / partir para estos Reynos de Castilla y ansimismo tenya //

/ 4 v. / nueba que la flota que él esperaba hera pasada y el dicho / licenciado le respondió que no hera su voluntad de seguir / el dicho viaje en la dicha nao porque al servicio de su magestad con / venía yr él con toda la brebedad que se pudiese y que para / su viaje que le hera mejor yr por la bía de Lisboa y que no en / bargante esto allí avía una cédula de su magestad en que man / daba que qualquier pasajero que allí se quisiese quedar nin / gund maestre fuese bastante a le ynpedir su persona y por / que esto ansí pasó como dicho tengo di esta firmada de / my nombre que es fecha día mes y año, susos dichos testigos que / fueron presentes a lo que dicho es Álvaro Hernández vezino de / la dicha ciudad e Hernando Diez marinero de la dicha nao, Alonso / Pérez Granillo. Sacra Cesárea Católica Magestad por nuestras cartas siempre el cavildo / de esta villa a tenido cuidado de dar quenta a Vuestra Magestad de / las cosas acaecidas en estas provincias y por aver avido / tantos enbarazos e ynconbinientes en los viajes de los men / sajeros lo tornaremos a referir en esta brevemente y a / Vuestra Magestad estará largamente informado como don Diego de / Almagro e sus secazes mataron al marqués don Francisco / Pizarro gobernador que fue de estos reinos y se apoderaron de / todas las armas y caballos que avía en ellos y tomaron / por fuerza de armas los pueblos y ciudades y villas e / hizieron recibir por fuerza por gobernador a don Diego e / tomaron y ocuparon los navíos que navegaban por esta mar / del sur por manera que tenían 
tiranizada y ocupada to / da la tierra haciendo muchas opresiones, fuerzas, muertes / robos y violencias que por ser muy largo no los espresamos / en esta e fue Dios seruido que en tiempo de tanta turbación lle / gase a estas provincias después de muchas peregrinacio / nes y trabajos el licenciado Vaca de Castro vuestro gobernador / de estos reynos cuya provisión pareze aver sido yns / pirada por Dios pues con ella se restrauraron y reduzie / ron estos reynos al seruicio de Vuestra Magestad y porque Vuestra Magestad / será informado del valor y buena maña con que comenzó / a caudillar y juntar gente y proveer de armas y munición / y otras cosas necesarias hasta juntar copia de gente bastante / aunque con mucha dificultad y trabajo, no lo diremos en esta //

/ 5 r. / más de que como Vuestra Magestad abrá sabido e se podía informar / los cavalleros y servidores de Vuestra Magestad que en esta villa residi / mos juntamente con el capitán Peranzures teniente que a la / sazón hera della con la lealtad y fidelidad que debíamos / como buenos vasallos y servidores de Vuestra Magestad luego que se supo / la muerte del dicho marqués y lebantamyento de don Diego y / sus secazes y la venida del dicho licenciado Vaca de Castro / a estas provincias alzamos bandera por Vuestra Magestad con la de / más gente que podimos acaudillar y juntar y fuimos / a la ciudad de Arequipa donde tomamos y juntamos con / nosotros algunos vezinos y servidores de Vuestra Magestad y las ar / mas y caballos que avía e de allí fuimos a la ciudad del / Cuzco donde estava Perálvarez Holguín con otra cierta copia / de gente y todos juntos fuimos en busca del dicho licenciado / Vaca de Castro para en su companya seruir a Vuestra Magestad y le dar / favor y ayuda para resistir el dicho lebantamyento e / delitos y fuimos con nuestras personas, armas y caballos has / ta un asiento que se dize Goaraz [sic] que serán doscientas y cin / quenta leguas de esta villa en lo qual pasamos muchos e / grandes trabajos y peligros porque como don Diego e / sus secazes tenyan usurpada a toda la tierra y a unos con / dádivas y a otros por temores y a otros por engaños avían / juntado consigo mucha copia de gente y como supieron / que los vecinos y personas de esta villa y Cuzco y Arequipa / nos avíamos juntado en servicio de Vuestra Magestad e ybamos / en busca del dicho licenciado Vaca de Castro nos salieron con / mucha gente y armas y munición a desbaratar si pudieran / y fue Dios seruido que nos dimos tan buena maña y priesa / que aunque llebabamos mucha gana de nos ver con ellos / por emplear nuestras vidas y personas en servicio de Vuestra Magestad con / tra tan grandes desvergüenzas y levantamientos pasamos / antes que ellos pasasen del paraje donde nos avíamos / de encontrar y fuimos al dicho asiento de Huaraz a donde / vino el dicho licenciado Vaca de Castro vuestro gobernador con cuya / venyda nosotros recibimos mucha consolación y alegría / porque a no venir Vuestra Magestad tenga por cierto que la tierra se perdiera //

/ 5 v. / sin poderse recobrar y nosotros no nos pudiéramos sus / tentar porque cada uno procuraba e pretendía sus fines / e ya avía muchas discordias y pasiones entre las perso / nas que se avían juntado en servicio de Vuestra Magestad e de allí nos / mandó venir al asiento de Xauxa y él con algunos de nosotros / vaxó a la ciudad de los Reyes de donde sacó mucha gente / armas y munición haciendo muchas prebenciones como / para la jornada hera menester en lo qual pasó mucho tra / vaxo y dificultad como por otras abrá visto Vuestra Magestad / y vino al dicho asiento de Xauxa a donde estaba la / más gente y con toda puesta en buena horden vino hazia / la ciudad del Cuzco el dicho don Diego y sus se / cazes al servicio de Vuestra Magestad y llegado a la villa de Goaman / ga tubo nueva como avía salido de la ciudad del Cuzco / donde avía venido y estaban y avía hecho muchos / robos, insultos, muertes y tiranías y lo mismo en es / ta villa y Arequipa los quales avían salido con muy / gruesa artillería y muy armados y a punto y en busca del / dicho gobernador y de 
los que con él venyan en servicio de / Vuestra Magestad para nos desbaratar y pensando destruirnos e / quedarse con estos reynos y aún con los de tierra firme / e que avían llegado a un asiento de Bilcas que es diez / leguas de la dicha villa de Goamanga donde el dicho goberna / dor les ynbió mensajeros y provisiones para los reducir / al servicio de Vuestra Magestad los quales con mucha desvergüenza e / deslealtad aorcaron al mensajero y no quisieron obedecer / y enviaron a decir que aparejásemos que nos venían a dar / la vatalla y que la tierra hera suya y que no conozian a / otro rey sino a don Diego de Almagro que ellos llama / van su gobernador y con esta determinación salieron del dicho / asiento de Vilcas sabido por el dicho gobernador con los ser / vidores de Vuestra Magestad, salió de la villa de Goamanga a un / asiento que llaman Chupas dos leguas della por es / tar en mejor sitio para esperar y acometer los contrarios / los quales vinyeron allí pensando de nos desbaratar e des / pués de aber hecho gobernador muchas deligencias //

/ 6 r. / e amonestaciones con ellos y visto que otro remedio no / avía para restaurar estos reynos ya que venían a / vista del real de Vuestra Magestad el dicho vuestro gobernador con mucho / esfuerzo y valor como si toda su vida se obiera exercitado / en semejantes cosas les salió al camino e hablada e a / nimada la gente y puesta en buena horden les dio la va / talla la qual fue muy renida y estando en alguna / duda el dicho gobernador entró con cierta parte de gente / que avía apartado consigo con la qual entrada fue / Dios serbido que se conociese luego la vitoria y los tiranos / fueron luego vencidos y desbaratados con lo qual en / la buena ventura de Vuestra Magestad fue Dios seruido de / nos hazer a todos muy gran merced porque los contra / rios trayan mucha e buena artillería y arcabuzería / y mejores caballos y más bien armados porque como / avíamos significado a Vuestra Magestad avían tomado / todas las de la tierra y en todo parece que Dios yns / piró en el Gobernador porque un punto que se per / diera de todo lo que se hizo y a no se dar aquel día / la vatalla todos los seruidores de Vuestra Magestad y la tie / rra quedava en mucho detrimento y peligro e ansí / benzidos el gobernador hizo justicia de los capitanes / principales y matadores del marqués como en tal caso / se requiere y como supo que don Diego de Almagro a / vía huido de la vatalla con la buena deligencia e / yndustria del gobernador fue preso cerca de la ciu / dad del Cuzco donde oydos y averiguados sus gran / des e inormes delitos se hizo justicia dél en lo qual / se hizo a Vuestra Magestad muy grande y señalado seruicio por / que en qualquier parte que estuviera aunque lo lle / bara a esos reynos de España que no se podía ha / zer sin mucha dificultad y peligro nunca en esta / tierra oviera pacificación ni sosiego y con hazer / justicia lo ovo y avrá perpetuamente acabadas //

/ $6 \mathrm{v}$. / las cosas de la guerra al gobernador le quedaron no / menos trabajos que con ella porque para deshacer / la gente que avía juntado no bastaba juicio umano / y Dios no lo guiara en ello porque como avía mil / ombres que avían servido a Vuestra Magestad en esta jornada / e cada uno pretendía un repartimiento y no a / bía para cumplir con cinquenta si aquello que avía / lo diera luego no se podían escusar muchos motines / y alteraciones y fue necesario dilatar y dar lo que / avía por algund tiempo y en este medio el gobernador / con mucha sagacidad y templanza probeyó a siete o / ocho capitanes que fuesen a descubrir nuevas tie / rras y conquistas con los quales ynbió toda la más gente / que avía aunque no a poca costa suya e de su hazienda / socorriéndolos con cavallos y armas e dineros / e otras cosas en lo qual no se a hecho menor servicio / a Vuestra Magestad que en lo pasado porque de algunos dellos / a avido noticias que se a descubierto mucha e muy bue / na tierra y esperamos que en breve tiempo con la buena / maña y dicha del gobernador se an de ensanchar y ampliar / muchos estos reynos e descubrir muchas y grandes / riquezas de que ha 
de ir a Vuestra Magestad mucho servicio, des / hecha ya la dicha gente de guerra por la horden que avea / mos dicho a Vuestra Magestad el dicho licenciado Vaca de Castro vuestro / gobernador a entendido en reformar vezindades e re / partir lo que avía entre las personas que avían ser / vido a Vuestra Magestad lo qual en la verdad a sido fecho / justo e rectamente como de mano de persona tan ca / lificada como él es puesto que avía muchos con quien / cunplir y poco quedar bien puede Vuestra Magestad ver que / segúnd la calidad de la gente desta tierra que como es tan / trasplantados, tan lexos desos reynos el que es de / menor calidad le parece que merece más que el mayor / y hera menester gracia divina para dar entero conten //

/ 7 r. / tamiento a todos porque no basta razón, ni / retitud humana mayormente que puesto que avía / algunos que avían servido avían hecho cosas que / tenían de méritos para no solamente no ser probeydos / pero aún castigados e a lo hordenado todo el dicho / vuestro gobernador con tan gran sagacidad y prudencia que / todos an quedado contentos e remediados muchos / después de esto ya que las cosas de la guerra dieron al / gún lugar a entendido con mucha deligencia e travaxo / en dar horden y poner remedio para que cesasen / los muchos y grandes daños muertes que con las al / teraciones y deshordenes pasadas avían recibido e / recibían los naturales ansí en cargas como de malos / tratamientos y en robarles lo que tenían que hera / cosa de muy grand lástima y con el ayuda de Dios a / puesto y pone tal horden con que cesan los ynconbinien / tes dichos y los naturales tienen bien entendido la / merced grande que Vuestra Magestad les haze en enviarles persona que / tanto cuidado tenga dellos y biben ya con mucho con / tentamiento como bien que poseen libremente lo que / tienen y ya no les toman las mujeres, hijos y hazien / das y se están quietos en sus cosas y todos le aman / y le quieren como a padre propio porque ansí lo es de todos ellos e de los españoles que acá están de lo que / avemos dicho a redundado que con el ayuda de nuestro Señor / an venido y vienen muchos gentiles al conocimiento de / nuestra santa fe cathólica e se an bautizado y cada día / se bautizan mucho número dellos y esperamos nuestro / señor que en muy breve tiempo ha de aber muy gran / yglesia de estos naturales ansímismo el dicho vuestro gober / nador a entendido y dado horden y aparejo para que / se hagan en todos los pueblos de estas provincias / yglesias y monasterios por manera que además de averlas / ganado de nuevo a Vuestra Magestad que fue más sin comparación / que descubrillas y conquistallas porque en lugar de los //

/ 7 v. / tesoros que hallaron en tiempo de Atabalipa tenían es / tos tiranos mucha e gruesa artillería donde no obo / defensa en los yndios ovo lo que avemos significado / a Vuestra Magestad en ellos a tenido e tiene muy gran cuidado de / lo que toca al descargo de la real conciencia de Vuestra Magestad / y sobre todo en la conversión y conservación y buen tra / tamiento de los naturales luego que el tiempo dio lugar / comenzó a entender en la reformación que por Vuestra Magestad / le fue encomendada y en averiguar y saver las cosas / y fraudes que avía avido en la hazienda real de / Vuestra Magestad y como esto toca especialmente a vuestros oficiales / y a otras personas que tenían execibo repartimiento / an lo tomado por áspero e subcedió que pensando / evadirse de esto enviando el gobernador por su teniente / a la ciudad de los Reyes a un bachiller Guebara que / fue capitán en la vatalla no le quisieron recibir / e hizieron ciertas cosas a manera de alteración e / aunque no fue ni aí nadie que sea bastante a / ponerla en la tierra con el valor del gobernador e / de los servidores de Vuestra Magestad que en ella estamos le obligó / a tener más costa y gasto de lo que tenía aunque / hera mucho porque como Vuestra Magestad abía entendido / por espiriencia de las cosas acaecidas en esta tierra / el poder de los gobernadores no consiste solamente / en muchas provisiones e facultades sino con valor / y autoridad porque la gente de esta tierra es tan / yndómita 
y mal inclinada y ella de tal calidad que / en juntando uno con duzientos hombres vasta para ser / señor della y por esto conviene que el gobernador della / tenga mucha estimación y valor como lo a hecho y haze / el licenciado Vaca de Castro que Vuestra Magestad podrá ser ynfor / mado que lo a tenido y tiene tanto que está enpe / ñado en muy gran suma de pesos de oro aunque / bien crehemos que no faltará como siempre en estas / partes se a vsado quien escriba y conponga cosas a sus //

/ 8 r. / fines y propósitos particulares a esta sazón vino / a estas provincias la provisión que Vuestra Magestad ynbió en con / firmación de la gobernación dellas al dicho licenciado Vaca / de Castro por la qual vesamos los pies y manos de Vuestra Magestad / porque todos sus vasallos recivimos dello mui gran / merced y toda la tierra en general mucho y gran beneficio / porque sabrá Vuestra Magestad que con ella se acabó de pacificar / e sosegar porque la gente desta tierra como tenemos dicho / es amiga de novedades e alteraciones y de senbrar / nuevas dañosas en la república y como algunas / personas de las que an ydo de estas partes que residen / en esa corte y otras de las que acá están que tienen deu / dos en ella pretenden parte de estas gobernaciones e / tienen acá personas apasionadas siempre avía entre / ellos nuebas que davan alguna alteración y desa / sosiego con ella cesó todo demás de esto avemos en / tendido que algunas personas no teniendo el zelo que / deven al servicio de Dios e de Vuestra Magestad sino por sus / particulares intereses an ydo a esa corte como fue / el capitán Alonso [sic] ${ }^{1}$ de Albarado e otros a procurar / parte de estas probincias en gobernación siendo mas pa / ra estragar que no para gobernar ya Vuestra Magestad por es / periencia tiene conoscido y visto los ynconbinientes / y grandísimos daños que an subcedido muertes y / escándalos y alborotos de la devisión de las goberna / ciones que conviene a la perpetuidad de esta tierra sosiego y / pacificación della que ser gobernada por sólo una persona / de quien Vuestra Magestad se confíe porque aunque en esto pue / dan poner alguna dificultad que no la ay de lo con / trario se siguirán muchos y grandes ynconbinientes acá / avemos entendido que el licenciado Vaca de Castro tie / ne voluntad de se volver a servir a Vuestra Magestad en esas partes / y aún somos informados que lo envía a suplicar / a Vuestra Magestad y si Vuestra Magestad lo permitiese le hazemos saber / que estas provincias y la real hazienda de Vuestra Magestad verná / muy gran daño porque qualquier otro que a ella viniese //

/ 8 v. / o de otra novedad o mudanza sería causa de mucho daño / porque estando como él está entendido en las cosas de / lla y teniendo conocida la gente y calidad primero que otro / la entendiese se destruiría la tierra mayormente teniendo / la como la tiene en tanta justicia y buena orden ser / bien quisto y amado de todos por ende a Vuestra Magestad unyll / mente [sic] suplicamos sea servido en satisfación de los / muchos servicios que en esta tierra avemos hecho de / mandar residir y estar en ella perpetuándole la gober / nación della haziéndole mercedes de calidad en pago e / gratificación de los muy grandes seruicios que a / Vuestra Magestad a hecho y grandes trabajos y gasto que a tenido / en hacer con tanto valor y fidelidad ganado e / restituido esta tierra al servicio de su Magestad y tenerla / en tanta justicia y retitud y para ello enviamos po / deres e procuradores nuestros que de nuestra parte lo supli / quen a Vuestra Magestad como leales vasallos y seruidores su / yos certificamos a Vuestra Mereced en cargo de nuestras concien / cias que lo que en esta le segnificamos es lo que pasa en / verdad y lo que conviene a su servicio y bien de toda es /

\footnotetext{
${ }^{1}$ Se refiere probablemente al capitán Diego de Alvarado, uno de los emisarios almagristas mandados a la corte a pedir justicia al Rey después de la ejecución de su líder en la batalla de la Salinas (1538). Albacea de Diego de Almagro el Mozo, también disputó en corte a los Pizarro la gobernación de Nueva Toledo.
} 
ta tierra y que los que otra cosa le ynformaren e / pretendieren es por fines y pasiones particulares / e no tienen el zelo que deben al serbicio de Dios y de / Vuestra Magestad ansímismo en satifación de los muchos servicios / y trabajos que avemos hecho y tenido, enviamos a / suplicar a Vuestra Merced nos haga merced de algunas cosas que / tocan a esta villa y a los vezinos della Vuestra Magestad sea ser / vido de nos lo mandar conceder y porque Francisco Paez de / nuestra parte ynformara a Vuestra Magestad de todo lo demás que / fuere servido de saber a Vuestra Magestad suplicamos le mande / dar crédito por ser persona que está bien informado de / las cosas desta tierra y zeloso del servicio de Vuestra Magestad e / conceder ansímismo lo que él de nuestra parte suplicara y por más çertificaçión desto firmamos de esta nuestros nom / bres y va firmada del escriuano de cabildo de esta villa / para que Vuestra Magestad sea servido de le dar entero crédito cuya vida //

/ 9 r. / e ynperial estado nuestro Señor guardó por muy largos / tiempos con acrecentamiento de muchos más reynos / e señoríos e vitoria de sus enemigos desta villa de Plata / que es en la provincia de las Charcas a diez e siete de di / ziembre de mil y quinientos e quarenta y tres años de / Vuestra Sacra Católica Magestad muy umildes vasallos que sus pies y / reales manos vesan Luis de Bera teniente, Alonso Pérez / de Castillejo alcalde, Alonso de Camargo regidor, Francisco / de Tapia regidor, Lope de Mendieta regidor por man / dado del teniente justicia e regimiento, Alonso de / Carmona escriuano público e del concejo. Su Sacra Católica Real / Magestad porque por otras cartas antes desta hemos dado / a Vuestra Magestad / que para en recompensa de los trauajos y grandes gas / tos que esta villa ha tenido mediante todas / alteraciones pasadas ansí entre los españoles como con / los indios, Vuestra Magestad nos haga merced de las libertades / y franquizias y mercedes que los principales suelen hazer / a sus vasallos y sean que Vuestra Magestad nos haga merced / de mandar al gobernador Vaca de Castro que perpetu / mente resida en esta tierra gobernándola pues en todo / lo en ella hasta ahora subcedido también y con tanta fi / delidad y valor a Vuestra Magestad a servido y en tanta quietud / e reposo a puesto esta tierra con hallarla tan perdida / que si algo más su venida se dilatara se acabará de / perder porque los naturales della se destruyeran e / los españoles padezieran tienelo en tan buena horden / ya enpieza a reformarse y esto es mediante / nuebas hordenanças que a hecho poniendo en ellas / grabes penas a los que por ella andan todas en favor / de los naturales ya Vuestra Magestad será informado como / dos leguas desta villa se dio la vatalla a los de Chile / y se venció mediante la voluntad de nuestro Señor y la / buena diligencia y grand valor del gobernador Vaca de / Castro no sin riesgo y gran trauaxo y gasto de los vezinos e //

/ 9 v. / della, porque aquí reparó el real de Vuestra Magestad / e se rehizo de las cosas necesarias y tubo avisos de / lo que convenía para deshacer los enemigos y pues es / to es ansí y los vezinos desta villa o la mayor parte / dellos se hallaron en la vatalla y la ayudaron a venzer / a Vuestra Magestad, suplicamos nos haga merced de mandarla yn / titular de ciudad y el renombre sea de la Vitoria e / confirmarle los términos que el gobernador Vaca de Castro / y el marqués don Francisco Pizarro le dieron y más de otros / tres repartimientos que el procurador desta villa en / nombre della a Vuestra Merced pedirá y suplicamos a Vuestra Magestad / nos haga merced de un escudo de armas para que quede de / memoria de la lealtad que esta villa siempre tubo / en seruicio de Vuestra Merced y suplicamos a Vuestra Magestad que para / en recompensa de los grandes gastos questa villa / a tenido Vuestra Merced le haga merced de que no se pague del oro / de minas, más del diezmo perpetuamente y que si al / gund vezino desta villa quisiere irse a los reinos / de España 
Vuestra Magestad le haga merced que con sus haziendas / puedan traspasar los indios que tubieren encomendado / a las personas que quisieren, a Vuestra Magestad suplicamos / tenga respeto a nuestros trauajos y grandes gastos / y nos haga estas mercedes que aquí pedimos pues todo / lo queremos para mejor poder servir a Vuestra Magestad, Sacra / Magestad, Dios Nuestro Señor la vida y enperial persona y estado / de Vuestra Cathólica Magestad guarde y en su servicio conser / be con acrecentamiento de su ynperial reyno e / señoríos y aumento de nuestra santa fe desta villa / de San Juan de la Vitoria, a doze de henero de quinientos / e quarenta y quatro años, ynvitísimo césar vesan / los reales pies y manos de Vuestra Magestad sus humildes / y leales vasallos, Lorenzo de Aldana, Pedro Diez, Julio de Barrio, Antonio de Oreiro, Hernando de Villalobos / Francisco de Cárdenas, Diego Gabilán. Sacra Católica Cesárea Magestad porque / de la villa de San Juan de la Frontera escribió a Vuestra Magestad / el cabildo desta çuidad de Arequipa la vitoria que Dios //

/10 r. / Nuestro Señor en ventura de Vuestra Magestad y la buena deligencia y / esfuerzo del gobernador Vaca de Castro dio a los leales / vasallos de Vuestra Magestad y del gran castigo que hizo el goberna / dor en los capitanes y personas principales y en los de / más que en la vatalla se prendieron, por esta daremos a / Vuestra Magestad relación de lo después acá subcedido, don / Diego caudillo principal de los rebelados contra el / servicio de Vuestra magestad fue preso en la ciudad del Cuzco e / con él Juan Rodríguez Barragán, uno de los prencipa / les de la muerte del gobernador, don Francisco Pizarro, / contra los quales el gobernador hizo proceso y los / oyó a justicia para más justificación suya guar / dándoles sus términos como bueno e reto juez / en el qual tiempo el dicho don Diego y los demás que / con él estaban presos de secreto se confederaron con / el ynga que está alzado contra el seruicio de Vuestra Magestad / para se ir a él y de nuevo ynbentar otras alte / raciones e desasosiegos y tiranías contra el seruicio / de Vuestra Magestad, permitió nuestro Señor que fuese descubierto / al gobernador, el qual mandó ver lo procesado e / viendo sus nefandos delitos les dio la muerte al dicho / don Diego y Juan Rodríguez Barragán y como se hizo / justicia de don Diego, la tierra quedó pacífica, el / gobernador para más sosiego y pacificación des / tos reinos y bien de los naturales e remedio de los / leales vasallos de Vuestra Magestad a repartido todos los / yndios que vacaron y los demás que justamente se / podían repartir a las personas que lo merezían e / an seruido a Vuestra Magestad en estas alteraciones pasadas / e con los que no pudo conplir les dio capitanes con / quien fuesen a poblar las provincias de Chile e / a descubrir otras de que se tiene noticia y a muchos / destos ayudó con su hazienda, ansímismo a hecho en la conversión gran bien y probecho en los natu / rales en traer como a traído a muchos a conocimiento //

/ 10 v. / de nuestra fe en especial a Paullo que agora se llama / don Cristóval con sus mugeres e hijos, hermano e se / gunda persona del señor principal que está rebelado / y en lo que toca a la libertad y buen tratamiento de los / naturales nunca lo an conocido de ningund gobernador / pasado hasta que el licenciado Vaca de Castro vino / a estos reynos y el buen tratamiento y libertad que / les ha dado, a hecho venir muchos al conocimiento / de nuestra Santa fe, pues en lo del gobierno de la tierra / sepa Vuestra Magestad que nunca a estado tan puesta en razón / como está oy ansí para los naturales como para los / súditos de Vuestra Magestad por el gran bien y merced / que a hecho a estos reinos en probeer al licenciado Vaca / de Castro de nueva provisión de gobernador porque / para el bien de la tierra ninguno pudiera Vuestra Magestad ynbiar / que más fruto obiera hecho ni hará en la tierra porque / mediante su muy reta y limpia justicia están en / ella estos reinos de Vuestra Magestad y en mucha quietud e porque / de él tenemos conocido, tiene deseo de volver a dar / quenta a Vuestra Magestad de los muy grandes servicios que / en estos reynos a hecho y como 
hombre de hedad y / que a pasado muy grandes trauajos querrá quedarse / en su casa, a Vuestra Magestad suplicamos por lo que con / viene al servicio de Vuestra Magestad y al bien de los naturales / no permita que destas partes vaya antes nos le per / petúe acá enviándole a mandar resida en estas partes / porque como verdaderos vasallos de Vuestra Magestad escribimoslo / que conviene para descargo de su real conciencia porque / tiene muy gran cuidado de la conversión de los yndios e / de su buen tratamiento Sacra Cesárea Católica Magestad Dios Nuestro Señor guarde a / Vuestra Católica Magestad y dé vida por muchos años y vitoria contra los / infieles porque nuestra fe sea aumentada, amén, des / ta ciudad de Arequipa, siete de julio, año del Señor, de mil e / quinientos y quarenta y tres años, vesan las manos y pies de Vuestra Sacra Cesárea Católica Magestad, sus //

/ 11 r. / leales vasallos Alonso de Cázeres, Noguerol de Ulloa, Hernan / do de Torres, Manuel de Espinar, Juan de Guzmán contador, Pedro / Godinez, Juan de Arbo por mandado del Cabildo, Alonso de / Luque escriuano público, lo qual visto por los del dicho nuestro / Consejo Real de las Yndias mandaron que el licenciado Sal / merón del dicho nuestro Consejo tomase su confisión al dicho / licenciado Vaca de Castro por ciertas preguntas el tenor / de las quales y de la confisión e declaración del dicho / licenciado Vaca de Castro es éste que se sigue. Las pre / guntas que ha de declarar el licenciado Cristóval Vaca de / Castro son las siguientes: primeramente si es verdad / que después que fue probeído por juez por su Magestad / para la provincia del Perú que fue en el mes de junio / del año de mil e quinientos y quarenta años el dicho / licenciado Vaca de Castro como tal juez recibió en sí e / le fueron entregadas la provisión principal de su comisión / e la instrucción de todo lo que avía de hazer y probeer / e seguir en el juzgado del Perú y de lo que avía de hazer / en el viaje y otras instituciones que avían sido dadas / a juezes pasados y al Obispo del Perú e a otras per / zonas y otras muchas cédulas e provisiones e horde / nanzas e cartas lo qual todo recibió el dicho licenciado / Vaca de Castro de Juan de Sámano secretario de su Magestad / para lo llevar consigo en el viaje para lo hazer cun / plir y executar y que todas las dichas cédulas, provisio / nes y escrituras y hordenanzas recibió el dicho licenciado / Vaca de Castro por ynbentario el qual ynbentario e / memoria quedó firmado de la propia letra y firma del dicho / licenciado Vaca de Castro de como lo recibió en los libros de / su Magestad que están en poder del dicho Secretario Sámano la / qual firma pido sea mostrada al dicho licenciado Vaca / de Castro y vista declare si aquella es su letra e firma / e si es verdad que recibió en su poder los despachos / contenidos y declarados en el dicho memorial. Yten / declare si es verdad que deviendo de dexar en la Real Au //

/ 11 v. / diencia de Panamá el sello Real que allí enviaba el señor / comendador de León el dicho licenciado Vaca de Castro hizo / por él hazer otro sello Real y le llevó consigo a las / probincias del Perú y le tubo allá consigo y mostraua, / declare qué autoridad y comisión tubo para lleuar / el dicho sello real y para qué hefeto usaua de él y le te / nía en el Perú. Yten si es verdad que luego que entró / en la provincia del Perú de su gobernación, el dicho li / cenciado Vaca de Castro tomó mucha cantidad de yndios pa / ra los llebar e llebaua cargados por el camino con su ropa / e de sus criados e de sus familiares e que tanta cantidad de / yndios lleuaua ansí cargados con la dicha ropa e que / tanto trecho le lleuó, si fueron más de trezientas / leguas o qué tanto, e si fueron con voluntad de los / mismos yndios o contra su voluntad, e si pagó e hizo / pagar a los dichos yndios el trauajo que sufrían en / lleuar las dichas cargas e quántos yndios murieron en el / camino por los llevar ansí cargados. Yten que diga e / declare qué repartimientos de yndios de los que es / taban vacos quando el dicho licenciado Vaca de Castro llegó / a la dicha probincia de los que después vacaron puso / el dicho licenciado Vaca de Castro en su cabeza, declare / particularmente qué repartimientos fueron y 
cuyos / heran y en qué partes estaban y quánto tiempo los tubo / en su cabeza y qué tributos, frutos e provechos tuvo / el dicho licenciado Vaca de Castro de los dichos yndios, de / clare particularmente qué hubo dellos en oro y en pie / dras y en vasijas de oro y plata e en joyas y en ma / iz y en carneros y ovejas e en corderos y en aves e / mantas y otras ropas y cosas de la tierra e que podía / todo valer y qué personas lo cobraban de los dichos yndios / por mandado del dicho licenciado Vaca de Castro. Yten declare / qué tanto tiempo duró el trato que tubo el dicho licenciado / Vaca de Castro por mano de un Gaspar Gil su criado e ma / yordomo de vender el ganado, carneros, corderos, ovejas //

/ 12 r. / e maíz e otras cosas de mudanzas de la tierra el / dicho licenciado por sí o por mano del dicho Gaspar Gil e / otros sus criados recibía de los tributos de los dichos / yndios y de lo que con ellos rescataua, declare quánto / duró el dicho trato de lo vender e a qué precios ben / día los carneros y ovejas y corderos en pie y fanegas / del maíz y otras cosas, e si es verdad que el dicho vedaua a los españoles e yndios y no les consentía que / vendiesen cosa alguna de las susodichas y que por el dicho / bedamiento todos los españoles que estauan en el Perú / y los dichos yndios avían de comer y comprar las co / sas necesarias de mano del dicho licenciado Vaca de Castro / e de la persona o personas que él para ello tenía pues / tas. Yten declare si es verdad que los españoles se / agraviaban mucho del dicho estanco de que no consen / tía que otra persona tuviese el dicho trato y que por / esto compraban las susodichas cosas del dicho li / cenciado Vaca de Castro, e sus fatores y criados a / precios muy excesivos y si es verdad que tubo el dicho / trato y estanco más de un año, declare qué ynterese e / probecho se siguió al dicho licenciado Vaca de Castro / del dicho trato y si fue en cantidad de más de cien mil / castellanos o qué tanto fue. Yten declare si es verdad / que estando el dicho licenciado Vaca de Castro en la ciudad de / los Reyes pidió a los oficiales el dicho licenciado de la hazienda / de su Magestad en oro y plata y ropa para lo susodicho / en valor de sesenta mil castellanos. Yten que de / clare si es verdad que de la dicha ropa y oro y plata / que ansí recibió de los dichos oficiales para pagar la / dicha gente el dicho licenciado retuvo en sí sin lo dar / a la dicha gente más de treinta mil castellanos de oro / declare en qué cantidad retuvo de lo susodicho. Yten declare //

/ 12 v. / si es verdad que la ropa de lo susodicho en sí retuvo / el dicho licenciado Vaca de Castro, entregó a dos criados su / yos que se llamaba el uno Mexia y el otro Gudiel los / quales por mandado del dicho licenciado lo vendieron / y para ello pusieron tienda pública en la dicha ciudad / de los Reyes y mucha parte de la dicha ropa lleuó / a la ciudad del Cuzco el dicho Gudiel por mandado del / dicho licenciado Vaca de Castro y puso en la dicha ciudad / del Cuzco a donde lo vendió a muy excesivos pre / cios, declare si es verdad que de la dicha ropa que / ansí retuvo hizo vender a sus criados el dicho licencia / do ubo de interese y ganancia más de cinquenta mil / castellanos, declare el ynterese y ganancia que dello / se le siguió. Yten declare qué otra cantidad de oro / plata, piedras e otras cosas de la hazienda de / su Magestad recibió el dicho licenciado Vaca de Castro por / sí e por otras personas de mando de los oficiales / de su Magestad y qué cantidad de lo susodicho recibió de los dichos oficiales / él e otras personas por su mandado y qué cantidad / hizo prestar a otras personas de la hazienda de / su Magestad e si lo hizo boluer e restituir a la ha / zienda de su Magestad. Yten declare qué requirimientos, jus / tificaciones y deligencias hizo el dicho licenciado Vaca / de Castro con don Diego de Almagro el Mozo y con las per / sonas que con él andaban en su favor para que se / reduxesen al servicio de su Magestad y se escusase el / ronpimiento de guerra. Yten declare si es verdad / que al tiempo que se uvo de dar la vatalla al 
dicho don Diego / de Almagro y estando para romper el dicho licenciado / se apartó de su gente y sacó consigo quarenta ca / balleros escogidos poco más o menos de los que es / taban de parte de su Magestad y se puso detrás de un cerro //

/ 13 r. / con ellos para guarda de su persona e que aunque se a / grabavan mucho la gente que estaua de parte de su Magestad / de les sacar aquellos caualleros escogidos en tal tiempo / e le dixeron que ponía en gran peligro la causa de / su Magestad no los quiso dexar allí antes los sacó to / davía y que por ello estubo en gran peligro de ser / desbaratada y perdida la gente y ejército de su Magestad / declare particularmente lo que cerca desto pasa. / Yten declare si es verdad que el dicho licenciado Baca / de Castro inbió a cabar en las minas de oro y pla / ta gran número de los yndios ansí de los que él tenía / puesto en su caveza como de otros muchos es / pecialmente a las minas de oro que son en la pro / bincia de Calabaya que están cinquenta leguas de / la ciudad del Cuzco poco más o menos los quales / yndios envió a las dichas minas para que sacasen / oro y plata para el dicho licenciado Vaca de Castro, / declare qué tanto número de yndios envió a las / dichas minas y a qué minas y qué tanto tiempo tubo / a los dichos yndios cavando y trauajando en ellas y / qué tanto número de yndios se murieron en las dichas / minas de los que el dicho licenciado Vaca de Castro hizo / yr a ellas e declare qué personas e criados inbió / con los dichos yndios a las dichas minas para hazer / trauajar a los dichos yndios en ellas e recibir lo / que dellas procediese e cómo se llamaban y a dónde / están las tales personas. Yten declare qué tanta can / tidad de oro y plata ubo el dicho licenciado de lo / que los dichos yndios sacaron de las dichas minas si fue / ron en número de cien mil castellanos o más o qué / tanto fue. Yten declare si los dichos yndios que an / si hizo yr el dicho licenciado a las dichas minas si fue / ron de su voluntad a ellas o forzados o ynduzidos / por parte del dicho licenciado o por otra persona y si / pagó a los dichos indios su trauajo por yr a las dichas //

/ 13 v. / minas e les hizo hazer descuento por ello de lo que / los dichos yndios avían de pagar de tributos. Yten declare si el dicho licenciado entregó a la hazienda de / su Magestad y a sus oficiales el oro y plata que con los / dichos indios hizo sacar de las dichas minas o si lo / manifestó a los oficiales de su Magestad y les pagó / el quinto dello y si lo presentó todo a los dichos ofi / ciales para que lo marcasen y quintasen. Yten declare a qué propósito hizo el dicho licenciado a / brir dos marcas para marcar y contramarcar el / oro y las pidió a los oficiales que las avían de / tener en el arca de tres llaues y tubo el dicho licen / ciado Vaca de Castro las dichas marcas tres o quatro / días sin voluntad de los dichos oficiales en su po / der, declare para qué efeto las tubo e qué hizo / con ellas aquel tiempo, declare si es verdad que / con color de la guerra el dicho licenciado tomó de la / hazienda de su Magestad más de ciento y cinquenta mil / castellanos en oro y plata y piedras e ropa e / otras cosas, declare qué tanta cantidad tomó / e hizo dar a personas y en qué lo gastó, si dio / quenta dello y a qué personas. Yten declare el dicho / licenciado Vaca de Castro si entendió en tasar los / tributos que avían de dar los yndios como le fue / mandado por la instruzión que le fue dada y si lo / dexó de hazer a causa que el dicho licenciado tenía mu / chos repartimientos ocupados en su cabeza. Yten declare qué deligencias hizo en cobrar para su magestad / los bienes confiscados de los rebeldes condena / dos y por qué causa no envió a su Magestad y al su Con / sejo de las Indias las sentencias y confiscaciones he / chas contra los condenados ni enbió la razón dello / para que de los bienes que los condenados tenían en es / tos reynos de España se cobrasen. Yten declare qué / cantidad de oro, plata, piedras y otras cosas enbió // 
/ 14 r. / el dicho licenciado desde las provincias del Perú para Cas / tilla e para otras partes e con qué personas e / qué cantidad envió con Alonso de Villalobos e con / Diego de Aller y con Fray Francisco Martínez fraile dominico / e con Juan de Carranza y con Francisco Bezerra e con / Peranzures, declare la cantidad que con cada uno en / bió y qué les mandó hazer dello y qué cantidad a / enbiado después con Francisco de Ruiloba su criado / y qué cantidad traxo el mismo Vaca de Castro y en qué / navío e donde lo puso e desenbarcó. Yten de / clare si es verdad que el dicho licenciado Vaca de Castro / mandó a los dichos Alonso de Villalobos e Diego / de Aller y Fray Francisco Martínez e Juan de Carran / za y Francisco Bezerra y Peranzures e Francisco / de Ruiloba que no registrasen cosa alguna / del oro y plata, piedras e joyas que traían por / hazienda del dicho Vaca de Castro ni en su cabeza salvo / que lo registrasen por hazienda de las mismas personas que lo traían, declare a qué hefeto e propósito les mandó lo susodicho que no registrasen / por suyo. Yten declare el dicho licenciado Vaca de / Castro si le fue noteficado en Tierra Firme una cé / dula de su Magestad para que volviese o enviase persona / con su poder al Perú a hazer residencia, declare / qué persona envió para lo susodicho a hazer la dicha re / sidencia y dar la quenta de lo que avía tomado de / su Magestad. Yten declare qué oro, plata, piedras e joyas / cobró el dicho licenciado en Panamá y en Tierra Firme / de lo que allí avían dexado las personas que él a / vía enviado e de qué personas lo cobró y en qué can / tidad. Yten declare si es verdad que estando en la / isla de Cuba y el dicho licenciado supo que avía llegado / a la dicha isla el dicho Francisco de Ruiloba su criado / con mucha cantidad de oro, plata, piedras e joyas //

/ 14 v. / de lo que el dicho licenciado Vaca de Castro avía enbia / do, declare qué cantidad traía e qué hizo el dicho Francisco / de Ruiloba y lo que ansí traía e esto declare muy / particularmente e de dónde es natural el dicho Fran / cisco de Ruiloba e cuyo [sic $]^{2}$ hijo. Yten declare si es verdad / que estando en la dicha isla de Cuba el dicho licenciado / quando agora venía tomó allí una carabela y enbió / en ella al reyno de Portugal a [en blanco en el original] ${ }^{3}$ de Arguello su / criado y no consintió que en la dicha carabela binie / se otro pasajero, ni carta alguna más del dicho su / criado y las cartas que el dicho licenciado enviaba, de / clare el dicho licenciado a qué efeto envió al dicho / su criado a Portugal desde la dicha isla e qué oro y / plata, piedras e joyas e otras cosas envió con el / dicho su criado y a dónde se lo mandó poner e puso. / Yten declare si es verdad que después de enviado / el dicho su criado con la dicha carabela viniendo el dicho / licenciado con la flota por la mar hizo al maestre e / piloto de la nao en que venía que se derrotase de / la flota antes de llegar a la isla de los Azores / e que se andobiese vagando por la mar porque se / viniesen sin los otros navíos como se hizo. Yten / si es verdad que después de lo susodicho el dicho / licenciado Vaca de Castro se vino con su nao a la dicha / isla de los Azores y que allí desenbarcó él y sus / criados e oro y plata y hazienda que traía y no / quiso volver a estar en la nao en que venía y la envió, declare cómo se llamaua el navío y el maestre y / piloto y marineros que en él venían e qué oro, plata / joyas e otras cosas envió secretamente en el dicho / nabío y confió del dicho maestre y a dónde y a qué / personas se las mandó entregar y declare qué oro e / plata, piedras e joyas desenbarcó el dicho licenciado / en las yslas de los Azores. Yten declare si es verdad //

\footnotetext{
${ }^{2}$ Se trataría de un error del copista. Leer "e su hijo".

${ }^{3}$ En otras partes, el nombre completo de este criado de Cristóbal Vaca de Castro aparece como sigue: Alonso de Arguello.
} 
/ 15 r. / el dicho licenciado se vino desde las dichas yslas de los / Azores al Reyno de Portugal y en qué puerto de / Portugal desenbarcó y qué cantidad de oro y plata / piedras e joyas e otras cosas metió el dicho licenciado / Vaca de Castro en el Reyno de Portugal y en qué luga / res lo puso y de qué personas lo confió y dónde lo an / mudado después y declare qué oro, plata, piedras / joyas y otras cosas dexó en las dichas yslas de los / Azores y en qué lugar e a qué otras partes a en / biado oro, plata, piedras e joyas y otras cosas. Y / ten declare en qué parte de estos reynos está / puesto en guarda y en poder de qué personas el oro / plata, piedras e joyas y otras cosas que el dicho / licenciado a enviado a estos reynos y él a traído a / ellos y al dicho reyno de Portugal y a otras partes. / Yten declare el dicho licenciado Vaca de Castro si es / verdad que quando después de la vatalla y ronpimiento / fue preso el dicho don Diego de Almagro el Mozo, le tubo / preso el dicho licenciado Vaca de Castro por espacio de / cinco o seis meses sin hazer justicia dél, declare qué fue / la causa que él detuvo tanto tiempo preso pues de o / tros culpados hizo luego justicia a otro día luego siguiente / después de la vatalla y de otros muchos hizo jus / ticia dende a dos o tres días sin lo más detener, de / clare el propósito y fin para qué le tubo tanto tiempo / preso al dicho Almagro sin hazer del justicia pues / su culpa hera manifiesta y hera el principal trai / dor y culpado. Yten declare si es verdad que du / rante el tiempo en que estuvo preso el dicho don Diego / de Almagro con la dilación que ubo en su prisión / trataua el dicho don Diego de Almagro de se soltar / della y tenía puestos cauallos en posta para / se ir con Mango Ynga que andaba alzado y que con la / dilación de la dicha prisión estuvo a punto de se ir //

/ 15 v. / y escapar de la prisión. Yten declare si cree y tiene por / cierto que si el dicho don Diego de Almagro se soltara de / la dicha prisión y se juntara con el dicho Mango Ynga y / con otros muchos españoles que avían quedado de / su opinión como lo trataba que fuera grand ynconbinien / te que se diera caussa a tornar a conquistar la tierra / de nuevo de su Magestad fuera muy desseruido. Yten declare si es verdad que durante todo el tiempo que estubo preso / el dicho don Diego de Almagro gozó a lleno el dicho / licenciado Vaca de Castro los frutos de sus yndios / del dicho don Diego de Almagro y que por esta causa di / lató tanto la prisión del dicho don Diego de Almagro, / declare lo que cerca desto pasa e a qué propósito / y fin dilató la dicha prisión y sentencia, sentenciando / y executando luego a los otros como dicho es. Yten / declare si es verdad que el dicho licenciado tubo preso / después del ronpimiento de la vatalla en la ciudad / del Cuzco a Diego Méndez el qual después del dicho / don Diego de Almagro hera el más principal culpado / en las traiciones y rebeliones contra su Magestad come / tidas. Yten si es verdad que el dicho don Diego Méndez / tenía un repartimiento muy bueno que ren / tava en cada un año más de doze [tachado] mil cas / tellanos y que el dicho licenciado Vaca de Castro dilató / la prisión del dicho Diego Méndez mucho tiempo hasta / que se fue della y que todo el tiempo que ansí le tubo pre / so hasta que se fue e después el dicho licenciado Va / ca de Castro puso en su cabeza los dichos yndios e / cobró e gozó para sí los frutos dellos, declare ansí / mismo si sauía que el dicho Diego Méndez hera cuñado de / Blas de Saabedra escriuano del Consejo Real y que el dicho / Blas de Saabedra habló al dicho licenciado Vaca de Castro / antes que se fuese al Perú e después le escribió rogándole que favoreciese al dicho Diego Méndez, declare la verdad //

/ 16 r. / lo que cerca desto pasa y si es verdad que por respeto / y contemplación del dicho Blas de Saabedra disimuló / y difirió el castigo del dicho Diego Méndez su cuñado has / ta que se fue. Yten declare si es verdad que como el dicho / licenciado Vaca de Castro supo que su Magestad enviaba Vi / sorrey e Audiencia al Perú y que abía hecho las hor / denanzas para que no se encomendasen 
yndios y que / ningún gobernador tuviese encomienda de yndios en / fraude de lo que su Magestad avía mandado por sus / hordenanzas reales después de por él sauidas dio / muchas encomiendas de yndios a muchas e diversas / personas que no avían sido conquistadores de la tierra ni / servido a su Magestad salvo por sus particulares respetos / e intereses por ser sus amigos parientes y criados e / personas de quien esperaba por ello aver yntereses e / favor y por dineros e dádivas que dellos recibió en / gran cantidad, especialmente declare si es verdad que / resciuió de Juan de la Rea en Riobanba una copa de oro / e un plato de plata con cierto diacitrón y que Carranza / criado del dicho Vaca de Castro preguntó al dicho Juan de / la Rea si también daua el dicho plato de plata con el / diacitrón y el dicho Juan de la Rea dixo que no sino la / copa de oro y el diacitrón, declare lo que valía la dicha copa / de oro y lo que sauía e declare si es verdad que / rescivio de Fonseca platero de Pihura una medalla / de oro y dos esmeraldas el dicho licenciado Vaca de Castro / por quel dicho licenciado le dio licencia para comprar los / yndios de Carrión el ciego vezino de San Miguel, declare lo / que valía la dicha medalla de oro y esmeraldas. Yten de / clare si es verdad que reciuió de Vergara un cauallo / morzillo rabicano en Xauxa declare la causa por / qué se lo dio y él lo resciuió. Yten si es verdad que ansí / mismo el dicho licenciado Vaca de Castro rescibió del licenciado / de la Gama un cauallo y una esmeralda y que la dicha esmeralda //

/ 16 v. / se la bolbió el dicho licenciado Vaca de Castro para que / pareciese que se la volvía y que después la tornó a / recibir de Pedro de Heredia con quien se la tornó a enviar / el dicho licenciado de la Gama porque le diese licencia pa / ra aver y comprar los yndios de Tunbez y que dio / por ellos al dicho licenciado Vaca de Castro tres mil e / ochocientos pesos de oro y la dicha esmeralda por los / dichos indios, declare la verdad de lo que sobre esto / pasa y cómo pasó. Yten declare si es verdad el dicho / licenciado Vaca de Castro dio a Diego de Aller los yndios / de Cayas que heran de Vernal en San Miguel y le lleuó / el dicho licenciado Vaca de Castro por se los dar dos mil / pesos de oro, declare lo que sobre esto pasa e como / fue e pasó. Yten declare si es verdad que el dicho / licenciado Vaca de Castro hizo a Porcel que le vendiese / una esmeralda en quinientos pesos la qual el dicho / Porcel la avía conpado de Bartolomé Pérez de Piura en / novecientos pesos, declare lo que cerca desto pasa. / Yten si es verdad quel dicho licenciado Vaca de Castro / consintió lleuar a Peranzures trecientos pesos de oro / a un Santiago porque no le lleuase preso lo qual / supo y consintió el dicho licenciado Vaca de Castro. Y / ten declare si es verdad que el dicho licenciado Vaca de / Castro ynbió a [en blanco en el original] de Orellana a ranchear los yndios / de Ysasaga en el Collado y les sacó valor de ocho mil / pesos, declare la verdad de lo que sobre esto pasa / y qué es la cantidad de lo que se hubo por el dicho Ore / llana el dicho rancho. Yten declare si es verdad que / dicho licenciado Vaca de Castro inbió a Heredia a / la ciudad de Lima y a otras partes del Perú a que / pidiese e recogiese para él vaxilla de plata de / los españoles y que desta manera rescibió de Cristóval / de Burgos una fuente de plata e de Ribera el viejo / e de Palomino y el Solano y de otras personas //

/ 17 r. / otras muchas piezas de plata de que hizo vaxilla / el dicho licenciado Vaca de Castro, declare qué piezas de / plata e de oro rescibió el dicho licenciado Vaca de / Castro por sí y por otras interpósitas personas e / qué piezas heran e de qué peso y valor e de qué / personas lo rescivió. Yten declare si es verdad que / rescibió mil e trezientos pesos de oro de Diego de Mora / o de Mera e que fue la causa porque los rescibió. / Yten declare si es verdad que el dicho licenciado Vaca / de Castro dio en encomienda al capitán Cáceres / unos yndios que avían sido de un Suárez y envió por / teniente a Arequipa al dicho capitán Cáceres e / por le dar la dicha encomienda de yndios y por le / 
ynbiar por teniente lleuó al dicho capitán Cáceres / mil castellanos de oro, diga lo que cerca de esto saue e / pasa. Yten declare qué otras cantidades de pesos de / oro y piedras y joyas de oro e otras cosas a reciuido / e de qué personas por les dar encomiendas de yndios / y por les dar oficios de sus tenientes de gobernadores / e por los inbiar a conquistar y por otros oficios / declárelo, particularmente las personas de quien / lo recibió y la cantidad que cada uno lleuó. Yten / declare qué otras cantidades de oro, plata, piedras / y cauallos y otras cosas recibió de personas que / fueron culpados en los levantamientos pasados / y en otros delitos por disimular con ellos por sus / culpas y no los castigar y porque no los privase de / los yndios que tenían declare las personas a / quien lo llevó y las cantidades que les lleuó por lo / susodicho. Yten declare si es verdad que de lo per / teneciente a su Magestad y de lo que le hera debido el dicho / licenciado Vaca de Castro rescivió para sí más de / ciento y cinquenta mil castellanos de oro declare lo que cerca //

/ 17 v. / desto pasa. Yten declare si es verdad que como el dicho / licenciado Vaca de Castro supo de las hordenanzas que / su Magestad mandó hazer para que no oviese encomiendas de / yndios de nuevo e supo que yba probeido vissorey e / audiencias para las executar antes que entrase el / dicho vissorey e audiencia en el Perú, el dicho licenciado / Vaca de Castro hizo juntar los pueblos de la dicha pro / vincia del Perú de los españoles y los persuadió e / aconsejó que no consintiesen ni obedeciesen las dichas / hordenanzas y que por causa e consejo del dicho licenciado / Vaca de Castro se levantó la tierra del Perú y se causa / ron los desacatos que en ella an subcedido en el Perú / contra el Vissorey y Audiencia Real y todos los otros / daños que se an ofrecido en la dicha tierra en / deseruicio de su Magestad y daño de su real patrimonio / en más cantidad de un millón de ducados. Yten / declare si es verdad que el dicho licenciado Vaca de / Castro por ser más aprovechado de los repartimientos / de yndios de los condenados y de otros e de las ha / ziendas de su Magestad e de particulares y porque su Magestad / no fuese informado de sus culpas y excesos para / lo proveer e remediar el dicho licenciado tubo mucho / tiempo detenidos los nabíos en los puertos sin los de / jar nabegar de que su Magestad fue muy desservido e / los españoles mercaderes, maestros, pilotos y mari / neros muy danificados y que por ello se siguió a / su Magestad de daño e interés e más de cien mil castella / nos de oro, declare la verdad de lo que cerca desto pasó. / Yten delare si es verdad que como ombre culpado / en las tomas que abía hecho de la hazienda de su / Magestad e de lo que abía recibido de particulares y en / otros delitos y culpas el dicho licenciado Vaca de Castro / teniéndose de la quenta que dello se le avía de pedir //

/ 18 r. / enviaba a dar dádivas de presentes de oro y otras / cosas a los del Consejo de las Indias y a sus mujeres e / a otras personas favorecidas de quien pudiese auer / favor para se hebadir de sus culpas y enbiaua colores / para que diesen para todas las culpas que contra él / avía y que ansí mismo enviaba poderes para re / cusar a los del Consejo Real y Oidores de Chancillería de / quien no estaua seguro que le avían de favorecer por / que rehiziesen contra él justicia, declare la verdad / de lo que cerca desto pasa. En la villa de Valladolid / a quatro días del mes de julio de mil e quinientos e / quarenta e cinco años, los señores del Consejo de las / Yndias de sus magestades dixieron que cometían e cometie / ron al señor licenciado Salmerón del dicho Consejo que / por ante mí Martín de Ramoyn escriuano de sus Magestades / e Oficial del secretario Juan de Sámano tomé el / juramento dicho y confisión del licenciado Vaca de / Castro estante en esta Corte sobre la horden y manera / que tubo en la gobernación de las provincias del Perú / durante el tiempo que las gobernó y en la administración / de la justicia y en el repartimiento y encomienda de / los yndios dellas y en su buen tratamiento instru / ción y conversión y en el buen recaudo y fedelidad / de la 
hazienda de su Magestad y castigo de los culpados / y en las otras cosas tocantes y concernientes a su / cargo y oficio y ansímismo de lo que pasa e hizo / cerca de lo contenido en un memorial e artículos de / preguntas que me fue entregado y el dicho señor licen / ciado viere que se le deue preguntar y sauer el qual / dixo que estaua presto de cumplir lo que por los dichos / señores le hera cometidos y encomendado e después / de lo susodicho en la dicha villa de Valladolid a quatro días / del mes de julio de mil e quinientos e quarenta //

/ 18 v. / y cinco años por mandado de los dichos señores del Consejo de / las Yndias de su Magestad el dicho señor licenciado Salmerón del / dicho Consejo en presencia de mí el dicho Martín de Ramoyn escribano / de su Magestad y oficial del dicho secretario Sámano tomó e reciuió / juramento en forma de vida de derecho del dicho licenciado / Cristóval Vaca de Castro para que so cargo del, diga y declare / lo que le fuere preguntado por el dicho señor licenciado cerca de / las cosas que le serán preguntadas el qual dicho licenciado dixo / sí juro e amén y prometió de dezir verdad, e luego el dicho / licenciado Vaca de Castro dixo que él no hera obligado a / jurar ni declarar sobre lo que no obiese información bas / tante y sin ver las probanzas e informaciones para / que le constase si auía alguna que le obligase a juramento / ni tanpoco sobre aquellas cosas que son artículos de / residencia por estar pendientes en el Perú ansí por la re / sidencia que le fue tomada por el Virrey e oydores como / por la que se mandó tomar por la provisión del Príncipe nuestro / señor, despachada por los señores del Consejo Real de las / Yndias ni tampoco sobre la que está pendiente ante Agustín / de Zárate contador por probissión de su alteza y por esto / que pedía que ante todas cosas se le diese el traslado / de las informaciones aunque fuese sin los nombres / de los testigos y que si otra cosa se manda y provee que / no le pare perjuicio lo que dixere e depusiere e luego / el dicho señor licenciado Salmerón dixo que los señores / del Consejo tienen probeído y mandado que el dicho licen / ciado Vaca de Castro haga la declaración sobre lo que a / jurado e que por tanto a de cumplir lo que el Consejo man / da y que tiempo abrá para todo lo demás que conviniere / a su derecho cerca de lo que tiene apuntado y el dicho / licenciado Vaca de Castro dixo que sola dicha protestación res / pondería y siendo preguntado por el tenor de un memorial / e interrogatorio dixo e depuso lo siguiente. Al primero //

/ 19 r. / capítulo y pregunta dixo que es verdad lo en el contenido / y que él resciuió y le fueron entregadas las provisiones, cédu / las y despachos que están asentados en el memorial de un libro / de la provincia del Perú que le fue mostrado, que está firma / do de su nombre y que la firma del es suya e que la hizo. / A la segunda pregunta dixo que no pasa ansí como la / pregunta lo dize porque él nunca hizo ni mandó hazer sello / ni tubo para que, que lo que pasa es que el doctor Robles oy / dor que fue de la audiencia de Panamá hizo un sello real / con que despachaua y sellaua y al tiempo que este que declara / le tomó residencia por cédula y provisión tomó este que / depone aquel sello y lo puso en poder del escrivano de la / causa y porque para despachar con sello en la dicha audien / cia por los tres oydores que ya auía dexó allí resciuido / con toda solepnidad el sello real que de acá lleuó para la / dicha audiencia y hizo cargo desto con otras cosas al dicho / dotor Robles y porque no pudo detenerse a fenescer la re / sidencia porque cesauan ya las brisas, se partió y quedó / cometida la dicha residencia a los oydores Villalobos y / Paz para que recibiesen las probanzas que el dicho dotor / Robles hiziese y verificasen ciertas cosas y lo enviasen / al Consejo y lleuó éste que depone consigo a gran guarda / el sello que tenía el dicho doctor Robles para lo enviar a / recaudo a estos reinos y traerlo quando viniese porque no o / saua confiarlo de nadie y que después arribando a la gober / nación de Venalcázar por mala navegación halló que estauan / en diferencia los 
gobernadores Andagoya y Benalcázar porque / aunque el dicho Venalcázar tenía detenido al dicho An / dagoya avía su hijo y muchos vizcaínos y gente de su / parte que subían ya quando este que declara llegó contra el / dicho Benalcázar y que visto el desseruicio que se recreciera / a su Magestad si entre ellos oviera ronpimiento puso mano en el / remedio y mandó que presentasen ante este que declara / los títulos que tenían para hacerlo que conviniese al / sosiego dellos y seruicio de su Magestad y porque el dicho Benalcázar / estaua en la posesión y se temía el dicho Benalcázar que perdería //

/ 19 v. / por aventura su posesión y gobernación trataua en ausencia deste / que declara que no tenía poder para lo que mandaua y entendido esto / porque no fuese causa de quedar aquella alteración ansí y / que no obiese entre ellos ronpimiento se ayudó de auer sido este / que declara residente de la dicha audiencia de Panamá y para / más sujetar los hizo en su presencia que sacaua unos pape / les de un cofre y entre ellos sacó el dicho sello de industria / para que viéndole sin tratar demás concibiesen que podía / despachar y proveer y se subjetasen y ansí fue que no habla / ron más en lo que tocaua al poder por donde este que depone / pudo pacificar aquella alteración y que quedase Benalcá / zar en la posesión como le pertenecía y el Andagoya se sa / liese de la tierra e se presentase en el audiencia de Panamá / por cierta deuda que debía a su Magestad y ansí se hizo e que / otra vez en el Perú porque por muchos se quería poner de / fecto en la provisión que lleuaua de gobernador por no ser / firmada de su Magestad sino del Reverendísimo Señor Cardenal de Sevilla / gobernador que a la sazón hera de las Yndias y se dezía que / por esto se venían menos gentes y se allegaban a / este que declara por más fortificar su poder y quieto / sosteniesen y viniesen a se juntar con él y fuese mejor / obedescido de yndustria delante de algunos que estauan / allí ansí de parte de don Diego de Almagro como de la deste / que declara hizo otra aparencia y demostración del dicho / sello sin usar dello en despacho ni otra cosa alguna y aun / que algunos desde que le vieron llegaron a besar el dicho sello / e que todas estas cosas heran necesarias para con mejor e / feto hacer lo que convenía al seruicio de su Magestad porque esto / y mucho más auía menester este que declara hallando a / quella tierra tan ocupada por don Diego de Almagro y sus se / cazes y estando este que declara tan solo de gente para que / mejor se juntasen y animasen y sirviesen y que ansí lo / tiene escripto a su Magestad y Consejo en sustancia lo que dicho tiene / y que antes fue merced de Dios ofresciese de auer aquel sello / e yr en su poder para que se ofreciesen los buenos efetos suso / dichos y que esto es lo que passa y no otra cosa alguna y que él //

/ 20 r. / no usó del dicho sello en cosa alguna e después de lo susodicho pa / sado el recuentro que se tubo con el dicho don Diego de Almagro ante / escribano y testigos, este que declara hizo quebrar por medio el dicho / sello y que lo tuviese en su poder Francisco Pérez escriuano y lo / truxese a España como lo hazía y que el virrey Blasco Núñez / Vela lo detuvo y ocupó sus escripturas y cree que también el dicho / sello quebrado que estaua allí y que desto no bien entendidos / los que le tomaron la residencia le dieron cargo a lo que este / que depone se acuerda que no se afirma. A la tercera pregunta / dixo que quando este que declara fue aquella tierra y / entró en la dicha provincia del Perú se cargauan los yndios sin / número de quantos sino los que cada uno quería e sin pagarles / cosa alguna por ello y desta manera pasaua en la tierra / después que se descubrió e ganó, e que quando este que de / clara entró en la dicha provincia la halló toda ocupada e al / terada, muerto el gobernador y las gobernaciones e justicias e / pueblos por don Diego de Almagro y tomados los quintos rea / les y robados los cauallos y armas de la tierra e muertas / muchas personas por sus manos en no obedecer las probi / ciones que llebaua y tener 
muchas gentes de guerra pa / ra se defender fue forzado para reducir aquellos / reynos al seruicio de su Magestad proveer las cosas que heran / necesarias para este hefecto que fue una cosa muy grande / y de mucho trauajo por no auer en toda la tierra cauallos, ni / armas, ni a un hierro de qué las hazer, ni pólbora, ni las / otras cosas necesarias, ni gente acaudillada e por esto / este que declara comenzó a juntar la gente que pudo y des / pués que tubo alguna junta y abiendo ya por sus men / sajeros reduzido algunos pueblos vaxó de Quito y / comenzó a entender en el exercicio de la guerra hasta la / fenecer por la vitoria que ubo de don Diego y que en este / tiempo fue forzado disimular con la gente de guerra. El / cargar algunos yndios y aún hablar a los caciques para / que los diesen de su voluntad e ansí se hazía porque de otra / manera no se podía en ninguna forma caminar la dicha / gente, ni hazerse el efeto que al servicio de su Magestad convenía //

/ $20 \mathrm{v}$. / e que para las armas e cosas deste que declara se tomauan / algunos yndios que heran menester, puesto que siempre tubo / azémilas en que lleuaba su hazienda y que sin estos yndios / de carga tanpoco él podía caminar ni hazer lo que al servicio de / su Magestad convenía por no auer bestias que comprar en la dicha / tierra para esto y questos yndios que se lleuauan con algunas / cargas deste que declara yvan de su voluntad y que sienpre / este que declara mandó a su criado que tenía cargo de sus / cosas y hazienda que les diese por ello alguna gratificación / y que antes en este tiempo sirbió todo lo posible este que declara en que los yndios no recibiesen daño y discurría cavalgando / por todo el camino por donde yban cargados y quitaua que / no fuesen en cadenas ni en cordeles como de antes ni obiese cepos / ni recibiesen otro mal tratamiento y que no saue que se muriese / yndio en todo este tiempo por razón del mal trauajo de las cargas / ni lo cree porque este que depone lo supiera y antes por / su persona y por otros muchos criados suyos se andauan / mirando todos los dichos yndios para que si alguno no estu / biese bueno lo soltasen y se fuese luego y que cierto día que / pasaron por cierta parte caliente aunque de noche e / de mañana por no auer agua y que no recibiesen detrimento / se adelantó este que declara a un tanbo donde a / vía agua y pepinos y fruta y probeyó de personas, criados / suyos que con barriles grandes de agua y con cestos de / pepinos fuesen corriendo a los yndios que venían de / trás y les socorriesen por manera que no muriese ninguno / de sed y ansí se hizo y que por la priesa que mandó dar / en ello e yr corriendo a ello sus criados le mataron este / día dos cauallos y que pasada la guerra y pacífica / la tierra luego este que declara hizo ordenanzas en / execución de un capítulo de su ynstrución y en reme / dio desto por tal vía y manera que remedió las cargas, / cadenas e colleras y cepos y lo que rancheaban a los yndios / y escusó que no fuesen rancheados ni anduviesen / valdíos por la tierra de que los yndios recibieron gran / dísima libertad, contentamiento y probecho por tal //

/ 21 r. / manera que los dichos yndios dezían que este que declara hera / su Guaynocaba [sic] y los caminos reales y pueblos que estauan / despoblados desos que la tierra se ganó se poblauan y la tie / rra se sembraba toda de manera que el tiempo que este que / declara estuvo en el Cuzco se hizieron más de tres mil / casas de yndios de los que andauan alterados y se recogieron / a poblar allí y así subcedía por la tierra adelante e / como veyan el buen tratamiento que este que declara les / hazía y como no resciuía dellos oro ni plata los capitanes / que andaban alzados y mataban españoles se venían de paz / y subcedió entre ellos la libertad y paz que tiene dicho por tal vía / que quando este que declara se partió del Cuzco para la ciudad / de los Reyes a proveer el recibimiento para quando viniese / el que abía de yr por birrey llorauan los yndios y hazían ta / quis de lloro y tristeza porque se partía este que declara del Cuzco por / entender que hera para venirse a España y que esto es lo que / pasa en este artículo. A la quarta pregunta y artículo dixo / que quando este que declara llegó a 
la dicha probincia del Perú / a la ciudad de Quito halló yndios vacos que fueron los / siguientes, los yndios del marqués don Francisco Pizarro porque aunque se dezía que los avía dado a sus hijos / este que declara los tubo por vacos por su muerte por la cédula / y probisión que ay de su Magestad en aquella probincia que yna / vilita para aver los yndios del padre a los hijos que no / fueren de legítimo matrimonio, nascidos y procreados y que es / tos yndios del marqués estauan en dos provincias, unos en la / probincia de la sierra de Guamanga avaxo hazia la parte / de los Reyes, Truxillo y San Miguel y otros en la probincia del / Cuzco y Collao. Yten los yndios de Diego Rodríguez Limosín / y los de Para y estando en Quito vacaron los yndios de Juan de Val / divieso y del Obispo en la dicha probincia del Cuzco y no se a / cuerda si a la sazón abía otro repartimiento vaco que le pa / reze que avía otro de que al presente no tiene memoria y que es / tos repartimientos que tiene dicho los puso todos en su cabeza / de este que declara ecepto los del dicho Para difunto que / dio a un Cristóval Rodríguez porque avía servido de los primeros //

/ 21 v. / y le auía quitado el dicho marqués unos yndios por auer / seguido la parte de Almagro y dádolos a otro con quien el dicho Cristó / val Rodríguez traya pleito y por gratificar a este sus servicios / e quitar el pleito se los dio y que los otros todos los pusso / en su cabeza deste que declara por conbenir ansí para que toda / la gente de guerra entendiese que heran para repartillos a los / que bien sirbiesen en reduzir aquellos reynos al seruicio de / su Magestad y con esto se animasen a lo hazer y cumplir y que no los / puso a cargo ni en cabeza de los oficiales de su Magestad porque / si ansí lo hiziera la gente toda entendiera y sospechara que hera / para su Magestad y no para se los repartir porque para todo esto / ay buen entendimiento en aquella tierra que ya se dezía en / tre ellos que yva este que declara para acrecentar el patri / monio real con los yndios y otras cosas y que esto que hizo / este que declara fue una cosa muy provechosa y necesaria / para el buen efeto de la guerra y que ansí lo escriuió a su / Magestad luego por sus cartas y que de todos estos indios vacos / antes del ronpimiento que se ubo con don Diego no se cobró / destos yndios cosa alguna que viniese a poder deste que / declara ni de otra persona en su nombre y que después del / dicho rencuentro y vatalla yendo este que declara al Cuzco / con toda la gente de guerra probeyó que se pidiese a ciertas / personas lo que destos indios avían llevado en tiempo / del dicho don Diego sin título y ansí se les pusieron demandas / ante la justicia hordinaria y acudieron a este que declara a / decir que bien entendían que lo avían lleuado sin título más que / por no sauer quanto se obiesen bien con ellos y se concertasen cerca / dello sin usar con ellos de rigor y mirando que estos tuvieron / alguna ynorancia pensando que el don Diego hera parte para / en su tiempo hazer aquello y por otros respetos justo que / concurrían en especial de pacificación habló éste que declara al / que lo pedía que se concretase con las dichas personas y ansí se hizo / que por ante la justicia se concertaron y se ubo de todas estos / fasta dos mil y ocho cientos o tres mil y ochocientos pesos de / oro que no se acuerda de presente la cantidad para lo dezir de / cierto, y puesto questos tributos pretendía este que declara per //

/ 22 r. / tenecerle por auer podido poner indios en su cabeza y aver / hecho hasta allí gastos necesarios a la guerra e tiempo en servicio / de su Magestad, que estos pesos que destos se ovieron se pusieron en el / libro deste que declara donde estaua hecho cargo de lo que auía a / vido de la hazienda de su Magestad [sic] ${ }^{4}$ de su Magestad fasta que sauido / por su Magestad proveyese lo que fuese seruido los quales se gasta / ron por mano deste que declara en seruicio de su Magestad en el

\footnotetext{
${ }^{4}$ Repetido en el original.
} 
tien / po de la guerra pagando las deudas que en ella se avían hecho / desto e de lo que cobró demás de lo susodicho de los indios / que estaban vacos del marqués en la dicha provincia del Cuzco / y Collao porque los otros de la otra provincia se dieron a / los hijos del marqués para su sustentación sin que quedase / blanca ni otra cosa dellos en poder deste que declara ni de / otra persona alguna por él ni en su nombre segund quedara / por su quenta y que ansímismo se gastaron suma de pesos de / oro en desazer y derramar la gente de guerra que vino con este / que declara al Cuzco donde casi se le amotinan por paga / y vino a tanto la alteración que ubo entre la dicha gente que / se pensó que mataran a este que declara e obiera otra al / teración en especial estando como a la sazón estaua bibo el / dicho don Diego de Almagro y entre otras mañas que este que / declara tubo en deshacer lo susodicho y pacificarlo fue en / viar a descubrimientos capitanes que fueron Diego de Rojas / y Felipe Gutierrez que fueron hazia el norte de la parte de la / cordillera nevada que va para el estrecho y descubrieron una / gran provincia y de mucha población de indios de que se espe / raua que verna gran probecho a su Magestad y Juan Porcel hazia los / Bracamoros donde pobló un pueblo y a Juan Pérez de Gue /bara a la parte de Rupa Rupa y laguna grande donde se cree / que naçe el principal brazo del Río de la Plata el qual descu / brió mucha tierra y servicio a este que declara que avía hallado / un pueblo de tres mil casas que hera cosa de ver la policía / que tenían en su limpieza de calles y casa y que a estos capitanes / y a Alonso de Monrroy a quien dio este que declara ciento / y treinta onbres para correr a Pedro de Valdibia a la parte de / Chili donde poblava porque tenía tan poca gente y por ser //

/ 22 v. / tan rica provincia aquella procuró como le fuesen por / mar navíos con herraje y sillas y armas y otras cosas nece / sarias para su conquista y población obligó a que gastasen / cierta suma en cantidad repartiéndola entre los soldados que este / que declara les nombrase y este que declara les nombraba / aquellos que heran más peligrosos para el sosiego y escu / sar la dicha alteración y este que depone por otra parte gastó / alguna suma de la que dicho tiene que cobró de los dichos yndios / vacos y de los del marqués que este que declara puso en su / cabeza y pretendía pertenecerle por la razón susodicha e / con esto y otros oficios que les dio en aquelles conquistas / se deshizo lo susodicho y obo sosiego en todo y con probeer / a los vezinos de otras cosas que dirá en su tiempo y que lo / que se cobró de los indios del dicho marqués de la dicha provincia / del Cuzco y Collao fueron doze o treze mil castellanos los / quales se cobraron y aunque pretendía pertenecerle como / dicho se los puso por de su Magestad hasta que sauido proveyese / y este que declara se hizo cargo dellos y dará quenta dellos / con lo demás y que destos yndios ni de los demás que tiene / dichos que estauan en su cabeza no se acuerda ni saue que se / aya cobrado más de las cantidades que arriba tiene dicha / porque luego se secretaron los dichos yndios para que dellos / se cobrase lo que el marqués debía a su Magestad y después / por una cédula y provisión emanada del dicho Real Consejo / de Yndias en que se proveyó que dando los hijos del marqués / fianzas de que se pagaría lo que pareciese dever el marqués / su padre a su Magestad se les volviesen sus bienes y cosas que les / oviesen secrestado se alzó el secresto porque Gonzalo Pizarro / se obligó conforme a la dicha provisión de lo hazer y cumplir e / que estos dichos yndios estuvieron en cabeza deste que declara por / proveerse después que llegó al Cuzco algunos días por dos res / petos, el uno porque si de luego comenzara este que declara / a repartirlos cada uno de los que avían servido les pa / reciera por lo menos que merecía un repartimiento entero e así / pudo mejor hazerles contentamiento con la dilación y por en / tenderse la falta que avía en los pueblos para refor // 
/ 23 r. / mar primero e ynchir la falta que avía en la vezindad de / pocos indios y pocos vecinos para la sustentación del pueblo / e ansí reformó primero a las Charcas donde por estar fron / tero de los Chiriguanaes que comen carne umana hera necesa / rio crecer en vecindad y en yndios para que los vezinos / pudiesen tener en su casa huéspedes estantes para a / yudar a la defensa y después reformó otros pueblos / y proveyó de nuevo a los que no tenían vezindad y merecían yn / dios y porque para esto nombró quatro personas uno de los / descubridores y conquistadores primeros, otro de los que vinie / ron a Caxamalca quando entró Almagro y vino el adelantado / don Pedro de Albarado, otro que vino al tiempo de lo de Xauxa / y defensa del Cuzco en levantamiento de la tierra e otro que / vino después para que con juramento hiziese memoria de las / personas que abían seruido y merecían yndios poniéndolos por / sus grados y entre estos repartió los que entonces auía vacos / y vacaron después y que se pudo tardar en todo aquesto / desde que este que declara entró en el Cuzco que fue a onze de / noviembre de quinientos y quarenta e dos hasta el mes de henero en / que se acabaron de probeer todos a lo que este que declara / al presente se acuerda como quiera que al presente no tiene / memoria tan particular dello e que otras cosas no se cobraron / de los dichos yndios eceto de los que vacaron por el dicho Diego / Rodríguez que se cobraron ciento y treinta ovejas que se / gastaron en casa deste que depone con la gente de guerra que a / llí comía y que la persona que cobró los dichos dos mil e / ochocientos o tres mil y ochocientos pesos fue Gaspar Gil vezino / del Cuzco con poder deste que depone y que los otros treze mil / pesos que se ovieron y cobraron de los otros yndios que a / rriba tiene dichos vinieron a poder deste que depone y de Anto / nio de Quiñones en su nonbre y que parte dellos cobró el dicho / Gaspar Gil que benefició de cierta cosa y que después del ron / pimiento con don Diego de Almagro y probeydos los susodichos / puso este que depone en su cabeza ciertos yndios que fueron / de don Diego de Almagro que estauan dados y los poseya el //

/ 23 v. / capitán Pero Alvarez Holguín como vacos por los delitos come / tidos por el dicho don Diego e otros que avían sido de Diego Méndez / y vacaron por muerte del capitán Castro a quien se avían / dado por vacos por el delito que avía cometido el / Diego Méndez de averse hallado en la ciudad de los Reyes / con el dicho don Diego quando mataron al marqués e quando co / metieron los otros delitos y otros que vacaron por muerte de / Pedro de Oñate y que el número destos yndios que puso en / su cabeza este que depone devieron ser hasta cinco mil yn / dios poco más o menos porque de los yndios que vacaron / por el dicho Pero Alvarez dio este que depone a tres personas / yndios e de los del dicho capitán Castro a otra y algunos de / los de Oñate de manera que sacados los que dio a estos podrían / quedar los que quedaron en su cabeza hasta los dichos cinco mil yn / dios e que estos yndios que dicho tiene que repartió fue bre / bemente después que este que declara llegó al Cuzco de / manera queste que depone no gozó dellos cosa alguna y que / los dichos cinco mil yndios que a dicho los gozó este que de / pone por espacio de un año e que demás desto puso este / que depone otros mil yndios en su cabeza en la probincia / de la ciudad de los Reyes que avía poseído el dicho marqués / que se dizen los yndios de Xauxa e la Barranca y que los / dichos yndios puso en su cabeza para sustentar su oficio e / cargo de gobernación porque sin ellos no podía con los cinco / mil ducados de su salario ni con veinte mil en especial en el / tiempo que este que depone andubo y estubo en la tierra que / fue todo de guerra donde fue menester hazer muchos gastos / en mesa y casa y aconpañamiento en especial tratándose / segund se dezía de algunas personas de le matar para todo / lo qual fue menester tener mucha conpañía y guarda como / dicho tiene y gasto y ansimismo porque mexor se guardase / lo que proveyó de que la tierra se anduviese por ciertos ca / minos reales señalados en las hordenanzas que sobresto hizo e / ninguno anduviese 
baldío por la tierra comiendo sobre los yn / dios ni rancheándolos convino meter en su conpañía y casa //

/ 24 r. / personas principales que no tenían yndios que de necesidad a / vían de andar comiendo por la tierra e con meter en su casa gente / principal como dicho es cesó todo lo susodicho y no hubo efeto / las muchas vezes que se trató de matar a este que depone e / para remedio destas cosas como dicho es fue necesario e con / vino poner los dichos yndios en su cabeza porque de otra / manera subcediendo qualquiera cosa de las susodichas la / tierra se tornaua a perder como de antes y su Magestad las ren / tas e tributos del medio tiempo sin los gastos de recobrar / lo y que con todo esto teniendo el dicho marqués quarenta mil yndios y el adelantado Almagro mucha copia en tiempo que por / la mucha abundancia de oro y plata que abía pudieran es al / sar parte este que declara aunque el tiempo hera aparejado / para mucha más costa y gasto se moderó a tener los dichos / seis mil yndios poco más o menos en su cabeza y si con menos / pudiera sustentar el cargo menos pudiera y que los dichos yndios / pudo poner en su cabeza y lleuar los tributos y aprobechamien / tos dellos por la costunbre uni formi generali que a auido / en las Yndias después que se descubrieron que los gobernado / res an puesto yndios en sus cabezas a su discribción y lo mis / mo se auía hecho en las dichas probincias del Perú por los gober / nadores pasados y el mismo oficio con las mismas prehe / minencias y facultades fue dado a este que declara y no / le fue hecha proybición en contrario y porque por cédula de / su Magestad dada a la dicha probincia del Perú y gobernador se dis / ponía que el gobernador podía tener yndios en cada lugar pa / ra tener de comer en cada pueblo por manera que así por / la necesidad de los gastos y sustentación del oficio que demás / de los que dicho tiene se recrezen otros muchos en ayuda a hazer / obras y reparos en yglesias y en salarios de criados que es / una cosa de mucha suma y por la dicha costunbre y por la dicha / concesión los pudo poner en su cabeza y lleuar los tributos como / dicho es y que lo que de los dichos yndios que declarado tiene ubo / no puede este declarante declararlo con certidunbre más de que / de los yndios de la probincia de los Reyes que dicho tiene al parezer / deste que depone pudo auer fasta dos mil pesos de buen oro //

/ 24 v. / en todo el tiempo que los tubo y algund mayz para el serviçio / hordinario de la casa que tenía en la ciudad de los Reyes que / hera necesario tenerla para que oviese allí quien mirase las / cosas cumplideras al servicio de su Magestad y recoger algunos ca / ualleros pobres que venían a la tierra que es cosa que cumple / al servicio de su Magestad que lo haga el que gobierna porque desta / manera todos se llegan a seruir al que gobierna e de otra manera / aparrichionanse [sic $]^{5}$ en otras partes de donde subceden deshor / denes como se hizo en tiempo del marqués e de don Diego de Almagro / que por no recoger el marqués los que venían y juntarse con don / Diego tubo conpañía para hazer lo que subcedió y que de los otros / yndios que estauan en la dicha probincia del Cuzco y Collao en cabeza / deste que depone se acuerda que yendo ellos a las minas de su vo / luntad les sacaron y dieron de tributo a este que depone veynte / y ocho mil pesos los quales vinieron a poder de Gerónimo de la Serna / en nonbre deste que declara y que sacados destos la parte que viene / a su Magestad y al Comendador mayor y la merma y las costas / de herramientas y bastimentos y salarios de los que andan / probeyendo lo necesario y del clérigo que está yndustriando los / yndios quedan en muy poca quantía de lo qual al presente no / sabría dar este que depone entera relación y que estos son los / yndios que puso en su cabeza y lo que dellos ubo y no otra cosa / alguna ecepto

\footnotetext{
${ }^{5}$ Leer "aprovechanse".
} 
algunas obejas y cosas de comida que este que / declara no saue ni se acuerda. A la quinta pregunta y artículo dixo que la niega como en ella se contiene porque no pasa co / mo lo dize y que consta claro porque segund la costa queste / que depone tenía en su casa y los pocos yndios y aprobecha / mientos para tan gran gasto no podía sobrar que tratar antes / se conpraba muchas vezes cosas para el dicho gasto y que si el / dicho Gaspar Gil algunas cosas destas hazía sería cosa parti / cular suya propia y del probecho que tenía de sus yndios y / que bien pudo ser que alguna vez le faltase alguna cosa para / el gasto de casa porque tenía cargo de la probeer y diese otra / por ella y que este que declara nunca vedó venta ni rescate ni con / tratación alguna en general ni particular antes la permitió unibersal / mente. A la sesta pregunta y artículo dixo que la niega como en ella se contiene //

/ 25 r. / e dize lo que dicho tiene. A la sétima pregunta y artículo dixo / que la niega que no pasa así como la pregunta dize mas antes en / contrario porque la verdad de lo que pasa sobre lo contenido en / la dicha pregunta es que yendo delante la gente de guerra que estaua / con este que depone en Guaraz a Caxatanbo él se quedó despachando / a Pedro de Anzures [tachado] que fuese a Piura a prender a Diego de Santiago / a secrestarle sus bienes y el oro y plata que tuviese y lo truxese / a la ciudad de los Reyes por aver sido este theniente del dicho don / Diego y con aquel oficio aver robado un cacique y después / quemádole y quando llegó este que depone al dicho tanbo de / Caxatanbo donde estaua la dicha gente halló mucha falta de sol / dados dixose que por averles hecho entender quel dicho licen / ciado Vaca de Castro los auía de tomar lo que en el Cuzco los / avía dado el dicho capitán Pero Alvarez y para remedio / desto juntó con los principales soldados que allí avía y les / habló lo que convino para amorarlos con palabras y darles / a entender que no se les avía de tomar ni quitar cosa de / las que se les oviesen dado pues lo avían menester para se / guir la guerra y las armas para pelear que antes pensaba / de yr a la ciudad de los Reyes luego y traerles de allá al / guna ropa con que se ayudasen y con esto y otras palabras / que este que declara les dixo se contentaron de tal manera / que lo devieron sauer los que andauan fuera e dentro / de pocos días estaba todo el real como de antes y ansí fue / que se partió este que declara para la ciudad de los Reyes pa / ra procurar allí de hazer más gente y juntar cauallos y armas / e munición porque avía quatro meses que avía despacha / do a Gómez de Albarado que hera una de las más princi / pales personas de la tierra con conduta de capitán y probisio / nes a la ciudad de los Reyes y oficiales que hiziesen gente / y viniesen en servicio de su Magestad e aun ynserta la ley pa / ra los atemorizar que dispone que en semejante casso to / dos son obligados a venir sin ser llamados y nunca ovieron / dineros ni gente y por esto fue forzado yr este que declara / en persona como fue e después que llegó hizo acuerdo / con los oficiales sobre el remedio de la dicha alteración //

/ 25 v. / e se acordó que se gastasen cien mil pesos por lo que conbenía / al servicio de su Magestad que se reduxesen aquellos reynos / a su servicio e que luego puso tal deligencia con los mercade / res que avía en la dicha ciudad que de su voluntad nonbraron / personas que repartiesen entre ellos hasta sesenta mil castella / nos a lo que este que depone se acuerda porque en toda la tie / rra no abía dineros de su Magestad que no oviese tomado el dicho don / Diego y su gente y aun los bienes de difuntos y depósitos de / yglesias y que estos sesenta mil pesos vinieron a poder de la / persona que nonbraron los oficiales de su Magestad y por libramientos / del contador pagaua y daba a los soldados y gente de guerra / lo que por este que declara y por los dichos oficiales les hera / señalado en lo qual procuró este que declara de servir a su Magestad / porque con ofrecerles que en la tierra avían de tener de / comer y miraría por todos y los gratificaría se contentauan / con poco e desto 
todo el dicho pagador ha dado quenta a / los dichos oficiales y sacado su fin y quito e que al tiempo / queste que declara se partió de la dicha ciudad de los Reyes / con la gente que en ella hizo de guerra y con ciertos tiros e otras / armas que se conpraron dexó dicho a los dichos oficiales que / procurasen de enviar siete u ocho mil pesos de ropa con persona / que lo lleuase a cargo y tuviese dello su quenta para repar / tilla entre la gente que avía quedado en Caxatanbo como les / avía ofrecido e que al tiempo que la persona que los dichos / oficiales nonbraron para ello y lleuaua la dicha ropa llegó / después del ronpimiento e vatalla que se obo con don Diego / yendo ya de camino con la dicha gente a la ciudad del Cuzco / y este que declara biendo que ya se abía cunplido con lo que la / dicha gente avía de servir proveyó como no se supiese que a / quella ropa hera llegada y la misma persona que la traya / que se llamaua Francisco de Gudiel la llebase a la dicha ciudad / del Cuzco y la bendiese y beneficiase por de su Magestad y diese / quenta de lo procedido a los dichos oficiales y ansí se hizo / y el dicho Francisco de Gudiel dio quenta con pago dello a los / dichos oficiales y sacó su fin y quito y que a poder deste que / declara no vino cosa ninguna de todo ello ni de otro por él //

/ 26 r. / e que antes procuró con gran deligencia que se beneficiase la dicha ro / pa por la forma que tiene dicha y que esto es lo que pasa y no / otra cosa alguna. A la otaua pregunta e artículo dixo que la niega y se remite a lo que tiene dicho en la pregunta antes / desta porque aquello es la verdad y no otra cosa. A las nueve / pregunta y artículo dixo que la niega y que lo que tiene dicho es la / verdad y no otra cosa alguna dello. A las dézima pregunta e / artículo dixo que la niega y que lo que a dicho es la verdad e que / estando Alonso de Albarado en sus yndios en los Chachapoyas es / criuió a este que declara que le enbiase cinco mil castellanos / significando que no podía salir de allí a seruir con la gente que / tenía sin ellos y puesto que su gente hera poca hasta cinquen / ta onbres poco más o menos porque otros tantos que después se / juntaron al dicho Alonso de Albarado este que declara se los / enbiaba porque escribió cartas a toda la comarca que se junta / se con él este que declara enbió libramiento a los oficiales / de la dicha ciudad de los Reyes para que diesen al dicho Alonso / de Albarado los dichos cinco mil pesos y que así se los dieron / e ansímismo dio este que declara un cauallo al mensajero / que le traxo la carta del dicho Albarado porque le escribió que / se lo diese y demás desto le escribió después el dicho $\mathrm{Al}$ / barado llegando este que declara más cerca de donde le estaua / una carta en que le pedía dos repartimientos de yndios / de mucho valor y este que declara pareciéndole mal que / en aquel tiempo se le pidiesen tantas cosas antes de salir / a servir a su Magestad delante de los mensajeros rompió la carta / y esta fue la respuesta puesto que visto que hera necesario / después le ubo de ofrecer uno de los repartimientos / de los dos dichos y se le dio y que a otra persona alguna no / tiene memoria aver mandado dar dineros de la hazienda de / su Magestad eçeto lo queste que declara gastó de los tributos que / vinieron a su poder como dicho tiene y de otros dineros demás / de los que declarado tiene que gastaron los oficiales los qua / les darán la data del descargo de los dichos dineros que vinie / ron a su poder y en quanto a lo que la pregunta dize se dio dineros al capitán Peranzures e a Diego de Roxas de la //

/ 26 v. / hazienda de su Magestad dixo que para remedio de la alteración que / ubo en el Cuzco entre la gente de guerra después de dada la vatalla / por querer ser pagados y gratificados como dicho tiene procuró de / ynbiar gente a Chile y a descubrimiento de provincias donde se / pensaua que se hallaría indios y población y entre ellos fue el / capitán Diego de Rojas y con él Felipe Gutierrez que fueron entre / la parte de Chile y del norte en el vientre de aquella tierra donde / se descubrió gran población de indios e tierra rica y que para aquel / gasto demás de lo que los dichos capitanes 
gastaron y de lo queste / que declara gastó también hubo menester más dinero el dicho Die / go de Rojas para poder salir con la gente y procuró de que le prestasen / los oficiales de su Magestad seis mil pesos de oro dando fiadores e / principales tomadores e pagadores y nombró para ello al licenciado / Venito de Caruajal y al capitán Peranzures y viendo este que / declara la necesidad en que estaua para echar la dicha gente de / guerra de la dicha ciudad y quán seguro estaua con tan ricos y abona / dos pagadores asistió en que se hiziese y ansí se hizo y a lo que se / acuerda los dos dichos fiadores fueron los tomadores y los / obligados a pagar cada uno por él todo a lo que más se acuerda e / después se dio con los dichos oficiales cierta horden para la paga / de los dichos seis mil pesos que se pagasen de la mina de plata que / dexó el dicho Diego de Rojas en las Charcas e de los tributos de / sus indios a voluntad de los dichos oficiales y no saue lo que / después se a hecho y questo es lo que pasa cerca de la dicha / pregunta como dicho tiene y no otra cosa. A las onze preguntas / y artículo dixo que no obstante que este caso es cosa del car / go de capitán general queste declarante tubo y no de visita / ni residencia los quales cumplen con decir que conbinó hazerse / lo que se hizo, dirá lo que cerca desto pasó que los delitos / y crímenes de traición que los dichos don Diego de Almagro y / sus secazes cometieron fueron los siguientes. Matar al marqués / don Francisco Pizarro gobernador de su Magestad públicamente y / a un hermano suyo y al capitán Francisco de Chavez e a otros / con ellos. Saquear sus casas, hazerse don Diego reciuir por / gobernador. Quitar justicias y ponerlas en su nombre en toda la / tierra, robar los quintos reales, bienes de difuntos, depó //

/ 27 r. / sitos de monesterios, matar muchas gentes, so color de justicia por / que entendía que le heran contrarios y servidores de su Magestad que fue / ron al secretario Antonio Picado, de Orihuela, Villegas, Vozmediano, Cabrera, Valtanas, Hernando de Montenegro y otras / personas como fue García de Alvarado que le mató don Diego y le dio / la primero cuchillada en su cámara y a un Picón y a otros que sa / caron de la Yglesia del Cuzco y los ahorcaron, quitaron la justicia / [al] theniente que estaua puesto en el Cuzco en nombre de su Magestad / por este que declara como su gobernador que con arcabuzeros fue / el mismo don Diego al arca de su Magestad en el Cuzco y robó lo que / en ella estaba contra voluntad de los oficiales hizieron con / juración pública en el Cuzco en un cadahalso que hizieron de / madera enzima del qual estaua el don Diego e otros que leyan / por un papel razones que persuadían a que todos jurasen de / le defender en la gobernación contra toda persona y el don Diego / juraría de les repartir la tierra y para los que no obiese dar di / neros para que fuesen a descubrimientos y en un altar questaba / devaxo del cadahalso con ara y misal pasaba la gente que / tenía de guerra jurando. Aviánse aliado con el ynga hijo de / Guaynacaua que después de auer obedecido a su Magestad anda al / zado contra su servicio recibieron dél armas y ciertos tiros de / artillería, heran enemigos de la república porque la robaban / e saqueaban cauallos y armas y lo que más hallaban de per / zonas que les fuesen contrarias dizen testigos que tenían concertado / de tratar con Francia para se ayudar e defender hizieron gen / te de guerra con banderas y capitanes públicamente para su / defensa fueron tras la gente que vinieron del Cuzco, Charcas e / Arequipa que heran los capitanes Pero Alvarez Holguín que sir / bió muy bien a su Magestad y Pedro Anzures y Garcilaso para los / ronper e destruir para que no se juntasen con este que declara / e nunca quisieron obedecer provisión que les enbiase este que / declara ni a él como a gobernador enbiáronle cartas de desafíos, / hizieron otras cosas ynormes que por los procesos se verán e / que en semejantes casos y delitos como los susodichos tan no / torios y ebidentes y permaneciendo en ellos y abiendo un leban / tamiento como lo susodicho contra el 
servicio de su Magestad y aquel / reyno y probincia no heran necesarias deligencias sino execuciones //

/ 27 v. / de las penas estatuidas. Todavía este que declara hizo las po / sibles presupuesto que el dicho don Diego y su gente tenían gran / recaudo en que a ellos no pudiesen pasar despachos ni probi / siones deste que declara que desde Quito luego que entró en la / tierra scribió al don Diego e a todos los precipales de su con / pañía con el capitán Pedro de Heredia y con Carreño y Pedro de Pue / lles porque si uno no pudiese llegar, llegase otro y el dicho Carreño / y el dicho Pedro de Heredia lleuaron los dichos despachos a la dicha / ciudad de los Reyes y de allí los lleuó al dicho don Diego y su gente / un Juan Alonso de Vadajoz y entonces supieron como este que / delara estaua en la tierra y venía por gobernador y hera receuido / como tal en todos los pueblos y en la dicha ciudad de los Reyes / e por esto scriuió el dicho don Diego al cabildo de la dicha ciudad en / respuesta de sus cartas amenazándoles porque avían recibido / a este que declara e siempre hazían toda la disimulación / posible para que recibiesen sus despachos deste que declara e / después les enbió otros mensajeros y cartas con yndios y otras / provisiones y aunque las recibían hazían la disimulación / ya dicha e por esto este que declara enbió perdones generales / a todos ecepto a ciertas personas que avían sido en la muerte / del marqués y esto porque mejor creyesen que a los otros se / les guardarían y las personas que los llebauan porque no / osaban entrar donde ellos estauan y tenían grandes guardas / alderredor de su asiento y estancia los fijauan por mandado / deste que declara en las estancias y caminos públicos y en o / tras partes ponían palos en que los pegaban y por esta causa / sabiéndose muy bien entre ellos se vinieron a este que declara / algunas personas de las que andaban con el dicho don Diego como fue / Francisco Hernández, Diego López de Ayala, Xara, Juan García, un / tal Gallego y otras personas y que al tiempo que a este que declara / enbiaron el dicho don Diego y sus capitanes cartas de desafío de / sacatadas y este que declara respondió disimulando sus delitos / y desacatamientos y scribiendo al don Diego como padre que se vi / niese para él que él le perdonaba y haría toda la buena obra que pu / diese en nombre de su Magestad y a los capitanes que bien entendía que hera / aquella carta para cunplir porque siendo vasallos de su Magestad se / avían de venir para él que así les pedía que lo hiziesen que les //

/ 28 r. / perdonaua y les daría de comer en la tierra, respondiéronle que / bien hera que pensase que su carta hera para bien parecer que / juraban a Dios e a esta cruz de la executar como avían / scripto y quando los corredores del canpo se topaban unos / con otros dezían los de la parte de este que declara a los de don / Diego que se pasasen con ellos pues estaua allí el gobernador del / rey y ellos respondían que allá estaua el rey don Diego de $\mathrm{Al} /$ magro y otros desacatos y no obstante todo les scribió otra vez / este que declara un vezino de la villa de Goamanga con cartas y / perdones y disimulado en ábito de yndio porque pudiese entrar / hasta donde ellos estaban y tomándole los despachos otro día / le ahorcaron el qual dicho mensajero se llamaba Alonso García y es / cribieron a este que declara que no les enbiase más mensajeros que se los a / horcarían y que ansí hiziese él a los que los ynbiasen y visto esto / por este que declara y que venían cerca procuró de proceder contra / ellos por bía de proceso que hasta allí se auía entretenido de / lo hazer porque no entendiesen que los tenía por culpados y con / denados para que con esto quando endureciesen su proterbia de / xasen de venir a servicio de su Magestad y enbioles a pedimento / del fiscal provisión en que se relataua la acusación que les / estaba puesta y se ynxirió ley de partida que los da por traido / res y habla en este caso propio para atemorizarlos y que mejor / viesen su daño y se remediasen y para que viniesen a ver declarar / sus delitos por notorios y condenarse en la pena y 
otras cosas / que justificauan la probisión a la qual se remite y esta pro / bisión enbió con Diego de Mercado fator del Nuevo Reyno de / Toledo y con Lope de Ydiaquez y los nombró por anuncios y cursores y escribanos para ello y en el proceso quedó otra semejante pro / visión concertada por dos escriuanos porque si la otra le tomasen / y no pudiese venir basta se dar fee de la noteficación los quales / llevaron las dichas probisiones y las mostraron al dicho don Diego / y sus capitanes y gente y volvieron con respuesta de la notificación / y se puso en el proceso y que la probisión oreginal la tomaron el / don Diego y su gente y declararon en sus dichos con juramento demás de / la notificación muchas palabras desacatadas y desvergonzadas que / los susodichos respondieron, espirose el término que les fue dado por / la dicha probisión para venir y parezer e después acusada la rebeldía //

/ $28 \mathrm{v}$. / por el fiscal se procedió hasta pronunciar sus delitos por notorios / y ebidentes y hasta sentencia de condenación e que después desto subçedió / el venir contra este que declara e su gente y subcedió el ronpimiento / donde por la buena ventura de su Magestad se ubo por su parte vitoria. A las / doze preguntas y artículo dixo que aunque la dicha pregunta es / fuera de horden de derecho de ponerse que no pasa lo en ella contenido / como la pregunta dize que lo que pasa es que estando un sábado de maña / na este que declara con la gente en su real que acababan de venirse / para sus toldos por auer estado toda la noche armados y en orden / pensando que los contrarios vinieran, vinieron los corredores del / canpo y dixeron que los contrarios venían e luego este que de / clara mandó que se publicase por todos y que comiesen y se a / parejasen para la vatalla que se auía de dar aquel día y ansí / lo hizieron todos y esto hecho este que declara juntó los capita / nes y sargentos y se trató y porfió de yr en la banguardia e todos / lo contradixeron y con toda eficacia le ynportunaron y rogaron / que no lo hiziese porque no entraría en la vatalla y aún el capitán / de arcabuzeros e ynfantería Nuño de Castro con los prenci / pales soldados hablaron a este que declara rogándole e ynpor / tunándole que no entrase en la vatalla que así le convenía, ordenó que fuese con la banguardia / el capitán Pero Alvarez Holguín y en otra esquadra y capitanía / de gente de cauallo puso el estandarte y con ellos capitanes Gómez / de Albarado y Alonso de Albarado para que ronpiendo los contra / ríos con la dicha banguardia de cauallo diesen estos por el lado y él fue / en la retaguarda con treynta y seis o treinta y siete de cauallo / y que destos abría algunos de calidad y de hecho y los demás / pajes y criados deste que declara y personas mal armadas / y que algunas personas destas dexó consigo porque heran a / ficionadas a la parte de don Diego y no las dexó poner en la ban / guardia y que se quedó con estos para entrar quando fue necesario / de refresco e yendo caminando contra los contrarios viendo que / estauan asentados enbió al sarjento mayor e a otros para que / supiesen por do convenía entrarles que menos daño recibiesen / de su artillería porque la que lleuaua este que declara no podía llegar / al tiempo por la priesa que lleuaban en el caminar aunque de su //

/ 29 r. / parte se hizo toda la deligencia posible para que llegase que por / pregón público dio libertad a todos los negros que fuesen / llevando el artillería y otras cosas y no bastó y después que lle / garon cerca este que declara habló a toda la gente por sus capi / tanías por las mejores palabras que pudo para que se anima / sen a servir a su Magestad e ansí con ánimo caminaron e acometie / ron por mandado deste que declara y porque los tiros de artillería / no cogiesen los que este declara llebaua de cauallo consigo / pusolos en un baxuelo que avía cerca de la vatalla e artillería / hasta que acauase de disparar y este que declara se subió en lo alto / a ver lo que pasaua e a hazer lo que debía y si auía necesidad / de entrar con su gente y aprovechó mucho quedar en aquella parte / 
porque algunos de los suyos comenzaban a salirse de la va / talla y este que declara los hazía tornar y con sauer que estaua / en la retaguardia y que veya lo que hazían procuraban todos / de adelantarse y estando en esto y la vatalla reñendo se / vio pasar dos banderas blancas por el lado de los capita / nes Alonso y Gómez de Albarado de los contrarios con su gente / y entonzes bio que hera necesario dar socorro aquellos capitanes / y vaxó a los que tenía y les dixo como conbenía que entra / sen a los socorrer y otras palabras que convenían dezirse e / ansí con toda buena voluntad entraron y este que declara con / ellos y subcedió que se adelantó algo más uno que se dezía / Diego de Agüero diziendo vitoria vitoria que agora / entra el gobernador y como por el repecho arriba subía la gente de / rramada que por ser pocos no yban puestos en hileras ni horden de / vió parecer a los contrarios mucha gente y supose que avía dicho / un Xuarez sargento mayor de Don Diego en quien tenía gran confían / za con esto estaua por entrar queda con Dios y se fue huyendo / y con esta entrada se conosció luego el desmayo de los contrarios y la / vitoria puesto que de los que entraron con este que declara le / mataron dos, un pariente suyo que se dezía Montalbo hijo del alcalde / de la Mota de Medina y un capitán Ximenez y le hirieron a / otros que uno dellos sacó nuebe heridas y luego que se reconoció la / vitoria como este que declara bio poca gente muerta y que si los / suyos se desmandaban a robar las tiendas y toldos agenos podían //

/ 29 v. / los contrarios rehazerse y bolber a desbaratar los mandó dar al / alarma y discurría por todas partes para que se juntasen todos con sus / banderas y ansí se hizo que con toda obidiencia se pusieron en horde / nanza y ansí estubieron aquella noche y que esto que declara / es por la necesidad de satisfazer a la pregunta que de otra manera / no se avía de tratar desto por su dicho y que lo mucho que aquí se dexa de dezir de lo que sirbió y trauajó se dirá por probanza / a que se remite. A las treze preguntas y artículo dixo que lo que / cerca desto pasa es lo siguiente que no obstante que ay probisión para que no vayan los yndios a las minas contra su voluntad / con penas a los que lo contrario hizieren y ansí paresce que en / general ay artículo en la ynstrución que a este que declara / se le dio que habla en esto auía en la dicha probincia del Perú cé / dula y probisión de su Magestad en que haze merced y permite a los vezinos / de aquella tierra que puedan hechar y traer yndios a las minas / que tubieren de su repartimiento siendo de su voluntad de / los yndios para que paguen lo con que an de acudir a sus a / mos y al tiempo que dicho tiene que en el Cuzco ubo al / teración y mobimiento de gente que fue allí con él después del / ronpimiento acudieron a este que declara los vezinos a / que mandase que se guardase aquella cédula e puesto que él hera / obligado a la cumplir pues hera limitación de las otras que / proybían en general y se daba esta merced en especial se dete / nía y detubiera fasta algund tiempo que más y mejor se en / tendiera en este negocio más fuele forzado concederles / lo que la probisión les daba por pacificar e sosegar la / vezindad que hera lo principal porque le dezían que ya / sabía que estaban robados por don Diego y su gente y sus / yndios tanbien por tal manera que no les podían dar susten / tación y que lo que les avía quedado de hazienda lo abían / gastado en cauallos y armas y cosas necesarias para yr a / servir a su Magestad en conpañía deste que declara y con concederles / lo que su Magestad les avía otorgado sin darles nada de nuevo se tu / vieron por pagados de sus servicios y que no obstante en la / probisión hera general para todos los yndios que cada uno / tuviese e vaxo de lo qual podían recibir mucho daño este que //

/ 30 r. / declara hizo e probeyó lo que como curador propio de los yndios / pudo hazer porque hizo hordenanzas en que declaró la hor / den que se deve tener para conocer y sauer que los yndios / yvan de su voluntad y no pudiese en esto auer fraude ni / fuerza ni persuasión yten que no fuese más 
de la quinta par / te de los yndios que cada uno tubiese e que no fuesen mu / geres ni muchachos, que no fuesen ni viniesen cargados, que tu / viesen vastante vastimento en las minas que les sobrase / e casas y bohíos en que estobiesen, que oviese clérigo que los / yndustriase en la fe, las fiestas, que no avían de hazer nada / que dexasen primero que fuesen sus panes cogidos y saliesen / a hazer sus sementeras, que todas vezes que pareciese en / fermar se saliesen y quando ellos quisiesen lo pudiesen ha / zer e que oviese alcaldes de minas y un alcalde mayor e bedor [sic] / general que andubiese mirando si se hazía alguna cosa con / tra lo susodicho e mandase salir los yndios y quando biese / que no andaban de su voluntad lo mismo y otras cosas con / tenidas en las hordenanzas en aprovechamiento de los yndios / a que se remite y que así lo a scripto a su Magestad y Consejo y en / biado las hordenanzas y que en poder del dotor Texada venían es / tas hordenanzas y otras cerca del buen gobierno de la tierra / e que entendido los yndios en esto de las minas de oro y como / de cinco en cinco años cabía a uno $[\mathrm{sic}]^{6}$ a uno medio año de servicio / por todo tributo y que no les avían de yr los dueños a / sus casas a pedir ni tomar lo que tenían y porque sien / pre les queda parte de lo que sacan con que conpran sus / vestidos, lana y coca y otras cosas y como son allí tan / bien mantenidos holgaron tanto con esto que con ninguno / pudo acauar este que declara que consintiese tasarse tri / buto y los que fueron un año en tiempo deste que declara a / las minas no querían que fuesen otros sino yr ellos, el / año siguiente y que conforme a esto los yndios queste que / declara a dicho que puso en su cabeza quisieron de su vo / luntad enviar algunos que segund este que declara oyó de / zian hasta seiscientos a las minas para pagar su tributo y / lo que solían dar antes que estuviesen en cabeza deste que declara / e aunque porfió con ellos muchas vezes que no fuesen, ni //

/ 30 v. / enviasen a las minas que de su parte no les abían de pedir / ni llevar más de los que le quisiesen dar e sobre esto trató mu / cho con ellos nunca lo pudo acabar sino que por su probecho / quisieron ir a las dichas minas de Calabaya que se avían des / cubierto, que estaban cerca de sus pueblos a quinze leguas e / otros menos e que lo que destos indios ubo y le sacaron lo / tiene ya declarado e que las personas que en ello entendían / heran Juan Alonso Palomino, vezino del Cuzco, e un Obregón, e / otro Muñoz y Muzientes e otras personas que no se a / cuerda e Pero Sanchez clérigo que estaua con los dichos indios / para los yndustriar y Gómez de Rojas que es un cauallero / honrrado por beedor y especialmente encomendó que si bie / se que los yndios queste que declara tenía no les iba bien / los hiziese salir de las minas o si les faltaba algo o al que / no andubiese de su voluntad por manera que siempre tubie / sen livertad de hazer lo que quisiesen y que no sabe que en las / dichas minas se muriesen indios y porque algunos querían / decir que sí hizo este que declara probanza e información / cerca dello para que si hallase ser ansí se ynpidiese el yr / los yndios a las dichas minas no obstante la dicha cédula e / que por la probanza pareció lo contrario e que se tomaron testigos / honrrados e de verdad entre los quales se acuerda que / fue el arcediano Rodrigo Pérez y el dicho Pedro Sanchez y el licenciado / Barba e otras personas y que en poder del dicho dotor / Texada avía de venir la probanza desto porque / esta que declara la enviaba con otras muchas cosas con / Francisco Perez y lo ynpidió el Birrey Blasco Nuñez Vela / e que esto es lo que pasa cerca de lo contenido en este artículo / y lo demás niega. A las quinze / preguntas dixo que dize lo que dicho tiene y lo demás niega. / A las diez y seis preguntas y artículo dixo que este que / declara ubo lo que sacaron los dichos yndios de las dichas / minas hasta en la quantía que tiene dicha y se manifestó en / la Casa de la fundiçion a los ofiçiales de su Magestad en la çibdad / del

\footnotetext{
${ }^{6}$ Repetido en el original.
} 
Cuzco y que porque más manifiesto fuese dio este que / declara mandamiento para los dichos oficiales que todo lo //

/ $31 \mathrm{r}$. / que se fundiese de minas se tomase por testimonio, cuyo / hera e que tanto abía sacado cada minero e con juramento / de los mismos e que ansí se hizo en lo deste que declara por / ante escribano e que se pagó dello el quinto e derechos que a / su Magestad pertenecen e al comendador mayor e salió marcado / y quintado. A las diez y siete preguntas dixo que la niega / e que esta pusición no se debía de poner ni como ella está / tiene obligación a se responder porque pregunta del pen / samiento y propósito más que no obstante todo para que / se vea las ynbenciones y maldades que se an tratado con / tra este que declara dirá lo que pasa y es que con el cuy / dado e deligencia que pudo entendió en las cosas que to / caban a la Hazienda Real de su Magestad y descubrió algunos / fraudes que en ella se hazían y remedió con hordenanzas / el aparejo que auía para hazerse adelante e porque / don Diego de Almagro e su gente avían hecho echar la con / tra marca que avía de oro fino en el Cuzco a todo oro / de quilates por crescer en moneda para gastar con su / gente puesto que procuró con heditos y pregones este que / declara que este oro tornase a la casa de la fundición / para que se quitase la marca y se pusiese en los quilates / que convenía tener todavía porque se temía queste / daño no se podría limpiar, hizo que los oficiales hizie / sen una contramarca con una $\mathrm{f}^{7}$ que se hechase al oro fino / de ay adelante y ansí lo escribió acá a su Magestad en una carta / e demás desto quitó la refación que se daua en la plata / porque los dueños de la plata perdían e su Magestad no ganaba / antes hera aparejo para poder aver fraude y menos / cabo en su hazienda Real y probeyó que toda la plata / e oro pasase por su ley y que hecho esto en la ciudad / del Cuzco entendió en la execución de cierta cédula y pro / bisión que le fue enbiada en que se mandaua que señalase / a los oficiales de Toledo su probincia para que usasen / sus oficios y porque lo de entrar en su probincia Charcas / e Arequipa hera claro y lo del Cuzco cosa para que avía //

/ 31 v. / menester yr al río de Santiago por donde se entra dende acá / en la probincia del Perú con pilotos para ver aquella al / tura que es el principio de la gobernación que se avía dado / al marqués don Francisco Pizarro y volver a tomar el / altura del Cuzco e por alguna diferencia que sobre esto re / sultaba de las provisiones dadas por esta causa declaró ser de lo de Toledo, Charcas e Arequipa e reserbó en sí la de / claración del Cuzco y también porque convenía que obiese / fundición en las Charcas y en Arequipa, dio en estos lugares / y provincia a los oficiales de Toledo la posesión de sus o / ficios y para que los exercitasen les dio lugar y mandó que / en presencia de escribano estando todos juntos un platero / abriese marca e contramarca como la avía en el Cuzco / para que la llevasen y traídas ante este que declara truxe / ren dos marcas reales prinçipales en que escoger e por / que la una estaua más relevada para mejor señalar se / hordenó que fuese a remacharla otra luego y ansí se hizo / e no se acuerda este que declara si luego o quándo bol / vieron de casa del platero de remachar la otra, metió / la marca en una arca e dio la llabe al contador e que / con deligencia les hizo buscar una arca que metie / sen en otra por manera que obiese tres llabes e metie / ron en ellas las marcas por ante escribano que dando cada uno / con su llabe y se fueron con ellas y questo se hizo con toda / fedilidad y cuidado de hazer lo que a servicio de su Magestad / convenía y que el propósito fue por confiar este que declara / más de sí que no de ninguno de los dichos oficiales en lo / que tocaua al seruicio de su Magestad y no dar la marca a / uno de ellos sólo hasta

\footnotetext{
${ }^{7}$ Es posible que sea la inicial del fundidor.
} 
que truxesen arca de tres llabes / y la truxeron e se la entregó y que no ovo aquí otro pro / pósito, ni pensamiento y otra cosa no se hizo con la dicha marca / e que desto desta pusición no se avía de preguntar a / onbre a quien se encomienda gobernación, ni de calidad e / esto es lo que declara y lo demás niega. A las diez e ocho / preguntas y pusición dixo que dize lo que dicho tiene e que //

/ 32 r. / lo que en el gasto de la hazienda de su Magestad pasa aunque / se puede colegir de lo que dicho es que estando este que declara / en la ciudad de Quito comenzando a buscar armas y gente / fueron menester dineros e allí se buscaron ciertos dineros / prestados la paga de los quales quedó a cargo de Rodrigo / Núñez de Bonilla thesorero que hera a la sazón de la dicha ciudad / e después en San Miguel procuró este que declara de cobrar / ciertos dineros que estauan allí depositados de Diego de San / tiago que avía tomado el gobernador Benalcázar del arca / de Quito e avíanse depositado allí y este que declara / los cobró e de todos estos que fueron seis mil e tantos / pesos dio cédula al dicho thesorero y se gastaron en los gastos / que se hizieron en Quito y en enbiar gente al socorro de San / tiago de Amay que le tenían cercado los yndios de la Puná / e si no se enbiara este socorro se perdía la dicha ciudad e / la de Puerto Viejo e aún San Miguel estaba en peligro / e la ciudad de Quito porque los yndios de la dicha ysla de / Puná se avían alzado e relebado e avían muerto los / españoles que allí estauan y por la mar al obispo del / Cuzco e dotor Blazquez e Juan de Baldibieso que este / que declara avía enbiado con cartas para que todos a / quellos pueblos estubiesen en servicio de su Magestad y le re / ciuiesen por gobernador e a que buscasen dineros en Piura / y comprase los cauallos y armas que obiese en aquella parte / y se viniesen a vender a la tierra e demás desto hazían gue / rra al dicho pueblo de Santiago de May [sic] e avían muerto a / llí españoles en la ría por manera que fue forzado a este / que declara aunque estaba en tiempo de tanta necesidad para / subjetar a don Diego y su gente de personas, armas e / compañía por no tener aquella guerra por las espaldas / e por el peligro que avía de perderse aquella ciudad y / las que tiene dicho en enviar a quarenta e cinco o cinquenta onbres / arcabuzeros y vallesteros y de a cauallo para el socorro de / aquella ciudad y porque ansimismo venían personas della / a le pedir socorro con lágrimas y fatiga de como dexaba allí / sus mujeres e hijos y con este socorro de quando llegó los /

/ 32 v. / yndios querían ya poner fuego a las casas, se remedió / e se retraxeron los yndios e después para fenecer / la conquista con estos y subjetarlos e castigarlos enbió de / la ciudad de los Reyes al capitán Pedro de Heredia con un na / vío e algunas personas e arcabuzes con lo qual e con un / vergantín que por respeto deste que declara vino a esto / e con la gente que tenía enbiada al dicho tiempo y con la que / tenía enbiada el capitán Diego de Orbina su theniente / se conquistó e pacificó e se hizo alguna justicia con mo / deración segund los delitos questos yndios avían co / metido e que en estas cosas y en otras se gastaron los / dichos dineros y más. Yten que este que declara tomó de los o / ficiales de Truxillo a lo que se acuerda cinco mil e tantos / pesos de oro y estos se gastaron ansimismo en la prosecución / de la guerra en armas y gente y en lo que se dio al capitán / Vergara y a los que consigo sacó e truxo de los Braca / moros donde andaba conquistando a donde desde Quito / le escribió este que declara que saliesen a seruir a su / Magestad en su conpañía e a gran peligro de los yndios de guerra / llegaron donde él estaba e salió y en Jayanca que es entre Piura / e Truxillo se les hizo todo socorro y lo mismo a los de la / capitanía de Rodrigo Docanpo y en otras cosas que se conpra / ron y se gastaron después de llegado este que declara a / donde estaban los capitanes Pero Alvarez Holguín e Pedro / Anzures e Garcilaso a donde se conpraron armas y mulas

\footnotetext{
${ }^{8}$ El topónimo correcto es "Santiago de Amay" y corresponde a la actual Guayaquil.
} 
/ que llebasen el artillería por el daño que recibían los yn / dios en la llevar y en otras cosas que parecerá por su cuen / ta donde se gastó esto e más queste que declara buscó / e ansimismo demás desto quando fue este que declara / a la ciudad de los Reyes e se acordó entre él y los oficiales / que se gastasen los cien mil pesos que dicho tiene e se buscaron / los dineros prestados entre los mercaderes en la quantía que / declarado tiene todo esto se gastó por los dichos oficiales / e no estuvo nada desto a cargo deste que declara ni vino / a su poder y que los demás que dicho tiene que hubo de los yndios / questaban vacos e de los del marqués se gastó en las cosas que //

/ 33 r. / fueron menester desque este que declara buelto de Lima bol / bió a Xauxa donde estaua la gente toda esperándole has / ta que se feneció la guerra e deshizo la gente que sal / ió en el Cuzco como dicho tiene e aunque gastó esto en / servicio de su Magestad, Gonzalo Pizarro en los bienes que le a / tomado a este que declara se a entregado de lo que este que / declara ubo de los yndios del marqués como dicho tiene e / de lo que se hubo de los indios que vacaron por muerte / del obispo que este que declara puso en su cabeza con los o / tros le tienen puesta demanda por su hermana del dicho / obispo que dize ser heredera e que en lo que la pregunta dize / que hizo dar a personas de la hazienda de su Magestad que / lo que este que declara dio e gastó se berá por su cuenta / e que todo lo demás que se gastó en la ciudad de los Reyes / que fue lo principal se hizo concierto de todos e / por todos los oficiales dará la cuenta desto e de lo que / toca a esto que se declara de su cargo e data dexó poder / y persona en la ciudad de los Reyes que fue Diego Mexia / que la diese por él al contador Zárate e dexó dadas fianzas / de vezinos muy abonados de pagar el alcance si alguno / se le hiziese y que esto es lo que declara a la dicha pusición. A / las diez e nueve preguntas y artículo dixo que no se hizo / la tasación de los tributos porque no vbo lugar por / que hera necesario hazer primero el quento de los ca / ciques e yndios e reformación que le fue encomendada / e que aun esto no se pudiera hazer si no fuera por la mu / cha deligencia que se dio este que declara por el poco tiempo / que tuvo pacífica la gobernación para entender en seme / jantes cosas porque hasta que pasó el ronpimiento / con don Diego que fue a diez y seis de septiembre de quarenta / e dos e después que de allí fue al Cuzco y allí e asta / el fallecimiento de don Diego e se hizo justicia e se de / rramó la gente a las entradas e de la manera que dicho tiene to / do fue guerra y ocupación tal de noche e de día que hasta / merced de Dios fue poderse despachar estas cosas y esto se / acabó de fenezer en todo el mes de marzo de quarenta e tres //

/ 33 v. / en el qual tienpo ansimismo entendió este que decla / ra en otras muchas cosas de la gobernación por la nece / sidad grande que de ello avía e después de pasado lo su / sodicho que se comenzó a entender en el quento de los yndios / y reformación y en otras cosas e no vbo tiempo para / más porque Blasco Núñez Bela llegó a la dicha pro / bincia en el mes de marzo del año siguiente de quarenta / e quatro de manera que sacado lo que este que declara / gastó de tiempo en el camino del Cuzco a la ciudad de / los Reyes que con estar malo en el camino y lo que estubo / en la ciudad de los Reyes hasta llegar allí el birrey e pa / saron más de dos meses por manera que bien mirado fue / diez meses governador libre de las cosas de guerra / para poder entender en lo de la ynstruçión e que an / tes en este tiempo se hizo mucho por este que declara / en servicio de su Magestad por lo que entendió en la libertad / de los yndios que de susodicho tiene y en bien de fee y / en prober como se hiciesen yglesias y monesterios y / entender en las cosas de la hazienda real en el Cuzco / y en el quento y reformación y horden de cabildos e / otras muchas cosas que dexa de dezir y que él se / ocupó también en servicio de su Magestad que no se hallara que / tobiese tiempo ocioso ni ocupado en otra cosa fuera de / hazer bien su oficio y que la brebedad del tiempo fue / la 
causa porque se dexó de hazer lo susodicho e no / los pocos yndios que este que declara tenía en su ca / beza antes le cumplía a él mucho que se tasaran los / tributos destos porque oviera más aprobechamiento / que de lo que ovieron de minas que lo que diesen hera $\sin /$ costa y esto de las minas la costa tanta que se lleba lo / principal y esto es lo que pasa e declara. A las veinte / preguntas y artículo dixo que todos los que se conde / naron por las dichas alteraciones y delitos por e / llos cometidos no vbo bienes que cobrar dellos sino //

/ 34 r. / males porque ninguno dellos tenía bienes y hazienda al / guna ecepto que quando huyeron de la vatalla fueron / algunos de los contrarios a la villa de Goamanga tres / leguas de donde se dio la vatalla y fue tras ellos en su se / guimiento Diego de Rojas con alguna gente e allí prendió / las que halló e de su oficio hizo allí justicia de al / gunos que fueron Diego de Hozes e Juan Tello y Oñate y / Erbolancha y tomó este capitán algunos cauallos y armas / e destribuyéronse por él en esta manera algunos que se / dieron a sus dueños porque se los avían robado don / Diego y sus secazes y otros a soldados e caualleros que avían / perdido los suyos en la vatalla con que se les hizo alguna / soldadura de su trauajo e se les dio algún contentamiento / y que fuera desto los bienes que se hallaron de los demás / fueron unas casas que tenía en el Cuzco Oñate e desta / hizo cargo al thesorero y oficiales y las vendieron e / pagadas las deudas que pareció tener hechas antes / del delito si restó lo cobrarían los oficiales a cuyo cargo / estaba y pareció con la deligencia que este que declara / puso que de los yndios que avían sido de Diego Mén / dez capitán de don Diego que estaban dados al capitán / Castro y los poseya avían sacado nueve mil pesos / más o menos que no se acuerda bien y porque no esta / va vien entendido e declarado si pertenencían al / Diego Méndez o al Castro los depositó este que declara / por su Magestad en poder de Diego Maldonado vezino del / Cuzco y pagadas las deudas que por suyas fueron sen / tenciadas e determinadas por los alcaldes hordinarios que / se devían de pagar y preferir con lo que restó se a / cudió a la cámara y lo reciuió Diego de Silba vezino de / la dicha ciudad del Cuzco que a la sazón hera thesorero / de lo qual ay carta quenta en su poder ante Pero López / escriuano de la gobernación e que otros bienes no sabe / ni se acuerda este que declara que oviese de todos //

/ $34 \mathrm{v}$. / los que se condenaron por delinquentes porque todo / lo queste que declara pudo inquirir y buscar lo hizo / como hera obligado y que en lo demás que la pregunta / dize de no aver ynbiado las sentencias que él hizo / en esto la deligencia que devía porque no se acuerda bien / si con Vezerra enbió las sentencias, que cree que sí, más que / se acuerda que las enbió con el capitán Pero Anzures e / que los procesos a la larga con las sentencias y execuciones en / biaua este que declara con Francisco Paez porque como heran / largos fue menester tiempo para los sacar por la falta que / ay en aquella probincia describientes y estando para se / enbarcar e hazer a la vela fue detenido el dicho Paez / por el virrey Blasco Núñez Vela e ocupadole las escri / turas que traya y por esto no an llegado mas no por / falta deste que declara ni de negligencia suya. A las / veinte e una preguntas y pusición dixo que en lo / desta pregunta no puede este que declara declarar cer / tidumbre de la cantidad de cada cosa de lo contenido en / la pregunta si no viese las scripturas que traya Pero Anzures / y las cartas que ansimismo traya más de lo que agora / se puede acordar es que este que declara dio cierta can / tidad de pesos de oro a Diego de Aller mensajero que en / bió a su Magestad a dar noticia de la muerte del marqués e al / teración de don Diego y del estado en que se hallaua la / tierra para los gastos de yda e venida a residir / en corte hasta que fuese despachado e le mandó que lo / que restase diese a su mujer deste que declara e ansi / mismo enbió con Alonso de Villalobos mensagero que / ansimismo vino con el qual scriuió a su Magestad e Consejo la / buena 
horden que se avía dado en la gente que tenía junta / e armas e munición para poder mexor ser seruido a / su Magestad e como don Diego venía con gente del Cuzco e / otras cosas que convenían y le mandó que fuera de lo / que gastase diese lo demás a su mujer deste que declara e questo //

/ 35 r. / que envió con los dichos mensajeros fue de cosas que / se vendieron de las que este que declara llebó Despaña / en la probincia de Benalcázar por no tener en que lle / varlas e no cargar yndios e de otras cosas que se fue / ron vendiendo y parte de su salario e que después / con Francisco Vezerra enbió poca cosa porque de / lo que le fue entregado avía de dexar en Lima di / neros para comenzar a hazer satisfacción a los na / víos que se abían detenido por ser necesario y ciertos de / los derechos del Comendador mayor de León que este que / declara cobraua con su poder e otros de personas / particulares como Gaspar Gil vezino del Cuzco e / de un Cáceres que enbiaba para los herederos de / un Suárez que murió allí en Arequipa e que tanbién / enbiava este que declara dineros con Peranzures al / gunos dellos deste que declara y otros de Diego de Aller / e de criados suyos difuntos de cuyos bienes se hizie / ron ynbentario e almoneda y enbiaba los dineros / para sus herederos y que los de Diego de Aller se en / biaban también para él porque entonces no sa / bía este que declara si hera partido de España e que / dos mil pesos poco más o menos venían para Renaldo / Estrozi vezino desta villa queste que declara cobró / allá luego que llegó a la tierra de Luis Suárez e de un / Requexo mercaderes que se los devían e otros que / avía de auer el secretario Juan de Sámano y el Comendador / mayor de sus derechos de oficios e que con el dicho / Alonso de Villalobos venía el dicho fray Francisco / Martínez toscano los quales juntamente trayan / a cargo lo que tiene dicho y más ciertas basijas e cosas / labradas de yndios las quales heran de este que de / clara conpradas por sus dineros e que de la cantidad de / estas cosas y que de lo que hera de cada uno particularmente /

/ $35 \mathrm{v}$. / particular memoria si no viese las escripturas y cartas que / estos traxeron que dichas tiene que se devieron de to / mar en la de Pero Anzures e que cierta quantía que hera / deste que declara o casi toda la vbo menester este que / depone en la ciudad de los Reyes después que llegó Blasco / Núñez Vela para acabar de satisfacer en nonbre de / su Magestad los dueños de los navíos de lo que se avían / detenido en aquel puerto y la tomó de personas que / se la dieron en la dicha ciudad de los Reyes que fueron / Luis García e un Yllescas y cree que un Balenzuela y / este que declara se lo libró en Panamá donde los a / vía dexado el dicho Pero Anzures en poder de Luis Sán / chez Dalvo el qual acudió a las libranzas y se los pa / gó y que lo que desto que enbiaba escribía que se hizie / se lo dirá su carta y que estos dineros escribía a su muger / dispusiese como suyos por ciertos respetos que a él / le convenían sin ofensa de su Magestad ni de otra persona alguna / y porque los dueños destos dineros que quedaban allá / no los avían de aber hasta que viniesen con este que / declara y a los dueños que estaban en estos reynos e / cepto lo de difuntos no quería que se les diesen hasta que / este que declara viniese e hiziese su quenta con ellos e / le diesen sus cartas de pago y porque tubo por cierto de a / ver de las minas con sus negros yanaconas mucha suma / para poder enbiar más y pagar a sus dueños esta / quantía en caso que su muger lo recibiese e después / hubo poco de las minas como tiene declarado e que / con Francisco de Ruiloba no enbió dineros algunos mas / de darle poder y escreuir al dicho Luis Sánchez Dalbo / le diese lo que allí avía dexado Pero Anzures para / dar a sus dueños que este que declara no truxo oro / ni plata sino deudas que dexó e otras que hizo por el / camino que ha de pagar acá porque lo que en aquella // 
/ 36 r. / probincia tenía de cauallos, acémilas, negros e negras e otras cosas le tomó Gonzalo Pizarro como / dicho tiene e a un plata de servicio e otras cosas que / este que declara tenía en el navío quando en él vino / al puerto de Guaura para se venir con todos los na / víos el e Cueto [sic] ${ }^{9}$ para Panamá que los entregó allí los / dichos nabíos el dicho Diego Alvarez de Cueto y en saltando / en tierra este que declara los soldados que se apo / deraron de los nabíos le saquearon lo que ansí te / nía e después en el mismo nabío bolbió este que / declara sin nada al dicho puerto de los Reyes por / carta de los oydores que le escribieron que se bolbiese / allí que luego le despacharían su residencia e pare / ció que fue para entregarle a Gonzalo Pizarro por / que a pocos días que llegó al puerto le puso capi / tán y guarda de soldados en el dicho nabío y ansí a / unque este que declara tubiera mucha hazienda en el / Perú no pudo tener nada en el navío ni él lo metiera / porque le avía de ser tomado y alzándose como se / alzó de repente con el nabío no podía traer más de / lo que consigo tenía y ansí se vino con lo que te / nía vestido solamente e con la cama en que dormía / y que en Panamá buscó dineros prestados para pa / gar los marineros y comer y en el Nombre de Dios an / simismo vendió un negro y una negra que traya / para que le sirbiesen y en Cartagena y en la Habana / e aún en la Terzera le prestaron dineros lo qual / fue todo en cantidad de la qual e de otras deudas / que traya debe agora muchos dineros e que así / al tiempo que desenbarcó no tubo dineros que aun / en Lisboa vbo de gastar de dineros agenos e questo / es lo que agora puede declarar a esta pregunta de lo / que al presente se acuerda. A las veinte e dos pre / guntas e artículo dixo que no se acuerda cosa cerca de lo que //

/ 36 v. / la pregunta dize. A las veinte e tres preguntas e / artículo dixo que es verdad que en Panamá le fue / noteficada la cédula de que en la dicha pregunta se haze / minción y que no obstante que por virrey y oidores / le avía sido tomada residencia haciendo el Birrey / pesquisa por su parte y los oidores por otra y le a / vían sido dado cargos y que daua en estado de prueba / este que declara cumplió lo contenido en esta cédula / que demás del procurador que tenía en la dicha ciudad de / los Reyes para la dicha residencia que hera un Francisco / de Talabera enbió desde allí de Panamá a un Miguel de / Robles con su poder e que en lo de la quenta de lo que to / caba a hazienda de su Magestad este que declara antes que / partiese de la dicha ciudad de los Reyes e puerto tenía / nonbrado a Diego Mexía para dar las dichas quentas / al contador Zárate y fianzas de vezinos de la dicha / ciudad e del Cuzco muy abonados de dar quenta y pa / gar el alcance si le oviese e demás desto ynbió poder / con el dicho Miguel de Robles para que por una bía o / por otra obiese esto entero efeto. A las veinte e qua / tro preguntas y pusición dixo que no cobró en Panamá / cosa alguna porque lo avía ya cobrado Ruiloba y / no avía nada en poder de Luis Sánchez como dicho tiene / e que si allí él obiera dineros no tomara los dineros / prestados que tiene dicho. A las veinte y cinco preguntas / y artículo dixo que estando este que declara en la / Habana puerto de la ysla de Cuba supo de personas / que llegaron entonzes del puerto de Santiago de la dicha / ysla questaba allí el dicho Francisco de Ruiloba e / que se quería venir al dicho puerto de la Habana y espe / rar nabíos de México para venirse en conpañía dellos / e que después no a sauido si a partido de allí o no y / que en lo demás contenido en la pregunta dize lo que / dicho tiene y que este que declara no a escripto al dicho //

/ 37 r. / Ruiloba ni recibió carta del. A las veinte e seis pre / guntas y artículo dixo que es verdad que estando en el / dicho puerto de la Habana pareciendo a este que declara / que conbenía al

\footnotetext{
${ }^{9}$ Se trataría de un error del copista. Leer "el de Cueto".
} 
servicio de su Magestad que supiese la al / teración y estado de la probincia del Perú e del virrey / e de como venía Francisco Maldonado por mensajero / de Gonzalo Pizarro y del dotor Texada ansimismo en / favor del dicho Gonzalo Pizarro e recibió dineros suyos / de otras cosas que le parecía que convenía supiese / su Magestad contenidas en sus cartas para que sabido lo uno y lo otro pudiese mejor su Magestad y Consejo tener / acordado la demostración que sobre todo convernía / hacer e dar la horden que más a servicio de su Magestad / conviniese acordó de ynbiar mensagero propio con este / despacho y que para esto conpró una carabela y dixo / que no se traxesen otras cartas porque no viniesen / algunas de Francisco Maldonado e del Texada a perso / nas con abisos que no convenía que los tubiesen ni con / ellos se tratase esta negociación ansí por que no diesen / retorno de avisos a los que venían como de abisarse / de lo que les conbenía acá hablar, tratar y res / ponder y fuese esto algún nocumento para no se / entender también los señores del Consejo ni su Magestad e / para desbiar la horden de los despachos que aque / llos trayan y que otras cartas no ynpidió que vi / niesen antes habló a Cueto e a otro hidalgo que venía / en su conpañía si quería scriuir o enbiar despachos a / su Magestad ansí de los que escribía el virrey como de los / que él quisiese escribir y enbiar y que al dicho mensajero que / vino en la dicha carabela ni le mandó ni se trató ni habló / ni pensó que avía de venir ni biniesen a Portugal / sino derecho a Sevilla e ansí traya cartas deste que / declara para personas de Sevilla así de la Casa de la / Contratación como para otras y que lo que ha sabido del //

/ 37 v. / dicho mensajero porque vino a Lisboa es porque en el camino / con tiempo contrario se les quebró el mástel y la antena y ron / pieron las velas e que con esto les rebatió el ayre las / corrientes por no poder forcejar con belas hazia la parte / de Portugal y que la primera tierra que vieron fue la roca / que está cerca de Lisboa y que aunque después quisieron / de allí bolber a Sevilla tuvieron tiempo contrario para no / lo poder hazer e que lo mismo dixeron e contaron a / este que declara en Lisboa el piloto e marineros que traje / ron la dicha carabela y al dicho mensajero y el dicho men / sajero no traxo oro ni plata ecepto una barrilla de / cinquenta pesos poco más o menos de lo que prestaron / a este que declara en el dicho puerto de la Habana. A / veinte e siete preguntas y artículo dixo que niega / lo contenido en la dicha pregunta porque no es ni pasa / ansí ni avía porqué y para qué se tratase de seme / jantes cosas que lo que pasa es que viniendo juntos / por la mar pasada la canal la flota que heran sie /te navíos una noche ubo tormenta e agua por do se / derramaron los nabíos a lo menos el en que este que / declara venía que traía un Juan Rodríguez Mon /dragón piloto e otro de la conserba que se adelantó / algo más del en que venía este que declara que se llamaba / del Zarco y que quando amaneció la nao deste que depo / ne se halló sola sin ver navío alguno de la conserba / e por si caso viniesen atrás y no venir sin el armada / esperaron casi un día mar al trabés teniéndose a la re / linga y que ansí lo negoció este que declara y el mismo / maestre y piloto lo tenían gana por asegurarlo que tra / yan en su navío y no lo lleuar a su riesgo y como no / parecieron pensando que yrían adelante se acordó que / fuesen a la Tercera donde se avía platicado que avía / de yr toda la flota porque se tenía por cierto que abía / de ser allí avisado el capitán por el Consejo de lo que //

/ 38 r. / avía de hazer si bernía así o esperaría otra conpa / ñía y para que sino fuese llegada la flota o armada es / perarle allí y que llegados a la tierra visto que no estaban / allí los nabíos los esperaron cinco o seis días e ansí le / convenía a este que declara hazerlo porque no le convenía / yr a Seuilla porque tenía avisos por cartas que algunas per / zonas apasionadas de parientes suyos que se avían muerto / en el ronpimiento con don Diego e otras por justicia le espe / raban para le matar como 
pudiesen y tenía este que declara / palabra del capitán del armada de que le hecharía en otro puer / to de la costa de España e por esto le convenía como dicho es / esperarla y visto que no venía y que se dixo que avían vis / to pasar ciertas naos lejos del puerto trató este que de / clara con el dicho Juan Rodríguez piloto que le traía que le / hiziese gracia de hecharle en Palos y nunca lo pudo acabar / con él aunque otras vezes y esta se lo rogó y por esto y / escusar el dicho ynconbiniente se vino a Lisboa a donde no / estubo más de un día y luego se partió derecho a esta corte e / que de allí a Lisboa hera el nabío en que se fletó en la tierra / y que no se acuerda del nombre del maestre ny piloto más / de que hera un navío que venía de Santo Tomé con negros / y en que tenía compañía y parte Lucas Giraldo de la Fetate / vezino de Lisboa y Vanco allí y que le parece aunque / no se acuerda bien que se llamaba el nabío de la Concepción / que tenía en la popa un corredor con barandas tan ancho / como es la popa por de fuera que sería de porte de más / de docientos toneles y el que venía por piloto hera un / onbre de poca vista. A las veinte e ocho preguntas e / artículo dixo que dize lo que dicho tiene y que en Lis / boa no metió oro ni plata eceto unos platillos en que / comía y que antes de una barrilla que traya Arguello / de encomienda comió hasta acá y lo demás niega. / A las treinta preguntas y artículo dixo que dize lo / que dicho tiene y lo demás niega porque no pasa cosa //

/ 38 v. / alguna de lo en ella contenido. A las treinta e / una preguntas e artículo dixo que este que declara des / pués de la sentencia que dio principal no fue juez de / la causa del dicho don Diego sino el licenciado de la Gama / su teniente e que cree que se tardaría tanto / en su determinación y de otros que se prendie / ron con él por sauer mejor e averiguar quién es e / quáles e por qué consejos se auía hecho la muerte del / marqués Pizarro y verificar lo que se dezía que te / nía tratos con Francia e otras semejantes y que no / tiene más que declarar a esta pregunta e que los / procesos y juezes darán razón de lo que en ello pasa. / A las treinta e dos preguntas e artículo dixo que / saue que el dicho don Diego de Almagro tenía concertado / de yrse para Mango Ynga y que este que declara / con la deligencia que tenía de hazer lo que hera obligado / a su oficio lo vino a sauer y lo remedió e que / no sabe otra cosa. A las treinta y tres preguntas e / artículo dixo que cree este que declara que si el dicho / don Diego de Almagro se soltará pudiera subceder yn / conbinientes pero que no saue que tales ni tantos ni / quantos y esto es lo que dize. A las treinta y quatro / preguntas y artículo dixo que antes del ronpimiento / estaban probeidos los yndios del dicho don Diego a / Pero Álvarez Holguín por este que delara por estar / vacos por los delitos que avían cometido el dicho / don Diego e que por muerte del Pedro Álvarez pusso / este que declara parte dellos en su cabeza como dicho tiene / y los otros repartió e que el dicho don Diego no los pose / ya ni gozaba para que se obiese respeto a lo con / tenido en esta pregunta y que antes si el dicho don Diego / poseyera los indios le convenía a este que declara para / gozar demás tiempo los tributos de los yndios que se / hiziera brevemente justicia del dicho don Diego y que an / tes por la dilación perdía que es al rebés de lo que //

/ 39 r. / la pregunta dize y que en lo demás dize lo que dicho tiene. / A las treinta e cinco preguntas y artículo dixo que es ver / dad quel dicho Diego Méndez estuvo preso y hera de los / principales capitanes del don Diego, puesto que no pa / reció aver sido de los matadores del marqués. A las tre / ynta y seis preguntas y artículo dixo que mucho antes / del ronpimiento estauan dados estos yndios del Diego / Méndez al capitán Castro por Pero Álvarez Holguín e después / por este que declara porque convenía gratificar y conten / tar al dicho capitán ansí porque fue requerido con car / tas e dineros del dicho don Diego y no se quiso juntar con él / antes juntó consigo la gente que pudo y 
vino con los / dichos capitanes Pero Álvarez, Peranzures y Garcilaso / en busca deste que declara para seruir a su Magestad y el / dicho capitán Castro poseía los dichos yndios cree que / antes del ronpimiento y poseyolos después hasta que / murió por manera que el dicho Diego Méndez no tenía yndios ni los / poseya el tiempo que estuvo preso y por muerte del dicho capitán / Castro vacaron los dichos yndios y los puso este que / declara en su cabeza como dicho tiene e dio parte dellos / cierto seruidor de su Magestad y que aún destos indios tenía / por cédula la mitad o mucha parte Pedro de León la / qual cédula hera del marqués y que no rentaban lo contado / en esta pregunta y que este que declara no dilató la pri / sión del dicho Diego Méndez ni fue juez de la causa sino el / dicho licenciado de la Gama su teniente e que si se dilató su / negocio sería por los respetos que tiene dichos y por otras / causas justas e que saue que el dicho Diego Méndez hera / cuñado del dicho Blas de Saabedra y lo demás niega por / que no pasa cosa alguna de lo en la pregunta contenido e / cepto que cierta carta que escribió el dicho Blas de Saabedra / no se acuerda bien si hablaba en favor deste, cree que sí, la /qual recibió después de dexado el oficio y queste que de / clara ni no sirve ni es persona que delata por los respetos con / tenydos en la pregunta, causas, ni dexa de hazer justicia. A //

/ 39 v. / las treinta e siete preguntas y artículo dixo que le nie / ga porque no pasa lo en ella contenido ni cosa alguna dello / porque a este que declara no vinieron hordenanzas que de / acá se le enviasen ni cosa cerca desto que a él fuese / auténtica más de dezirse que avía un treslado de cosas / que acá se avían probeido por hordenanzas contando de las / cosas y particularidades en ella contenidas más que este / que declara no las leyó y que después desto no vbo yndios / vacos ni bacaron en la tierra que este que declara probeyese / ni proveyó ecepto los yndios que tenía en su cabeza que / por cumplir lo que a la gente de guerra avía prometido / en Guaraz cuando todos le obedecieron por gobernador / que hiziesen servicio a su Magestad en reduzir aquellos Rey / nos a su servicio que él les repartiría los yndios que / oviese bacos en la tierra e por cumplir ellos como cun / plieron de su parte para cumplir del todo lo que en nonbre / de su Magestad les avía prometido dio lo que quedó en cabe / za deste que declara y que ansimismo le fue necesario / porque la compañía de gente que con él venía quando salió / del Cuzco tan desesperada que cree este que declara / que corriera algund peligro si no hiziera el dicho cumplimiento / y lo demás contenido en la dicha pregunta niega. A las treinta e ocho preguntas e artículo dixo que la niega / que no pasa lo en ella contenido ecepto que del dicho Juan / de Larrea se conpró una copilla para este que declara / por cierto criado suyo que podía valer de buen oro de / quarenta y cinco a cinquenta pesos e se le dio por ella al / dicho Juan de Larrea sesenta e tantos o setenta pesos / de oro. A las treinta e nuebe preguntas y artículo / dixo que niega como en ella se contiene porque no pasa / cosa alguna de lo en ella contenido. A la quarenta pre / gunta y artículo dixo que es verdad que el dicho Pedro / de Vergara hera capitán deste que declara y le dio / un cauallo y por darle contentamiento e amorarle a / que mejor sirbiese lo reciuió y lo dio después a un criado deste que //

/ 40 r. / declara porque no hera para él y dio después al dicho / Vergara otro cauallo de mucho más valor. A las quarenta / y una preguntas e artículo dixo que la niega porque / no pasó cosa de lo en ella contenido y que de un Sebastián / de la Gama compró este que declara un cauallo dándole otro / puesto un tasador vezino e alcalde de la ciudad de San / Miguel y que aquel tasó que le diese este que declara sobre / su cauallo quatrocientos castellanos e que este que declara / fue muy agrauiado en esto en mucha suma porque poco / antes el dicho Sebastián de la Gama lo daba al licenciado / León en trecientos y veinte pesos y que no obstante es / to le pagó luego los dichos quatrocientos 
pesos y el / dicho cauallo que por lo menos valía dozientos por / manera que salió conprado en seis cientos castellanos / e que lo demás niega como dicho tiene y que la misma pre / gunta se confunde por su contradición. A las quarenta e dos preguntas y artículo dixo que la niega como en ella se contiene porque nunca dio yndios algunos en San Miguel / ni los que la pregunta dize al dicho Diego de Aller ni a / Diego de Aller por ningund beneficio que este que de / clara le hiciera le auía de cobrar gracias porque le a / vía llevado de Castilla y le envió por mensajero a su / Magestad a su trauaxo y costa en que los yndios que le dio es / tán al pie de más de trecientas y cinquenta leguas de Piura / y San Miguel que fueron los que heran de Antonio de Oriuela / a quien mató don Diego y vacaron por su muerte los quales / le dio libremente como este que declara dio y encomendó / todo lo demás en aquella tierra y que los yndios del / Bernal que la pregunta dize se dieron a un Grejeda por aver / seruido a su Magestad. A las quarenta e tres preguntas e ar / tículo dixo que la niega porque no pasa ansy y que un criado deste que declara conpró al dicho Porcel una sortija / en lo que un platero jurado tasó que valía e le fue pagado / la tasa y esto es lo que pasa y no otra cosa. A las quarenta e //

/ 40 v. / quatro preguntas e artículo dixo que la niega que nun / ca tal pasó y que la pregunta se contradize porque el dicho Per / Anzures lleuó preso al dicho Santiago desde San Miguel a / Truxillo y a la ciudad de los Reyes por mandado deste que / declara. A las quarenta e cinco preguntas y artículo di / xo que la niega que no consintía este que declara que se / tratasen ansí los yndios y porque se dixo que cierta persona / que avía ydo a los yndios de Diego de Aller les hazía / alguna vejación, envió luego un escriuano que sacase la / pesquisa y hallose sin culpa que después tornó a enviar / a ello a un Gerónimo de Villegas y halló lo mismo. A las qua / renta y seis preguntas e artículo dixo que la niega que / no pasa cosa alguna de lo en ella contenido porque / no se hallara con verdad queste que declara aya / reciuido todo el tiempo que fue gobernador de aquella pro / bincia peso de oro ni plata, ni piedra dádiva graciosa. / A las quarenta e siete preguntas e artículo dixo / que la niega porque no reciuió del dicho Diego de Mora / cosa alguna por sí ni por ynterpósita persona ecepto / que pasando de camino por Truxillo dio en su posada el dicho / Diego de Mora a donde este que declara posó, dos azunbres de vino / poco más o menos e después en otro pueblo adelante / se mandó dar e se le dio una botija entera por ello. A las / quarenta e ocho preguntas e artículo dixo que la niega / porque no pasó en ella contenido ni tal se abía de / hazer en la probincia ni pensarlo. A las quarenta e nueve / preguntas e artículo dixo que lo niega que no había de hazer / cosa de lo que la pregunta dize ni pensalla, e que antes / gastó este que declara dineros con algunos que nombró / por tenientes y capitanes y encomendaua otros cargos / e oficios a unos dándoles e a otros teniendo en su / casa a su costa e a otros dándoles de su hazienda que / comiesen durante su oficio. A las cinquenta pregun / tas e artículo dixo que la niega porque lo en ella contenido //

/ 41 r. / no lo avían de cometer sino onbres infames. A / las cinquenta y una preguntas e artículo dixo que la nie / ga y quél quisiera procurar como procuró por todas las vías / del mundo el acrecentamiento de la hazienda de su Magestad e / ansí lo hizo como se verá por las cuentas quando se / vieren y por las ynformaciones que se tomaron por este que / declara sobre ciertos fraudes que se hizieron en la hazienda / de su Magestad e las hordenanzas que cerca del recaudo de la / hazienda de su Magestad tiene hechas. A las cinquenta e dos / preguntas dixo que niega lo en ella contenido porque / no es ni pasa ansí ni uvo junta de pueblos, ni de procura / dores, ni vecinos dellos, ni otra cosa alguna antes / este que declara tubo mucho cuidado y puso toda / la deligencia posible en que 
cierto murmullo que hubo en / la ciudad del Cuzco quando llegó a la ciudad de los Reyes / cierto traslado de las dichas hordenanzas que este que / declara no leyó y fueron de la ciudad de los Reyes dos / personas a la del Cuzco con carta para este que declara / e para el cauildo sobre que hiziesen cierto seruicio a / su Magestad para que les hiziese merced de remediar algunas / cosas que de las hordenanzas les estaua mal cesase / proveyendo que los alcaldes y teniente y aun los regidores / saliesen por el pueblo y si hallase que alguno habla / va desacatadamente cerca de lo que se dezía que su Magestad / avía probeído que lo hiziesen sauer a este que de / claria [sic] que él ahorcaría a los que en ello hablasen e / haría quenta que ganaba otra vez el reino al Rey e cas / tigar tales desacatos y con esto cesó todo como si / no se oviera tratado de cosa de las susodichas e res / pondió a la ciudad de los Reyes entre otras cosas que / les dezía sobre el obedecer e cumplir lo que su Magestad man / dase reprehendiendo e ansí lo dixo a las dichas personas / que vinieron al Cuzco que porque avían juntado vezinos / de la ciudad de los Reyes para les dar noticia de las dichas hor //

/ 41 v. / denanzas porque aquello no hera buena horden / ni seruicio de su Magestad y demás desto siempre tractó e habló / como se obedeciesen y justificándolas por todas las vías quél podía y sabía hasta mostrar ley de romana pu / blicamente por donde entendiesen que su Magestad conforme / a derecho podía quitarles los yndios y estrecharles / en lo que en esto fuese seruido presupuesto culpas que / de su parte les proponía de malos tratamientos de yn / dios, e que obedecido que lo que su Magestad mandase podían / suplicar e yr a su Magestad que príncipe tan cristianíssimo hera / que si en alguna cosa reciuiese agrauio les haría merced / de lo mandar enmendar y para mexor execución de / todo lo que su Magestad proveyó vino este que declara / con deligencia del Cuzco a reciuir a la persona que fuese / por Virrey porque le avía su Magestad escripto que en ha / llándose persona en quien concurriese las calidades / necesarias la enviaría e ansí antes que llegase a la ciu / dad de los Reyes supo como hera desenbarcado / Blasco Núñez Vela y le fue noteficada la provisión que / llevó de Visorrey con cierto testimonio que ynbió / y aunque fue treslado y no espacificaba la goberna / ción de Toledo sino de Castilla la obedeció así para / Toledo como para Castilla porque entendió que de / vía de ser esta la voluntad de su Magestad y por el deseo que / tenía de venirse a su casa y que en la dicha ciudad de / los Reyes entendió que no estauan en recibir al / Virrey actualmente y este que declara puso la mano / en ello aunque estaua sin el cargo por tal vía que / cesó todo e se hizo el recebimiento con la obidiencia e / acatamiento que debía y ansí fue reciuido en todos los / pueblos del Reyno ecepto en lo del Cuzco que este que / declara no saue porque nunca llegó allá probissión / suya queste que declara sepa por manera que hizo a / dolo que pudo y debió para que se obedeciese y cumpliese //

/ 42 r. / lo que su Magestad mandaua e su Virrey fuese resciuido e / obedezido y este que declara se pudiese venir a su casa e / que no tenía este que declara para qué pretender otra cosa / ni dilatar su estada, porque los yndios que tenía en su cabeza / antes que supiese de la venida del Virrey los tenía dados / y en los cinco mil ducados no avía para gasto de tres / meses y por muchos respetos que son claros tanto que no / tiene que hablar más sobre esto. A las cinquenta e / tres preguntas y artículo dixo que la niega que no pasa co / mo en ella se dize porque la causa y causas porque se de / tuvieron los navíos fueron necesarias y cunplideras al / seruicio de su Magestad que son las siguientes: una para que / durante la guerra con don Diego de Almagro y su gente y / secazes si por otro camyno del que yba este que declara / torciese su camyno el dicho don Diego e capitanes suyos / para la ciudad de los Reyes tuviesen los vezinos y / estantes en la dicha ciudad en que se acoger e salvar sus / personas, hijos y mugeres y haziendas de que se tenía mu / cho temor en la dicha 
ciudad, así porque capitanes del dicho / don Diego avían robado otros pueblos como porque / su carta los tenía amenazados porque avían reciuido / a este que declara por gobernador y ansí por sospecha / e o nueva que obieron en la dicha ciudad de los Reyes que / don Diego y sus capitanes venían sobre la dicha ciudad, se / fueron a los dichos navíos los de la dicha ciudad y se reco / gieron en ellos con sus haciendas. Otra porque si este que / declara y su gente fueron desbaratados y subce / diese el negocio de tal manera que conviniese retirarse / e apartarse lejos lo pidiesen hazer por la mar pa / ra lo qual hera menester los dichos navíos. Otra por / que los oydores de Panamá escribieron a este que de / clara una carta por audiencia en que le dezían e / hazían sauer como tenyan aviso de acá de España / por una carabela que llegó al Nombre de Dios //

/ 42 v. / como abían enbocado por el Estrecho de Magallanes diez / nauíos de armada franceses que se lo hazían sauer para / que pusiese recaudo en aquellos reinos e costa e que / después de reciuida esta carta vinieron personas al Cuzco / a donde este que declara a la sazón estaua que dezían / que por muchos yndios se auía sauido como venían hazia / la parte de Chile que es hazia la banda del dicho estrecho na / víos por la mar y gente por la tierra e que no hablauan como / los españoles e tras estos vinieron otros y cartas que / escribieron a este que declara de las minas de Tarapacá ques / hazia aquella parte de lo mismo e como dezían que no ha / blaban como los españoles tubiéronse por franceses e por esta causa fue necesario que los nabíos estubiesen en defensa de los puertos hasta saber la verdad. Otra que concurría con esto que según dizen algunos testigos / en las probanzas que se hizieron sobre los delitos / de don Diego y su gente tenían concertado de tratar / con Francia y se ayudar para su defensa. Otra que / en este tiempo se supo la nueba guerra que avían yn / bentado el rey de Francia contra su Magestad y por las dichas / causas fue necesario como dicho es detener e se detu / vieron los dichos nabíos que fueron pocos meses por / que sabida la verdad de lo susodicho luego se les dio lu / gar para que se fuesen y no fue por las causas que la / pregunta dize que no fue ni pasan ansí e que en estos meses en los dichos nabíos se detubieron que fue desde / setiembre hasta en fin de henero este que declara no a / vía gozado de yndios e aunque los gozara entendien / do como entendía que justa y necesariamente como / tiene dicho en las preguntas antes desta no tenía ni a / vía causa para dilatar que su Magestad lo supiese e por / que en las cartas que abía escripto a su Magestad antes desto / daua cuenta como ponía yndios en su cabeza y que de los / otros bacos para su Magestad se cobraua lo que pudo averse //

/ 43 r. / dellos como tiene dicho para su Magestad y que de otros particula / res no avía abido nada ni lo avía de auer por no ser justo / ni cosa hazedera para este que declara y por esto no tenía que / encubrir e muy menos por los excesos que la pregunta / dize que avía cometido porque este que declara no es / persona que ha de cometer delitos y excesos aunque co / mo onbre pudiese hazer alguna negligencia o herror an / tes le conbenía e conbiniera mucho a este que declara que / viniesen cartas suyas e de todos los que dixesen ver / dad en la tierra para que su Magestad fuese ynformado de / los grandes serbicios que le avía hecho ansí en ganar a / quella tierra de gente que tan apoderada estaua sin ha / llar quando a la tierra llegó ni aber con qué ni con quién / e en las otras cosas que a su Magestad sirbió que dicho e / declarado tiene sin otros muchos que a dexado de de / zir y que para sauer su Magestad lo que en la probincia pa / saba y poder escribir todos los que quisiesen sienpre / hubo nabíos que partiesen de brebe tiempo a tiempo / ansí quando partió Diego de Aller mensagero deste / que declara como quando vinieron Villalobos e / fray Francisco Martínez como quando enbió este que / declara nabío a la Puná que pasó para Panamá y / esto es lo que responde a esta pregunta. A las cinquenta / y quatro preguntas y artículo dixo que la niega que 
si / alguna cosa escribió o dixo que se diesen acá sería a / algunos para que se tomasen en quenta de quantía / deste que declara les avía de dar y les debía y a otros / por gratitud de amistad o de buenas obras recibidas / como deue hazer qualquier cauallero y onbre de bien y no / por causas de las contenidas en la pregunta porque no a / vía este que declara cometido culpa sino seruicios como / dicho tiene que de los poderes para recusar que la / pregunta dize este que declara no tiene memoria más que / podría ser ansí que otorgase poderes generales sin tratar //

/ 43 v. / del porqué ni para qué más de que si fuese necesario / oviese acá poderes generales como suele hazer qual / quier onbre que pretende tener negocios y pleitos e / causas e lo demás niega fuele mostrado por el señor / licenciado Salmerón al dicho licenciado Vaca de Castro / un memorial que comienza en la margen de arriba lo que / llebaron el padre fray Francisco Martínez e Alonso / de Villalobos para dar a doña María de Quiñones mi muger fecho en la ciudad de los Reyes a ocho de / setienbre de mil e quinientos e quarenta e dos a / ños que está escrito en una hoja e más de media / plana de papel firmado de una firma que dize / el licenciado Vaca de Castro y siéndole mostrado para / que diga e declare si la firma del dicho memorial es / suya e ansimismo la cabeza del que parece estar es / crito de su letra dixo que el comienzo del memorial que / son los quatro renglones primeros son de su letra e / mano y ansimismo la firma dél es suya y este que / declara la hizo y firmó e por tal la reconoció e que / este que declara enbiaba lo en el dicho memorial conte / nido con los susodichos, fuele mostrado otro memorial / e quenta que está escrito en un pliego y media plana de otro pliego de papel que está firmado de dos / nombres, quel uno dize Francisco Bezerra y el otro / Juan de Carranza que comienza en primero día del / mes de henero de mil e quinientos e quarenta e / tres y acaba en la misma data que parece ser un / memorial de lo que Francisco Bezerra e Juan de Carran / za recibieron de Antonio de Quiñones camarero del / dicho licenciado Vaca de Castro e siendo preguntado si las / firmas que en él están si son de los dichos Juan de Ca / rranza e Francisco Bezerra y si lo contenido en el dicho / memorial es verdad y si lo contenido en el dicho / memorial es verdad e pasa ansí dixo que las dichas / firmas las tiene por de los susodichos e que tiene por verdad //

/ 44 r. / quellos recibieron lo en el dicho memorial contenido e / puesto que en el dicho memorial e cuenta se dize / que se acusa con lo en el contenido a la dicha doña María / de Quiñones después de aver cumplido ciertas partidas / que casi todo lo demás heran dineros agenos como de / clarado tiene e que las cosas que por el dicho memorial / parece que se probeya que se diesen al Comendador mayor / y al secretario Juan de Sámano hera por la quenta de lo / que este que declara cobraba por ellos como dicho tiene, / fuele mostrada una carta mensajera que está escripta / en quatro hojas de papel que comienza señora porque / sé la pena en que estará vuestra merced su hecha a [en blanco en el original] de marzo de / mil e quinientos e quarenta y tres años que los días / está así en blanco firmada de un nonbre que dize / el licenciado Vaca de Castro e siendo preguntado si la letra / y firma de la dicha carta es suya / y la escriuió y firmó / dixo que es verdad que la letra y firma de la dicha / carta es deste que declara y la escribió y firmó e por / tal la reconoce e que la causa porque en la dicha car / ta representaba todo lo que allí dize ser suyo e / daua demostración de mucho acrecentamiento en a / quella probincia hera por contentamiento de su casa y / muger y que sufriese su ausencia con menos pena e / con plazer e por otros respetos buenos sin que dellos / naciese ofensa a su Magestad ni a lo que este que declara / debía a su seruicio los quales declarará siendo ne / cesario, fuele mostrado otro memorial que venía dentro / de la dicha carta mensajera escripto en una hoja de papel / que comienza Memorial de lo que lleuó Diego de Aller / para dar a 
doña María de Quiñones mi muger en Valladolid / que está firmado de un nonbre que dize el licenciado / Vaca de Castro y siendo preguntado si la letra y firma / del dicho memorial es suya dixo que la letra y firma //

/ $44 \mathrm{v}$. / del dicho memorial es deste que declara e que por / tal le reconoce, fuele mostrada una cuenta e memorial / que está escripta en quatro hojas enteras de papel firma / da de un nombre que dize Pero Anzures que comienza / Miércoles veinte e uno de hebrero de mil e quinientos / e quarenta e tres años reciuí yo el capitán Pero Anzures / de vos Antonio de Quiñones camarero del Ilustre Señor / el licenciado Vaca de Castro gobernador destos reynos / y en su nombre y acaba entiéndese que van a risgo del / gobernador mi señor por mar e tierra dixo que / este que declara tiene poder del dicho capitán Pero An / zures la firma en el dicho memorial contenida y que cree / que tiene por cierto que él reciuió todo lo en él con / tenido y que como dicho tiene esto y lo demás es ageno / y que lo que de las dichas partidas y cartas quentas de / Vezerra y Pero Anzures hera deste que declara bolbió / a la ciudad de los Reyes para hazer satisfacción / a los dichos nabíos en nonbre de su Magestad y si algo que / dó este que declara no fue mucha quantía que no / la sabría declarar al presente escripto las vasijas / e cosas que trayan que heran conpradas de sus dineros / en lo qual se remite ansimismo a lo que dicho tiene, fue / le mostrado una ynstrución y memorial que está escripta / en diez hojas de papel firmada de un nonbre que dize / el licenciado Vaca de Castro que comienza para que vos el / señor capitán Pero Anzures bays mexor adbertido en las / cosas de la jornada a que vais a España etcétera y acaba y / pleito se declare que no los dé y siendo preguntado si la / firma de la dicha ynstrución es del dicho licenciado Vaca de / Castro y la dio al dicho capitán Pero Anzures, dixo que / la firma de que está firmada la dicha ynstrución es des / te que declara y él la hizo e que de lo contenido en la dicha / ynstrución no puede dar certidunbre porque no se acuerda / averla leído sino que como la hordenó Francisco Paez / que tenía cargo desto en su casa la firmaría este que declara //

/ 45 r. / porque las ocupaciones heran tantas que no se pornía a / leer tanta cosa, fuele mostrado una memoria o ynstrución / que está escripta en una oja entera de un pliego de papel / que comienza las ventas de que se trataua quando yo salí de / España en que vos el señor capián Pero Anzures podéis en / tender son las siguientes y acaba y querra vender algo / para ello e siendo preguntado si el hordenó e hizo el dicho / memorial e si lo entregó al dicho capitán Pero Anzures dixo / que no se acuerda aver hordenado ni hecho el dicho memorial / más que de que está escripto de letra del dicho Francisco Paez e / queste que declara diría que hiziese alguna memoria de co / sas que doña María su muger pudiese acá comprar por / los respetos que dize aver rescripto la carta y que a este / fin y efeto se haría el dicho memorial, fueronle mostrados / dos poderes que parece aver otorgado el dicho licenciado / Vaca de Castro ante Francisco Paez escriuano de quien están / signados y firmados de un nonbre que dize el licenciado / Vaca de Castro, el uno para el dicho capitán Pero An / zures para cobrar e tomar quentas e revocar otros / poderes y el otro para cobrar deudas en sustancia dixo / queste que declara otorgó los dichos poderes ante el dicho / escriuano, fuele mostrado un memorial e cuenta questá / escripto en tres planas de un pliego de papel firmado / de un nonbre que dize Luis Sanchez Dalvo y comienza / Digo yo Luis Sanchez Dalvo que recibí del señor ca / pitán Peranzures de Canpo Redondo las barras de oro siguientes / etcétera y acaba fecha en el Nombre de Dios a diez e ocho de / agosto de mil e quinientos y quarenta y tres años e / siendo preguntado de la firma del dicho memorial e / cuenta es del dicho Luis Sanchez Dalvo e si es verdad lo / en ella contenido dixo que no lo saue ni lo avía visto has / ta agora más de que Pero 
Anzures escribió a este que / declara que no traya acá a España todo lo que se le / avía dado porque dexaba parte dello en poder / de Luis Sanchez Dalbo a dispusición deste que declara, //

/ 45 v. / fue preguntado diga e declare qué dineros, oro y plata / piedras, joyas e otras cosas dexó en las dichas pro / bincias del Perú e otras partes de las Yndias público / y secretamente suyos y en poder de qué personas, dixo / que ninguna barra de oro ni plata ni tejuelo ni piedra ni / joya dexó este que declara suya en aquella probincia / ni en otra parte, ecepto cierta plata que le fue setres / tada $[\text { sic }]^{10}$ por el virrey Blasco Núñez Bela e después se alzó / el secreto e se puso en poder de Bobadilla estante /en los Reyes e que la cantidad della podría valer a lo que / le parece hasta dos mil pesos e que el dicho Bobadilla dio a / este que declara ya pagado por él en cosas que fueron ne / cesarias al tiempo de su residencia y algunas en servicio de / su Magestad e descargo de su conciencia real cree que hasta / quatro mil e quinientos pesos e demás desto quedó / a deber otras debdas de servicios de criados como / tiene dicho en suma de más de quatro mil castellanos / sin lo que se enpeñó para alzarse con el nabío que su Magestad / fue tan servido y en venir hasta esta villa demás / de otras deudas que trae para pagar acá que podrán / sumar hasta cinco o seis mil pesos e que estos son los / thesoros que este que declara tiene y no se acuerda de otra / cosa por el presente, fue preguntado si demás de lo que / declarado tiene que enbió a estos reinos con Diego de / Aller y Villalobos y fray Francisco Martínez e Carran / za y Francisco Bezerra y capitán Pero Anzures si en / bió con otras algunas personas otras cantidades de oro / y plata, piedras e joyas y otras cosas pública o secre / tamente y con quién, dixo que no abía enbiado otra cosa / alguna más de lo que tiene dicho y parece por los dichos me / moriales que tiene declarado y siéndole leído esta dicha / su confisión de verbo ad berbun como en ella se contiene / dixo este que declara que lo que en ella a dicho e decla / rado es la verdad y lo que a pasado y no otra cosa alguna / y que en ello se afirmaua y afirmó, ratificaua e ratificó //

/ 46 r. / e firmólo de su nonbre e porque al fin de la segunda pregun / ta dixo que creía que se le auía dado por cargo en la residen / cia lo tocante a lo en ella contenido que después se a acordado / e saue que no le fue esto puesto por cargo va escripto entre / reglones en esta confisión lo siguiente ${ }^{11}$ : o dize dicho en el / memorial, y en las márgenes de la primera plana de la quarta / oja. O diz y puesto que los tributos e pretendía este que declara / pertenecerle por aber podido poner yndios en su cabeza e / aver hecho hasta allí gastos necesarios a la guera e / tiempo en seruicio de su Magestad, y o diz hasta que sabido por su Magestad / proveyese lo que fuese seruido los quales. Y entre renglo / nes y en la margen de la segunda plana de la dicha hoja, o diz / de los dichos yndios vacos de los del marqués queste que / declara puso en su cabeza e pretendía pertenecerle por la / razón suso dicha. Y o diz y aunque pretendía pertenecerle / como dicho es los puso por de su Magestad hasta que sabido / proveyese. Y entre renglones, o diz se acuerda e probeídos / los susodichos ser seis mil pesos de oro más a con Fran / cisco Páez, ordenó. Y entre renglones y en la margen de la / segunda plana de las treze ojas, y que el propósito / fue por confiar éste que declara más de si que no de ninguno / de los dichos oficiales en lo que tocaua al seruicio de su Magestad / y uno dar la marca a uno dellos sólo hasta que traxe / se marca de tres llaues y que luego la traxeron y se la entregó / como dicho tiene. Y entre renglones que se. E que de allí. De / Lisboa dixo los. O setenta. Y a la ciudad de los Reyes / que se tomaron por este que declara ley enmendado dos /

\footnotetext{
${ }^{10}$ Leer "secuestrada".

${ }^{11}$ Notas de salva.
} 
vezes. O diz dicho declara decláralo con que aún sí en el ar / en. Y va testado, o dezía lo siguiente: unibersal luego que ha / ensy conforme a un capi [tulo] dando trato co. que se remite / al libro que Gaspar Gil vezino y por su Magestad [sic $]^{12}$ por de su Magestad / y por de. Dos. Anse un mes que demás desto el pudo po / ner los dichos yndios en su cabeza podía y de en caso testigo / se acu. Estaban todos contentos e dado dineros. Ge. Po. No / hera. Nes. Conforme a llegar de quedó original en el proceso //

/ 46 v. / ro. Se quedó cerca de la artillería de su Magestad y sosegar a los / vezinos ques cada un y que lo que con heditos y pregones de / Toledo mandó de e se conpraron por testigo que avía que los yndios / de los de Francisco sentenciado este que decla[ra] parte en el, se que / antes. Dexa. Y que de dando. Quando fu. Los. Antes y des / pués de la. Prisión de justo. No es persona más los contenidos / en la pregunta dichos cosa graciosa. A las cinquenta preguntas / y artículo dixo dize aviendo y venido a la ciudad de los Re / yes porque vio alguna manera para el dicho. Pu. De cómo. V. / contra su Magestad estos dexaba e que por esto el licenciado Vaca / de Castro pasó ante mí el dicho Martín de Ramoyn. Después / de lo qual los del dicho nuestro Consejo de las Yndias mandaron / dar traslado de las dichas acusaciones al dicho licenciado Va / ca de Castro el qual por una petición que presentó dixo / que las dichas acusaciones ni algunas dellas no heran hechas / por parte bastante ny abiendo delator ni precediendo / delación y fianzas conforme a las leyes destos rey / nos ni heran puestos en forma ni segund e como de / vían y heran generales y confusas e tales que no de / vían ser admitidas y la relación que hazía el dicho nuestro / fiscal no hera cierta ni verdadera e a mayor abundamiento / la negaua en todo y por todo como en ella se contenía por / que el hecho en realidad de verdad pasaba como él / lo tenía dicho y declarado ante el dicho licenciado Salmerón del / nuestro Consejo a que se refería lo qual de nuevo dezía e / respondía a cada uno de los dichos capítulos y aquello / mismo ponía por execiones y nos pedía y suplicaba / que pronunciando el dicho nuestro Fiscal no ser parte e sus a / cusaciones no proceder le mandásemos asolber de la yns / tancia e donde esto cesase fuese dado por libre e quito de / todo lo en contrario acusado y pedido e ynponer sobre ello / perpetuo silencio al dicho nuestro fiscal al qual mandásemos / condenar en treinta mil e novecientos y nobenta e nueve / pesos e quatro tomines que alcanzaba en la data de sus quentas //

/ 47 r. / e avía gastado en nuestro seruicio en reducir y ganar / los reynos del Perú de poder de don Diego de Almagro y sus / secazes y en los sustentar y pacificar y ganar otros / de nuevo segund paraecía por las cuentas y probanzas y / escrituras que presentaua y en cinco mil ducados que se le / debían de su salario de juez y en el salario de gobernador / de las gobernaciones de la Nueva Castilla e Nuevo Reino / de Toledo del tiempo que avía sido gobernador conforme / al salario que se daua a los gobernadores, don Francisco / Pizarro e adelantado don Diego de Almagro con las dichas / gobernaciones lo qual pedía al dicho nuestro fiscal por bía / de reconvención o mutua petición o como mejor obiese lu / gar de derecho y cerca dello pedía complimiento de justicia por / aquella vía e remedio que le conpetiese e pudiese con / peter e juró en forma que las dichas execiones e recon / bención no ponía maliciosamente e hizo presentación de / dos cartas nuestras enviadas al dicho licenciado Vaca de Cas / tro e de una nuestra cédula e de ciertas cartas de pueblos / y personas particulares de la dicha provincia dirigidas al / dicho licenciado e de cierto testimonio su thenor de lo qual / uno en pos de otro es este que se sigue. El Rey, licenciado / Vaca de Castro

\footnotetext{
${ }^{12}$ Repetido en el original.
} 
del nuestro Consejo cauallero de la horden de Santiago / nuestro gobernador de la probincia del Perú vi vuestras letras / de quinze y diez e seis de noviembre y veinte e uno de diciembre / del año pasado e de veinte e nueve de hebrero del presente / por las quales y por la relación de Diego de Aller vuestro criado / he entendido larga y particularmente todo el subcesso / de vuestro viaje y el estado en que quedaban las cosas de esas / probincias de que he holgado ansí por os llevar Dios en sal / bamiento a cauo de tantas peregrinaciones e trauajos como / porque en vuestra llegada tenemos por cierto esas probincias / se pornán en toda paz y quietud e reducir todo a nuestro / seruicio e ansí parece e lo comenzaua a estar por vuestra pos / trera carta e por la relación del dicho Diego de Aller quando / vuestras cartas llegaron y muchos días antes se sabía acá la //

/ 47 v. / muerte de don Francisco Pizarro nuestro gobernador desa provincia / de que nos desplugo mucho principalmente por le aver / muerto tan desastrada y malamente como por los yn / conbinientes daños e robos que de su muerte an subcedido / en desseruicio de Dios nuestro Señor y nuestro y porque le teníamos / por muy seruidor nuestro y como quiera que segund la confianza / que de vuestra fidelidad, letras y prudencia tenemos somos / cierto que en la execución del a nuestra justicia y en proveer / que hesa tierra esté en toda paz y en la horden que a / servicio de nuestro Señor y nuestro conviene abreis hecho lo / que como buen gobernador e seruidor nuestro sois obligado / todavía por ser esto cosa tan importante a nuestro servicio / vos mandamos y encargamos mucho que así en la execución / de la nuestra justicia e administración della como en la e / xecución de todas las otras cosas que os están cometidas / y vos bieredes que conviene a seruicio de Dios nuestro Señor / y nuestro y buen recaudo de nuestra hazienda las hagáis y probe / ays sin tener respeto a persona particular alguna de acá / ni de allá ni a deudo suyo y solamente tengáis en estos / negocios respeto a la obligación que vos teneis a nuestro / seruicio y hazer bien el oficio de buen gobernador e minis / tro nuestro porque allende de hazer vos en esto conforme / a la confianza que de vos tenemos y sois obligados nos / terniamos por muy desseruido de qualquier falta que / en esto oviese, a las dichas vuestras cartas os mandaré res / ponder particularmente que por la priesa con que he / mandado escribiros esta no se a podido hazer en ella vos / por my servicio tened cuidado de nos avisar del estado de / esas provincias e de todo lo en ellas se ofreciere en / mención a ocho días del mes de agosto de mil e quinientos / e quarenta e dos años, yo el Rey por mandado de su Magestad / Joan de Samano. El Rey, nuestros gobernadores concejos jus / ticias, regidores, caualleros, escuderos, oficiales y omes buenos / ansí de las provincias de la Nueba Castilla llamada Perú y / Toledo como de todas las otras yslas e provincias a ellas //

/ 48 r. / comarcanas y a otras qualesquier personas nuestros súbditos / e naturales de qualquier estado, condición y calidad que sean / e a cada uno de vos ya sabeis y os es notorio como nos man / damos ynbiar por nuestro juez de comisión a las dichas provincias / de la Nueva Castilla y Toledo al licenciado Vaca de Castro del / nuestro Consejo cauallero de la orden de Santiago para que enten / diese en ciertas cosas que por nos le fueron cometidas to / cantes a nuestro seruicio y execución de nuestra justicia al qual man / damos dar probisión y poder nuestro que en casso quel / marqués don Franisco Pizarro nuestro gobernador que fue de la / dicha probincia del Perú falleciese por ser tan constituido / en hedad, él pudiese tener e usar el oficio y cargo de / nuestro gobernador de las dichas provincias administrar la nuestra / justicia en ellas en lo cebil y criminal e hazer todas las / otras cosas que como nuestro gobernador de la dicha provincia / podía e debía hazer e yendo a las dichas provincias / mataron al dicho marqués don Francisco Pizarro por / cuya causa el dicho licenciado Vaca de Castro quedó y está / por nuestro gobernador e justicias de las dichas provincias con / 
forme a la prouisión y poder que de nos tiene por ende yo / vos mandó a todos e cada uno de vos que obedezcáis al dicho / licenciado Vaca de Castro como a nuestro gobernador de las dichas / probincias y le tengáis por tal e useis con el dicho oficio / e cumpláis y executeis los mandamientos y provisiones que / diere en todas las cosas y casos que se ofrecieren y siendo / vos por su parte pedido favor e ayuda vos junteis con / él e con las personas que por él vos fuere mandado con toda / la gente y otras cosas que os pidiese e se lo déis e fagais dar / bien e cumplidamente y en todo lo que se le ofreciere haréis / e cunpliréis lo que debéis e sois obligados a hazer como / vasallos y seruidores nuestros sin que en ello le pongáis ni con / sintáis que le sea puesto escusa ni enpidimento alguno / ni esperar para ello otra mi carta segunda, ni tercera jussion / so pena de ser avidos por traidores y alebes y caer en mal casso //

/ 48 v. / y en las otras penas en que caen e yncurren las personas / que no obedecen ni cunplen lo que les es mandado por sus re / yes e señores naturales. Fecha en la villa de Monzón a ocho / días del mes de agosto de mil e quinientos e quarenta e dos años / Yo el Rey, por mandado de su Magestad, Juan de Samano. El príncipe, Licenciado Vaca de Castro / del nuestro Consejo, cauallero de la horden de Santiago vi vuestra / letra que escribistes al enperador e rey mi señor de Xau / xa en diez e ocho de agosto del año pasado de mil e / quinientos y quarenta e dos con Alonso de Villalobos en que / hazéis larga y particular relación del estado desa tierra / e de lo que os ha subcedido en ella e de la gente que vino a / obedeceros en nuestro nonbre e a juntarse con vos contra / don Diego de Almagro e del número que teníades junto / y los que particularmente se mostrauan seruidores nuestros / y la horden e yndustria que en todo avíades tenido e / como fuiste obedecido en la ciudad de los Reyes / y los robos y excesos, muertes e delitos cometidos por don / Diego e sus secazes y como por su parte vino a vos el / licenciado de la Gama que procuró ser el mensajero por salir / de entre ellos como seruidor nuestro y un Gonzalo Hernández a / deziros que les dexásedes el Nuevo Reyno de Toledo / sin tratar más de cosa alguna pasada y el entretenimiento / que teníades en dalles respuesta hasta llegar cerca / de donde el dicho don Diego e su gente estaban e para probeer / en ello lo que conbiniese al seruicio de su Magestad y finalmente / de todo lo que os avía subcedido hasta entonzes y / la probisión e buen recaudo que avíades hecho para / el remedio y castigo de los culpados y que no pudiese / huyr ninguno y para lo que tocaua al bien conserbación y / paz desa tierra lo qual bí y entendí particularmente e / mucho os agradezco e tengo en seruicio el gran cuydado e / deligencia que en esto avéis tenido y tenéis e de avisarnos / tan largo del estado de las cosas desas partes que bien pare / ze ser guiado y encaminado con la prudencia y buena horden //

/ 49 r. / que se requería para el buen suceso desas cosas e / como de tan buen y fiel criado e seruidor de su Magestad cores / pondiendo a la confianza e fedilidad que de vuestra per / zona a tenido y tiene e yo soy cierto que no a sido / sin gran trauajo e yndustria vuestra e ansí su Magestad terná / memoria de os hazer merced e acrecentar vuestra persona como / vuestros seruicios lo merecen e por estar su Magestad ausente de / estos Reinos se le a enbiado una carta para que tenga / noticia de lo que avéis seruido e trauajado e del buen / subceso que dello se espera e porque antes e después / que vuestra carta llegó se an enbiado a estos reynos algunas / relaciones e cartas dando a entender que vos avéys / dado vatalla a don Diego e desbaratádole y hecho jus / ticia de algunos culpados y por no aver visto carta / vuestra en que nos hagáis relación de lo subcedido ni aver / venydo persona que se hallase presente a ello deseamos / mucho sauerlo y ansí crehemos que lo abréis hecho e que / esos abrán sido castigados como sus culpas y ex / cesos lo ovieren merecido las cartas para las ciu / 
dades del Cuzco y otras desa probincia y capitanes que / dezis que os han obedecido e ayudado en nuestro seruicio / que enbiáys a pedir van con esta agradeciéndoles / lo que an hecho e encargándoles lo continúen e porque / algunas ban en blanco como vos lo serebistes envihirlas e yo e hacerlas e yo dar a quien os pareciere ${ }^{13}$ hezistes / bien avisarnos de lo que dezis que el adelantado / Venalcázar a hecho mostrándose más parte por / don Diego de Almagro que todos los que le syguían e de lo / demás que hizo con el capitán Francisco Núñez re / moviéndole del propósito que lleuaba de yr a vos abi / saros de las cosas que tenían hordenadas el don Diego e / los suyos en lo que dezis que os parece que no conbenía / dividirse desa probincia la probincia de Quito e que es / necesario juntar a la villa del Pasto con la de Quito por las //

/ 49 v. / causas e ynconbinientes que en vuestra carta dezis su / Magestad lo mandará ver e probeer lo que convenga vos / avéis hecho bien avisar dello lo que toca a la / probisión del Obispo del Cuzco questá vaco su Magestad man / dará probeer brebemente perlado qual convenga / ame parecido bien lo que dezis que avéis hecho en / recoger a los hijos del marqués y puesto personas / que los doctrinen y traten como es razón y que los te / neis en la ciudad de Truxillo yo vos agradezco el cuyda / do que dello tubistes por ser el marqués tan buen ser / vidor de su Magestad y ansí mandará tener memoria dellos / e porque como avéis visto por la que su Magestad os mandó / seruir en primero de marzo deste año por las conside / raciones e causas contenidas en su carta acordó de man / dar probeer una audiencia y chancillería real en / esas probincias que resida en la ciudad de los Reyes / en que aya un presidente y quatro oydores e des / pués acá se a entendido en nonbrar para ello per / sonas quales conbienen e por concurrir en Blasco Núñez / Vela las calidades necesarias e ser tan fiel criado / e seruidor de su Magestad le a probeído por su visorrey e / gobernador desas probincias y presidente de la dicha / abdiencia el qual con los oydores que para ello se / nonbraron van a esa audiencia a residir en sus cargos, / vos encargo que como persona que estáis más ynformado / del estado y calidad de las cosas desa tierra e de lo / que en ella conbiene probeer aviséis e adbirtáis de lo / que os pareciere que lo deben ser para que mexor puedan / entender en la gobernación desas probincias e adminis / tración de nuestra justicia y entender en la probissión e / despacho de las cosas del serbicio de Dios nuestro señor y / nuestro bien y oblación dellas y de sus naturales y hecho / esto vos os partiréys y vernéis con la bendición de Dios / a residir en el nuestro Consejo con la más brebedad que ser pueda //

/ 50 r. / a nos ynformar de las cosas desas partes e si por / algunas causas os detubiéredes algunos días en esa pro / bincia vos juntamente con el dicho nuestro virrey e oydores / entraréis a poner en horden e razón la dicha audiencia / e las vezes que os pareciere entréis e residays en ella / e a probeer e determinar las cosas que se ofrecieren / e tengáis voz y voto en lo qual y en el asunto y en to / das las otras preheminencias que allí se requieren vos / prifiráis a los dichos oydores como onbre del nuestro Consejo / que para ello por la presente vos doy poder cumplido de Valladolid a / treze días del mes de septiembre de mil e quinientos y quarenta e tres años Yo el príncipe, por mandado de su alteza, Juan de Sá / mano. Ilustre señor quando a esta ciudad vino Gómez / de Rojas con los despachos de vuestra señoría hezimos lo que / por ellos se nos mandaba y escribimos largo dando quenta / a vuestra señoría del estado desta tierra e diziendo la < marcada > merced que Dios nuestro señor y su Magestad hizo a estos reinos en enbiar / a vuestra señoría a la gobernación y pacificación dellos y esta ciudad / quedó con todo contentamiento como hera razón con las /

\footnotetext{
${ }^{13}$ Vendría a significar "como vos las servistes enviar y yo a hacerlas dar a quien os pareciere".
} 
justicias que en ellas se nonbraron de parte de vuestra señoría e / parece que del camino bolbieron la gente de don Diego de Al / magro a Gómez de Rojas a esta ciudad con los despachos que / llevaba y con mucha copia de gente de armada entrara / en esta ciudad e teniendo opresos e atemorizados a / todos los caualleros deste cabildo hizieron lo que quisie / ron haziendose forziblemente contra la opinión e vo / luntad de todos e contra toda justicia e razón re / cibir e obedecer por gobernador desta tierra y hemos es / tado tan opresos y maltratados nuestras personas e / haciendas e de los vezinos desta ciudad que ninguna / livertad poca ni mucha hemos tenido para poder / avisar a vuestra señoría y hazer lo que héramos obligados / bien crehemos que dello vuestra señoría abrá tenido entera relación / e que terná creydo y entendido que no a sido por nuestra ynsolencia //

/ 50 v. / e descuido ni que nuestros ánimos ayan en un solo punto / tenido pensamiento demás de lo que conviniese al seruicio / de nuestro rey e de vuestra señoría en su nonbre porque después que / en esta ciudad se tubo noticia de la felize venida de / vuestra señoría a estas probincias hemos estado esperando su venida / como aquellos que por medio della consiguen libertad / de sus vidas y haziendas e bibir libres y no como esclabos / en veinte y un días del presente vinieron a esta ciudad dos / o tres personas de la gente de don Diego de Almagro y por / ynsinya alcanzamos a entender que entre su gente y el / exército de vuestra señoría vbo recuentro e que en el vuestra señoría fue vi / torioso y esta gente desbaratada y abaxada su sober / bia y atrebimiento dimos por ello muchas gracias a / Dios pues fue seruido mostrar su justicia contra quien / tantos daños y desasosiegos e muertes a causado en / la tierra e favorecer a vuestra señoría que con tanta retitud / y celo de hazer justicia es venido a ella y estamos muy / gozosos que mediante la dibina voluntad por me / dios de vuestra señoría se ayan quitado los turbios y escuros / nublados que sobre la haz destos reinos estauan pues / tos que ynpidían el beneficio general de la república / e seruicio que a su Magestad como sus vasallos devemos / e aunque por premio de nuestras obras si algunas / buenas emos hecho, nuestro Señor otra merced no nos obiese / fecho, con esta nos tendríamos por bien contentos e remu / nerados luego que esto se supo, esta ciudad se tornó / a reduzir al seruicio de vuestra señoría agora en lo público como / sienpre a estado en lo oculto y probeymos guardas / en el pueblo y se an rendido los que an venido huyen / do e se les tomaron las armas e cauallos especial / mente se tubo nueba que don Diego de Almagro se yva / al Inga e con el Juan Rodríguez Barragán e un Cepeda / e fuimos con el alcalde Antón Ruiz de Guebara en / su seguimiento seys leguas desta ciudad con toda deligencia //

/ 51 r. / e se prendió aunque con mucho trauajo e se traxeron a esta ciu / dad y están en poder del alcalde a muy buen recaudo hasta tanto que / vuestra señoría en buena ora venga a esta ciudad o ynbíe a mandar lo que fuere ser / vido que se haga, crea vuestra señoría que se a hecho muy gran cosa en esta prisión por / que él yba con determinación de se juntar con el Inga e acoger allí los es / pañoles que pudiera de su parcialidad e hazer otra junta con que pusie / ra nuebo escándalo y subcedieran otros ynconbinientes de los pasados. / El alcalde lo a hecho y trauajado tan bien que a mostrado quanto servidor es / de su Magestad y de vuestra señoría lo tenga por tal pues su obra y voluntad lo / merece. Aquí presentó Rodrigo de Salazar una prouisión firmada de / vuestra señoría que dize auerle dexado Gómez de Rojas en que vuestra señoría le haze teniente y ca / pitán desta ciudad y fue reciuido por tal como vuestra señoría lo mandaba, suplicamos / a vuestra señoría con toda brebedad se venga a esta ciudad a descansar de los trauajos / pasados pues de aquí como cabeza destos reynos los podrá mejor / gobernar y probeerá en el estado y quietud dellos que de otra parte y / porque cada día avisaremos a vuestra señoría de lo que subcediere no diremos más / sino 
que estamos esperando su felize venida cuya ylustre persona y casa / guarde nuestro señor y en mayor estado acreciente como los seruidores de / vuestra señoría deseamos. Del Cuzco a veinte y tres de setiembre de vuestra ylustre señoría muy / ciertos seruidores Rodrigo de Salazar, Antonio Ruiz de Guebara, Antonio Altamirano, Bernaldino de Mella, Francisco Manuel del Espinar, por mandado del cabildo del Cuzco, Diego / de Galbez. Ylustre señor ayer se contaron diez e ocho del presente re / cibimos una carta de vuestra señoría hecha de Goamanga a veinte del pasado / por la qual y otras muchas ocasiones que ay quedamos obligados a / seruidores perpetuos de vuestra señoría y a tenerle por padre desta república y li / brador y amparador della a nuestro Señor plega de lo pagar a vuestra señoría en la otra / vida y a su Magestad en esta pues si el tierra tiene vuestra señoría se la a dado porque la / quitó de poder de tiranos porque así como el marqués que en gloria sea la / ganó a los yndios ansí vuestra señoría la a ganado a la gente dicha por lo qual / merece tanto más mérito quanto diferencia auía de los conpetidores y / poseedores dichos no podremos dexar de conocer perpetuamente nos / otros y nuestros hijos auer reciuido de vuestra señoría la obra que recibió el / pueblo de Ysrael de Moysen quando le sacó de la cautibidad de faraón / en lo que vuestra señoría manda que hagamos regocijos y procesiones ello es ansy muy / justo y muchas avíamos hecho abrá quinze días por nuebas que desta //

/ 51 v. / vitoria nos dio Pedro de Heredia y el teniente soltó los presos que en / cárcel auía y en conclusión señor hezimos todo lo a nos posible en lo / que vuestra señoría manda que se tenga espías y gran cuydado que no pasen estos ti / ranos para acá el teniente tiene muy especial cuydado y a tenido de / todo eso y en lo advenydero crehemos hará lo mismo demás desto / sepa vuestra señoría que en esta ciudad ay algunos tratantes que biben dello y nos pro / been esta ciudad y la de los Chachapoyas nosotros y los quales re / civimos mala obra en no dexarlos yr ni vasta nadie con el teniente / para que tal haga, suplicamos a vuestra señoría que de las personas que el teniente se satisfa / ziere devaxo de fianzas y de otras seguridades que él les sabrá / pedir vuestra señoría no permita se pierda el trato sino que se les de licencia de / más desto sepa vuestra señoría como estamos sin yglesia hemos llegado hasta / ochocientos castellanos de penas y limosnas los quales no basta / para el edificio della, suplicamos a vuestra señoría pues su Magestad sienpre en / carga el culto dibino y edificios de sus tenplos de su real hazienda / nos mande ayudar y demás desto mande a los oficiales del rey / que lo que a sobrado de los diezmos los años pasados que será hasta / dozientos o trecientos pesos los den para ayuda a la fábrica, ya / vuestra señoría saue los traubajos que estos pobres yndios de los llanos an / pasado y continamente pasan porque como es este camino por la ciudad de los Reyes tan pasajero en llebar cargas y dar de comer a / caminantes se les ocupa la vida, a vuestra señoría suplicamos pues saue que de / tiempo inmemorial acá estos no son obligados a los seruicios personales / y si nos sirben a nosotros es devaxo de las condiciones que vuestra señoría saue / no permita que más cetos se carguen sino fuere pagándoselo e / con su voluntad porque de lo contrario sería que ellos viniesen en / total destruyción la qual tenemos entendido de vuestra señoría a procurado / e a de procurar de evitar como zeloso del seruicio de nuestro Señor e / de su Magestad nuestro señor la ilustre persona y casa y estado de vuestra señoría guar / de y con el estado que vuestra señoría desea acreciente en su santo seruicio de Truxillo / veinte de otubre de mil y quinientos y quarenta y dos años de vuestra ilustre / señoría muy ciertos seruidores que sus pies y manos besan Diego / de Mora, Diego de Vega, Lorenzo de Ulloa, Francisco de Fuentes, Pedro Gonzales escriuano. / Ylustre y muy magnífico señor yo vine desta ciudad de San Miguel el prin / cipio de la Semana Santa y desde antes de Payta me dio el mal de // 
/ 52 r. / la tierra que he pensado perder un ojo y ansí por esto como por visi / tar esta yglesia y ciudad y tanbién la de Truxillo y de para alguna horden / en las cosas espirituales que me parece ques bien menester me deterné algo / de todo me despacharé presto de manera que para quinze o veynte de / mayo estaré en la ciudad de los Reyes aquí e sauido por entero la vi / toria que Dios a dado a vuestra señoría de los tiranos que verdaderamente a / sido más que ganar de nuebo estos reynos el hecho a sido tan / grande que cierto su Magestad deve a vuestra señoría gran gratificación y todos los / desta tierra sus vidas e haciendas, vuestra señoría de sienpre gracias a Dios / e como cathólico que con su temor gobierne estos reynos para que / no solo en la libertad dellos sino en su buena governación con paz / e justicia dexe vuestra señoría de sí gloriosa fama e de tanta honra cierto / yo no acabo de dar gracias a Dios y bendiciones a vuestra señoría deseo en / gran manera velle y sy vuestra señoría se detiene en esas partes mucho en des / cansado algo en Lima me partiré para donde vuestra señoría estubiere por / que para poner alguna horden en las yglesias y en lo que su Magestad me manda / y toca a mi persona no e de salir de lo que a vuestra señoría pareciere e de su con / sejo y sé que con la conpañía y conbersación de vuestra señoría me parecerá el Pe / rú España, mucho temo estos arenales e despoblados que me quedan / de aquí a Lima, yo traya para vuestra señoría un pliego de su Magestad y porque / como tengo dicho me deterné algo le e dado al alcalde Juan Barbarán / para que le lleue a Lima y de allí el fattor Yllen Xuarez y le enbien lue / go a vuestra señoría por ventura abrá algo que sea menester probeer luego / yo hallé aquí cierto recaudo del señor eleto de Quito para que / en su nombre tomasen la posesión desta yglesia por virtud de la / devisión que vuestra señoría a hecho de los términos de los obispados e / aunque esto tenía poco efeto no siendo venidas sus bulas y e / xecutoriales de su Magestad ni ynterbiniendo mandamiento de vuestra señoría sino sola / la declaración de los términos de los obispados porque en todo deseo concordia / y no salir de lo que vuestra señoría mandare y le pareciere le suplico mande que se sobre / sea en lo que toca a esta ciudad y sus términos la debisión hasta que yo bea / a vuestra señoría o le ynbíe el recaudo del derecho como obispo de los Reyes tengo a / esta yglesia que entre otras cosas es una prouisión de su Magestad por la qual / presenta un clérigo al beneficio sinple de aquí y habla conmigo ex nomine propio como obispo de la ciudad de los Reyes, no escribo más / nuebas de España porque pienso que en estos pliegos las terná vuestra señoría //

/ 52 v. / de veinte y dos de otubre ay nabíos la guerra de su Magestad y entre el / Rey de Francia estaua ya travada, el Papa entendía mucho en las pa / zes y a lo que parecía el franzes las deseaba ya, dizen que su Magestad / como tiene la razón y justicia por sí y está injuriado con el Rey de / Francia no vernía en ellas aunque también se esperaba que como cristianí / simo no huyría la paz, estaua su Magestad en Monzón, el Cardenal, mi señor, / está con él y fue desde Valladolid bueno de su gota, esto sé de veinte / e ocho de agosto, el señor Obispo de Lugo hera ydo a visitar su Yglesia / llevó cinquenta días de plazo para yr y bolber tienese por cierto / que su Magestad se seruirá más que hasta aquí dél, no me acuerdo de otras / particularidades porque van las cartas en mi nabío desde la ciu / dad de los Reyes escribiré a Vuestra Señoría más largo, guarde Nuestro Señor la / ylustre y muy magnífica persona de Vuestra Señoría con el acrecentamiento y salud que yo / le deseo. En San Miguel veynte y siete de marzo perdone Vuestra Señoría mis ojos / no dan lugar a escreuir de mi mano no sé si an llegado a Vuestra Señoría las nuebas que por acá se an derramado de Panamá y otras partes el Cardenal / Nuestro Señor está más adelante con su Magestad que nunca y en lo que toca al Consejo / de Yndias se tiene por cierto que si el Cardenal deja la presidencia porque / como Vuestra Señoría saue a tanto que lo desea se a de dar al Señor Obispo de Lugo / y porque no puedo con este ojo no digo más, Vuestra Señoría me haga Merced / escreuirme largo, 
seruidor de Vuestra Señoría, el Obispo de los Reyes. Ilustre / Señor porque de Chiquana [sic] ${ }^{14}$ escreuí a Vuestra Señoría el subceso que hasta allí en es / ta no me alargaré más de que yo me partí de aquel pueblo a ver la tierra / que a Vuestra Señoría escreuí, tenía noticia y andadas cinquenta o sesenta leguas / pasé un puerto no muy grande y tres o quatro días de monte y de tan / grandes llanuras y tierra fría donde allé mucha gente poblada en / ríos que salen destas sierras nebadas la gente desta tierra es mucha della / desnuda e della vestida tienen ovejas chicas y grandes, no muchas y a / bestruzes allé entre estos indios desta tierra gran cantidad de / gallinas de Castilla dizen vienen de la tierra adentro hazia donde sale / el sol tengo gran nueva de gente hazia aquella parte donde con / ayuda de Dios pienso se descubrirá el río de la Plata salieronme / muchos pueblos de paz por donde anduve y los señores dellos a Vuestra Señoría suplico en lo que a ella se ofreciere en el aviamiento de la gente / que acá quisiere venir, Vuestra Señoría lo favorezca y encamine pues todo es para seruir / a su Magestad y Vuestra Señoría siempre a tenido este celo, sy Vuestra Señoría quisiere //

/ 53 r. / ynbiar acá algunos criados o seruidores acá haremos el capitán / Felipe Gutierrez y yo por ellos lo posible por ynbiallos Vuestra Señoría en lo de la / joya perteneciente a Vuestra Señoría no se a auido cosa que sea nada en abiendose / yo terné especial cuidado de inbiallo a Vuestra Señoría porque los morteros / questa gente tiene no son de oro ni de plata sino de madera y si son tan / grandes los de oro como los que aquí se han visto buena joya tie / ne Vuestra Señoría cuya Ilustre persona Nuestro Señor dé el estado e descanso que por / Vuestra Señoría es deseado, fecha en Tucumán principio de la nueva tierra quatro / días del mes de agosto de quinientos y quarenta y tres años seruidor de / Vuestra Señoría en sus manos vessa, Diego de Rojas. Muy magnífico Señor reciuimos / la de Vuestra Merced y por ella vemos la ventura grande que para poder / salir con el nabío en que vino tubo y fue Dios seruido de se la dar y / tenemosla y es de tener en mucho pues puede ser causa de evitar tan / to daño atribuymoslo a la dicha y ventura de nuestro enperador y a la / que vuestra merced en su nonbre en estas partes a tenido e devaxo della confiamos / en nuestro Señor que vernán a tener buen fin las cosas del Perú aunque / de presente estén de mala desistion [sic] y que no será seruido que tan / buena tierra se pierda, entendidos hemos la mala yntención que la gente de / aquella tierra tiene de ocupar estos dos puertos y para que no sal / gan con tan mal pensamiento en caso que lo quieran yntentar en esta / ciudad y en esa se hará todo lo que se pudiere hazer por el aviso ve / samos las manos a vuestra merced y en el reciuir de la nao y artillería que en el / viene los señores oficiales y el cabildo de esa ciudad ternán cargo / dello y con tanto vuestra merced sea muy bien venido y nuestro Señor guarde / y prospera la muy magnífica persona, casa y estado de Vuestra Merced. Del Nonbre / de Dios, nueve de diziembre de mil y quinientos y quarenta y quatro vessan / las manos a vuestra merced Fernando de Carmona, Juan de Zauala, Alonso de Almaraz, Juan Gómez de Anaya, Andrés de Arica. En la ciudad / de Panamá deste reyno de Tierra Firme de las Yndias del mar océano / a tres días del mes de diziembre de mil e quinientos y quarenta e / quatro años ante mí Melchor de Vitoria escriuano de su Magestad y su escriuano / público del número desta ciudad estando juntos y ayuntados los se / ñores Diego Ruiz e Baltassar Diez alcaldes hordinarios en esta dicha / ciudad e Juan Vendiel e Juan Fernández de Rebolledo regidores / desta ciudad y el muy magnífico señor licenciado Cristóval Vaca de Castro / cauallero de la horden de Santiago del Consejo real de su Magestad luego el dicho señor //

\footnotetext{
${ }^{14}$ Es probable que se trate del pueblo de "Chiguana"
} 
/ 53 v. / licenciado dixo a los dichos señores alcaldes e regidores que después que el señor / Virrey fue preso fue del puerto de Guarua cerca de Lima y fuera de a / quella probincia el dicho señor licenciado por parte de los oydores bolbió al puerto de Lima un nabío grande que hera de Muñoz de Áuila / vezino desta ciudad y estando allí se conpró el dicho nabío por / parte de Gonzalo Pizarro y para él e después que vino a la / ciudad de los Reyes y por los oydores fue nombrado por / gobernador se dibulgó como quería ynbiar gente de guerra en el / dicho nabío a esta ciudad diziendo que hera para hechar al virrey / en el Nombre de Dios y para esto metieron en el nabío algún / vastimento y catorze o quinze tiros de artillería y concertada / la gente y capitán que avía de venir e que biendo el dicho señor licenciado / questo hera tan en deseruicio de su Magestad hazerse esto contra su / virrey e porque se sospechaua e dezía por algunos que hera para / ocupar esta ciudad y la del Nombre de Dios y para hechar los / oydores fuera de aquella provincia aunque él tenía mucho / que hazer en ser bien despachado de su visita e residencia se puso / a toda ventura y peligro de la vida por seruir a su Magestad se / alzó con el nabío con tres personas que estauan en él, e rindió / al maestre y marineros y con esto él a satisfación y paga que les / ofreció por su trauajo vino a este puerto de Panamá con el dicho / nabío y por lo que toca al seruicio de su Magestad y guarda desta ciudad / e la del Nombre de Dios declaraua e notificaua a los dichos se / ñores justicia y regidores para que ocupen y tengan el dicho nabío / en guarda desta ciudad y para aprobechamiento del señor virrey / y pongan el recaudo que deven y son obligados a la guarda del / dicho nabío e desta ciudad y puerto hasta tanto que lo sepa su / Magestad y probea lo que fuere seruido y si necesario hera se lo pedía / e requería y questo lo hablaua e dezía como seruidor de su Magestad / e lo pidió por testimonio y los dichos señores alcaldes y re / gidores lo oyeron y dixeron quellos se juntarían e abrían so / bre ello su deliberación e acuerdo como seruidores de su Magestad e / probeeran aquello que sea seruido de su Magestad y guarda deste / reyno y después de lo susodicho doze días del dicho mes de diziembre e / del dicho año estando juntos en su cabildo segund lo an de vso e / de costunbre de se ayuntar. El muy magnífico señor //

/ 54 r. / Pedro Casares alcalde mayor en este reyno y los muy nobles señores jus / ticia e regidores desta dicha ciudad conbiene a sauer Valtasar Díaz, Diego / Ruiz alcaldes hordinarios en esta dicha ciudad e Arias de Acebedo e Juan / Vendiel e Juan Fernández de Rebolledo regidores por presencia de / Francisco de Santander escriuano público e del consejo de la dicha ciudad / de Panamá por fee que dello me dio a mí el dicho Melchor de Vitoria escriuano / estando en el dicho cauildo se metió por el portero dél la petición siguiente: / Magníficos señores Mauricio Zapata en nonbre del licenciado Cristóval Vaca de / Castro del Consejo de su Magestad pide a vuestras mercedes manden dar a mi parte / el pedimento que hizo sobre el nabío que traxo que fue de Muñoz de Áuila / e que conpró Gonzalo Pizarro con la respuesta y si para esto es necesario que / se buelba e de a Melchor de Vittoria ante quien pasó para que lo de lo / pido ansimismo para lo qual el oficio de vuestras mercedes ynploro e ansí / presentando en la manera que dicha es los dichos señores justicia e regidores / por presencia del dicho Francisco de Santander escriuano público dixeron / que se responda al dicho requerimiento del dicho licenciado Vaca de Castro / acerca de lo por él pedido en razón del dicho nabío y lo demás con / parecer de un letrado y se comete al señor Valtasar Diez para que lo / haga e se responda por él a ello e después de lo susodicho este dicho día / e mes e año susodichos el dicho señor Valtasar Diez alcalde por presencia / del dicho Francisco de Santander escriuano público susodicho dixo que en lo / de la nao esta ciudad no tiene por que encargarse della ni tiene necesidad / della y quanto a la guarda desta ciudad que los dichos señores jus / ticia y regidores tienen cuydado de lo que toca al seruicio de su Magestad / que se le de con esta respuesta 
y lo firmó Baltasar Díaz e yo el / dicho Melchor de Vitoria escriuano público susodicho presente fuy a lo que dicho es / que ante mí pasó y lo escreuí y fize aquí este mío sino en testimonio / de verdad Melchor de Vitoria escriuano. De lo qual ansimismo fue / mandado dar treslado por los del nuestro Consejo al dicho licenciado Villalo / vos nuestro fiscal el qual respondió por auto que negaba la dicha reconben / ción en todo y por todo como en ella se contenía con ánimo de la con / testar si de contestación hera dina y con protestación de alegar / más largamente del derecho de nuestro fisco e después por otra petición / que presentó dixo que devía hazer y proceder contra el dicho licenciado Vaca / de Castro segund que por él estaua pedido y suplicado sin embargo de lo en contrario //

/ 54 v. / dicho e alegado porque por información bastante constaua de sus culpas / e allende de lo que estaua acusado se averiguaría en la prosecución de la / dicha causa que como supo que avíamos hecho las hordenanzas generales / para que en las Yndias no se encomendasen indios y los quitasen a todos los / que oviesen sido culpados en fauor de Diego de Almagro e de Pizarro / e sobre otras cosas luego el dicho licenciado Vaca de Castro avía hecho men / sajeros propios a todas las ciudades, villas e lugares de los españoles / del Perú haziéndoles sauer las dichas hordenanzas y lo que avían de ha / zer y por su aviso y consejo se avían juntado todos los pueblos de los / españoles e se avían alterado para desobedecer como avían desobe / decido las dichas hordenanzas y también como supo que ynbiábamos por / Visorey a las dichas provincias del Perú a Blasco Núñez Vela luego a / vía enviado otros mensajeros propios con cartas suyas y avisos / a muchas ciudades, villas y lugares del Perú y a personas principales / lo qual auía sido causa de todas las alteraciones y desobediencias que / avía auido en el Perú contra el dicho Visorrey en nuestro desseruicio tenien / do él obligación de avisarle de lo que convenía hazer en nuestro seruicio lo / qual no avía hecho e dixo e alegó otras muchas razones afir / mándose en la contestación y negativa que tenía hecha en lo tocante a / la dicha reconvención y pidió y suplicó se procediese contra el dicho licenciado / Vaca de Castro sobre todo lo susodicho y fuese condenado en las pe / nas en que avía incurrido e intereses y menoscabos que se avían / seguido y podían seguir por su culpa a nuestro fisco sobre lo qual por las / dichas partes fueron dichas y alegadas otras muchas razones cada / una dellas en guarda de su derecho hasta tanto que concluyeron e / por los del nuestro Consejo fue auido el dicho pleito por concluso y visto / dieron sentencia interlocutoria en que recibieron a las dichas partes a prueba / de todo lo por ellas e cada una dellas dicho pedido e alegado en cier / ta forma e con cierto término ansí para estos reynos como para las / Yndias dentro del qual hizieron ciertas probanzas por testigos y escripturas / e las presentaron ante los del dicho nuestro Consejo y parece quel dicho licenciado / Vaca de Castro entre otras cosas que articuló para su descargo fueron / ciertas preguntas de dos de sus interrogatorios para probar lo que / nos sirvió en el Perú y en la vatalla que ubo con el dicho don Diego de Almagro / el tenor de las quales dichas preguntas e de lo que en ellas dixeron e de / pusieron algunos de los testigos presentados por parte del dicho licenciado Vaca de Castro. //

/ 55 r. / E de otra pregunta que articuló el dicho nuestro fiscal y de lo que en el dixo e / depuso uno de sus testigos es este que se sigue: Yten si sauen e que al tiempo que / en el Perú se supo que yua el dicho Blasco Núñez Vela por visorrey y llebaba / las hordenanzas y leyes nuebas el dicho licenciado Vaca de Castro estaua muy a / poderado en la tierra y tenido y obedecido y que si él quisiera pudiera muy / bien estorbar que no se hizieran juntas ni alteraciones ni obiera quien lo o / sara hazer sino fuera con su sabiduría y consentimiento digan lo que cerca de / esto sauen los testigos y si sauen que fuera parte el dicho licenciado Vaca de / Castro para estorbar lo susodicho si 
quisiera segund el poder y mandado que / tenía en la tierra el licenciado García de León. A las doze preguntas dixo que lo / que saue de la dicha pregunta que vido al dicho Vaca de Castro apoderado en es / ta tierra y todos le obedecían entonces por governador quando obo nue / va que venía el visorrey y a lo que la pregunta dize quel dicho Vaca de / Castro pudiera estorbar la junta de gente que después vbo por el ju / ramento que tiene dicho este testigo que es falsedad y maldad lo que en este caso / se le pone porque el dicho Vaca de Castro procuró evitallo estando en / la ciudad de los Reyes y no fue parte para ello porque estaua ya en Truxillo / el visorrey y lo saue este testigo porque aviéndole llamado a este testigo / e a otros letrados para informarse si podrían los vezinos destos / reynos suplicar de las hordenanzas y podían resistirle o yr a / la mano al dicho visorrey para que no hiziese lo que hazía obo pare / cer de letrados que dieron voto que se le podía resistir sin suplicar y / prendello y llevallo a España y este testigo dio parecer que se suplicase / en forma e quél haría la suplicación y que no se entremetiesen en lo / demás sino fuese haziendo fuerza el dicho visorrey y para sauer / lo que más se podía hazer los regidores fueron a preguntar al dicho Va / ca de Castro el thesorero Alonso de Riquelme y el fator Yllen Xua / rez y este testigo que qué le parecía en aquello y el dicho Vaca de Castro / dixo que no se pusiesen en nada de aquello porque por ventura / deserbirían a su Magestad en ello y que la suplicación muy bien lo po / dían hazer con que lo hiziesen sin escándalo por si él fuera persona / a quien le tocara que él ynbiara procuradores a su Magestad para que lo / remediase y que la suplicación no la hiziera él acá y quedándose este / dicho testigo solo con el dicho Vaca de Castro después de salido el dicho theso / rero y fator le dixo este testigo que para qué dezía aquello pues sabía / que de derecho se podía poner la suplicación acá y el dicho Vaca de Castro le / dixo: con el rey no se a de poner ná y de papo a papo ${ }^{15}$ y más vale quedar //

/ 55 v. / corto en tal caso que ser ocasión que venga algún mal en el Reyno e yo / no tengo parecer en este caso que soy criado del rey y llebándole otro día / la suplicación que la ciudad avía hecho para ver si estaba buena por / quél no la quiso hazer por muchos ruegos que le hizieron nunca lo quiso / ver aunque mucho se lo rogó este testigo porque yva a ello y no a otra cosa / e el licenciado Rodrigo Niño que hera primero diziendo quél no tenía parecer en / aquel caso y este testigo se salió mohíno de ver que no la quería ver e se / quedaron allí ciertas personas no se acuerda quien para hazérsela ver / e ansímismo lo saue este testigo porque queriéndose venir a esta ciudad / Diego Maldonado y Vachicao y Gaspar Rodrígues y Pedro de los Ríos y otros el / dicho Vaca de Castro ynportunó a algunos dellos que no se viniesen a / esta ciudad especialmente se acuerda que dixo a Gaspar Rodrígues yn / portunándole mucho que se quedase y que diese al diablo la hazien / da que acá no podía dexar de auer alteraciones a lo que entendía / que se estobiese quedo que no se perdiese y quél le dava en aquello consejo / de padre y no enbargante las persuacyones que hizo se volvieron / a esta ciudad muchas personas que avían con él de las quales al / gunas se juntaron con el dicho Gonzalo Pizarro y para el juramento queste / testigo tiene hecho dixo que en todo lo que entendió del dicho Vaca de Castro / en las muestras exteriores daua a entender que le pesaua de que se vi / niese acá ninguna gente a hazer alteración aunque este testigo cree / que por redimir su vexación y las molestias que le hazía el dicho / Visorey se holgó después que las oviese porque el dicho Visorey en / tendiese y todos viesen falta que le hazía en la gobernación de / la tierra y que

\footnotetext{
${ }^{15}$ Expresión coloquial que viene a significar que con el rey se ha de hablar directa y valientemente. Otra ocurrencia aparece señalada en José Antonio Mazzotti, "Garcilaso en el Inca Garcilaso: los alcances de un nombre", Lexis, XXIX.2 (2005):179-219.
} 
esto saue desta pregunta. Yten si sauen que en la dicha / hazienda quel dicho señor gobernador traya en la dicha nao del dicho Cosme / Farfán se enbarcó en Panamá en un galeón que se llamaba Sepúlbe / da y por la mala navegación que tubo el dicho Señor licenciado por esta / mar del sur por andar como anduvo porfiando por venir camyno de / recho se perdió y pudrió mucha parte de la dicha hazienda que en el dicho / navío trayan y si sauen que desde la dicha isla de Santo Domingo / hasta arribar al puerto de la Buenaventura se le murieron mu / chas bestias en el navío en que fueron más de catorze cauallos / e azémilas. Yten si sauen que después que arribó el dicho Señor e / licenciado y gobernador al puerto de la Buenaventura después de aver / andado tres meses por la mar determinó de venir allí por tierra //

/ 56 r. / a estas provincias del Perú cosa muy trauajosa y peligrosa e si / sauen que desde el dicho puerto de la Buenaventura hasta Cali pueblo de / la governación de Venalcázar se perdió parte de la dicha hazienda quel / dicho señor governador traya en el dicho camino y ansimismo se le despe / naron y perdieron cauallos y vestias y se le murieron muchos criados / de los que consigo traya. Yten si sauen que en el dicho puerto de la dicha Bue / naventura enfermó el dicho licenciado y gobernador y fue por el dicho / camino hasta Quito purgándose y sangrándose por los arcabuzazos / y llegado a Cali estuvo a la muerte tres meses en la cama con grabe enfer / medad y con su enfermedad y con la de criados suyos que allí enfermaron / en el tiempo que allí se detubo con las dichas enfermedades gastó lo que le quedó / de la dicha hazienda y bendió allí todo lo que traya para los gastos de / las dichas enfermedades suyas e de sus criados en hazienda que valía / más de quatro o cinco mil castellanos. Yten si sauen que despachado lo / susodicho en la dicha ciudad de Cali aunque tan enfermo que llevaba / consigo la unción se partió para venir a estas probincias y en Popa / yán supo por cartas de Quito como don Diego de Almagro y sus secazes / avían muerto al marqués don Francisco Pizarro governador destas pro / vincias del Perú e robado la tierra e alzádose con ella y apoderádose de / todos los pueblos y ciudades destas provincias ecepto Quito e no obstante / que se halló tan enfermo y solo sin gente y sin dineros y los que allí esta / van le dezían que se volbiese a Panamá que no hera cosa de enprehender / lo quel dicho señor governador quería hazer en el venir a estas provin / cias para las recobrar para su Magestad porque estaua todo el reyno to / mado por el don Diego y no auía gente que se poder juntar con él ni / cauallo ni armas todavía tomó su camino y vino a Quito con gran / travaxo por el mal camino fragoso y áspero y grandes ríos que / en el uno se le ahogó un escudero al pasar en el río grande que / llega a Santa Marta. Yten si sauen que luego que llegó a la ciudad / de Quito fue reciuido por governador el dicho señor licenciado y probe / yó de ynbiar muchos mensajeros con cartas a todos los pue / blos y ciudades destos reynos y hasta el Cuzco ansí para pro / curar de ser reciuido [en] los pueblos e quitar las justicias de / don Diego como para apercebir vezinos y otra gente y cartas al dicho don / Diego e a muchos de sus secazes y principales que derramasen la gente //

/ 56 v. / e que les haría justicia en todo lo pasado y presente como su Magestad / lo mandaua. Yten si sauen que aprovechó lo susodicho en tal manera que / fue reciuido el dicho señor licenciado por governador en todas las ciudades de / estos reynos y en la ciudad de los Reyes porque quando allí llegó su / mensajero ya el don Diego y su gente hera salido de la dicha ciudad y quando / llegaron sus gentes al Cuzco ya hera reciuido por gobernador el dicho señor / licenciado. Yten si sauen que luego el dicho señor licenciado Vaca de Castro comenzó a hazer la gente que pudo y conpró los cauallos que hallaba / e armas las que podía y luego proveyó que se hiziesen hierros / para picas y otras municiones para se venir a juntar con todos / los dichos caualleros visto quel dicho don Diego 
y sus secazes porfia / van en su ruyn propósito y tiranía. Yten si sauen que llegado el dicho / señor licenciado y governador a donde estaba el capitán Pero Alvarez Holguín / con la gente de las Charcas, Arequipa y Cuzco y apoderado del real e de / toda la gente para lo qual fue menester muchas prebenciones y tra / vajos y valor halló muy desprobeydo la dicha gente de armas y / munición e conpró allí todas las adargas que halló que se vendían e / otras cosas y las repartió entre la gente de guerra y conpró quatro / mulas para llevar la artillería porque morían los yndios llevándola / de camino y probeyó de personas que fuesen a hazer picas a una / parte y a otros armas e a otros arcabuzes, pólbora e otros / hachería e azadonería y otras cosas necesarias. Yten si sauen que lle / gado el dicho señor gobernador a Xauxa donde estaua la gente con la / demás quél sacó de Lima se le recrecieron muchos gastos en dar soco / rros y contentamientos a algunos soldados y mesa larga hordinaria para / todos quantos querían e ansí lo hazía hasta quel dicho don Diego e sus / secazes le vinieron a dar la vatalla con más de quinientos onbres muy bien / armados y encabalgados y entre ellos dozientos arcabuzeros e / más de veinte piezas de artillería, las treze medias culebrinas que / tenían a doze e a treze pies de largo y cinquenta onbres de armas / lo qual el dicho señor gobernador les dio valerosamente con poca / más gente y mal armada y sin artillería que no pudo llegar a tiempo / y estando en duda el vencimiento entró con quarenta lanzas / que tenía y ansí se ganó la vitoria y el reyno para su Magestad digan lo / que cerca desto se acordaren y supieren. Yten si sauen que todos //

/ 57 r. / los dichos gastos que hizo el dicho señor gobernador fue gran seruicio de su Magestad porque con ellos ajuntó, / animó gente para dar la dicha vatalla y que con esto se ganaron estos reynos / para su Magestad que a no hazerse ansí se perdieran por mucho tienpo y aun estu / bieran en mucho ynconbeniente de perderse las probincias de Tierra Firme digan lo que sauen. Yten si sauen que por las causas e razones su / sodichas el dicho señor gobernador está adeudado e deue mucha suma de pesos / de oro que a recibido y tomado prestados digan lo que sauen. Juan Alonso / Palomino vezino de la ciudad del Cuzco a las veinte e ocho preguntas dixo / que lo saue de la pregunta es queste testigo salió de la ciudad del Cuzco con / el capitán Peralvarez Holguín e con la gente que con él fue en busca del / dicho señor gobernador y le topó en un pueblo de yndios de los llanos que se dize / Motupe término de San Miguel y que desde allí este testigo vino con el dicho señor gobernador / hasta la ciudad de Truxillo e dende allí el dicho señor gobernador ynbió a este testigo / con ciertas cartas y despachos para el dicho capitán Peralvarez y los otros / capitanes que con él estauan para conformallos < porque fue ynformado > que no estauan conformes / y este testigo vino con los dichos despachos a la dicha probincia de Guaraz y los / dio al dicho capitán Peralvarez e que cree este testigo y tiene por cierto que con ellos / se pacificaron los dichos capitanes y estubieron en paz de allí adelante / e que dende ciertos días el dicho señor gobernador llegó al dicho pueblo de Guaraz don / de estaua el dicho capitán Peralvarez con la dicha gente y que al tiempo quel dicho / señor gobernador entró entre la dicha gente y capitanes vido este testigo quel dicho señor / gobernador mostró muy gran valor para ser obedecido entre los dichos / capitanes e gente e que vido este testigo que al tiempo que salieron a recibir al / dicho señor gobernador el dicho capitán Peralvarez y los demás capitanes e gente / el dicho capitán Peralvarez llevaua como general un estandarte real / y los demás capitanes sus banderas estendidas y ansó como llegaron al dicho / señor gobernador tomó en sí el estandarte real y vanderas y las recibió como / tal gobernador e capitán general e hizo coger el estandarte que dicho capitán Pe / ralvarez llevaua e dixo que no auía de auer otro sino el que él llevaba / en nombre de su Magestad como su capitán general y vido que ansí se hizo y las demás / vanderas vido como el dicho señor gobernador las dio y entregó por 
su mano a / los demás capitanes porque allí el dicho señor gobernador los nonbró por capitanes / en nombre de su Magestad aviéndose ydo primero por los dichos capitanes y gente re / cibido por tal governador y capitán general en nombre de su Magestad y que vido este testigo //

/ 57 v. / que después de pasado esto el dicho capitán Pero Alvarez se agrauió e quexó / por quel dicho señor gobernador le mandó coger su estandarte y no traerlo tendido / como lo traxo e que dezía que lo avía de traer como sacado / desta ciudad e que sobre esto andubo quexándose a los otros capitanes y / a mucha gente sintiéndose por agraviado dello y dando a entender que di / xesen al dicho señor gobernador que le diese su estandarte e que se lo / dexase traer tendido y que sobre esto andubo en muchos ruegos al / dicho señor gobernador e que sobre ello a este testigo le parece que vbo muchas mur / muraciones e dichos de capitanes y soldados diziendo que si el dicho / señor gobernador no le daua su estandarte al dicho capitán Peralvarez / e no se lo dexaua traer tendido que no avía de ser gobernador / e otras cosas semejantes a esta y le pareció a este testigo estar / mucha gente alborotada sobre ello y saue y vido este testigo quel dicho / señor gobernador con su valor y sauer lo supo apaciguar e apa / ciguó todo no mostrando ninguna vajeza sino antes muy gran / valor e representándolo en todo diciendo que no avía / de aver otro capitán general ni estandarte real sino el / que él traya e que ansimismo saue y vido que antes que el / dicho señor gobernador entrase en el dicho real algunas personas / de las del real del dicho Peralvarez hablaban e dezían que no / avía de gobernar el dicho señor gobernador ni avía de ser re / cibido por gobernador y que avía de gobernar el capitán Pero Alvarez / e quel dicho señor gobernador tubo necesidad de mucha prudencia, valor / e sagacidad para apaciguallo todo y para ser reciuido e que ansí lo tubo / e mostró en todo lo que se ofreció e que demás desto este testigo saue y vido / quel dicho señor gobernador luego que fue reciuido por gobernador supo que el capitán / Peralvarez e la gente de su real estaua desproveyda de ar / mas e munición e de otros adrezos y sauido el dicho señor gobernador probeyó / luego que fuesen a la ciudad de los Reyes personas en su nombre / a hazer arcabuzes y escopetas e otros que fuesen a hazer pólbora e / buscar carpinteros para que fuesen a cortar picas de la otra parte / de los puertos e sierras nevadas y ansimismo hizo a otros muchos / e muy buenos probeymientos ansí como fue ynbiar a hazer artillería / a la probincia de Xauxa ques cinquenta leguas del dicho real donde el / dicho señor gobernador estava y ansimismo en buscar adrezos para ha / zer fraguas para con que se fundiese y hiziese la artillería las //

/ 58 r. / quales dichas fraguas fueron muy trauajosas de auer porque en aquella / coyuntura no auía fuelles y fue necesario buscar cuero para hazerlos e / hazer de nuevo cañones para los dichos fuelles y vido que se proveyó de todas / las fraguas necesarias y ansimismo vido quel dicho señor gobernador enbió / a la provincia de Tarama a hazer pólbora que es quarenta leguas de don / de estaua el dicho real y que este testigo es la persona a quien el dicho señor gobernador / mandó que fuese a hazer la dicha pólbora y la fue a hazer e hizo con cierta / gente que para ello le dio el dicho señor governador la qual dicha pólbora fue / muy trauajosa de hazer por causa de yr lexos por el salitre y por la falta / de morteros e de todas las otras cosas necesarias y que ansimismo saue / y vido que en el dicho real de Goaraz el dicho señor gobernador conpró las a / dargas y las otras armas que halló y las repartió todas entre los soldados / e que ansimismo fue público y notorio quel dicho señor gobernador con / pró las dichas quatro acémilas para la dicha artillería por el reparo de los / yndios que la trayan que morían y padecían muy gran trauajo en traer / la dicha artillería y que ansimismo saue que desde allí ynbió a los / llanos a probeer de las cosas que convenían al seruicio de su Magestad y execución de la / guerra e que con todo lo que dicho tiene, saue y vido quel dicho 
señor gobernador / se supo muy bien valer e darse muy buena maña y sagacidad ansí / para que le obedeciesen como después para que le amasen como para dar / muy buena yndustria a muchas cosas de la guerra que los dichos capitanes / no caían en ellas y que saue y vido que toda la deligencia e buen recaudo / quel dicho señor gobernador puso estando en el dicho real fue muy necesario / e convenía y conbino mucho y que le pareció a este testigo que si en alguna del / las oviera descuido parará mucho perjuizio al seruicio de su Magestad / e que esto que dicho tiene. A las treinta e ocho preguntas dixo que lo que saue de / la pregunta es que luego como el dicho señor gobernador vino a la provin / cia de Xauxa al real e gente donde estaua el dicho capitán Peralvarez Hol / guín donde estaua recogida la gente que de una parte e de otra avía llegado / el dicho señor gobernador vido este testigo quel dicho señor gobernador dende a pocos días que a / llí estubo mandó hazer alarde de toda la gente de pie e de cauallo que a / vía en el dicho alarde andaba el dicho señor gobernador requiriendo como capitán / general todas las capitanías y gente de pie y de cauallo que auía en el dicho real / e vido este testigo como el dicho señor gobernador halló alguna falta de armas a alguna gente / de a cauallo y luego proveyó y ynbió a este testigo a la dicha ciudad de los Reyes / a hazer quarenta o cinquenta coseletes de hierro y este testigo vido que en el dicho alarde / el dicho señor gobernador dándose muy buena horden y maña como buen capitán general //

/ 58 v. / puso cada capitanía e gente della en su horden y vido toda la dicha / gente e andubo de uno en otro mirando si les faltaua alguna cosa de / armas e otros adrezos porque este testigo por mandado del dicho señor gobernador entendía / en mucha parte dello y que demás desto vido este testigo quel dicho señor gobernador / de noche e de día y a la contina no entendía en otra cosa sino en re / querer los dichos capitanes y sargentos y procurar si les faltaua algunos a / drezos y si estauan bien adreçados los arcabuzes y artillería que trayan / e andando pesquisando esto supo como muchos arcabuzes no estauan / adrezados y muchos soldados de a pie no tenían picas y el dicho señor gobernador / mandó que con toda brevedad se traxesen las picas que abía enviado / a cortar y hazer como dicho tiene a fulano Pardo y Martín de Andía carpintero / e a Gomez de Carabantes como señor de parte de los yndios de Xauxa e / las traxeron allí ante el dicho señor gobernador mucha cantidad dellas e / en la cámara del dicho señor gobernador vido este testigo como el dicho señor gobernador las mandó / repartir e repartió entre muchos solados y hizo sacar una petaquilla / o cesta de hierros de picas quel dicho señor gobernador dixo que traya desde la prouincia / de Quito que los avía mandado hazer allí para las dichas picas y los repartió / con ellas a los dichos soldados de a pie e ansí mismo vido que repartió canti / dad de celadas y barbotes y brazales y quijotes quel dicho señor gobernador mandó / hazer al capitán Martín de Florencia porque desde la provincia de Goaraz / estando allí el dicho señor gobernador ynbió al dicho capitán Martín de Florencia a / la dicha provincia de Jauja a hazer las dichas celadas e adreços susodichos / de cobre el qual dicho cobre el dicho señor gobernador hizo buscar y buscó con mucho / trauajo recogiéndolo de muchas partes e ansimismo vido quel dicho señor / gobernador buscó dos herreros para que adrezasen los arcabuzes y llabes dellos / de los dichos soldados e carpinteros para que hiziesen cajas y mandó a / drezar todos los dichos arcabuzes y les dio a los dichos soldados mucha / cantidad de mecha de algodón quel dicho señor gobernador traya hecha de los llanos / porque en la sierra no avía de qué hazerse la dicha mecha y se proveyó / desde los llanos de traer una acémila cargada de la dicha mecha e que a no / averla traído el dicho señor gobernador tuviera muy gran falta della e avía por / fuerza de enviar a los llanos a hazello e se tubo por los dichos capitanes / e gente del dicho real por muy buena provisión e se la loaron mucho / al dicho señor gobernador y que ansimismo vido este testigo que ubo falta allí en la dicha prouincia / de piedra zufre para hazer 
pólbora y el dicho señor gobernador la ynbio a bus / car e comprar a la dicha ciudad de los Reyes y no se halló alguna porque / los de Chile la avían gastado toda e visto esto el dicho señor gobernador ynbió a ciertos / onbres por la tierra a buscar veneros de piedra zufre en lo qual se pusso //

/ 59 r. / mucha deligencia y se fue a hallar en la probincia de los Soras y Lucanas que / son casi sesenta leguas de la dicha provincia de Xauxa e de allí se traxo el dicho / piedra zufre para hazer la dicha pólbora y que ansimismo saue y vido que / la dicha pólbora se hizo con carbón de madera saoz [sic] porque con otra / madera no se puede hazer y para yrla a buscar porque no la auía en la dicha / provincia de Xauxa se puso mucha deligencia por el dicho señor gobernador / e se traxo de doze o quinze leguas de donde se hazía la dicha pólbora e que / todo lo que dicho tiene vido este testigo e en la mayor parte dello entendió por mandado del / dicho señor gobernador y este testigo se fue a la dicha ciudad de los Reyes por mandado / del dicho señor gobernador a entender en hazer los dichos coseletes y petos / de hierro y se dio mucha priesa y bolbió con ellos y traxo cerca de cinquen / ta y ansimismo traxo muchas cotas e corazinas y ansimismo vido / que se traxeron ciertos tiros que se sacaron de los nabíos y con todo esto / alcanzaron al dicho señor gobernador en el camino que hera partido el dicho señor / gobernador de la provincia de Xauxa para la villa de Guamanga que agora se / llama San Juan de la Vitoria y luego como llegó este testigo le mandó el dicho señor / gobernador que fuese con todas las dichas armas a la dicha villa de Guamanga e / le mandó que hiziese echar ristres a los dichos petos y ansimismo mandó a / este testigo que hiziese hazer en la dicha villa cinquenta lanzas de armas / para onbres de armas y otros muchos proveymientos de que este testigo / no tiene noticia entre los quales le mandó que hiziese muchas pelotas / de plomo para los arcabuzes y tiros de artillería porque avía necesidad de / llas. Y de más desto saue este testigo quel dicho señor gobernador tenía en la dicha villa / de Guamanga al capitán Diego de Rojas con cinquenta onbres para sauer a la / contina nuevas de los dichos don Diego y sus secazes y donde estaban e / venían y para anparo de la dicha villa porque algunos vezinos della se tenía / por cierto que heran amigos del dicho don Diego y le avisaban y que estando / tres o quatro jornadas de la dicha villa el dicho señor gobernador el dicho capitán / Diego de Rojas le enbió a abisar al dicho señor gobernador como don Diego de / Almagro y sus secazes venían muy cerca de la dicha villa para la tomar / y sauido por el dicho señor gobernador vino a muy gran priesa por tomar / la dicha villa antes quel dicho don Diego y entró en ella con su canpo y gente a tres / oras de la noche y se fue [a] aposentar fuera de la dicha villa un tiro de balles / tas y ansí de noche como hera visto por el dicho señor gobernador quel dicho / asiento no hera conviniente para estar allí hizo recoger toda la gente del / dicho real y se recojó en la dicha villa en la plaza pública della e hizo que todo / el dicho real se aposentase por quarteles en la dicha plaza a las esquinas della //

/ 59 v. / e hizo que oviese cuerpo de guarda y mandó poner el artillería en ciertas calles / por donde se pensaua que los dichos don Diego y sus secazes avían dentrar e / porque tobo nueba e se tubo por muy cierto quel dicho don Diego y su gente / avía dentrar aquella noche en la dicha villa mandó a este testigo que fuese a / llamar al dicho capitán Diego de Rojas e al capitán Francisco de Caruajal como / sargento mayor a los quales mandó que requiriesen las casas de la dicha villa / e hechase todos los vezinos e gente que en ella auía fuera e cerrase / las puertas e que hiziese salir toda la gente que en ellas auía a plaza y / estubiesen a punto de guerra y vido este testigo que todos los capitanes que / avían en el real de su Magestad cenaron aquella noche con el dicho señor gobernador a los / quales sobre mesa vido este testigo quel dicho señor gobernador le mandó a cada uno dellos / e les dio horden de lo que avían de hazer y probeer e que en toda la noche / este testigo 
vido quel dicho señor gobernador estubo en pie e armado probeyendo mu / chas cosas y proveyó muchos corredores y centinelas para que corriesen el / canpo y otros muchos probeymientos que hera menester e conbenía pro / veerse porque todo colgaba del dicho señor gobernador como de capitán general / e que este testigo vido quel dicho señor gobernador estubo en la dicha villa / siete o ocho días porque tubo nuebas que los enemigos estaban en la pro / vincia de Bilcas diez leguas de la dicha villa y que en estos ocho días quel / dicho señor gobernador estubo en ella vido quel dicho señor gobernador repartió / allí los dichos petos y cotas y corazinas y lanzas que este testigo tenía a / su carga e auía traydo e ansimismo hizo otros socorros y pro / veimientos que muchos soldados a la contina le venían a pedir ansí de dineros / como de armas y otras cosas en todo lo qual este testigo bía andar al dicho señor gobernador / de la uno en otro contentándoles y mostrándoles mucho amor para / tenerlos a todos muy contentos y pacíficos e que estobiesen a punto / de guerra para quando fuese menester no dexando por esto de mostrar / siempre el dicho señor gobernador muy gran valor e muy buen govierno en la / guerra como convenía e que demás desto vido este testigo que antes quel dicho / señor gobernador entrase en la dicha villa de Guamanga e después de en / trado enbió muchas cartas y mensajeros a los dichos don Diego y sus capi / tanes y gente ynbiándoles a rogar y amonestar se viniesen al seruicio / de su Magestad para el dicho señor governador ynbiándoles seguros y perdones es / pecialmente ynbió Alonso García Zamarilla con muchas cartas e des / pachos para los susodichos y no bolbió más porque se dixo públicamente / e ansí fue que los dichos don Diego y sus capitanes lo avían ahorcado en / la dicha provincia de Vilcas y después desto tornó a enviar el dicho señor gobernador //

/ 60 r. / al fator Diego de Mercado e a Lope Ydiaquez a los dichos don Diego y su gente con / cartas y prouisiones de amonestaciones e cartas de seguros en blanco para los / que se quisiesen venir al dicho señor governador viniesen seguramente e dende / a tres o quatro días tornaron a bolber los dichos mensajeros e dixeron pública / mente como los dichos don Diego de Almagro e sus capitanes y gente no querían / venir al seruicio de su Magestad sino dar la vatalla al dicho señor gobernador e que / avían salido medio huyendo dellos porque no los matasen y venidos e / sauido por el dicho señor gobernador la mala respuesta de los susodichos e / que no querían reduzirse al seruicio de su Magestad por mucho quel señor gobernador / lo auía procurado e deseado se salió de la dicha villa con el real de su Magestad / e se fue al asiento de Chupas ques dos leguas de la dicha villa e allí es / tubo ciertos días en todos los quales el dicho señor gobernador vido que / a la contina requería el dicho su canpo y probeya de todo lo que en el faltaua / e mandaua muchas vezes dar alarma para ver si la gente estaua a punto e a / derezada y no estubiese descuydada y como los enemigos estauan cerca a / la contina de día e de noche enbiando corredores de canpo muy a menudo / y probeyendo de centinelas e haciendo hazer enboscadas y otros muchos / e muy buenos probeymientos hasta tanto que se tubo nueba que los enemigos ve / nían muy cerca del real del dicho señor gobernador por unas lomas y sauido por el dicho / señor gobernador mandó dar alarma e demás de las armas que hordinariamente traya bido / este testigo quel dicho señor gobernador se armó en blanco y subió enzima de un cauallo mor / cillo suyo y enzima de las armas vna ropa de brocado y vn ábito de Santiago / grande en los pechos que aposta el dicho señor gobernador lo hizo hazer grande para / ponérselo el dicho día porque supo que los dichos don Diego y su gente trayan jura / mentados cinquenta soldados arcabuzeros para que buscasen al dicho señor gobernador / e le mirasen por la encomienda para le matar y que puesto de la manera que / dicha es vido este testigo que dio muchas bueltas por el canpo sacando de los toldos / toda la gente e desque la tubo fuera e a punto hordenó muy bien sus esqua / drones de pie e de cauallo haziendo las vatallas e probeyó de yndios e / negros 
que llevasen el artillería y proveyendo todo lo demás que convenía él / solo por su persona y estando todo hordenado mandó al capitán Pero Anzures / que subiese las lomas con alguna gente de a cauallo e al capitán Castro con al / gunos arcabuzeros para que entretuviesen al dicho don Diego e su gente para que / con alguna priesa no tubiesen lugar de escoger sitio a su contentamiento para asentar / su artillería y enbiando los dichos capitanes el dicho señor gobernador tomando el aban / guarda de todo el canpo para subir e yr en la delantera vido este testigo que todos / los capitanes y otros caualleros que yvan en el dicho canpo se juntaron e requirieron //

/ 60 v. / e suplicaron al dicho señor gobernador no tomase la dicha abanguarda sino que / tomase la retaguarda por muchas causas y razones que para ello dieron / porque ansí convenía al seruicio de su Magestad y buen efeto de la guerra y el dicho señor governador porfió mucho con los dichos capitanes por llebar la dicha / abanguardia e al fin por los conplazer e porque convenía ansí en el / punto que estaban y darles contentamiento tomó la dicha retaguarda con quaren / ta de a cauallo que por todos los dichos capitanes fue acordado que quedasen / con el dicho señor gobernador tomó la dicha retaguarda y llevó por delante / todo el campo y vido quel dicho señor gobernador por su persona bolbió tres o quatro / vezes a probeer como subiese la dicha artillería e de negros e yndios que / la llevasen porque quedaua algo trasera y no enbargante que llebase la / dicha retaguarda a la contina subiendo por las dichas lomas vido este testigo / que el dicho señor gobernador yva e venía e daua buelta a la banguardia e a to / dos los esquadrones y a todos los ponía en horden y les hazía muchos e / buenos razonaminetos animándolos y esforzándolos a todos e que se a / cuerda que en subiendo las dichas lomas se les apareció un benado corrien / do entre los esquadrones y gente y quel dicho señor gobernador como lo vido / les dixo públicamente a todos que lo tubiesen por muy buena señal de / vitoria porque antiguamente en otras vatallas se auía visto por / espiriencia lo del dicho venado y que yendo como dicho es subidas las dichas / lomas vieron en el canpo del dicho don Diego sus vanderas tendidas y sus / esquadrones puestos enpezando a jugar su artillería y que luego el dicho / señor gobernador a mucha priesa requirió al dicho canpo de la banguarda / a la retaguarda y por todos los esquadrones por si muy gran valor / y esfuerzo les hizo parlamento a cada esquadrón por si diziéndoles tales / palabras que este testigo vido que todos tomaron muy grande ánimo y es / fuerzo de querer morir en seruicio de su Magestad e del dicho señor gobernador biendo el / ánimo y valor quel dicho señor gobernador mostraba en sí para animar / los a todos y ronper con los enemigos y visto por el dicho señor gobernador / quel asiento que los contrarios tenían y que si fueran camino derecho les ases / taua su artillería e hazía mucho daño porque yvan afrontar con ella e / visto esto mandó que caminase la gente por un lado por manera que no fuesen / derechos y mandó al capitán Peralbarez Holguín que rompiese con la aban / guardia y mandó a ciertos arcabuzeros que andubiesen sobresalientes e / yendo caminando se llegaron afrontar el un real con el otro y el dicho señor gobernador / quedó con las dichas quarenta lanzas las quales puso en un llano donde no las podía / coger el artillería de los contrarios y el dicho señor gobernador se puso en un cerrillo //

/ $61 \mathrm{r}$. / un poco desbiado donde estaua en mucho peligro porque pasauan muchas pelo / tas de arcabuzería y artillería por donde estaua y tras dél mataron un peón / que estaua un poco atrás del dicho señor gobernador que pareció estar escondido y que estando / ansí en la mayor furya de la dicha vatalla vido este testigo como el dicho señor gobernador $\sin$ / tiendo que auía alguna flaqueza en su gente especialmente aquel esquadrón de / Alonso de Albarado porque avía ocurrido allí gente de los contrarios el dicho / señor gobernador con los dichos quarenta lanzas estando la dicha vatalla 
en peso / arremetió con muy gran valor y esfuerzo diciendo los que con él yban ynperio / ynperio Vaca Vaca aquí viene el gobernador e que como entró en la dicha vatalla / tan valerosamente y con tanta furya y a tan buen tiempo los enemigos desde / a poco enpezaron a huyr e se reconoció vitoria de parte de su Magestad y en la en / trada del dicho señor gobernador le mataron y hirieron algunos de los / que consigo metió y questo lo vido este testigo porque a la contina anbubo con el / dicho señor gobernador en todo el dicho día y no se quitó de su lado y es una de las quaren / ta lanzas quel dicho señor gobernador metió consigo y lo vido y se halló a todo ello pre / sente y que tiene por cierto y es ansí que con la entrada del dicho señor gobernador en / la dicha vatalla tan balerosamente y con tanto ánimo se recobró la vitoria / por su Magestad y se desbarataron los enemigos y que demás desto vido este / testigo que acabado de reconocer la vitoria el dicho señor gobernador probeyó y mandó / dar alarma porque no se rehiziesen los enemigos y mandó juntar toda / la ynfantería y que estubiese toda la noche junta y en bela porque como / dicho es no se rehiziesen algunos de los dichos enemigos y no les tomasen / descuydados y que en todo lo que dicho tiene este testigo vido quel dicho señor gobernador / se dio muy buena maña y sagazidad y mostrando a la contina muy gran / valor y esfuerzo como muy buen capitán general andando sienpre este / testigo como dicho tiene con el dicho señor gobernador y viéndolo pasar así como lo tiene / declarado. A las treynta y nuebe preguntas dixo que dize lo que dicho tiene en / la pregunta antes desta y que demás de lo que dicho tiene saue este testigo y tiene por / muy cierto y es ansí que la venida del dicho señor gobernador a estos reynos fue / muy conbiniente y muy necesaria para el reduzimiento e remedio dellos porque / como supieron de la venida del dicho señor gobernador se juntaron luego los vezinos / e otras gentes desta ciudad del Cuzco e de Arequipa y las Charcas y fueron en bus / ca del dicho señor gobernador con la nueba de que estaua en la tierra que con su anparo restau / rarían estos dichos reynos a su Magestad y ansimismo con su venida se juntó la gente / del capitán Alonso de Albarado e la gente de los Bracamoros e la gente de Mo / yobanba con sus capitanes Pedro de Vergara e Juan Pérez e con el resuello del dicho / señor gobernador se juntó mucha copia de gente que no se juntara si el dicho señor gobernador no biniera //

/ 61 v. / es que saue este testigo y es ansí muy cierto y claro quel dicho capitán Peralvarez / y su gente no fueran ninguna parte para resistir al dicho don Diego ni para juntar la co / pia de gente que después el dicho señor gobernador juntó ni para prevenir ni pro / ver todo lo que dicho tiene quel dicho señor gobernador probeyó sino que al fin se fuera / huyendo del dicho don Diego o hiziera lo quél quisiera porque desde la prouincia de / Xauxa los siguió el dicho don Diego hasta la provincia de Bonbón seys jor / nadas no los pudieron alcanzar y que con la venida del dicho señor gobernador / e buena deligencia que en todo se dio se ovieron dineros en la dicha ciudad de / los Reyes y en otras partes y se sacó y juntó la gente y se proveyeron todos / los demás adrezos y pertrechos de la guerra que dichos tiene y si el dicho / señor gobernador no traxera los hierros de picas dende Quito y la mecha dende los / llanos hiziera muy gran falta y no se pudiera aver por entonces por / que halló el real del dicho Peralvarez muy desprobeído de todo y no les dieran / lugar los contrarios para hazer los dichos hierros y mechas y que en quanto / a lo que la pregunta dize de que si los gastos quel dicho señor gobernador hizo en / todo lo que dicho es fueron necesarios y convinieron saue este testigo y tiene por / muy cierto y está muy claro que a no hazerlos y a no darse tan buena maña / el dicho señor gobernador ni juntara la dicha gente ni se hiziera cosa acertada en el / seruicio de su Magestad sino questos dichos reynos se perdieran totalmente y el / dicho don Diego y su gente fueran señores dellos y prevalecieran teniéndolos / tiranizados muchos días y demás desto corrieran peligro el reyno de Tierra / Firme y las probincias de Nicaragua porque públicamente se dezía / 
entre los dichos don Diego y sus gentes que venzido el dicho señor gobernador se apodera / rían en la tierra y en la mar y matarían todos los principales e hazer / nabíos de armada para que andubiesen por la costa con mucha artillería / y gente y echar todos los nabíos que topasen a fondo y saquear a Pana / má y el Nombre de Dios y a la contina traer armada de cosarios por toda la cos / ta hasta la Nueba España de arte que no entrasen en estos Reynos nadie / contra su voluntad e demás desto se recrecieran otros muchos e muy grandes daños y muertes y disensiones todo lo qual cesó con la venida del dicho / señor gobernador y su buena prudencia y valor y maña que en todo se dio y / demás de lo que dicho tiene cumplió la venida del dicho señor gobernador porque entre el dicho / capitán Peralvarez y los otros capitanes avía muchas disensiones e / pasiones de tal arte que cree este testigo y tiene por cierto que no se pudieran conservar / sino que se perdieran porque este testigo salió con ellos desta ciudad del Cuzco y lo vido //

/ 62 r. / e questo dize que saue y vido de la pregunta. A la cinquenta e siete / preguntas dixo que dize lo que dicho tiene en las preguntas antes desta e / que demás dello este testigo a oydo dezir muchas vezes al dicho señor gobernador / que deue casi más de cinquneta mil pesos dándole quenta a este testigo a quien e como lo / devía y que se los avían prestado para todo lo que dicho tiene en las preguntas / antes desta y que lo que dicho tiene es lo que saue deste caso y la verdad para el / juramento que hizo y en ello se afirma e ratifica e firmólo de su nonbre en ansy / mismo el dicho señor alcalde Grabiel de Rojas, Juan Alonso Palomino, el / canónigo Diego García Vidal canónigo de la santa yglesia de Panamá y cura de la / yglesia mayor desta ciudad del Cuzco. A la otaua pregunta dixo que lo que saue y bido / de la pregunta es que como dicho tiene en la pregunta antes desta este testigo se enbarcó / con el dicho señor gobernador en el dicho galeón de Sepúlbeda y nabegaron por esta Mar/ del Sur y que vido que en la dicha nabegación se pasó gran trauajo y que a la contina el / dicho señor gobernador porfió mucho por venir camino derecho a estos reynos y por traer / mala nabegación no pudo sino fue a aportar al puerto de la Buenabentura de las / provincias de Cali y Popayán e que ansimismo vido este testigo que por respeto de la / dicha mala nabegación que tubieron el dicho señor gobernador hechó a la mar muchos / cauallos e azémilas no tiene memoria que tantos mas de ser casi todos los que / llevaba e auía enbarcado y que ansimismo vio este testigo que el dicho señor gobernador lle / vaua cargado mucha parte de ropa e hazienda y vastimentos en el dicho galeón / e que se pudrió y dañó mucho dello que no se ovo ningún probecho porque / fue todo dañado e podrido por respeto de la mala nabegación y que a este testigo / se le perdieron más de mil pesos de oro que traya de ropa e adrezos de su persona / en el dicho galeón y todo vino dañado y podrido que no valía nada y que le / parece a este testigo que fue milagro de nuestro Señor el dicho señor gobernador de yr a parar / al dicho puerto de la Buenaventura abiendo traydo como traxeron muy mala / nabegación y tanbien porque si viniera camino derecho a desenbarcar a Payta o a / Tunbez o a otro puerto de la costa cayera en manos de García de Albarado e de cier / ta gente suya que estaua en la ciudad de San Miguel y hera público y notorio que es / tauan esperando al dicho señor gobernador e ansimismo porque a la sazón quel dicho / señor gobernador llegó al dicho puerto de la Buenaventura abía gran diferencias / entre los gobernadores Venalcázar y Andagoya y tenía cada gobernador su gente a punto / de guerra y se cree y tubo por cierto que a no pasar por allí el dicho señor gobernador para a / beriguarlos como los averiguó oviera vatalla entre ellos donde se recrecieran / muertes de onbres y otros daños y con venir por allí el dicho señor gobernador e aberiguallos // 
/ $62 \mathrm{v}$. / se escusaron y quedaron en paz y la tierra quieta y segura en lo qual vido este testigo / quel dicho señor gobernador en la aberiguación de los dichos dos gobernadores mostró / mucho valor y esfuerzo porque se halló presente este testigo a todo ello. A la nobena / pregunta dixo que saue la pregunta como en ella se contiene, preguntado como la saue di / xo que porque vido quel dicho señor gobernador llegó al dicho puerto de la Buenaventura e / que visto la mala nabegación que auía traído no quiso andar más por la mar e que / se determinó de venir por tierra y que vido quel dicho señor gobernador y sus criados e / seruidores que con él venían pasaron muy grandes y excesibos trauajos y peligros / por el camino muy áspero de sierras e muchos malos pasos e que no podían / caminar a cauallo por ninguna vía ni manera y muchos ríos e muy peligrosos / e que vido que desde el dicho puerto de la Buenaventura hasta el puerto de / Cali de la governación de Benalcázar se le perdió al dicho señor gobernador / mucha parte de la hazienda que avía escapado y venía algo buena de la / mar e ansimismo se le despeñaron ciertos cauallos y se le murieron casi todos / los criados que traya y que fueron tantos y tan grandes los travajos que en el / dicho camino se pasaron que este testigo tubo por cierto que ni el dicho señor gobernador ni los / que con el venían los pudieran sufrir sino que murieran y peligraran todos. / A la dézima pregunta dixo que dize lo que dicho tiene en la pregunta antes desta e que / vido este testigo demás dello que llegado que fue el dicho señor gobernador al dicho puerto de / la Buenaventura enfermo y le dieron ciertas calenturas y con temor de / ser enfermo el dicho puerto de la Buenaventura no quiso estar allí sino / caminar hazia el dicho pueblo de Cali y queste testigo vido que desde a ocho días / quel dicho señor gobernador salió del dicho puerto biniendo enfermo se purgó y / sangró de la enfermedad que traya y queste testigo vido que entre otros muchos tra / vaxos quel dicho señor gobernador y los que con él venían pasaron especialmente / el dicho señor gobernador viniendo como venía enfermo pasó un río muy grande en / una tarde diez e siete vezes estando purgado de un día antes el qual dicho / río se pasó por diez e siete partes y llevaua mucha agua porque daba a / los cauallos a la gineta a las rodillas en muchas partes e yva tan recias que la / primera vez que lo pasaron se pensó ahogar don Pero de Cabrera que venía con / el dicho señor gobernador y que demás desto vido que muchos días pasaron / mucha hanbre y no tenían que comer el dicho señor gobernador y los que con él ve / nían y se mantubieron con unos pocos de salbados de mayz por no tener / otra cosa salvo raízes y hojas de bijaos que no es mantenimiento que se pue / da comer y que fueron tan grandes y tan excesivos los trauajos que pa / saron que le requirieron al dicho señor gobernador muchos de los que con él venían que se bol //

/ 63 r. / viese al dicho puerto de la Buenaventura y no caminase por mal camino muriendo / de hanbre no obstante esto el dicho señor gobernador pasó adelante pasando los dichos / trauajos y enfermedades mostrando a ellos muy buen valor y esfuerzo y caminando sien / pre por venir a estos dichos reynos y que este testigo cree y tiene por cierto que si bolbie / ran al dicho puerto de la Buenaventura muriera el dicho señor gobernador y todos los / que con él venían porque murieron todos los que quedauan atrás por que demás de / ser la tierra muy enferma no tenían ningunos bastimentos que comer sino heran / raízes o yerbas y estas se buscaban con mucho trauajo y que este testigo cree y tiene / por cierto que segund los muchos e muy grandes trauajos que se pasaron le parece que / quiso Nuestro Señor Jesucristo mostrar milagro en el dicho señor gobernador y todos los que con él / venían en darles vida y que desde entonzes hasta agora este testigo a estado y está / enfermo del mal que por allí pasó que no a podido restaurar en su salud / e que vido quel dicho señor gobernador legó al dicho puerto de Cali muy en / fermo y que allí estubo más de sesenta días muy malo en la cama e / ansimismo muchos criados suyos y que vido con la dicha enfermedad / 
gastó mucha cantidad de dineros porque algunos mantenimientos que allí a / vía valían muy caros porque valía una gallina peso y medio y dos pesos e una / dozena de huebos vn peso y por este precio otras cosas que conpravan y que / vido que en gallinas e huevos gastó el dicho señor gobernador el tienpo que / allí estubo en el dicho puerto de Cali casi mil pesos de oro porque este testigo conpró / mucho dello o lo tubo por quenta e que vido que para estos gastos quel dicho / señor gobernador hizo con su persona e criados en la dicha enfermedad vendía quanta hazienda / el dicho señor gobernador tenía e le auía quedado tanto que no vastó la suya e se bendió la / de sus criados e que a lo que se acuerda este testigo y tiene por cierto se gastaron allí al / pie de cinco mil castellanos e que quando llegó a la ciudad de Popayán que es otro / pueblo adelante de Cali veynte e cinco leguas quedó tan gastado el dicho señor / gobernador que no tenía un peso suyo ni de criado porque todo lo auía gastado / en el dicho camino y enfermedades y questo saue y vido desta pregunta. / A las doze preguntas dixo que dize lo que dicho tiene en las preguntas antes / desta e que demás dello saue quel dicho señor gobernador hecho lo que dicho tiene en / la pregunta antes desta se partió del dicho pueblo de Cali a diez días del mes / de agosto del año de quarenta y uno para la ciudad de Popayán o media legua / antes que entrase en ella abiendo pasado muchos trauajos en el dicho camino por / ser ápero y fragoso y el dicho señor gobernador venir muy enfermo tanto que tra / ya consigo la estremaunción teniendo por cierto que no escapara pasando un río / media legua de la dicha ciudad de Popayán se le ahogó un criado del dicho señor gobernador / que se llamaua fulano Valdes y se pensaron ahogar otros en el río grande que sale a / Santa Marta que nace junto a la dicha ciudad de Popayán y que llegado el dicho señor gobernador a la dicha //

/ 63 v. / ciudad dende a ocho días que en ella estaua llegaron allí el capitán Lorenzo de Al / dana y un Antón Diez e otro que se dezía Arguello vezinos de la ciudad de Quito de / los quales supo la muerte del marqués y gobernador don Francisco Pizarro como le / avían muerto don Diego de Almagro y sus secazes y como tenían robada e / tiranizada la tierra y estauan apoderados de todos los pueblos destos rey / nos saluo de la ciudad de Quito y que vido este testigo quel dicho señor gobernador fue / ynportunado e aconsejado que se bolbiese a Panamá porque no era cosa de en / prehender pasar adelante ansí por la enfermedad que traya porque no tenía gente / ni adrezos ni dineros con que probeerla ni hazerla e quel dicho señor gobernador mostran / do mucho esfuerzo y valor tomó su camino adelante para la dicha ciudad de / Quito con toda su enfermedad y pasando muy grandes y excesibos trauajos / por el mal camino fragoso y áspero y por los grandes ríos que se pasauan con / otros muchos trauajos y ansí siguió su camino hasta llegar a la dicha ciudad / de Quito e questo saue y vido de la pregunta y que demás desto se acuerda / este testigo que desde la dicha ciudad de Popayán el dicho señor gobernador sabida la dicha / nueba ynbió a la dicha ciudad de Cali a llamar al gobernador Benalcázar para que / viniese con él el qual vino y lo alcanzó en la dicha ciudad de Popayán. A las treze preguntas dixo que dize lo que dicho tiene en la pregunta antes desta / e que demás dello saue y vido que después quel dicho señor licenciado y gobernador llegó a / la dicha ciudad de Quito el propio día que llegó fue reciuido por gobernador con mucha a / legría que reciuió toda la ciudad y vezinos della porque su venida por / que lo tubieron por prencipal remedio de sus vidas e haziendas por res / peto de la tiranía del dicho don Diego y que cada día estaban con sobresalto / quando avían de yr a la dicha ciudad a la robar e saquear e hazerles otros / daños e que demás desto saue y vido este testigo que luego el dicho señor gobernador enpezó / a despachar muchos mensajeros con cartas e despachos a todos los pueblos / e ciudades destos dichos reynos para procurar de ser reciuido por gobernador en / cada uno dellos y ansimismo enbió muchos despachos a los dichos don / Diego de Almagro y sus capitanes y aliados para los reducir al seruicio 
de su Magestad / si pudiese e que especialmente saue y vido que despachó con los dichos des / pachos al capitán Pedro de Puelles e al capitán Pedro de Heredia y a Gómez / de Rojas e a fulano Sandoual y a Francisco Carreño e a otros con los despachos / que dichos tiene para todos los pueblos destos dichos reynos hasta esta dicha ciudad / del Cuzco para el efecto que dicho tiene arriba y para hazerle sauer la venida / del dicho señor gobernador e que se aparexasen y apercibiesen para seruir / a su Magestad en el reduzimiento destos dichos reynos y ques público y notorio / e manifiesto el provecho y utilidad que dello se siguió porque con la / venida del dicho señor gobernador luego todos los dichos pueblos recibieron muy gran consuelo //

/ 64 r. / e fabor e se enpesó a juntar gente e hirse hazia donde venía el dicho señor / gobernador todo lo qual e la buena providencia del dicho señor gobernador dio / causa a questos dichos reynos se reduziesen a su Magestad y los sacasen fuera / de la tiranía del dicho don Diego de Almagro y questo saue y vido de la pregunta. / A las catorze preguntas dixo que dize lo que dicho tiene en la pregunta antes desta / e que público y notorio es en estos dichos reynos quel dicho señor gobernador / por virtud de los dichos despachos que enbió desde la dicha ciudad de Quito fue / reciuido por gobernador de todos estos dichos reynos y en las ciudades de los Re / yes y el Cuzco e que al dicho capitán Pedro de Heredia que vino a la dicha ciudad / de los Reyes por mensajero del dicho señor gobernador le oyó decir este testigo cómo / quándo llegó a la dicha ciudad de los Reyes e se recibió en ella por gobernador / el dicho señor licenciado Vaca de Castro que avía muy poco que auía salido / della el dicho don Diego y sus secazes y al dicho Gómez de Rojas que vino a / esta ciudad del Cuzco que quando a ella llegó el dicho don Diego y sus secazes / ya estaua reciuido en ella el dicho señor gobernador e questo saue de la pregunta. / A las diez e seis preguntas dixo que lo que saue de la pregunta es que este testigo vido que / estando el dicho señor gobernador en la dicha ciudad de Quito comenzó a hazer toda la gente / que pudo y conpró todos los cauallos y armas que halló e hizo hazer ciertos / arcabuzes y mucha cantidad de hierros de picas y conpró ansimismo ar / cabuzes hechos y toda la demás munición que podía para efeto de se venir e / ajuntar con los caualleros e vezinos desta ciudad del Cuzco que estauan / juntos aguardando al dicho señor gobernador y que vido este testigo que asy en la / dicha ciudad como en todo el camino se venía probeyendo de todos los a / drezos de guerra y conpraua todas las armas y cauallos que hallaba e / hazía toda la gente que podía y que se acuerda este testigo que en Quito el dicho señor gobernador / hizo hazer e se hizieron más de trecientos hierros de picas y en Payanca se / probeyó de más de dos cargas de mecha para los arcabuzes y tiros y no se acuerda / en que parte si hera en San Miguel o en Truxillo se proveyó de cantidad de plo / mo para pelotas y por todo el camino se yva probeyendo de todo lo que / hallaba que hera necesario lo qual aprovechó mucho estando en la probincia de / Xauxa porque el dicho señor gobernador halló toda la gente questaua con el dicho / capitán Peraluarez Holguín muy desprobeída de todo e aprovecharon mu / cho los dichos hierros de picas porque con ellos se hizieron docientos pi / queros y más y la dicha mecha aprovechó mucho porque auía muy poca en / tre la gente del dicho Peraluarez y no se podía auer por allí sino se bolbía a / los llanos por ella. A las veinte e ocho preguntas dixo que lo que saue de la / pregunta es que vido quel dicho señor gobernador vino a la prouincia de Guaylas e Guaraz / donde le estauan esperando el capitán Pero Aluarez con los cauallos e gente que con el / se auía juntado del Cuzco y Arequipa y Charcas y ansy mismo el capitán Alonso de Alba / rado con su gente el qual dicho capitán Pero Aluarez estaba apoderado de toda la gente // 
/ 64 v. / e que vido este testigo quel dicho señor gobernador con mucho valor entró en el real del dicho / Pero Aluarez e que en el recibimiento que se hizo vido este testigo que salió el dicho Pero Aluarez / con toda su gente llevando estandarte como capitán general y que asy / como llegaron al dicho señor gobernador el dicho capitán Pero Aluarez y los demás ca / pitanes entregaron al dicho señor gobernador el dicho estandarte y vanderas que / llevauan y entregadas, el dicho señor gobernador por su propia mano dio el dicho / estandarte real quel dicho Peraluarez llevaua a Rodrigo de Ocanpo su capitán / de guarda y le mandó que lo cogiese e lo arrollase y no fuese tendido por / que no auía de auer otro estandarte sino el quel dicho señor gobernador traya / como capitán general y no auía de auer otro y que asímismo vido / como el dicho señor gobernador por su propia mano tornó a dar / a los otros capitanes las vanderas que trayan las quales las / recibieron en nombre de su Magestad el del dicho señor gobernador saluo el dicho es / tandarte que como dicho tiene lo mandó arrollar e lo dio al dicho su ca / pitán de la guarda y que vido este testigo quel dicho capitán Peraluarez antes / que entrase el dicho señor gobernador en el dicho real ni llegase a él el dicho / capitán Peraluarez e su gente ynbió a Gómez de Tordoya e al padre / regente para que suplicasen al dicho señor gobernador sospechando lo que después fue / que le consintiese lleuar y traer al dicho capitán Peraluarez su estandarte / descogido e alto e quel dicho señor gobernador no consintió ni quiso sino siempre / dixo que no auía de auer otro estandarte sino el quél traya el dicho / señor gobernador y el del dicho Peraluarez avía de yr cogido e arrollado y no le / bantado y no pudieron acabar con él otra cosa sobre esto e que an / simismo vido que en el dicho recibimiento quando el dicho señor gobernador tomó el dicho / estandarte y lo mandó arrollar y lo dio al dicho su capitán de la guarda / vido como el dicho capitán Peraluarez se sintió y corrió mucho de / llo y se le conoció estar desabrido y que ansimesmo se conoció de mucha / gente y soldados de la del dicho Peraluarez estauan muy descontentos / e desabridos de lo quel dicho señor gobernador hazía con el dicho capitán Pero Aluarez / sobre el dicho estandarte e dezían muchas palabras soberbias e desacato / e ansimismo vido este testigo que algunas personas venían al dicho señor / gobernador y le dezían como el dicho capitán estaua muy desabrido y enojado / e diziéndole y poniéndole muchos temores que auía de pasar por muchos / tiros de artillería y por muchos soldados y que no estaría en más de an / tojársele a un soldado de hazer lo que quisiese por conplazer al dicho / capitán Peraluarez y que a todo esto vido este testigo quel dicho señor gobernador / mostrando muy gran valor y ánimo diciendo que si alguno se le desgobernase //

/ 65 r. / a hazer la menor cosa del mundo le cortarían la cabeza fuese capitán o sol / dado o quien quiera que fuese y que vido que en ninguna cosa de valor pudie / ron el dicho señor gobernador se auajase asi con temor como con amor y que en esto vido / este testigo quel dicho señor gobernador con el dicho valor que siempre mostraba y con muchas / prebenciones que probeyó e sagacidad que en todo tubo lo apaciguó todo / y lo puso en paz y al fin el dicho capitán Peraluarez se fue con el dicho / su estandarte y entró en el dicho real el dicho señor gobernador y fue reciui / do y obedecido por tal y luego el dicho señor gobernador enpezó a saber si estaba / bien proveído de todo lo necesario e halló que toda la gente con el dicho / capitán Peraluarez estaua muy desprobeída de muchos adrezos / de armas y munición e que visto esto tomando el dicho señor gobernador muy a pecho / las cosas de la guerra y sabiéndose muy bien valer entre todos luego enpezó / a probeer gentes unos que fuesen a hazer picas a los Andes que es / pasados los puertos de la otra parte de las syerras nebadas y a otros que fue / sen a hazer armas a la probincia de Xauxa e a otros pólbora a la probin / cia de Tarama y Bonbón y otros a hazer arcabuzes a la ciudad de los / Reyes e otros a hazer hachería y azadonería y otras cosas necesarias en / todo lo qual se pasó muy gran trauajo 
porque dende la dicha probincia de Guaraz donde el dicho / señor gobernador estaua a la provincia de Xauxa ay más de cinquenta leguas y a la dicha pro / vincia de Tarama y Bonbón cerca de quarenta leguas y a la dicha ciudad de los Reyes a / vía cinquenta leguas y para todo fue menester probeer gente que fuese a cada parte y otros / adrezos para hazer las dichas municiones e que demás desto vido este testigo en la dicha provincia / de Guaylas e Guaraz el dicho señor gobernador conpró allí cantidad de veinte y cinco o tre / ynta adargas que costaron a veinte pesos cada una las quales repartió el dicho señor / gobernador entre alguno de la dicha gente e ansimismo vido que conpró quatro mulas para el / artillería por escusar el trauajo que se seguía a los yndios de llevarla las quales / le costaron a trecientos pesos cada una e que demás desto vido este testigo quel dicho / señor gobernador hizo otros muchos probeymientos muy conbinientes y muy necesarios / que cada día se ofrecían para probeer la gente que venía en el dicho real e otros / muchos adrezos para la guerra pasando a la contina muy grandes y excesi / bos trauajos y zozobras porque muchos de los dichos capitanes y gente que te / nían cargo del dicho real no estauan tan diestros en las cosas de la / guera ni en la provisión della como el dicho señor gobernador e que esto saue / e vido de la pregunta. A la treinta e ocho preguntas dixo que / lo que saue de la pregunta es que después quel dicho señor gobernador / despachó en la ciudad de los Reyes lo que tiene dicho en las pregun / tas antes desta salió della y fue a la probincia de Xauxa donde es / taua el dicho capitán Pero Aluarez con toda la gente y este testigo salió con el dicho / señor gobernador porque como su capitán no le dexaua a la contina y que vido que / llegado el dicho señor gobernador a la probincia de Xauxa luego empezó a poner en orden //

/ $65 \mathrm{v}$. / toda la dicha gente e a sauer si se auía probeydo todo lo quel avía / mandado ansí en el hazer de la pólvora como en el traer e hazer / de las picas e pelotas para el artillería e arcabuzes e re / quirió a todos los capitanes y conpañías par ver si fal / taua algo e aunque dicho señor gobernador avía proveido / muchas cosas no se avían acabado de cumplir ni hazer / e para mejor ver lo que faltaua hizo hazer alarde de toda / la gente el qual se hizo un día de fiesta y que vido quel dicho señor / gobernador el dicho día anduvo en el dicho alarde requiriendo / todos los capitanes e conpañías e soldados ansí de cauallo como de / pie y poniéndolos por memoria todos por ver lo que faltaua e / que después de hecho el dicho alarde vido como el dicho señor gobernador pro / veyó que se traxese la pólvora quel dicho señor gobernador avía / mandado hazer en la provincia de Tarama y ansí mismo proveyó / como se traxese las picas quel dicho señor gobernador auía enviado / a hazer a los Andes e que vido que se traxeron e traídas el dicho / señor gobernador las repartió en su propia cámara y les dio / para con ellas los hierros de picas quel dicho señor gobernador / traya desde Quito que a no traerlos se perdían más de doscientos / piqueros que no se pudieran hazer como se hizieran por / tener tan cerca los enemigos y no obiera tiempo para ha / zerse e ansímesmo repartió quatro petacas de / mecha que traya el dicho señor gobernador desde los llanos / de un pueblo que se dize Payanca de la qual dicha mecha / avía muy gran falta en todo el real y a no traer / la el dicho señor gobernador hiziera muy gran falta / porque no se pudiera aver en la dicha provincia por / ser sierra e no se hazer en ella sino que por fuerza a / vían de volver a los llanos por la dicha mecha los quales / dichos dos probeymientos de hierros de picas y mecha balyeron e aprovecharon mucho porque como dicho tiene si el dicho señor / gobernador no tuviera los dichos hierros de picas no se hizieran los dichos doscientos / piqueros que se hizieron y también fuera muy gran falta no tener la / dicha mecha porque con la quel dicho señor gobernador traxo se proveyó todo el / dicho real así para la artillería como para el arcabucería y que demás / desto vido este 
testigo que como el dicho señor gobernador envió a Juan Alonso Palomino / a la dicha ciudad de los Reyes a que hiziese hazer cantidad de petos y espaldades de hierro //

/ 66 r. / e por otras cosas de munición de que al presente no tiene memoria porque fue / ron tantos y que demás desto vido que proveyó a muchos soldados dándoles / socorros a unos dando cauallos e a otros armas e a otros dineros y contentán / dolos y apaciguándolos pasando en esto muy continuo y execibo trauajo de noche / e de día porque a la contina avía muchos desasosiegos e disensiones entre / soldados y a todos ocurría el dicho señor gobernador y los alagaba y contentaba y / socorría demás de que ansí mismo pasaua muy gran trauajo en el buen gobierno / de la guerra dándose en todo muy buena orden y que vido como salió con toda / su gente de la dicha provincia de Xauxa a prisa para tomar la villa de Goa / manga porque tubo nueva que los enemigos se acercaban a tomar la dicha villa / por tomarla el dicho señor gobernador primero e que en todo el camino / vido este testigo como el dicho señor gobernador a la contina de noche y de día no se / desbelaua en otra cosa sino en el buen gobierno de la guerra y en proveer todo lo que / faltaua y en contentar a todos los soldados y tenerlos quietos y pacíficos e / animándolos en el seruicio de su Magestad y entre esto vido que muchas vezes despa / chaua cartas e despachos al dicho don Diego e a muchos capitanes y aliados su / yos para atraerlos al seruicio de su Magestad porque a esto le conoció al dicho señor / gobernador tener muy gran deseo de atraer e reducir al dicho don Diego y sus / secazes al seruicio e obidiencia de su Magestad y que no oviese ronpimiento / e que siguiendo su camino hazia la dicha villa de Guamanga estando una / o dos jornadas della supo como los dichos don Diego de Almagro y sus secazes estauan muy cerca de la dicha villa e que la venían a tomar el dicho señor / gobernador se dio muy gran priesa para tomar la dicha villa y caminó / un día entero a muy gran priesa con todo su canpo y tomó la dicha villa / a dos oras de la noche y entró en ella e salió a hazer asentar su canpo y gente fue / ra de la dicha villa un tiro de ballesta porque le pareció que estaua más segura que / no dentro e con ser de noche visto que el dicho asiento no hera conviniente / e que estaría[n] más fuertes aquella noche en la dicha villa hasta que otro / día de día se buscase un asiento e que aquella noche se retrajo con to / da su gente en plaza pública de la dicha villa e hizo que las capitanías / de gente de a cauallo se repartese por toda la dicha plaza por todas las es / quinas della y estobiesen toda la noche a punto de guerra e apercebidos sos / pechando de que avían de venir aquella noche a dar sobre el pueblo e también / hizo quel artillería se pusiese en ciertas calles asestada para que si vini / esen estuviesen todos apercebidos y mandó a los capitanes Nuño de / Castro y Guebara que con toda su gente de infantería hiziesen cuerpo de / guarda toda la noche e sus enboscadas de arcabuceros para questo viesen / a punto si viniesen los enemigos y toda aquella noche estando en vela / el dicho señor gobernador y armado como a la contina venía probeyó de corre //

/ 66 v. / dores de canpo muy a menudo para sauer donde estaban los enemigos e ansy / mismo hizo otros muchos probeymientos muy necesarios y que otro día vido / como el dicho señor gobernador tornó a mandar salir toda la gente e andubo / con su persona a buscar sitio conviniente donde asentó su real fuera de la / dicha villa e que demás desto vido este testigo quel dicho señor gobernador con el deseo que / tenía de reduzir al seruicio de su Magestad a los dichos don Diego y sus secazes enbió / muchos mensajeros con cartas e despachos entre los quales enbió a Alonso García / Zamarilla con cartas e despachos y perdones para que se viniesen al seruicio de / su Magestad e que dende a cinco o seis días que enbió al dicho Alonso García Zamarrilla se dixo públicamente en la dicha villa y en el real del dicho señor / gobernador y se tubo por nueba como el dicho don Diego y 
sus capitanes a / vían ahorcado al dicho Alonso García Zamarrilla porque dezían que avía / ydo por espía a su real e que después desto vido como el dicho señor gobernador / enbió desde la dicha villa cartas perdones y despachos a Lope Ydiaquez y al fator / Mercado a los dichos don Diego y sus secazes para conbencerlos si pudiese / e atraerlos al seruicio de su Magestad e derramase la gente y no obiese rencuentro / e que desde a tres o quatro días que fueron los dichos mensajeros bolbieron a / la dicha villa e bueltos dixeron y publicaron como avían salido huyendo / del real del dicho don Diego e que dezían los dichos don Diego y sus capitanes que no / querían paz sino guerra y venir a buscar al dicho señor gobernador y darle la vata / lla y que en execución desto se partían del tanbo de Bilcas donde estauan pa / ra donde estaua el dicho señor gobernador y visto esto el dicho señor gobernador hizo salir / su gente al asiento de Chupas ques dos leguas de la dicha villa e allí estubo / con toda su gente ciertos días esperando si los dichos don Diego de Almagro y sus se / cazes y que en los días que allí estubo vido como el dicho señor gobernador / no entendía ni se desbelaba en otra cosa sino en adrezar y animar su gente e / requerirá ${ }^{16}$ todos los capitanes e conpañías si les faltaua alguna cosa e / si les faltaua les probeya luego y ansimesmo probeya cada día sus corre / dores de canpo muy a menudo e de noche sus centinelas por sus quartos / e que cada noche hiziesen su cuerpo de guarda por capitanías y requirien / do los sargentos para que no oviese descuydo en ninguna cosa entendiendo / en ello de día e de noche el dicho señor gobernador animando y esforzando su gente / mostrando muy gran valor en el seruicio de su Magestad teniendo cada día nueva co / mo se acercauan los enemigos un día sáuado que se contaron diez e seis días / del mes de setienbre del año pasado de mil e quinientos e quarenta y dos / años a más de medio día vinieron los corredores del canpo que avían ydo / a correr aquella mañana e dixeron como el dicho don Diego y su gente estaua / en las lomas enzima del dicho asyento y que venían caminando e que podrían //

/ 67 r. / estar una legua poco más o menos donde estaua el dicho señor gobernador e que yban ca / minando hazia Guamanga e que sauido esto por el dicho señor gobernador mandó dar a / larma muy apriesa y que saliese toda la gente al canpo e luego probeyó de otros corredores de refresco que fuesen a ver donde caminaba / el real del dicho don Diego y probeidos el dicho señor gobernador se armó en blanco / e se puso enzima de las armas una ropeta de brocado con un ábito de Santiago en los pechos grande y subió enzima de un cauallo morcillo / rabicano que agora tiene el dicho señor gobernador y deste arte andubo / por todos los toldos hechando toda la gente fuera hasta que se jun / taron todos en un llano e puestos allí el señor gobernador hordenó sus / esquadrones de gente de cauallo e de pie y los puso todos a punto e / que estando en este estado le parece a lo que se acuerda este testigo quel dicho señor / gobernador quería tomar el abanguarda o yr en delantera e que los capita / nes rogaron e suplicaron al dicho señor gobernador y porque convenía al seruicio / de su Magestad y buen subcesso de la guerra que no tomase la abanguarda syno / que tomase la retaguarda y llevase toda la gente por delante y el dicho señor / gobernador por conplacer los dichos capitanes tubo por bien tomar la / dicha retaguarda y con este acuerdo el dicho señor gobernador mandó al capitán Castro / que subiese las lomas arriba con su gente para entretener la gente del dicho / don Diego entre tanto que subían los demás capitanes e gente y luego tras / el dicho capitán Castro mandó al capitán Peranzures que subiese las / dichas lomas con su gente de cauallo para el efeto que dicho tiene y hecho entró / el dicho señor gobernador recogiendo toda la gente ordenó sus esquadrones y va / tallas e andubo por todo el real derrocando toldos porque no se le escon / diese ni quedase nadie y proveyó de yndios y negros que llevasen el / artillería y proveyendo todo lo que

\footnotetext{
${ }^{16}$ Leer "requerir a".
} 
más conbenía e ansí proveydo mandó / subir toda la gente puesta en orden por sus esquadrones y vatallas y / tomó la retaguarda tomando consigo cerca de quarenta onbres de a ca / vallo que apartó para socorrer en la vatalla al tiempo que fuese menester / e suviendo las dichas lomas ya casi que estauan en lo alto de las dichas / lomas travesó un benado por todo el esquadrón sin podello resistir / con muchas vozes e gritos que le dieron y vido quel dicho señor gobernador al subir de / las dichas lomas se apartó con su capitán de guarda e andubo de esquadrón / en esquadrón e de vandera en bandera requiriendo los dichos esquadrones / e mirándose yvan a punto o si faltaua alguna cossa e si yvan bien / puestas y bien hordenadas las vatallas animándolos y esforzándolos / a todos e diziéndoles que mirasen que aquel día restauraban a su Magestad //

/ $67 \mathrm{v}$. / su tierra y se la sacauan de poder de tiranos y que hiziesen como seruidores / de su Magestad y como dellos se esperaua y que tubiesen por buena señal de vitoria / el dicho venado trayéndoles por exenplo que los Reyes de Francia lo / tenían por buena señal de vitoria en sus guerras diziéndoles otras / muchas cosas para animarlos y esforzarlos haziéndoles muchas plá / ticas sobrello a todos juntos e a cada uno por sí a tanto que toda la gente / se animó y esforzó mucho para seruir a su Magestad y pelear en la dicha va / talla valerosamente y que suvidas las dichas lomas visto que si y / van camino derecho se yban afrontar con el artillería de los contrarios y que / se les podría hazer mucho daño y para evitarlo mandó al capitán Alonso de / Albarado que fuese a ver por donde se podría mejor entrar a los contrarios / y visto por donde mexor se podría entrar mandó al capitán Pero Aluarez / que tomase la abanguardia con quatro banderas y a Alonso de Albarado con / el estandarte real en otra parte y mandó caminar la dicha gente hazia / los contrarios e que estando en esto este testigo y Hortun Sánchez de Olabel / clérigo e otros religiosos frailes e clérigos se apartaron vn poco y vieron / caminar la dicha gente y se vieron afontar unos con otros y que vido quel / dicho señor gobernador se apartó en un valle con cerca de quarenta ombres que consigo / apartó y los puso allí y el se desbió vn poco dellos en vn altillo para ver / lo que pasaua y estando la dicha gente una con otra peleando vió co / mo el esquadrón del capitán Alonso de Albarado estaua ronpido por / que avía ocurrido a él muchos de los contrarios y en aquella sazón el / dicho señor gobernador socorrió por aquella parte y entró en la dicha vatalla con / la gente de cauallo que consygo tenía los quales a grandes vozes entraban / diciendo ynperio ynperio Vaca Vaca aquí viene el gobernador y el dicho señor / gobernador acometió tan valerosamente y con tanto esfuerzo que en / muy poco espacio después de entrado en la dicha vatalla se reconoció la / vitoria por la parte de su Magestad y el dicho don Diego y sus capitanes e / gente es [sic] comenzaron a desbaratarse y fueron huyendo a rienda suel / ta y este testigo vido que sobrevino luego la noche y tiene por cierto que / Dios nuestro señor lo permitió así porque no muriese más gente de la que / allí quedó muerta que no fue poca y saue e vio quel dicho señor gobernador mandó / tocar las trompetas e menestriles para recoger su gente la qual se / recojó y el dicho señor gobernador hizo que toda aquella noche estobiesen armados y / sus esquadrones por si los contrarios se rehiziesen e bolbiesen so / bre ellos no les hallasen desapercebidos y saue y vido quel dicho señor / gobernador no durmió en toda aquella noche y trauajó mucho visitando e requiriendo //

/ 68 r. / su gente hasta que amaneció otro día domingo el qual el dicho señor gobernador es / tubo en el dicho canpo donde se dio la vatalla donde mandó a hazer quartos a cinco / o seys onbres de los matadores del dicho marqués que fueron presos en la dicha / vatalla e saue y vio que otro día lunes o martes siguiente el dicho señor gobernador / caminó con toda su gente a la dicha villa de Guamanga donde hizo llebar to / dos los heridos que de la dicha vatalla salieron de parte de su 
Magestad e que este / testigo saue y vio quel dicho señor gobernador sirbió mucho a su Magestad en el dicho día de la / dicha vatalla porque demás de lo que dicho tiene saue y vio que antes que en / trase en la dicha vatalla estaua en parte muy peligrosa e vi las muchas / pelotas de arcabuzes e artillería que pasaua por cima del una de las quales / oyó decir este testigo que auía muerto un ombre que estaua detrás de toda la / gente e del esquadrón del dicho señor gobernador que pareció estar escondido y que / porque al tiempo quel dicho señor gobernador entró en la dicha vatalla avía rendidos / algunos dellos de su parte los quales auía rendido la gente del dicho don Diego / e con su entrada en la dicha vatalla < se recobró y ganó la vitoria >. A las treynta e nueve preguntas dixo / que demás de lo que dicho tiene en las preguntas antes desta este testigo tiene / por cierto que en los dichos gastos y en gastar el dicho señor gobernador lo que gastó se hizo / gran seruicio a su Magestad porque tan claro que sino hizieran los dichos gastos / no se pudieran juntar ni se juntara tanta copia de gente como se juntó y que no / aviendo la copia de gente que vbo no se pudiera benzer la dicha vatalla / e que Dios nuestro señor fue seruido de guardar al dicho señor gobernador de las en / fermedades e trauajos pasados para que viniese a poner remedio en estos Reynos / e para que se pudiese juntar la dicha gente que se juntó para seruir a su Magestad / porque con fama quel dicho señor gobernador estaua desenbarcado se juntó la gen / te que salió del Cuzco con el capitán Peraluarez los quales ni los demás que / con él se pudieron juntar no fueran parte para resistir al dicho don Diego del / qual el dicho capitán Peraluarez salió huyendo de la prouincia de Xauxa / la buelta de Bonbón por la poca posibilidad que tenía para darle la vatalla / e que así el dicho capitán Peraluarez como el capitán Alonso de Albarado / se juntaron para yr como fueron a buscar al dicho señor gobernador la venida del / qual los animó a ellos e a los caualleros y soldados que con ellos estauan / con los quales y con la gente que después el dicho señor gobernador hizo como dicho tiene / fue muy necesario hazer los dichos gastos que se hizieron ansí en cauallos / como en armas e otros adrezos de guerra mediante todo lo qual fue Dios / nuestro señor seruido de dar la vitoria al canpo de su Magestad y al dicho señor gobernador / en su nombre y está claro que a no hazerse los dichos gastos y no venzerse la dicha / vatalla se perdían estos Reynos e quedauan tiranizados en poder del dicho / don Diego y sus secazes los quales fueran malos de sojuzgar porque cada día se / rehizieran de más gentes y de armas y cauallos porque entre ellos estaua platicado //

/ 68 v. / e acordado que si venziesen la dicha vatalla avían de hechar a la mar tres / o quatro nabíos de armada y con ellos correr toda la mar sojuzgar las gober / naciones de Tiera Firme y Nicaragua y Guatemala hasta la Nueba España / e de no consentir dejar entrar nabío en esta tierra sino fuese el quellos quisiesen / e que esto cree y tiene por cierto de lo contenido en esta pregunta. A las cinquenta y siete preguntas dixo queste testigo saue por muy cierto quel dicho señor gobernador / para hazer todos los gastos que tiene dichos en este su dicho a tomado mu / chos dineros prestados y que saue que está adeudado con mucha suma de pesos de oro / que deue oy en la tierra e que lo que dicho tiene es la verdad y lo que saue deste caso / es público y notorio para el juramento que hizo y firmólo de su nombre. / El canónigo Diego García Vidal. Grabiel de Rojas, Seuastián de Merlo vezino / de la ciudad de los Reyes. A la otaua pregunta dixo que lo que della saue es que / el dicho señor gobernador se enbarcó en la ciudad de Panamá en el galeón / del dotor Sepúlbeda a diez e ocho de marzo de quinientos y quarenta y un años para / pasar a estas dichas probincias del Perú e andubo por la mar mucho tiempo / por tener mala nabegación y estando en la costa del Perú se reconoció / la ysla de la Gorgona y el dicho señor gobernador porfió muy mucho porque el dicho / galeón subiese arriba la vía de Puerto Viejo y estando en la punta de An / cón de Sardinas que a lo queste testigo oyó decir estaua de Puerto Viejo tre / ynta o quarenta leguas surcó el dicho galeón un 
día dos oras antes que / anocheciese se quebró el cable con que la dicha nao estaba surta que hera muy / gordo sin hazer mucho biento en tal manera que se tubo por cierto que se / perdería el dicho galeón el qual andobo aquella noche al reparo sin poder / surgir en parte ninguna y otro día de mañana amaneció junto a la ysla / del Gallo que del dicho Ancón a lo que dizen doze leguas y allí surgió el dicho / galeón e surcó sin que hiziese mucho biento se tornó a quebrar el dicho / cable y todavía el dicho señor gobernador mandó al dicho maestro que surgiese / e con mucho trauajo se tornó a surgir en la dicha ysla y estubo allí / aquella noche y otro día de mañana tornó a navegar hazia la bía de Puerto / Viejo y en todo un día no pudo arribar de tres leguas adelante a parecer / deste testigo y visto por el dicho maestre e los demás que en la dicha nao y galeón / venían que lo questaua en la dicha nao se perdía e que no podían nabegar / se juntaron y suplicaron al dicho señor gobernador que arribasen y tor / nasen a Panamá e visto por el dicho señor gobernador quel dicho galeón no podía / nabegar ni pasar adelante con parecer de todos los que en la dicha nao / venían o la mayor parte se arribó al puerto de la Buenaventura que / es un puerto que tiene descubierto el adelantado Andagoya en aquella cos / ta y el dicho galeón arribó a una ysla que se dize de Palmas y surgió en ella //

/ 69 r. / y el mesmo día que surgió el dicho señor gobernador ynbió a este testigo en / una barca con ciertos marineros para que fuesen a descubrir y buscar el / puerto por no entrarse con el dicho galeón por no ser puerto cursado y aver / poco que se auía descubierto y este testigo andubo ocho días en busca del dicho / puerto y nunca lo pudo hallar y bolbió a la dicha ysla donde el dicho señor / gobernador estaua y le dixo que no se podía hallar el puerto y visto por / la gente que en la dicha nao venya que no se podía hallar el puerto y que se / padecía mucha hanbre y trauajo que ya la gente no tenya que comer sino / maíz crudo y esto por razión muy poco todavía, el dicho señor gobernador / mandó se tornase a buscar el dicho puerto porque la dicha gente quería que / arribase el dicho galeón a Panamá porque se perdía todo lo que en el dicho / galeón venya que hera en mucha cantidad de mercaderías y el dicho señor gobernador / tornó a mandar a este testigo y a otro criado suyo que se dize Diego de Aller que / fuesen en el dicho vatel para que se buscase el dicho puerto y este testigo y el dicho Diego / de Aller y ciertos marineros tornaron en busca del dicho puerto en la barca / del dicho vatel y andubieron en busca del diez días sin lo poder hallar ya queste / testigo y el dicho Diego de Aller y marineros se bolbían que no lo podían hallar vieron / un nabío que venía de Puerto Viejo y fueron a él y le preguntaron si sabían don / de estaua el dicho puerto de la Buenaventura y el maestre ni ninguna persona / que en la dicha nao venía no lo sauía y luego vieron otro nabío el qual venía an / si mismo en busca del dicho puerto y tanpoco sabían del dicho puerto syno / por ciertas señas que trayan dello y este testigo se entró en vno de los dichos na / víos y el dicho Diego de Aller en el otro y por las dichas señas fueron a buscar / el dicho puerto y llegando a un ancón donde el dicho puerto está vieron un na / bío que venía ansimismo en busca del dicho puerto de la ciudad de $\mathrm{Pa}$ / namá al qual dicho nabío el dicho señor gobernador avía ynbiado a ver / si sabrían del dicho puerto al maestre del galeón donde el dicho señor gobernador venía / y tanpoco la gente que venía en él no sabían del dicho puerto y estando sur / tos en el dicho ancón los dichos nabíos donde este testigo y el dicho Diego de Aller yban / después de anochecido venía una barca por el dicho ancón dando vozes pi / diendo vn cabo de una de las dichas naos que la llevaua la corriente ques / muy grande la que en el dicho ancón ay y este testigo a las vozes que la gente que / traya el dicho vatel daba se lebantó este testigo que estaua ya durmiendo y llamó / al maestre y marineros de la dicha nao y se le dio a la dicha varca vn cabo en que / se asió al dicho nabío y este testigo preguntó a los que dentro en ella venían / que de adonde venían los quales respondieron que 
del puerto de la Buenaventura / en la qual dicha varca venía don Juan de Andagoya hijo del adelantado Andagoya el qual //

/ 69 v. / dixo este testigo que auía salido por ver si venía un nabío que avía / enbiado a Panamá a pedir remedio [a] aquella real audiencia porque tenía / preso a su padre el gobernador Venalcázar y tenía por cierto le mataría / si de la dicha real audiencia no le ynbiaban remedio y este testigo le respondió / que allá estaua en la ysla de las Palmas el licenciado Vaca de Castro presiden / te de la dicha real audiencia que < avía > arribado en busca del dicho puerto por mala na / vegación que avía tenido e oydo esto por el dicho don Juan y la dicha gente que / en la dicha varca venía se alegraron mucho y dezían ser muy gran milagro / porque hasta oy avía arribado nabío [a] aquel dicho puerto y este testigo otro / día de mañana escribió al dicho señor gobernador todo lo que auía pasado / e que este testigo se yva al dicho puerto para le ynbiar alguna comida por la / mucha necesidad que padecían y el ynbió el piloto que venía en la dicha varca / para que metiese el nabío en quel dicho señor gobernador venía en el dicho puer / to y llegado este testigo al dicho puerto de la Buenaventura se regocijó to / da la gente que en el estaua por tener por cierto que Dios nuestro señor auía re / mediado al dicho Adelantado de la prisión en quel dicho Venalcázar le / tenía e desde a día y medio el dicho señor gobernador desenbarcó en el dicho puer / to y despachó a este testigo por la posta a pie porque por aquella tierra no se / puede yr a cauallo con un mandamiento en que mandaua al dicho Venalcázar / y al dicho Andagoya estubiese todo en el estado en que su mandamiento les tomase / so ciertas penas con el qual este testigo fue hasta la ciudad de Cali que son treyn / ta y cinco o quarenta leguas del dicho puerto con la más brebedad que puedo / y llegado notificó el dicho mandamiento al dicho Venalcázar y este testigo escribió al / dicho Andagoya lo que pasaua porque estaua en Popayán preso que son ve / ynte e cinco leguas de la dicha ciudad de Cali y noteficado el dicho mandamiento / cesó todo y no se entendió en cosa alguna hasta quel dicho señor gobernador / llegó lo qual fue causa de no llevar al dicho Andagoya a la ciudad de Timana / donde tenía por cierto en el camino moriría por ser tierra muy ás / pera e de grandes niebes y enferma e yr el dicho Andagoya aprisonado / y este testigo de que vido quel dicho Venalcázar no entendía más en lo que / tocaba al dicho adelantado hasta quel dicho señor gobernador llegase / procuró de auer alguna comida de la que en la tierra abía que heran / puercos y algunas abes para les llevar al camino por donde el dicho / señor gobernador e la gente que con el venía avía de pasar y algunos yndios con / que mejor pudiesen venir y escribió al dicho señor gobernador todo lo que pasaua el qual / se partió luego para la ciudad de Cali enfermo con muy rezias calen / turas donde se sangró y purgó muchas vezes en el qual dicho camino se le //

/ 70 r. / murió al dicho señor gobernador muchos criados de los que consygo traya y / cauallos y azémilas e se le perdió mucha hazienda de la que en la dicha nao traya / la qual dicha arribada al dicho puerto de la Buenaventura fue caussa de poner en / quietud aquella tierra porque segund estaua alborotada no podía ser menos / al parecer deste testigo sino tener muy grandes diferencias entre los dichos Venalcá / zar e Andagoya por tener cada uno dellos mucha gente todo lo qual cesó con / la llegada del dicho señor gobernador y se tiene por muy cierto y este testigo ansí lo cree / que si el dicho gobernador no aportara al dicho puerto de la Buenaventura / e viniera su viaje derecho topaua en la ciudad de San Miguel con García de / Albarado capitán de don Diego de Almagro que lo enbiaba el dicho don Diego según se / dixo a prender al dicho señor gobernador porque se tenía noticia que a / vía desenbarcado en Payta y fuera parte para si se prendiera el dicho señor / gobernador para perderse estos Reynos. Todo lo qual que dicho tiene este testigo en esta / pregunta 
lo saue porque venía en el dicho galeón donde el dicho señor gobernador benía / y lo vido este testigo pasar como dicho e declarado tiene. A la dézima pregun / ta dixo que como dicho tiene en la otaua pregunta antes desta dende a dos días / quel dicho señor gobernador desenbarcó en el dicho puerto de la Buenaventura / ynbió a este testigo a la ciudad de Cali con los despachos que dicho tiene y el dicho / señor gobernador quedó de se partir desde a ciertos días y mandó a este testigo que le yn / biase ciertos yndios para poderse abiar y este testigo llegado que fue a la / dicha ciudad de Cali procuró de ynbiarle al dicho señor gobernador los dichos vas / timentos e yndios que dichos tiene y antes que cosa desta llegase al dicho puer / to de la Buenaventura enfermó el dicho señor gobernador el qual con la / dicha su enfermedad se partió luego para la dicha ciudad de Cali y en el camino / el dicho señor gobernador se purgó y sangró muchas vezes y malo con la dicha su en / fermedad sin se parar un día en el dicho camino y pasando un día un río / muy caudalosso diez e siete o diez e ocho vezes todo por pasar el dicho camino / por ser muy montuoso e de grandes ríos y muchas aguas que le parecía / a este testigo ser muy gran milagro el dicho señor gobernador escapar porque este testigo / con ser buen nadador y venir a la ligera pasó muy gran peligro de la bida / por pasar el dicho río tantas vezes y por ser tan caudaloso y tan áspero / e trauajoso el dicho camino y este testigo volbió a reciuir al dicho señor gobernador a la / mytad del camino a donde topó al dicho señor gobernador muy malo e de gran en / fermedad de la qual este testigo pensó que no llegaría a la dicha ciudad de Cali / y el dicho señor gobernador con gran ánimo y esfuerzo que tubo no quiso detenerse / en el dicho camino sino todavía proseguirle y llegó a la dicha ciudad de Cali / y estubo en ella tres meses muy malo de grabe enfermedad que se pensó / nunca escapar y este testigo oyó decir a los que con el dicho señor gobernador venían des / de el dicho puerto de la Buenaventura hasta donde toparon a este testigo quel dicho señor gobernador / e los que con él venían avían pasado mucha hanbre e avían comido salvados de mayz //

/ 70 v. / e se avían ahogado en el dicho río dos o tres onbres y a don Pedro Luis de Cabrera / que con el venía le auía llevado el río muy gran trecho e auía ydo a nado tras / él un Alonso de la Peña e se auía sacado del dicho río por todos los quales / dichos peligros los que venían con el dicho señor gobernador le suplicaron mu / chas vezes se bolbiese al dicho puerto de la Buenaventura y nunca de / jando [?] acabar con el dicho señor gobernador lo qual cree este testigo que si el dicho señor / gobernador bolbiera muriera porque otros que se bolbieron del dicho camino murie / ron y llegado a la dicha ciudad de Cali vendió mucha hazienda de la que traya a / menos precio para gastar en la dicha enfermedad suya e de sus criados e / que al parecer deste testigo se pudieron gastar lo contenido en la pregunta po / co más o menos por ser los gastos muchos y la dicha enfermedad del dicho señor / gobernador e de sus criados muy grave y questo saue desta pregunta. / A las veinte e ocho preguntas dixo que lo que della saue que al tiempo quel dicho señor / gobernador llegó al real donde estaua Peraluarez Holguín y los demás capita / nes y gente del Cuzco e Charcas e Arequipa e la demás que en conpañía del / dicho Peraluarez venía al dicho capitán y gente dél le salió a reciuir con el / estandarte quel dicho capitán Peraluarez tenía y las demás vanderas que / los demás capitanes tenían y el dicho señor gobernador con su valor y persona aunque le a / vían puesto muchos temores diciendo que lo querían matar el dicho Peral / uarez e gente del dicho real tomó el estandarte quel dicho Peraluarez tenía / e lo dio y entregó al capitán Rodrigo Docanpo para que lo llevase el qual vido / este testigo que se arrolló a una bara en que venía asido y vaxo lo llebaron al dicho / real y el dicho señor gobernador dixo que no auía de auer otro estandarte más de vno / e auía de ser el que traya e ansí fue el dicho estandarte real quél traya es / tendido y el otro como dicho tiene cogido e después de entrado en el dicho real / el dicho señor gobernador otro día de mañana 
mandó juntar todos los capita / nes y cauildos que en el dicho real avía y platicó con ellos sobre la / providencia de las cosas necesarias para la guerra e platicada so / bre ello vido este testigo que no auía en el dicho real adrezos de guerra ni las / cosas necesarias de pertrechos para ella segund y de la manera que / convenía y el dicho señor gobernador juntamente con los dichos capitanes / dio la horden que se requería enviando personas unos a la prouincia / de Xauxa a hazer picas e armas y otros a Lima a hazer arcabu / zes e otros a la prouincia de Tarama y Bonbón a hazer pól / bora e otros a otras partes a buscar piedra zufre para la dicha / pólbora porque no se hallaua porque el dicho don Diego dezían la avía / toda recogido e ansimismo conpró en el dicho real ciertas adargas //

/ 71 r. / que allí estauan y otras armas que halló que se vendían y ansimismo conpró / ciertas azémilas para en que se llevase la artillería porque los yndios no / pasasen tanto trauajo y ansimismo el dicho señor gobernador enbió a la dicha ciudad de los Re / yes a Cristóval Rodríguez su criado para que comprase azadones e hachas e otras / cosas necesarias para el dicho real e saue y vido este testigo que dende a dos o tres / días quel dicho señor gobernador entró en el dicho real del dicho Peraluarez enbió / a decir al dicho Peraluarez Holguín que por qué se nonbraua capitán general / que no se nonbrase tal que donde él estobiese no auía de aver otro / syno él y el dicho Peraluarez enbió a dezir con el regente que qué hera lo que su / señoría mandaba que hiziese e se juntaron el dicho señor gobernador y el dicho capitán / Peraluarez y el regente y entre ellos se acordó que usase el oficio de maestre / de canpo y el dicho capitán lo acetó con cargo que se le diese la judicatura y el / dicho señor gobernador dixo que no se la auía de dar sino que auía de auer / un letrado que oyese como alcalde mayor a las partes e hiziese jus / ticia en lo qual vbo muchas diferencias y allí mostró el dicho señor gobernador / el valor de su persona no obstante los temores que le avían puesto / por estar el dicho Peraluarez muy bien quisto en el dicho real y al fin / se hizo lo quel dicho señor gobernador mandó y no otra cosa e que demás desto / vido este testigo quel dicho señor gobernador regía e governaba todo el real, capi / tanes e gente del sin que uno se le desmandase, con mucha cordura / e valor de su persona en tal manera que se obedecía y cunplía todo / lo quel mandaua sin se osar menear ni eceder dello un punto / e questo es lo que saue desta pregunta. A las treynta e ocho preguntas / dixo que lo que della saue que después que llegó el dicho señor gobernador / a las provincias de Xauxa donde estaua el real de la gente el dicho / señor gobernador entendió en dar socorro y armas y otras cosas / a todos los soldados que lo avían menester e ansimismo vido este / testigo quel dicho señor gobernador daua de comer e tenía su mesa larga para / todos los caualleros e gente que querían comer a ella y ansí lo hizo / hasta tanto quel dicho don Diego y su gente vinieron a dar la vatalla al / dicho señor gobernador a Chupas ques dos leguas de Guamanga el / qual dicho don Diego de Almagro a lo que todos dezían traya en su exér / cito quinientos onbres muy bien armados e vasteados de cauallos e / de lo demás necesario e traya dozientos arcabuzeros e mucha artillería / ansí gruesa como pequeña y ciertos onbres de armas para con ellos / romper en la vanguarda e que saue y vido este testigo quel dicho señor gobernador con poco / número de gente que la quel dicho don Diego dezía que traya y no muy bien armada //

/ $71 \mathrm{v}$. / porque entre la gente que el dicho señor gobernador llebaba yvan muchos que no llebauan / más de las espadas y picas sin otras armas ningunas y sin llebar ninguna / artillería al tiempo del romper porque toda se quedó atrás que no pudo al / canzar pasar la vatalla e que bido este testigo al tiempo quel dicho don Diego / de Almagro estubo sobre el real del dicho señor gobernador a legua y media del / un biernes en la noche el dicho señor gobernador mandó que se quitasen todos los / 
toldos que en el dicho su real estauan e aquella tarde mandó hazer e / hizo su alarde y mandó que toda la dicha gente se pusiese en arma por / temor quel dicho don Diego y su gente por estar tan cerca no diesen en el real / del dicho señor gobernador en que antes quel dicho señor gobernador entrase en la villa de San Juan / de la Frontera le vinieron muchos mensajeros e corredores del campo / que el señor gobernador auía ynbiado adelante para ver que no entrase el dicho / don Diego e se apoderase de la dicha villa de Guamanga por el daño que /se podía reciuir los vecinos della los quales ynbiaron a decir al / dicho señor gobernador como el dicho don Diego y la dicha su gente se yvan a entrar / en la dicha villa de Guamanga y visto por el dicho señor gobernador ynbió a los / capitanes Nuño de Castro y a los demás se fuesen a apoderar en la / dicha villa de Guamanga hasta tanto que el dicho señor gobernador se juntase con ellos / y el dicho capitán Castro y los demás capitanes asentaron su real / cerca de la dicha villa de Guamanga en una estancia que dizen de Gabilán / y estando allí el dicho señor gobernador llegó a donde estaua el dicho real y otro día / de mañana alzó el dicho real y caminó hasta dos oras de la noche o tres / e hasta se meter en la dicha villa de Guamanga e los capitanes y gente / que della se avían salido se fueron aposentar fuera de la dicha villa / e llegado el dicho señor gobernador y visto que el dicho sitio no estaua bueno / para poder estar en él mandó a la dicha gente que se entrase en la dicha ciu / dad y allí se tobiesen e se hiziesen fuertes hasta otro día de maña / na y vido este testigo que en toda aquella noche el dicho señor gobernador reposó sino que estubo armado y ansó se hechó un poco a reposar y otro día en a / maneciendo día el dicho señor gobernador cabalgó con los dichos capitanes y an / dubo por el canpo biendo donde se podría asentar el dicho real para / que si los enemigos viniesen se pudiesen mejor resistir y allí estu / vo el dicho real hasta siete o ocho días desde donde el dicho señor gobernador / ynvió mensajeros con cartas e despachos para el dicho don Diego de $\mathrm{Al} /$ magro y los capitanes que con él estaban unos primeros con perdón para / que todos los que a él se viniesen y otros secretos e haziéndoles sauer //

/ 72 r. / al don Diego y a los dichos capitanes que con él venía a les oyr e hazer justicia / de los agrauios que se les oviesen fecho e que derramasen la gente y se viniese / para él quél en nombre de su Magestad y como cauallero les daua su palabra que / qualesquier personas que para él se viniesen serían perdonados de qua / lesquier delitos que oviesen hecho e cometido y ansí fueron por mensa / jeros el fator Mercado y Lope de Ydiaquez y a uno que se llamaua Zama / rrilla vezino de la dicha villa de Guamanga e después vido este testigo quel dicho / don Diego e los dichos capitanes respondieron al dicho señor gobernador como ellos / estauan en su gobernación e que a quien se la quisiese perturbar se la de / fenderían en el canpo e otras cosas que se contenían en la carta de queste / testigo no tiene memoria y los dichos Lope de Ydiaquez y fator Mercado vinieron / muy temerosos porque en el dicho real los avían querido matar la gente / del dicho don Diego e oyó dezir este testigo a los dichos fator e Ydiaquez como / avían ahorcado al dicho Alonso García Zamarrilla mensajero que ansy / avía enbiado el dicho señor gobernador todo lo qual visto por el dicho señor gobernador / e las desbergüenzas quel dicho don Diego y capitanes le avían escripto a / cordó que se fuesen a poner con el dicho real al dicho asiento de Chupas e / ansí se fue el dicho real donde estubo quatro o cinco días de donde el dicho / señor gobernador procuró por todas las vías que pudo de hazer sauer a la gente / que en el real del dicho don Diego estauan el hierro en que andauan e que se vinie / sen para él que los perdonaba y ansí aprovechó que algunos de los del / dicho real del dicho don Diego de Almagro se vinieron para el dicho señor gobernador e / visto por el dicho señor gobernador que no aprovechaua cosa alguna lo que les a / vía apercebido e quel dicho don Diego e la dicha gente se venían hazia / donde estaua el dicho señor gobernador e que se acercaban hazia 
donde el dicho señor gobernador / estaua asentado su real y estaua ya a vista dondel dicho señor gobernador mandó / que se quitasen todos los toldos que avían en el dicho real y tornando a ha / zer alarde de toda la dicha gente ansí de pie como de a cauallo e la hizo / estar toda aquella noche en arma por temor quel dicho don Diego y la dicha / su gente no biniesen de noche a dar en el real del dicho señor gobernador y otro día de / mañana el dicho señor gobernador se lebantó en siendo el día y mandó apercebir / e se apercibió el capitán Peranzures con cinquenta onbres de a cauallo e / al dicho capitán Castro con otros cinquenta arcabuzeros ansí de a cauallo / e los envió el dicho señor gobernador arriba de las lomas de Chupas por donde el / dicho don Diego y la dicha su gente avían de venir e les dixo que procurasen / como el dicho don Diego no asentase real por el temor de la artillería que traya //

/ 72 v. / el dicho don Diego e le hiziesen luego sauer al dicho señor gobernador lo que pasaua e / aquel dicho día a mediodía el dicho capitán Peranzures y el dicho capitán Castro / enviaron muchos mensajeros al dicho señor gobernador diciendo como / el dicho don Diego e la dicha su gente se yban a entrar en la dicha villa de Gua / manga e que si ansí fuese que reciuirían mucho daño por tanto su señoría / se subiese luego con toda la dicha gente a se lo perturbar e luego visto / por el dicho señor gobernador lo que los capitanes le ynbiaban a dezir caualgó en un / cauallo armado de todo armas llevando consigo la dicha gente e / fecho los esquadrones e recogiéndolos a todos para que ninguno se desman / dase sino que fuesen en toda horden de guerra e subió a donde los dichos / capitanes Pero Anzures y Castro estauan y al tiempo que a ellos llegó / serían dos oras antes de la noche poco más o menos y visto por la / gente del dicho don Diego quel dicho señor gobernador y la gente que con él yba subía / por las dichas lomas asentó su real e empezó a jugar de su arti / llería gruesa y visto por el dicho señor gobernador quel dicho real estaua a / sentado mandó juntar todos los capitanes e gente de guerra que le pa / recía ser del consejo de guerra y entre ellos acordaron qué debía hazer / e el dicho señor gobernador acordó que aquella tarde se les diese la vatalla / porque si aguardauan para otro día como para algunos de los dichos capi / tanes se dezía el dicho don Diego pornía su artillería en parte donde hi / ziese mucho daño e acordado se mandó por el dicho señor gobernador que aquella tarde / se diese la dicha vatalla mandó a todos los capitanes que fuesen a su / gente e la pusiesen en horden para yr a romper con los dichos enemigos / y el dicho señor gobernador ynvió al capitán Caruajal soldado viejo en Y / talia que hera sargento mayor fuese a buscar e mirase por qué parte / le parecía que se les entraría a los dichos enemigos e ydo el dicho Caruajal / e visto el dicho sitio y parte por donde se les entraría el dicho señor gobernador / fue a los dichos esquadrones ansí de a pie como de a cauallo y les hizo / un valeroso parlamento diziéndoles que no hera menester hablarles / para les poner ánimo por lo mucho que ellos tenían sino acordarles que / don Diego y sus secazes tenían a su rey desacatado y que los otros / heran traydores y ellos leales y que aquel día ganaban la tierra para sy / e para su Rey y vido este testigo que entonzes Gómez de Tordoya dixo / al dicho señor gobernador agora verá Vuestra Señoría quién es Gómez de Tordoya y la gente / del Cuzco y el dicho señor gobernador le respondió pues agora bereys todos el gobernador que / teneys y vamos a ellos e restauremos la tierra a su Magestad pues su Magestad //

/ 73 r. / no la quiere sino para que los caualleros y tales personas como vosotros soys / la tengan e se sustenten della y otras cosas queste testigo no tiene memoria e / ansí mandó al capitán Peraluarez Holguín que él fuese a ronper en la / abanguarda con los demás capitanes y el dicho señor gobernador se quedó / en la retaguarda con quarenta onbres poco más o menos para ronper / en los dichos enemigos en su tiempo y ansí fueron los dichos capitanes y gente / a donde estaua el dicho 
don Diego y la dicha su gente toda puesta a punto de / guerra e jugando con su artillería gruesa y pequeña que hera cosa de espanto en / estas partes el dicho señor gobernador se quedó como dicho tiene este testigo en la reta / guarda e se puso en una loma de un cerro donde claramente se veían los / dichos esquadrones e ansí de los de la parte del dicho señor gobernador como de / los de don Diego y en parte por donde todos los tiros de la artillería del / dicho don Diego venían a dar e muy a peligro porque estando un soldado de / tras del dicho señor gobernador y muy cerca una pelota de uno de los dichos / tiros le mató y ya quel dicho señor gobernador vido que los dichos esquadrones en / pezaban a ronper los vnos con los otros cauallero en un buen cauallo mor / cillo y armado de las armas que dicho tiene este testigo dixo animosamente a la gente / que con él estaua Ea Ea caualleros que agora es tiempo y ansí animosamente / se fue a meter entre el batallón de toda la dicha gente donde pasó muy / gran peligro su persona y gente que con él yva por llegar a tan buen tiempo / que no se conocía vitoria por ninguna de las partes y estaua en un peso / e con la gente que con el dicho señor gobernador entró de refresco y con el apellido que / se llevaba de Vaca Vaca desanimó la gente del dicho don Diego y fue mucha parte / para que la gente del dicho don Diego fuese benzida porque al tiempo quel dicho señor gobernador / entró aun se estauan enteros dos esquadrones y vanderas de las del dicho / don Diego que se avían quedado a la mano derecha y este testigo fue uno de / los que entraron con el dicho señor gobernador y se quedaron con él o fue / uno de los que dio en los dichos esquadrones en los quales mataron dos / onbres de los quel dicho señor gobernador metió y este testigo salió herido de muy grabes / heridas y otras personas de las que con el dicho señor gobernador entraron y vido / quel dicho señor gobernador por se dar tan buena maña y tener tan buena deligencia e / solicitud de alarma luego que se vido e reconoció vitoria fue parte / para desanimar la gente del dicho don Diego y empezaron a huyr por todas partes / donde se conoció más enteramente tener vitoria su Magestad y estar la tierra / reduzida en su real nonbre e que este testigo oyó decir que al tiempo quel dicho señor / gobernador entró en el dicho ronpimiento andava ya gente del dicho don Diego rindiendo / a gente de la quel dicho señor gobernador llevó e que como avían visto entrar al dicho señor gobernador / con el dicho socorro avían desmayado diziendo pese a tal lluebe Dios gente //

/ 73 v. / lo qual oyó dezir este testigo a muchos soldados ansí de los del dicho don Diego como del / dicho señor gobernador porque desde a media hora que la gente enpezó a ronper / estaua este testigo muy mal herido e questo es lo que saue y vido este testigo / de lo contenido en la pregunta. A las cinquenta e siete preguntas dixo que / dize lo que dicho tiene en las preguntas antes desta y questa es la verdad / para el juramento que hizo y en ello se afirma e ratifica y firmolo de su nombre / Sebastián Sánchez de Merlo, Gómez de Rojas vezino de la ciudad del Cuzco. / A las treze preguntas dixo que como dicho tiene este testigo se halló en la ciudad de / San Francisco de Quito al tiempo que en ella entró el dicho señor gobernador e que luego como / llegó la dicha ciudad y vezinos estantes en ella con mucho gozo e alegría / le recivieron en la dicha ciudad e que otro día que llegó el dicho señor / gobernador fue reciuido en la dicha ciudad y cabildo della por goberna / dor destos reinos e probincias por su Magestad por virtud de sus rea / les probisiones y poderes e que reciuido el dicho señor gobernador enpezó a probeer de todos adrezos para ser reciuido por / tal gobernador en nonbre de su Magestad en todos los pueblos destos / dichos reynos y que en execución deste despachó luego mensa / jeros con cartas e despachos para todos los dichos pueblos en / tre los quales despachó a Juan de Valdibieso para las ciudades / de la Culata ${ }^{17}$ y San Miguel e adelante

\footnotetext{
17 "Santiago de la Culata" era uno de los toponimos que designaba la actual Guayaquil.
} 
para la ciudad de Truxillo / al capitán Pedro de Puelles e para adelante para la ciudad de / los Reyes al capitán Pedro de Heredia e para adelante para esta ciudad del Cuzco a este testigo y que a todos los dichos mensajeros e a cada / uno dellos el dicho señor gobernador les dio despachos duplicados / para que viniesen a las dichas ciudades a que fuese reciuido por gobernador de su / Magestad en ellas y ansí salieron de la ciudad de Quito y este testigo vido que en la / dicha ciudad de Santiago de la Culata que fue el primero pueblo don / de llegaron fue reciuido el dicho señor gobernador e de allí bi / nieron a la ciudad de San Miguel y ansimismo fue recibido el / dicho señor gobernador e se quedó allí el dicho capitán Pedro / de Puelles y este testigo y el dicho capitán Pedro de Heredia / pasaron adelante hasta la ciudad de los Reyes e llegados / allá tobieron nueba como el dicho don Diego e sus seca / zes avían salido della pocos días avía y llegados el / dicho Pedro de Heredia presentó sus probisiones e / despachos en el cabildo de la dicha ciudad e presentados //

/ 74 r. / fue recibido el dicho señor gobernador en la dicha ciudad con mucha / alegría e regocijo e después de reciuido este testigo salió / de la dicha ciudad ascondidamente para esta ciudad del Cuzco por / el camino de los llanos porquel dicho don Diego de Almagro e / sus secazes venían por el de la dicha sierra e caminando muy a prie / sa de noche e de día llegó a esta ciudad del Cuzco donde luego como llegó / hizo juntar a cabildo al concejo e vezinos desta ciudad e juntos / presentó las probisiones e despachos que traya por virtud de las quales / el dicho señor licenciado Vaca de Castro fue reciuido por gobernador / destos reynos en nonbre de su Magestad con mucha alegría e regocijo que en / toda la ciudad se hizo por la venida del dicho señor gobernador e / nuevas que hera bibo porque por cartas de don Diego y sus secazes / hera público que hera muerto e que ansí reciuido el dicho señor gobernador / este testigo puso por su teniente al licenciado de la Gama y por al / guazil a Bernaldino de Mella vezino desta ciudad e que saca / do testimonio de todo este testigo se partió desta ciudad de buelta / donde estaua el dicho señor gobernador e que llegando quarenta leguas / desta dicha ciudad en los Aymarays salieron al camino a este testigo / un fulano Enrique alférez de Cristóval de Sotelo capitán del dicho / don Diego e otros tres de a cauallo con él sus secazes amigos e / prendieron a este testigo por mandado del dicho Cristóval de Sotelo / y preso le bolbieron a esta ciudad y que quando llegó a ella halló que / estaua ya el dicho Cristóval de Sotelo con cierta gente que avía traído / consigo de los secazes del dicho don Diego en esta dicha ciudad / e por fuerza avía hecho reciuir en ella por gobernador al / dicho don Diego y quitado la vara al dicho licenciado de la Gama te / niente del dicho señor gobernador e al dicho Bernaldino de Mella al / guazil mayor e puesto otro en nonbre del dicho don Diego e que llega / do este testigo como dicho es a esta ciudad e metiéndole / en ella a medianoche le llevaron a donde estaua el dicho Sotelo / el qual hizo a este testigo muchas preguntas de donde estaua / el dicho señor gobernador e si hera bibo y que las probisiones / que este testigo auía traído si heran falsas e que juraba que si al / tienpo queste testigo auía entrado en esta dicha ciudad esto / biera reciuido en ella el dicho don Diego por gobernador //

/ 74 v. / e después ovieran reciuido al dicho como gobernador por cédula de / fray García Cardinalis que él les cortara las cabezas a todo el cabildo e regidores / desta ciudad queste testigo dio respuesta al dicho Cristóval de Sotelo de lo que le / preguntaua diciendo quel dicho señor gobernador hera bibo y quedaua en / Quito sano e muy bueno y que las dichas provisiones heran verdaderas por quel / original dellas este testigo le auía visto sellada con el sello real e señalada de / los señores del Real Consejo de las Indias e que entonces en tres días que tubo / encerrado a este testigo en una cámara sienpre le amonestó y dixo que no / dixese nada del dicho señor gobernador ni de lo que le auía 
preguntado ni / que tenía ningún poder ni gente ni otra cosa poniéndole sobre ello muchos te / mores e amenazas diziéndole que si algo hablaua le cortaría la cabeza / e queste testigo le respondió que lo que auía dicho en esta dicha ciudad / al tiempo que en ella avía entrado primero quel dicho Sotelo que no podía / desdecirse dello e que sino quería que hablase que le diese licencia para / se bolber e que después desto a ruego de muchos caualleros el dicho / Sotelo tubo por bien de darle licencia y enbiar a este testigo a donde / venía el dicho don Diego y ansí lo ynbió con dos o tres de a cauallo de sus / amigos e alcanzaron al dicho don Diego y su gente en la probincia de / Vilcas y allí este testigo le habló al dicho don Diego y a Juan Balsa e a Rodrigo de Sauzedo sus capitanes y dio al dicho don Diego una carta del dicho señor gobernador y le hizieron / muchas preguntas de las quel dicho Sotelo le auía hecho en esta ciudad y le man / daron y amonestaron a este testigo lo mismo quel dicho Sotelo y no quisieron dar a / este testigo licencia para que pasase adelante sino bolberlo consigo a esta dicha ciudad y que por temor que este testigo no hablase ni diese nuevas del dicho señor gobernador le traxeron dos jornadas / delante de su real a la contina con quatro de a cauallo que le guardauan y que llegados / a esta dicha ciudad el dicho don Diego y su gente, el dicho don Diego usó del oficio de gobernador / e puso sus ministros y teniente y alguaziles e hizo el que sus capitanes y gentes / muchas fuerzas y robos, tiranías e muertes que son públicas y no / torias en estos reynos y tubo a este testigo en esta dicha ciudad / muchos días opreso y detenido hasta tanto que le dio licencia que / volviese a donde estaua el dicho señor gobernador juntamente con el licenciado / de la Gama y otros dos mensajeros del dicho don Diego que ynbió al dicho señor gobernador / e questo saue de la pregunta porque se halló presente a todo lo contenido en ella e pasó / por este testigo juntamente con mucho riesgo que a la contina corrió. A las / treynta y ocho preguntas dixo que el dicho señor gobernador tubo maravillosos probey / mientos para la guerra antes que la vatalla se diese a cuya causa tiene por //

/ 75 r. / cierto este testigo que Dios nuestro señor dio la vitoria a su Magestad / porque este testigo saue que antes quel dicho señor gober / nador llegase a la dicha provincia de Xauxa siendo avisado / que en el campo real del dicho don Diego de Almagro venían / muchos onbres de armas probeyó e despachó luego un criado / suyo que se dize Juan Alonso Palomino onbre ábil e deli / gente para que con breuedad bolbiese a la ciudad de los / Reyes e hiziese hazer cinquenta o sesenta petos con sus / ristres para la gente del dicho real de su Magestad para que / ronpiesen en la delantera lo qual el dicho Juan Alonso / Palomino hizo con mucha deligencia y cuydado como le fue / mandado y bolbió con ellos en breue tiempo a la probin / cia de Xauxa los quales petos fueron muy necesarios / porque avían necesidad dellos los que tenían necesidad / de armas. Yten llegado el dicho señor gobernador a la dicha / probincia de Xauxa con el resto de la gente quél con / sigo traya fue muy bien reciuido de los capitanes y gente / que allí estauan aguardando e cobraron con su venida / mucho ánimo biendo la mucha gente e adrezo que tra / ya para la guerra adonde se le recrecieron al dicho señor / gobernador muchos gastos sin los pasados ansí en / tener mesa larga para los que querían comer como en / contentar soldados y darles ayuda de costa y este tes / tigo saue quel dicho señor gobernador antes que entrase / en el dicho pueblo de Xauxa abía probeído y mandado / a un vezino que se dize Mazuelas tubiese cuydado / de hazer muchas hastas de picas y lanzas porque / la gente que estaua en la dicha probincia de Xauxa con el / dicho capitán Peraluarez Holguín e con los demás ca / pitanes avía pocos o no ningunos y quando el dicho señor / gobernador llegó a la dicha probincia de Xauxa halló mucha / cantidad dellas hechas lo qual fue muy buen probey / miento porque a descuidarse el dicho señor gobernador / en esto y a cada uno puede ver qué balía la ynfantería // 
/ 75 v. / sin picas allende desto el dicho señor gobernador antes que lle / gase a la dicha probincia de Xauxa probeyó a Martín de / Florencia vezino desta ciudad del Cuzco para que tobiese / hechas mucha cantidad de armas de cobre que son muy bue / nas a falta de armas de acero e de hierro lo qual fue / muy buen probeimiento e aviso quel dicho señor gobernador / tubo porque quando llegó a la dicha probincia de Xauxa / halló hechas cantidad de las dichas armas las quales el / dicho señor gobernador repartió luego que llegó a la dicha pro / bincia de Xauxa. Yten tubo el dicho señor gobernador / muy buen abiso y probeimiento en mandar yr al capitán / Diego de Rojas con quarenta o cinquenta ombres de a pie / e de a cauallo a la villa de Guamanga para que desde allí / corriesen el canpo y supiesen la venida de los enemigos e / abisasen al dicho señor gobernador lo qual fue muy / gentil abiso porque con su yda del dicho capitán Diego / de Rojas aquel pueblo se consoló e sosegó que estaba / en términos de despoblarse temiendo la venida del dicho / don Diego y su gente y el dicho señor gobernador y sus capitanes / heran avisados todos los días de lo que pasaua en el campo / del dicho don Diego y de sus secazes y valedores. Yten / este testigo bio que dende a pocos días quel dicho señor / gobernador llegó al dicho pueblo de Xauxa mandó hazer / alarde general de toda la gente de a pie e de a cauallo an / si de la questaua en Xauxa con el capitán Peraluarez / Holguín como de la quel dicho señor gobernador traxo de / Lima al qual alarde el dicho señor gobernador salió ar / mado en blanco sobre un cauallo morcillo donde vio / y visitó todas las banderas de a pie y de a cauallo pro / veyendo al que le faltaba alguna arma, biendo los arcabuzes el recaudo que tenían de mecha y pólbora / donde fueron muy buenos y provechosos los hierros de / picas quel dicho señor gobernador traxo de Quito porque en el /

/ 76 r. / dicho alarde avían salido todas las más picas sin hierros an / si que en este dicho alarde se mostró el dicho señor gobernador / onbre de guerra y como si en ella se oviera criado ansí en / poner e hordenar las azes como en ver las faltas e de / fetos que en cada uno avía. Yten este testigo bio como es / tando el dicho señor gobernador en la probincia de Xauxa / le vinieron mensajeros e cartas ansí del capitán Diego de / Rojas que estaua en Goamanga como de yndios de Andaguay / las e de otras partes que dezían quel dicho don diego y sus se / caces se acercaban a la villa de Guamanga lo qual sauido / por el dicho señor gobernador mandó que enpezase a mar / char su real la vía de la villa de Guamanga en cuya coyun / tura a no se hallar el dicho señor gobernador en Xauxa / se perdiera todo el canpo de su Magestad porque entre el dicho / Peraluarez Holguín y el capitán Alonso de Albarado / hubo ciertas diferencias de las quales se siguiera muy / gran daño porque se enpezaua a juntar gente de una parte / e de otra lo qual el dicho señor gobernador remedió / con mucho valor y prudencia conforme al tienpo / e sazón y luego partió el dicho señor gobernador con / toda la dicha gente la vía de Guamanga con mucho re / caudo e horden a punto de guerra donde llegado dos / jornadas de Guamanga fue avisado por corredores / del dicho capitán Diego de Rojas como el dicho don Diego / e su gente venían a tomar la villa de Guamanga lo / qual sabido por el dicho señor gobernador puesto que / avía ya andado su jornada estaua ya la gente / aloxada tocó alarma y partió con mucha deligencia / y entró a prima noche en la villa de Guamanga y pasó / adelante al canpo donde pareciéndole que podía / reciuir daño si fuera acometido de los enemigos / donde no podía dexar de reciuirlo por el mal sitio a / donde estaua el dicho señor gobernador con solo su pare / cer tornó a la dicha villa de Guamanga y asentó su real //

/ $76 \mathrm{v}$. / en la plaza della e tomó las calles con gente y artillería / en tal manera que no podía reciuir ningún daño e luego o / tro día el dicho señor gobernador salió al canpo con cier / tos caualleros e bio e miró la disposición de la tierra e / hizo salir toda la gente fuera de la dicha villa y asentó / su 
real en lo que mexor le pareció de donde deseando el dicho / señor gobernador que no oviese muertes ni otros daños / que de las vatallas se siguen codiciando como buen / seruidor de su Magestad restaurar estos reinos a su servicio / sin guerras e vatallas doliéndose del dicho don Diego de Al / magro e de los suyos como de vasallos de su Magestad ynbió / a un Alonso García Zamarrilla con cartas y probisio / nes para el dicho don Diego y sus capitanes si quisie / sen venir al seruicio de su Magestad y otrosi les enbió la / probisión que de su Magestad tenía de la dicha gobernación / puesto quellos la avían visto y en ella inserta la / ley en que dize las penas que tienen aquellos que son / traidores a su rey e señor, todo esto hazía e hizo / el dicho señor gobernador con celo de cristiano e con deseo / de sin muertes de onbres reduzir estos Reynos a / su Magestad y el dicho Alonso García fue a la probincia / de Vilcas donde se auía llegado el dicho don Diego y su / gente poco avía que es diez leguas de Guamanga donde el / dicho señor gobernador estaua y no solamente des / agradó al dicho don Diego lo quel dicho señor gobernador / le escriuía a él y a sus capitanes e les enbiaba a / dezir pero ahorcaron al dicho Alnso García diziendo / palabras feas contra el dicho señor gobernador e / los que con él venían y en este comedio avía venido Lo / pe Ydiaquez del campo del dicho don Diego a la dicha / villa de Guamanga adonde estaua el dicho señor gober / nador e a ruego del dicho señor gobernador el dicho Lope / Ydiaquez y el fator Mercado fueron a la dicha probincia / de Vilcas al dicho don Diego con cartas y amonestaciones //

/ 77 r. / del dicho señor gobernador como onbre que todavía / se dolía del daño de los vasallos de su Magestad y tanpo / co aprobechó lo uno como lo otro porque no solamente / les fueron henojosas las cartas y mensajeros del dicho señor / gobernador pero quisieron matar a los dichos mensajeros / y este testigo cree que lo hizieran si no fueran amigos / del dicho don Diego e de los que con él venían y con todo / esto vinieron espantados y aun medio huyendo e / traxeron en respuesta de lo que lleuaron una carta / del dicho don Diego firmada del dicho don Diego y otra / firmada de todos sus capitanes muy mal criada e / desonesta por la qual dezían que no querían sino / guerra y en este comedio mientras andaban estos men / sajeros el dicho señor gobernador estaua muy alerto / e sobre aviso en tener su canpo a muy buen recau / do con muchas espías, velas e centinelas por todos los / pasos e caminos que heran muy necesarios e te / miéndose de no ser salteado de noche mandó al capitán / Nuño de Castro que estubiese enboscada con ochenta / arcabuzeros en la qual estubo todas las noches mien / tras el dicho señor gobernador y su canpo estubo cerca / de la dicha villa de Guamanga y de allí sabiendo el dicho se / ñor gobernador la yntención de don Diego y sus capi / tanes por el dicho Ydiaquez y fator Mercado y por / muerte del dicho Alonso García salió del dicho pueblo / de Guamanga la vía de Bilcas donde los dichos enemigos / estauan y fue a dormir aquella noche con todo su / canpo dos leguas de la dicha villa en el asiento de / Chupas donde por sus corredores fue abisado quel dicho / don Diego y los suyos venían marchando su gente en / horden sus banderas tendidas en busca del dicho señor go / bernador donde luego el dicho señor gobernador hizo / un auto muy apacible para los soldados con que les dio / mucho contento e alegría porque dio a don Diego e //

/ 77 v. / sus secazes por traidores y canpo franco de todo lo que / se obiese lo qual fue bien acordado porque ansí con / venía para el contento de la gente de guerra e luego a / quella mesma noche viendo el dicho señor gobernador que / los enemigos estauan tan cerca quiso ver la gente que te / nía e las ganas de los soldados para lo qual mandó tocar / alarma diziendo que venían los enemigos y salió la / gente tan bien y tan presto y con tanta gana de pe / lear quel dicho señor gobernador se contentó mucho / e de tal manera que no fue menester dar otra / de burla hasta las veras. Otrosi tubo 
el dicho señor / gobernador muy buen aviso en mandar y probeer / todas las tardes antes que se pusiese el sol salir / toda la gente al canpo fuera de los toldos e que an / si estobiesen a punto de ronper toda la noche te / miendo ser cometido de noche lo qual duró tres o quatro noches que allí estubo el canpo hasta que se dio la / vatalla. En este medio tiempo el dicho señor gobernador / estaba muy desbelado en el probeimiento de su real / ansí en los bastimentos como en todo lo demás en / tener sienpre corredores y espías sobre los enemigos / y un biernes quinze días del mes de setiembre un / día antes que se diese la vatalla fue avisado el dicho / señor gobernador como los enemigos dormían media / legua o poco más de donde el dicho señor gobernador / estaua e con ánimo baronil fue de parecer que a / quella noche se les tomase lo alto porque los ene / migos por la vía que llebauan no le tomasen la de / lantera e se metiesen en Goamanga lo qual se dexó / de hazer porque entre los corredores obo diferencias e / dibersos pareceres si estaban los enemigos tan cerca o no / y en todo esto el dicho señor gobernador aquella noche aun / que llobía mucho sacó su gente al canpo como buen capi / tán y visto las estancias y dormitorios armado con mucho //

/ 78 r. / cuydado hasta el día que fue a correr el canpo el capitán Pe / ranzures que traxo nueba como los enemigos yban por lo alto ha / zia la villa de Goamanga e luego el dicho señor gobernador con / presteza baronil puso la gente a punto e ynbió adelante al / capitán Nuño de Castro con arcabuzeros para que escaramuzasen / con la gente del dicho don Diego y les detubiesen y no se les metie / sen en Goamanga y tras él enbió al capitán Peranzures en la / bandera e gente de su compañía para que socorriesen al dicho Cas / tro si fuese menester e tras dél el dicho señor gobernador en / comenzó a caminar y hazer subir toda la gente con mucha / presteza e deligencia lo qual fue causa que los enemigos no / tomasen campo a su voluntad ni asentasen el artillería como / quisiesen pues subido el dicho señor gobernador en lo alto / a vista de sus enemigos hordenó sus vatallas con / muchas presteza e deligencia y como conbenía a la guerra / enbió a Rodrigo Docanpo capitán de su guarda e a Diego / de Agüero y al capitán Castro para que fuesen e bie / sen el real de los enemigos cómo estaua asentado / y en qué horden y por qué parte se pudiesen mejor a / cometer sin reciuir daño del artillería y arcabuzería / del dicho don Diego que hera mucha y muy buena y en es / te comedio y antes muchas vezes el dicho señor goberna / dor fue requerido e ynportunado de los capitanes e / gente de guerra que estaua en este canpo y este testigo lo / bio algunas vezes quel dicho señor gobernador no en / trase en la vatalla porque le vían con voluntad de / ánimo de ronper en la delantera como bueno y esforzado / capitán y en todo esto no lo podían acabar con él hasta / y en este ystante del ronper los capitanes e toda la gen / te le dixeron que se reportase su señoría pues sabía quel / remedio todo desta tierra estaba en él e que bien sabía / el dicho señor gobernador que aunque ellos lleuasen la vi / toria si él moría en la vatalla se avía hecho poco pues que / daua la tierra más rebuelta que antes como hera la //

/ $78 \mathrm{v}$. / verdad por morir el dicho señor gobernador en la dicha vatalla / más guerras que de antes quedarán puesto caso que llevara / la vitoria como la lleuó. Pues conbenzido el dicho señor / gobernador de la razón e ruegos de los dichos capitanes / acauaron con él que tomase quarenta lanzas e con e / llas estubiese como sobresaliente y socorriese a la más / necesidad como se hizo y pareció que Dios ansí lo auía hor / denado pues fue parte con sus quarenta lanzas para a / rancar los dichos enemigos pues después quel dicho señor / gobernador hubo hordenado sus vatallas y esquadrones / hera grandísima alegría e consuelo de los soldados e / gente de guerra ver al buen viejo armado de puntan / blanco y en un gentil cauallo y con una ropa de bro / cado y un ábito de Santiago en ella sobre las armas / e aquella cara llena de risa e alegría que hera mucho con / suelo y 
esfuerzo para los soldados ver al capitán con / tal continente animar la gente y llegar como llegó y / este testigo lo bio a la gente de a cauallo y él ha / bló desta manera Caualleros en tiempo de tanta prisa / no ay necesidad de largos razonamientos sino que / veays a vuestro rey quan afrentado estos lo tienen / y trayays a la memoria como con estos con quien bais / a pelear los aueis sabido bencer y ellos saben muy / bien huyr e con estas palabras quedó toda la gente / de a cauallo tan esforzada y contenta como en otro tiempo / quedauan los romanos con una oración muy larga / de sus capitanes e de allí fue a la ynfantería y arre / metió el cauallo a ellos dos o tres vezes estando los / soldados piqueros y arcabuzeros tan alegres e / contentos como si la persona de su Magestad estobiera / presente y el dicho señor gobernador llegó a ellos con ros / tro alegre y les dixo caualleros los capitanes ge / nerales tienen por costunbre de dezir a sus soldados / e gente de guerra palabras con que se esfuercen y tomen //

/ 79 r. / ánimo y vosotros soys tan esforzados y animosos ques menester qui / taros parte del mucho ánimo que teneys por amor a Dios que os ayais / sesuda e atentadamente las quales palabras fueron tan sabrosas / a los dichos soldados que muchas vezes este testigo oyó dezir a algunos de / llos que con aquella palabra se dauan por muy contentos aunque / otras mercedes no les hiziese pues mientras el dicho señor gobernador / hordenó como dicho tiene sus vatallas y puso en horden su gente / que fue desta manera el capitán Peraluarez Holguín y el capi / tán Peranzures y el capitán Garcilaso de la Vega y el capitán Gó / mez de Albarado todos quatro con sus banderas en un batallón de / treze en treze por hilera avían de ronper la abanguardia el / capitán Alonso de Albarado con el estandarte real en conpañía / del dicho señor gobernador e con su bandera e conpañía ronpiese / por un lado y el señor gobernador con sus quarenta de a cauallo / acometiese por donde le pareciese que hera más menester y la yn / fantería hordenó desta manera que toda fuese en un batallón / como es uso y costunbre y el capitán Castro fuese sobresaliente con / sesenta arcabuzeros y el capitán Guebara y el capitán Vergara / fuesen con un esquadrón haziendo lo que heran obligados como / buenos capitanes, ansí hordenadas las vatallas como dicho es bol / vieron el capitán de la guarda Rodrigo Docanpo y los demás que / avía ydo a uer el real de los enemigos dieron relación al dicho / señor gobernador mandó mober las hazes con el alegría en el rostro que / de antes e descubriendo los enemigos y saviendo donde estaba / su artillería asentada que a la verdad estaua puesta en parte / donde pudiera hazer muy gran daño en el canpo y gente de su Magestad / si Dios nuestro señor no lo remediara y el buen aviso del dicho señor / gobernador porque biendo los enemigos delante que estaban pues / tos aguardando como gente de guerra y muy bien armada e muy con / fiada en la mucha artillería e arcabuzes que tenían porque heran / muchos más y mexores que los quel canpo de su Magestad tenía el / dicho señor gobernador les dio lado dando a entender que los yba acometer por / un lado de su artillería la gente de don Diego se dieron mucha priesa / a mudar el artillería y ponella hazia la parte quel dicho señor gobernador yba / lo qual ellos no pudieron hazer como quisieron e la causa fue la //

/ 79 v. / mucha priesa quel dicho señor gobernador dio de ajuntarse con ellos por de ve / ynte y tantas piezas de artillería que tenían de los quales las doze / dellas heran medias culebrinas y no pudieron pasar ni aprobe / charse de más de las seis porquel capitán Castro con sus arcabuzeros / sobresalientes andaua ya enbuelto con ellos en la escaramuza pues / viendo el dicho señor gobernador que las hazes se yvan ya acercando con sus qua / renta lanzas y las puso en la parte que le pareció que menos daño po / dían reciuir de la arcabuzería y artillería y el dicho señor gobernador / con dos o tres se pasó en un alto a ver lo que pasauan y para soco / rrer donde más fuese menester 
y en el asiento y lugar dondel dicho / señor gobernador se puso fue a mucho peligro de su persona porque jugaba / toda la artillería hazia aquel lugar y este testigo confiesa que le pesó / hartas vezes por berle allí puesto e deseaua verle quitado al dicho / señor gobernador porque le parecía que avello escusado que fuese en la de / lantera del esquadrón como él deseaua no hera para que se pusiese / en otro tal o mayor peligro en tal manera queste testigo siendo uno de / los quarenta que con el dicho señor gobernador yvan no lo pudiendo / sufrir fue donde el dicho señor gobernador estaua de parte de los qua / renta caualleros a dezille que ronpiese su señoría que ya hera tiempo / pareciéndoles a todos que estaua más seguro en el esquadrón que / no en aquel otero y él con el rostro muy sereno como si estobie / ra en Valladolid dezí a esos caualleros que les pido mucho por merced que / tengan sufrimiento que aun no es tiempo y el dicho señor gobernador se estuvo quedo / mirando el tiempo y coyuntura decente pues en este tiempo las vatallas / se vinieron a juntar de una parte e de otra donde fue bien reñi / do el negocio y tanto que entre tan poca gente no cree este testigo se aya visto / muchas vezes y en la parte que ronpió el capitán Alonso de Alba / rado con el estandarte real sin bandera ronpió con la mejor e más / luzida gente del dicho don Diego porque ronpió el mismo don Diego y el / capitán Diego Mendez con su compañía y el capitán Diego de Hozes / con la suya e como la gente del dicho capitán Alonso de Albarado / no estaua con mucha parte tan bien armada como la de los enemigos / pasáronlo muy mal y tan mal que estubo la cosa en punto de per / derse sy el dicho señor gobernador Vaca de Castro no arremetiera con sus qua / renta lanzas diziendo ynperio ynperio Vaca Vaca e queste / hera el apellido por donde avían de conocer y entró el dicho señor gobernador //

/ 80 r. / a tal coyuntura y tiempo que algunos de los del estandarte real y su conpa / nía del capitán Alonso de Albarado estauan a mal traer y dos conpañías del / dicho don Diego enteras en el canpo y con la entrada del dicho señor gobernador fueron / desbaratados donde le mataron al dicho señor gobernador algunos de los que con el / entraron y a otros muy malhirieron de parte de su Magestad y comenzaron / a huir alguna gente de la del dicho don Diego y estando la dicha gente del e / xército de su Magestad repartida y corriendo el alcance para efecto de que se / recogiesen y no andubiesen desmandados y los contrarios se rehizie / sen el dicho señor gobernador mandó dar luego alarma andando él por el canpo / dándola a muy grandes vozes de arte que hizo recoger toda la ynfan / tería y ponerla junta toda y a punto y lo mismo las capitanías de / a cauallo para el efeto que dicho tiene y toda la dicha noche hizo / estar toda la dicha gente de a cauallo e de a pie en vela puesta en horden / los cauallos ensillados y enfrenados y las lanzas en las manos hasta / otro día por la mañana quel dicho señor gobernador empezó a entender / en la execución de la justicia entre algunos de los secazes del dicho don / Diego que fueron en la muerte del dicho marqués y otras y que estonzes / este testigo vido la artillería de los contrarios y que al parecer deste / testigo hera tan grande y tan fuerte y tan bien hecha quanto se podía ha / zer en Milán y que a todo esto que dicho tiene este testigo se halló presente / con el dicho señor gobernador devaxo del estandarte real de su Magestad e que / ansí es público y notorio en estos dichos reynos. A las treinta e / nueve preguntas dixo que dize lo que dicho tiene en las preguntas an / tes desta e que tiene por cierto si el dicho señor gobernador no se hallara / en estos reynos todos ellos estobieran rebelados oy día y ningún / de gente fuera bastante para recoperallos porque este testigo / oyó dezir estando preso entre ellos a Pedro de Sanmillán que hera / uno de los del consejo del dicho don Diego que no entraría el rey en el Perú / hasta tanto que hechase de su consejo al Cardenal de Sevilla porque / hera el Obispo de 
Norpas [sic] ${ }^{18}$ y al Obispo de Lugo porque hera Galalón ${ }^{19}$ y al / dotor Beltrán porque hera Judas y a otros muchos soldados oyó dezir / otras cosas a este propósito por manera que lo queste testigo entendía / dellos hera que estauan rebelados del seruicio de su Magestad y con propósito / de tener e defender la tierra porque en un alarde general quel / dicho don Diego hizo en esta ciudad del Cuzco este testigo vio tomar juramento / a todos los capitanes y otros muchos soldados que defendían / la tierra a quien quiera que les viniese a hechar della o se la defendiese //

/ 80 v. / por manera que lo queste testigo alcanzó a no se hallar el dicho señor / licenciado Vaca de Castro gobernador destos reynos en ellos estobieran / oy día rebelados como dicho tienen porque al tiempo queste testigo vino a / esta dicha ciudad del Cuzco por mandado del dicho señor gobernador aliende de la / gente quel dicho don Diego tenía en su real vio y conoció en la gente que topó en / las otras ciudades y villas destos reynos y en esta dicha ciudad to / da la gente dellos estaua aficionada al dicho don Diego y como este testigo / les dezía de la venida del dicho señor gobernador todos se remontaban del pro / pósito que tenían unos con yntención de yr a buscar e a seruir e otros / con propósito de no faborecer ni ayudar al dicho don Diego con solo el temor / de la boz del rey por manera que sola la venida del dicho señor gobernador / en nombre de su Magestad no solo puso temor y desmayo a la gente de don Diego de / Almagro pero fue causa que todos los que tenían voluntad de / seruirle lo dexasen por manera que si los dichos don Diego de Almagro / e los suyos no tubieran mucha más gente en mayor cantidad de la / que tobieron solo el señor licenciado Vaca de Castro gobernador destos / reynos fue la causa ansimesmo queste testigo saue como parece / por los requerimientos que en esta ciudad se hizieron e pregones que la / gente de Charcas y Arequipa y esta ciudad del Cuzco yvan en busca / del dicho señor gobernador Vaca de Castro porque con sola esta voz / se apellidaron e juntaron en busca del dicho señor gobernador y no / para dar vatalla ni resistir al dicho don Diego como pareció claro quan / do Peraluarez y la gente que con él yva llegaron a Xauxa que sauido / que venía don Diego y su gente a afrontarse con ellos no solamente no qui / syeron pelear pero fueron la buelta de Bonbón huyendo del dicho / don Diego diziendo yr en demanda del dicho señor gobernador donde después de / aver venido el dicho señor gobernador hera muy poca parte la gente que allí a / vía si el dicho señor gobernador no fuera a la ciudad de los Reyes e hiziera la gente / que hizo y otros probeymientos e adrezos de guerra como este testigo tiene dicho / en otras preguntas antes desta y que este testigo oyó dezir a algunos de los se / cazes del dicho don Diego después de desbaratados y venzidos que no solamente / avían de ser señores desta tierra pero aun de los puertos de Panamá / e Nombre de Dios y de toda la costa desta Mar del Sur e que claro está / y parece que si el dicho señor gobernador no se hallara como dicho tiene en estos / reynos y no se oviera mostrado tan baleroso ansí en valor de persona / como en los muchos e grandes gastos que en la guerra e pacificación de / estos reinos hizo que solo el poder de Dios bastaua a poner la tierra //

/ 81 r. / en el estado en questá y questo tiene este testigo y cree como cree en Dios / e questo saue desta pregunta. A la cinquenta y siete preguntas dixo / que saue que para los dichos gastos quel dicho señor gobernador a hecho está adeudado / e a tomado dineros prestados y que no los a podido pagar hasta agora / segund la mucha costa e demasiado gasto que tiene y que esto es lo / que saue y

\footnotetext{
${ }^{18}$ Probablemente "Oppas" (obispo visigodo de Sevilla que apoyó la invasión musulmana de la Península después de la batalla de Guadalete contra las tropas de Rodrigo).

${ }^{19}$ Otro nombre del traidor Ganelón en el cantar de Roldán.
} 
es verdad para el juramento que hizo y firmolo de / Gómez de Rojas, Grabiel de Rojas, Pedro Orejón vezino de la dicha ciudad de León / de las provinicas de Nicaragua. A la dezima pregunta dixo que dize lo que dicho / tiene en la pregunta antes desta e queste testigo saue e vido como el dicho señor gobernador / enfermó en el dicho puerto de la Buenaventura e que enfermó co / mo estaba camino el dicho camino y viniendo enfermó pur / gándose e sangrándose e que se acuerda este testigo que una tarde / estando el dicho señor gobernador purgado de aquel día passó / él y todos los que con él venían un río muy grande diez e siete / vezes por diez e siete partes del e que por cada una dellas pa / sauan el dicho río casi a nado enzima de un cauallo a la gineta / en lo qual se pasó tanto risgo que pensaron ahogarse y aún es /te testigo lo pensó porque el dicho río lo llevó una vez a él y al cauallo / donde yva gran trecho que fue Dios seruido de sacarle a puerto / e que demás desto se pasaron otros muchos y infinitos / trauajos así de malos caminos como de hambre porque no comían o / tra cosa sino hierbas e algunos saluados de mays e que se a / cuerda este testigo que al pasar del dicho río que tiene aviéndolo pa / sado una vez por el peligro que avían pasado en el río re / quirieron al dicho señor gobernador don Pedro Luis de Cabrera / e el contador Juan de Cáceres y otros que se volviese al dicho puer / to de la Buenaventura y no pasase adelante porque no muriesen / todos e quel dicho señor gobernador veniendo como venía enfermo mostran / do mucho esfuerzo y valor no quiso volver sino pasar adelante / aunque más trauajoso oviese hasta que llegó a la dicha ciudad de / Cali que allí vido este testigo que estuvo el dicho señor gobernador muy enfermo / tres meses poco más o menos en la cama con grabe enfermedad / pensaron que se muriera e que no pudo ser menos sino que / en la dicha su enfermedad y en la de sus criados e seruidores gastó / mucha cantidad de pesos de oro y que allí vido este testigo que vendió toda / la ropa e hazienda que allá abía quedado para gastar en //

/ 81 v. / lo que dicho tiene y que no saue lo que podría montar el gasto que allí hizo / más cree que gastó todo lo que traya porque la tierra estaua muy cara e / se gastaua mucho en la dicha enfermedad él y questo saue y vido de la / pregunta porque se halló en todo ello. Yten si sauen que al tiempo que / llegó el dicho licenciado a la dicha ciudad del dicho Cali halló que avía / mucha diferencia sobre la dicha gobernación entre el adelantado / Andagoya y Venalcázar e que avía gente por anbas partes e / don Juan su hijo del dicho adelantado trataua de subir con la que / tenía en el río de San Juan contra el dicho Venalcázar y el dicho / licenciado les hizo mostrar sus títulos y visto dio horden como / Venalcázar quedase en la gobernación y el adelantado Anda / goya saliese libre a seguir su justicia e se presentase en / el audiencia de Panamá por cierta deuda que dizque debió / a su Magestad e ansí se remedió la dicha discordia e aparejo que / avía por matarse y cesó el escándalo y muertes que se pu / diera recreer y perderse la tierra y tornar a ser de yndios / e si sauen que en esto hizo el dicho licenciado mucho seruicio a su Magestad / digan lo que sauen. Yten si sauen que luego el dicho licenciado Vaca de Castro / sabido lo susodicho puso gran deligencia en el remedio de los / dichos daños e reduzió aquellos reynos al seruicio de su Magestad y en / execución puso cuidado de allegar gente la que en aquella comar / ca se pudo auer e hazer las armas que pudo además desto / envió cartas y mensajeros a los pueblos de la tierra e a todos / los pueblos de los vaxos y llanos y ciudad de los Reyes a Pedro / de Puelles y a Pedro de Heredia e Carreño e ansí mismo a la ciudad / del Cuzco a Gómez de Rojas las quales llevaron provisiones / e recados para juntar e acaudillar la gente que pudiese / e ynbiarla al dicho licenciado. Yten si sauen que sabido por el dicho / don Diego e su gente e secazes la venida de los dichos capitanes / e gente < el dicho don Diego > en horden e de guerra con sus banderas y estandartes / e capitanes de a cauallo e de a pie encabalgados y armados / salieron de la ciudad de los Reyes a deshacer e desbaratar al dicho / 
capitán Peraluarez Holguín con determinación de bolber después / sobre el dicho licenciado < Vaca de Castro >. Yten si saben que en una estancia de yndios que / se llamaYugay que serán trezientas leguas de Quito la bía del Cuzco //

/ 82 r. / le salió el dicho Alonso de Albarado con vecinos de la villa de Lebanto / o Chachapoyas como de los que por el dicho mandamiento y provisión del / dicho licenciado se le llegaron y recibieron al dicho licenciado por gobernador e / allí le vinieron a ver e dar la obidiencia el capitán Peraluarez / Holguín y los demás capitanes e se concertó él de partir de allí a / los ver e se juntar todos para seruir a su Magestad digan lo que / saben e cómo se ubo con todos en sus pláticas el dicho licenciado / para los animar a seruir e para ser temido, amado e / obedecido. Yten si sauen que de allí partió el dicho licenciado para / donde estaua el dicho Peraluarez Holguín y los dichos capitanes / Pero Anzures e Garcilaso de la Vega e Núñez de Castro con la / gente que allí estaua de que de suso está hecha mención los / quales le estauan esperando para le reciuir en el canpo pues / ta la gente en hordenanza y los tiros que tenían en el canpo / pequeños a una parte a donde recibieron al dicho licenciado Vaca de / Castro y al dicho Peraluarez e los otros capitanes y entregaron / las banderas e dieron la obidiencia y el dicho licenciado les tornó / las banderas eceto la que llevauan por estandarte porque el / dicho licenciado le llevaua e les habló palabras con que todos recibieron / mucho contentamiento digan lo que sauen y cómo se vbo en todo / lo que aquel día pasó el dicho licenciado. Yten si sauen que otro día juntó / el dicho licenciado toda la gente ansí la que llevaua como la que / estaua con los dichos capitanes y presentó la provisión que / llevaua de gobernador e juntamente les habló e prometió / que sirbiesen todos con buen ánimo a su Magestad en obedecer sus probi / syones e en reduzir aquellos reynos a su seruicio y en que / castigasen los desacatamientos hechos por don Diego e sus gen / tes no queriendo venir a la ovidiencia que devían e que / tubiesen por cierto e ansí lo prometió en nombre de su Magestad / de les repartir los yndios que avía vacos en la prouincia / e vacasen y otras palabras que convenían por lo qual todos / alegremente le recibieron y obedecieron por gobernador e capitán general e / si sauen que la dicha promesa y esperanza que tenían y les quedó a / la dicha gente fue la principal y final causa por donde todos se //

/ 82 v. / juntaron con el dicho licenciado y fueron e se hallaron en la dicha vatalla / para reducir y ganar aquellos reynos al seruicio de su Magestad de / mano de don Diego y sus gentes, digan lo que sauen. Yten si sauen que lue / go el dicho licenciado se apoderó de la capitanía general e dio a / Peraluarez Holguín la capitanía de cinquenta lanzas e le hizo / maestro de canpo al qual e a los otros capitanes dio sus / condutas con pleito omenaje que se les tomó que sirbirían a su Magestad / como buenos e leales vasallos e seruidores e luego se ynformó / por las listas y memorias que avía de la gente de la falta que / avía de armas e arcabuzes y pólbora e munición e con deli / gencia procuró de lo remediar en esta manera que ynbió a Martín de / Florencia a Xauxa a hazer armas de cierto depósyto de cobre / que se halló enbió metal para ellas y a Carabantas [sic: Caravantes] con maestros / que le dio a hazer picas a la provincia de Xauxa e a Juan Alonso Palo / mino a procurar materiales para hazer pólbora que no se halla / van e a la ciudad de los Reyes a hazer arcabuzes e petos de hie / rro e hizo todo lo que convenía ansy para armar la gente como / para probeer las otras cosas necesarias digan lo que sauen y / pasó. Yten si sauen que en este medio tienpo el dicho don Diego de / Almagro e su gente fueron a la dicha ciudad del Cuzco y se apode / raron della e quitaron las justicias questauan puestas / por el dicho licenciado Vaca de Castro como gobernador en nonbre / de su Magestad e pusieron justicia de su mano e saquearon casas e / pusyeron fuego ; 
otras inbiaron a las Charcas por la plata / que allí se halló y a poner justicia y lo mismo Arequipa y en / todas partes mataron personas e el dicho don Diego tomó por / fuerza el dinero que halló en el arca de las tres llabes de los / quintos reales de su Magestad hizieron un cadahalso de madera / en el canpo enzima del qual estaua el dicho don Diego con uno que le / leya hablando a la gente que tenía de guerra questaua toda al / derredor palabras de persuasyón para que todos jurasen / en un altar que tenía hecho al pie del cadahalso de le defender / en la gobernación contra toda persona y él a ellos de les repartir / la tierra y en execución desto salió con toda la gente en busca //

/ 83 r. / del dicho licenciado Vaca de Castro para le desbaratar e destruir con / la gente que llevaua e que ciertas personas que tubieron ne / gligencia de salir los sacaron de la yglesia y los ahorcaron, digan lo / que sauen. Yten si sauen que después quel dicho licenciado hizo lo que dicho / es en el asiento de Xauxa contenido en la pregunta antes desta / enbió a la villa de Guamanga adelante al dicho Diego de Rojas / con gente de cauallo para que estobiese allí e supiese lo que los / contrarios hazían e para tener aviso de lo que convenía hazer / e estando allí le ynbió a decir cómo el dicho don Diego venía con / toda su gente e si sauen que el dicho licenciado luego hizo alarde de / toda la gente que tenía con el mexor recaudo que puso e / hecho partió con la gente a la dicha villa de Guamanga porque / savía que las mugeres e otras gentes estauan fuera de la dicha / villa de temor e porquel dicho don Diego no la entrase e que / llegó una noche a la dicha villa con toda su gente adonde puso / el recaudo que convino. Yten si sauen que desde el dicho asiento / de Caxatanbo escribió el dicho licenciado al dicho don Diego e muchos / de su gente e capitanes para que se dexasen de la opinión e / desovidiencia que trataban con perdones para todos que / ansí lo hiziesen y lo mismo hizo desde la ciudad de los Reyes / e demás desto ynbió muchos perdones duplicados con perso / nas que lo fixasen en partes cercanas del Cuzco porque pudiese / venir a noticia de todos e si sauen que hizo el dicho licenciado escre / vir cartas a muchos caualleros de los questaban en su con / pañía e amigos que tenían en la conpañía del dicho don Diego / para que se viniesen al dicho licenciado y les daua de comer en la / tierra, digan lo que sauen. Yten si sauen que no obstante lo / susodicho perseberaron los dichos don Diego e su gente desde el a / siento de Vilcas estando el dicho licenciado en Guamanga escribió / el dicho don Diego e sus capitanes dos cartas firmadas de de / safíos y no obstante esto el dicho licenciado respondió cartas / con toda desimulación amorosas e a muchos dellos que con él / estaban con un Alonso García vezino de Guamanga y le a / horcaron en llegando y en este estante les enbió el dicho licenciado dos / mensajeros que fueron Diego de Mercado e Ydiaquez con perdones / cartas de seguro que ynbiasen quien contratase lo que quisiesen //

/ 83 v. / para su seguridad y tanpoco aprovechó antes tornaron / a escreuir cartas al dicho licenciado afirmándose en su proterbia. Y / ten si sauen que si por el dicho don Diego y su gente no acetasen / los perdones ni biniesen a obidiencia de su Magestad llevaron los dichos / mensajeros a quien el dicho licenciado Vaca de Castro constituyó y pro / cusores [sic] y seruidores para los susodichos cartas de enplazamiento e cita / ción con relación de la causa que el fiscal les tenía puesta / insertaba dicha ley de la partida que les da por traidores no vi / niendo con apercibimiento que viniendo en el término que les he / ra señalado serían oydos e pasado el dicho término se proce / dería contra ellos hasta difinitiba en su rebeldía y se pronuncia / ría sus delitos por notorios e se procedería a la condenación legal / conforme a derecho para lo qual fueron citados en forma la qual dicha carta / les fue mostrada por dichos mensajeros de lo qual dieron / fe con juramento se procedió a pedimento del fiscal fasta condena / ción e la sentencia fue pregonada públicamente y se les ynbió / seguro 
para todo. Yten si sauen que después de lo susodicho el / dicho don Diego de Almagro e sus capitanes e gente en execución / de su propósito vinieron a dar vatalla al dicho licenciado y le des / baratar e para lo mexor hazer pasaron por cerca dondel / dicho licenciado Vaca de Castro estaua con los capitanes e gente de / su Magestad para le tomar la dicha villa de Guamanga e quitar los / vastimentos al dicho licenciado e su gente e juntar consigo al ynga e / la gente que tenía que andaua alzado contra el seruicio de su Magestad / con quien el dicho don Diego estaua aliado digan o declaren si es / y pasa ansí como en esta pregunta se contiene y ansí subce / diera que tenían ventaja al dicho licenciado Vaca de Castro si vinien / do como venían las aguas y siendo ynbierno estubiera la / gente de Vaca de Castro en el canpo se deshiziera y enflaque / ziera el real e si sauen que si se pasara el dicho don Diego e su gente de largo para la ciudad de los Reyes la destruyera según / que los avía enviado a amenazar según dicho es en otras pregun / tas antes desta e se apoderara de manera que fuera de / ficil la vitoria e vencimiento. Yten si sauen que visto por el licenciado / que convenía seguir e ronper a los contrarios para escusar los / ynconvinientes luego que supo un sábado de semana diez e //

/ 84 r. / seys días del mes de setiembre de mil e quinientos e quarenta y / dos por los corredores del canpo que pasaban cerca del dicho don / Diego e gente por los efectos proveyó y mandó que toda la / gente comiese para dar aquel día la vatalla y fuese el capitán / Peranzures e Nuño de Castro entretenerlos con algunas es / caramuza[s] e andubo por el real derrocando toldos e hizo salir / la gente al canpo que se pusiese en horden e dio la banguardia / al capitán Peraluarez Holguín e al capitán Alonso de Albarado con / noventa o cient lanzas con estandarte real y él se quedó en / retaguarda con treynta y siete lanzas veynte que tomó de todos / los de a cauallo e los demás sus criados para socorrer al tiempo / de la necesidad e ansí comenzó a caminar en seguimiento de los con / trarios digan lo que sauen. Yten si sauen que llegado cerca de los / enemigos que estauan esperando el dicho licenciado habló a toda la / gente por todos sus esquadrones palabras en que puso ánimo / e contentamiento en especial en lo mucho que entendieron que serbían a su / Magestad con el qual llegaron e acometieron a los contrarios y se mezcló / en la vatalla y estando el dicho licenciado con las dichas treynta e siete / lanzas al tiempo que pareció ser necesario entraron en la vatalla y luego / se reconoció la vitoria e si sauen que le mataron dos a García de / Montalvo e al capitán Ximenez e hirieron otros y si sauen que / luego yncontinente que reconoció la vitoria el dicho licenciado / remedió lo que pudo porque no matasen más gente e defendió al / gunos especialmente a Sanmillán y a otros e que ansimismo luego / junto con esto temiendo que los contrarios se juntasen mandó dar / alarma y andubo juntando la gente en su esquadrón e ansí se hizo / e pasó, digan lo que sauen. Yten si sauen que todos los capitanes / e gentiles onbres que se hallaron en la vatalla lo hizieron muy bien / e pelearon animosamente con gran deseo de seruir a su Magestad como / buenos y leales seruidores y tobieron toda ovidiencia e acatamiento / al dicho licenciado e con esto se juntaron luego como dicho es con sus ban / deras y esquadras y ansí estubieron toda la noche no estante / que estauan cerca los toldos y tiendas de los contrarios e que el / dicho licenciado se vbo en todo lo que hizo e trauajó como buen capitán general //

/ 84 v. / digan lo que sauen. Yten si sauen que atentas las causas suso dichas / contenidas en las preguntas antes desta desde la entrada de Quito / hasta el bencimiento de la dicha vatalla quel dicho licenciado hizo y proveyó des / de que llegó a Quito hasta el día del dicho ronpimiento y la buena horden / e maña que tubo en auer dineros y acaudillar gente e hazerla e / juntarla y en auer cauallos y en comprar e hazer armas y pól / bora, arcabuzes, picas y munición y el trauajo e regimiento que 
puso / durante la guerra y lo que trauajó e abló el día de la vatalla e / ronpimiento con don Diego se vbo la vitoria con ayuda de los caualleros / e gentiles onbres seruidores de su Magestad e que si el dicho licenciado no hizie / ra las dichas probidencias y faltara su persona que ni se juntara / la dicha gente que se juntó con él ni oviera quien resistiera al dicho / don Diego e se perdiera todo o se apoderara don Diego de manera que / a grande dificultad se pudiera recobrarse la tierra digan lo que sauen / de lo contenido en la pregunta. Yten si sauen que después de lo / susodicho en la villa de Guamanga el dicho licenciado enbió con deligencia / al capitán Garcilaso de la Vega a la ciudad del Cuzco donde se supo / quel dicho don Diego de Almagro yva huyendo para se meter con el / ynga para que le prendiesen e a los que por allí fuesen por / que se ynpidiese el daño que se hiziera si con el dicho ynga se jun / taran e quel dicho don Diego fue preso e otros con él, digan lo / que sauen. Yten si sauen que de la villa de Guamanga despa / chó el dicho licenciado a todos los pueblos de la probincia para que / supiesen el bien que Dios nuestro señor les auía hecho y cómo se a / vía avido vitoria que tobiesen todos pacificación e justicia / e despachó al capitán Vergara para poblar los Bracamoros e / hizo e probeyó otras cosas necesarias. Yten si sauen que adelan / te camino de Cuzco en el tanbo de Vilcas hordenó como se poblase / en la provincia de Guanuco la ciudad de León e allí hizo repartimientos / de vezinos y lo necesario para esto y concertó ciertas diferencias que / avía entre los vezinos de Lebanto y los que pretendían tener yndios / en la dicha provincia e si sauen que poblarse el dicho pueblo fue / mucho seruicio de su Magestad y bien de la tierra porque con esto se escusaron / los daños que en aquella provincia hazían los yndios en los cristianos y con / esto quedaron reformadas las dichas ciudades de León y Lebanto //

/ 85 r. / y los vezinos en pacificación y paz lo qual hasta allí no tenían. / Yten si sauen que en los dichos reynos y probincia del Perú al tiempo / quel dicho licenciado la recobró y pacificó estaua descubierta la cor / dillera de la costa de la mar desde Puerto Viejo hasta donde está / hecha la ciudad de Santiago en la probincia de Chile y por la sie / rra estaua descubierto desde la ciudad de Quito otra cordille / ra hasta las Charcas y villa de Plata y todo lo que desde la dicha / cordillera ay hazia el mar del norte no estaua descubierto co / sa alguna y quel dicho licenciado por hazer seruicio a su Magestad e porque la / gente que no tenía yndios en las dichas probincias hera mucha e no se / podían sustentar en la probincia sin que la destruyesen e obiese / cada día ynconbinientes trauajos de los remediar, probeyó capi / tanes que fuesen a entradas desde la dicha ciudad de Quito e cor / dillera de sierra hazia la mar del norte hasta enzima de la dicha / villa de Plata e de las Charcas que fueron los siguientes entre / Puerto Viejo, Quito y los Caragues al capitán Juan de Olmos y / en la provincia de Quito en la provincia que dizen de Zu / maco al capitán Rodrigo Docanpo e adelante otra conquista / a Rodrigo Núñez de Vonilla tesorero de su Magestad en Quito y en o / tro pedazo que está entre esto y Bracamoros a Juan Porcel / e adelante en la provincia que dizen de Bracamoros al capitán / Pedro de Vergara como dicho es e adelante en la que dizen de Mo / yobanba en la qual parece que ay una laguna grande que se tie / ne por cierto que es un brazo de río de la Plata al capitán Juan / Pérez de Guebara y en la provincia que dizen de Ruparupa al / capitán Pedro de Puelles y enzima de la provincia de los Moxos a / otro capitán y en los dichos Chiriguanaes que comen carne uma / na como dicho es questán enzima de la dicha villa de la Plata al / capitán Grauiel de Rojas con otra compañía e adelante en to / do lo que de allí quedaua hasta el estrecho a los capitanes Diego / de Rojas y Felipe Gutiérrez. Yten si sauen quel dicho licenciado en el dicho tiempo / puso mucho cuydado en todo bien de fe y en la conbersión de / los naturales e hizo e se hizieron en su tiempo las cosas siguientes que / por su trauajo, persuasyón y palabras de buen tratamiento de propio / hizo que hizo a Paulo ynga acabó con el que tornase cristiano e a // 
/ 85 v. / prendiese la doctrina cristiana para ello y así lo hizo que luego / tomó un clérigo y estubo sienpre consigo y se bautizó y tornó / cristiano con su muger e hijos y en ello a perseberado y continuó sienpre después en oyr misa, e hizo en su casa una muy buena / hermita en que se dezía misa que fue este grande aparejo para / que otros yndios se tornasen cristianos y el día de su bautismo / gastó mucho el dicho licenciado en lo que le dio y gastó con él. Yten que / a tres criados del dicho licenciado dexaron su ábito seglar y pusieron / escuelas por el Collao y enseñaron a muchos yndios la do / trina cristiana e se tornaron muchos cristianos de más de o / tras esquelas que hizo poner el dicho licenciado y puso el provincial / e religiosos de la horden de Santo Domingo y en el Cuzco salían / los biernes de las esquelas los yndios a visitar las yglesias / e sacramentos con cruces cantando la doctrina cristiana y si sa / ven que la sabía también que por los caminos y en las labores / la cantaban en su lengua y que para esto el dicho licenciado probeyó por / mandamiento que todos los hijos de los caciques y precipa / les fuesen a deprender la doctrina cristiana por manera que / quando dexó el cargo el dicho licenciado auía en la dicha tierra quatro mil / yndios cristianos poco más o menos. Yten si sauen que luego que cesó / la suso dicha necesidad y se pacificó la tierra luego el dicho licenciado en execución / de un capítulo de su ynstrución hizo hordenanzas en remedio de lo su / so dicho e en libertad de los yndios naturales e buena gober / nación por las quales se remedió las cargas, cadenas, colleras / e cepos y el pasar los yndios de una parte a otra e se pro / veyó e dio horden como no obiese valdíos por la tierra co / miendo sobre los yndios proveyó como no fuesen ranchea / dos ni tomados bienes suyos por tal manera se executó lo suso / dicho que cesaron los dichos daños y los dichos yndios recibieron / gran libertad, probecho y contentamiento lo qual todo parece / por las dichas hordenanzas que están presentadas. Yten si / sauen que fue tanta la livertad de los dichos yndios que los / que andauan ausentados de sus sitios naturales se bolbieron //

/ 86 r. / e se poblauan los caminos reales y pueblos que estauan / despoblados desde que la tierra se entró y en la ciudad del Cuzco por / tal manera que en poco más de año que allí estubo el dicho licenciado / se hizieron en el Cuzco y en sus arrabales tres o quatro mil / casas y sy sauen que se senbraba toda la tierra y lo que a / vía muchos años que no se auía senbrado y que los yndios y / van en gran riqueza, seguridad, contentamiento. Yten si sauen que / quando el dicho licenciado fue a la dicha provincia halló que an / dauan las hijas de Guaynacaua, señor que auía sydo de aquella / tierra que fue estimado e adorado de los indios, perdidas / y tornó dos dellas cristianas y casó la una con español y le / dio yndios y procuró que se buscase una hija de Tabalipa [sic] niña / y la hizo bestir y probeer y poner en casa de la dicha yndia que casó / e des que supo la doctrina cristiana la hizo bautizar y casó con / un español que tenía buenos yndios y dos hijos de Tabalipa me / tió en su casa y vistió e adrezó e otros hijos de algunos vezinos / y los hazía enseñar a leer y escreuir a costa del dicho licenciado que tenía en / su casa clérigo que enseñaua a todos los yndios que en casa estaban / la doctrina cristiana. Yten si sauen que hera tan amado el dicho licenciado / de los dichos yndios generalmente que quando se partió del Cuzco / para la ciudad de los Reyes entendiendo los yndios que se y / va a España hazían taquis de lloro en sus casas y por toda la / provincia hazían sentimiento los yndios, digan lo que sauen. Yten si sauen que después que se hizo justicia del dicho don Diego / de Almagro y pacificó la tierra el dicho licenciado tubo grandes o / cupaciones en el gobierno general y probisiones de tenientes / e justicias en la tierra e cosas necesarias a pueblos y / cavildos e otras cosas concernientes a la gobernación. Yten / si sauen que no obstante las dichas ocupaciones el dicho / licenciado hizo e cumplió muchas cosas de las contenidas en la / ynstrución 
y cédulas en especial las cosas syguientes que reformó / e moderó los repartimientos que pareció ser excesibos en número / de yndios y si sauen questo fue cosa ardua de hazer e que //

/ 86 v. / el dicho licenciado se dio tan buena maña que poso por ello y / se efetuó por manera que quedaron pocos repartimientos en la / tierra por reformar e que señaló los límites de los obispados e / los dividió e que esto hizo con todo buen acuerdo y retamente / que lo que se pudo berificar por pilotos ser del reyno de Toledo / lo declaró e si saue que berificó el sitio y grados en que es / taua el Cuzco para declarar sobre ello tomando el altura e / grados del río de Santiago que se dize Tenunpalla que comenzó / a tomar información sobre lo tocante a la hazienda de / su Magestad e si por los oficiales se abía hecho fraude alguno / o oviese tratado y la tomó ansímismo sobre lo tocante / a los yndios de su Magestad que proveyó que qualquiera persona / pudiese rescatar syn licencia y en general que secrestó los bienes / del marqués hasta que se pagasen las deudas de su Magestad que puso / gran cuydado y deligencia en la conversión de los yndios, yglesias y monasterios en dar sytios conbinientes para que se hiziesen / otros que proveyó como obiese esquelas donde fuesen / los caciques principales e sus hijos aprender la doctrina / cristiana e que los yndios e yndias que sirbiesen a los / españoles fuesen a la yglesia a deprender la doctrina cristiana / en cierto tiempo e en execución de la hordenanza que se casasen / los españoles hizo casar e casó muchos que proveyó como / no se casasen yndios de la probincia que hizo hordenanzas en la libertad de los yndios y en remedio de las cargas e de que / no oviese baldíos ni rancheadores, ni quien les hiziese daño / que proveyó como los yndios libres de la sierra no fuesen / a seruir a la ciudad de los Reyes y llanos que proybió los / juegos excesibos con grandes penas que dio a yndios here / dades que pudiesen senbrar que por todas partes donde / fue declaraua a los yndios como yba a que cesasen las gue / rras e trauajos pasados que se les avían recrecido y todo mal / tratamiento y vibiesen en libertad que proveyó como oviese buen / recado quel almojarifazgo y abaliación de las mercaderías que hasta //

/ 87 r. / alli no se avía hecho ni hazía ninguna que se apregonaron to / das las cédulas y provissiones que llevaua de su Magestad e hizo / otras cosas muchas concernientes a la ynstrución y cédulas / y provisiones que de su Magestad llevó digan lo que sauen y vieron par / ticularmente. Si sauen que a la dicha provincia del Perú cier / to traslado sinple que sonaba ser de ciertas hordenanzas que se a / vían hecho en España e hablauan e disponían ciertas cosas so / bre los yndios de que en la dicha provincia se dezía que su Magestad no / auía sido informado para hazer las dichas hordenanzas y que / les heran muy perjudiciales a todos en general y que esto dio desa / sosiego entre la gente de aquella tierra e que se trataua de enviar /a su Magestad personas de la tierra para suplicar hiziesen merced cerca de / lo contenido en el dicho treslado y trecientos o cuatrocientos mil / castellanos de seruicio y si sauen quel dicho licenciado estando en el Cuzco / se dio tan buena maña que lo sosegó y pacificó todo y ansí lo es / taua quando Blasco Núñez llegó < aquella prouincia > y se la entregó el dicho licenciado paci / fica y fue reciuido en los pueblos. Yten si sauen que no solamente / estando el dicho licenciado en el Cuzco más después por el camino / e yendo a la ciudad de los Reyes y en todo tiempo el dicho licenciado Vaca de Castro dixo y habló muchas cosas y palabras en justi / ficación de las hordenanzas y lo que dezían estar en el dicho traslado / para que mexor se obedeciese < y cumpliese > lo que su Magestad mandase y para te / ner la tierra pacífica. Yten si sauen que lo mismo hizo en la / ciudad de los Reyes después que se supo la llegada de Blasco Núñez / e dexado el cargo hasta mostrar leyes de romance por donde todos / pareciese ser ansí y si sauen y lo vieron y entendieron e / conocieron del dicho licenciado su voluntad y obras fue de seruir / en lo que su Magestad mandase fuese obedecido y executado e / traer para esto buenas maneras y 
mañas, digan lo que vieron e / sauen. Yten si sauen que después de salido el dicho licenciado de la villa / de Guamanga viniendo camino de la ciudad de los Reyes supo / como hera desenbarcado Blasco Nunez Vela e que venía por / visorey y luego ynbió a Gerónimo de la Serena que hera de las principales personas que con él estauan a le dar obidiencia //

/ 87 v. / e la enorabuena de su venida e se diese priesa e que hasta / que se viesen e se hallasen lo que al seruicio de su Magestad convenya / se detuviesen de tratar de las cosas del reyno. Yten si sauen que / luego que supo de la venida del dicho Blasco Nuñez Vela el dicho licenciado / escribió al cabildo de la dicha ciudad del Cuzco haziéndole sauer que / luego enviase en persona a le dar la ovidiencia por aquella ciudad co / mo heran obligados e razón que se hiziesen y que la dicha carta llegó / a su poder e que por su parte se puso en excecución y señalaron per / sonas para ello. Yten si sauen que sauido esto por la ciudad de los / Reyes acordauan de no le reciuir en persona sino salir al canpo e / requerirle que suspendiese e repusiese lo hecho y le adminis / trase e otorgase suplicación y si no lo quisiese hazer se volviese / e que ententido por el dicho licenciado Vaca de Castro habló al licenciado / Rodrigo Nuño que hera procurador de la ciudad al licenciado León que hera / asesor tales palabras persuadiendo a que no se podía hazer / ni se hiziese tal cosa que sería gran deseruicio de su Magestad o tra / tasen con el cauildo que cesase que vastaron para que ellos / dado cuenta al cabildo sabido lo que el dicho licenciado dezía / se dexaron de todo e le hizieron recibimiento y si sauen que luego / quel dicho licenciado supo lo contenido en esta pregunta envió mensajero / al dicho Blasco Nuñez y le escribió que se diese priesa a venir / aquella ciudad e ansí lo hizo. Yten si sauen que estando el / dicho licenciado en el dicho navío llegado cerca el dicho Gonzalo / Pizarro de la dicha ciudad de los Reyes enbió gente al dicho nabío / e puso un capitán e arcabuceros en guarda del dicho licenciado / so color que auía de pagar primero que se fuese e los hijos / del marqués, sus sobrinos lo que auia auido de los yndios / del marqués e que lo que creya por las gentes hera que bus / caba aparejos para matar al dicho licenciado e que no le dexaua ver / ni hablar a nayde. Yten si sauen que estando ansí el dicho licenciado / en dicho nabío vino a él el dotor Texada de parte de los oydores / a que diesen parecer que hera bien hazer ellos governador de a / quellos reynos al dicho Gonzalo Pizarro y si sauen que aunque el dicho licenciado es / taua preso en poder del dicho Gonzalo Pizarro y se pensaua //

/ 88 r. / que contradiziendo lo susodicho lo matarían por hazer lo que se debía / en seruicio de su Magestad lo contradixo y dio ciertos enxenplos e / otras cosas semejantes al dicho doctor Texada para que no le de / vían hazer e si sauen que después desto enviaron los oydores / un escriuano de la audiencia con requirimiento que se diese el dicho parecer / e tanpoco quiso. Yten si sauen que estando dicho licenciado en el dicho / navío le comenzaron a artillar de parte del dicho Gonzalo / Pizarro e a meter en él vizcocho e agua y tomados pilotos y / maestros para navegar en el dicho nabío y se dezía que metían en él do / zientos onbres para yr en seguimiento de Blasco Núñez Vela a ocu / par a Panamá y Nombre de Dios e que visto esto por el dicho licenciado y que auía más de aquel navío en que lo poder hazer y quitado / aquel no tenían nada en la mar se puso a perder la vida si / no saliese con ello e se alzó con el dicho nabío con dos o tres personas que / se hallaron con él y le ayudaron e rindieron los marineros y vinieron / a Panamá con harto trauajo de fortuna y falta de bastimientos. Yten si / sauen que luego quel dicho licenciado llegó a la ciudad de Panamá juntó al / cavildo della y les habló dándoles noticia de lo que pasaua en la / dicha provincia como se dezía que por parte de Gonzalo Pizarro se pretendía yn / biar a la dicha ciudad para lo ocupar y aprobecharse de lo que en ella / oviese quel dicho licenciado traya un nabío grande que tenía el dicho Gonza / lo 
Pizarro con diez e siete tiros de artillería que pusiesen defensa y recau / do en la ciudad y puerto para ello les entregó el dicho nabío y les dixo / que en esto serbía a su Magestad y lo mismo escribió al cabildo y oficiales / de su Magestad que estauan en Nombre de Dios y puso toda la deligencia posi / ble cerca desto como buen seruidor de su Magestad, digan lo que sauen. Yten / si sauen que después que partió el dicho licenciado del puerto de la ciudad / de los Reyes como dicho es en el nabío en que estaua el dicho Gonza / lo Pizarro enbió un Hernando Vachicao por su capitán / en seguimiento del dicho licenciado para le bolber por fuerza a / la ciudad de los Reyes al dicho Gonzalo Pizarro e que antes que / entrase el dicho Vachicao en la ciudad de Panamá pidió al cabildo / e ciudad le entregasen al dicho licenciado sino que les haría mucho daño. / Yten si sauen que después que partió el dicho licenciado del puerto de la / cibdad de los Reyes y estando ya en el puerto de Guarua y en entregando / los navíos el dicho Diego Aluarez Cueto como dicho es en otra pregunta //

/ 88 v. / e saltando en tierra el dicho licenciado los soldados que / yvan para reciuir los dichos nabíos avían sido en / la prisión de Blasco Núñez Vela saquearon todo lo que / el dicho licenciado Vaca de Castro tenía en el dicho nabío en / que él estaua e si sauen que después que bolbió al dicho puerto / de los Reyes en el dicho nabío no tenía bienes sino ciertos pla / tillos de plata de seruicio que allí truxeron y después que allí llegó / se salió con el dicho nabío y vino sin oro ni plata que del Perú sa / case y si los tubiera o truxera los testigos lo supieran y no pu / diera ser menos por venir en el dicho nabío con el dicho licenciado / e desenbarcar con él en Panamá y por tener conpañía y con / tinua ynsistancia con el dicho licenciado y por venir con él en un / nabío el viaje de España digan lo que sauen. Yten si sauen que estando el / dicho Vaca de Castro a la sazón que truxeron allí al dicho Blasco Núñez / Vela en el tanbo que dizen de Guarua estando allí comiendo el / dicho Blasco Núñez antes que entrase en el nabío di / xo con juramento a Dios e a la cruz que hizo con sus ma / nos al dicho Vaca de Castro que le perdonase que no le / tenía culpa que los oydores se lo avían hecho en el hazer / e si sauen que después los oydores pronunciaron en au / diencia un auto en que dixeron quel dicho licenciado Vaca de Castro no / avía sido preso ni estaua detenido por oydores ni au / diencia ni por su residencia que ya estaua mandado soltar quel virey / lo avía hecho que diese quenta digan lo que sauen y vieron pa / sar. A las veinte e dos preguntas Antonio de Dueñas dixo que la / saue como en ella se contiene, preguntado como la saue dixo que / porque este testigo al tiempo quel dicho licenciado Vaca de Castro llegó / a la ciudad de Cali este testigo hera vezino della y al tiempo que llegó / e antes saue este testigo que auía avido diferencias entre don Pasqual / de Andagoya e don Sebastián de Venalcázar que heran españoles so / bre la gobernación de la tierra e avía gente de anbas partes e que / la gente de don Pasqual de Andagoya le faltó y el dicho Venalcázar / prendió al dicho Andagoya con propósito de le enbiar como le enbió / a Popayán y le auía de enbiar a Timana y en esto el dicho licenciado / Vaca de Castro dio su mandamiento para que bolbiesen al dicho An / dagoya a la ciudad de Cali y le bobieron por virtud del dicho //

/ 89 r. / mandamiento e allí el dicho licenciado vio y examinó las probisiones del dicho Ve / nalcázar e Andagoya y vistas mandó quel dicho don Pasqual de An / dagoya ya se fuese a presentar a la chancillería de la ciudad de Panamá / porque halló que devía ciertos dineros a su Magestad y le mandó llebar luego an / tes que de allí se partiese por ebitar pasiones y enojos en lo qual / saue este testigo quel dicho licenciado Vaca de Castro hizo muy gran seruicio a / Dios e a su Magestad porque evitó muchas muertes de honbres que pudiera / suceder sobre ello porque don Juan hijo de don Pasqual de Andagoya / estaua en el río de San Juan que se sonaua que quería yr con gente de 
yndios / e cristianos a quitar a su padre que le llevauan a Timan[a] con lo qual / saue este testigo que se remedió la dicha discordia que auía entre los dichos / dos gobernadores y podía ser que de la dicha discordia murieran / muchos cristianos de lo qual se redundaba mucho deseruicio a / Dios e a su Magestad porque quedara la tierra en poder de yndios e / que esto saue porque como dicho tiene hera vezino de la ciudad / de Cali e amigo de los dos gobernadores e vio lo contenido en / la dicha pregunta y se halló presente en la dicha ciudad de Cali don / de hera vezino como dicho tiene el capitán Cristóval Peña gobernador del / ducado de Beragua estante en la ciudad de Panamá dixo ser de hedad / de quarenta e cinco años poco más o menos e que no le toca ninguna de / las preguntas generales dixo que lo que desta pregunta saue es que / este testigo estando el dicho licenciado Vaca de Castro en el camino de / Cali que va dende el puerto de Buenaventura a Cali este testigo yva de / esta ciudad de Panamá de llebar ciertas probisiones de la au / diencia real que a la sazón aquí residía por los quales man / dauan quel dicho adelantado Venalcázar que tenía preso al a / delantado Andagoya ynbiase preso a esta ciudad e yendo / con las dichas provisiones este testigo y el dicho licenciado Vaca de Castro / llegaron a la dicha ciudad de Cali donde se hallaron al dicho Venalcá / zar con su gente de guerra y ansimismo antes queste testigo y el dicho / licenciado Vaca de Castro llegasen a la dicha ciudad de Cali vido / que quedaua en el río de San Juan don Juan de Andagoya hijo del dicho / adelantado Andagoya con hasta cinquenta o sesenta onbres / de guerra los quales dezían que heran para yr a sacar al dicho / Andagoya de la prisión en quel dicho Venalcázar le tenía e / quel dicho licenciado Vaca de Castro vio las dichas provisiones que este testigo //

/ 89 v. / desta ciudad les llebaba para lo susodicho dio horden e ma / nera con que pacíficamente sin ronpimiento ni peligro de persona al / guna se saliese de la tierra el dicho adelantado Andagoya y se vi / niese a presentar en esta dicha ciudad ante los oydores della e ansí lo / hizo el dicho adelantado y el dicho don Juan de Andagoya hijo del / susodicho se vino con su padre a esta dicha ciudad de Panamá y el / dicho Venalcázar quedó pacífico en la tierra y gobernación e / en lo ansí hazer el dicho licenciado Vaca de Castro segund la buena hor / den y forma tubo en lo susodicho sirbió e hizo gran seruicio a / su Magestad porque evitó que no oviese escándalos e alborotos / en la dicha tierra que por razón de lo susodicho se podía re / crecer e que esto saue desta pregunta y es público y notorio. A / las veinte e siete preguntas Diego de Hontiberos dixo que la saue / como en ella se contiene preguntado como la saue dixo que por / que este testigo se halló presente en la dicha ciudad de Quito al tiempo / quel dicho licenciado ynbió a los dichos Pedro de Puelles y Pedro de Heredia / e Carreño y Gómez de Rojas los quales llevaron las dichas pro / visiones e recaudos para el efeto questa dicha pregunta dize / e ansí fue público e notorio. Fabián de Estrada dixo que / la saue segund e como en ella se contiene porque este testigo se halló / presente a lo contenido en la pregunta y vio que pasó lo en ella / contenido y questo es lo que saue de la pregunta. Francisco de Cáceres dixo / que saue que luego quel dicho licenciado Vaca de Castro sabido lo que este testigo / tiene dicho en la pregunta antes desta puso gran deligencia en el remedio / de los dichos daños e reduzir aquellos reynos al seruicio de / su Magestad y puso mucho cuydado de llegar gente que por aquella co / marca se pudo auer e hazer armas que pudo y ynbió cartas e / mensajeros a los pueblos de la tierra e a los pueblos vaxos / e llanos y ciudad de los Reyes a Pedro de Puelles a Truxillo e a Pedro / de Heredia e a Carreño a la ciudad de los Reyes e a Gómez de Rojas / a la ciudad del Cuzco los quales llevaron provisiones e / recaudos para los cabildos de la tierra para que juntasen / la gente que pudiesen e la enbiasen al dicho licenciado y a dezirles / como el dicho licenciado venía por gobernador de donde estaua y que les viniesen / a seruir y manifestar algunos agrabios si avían recibido quél / venía allí para hazerles justicia y que esto fue ansy muy público e // 
/ 90 r. / notorio en aquellas provincias y lo vido y supo este testigo y que / es todo lo que saue desta pregunta. A las treynta y una preguntas / el licenciado Francisco de Abreo dixo que la saue porque este testigo vido salir / la gente e capitanías del dicho don Diego de Almagro y sus banderas y / estandartes alzados de la ciudad de los Reyes a la probincia de Cari / ca donde pasó lo contenido en la pregunta e de ver que la gente del / Cuzco hera pasada a se juntar con el dicho licenciado de pesar y enfermedad / murió Juan de Herrada montañes y capitán general del dicho don Diego y todo / lo susodicho es y pasó ansí y es público y notorio. Gonzalo de Obregón dixo que / este testigo saue como el dicho don Diego de Almagro salió de la ciudad / de los Reyes como supo la venida del capitán Peraluarez Hol / guín y los demás capitanes que venían del Cuzco para se juntar / con el dicho licenciado Vaca de Castro y salido fue con su gente de guerra y / vanderas y estandartes y capitanes de a cauallo y pie bien en / cabalgados y armados para desbaratarlos y si pudiera con ellos / yr a tomar al dicho Vaca de Castro syno que no los alcanzó y esto / saue porque a la sazón este testigo estaua en el real del licenciado Vaca de / Castro. Esteuan Rodríguez dixo que viniendo este testigo con el dicho Peralua / rez Holguín y los demás capitanes llegando a Guamanga tubieron / noticia cómo don Diego de Almagro salía de Lima con seiscientos o setecientos / onbres bien adrezados y en horden de guerra a deshazer e desbaratar / al dicho Pero Aluarez y a los que con él venían porque no fuesen a se juntar / con el dicho licenciado Vaca de Castro sino que no los alcanzaron porque el dicho / Peraluarez y la demás gente que con él venía se dieron prisa por pasar / de una probincia que se dize Xauxa donde se pensaua que obie / ran de tener requentro con el don Diego e aun después quel dicho / don Diego supo que heran pasados o se yvan a juntar con el dicho licenciado / Vaca de Castro viendo que por aquello le avía de venir daño yn / bió cierta gente tras ellos para el efeto susodicho y tanpoco / no los pudieron alcanzar y < como no los alcanzaron > se bolbieron para el dicho don Diego y esto / saue desta pregunta. A las cinquenta preguntas Rodrigo Salguero / dixo que saue que en una ystancia de yndios que se llamaba Yungay / que serán trecientas leguas de Quito la vía del Cuzco les salió el / dicho Alonso de Albarado con vezinos de la villa de Lebanto e Chachapoyas como / de los que por mandamiento y probisión del dicho licenciado se llegaron e recibie / ron al dicho licenciado por gobernador e allí le vinieron a uer e a dar //

/ 90 v. / la obidiencia el capitán Pero Aluarez Holguín y los demás capitanes / e se concertó de se partir de allí a los ver e se juntar todos para ser / vir a su Magestad e que vio quel dicho licenciado Vaca de Castro habló a los ca / pitanes muy cortesmente con muy grande ánimo encargándo / les la honra de su Magestad e cómo aquellos tiranos traydores te / nían usurpado el Reyno e que aún no solamente lo que tenían / hecho sino a ellos prenderlos e herirlos y matarlos y questas / palabras se acuerda este testigo que dixo el dicho licenciado entre otras / e que a este testigo le pareció que le avían hablado con muy gran pendencia e vio / lencia e que esto es lo que saue de la pregunta. Diego González dixo que / lo que saue desta pregunta es que este testigo llegó juntamente con el dicho Vaca / de Castro e su gente yendo en aconpañamiento suyo a la dicha ystancia de Yu / cay que podía auer las trecientas leguas contenidas en la pregunta / poco más o menos e aquel Alonso de Albarado contenido en la pre / gunta con la gente que tenía en el dicho asiento de guerra le salió a reciuir / al dicho licenciado Vaca de Castro como a gobernador de su Magestad y estan / do en el dicho asiento de Yucay vido este testigo que vino el capitán / Peraluarez Holguín y el capitán Nuño de Castro e otros caualleros a / los quales dichos caualleros capitanes el dicho licenciado Vaca de Cas / tro les habló e recibió muy alegremente agradeciéndoles y estimán / doles mucho el deseo y celo que en seruicio de su Magestad le avían mostra / do como leales vasallos e que los dichos 
capitanes e gente de guerra / se holgaron con su venida por ver quanto ynportó al seruicio de / su Magestad y el buen efeto que esperaban se auía de seguir con su ve / nida a los dichos reynos entre los quales capitanes y gente de guerra / dio gran contentamiento de su persona por el mucho valor que mostró / e usó en las cosas de la guerra y las probidencias a ellas / necesarias y en la buena gobernación de la tierra e que este testigo tie / ne por muy cierto que si el dicho licenciado Vaca de Castro no mostraría / tanto valor de su persona e les hablara e animara no fuera tan bien / reciuido por ser las gentes de aquellas partes muy sobre sy y / en todo bio este testigo quel dicho licenciado Vaca de Castro se dio muy / buena maña y horden en las cossas de la guerra y lo demás de / la buena gobernación e que el dicho Vaca de Castro se partió del dicho / valle de Yucay y se fue al asiento de Guaraz donde estaua su gente / e real del dicho Peraluarez Holguín donde fue recibido //

/ 91 r. / por gobernador con mucho regocijo de la gente de guerra que allí es / taua e les hizo las pláticas que arriba tiene dichas a las unas y / a las otras y esto saue desta pregunta porque se halló presente $/<$ y lo vio como dicho tiene e pasó ansy >. A las cinquenta e una preguntas Diego Gonzalez dixo que como dicho / tiene en la pregunta antes desta el dicho licenciado Vaca de Castro llegó / al dicho asiento de Guaraz donde estaua el real del dicho Peraluarez / Holguín y lo demás contenido en la dicha pregunta los quales capi / tanes e su gente estauan esperando en el campo en hordenanza de / guerra con sus arcabuzes cargados y tiros de artillería e ansí como / el dicho licenciado llegó dispararon los dichos arcabuzes y tiros gruesos / en señal de alegría e regocijo y queste testigo saue y vido que los dichos / capitanes que allí se hallaron e sus alférez le entregaron las / vanderas que tenían al dicho Vaca de Castro y el estandarte quel dicho / Peraluarez Holguín y su alférez trayan las quales dichas vande / ras y estandarte lo entregaron al dicho Vaca de Castro en señal de / ovidiencia e en reconocimiento de su Magestad, el dicho Vaca de Castro / le pareció a este testigo las bolbió a los capitanes de su mano eceto / el estandarte quel dicho capitán Peraluarez Holguín traya que man / dó al capitán Rodrigo Docanpo su capitán de la guarda que lo doblase / e cogiese diciendo que en el real de su Magestad no auía de auer otro / estandarte real sino el suyo el quel traya en lo qual mostró / gran valor en su persona por ser como de cosa en quel dicho capi / tán Peraluarez Holguín capitán del dicho exército le avía de / pesar e quedar desabrido e ansí oyó decir este testigo quel dicho / capitán Peraluarez Holguín lo estuvo e muchos amigos su / yos porque hera muy buen cauallero e buen capitán e muy amado / de los suyos e deseaban verle muy adelante e que en quitar el / dicho estandarte al dicho Peraluarez Holguín dio a entender el dicho / licenciado Vaca de Castro que todos le avían de obedecer como a / gobernador de su Magestad sin que obiese otra cabeza donde se pudie / se resultar no ser tan obedecido como hera razón e que de / más desto el dicho licenciado Vaca de Castro hablaba con algunos capitanes / e gente de guerra públicamente a las cosas de la guerra y en secretos / della dándoles a entender la mucha noticia y espiriencia que en //

/ 91 v. / las cosas e plática de la guerra tenía e a esto fue muy necesario que / ansí los dichos capitanes e gente de guerra lo tuviesen entendido e / ser muy hordinario entre gente de guerra tener en poco a los capitanes / e gobernadores que tienen espiriencia e plática e valor en las / cosas de la guerra e que saue este testigo que en el dicho real el dicho / Vaca de Castro fue muy loado que siendo letrado y no usado en la / guerra fuese tan plático en ella e ansí en la general plática que les hazía y en las probidencias < a unas partes > e a otras y en la / buena horden que tubo en el dicho real y en todo lo demás y en ser / muy gracioso e apacible a los capiatnes y gente de guerra y tener / tanta noticia en todas las cosas necesarias y los dichos capi / tanes e gente de guerra tuvieron gran 
respeto a su persona e / fue muy obedezido y amado y temido de todos que en todo / lo que dicho tiene que pasó en el dicho recibimiento quel dicho Vaca de / Castro lo hizo como buen capitán e criado de su Magestad con muy gran / valor e prudencia e ansí convino que se hiziese para ser / ovedezido y tenido no mostrase flaqueza por ser el pri / mer escalón donde se avía de mostrar y esto saue desta / pregunta porque se halló presente a todo ello como dicho tie / ne. Francisco de Cáceres dixo quel dicho licenciado partió de Yugay para / donde estaua el dicho Peraluarez Holguín e los dichos capitanes Pe / ranzures e Garcilaso de la Vega e Nuño de Castro con la gente que / llevauan los quales estauan esperando para le reciuir en el can / po puesta la gente en hordenanza y los tiros que tenían de can / po pequeños a una parte e allí recibieron al dicho licenciado Vaca / de Castro y al dicho Peraluarez e los otros capitanes le entregaron / las banderas e dieron la obidiencia y el dicho licenciado les bolbió las ban / deras eceto la que llebauan por estandarte porque el dicho licenciado la lle / vaua e allí les habló palabras con que todos recibieron conten / tamiento e que saue que lo que en aquel día pasó se vbo el dicho licenciado como / buen gobernador e seruidor de su Magestad e que saue lo que dicho tiene por lo que vido e se halló / presente a ello. A las cinquenta e dos preguntas Santiago de Arau / co dixo que saue ser verdad lo en ella contenido, preguntado cómo / e por qué lo saue respondió y dixo que porque este testigo se acuerda / e vio hallándose presente como el otro día después que pasó //

/ 92 r. / lo contenido en la pregunta antes desta juntó el dicho licenciado toda la gente / ansí los quél llebaua como la que estaua con los dichos capitanes / e presentó la dicha prouisión que llevaua de gobernador e juntamente con esto / les habló y les prometió que sirbiesen todos con buen ánimo a / su Magestad en obedecer sus probisiones e reduzir aquellos Reynos a su / seruicio y en que se castigasen los desacatos hechos por don Diego y su / gente no queriendo venir a obediencia que devían e que tubiesen por / cierto y ansí se lo prometía en nombre de su Magestad de les repartir los yn / dios que avía vacos en la provincia y vacasen y todos bio este testigo que / alegremente recibieron al dicho licenciado y le obedecieron por gobernador / e capitán general e que con las dichas promesas que les hizo y espe / ranza que dellas cobraron quedó la dicha gente prendada y ansy / mismo este testigo para que se juntasen con el dicho licenciado y fuesen y sir / viesen en la dicha vatalla segund que fueron y se juntaron e sir / bieron para reduzir y ganar aquellos Reynos del Perú al seruicio / de su Magestad de mano de don Diego de Almagro e de sus gentes y que es / to responde a esta pregunta. Francisco de Cáceres dixo que saue que / otro día el dicho licenciado juntó toda la gente ansí la quél llevaua / como la que estaua con los dichos capitanes y presentó la prouisión / que llevaua de gobernador e junto con esto les habló y les prometió / que sirbiesen todos con buen ánimo a su Magestad en obedecer sus prouisiones / y en reducir aquellos reynos a su seruicio y en que se castigasen los / desacatamientos hechos por don Diego y sus gentes no queriendo venir a la / ovidiencia que venían y que tuviesen por cierto y ansí se lo prome / tía en nombre de su Magestad de les repartir los yndios que avía vacos / en la provincia y vacasen y otras palabras que convenían por / lo qual todos alegremente le recibieron y obedecieron por gobernador y / capitán general e que saue que la dicha promesa y esperanza que te / nían e quedó a la dicha gente fue causa principal por donde todos / se juntaron con el dicho licenciado Vaca de Castro e fueron e le sirvieron en la / vatalla para reducir y ganar aquellos Reynos al seruicio de su Magestad quel dicho don Diego tenía vsurpados e que saue lo que dicho tiene porque / lo vido e se halló presente a la plática que hizo el dicho licenciado e a todo / lo demás contenido en la dicha pregunta. A la cinquenta e tres preguntas / Santiago de Arauco dixo que después de lo que dicho tiene desuso 
vio este testigo / quel dicho licenciado se apoderó de la capitanía general y dio a Peraluarez Holguín //

/ 92 v. / la capitanía de cinquenta lanzas e le hizo maese de canpo al qual / e a los otros capitanes dio sus condutas con pleito omenaje que / se les tomó que sirbirían a su Magestad como buenos y leales vasallos / e seruidores e luego se informó por las listas y memoriales que / avía de la gente e de la falta que auía de armas, arcabuzes y pól / bora e munición y dio que con mucha deligencia procuró de lo re / mediar porque envió a Martín de Florencia a Xauxa a hazer / armas e de cierto depósito de cobre que se halló le ynbió me / tal para ello e a Carabantes con maestros que le dio a hazer / picas a la provincia ya dicha de Xauxa e a Juan Alonso Palomino / a procurar materiales para hazer pólbora que no se halla / va e a la ciudad de los Reyes a hazer arcabuzes y petos de / hierro e hizo todo lo que convenía al parecer deste testigo ansí / para armar la gente como para probeer de las otras cosas / necesarias que fueren menester e que esto responde a esta pregunta. / Francisco de Cáceres dixo que saue quel dicho licenciado Vaca de Castro se a / poderó luego de la capitanía general e dio a Peraluarez Holguín / una conpañía de gente de a cauallo y le hizo maestre de canpo / al qual e a los otros capitanes dio sus condutas e luego / se ynformó por las listas y memoriales que avía de la gente de / la falta que avía de armas e arcabuzes y pólbora y munición / e con deligencia procuró de lo remediar en esta manera que ynbió / a Martín de Florencia a Xauxa a hazer armas y de un depó / sito de cobre que se halló enbió metal para ello y a Carabantes / con maestros que le dio a hazer picas a la provincia de Xauxa / e a Juan Palomino a procurar materiales para hazer pólbora / que no se hallavan e a la ciudad de los Reyes a hazer arcabuzes / e petos de hierro e hizo todo lo que convenía ansí para armar / la gente como para probeer las otras cosas necesarias y que lo / saue porque lo vido y estubo presente a todo ello. A las sesenta e / tres preguntas Sancho Tofino dixo que lo que saue que estando / este testigo en la dicha ciudad del Cuzco vido allí al capitán Sotelo que yva por el dicho don Diego e al capitán Diego Mendez e a otras gen / tes que llevauan los quales hizieron reciuir al dicho don Diego de $\mathrm{Al} /$ magro por gobernador e quitar las justicias que estaban puestas por Vaca / de Castro y pusieron otras de su mano y luego dende a poco tiempo //

/ 93 r. / llegó el dicho don Diego e antes quel dicho don Diego llegase el dicho Sotelo lo / avía probeído al dicho Diego Mendez que fuese a las Charcas a traer / los dineros que allí oviese y ansimismo oyó dezir este testigo e ansy fue / público y notorio quel dicho don Diego con toda su gente avían salido al / canpo e que allí avían jurado al dicho don Diego de le seguir e defenderle / en su gobernación pues que se la auía dado su magestad e ansimismo oyó dezir / que al tiempo quel dicho don Diego salió del Cuzco porque ciertas personas de / zían que quería yr a seruir al dicho Vaca de Castro un Juan Balsa que he / ra teniente del dicho don Diego las auía sacado de la yglesia donde estaban / huydos e que los auía ahorcado y esto ansí fue público y notorio / e no saue ni vido otra cosa desta pregunta. Frai Juan Baptista / dixo que lo que saue della es quel dicho don Diego fue al Cuzco y quitó las / baras a los que las tenían e las dio de su mano a quien él quiso y / enbió a las Charcas a lo mismo y enbió a Arequipa a Albarado [testado: a lo mes / mo] donde murieron onbres y vbo robos y aun de la yglesia de Santo / Domingo la robaron y acabaron buscando lo que avía escondido / en ella e que saue quel dicho don Diego salió de la ciudad del Cuzco / con su exército hazia donde venía el dicho licenciado Vaca de Castro / y esto fue muy público en aquella tiera. A las sesenta y quatro / preguntas Gonzalo de Obregón dixo que saue que este testigo quel dicho licenciado Vaca / de Castro ynbió al dicho Diego de Rojas con gente a la dicha villa de / Goamanga 
para que de allí viniese o ynbiasen aviso al dicho / licenciado Vaca de Castro de lo que supiesen de don Diego de Almagro el / qual abía nuevas que venía de Cuzco a encontrarse y entrar /se en la dicha villa de Guamanga e ansí el dicho Diego de Rojas / como supo las nuevas del dicho don Diego y que venía lo ynbió a / hazer sauer al dicho licenciado Vaca de Castro y como lo supo el dicho / licenciado hizo alarde e se previno y aparejó para yrle a detener e darle / vatalla e ansí se partió con todo el mejor recaudo que pudo / a la dicha villa de Goamanga porque sabía las mujeres e o / tras gentes se avían salido de la dicha villa de temor del dicho don / Diego de Almagro que venía a dar vatalla al dicho licenciado Vaca de Castro / e yendo allegó vna noche a la dicha villa de toda su gente e hizo to / do lo que más convino y esto dixo que saue porque se halló pre / sente a todo ello. Francisco de Cáceres dixo que después quel dicho licenciado //

/ 93 v. / hizo lo que dicho es en el asiento de Xauxa contenido en la sesenta y dos pre / guntas enbió a la villa de Guamanga al dicho Diego de Rojas con gente de a cauallo / para que estubiese allí y supiese lo que los contrarios hazían y que guardase / la villa y para traer aviso de lo que convenía hazer e que estando a / llí el dicho Diego de Rojas el dicho licenciado hizo alarde en Xauxa de toda la gente / que tenía e hecho partió con la dicha gente a la dicha villa de Guamanga / porque supo que las mugeres e otras gentes estauan en la dicha villa con / temor quel dicho don Diego de Almagro la venía a tomar e que esto hizo con / mucho cuydado e con el mayor recaudo que pudo y esto lo saue porque / así lo vido e se halló presente e yva con el dicho licenciado Vaca de Castro. A / las sesenta y cinco preguntas Nicolás García dixo que lo que della saue es / que este testigo vido quel dicho licenciado ynbió a este Diego de Mercado contenido en / la pregunta e Ydiaquez con despachos a don Diego de perdón para que viniese / al seruicio de su Magestad e que saue que los sobredichos le respondieron muy áspera / mente y le escribieron una carta en que vinieron firmados todos los ca / pitanes de su campo en que dezían que si no les dauan su gobernación / que darían la vatalla contra don Carlos e que ansí fue público e / notorio en el campo por donde a todos pusieron gran voluntad de / yr contra ellos. Juan de Herrera dixo que saue quel dicho licenciado Vaca de / Castro escribió al dicho don Diego muchas vezes y le enbiaba muchos / requerimientos con perdones para todos si biniesen al seruicio de su Magestad / el qual dicho don Diego le respondió que no aprobechaba nada que la / tierra hera suya y que su padre la auía ganado quel que pensase hecharle / della le auía de matar a él e a todos los que con él andauan y esto saue / porque lo vido ansy y se halló presente a ello este testigo con el dicho Vaca de / Castro e ansí es público y notorio. A las sesenta y seis preguntas / Cristóval de Barrientos dixo queste testigo vido dos cartas quel dicho don / Diego e sus capitanes escribieron al dicho licenciado Vaca de Castro desaca / tadas diziendo quellos avían de poseer la tierra y el dicho licenciado / la avía de dexar y otras cosas que mostrauan amenazas contra / el dicho licenciado e su gente y el dicho licenciado le enbió a un Alonso García vezino / de Guamanga con cartas el qual dicho Alonso García el dicho don Diego de $\mathrm{Al} /$ magro e su gente ahorcaron en el tanbo de Bilcas y sabido por / el dicho licenciado les bolbió a a [sic] escreuir con Diego Mercado [y] Ydiaquez perdonán / doles e ofreciéndoles grandes partidos porque viniesen a la ovidien / cia y seruicio de su Magestad y el dicho don Diego y su gente no lo quisieron abcetar //

/ 94 r. / e trató mal a los mensajeros diziendo que no bolbiesen más por / mensajeros que los ahorcaría e bolbieron a escreuir al dicho licenciado como / de antes. El canónigo Diego García Vidal dixo que lo que saue de la / pregunta es que estando el dicho licenciado Vaca de Castro en la villa de / Guamanga tubo nueva quel dicho don Diego de Almagro e su gente es / taua en el asiento 
de Vilcas que es diez leguas de Guamanga saue este testigo / e vido que vinieron allí ante el dicho licenciado Vaca de Castro dos om / bres queste testigo no es acordado como se llamauan e dixeron venir / con cartas del dicho don Diego de Almagro y su gente e ansí fueron co / nocidos y tenidos por mensajeros venidos por parte del dicho don / Diego de Almagro e dieron cartas al dicho licenciado Vaca de Castro no / vido este testigo lo que dezian las dichas cartas e que saue este testigo e / vido quel dicho licenciado envió con un Alonso García Zamarrilla vezino / que hera de Guamanga para que entrase de noche en el asiento donde es / taua el dicho don Diego de Almagro y diese ciertas cartas suyas / a personas particulares de su gente y fue pública voz e fama / que las cartas dezían que los que se viniesen a seruicio de su Magestad de les per / donar e quel dicho Alonso García mensajero nunca más bolbió antes / fue pública voz y fama que estando aguardando en vna sierra cer / ca del dicho asiento para entrar de noche le auía topado Juan Diente / e ciertos yndios que le avían llevado preso ante el dicho don Diego de Al / magro e que le avían ahorcado e que después que supo donde lo a / vía enterrado y este testigo dixo una misa de requien por su ánima y / questo saue de la pregunta por lo que dicho tiene e que en lo demás se / remite a lo que tiene dicho e declarado en el dicho que dixo en la ciudad / del Cuzco y en otro dicho que dixo en la ciudad de Panamá que le fueron / leydos e mostrados amvos sacados y sinados de Martín de Ramoyn / e se retificó en lo en ellos por el dicho e declarado. Martín de Sancho / Hernández dixo que dize lo que dicho tiene en la pregunta antes desta e / demás dello saue que fueron los dichos Mercado e Diaquez [sic] y el dicho / don Diego con los despachos que la pregunta dize y que saue que vinieron / huyendo del dicho don Diego porque le notificaron la sentencia e des / pachos que llevauan e que como dicho tiene siempre Vaca de Castro / trauajó y escribió y trató con el dicho don Diego y su gente que viniesen al / seruicio de su Magestad sin vatalla y que nunca lo quiso hazer y que no se pudo escusar //

/ 94 v. / e ansí fue necesario que Vaca de Castro saliese a dárselo e recobrar a / quellos reynos al seruicio de su Magestad e quel día que se dio este testigo vio que / el dicho Vaca de Castro salió armado < en blanco > en un cauallo morcillo rabicano / muy bien adrezado y enzima de las armas estaua vna ropeta de / brocado con un ávito de Santiago en los pehos y ansí salió al can / po e hizo derrocar los toldos y tiendas para que toda la gente sa / liese e hordenó sus vatallas < y esquadrones $>$ con gran concierto e les dixo e habló a / esta sazón e hasta que llegaron a los contrarios palabras de / tal contentamiento que le parecía a este testigo que aquellas vastauan / para que cada unos tuviera por obligado a morir por seruicio de su / Rey aunque fuera muy gran ventaja la de los contrarios e que yendo / caminando desta manera atravesó un ciervo de la tierra por el real / y el dicho Vaca de Castro dixo que aquellas heran buenas nuevas e / señal de vitoria e que en este día el dicho Vaca de Castro trauajó mu / cho e hizo oficio de capitán general como si fuera en Ytalia e / que no se puede sinificar ni dezir por escrito los ardides y probey / mientos y horden y plática del dicho licenciado y lo que en este día hizo / e questo dize desta pregunta. A las sesenta y siete preguntas / Cristóval de Barrientos dixo queste testigo vido quel dicho licenciado Vaca de Castro / visto quel dicho don Diego y su gente no querían venir a paz y concor / dia ni obidiencia e seruicio de su Magestad los citó y llamó a pedimento del / fiscal que crió para ello como esta pregunta dize y queste testigo no / saue si le fueron noteficadas las citaciones y enplazamientos pero / que vido que se procedió contra ellos e en ausencia e rebeldía / el dicho licenciado pronunció sentencia en que les daua por traydores e contra / tales mandó hazer la guerra contra ellos a fuego y a sangre y ansí / se pregonó en el real junto al estandarte. Diego de Aguilera dixo / queste testigo vido como el dicho licenciado replicó muchas veces al dicho / don Diego e su gente e que vido como fueron 
sentenciados y pregonados / en el real públicamente por traydores. A las sesenta e ocho / preguntas dixo Rodrigo Salguero que lo que saue es quel dicho don / Diego de Almagro vino con toda su gente por junto por donde estaua / el dicho licenciado Vaca de Castro con sus capitanes e que hera pública / voz e fama y notorio quel dicho don Diego de Almagro y su gente / venía para el efeto contenido en la pregunta y saue este testigo //

/ 95 r. / que si subcediera quel dicho don Diego de Almagro y su gente se juntaran con / el Ynga tenían gran ventaja al dicho licenciado Vaca de Castro y a su gente / porque este testigo saue que sin juntarse con el linga [sic] este testigo oviera de / escoger aquel día para dar la vatalla los reales no teniendo el / rey por delante como el dicho licenciado Vaca de Castro tenía queste testigo / escogiera el real del dicho don Diego porque en armas le pareció a este testigo / que tenía el dicho don Diego al dicho licenciado mucha ventaja ya que por es / ta causa cree este testigo y es cosa cierta que si el dicho don Diego juntara su gente / con el linga [sic] fuera mucha más y tubiera mucha más ventaja al dicho licenciado / e que la tierra se perdiera y que esto saue desta pregunta y que le / parece que si la gente del dicho licenciado Vaca de Castro tubiera el yn / bierno en el canpo y vinieran las aguas y los contrarios les to / maran las comidas este testigo tiene por cierto quel dicho licenciado no le que / darán docientos onbres e que según las cosas que dezían que avían / hecho don Diego de Almagro a vezinos y estantes y avitantes que si el dicho / don Diego pasara con su gente a la ciudad de los Reyes y se perdiera porque / no avía en la dicha ciudad resistencia según el gran poder de la / gente que llevaua el dicho don Diego y esto es lo que saue desta pregunta. / El comendador Juan Xácome dixo que lo que desta pregunta saue es / que vido como el dicho don Diego de Almagro y su gente que traya contra / el dicho Vaca de Castro se juntauan muchas vezes e hazían a / larde e requerían a los arcabuzeros e gente de guerra para que / estobiesen a punto para defender al dicho licenciado Vaca de Castro no / entrase en la dicha ciudad del Cuzco e que contratauan con el inga que / les diese favor y ayuda y quel dicho ynga avía enbiado al dicho don Diego / de Almagro arcabuzes y cotas e otras armas para yr contra el dicho / licenciado Vaca de Castro y ansí el dicho don Diego de Almagro y su gente en e / xecución de su propósito vinieron al dicho licenciado Vaca de Castro / a le desbaratar la qual dicha vatalla se dio dos leguas de la dicha / ciudad de Guamanga donde fue muy público quel dicho don Diego se yva / a meter en la dicha ciudad de Guamanga para se hazer fuerte e / hazer todo el mal que pudiese al dicho licenciado y esto saue desta pregunta. / A las sesenta preguntas Gonzalo de Obregón dixo que la saue como / en ella se contiene, preguntado como la saue dixo que porque es verdad como / en ella se contiene e declara por se hallar presente a ello y convenía seguir //

/ 95 v. / y ronper al dicho don Diego para escusar los ynconbienientes que / dicho tiene en las preguntas antes desta y luego que lo susodicho / se puso por la obra el mesmo derrocaua las tiendas como e / celente varón y animoso para que con verdad saliesen e diesen / tras ellos pues de la tardanza no se podía remediar sino más tra / vaxo lo uno para alcanzarlos lo otro porque sy alcanzaran a / entrar en algún pueblo que la pregunta dize fuera para no los po / der resistir y mandó como tal señor y gobernador astuto en guerra al / capitán Nuño de Castro y Peranzures para que diesen escaramuza / entreteniéndolos hasta tanto que la gente saliese de las / tiendas y más a su salbo se pudiese dar la vatalla y ansí enbió / al capitán Alonso de Albarado con quien este testigo yva y fue ansi / mismo con el estandarte real e dio la vanguardia al capi / tán Peraluarez Holguín y el dicho Vaca de Castro se quedó en la re / taguardia y en todo hizo aquello que qualquier buen caudillo / haría y con tanta diligencia y astucia como después pareció en / la vitoria. Martín de 
Sancho Hernández dixo que saue la dicha pre / gunta como en ella se contiene preguntado como la saue dixo que / porque el día que la pregunta dize vio este testigo que los corredo / res del canpo del exército del dicho Vaca de Castro vinieron a dar / aviso quel dicho don Diego y la suya venían muy cerca a dar la vatalla / al dicho licenciado como dicho tiene lo qual sauido por Vaca de Castro con / gran presteza mandó que toda la gente comiese porque se auía de dar a / quel día la vatalla y enbió delante al capitán Peranzures y Nuño de / Castro con gente para que mientras salía el real los entretubiese / con alguna escaramuza, en este tiempo el dicho Vaca de Castro daua gran / priesa a la gente para que se pusiese en horden de guerra como dicho tie / ne en las preguntas antes desta, e que estando junto el dicho Vaca de / Castro hordenaua la gente por sus esquadrones como avían de yr / e que el dicho Vaca de Castro quería llevar como capitán general a la van / guardia e delantera e ansí lo dixo y queste testigo vido que muchos / capitanes e gente del dicho real y aun este testigo hera uno de ellos ro / garon y pidieron muy afincadamente al dicho Vaca de Castro que no / fuese en la abanguardia ni entrase en la vatalla e que guardase / mucho su persona porque si esta faltaua quedauan todos perdidos / e sin dueño y que se matarían unos a otros sobre que la auía de gobernar //

/ 96 r. / e que de más de dezirselo muchas vezes le hizieron protestación dello poniéndole delante que su Magestad sería deser / vido si a causa de morir él perseverase la tiranía en que estaua puesta la tierra por el dicho don Diego pues ansy / subcediera faltando su persona que con todo esto fue duro de acabar con él y al fin concedió con su voluntad / e dixo que yría en la retaguardia y al tiempo de dar la vatalla el dicho Vaca de Castro estando con treynta e siete / lanzas que tubo consigo veynte que sacó del dicho real y los demás sus criados juntos a donde se daua la / vatalla e donde vía lo que pasaua para entrar al tiempo de la necesidad y que vio este testigo que la dicha vatalla / fue muy reñida y tanto que muchas vezes dado vitoria de parte de Vaca de Castro pero vio que por la / parte del estandarte real del que hera capitán Alonso de Albarado auía mucha priesa y el dicho / Aluarado daua lado a los contrarios y le dio y se metían por aquella parte de las banderas blancas / del dicho don Diego y que segund este testigo entendió llegó a tanto estremo que auía ya redidos muchos / de los de la capitanía del dicho Alonso de Albarado y questa coyuntura tan necesaria e yn / portante socorrió el dicho Vaca de Castro porque entró con las dichas lanzas muy denodadamente y con gran furia diciendo vitoria vitoria Vaca Vaca y con esta entrada los contrarios desmayaron y / comenzaron a huyr aunque todavía mataron de las dichas lanzas que yvan con Vaca de Castro dos per / sonas e hirieron otras y que le parecía a este testigo que murieron de vna parte y de otra al pie de trecientos / onbres y queste testigo se halló con la dicha vatalla de principio y salió herido della en vna pierna y / queste testigo vio como luego que se conoció la vitoria el dicho Vaca de Castro andaua por el real la espada des / enbaynada y aún sangre en ella defendiendo que no matasen más gente de los contrarios y a esta / razón vio este tetigo y mandó tocar alarma el dicho Vaca de Castro y que todos que se juntasen pusiese / en horden diziéndoles que como hera de noche podría subceder el dicho don Diego se rehiziese de alguna gente / e tornase contra el dicho real y hallándolo desbaratado ronpiesen y ansí estuvieron a / quella noche en gran recaudo y el dicho licenciado estuvo armado toda la noche hasta la mañana e / queste testigo se espantó muchas vezes de la gran vitoria y ventura que Dios dio a la parte de su Magestad / e questo dize desta pregunta. A las setenta y una preguntas Gonzalo de Obregón dixo < este testigo sabe que > quel dicho / licenciado Vaca de Castro como se fue en pos de los contarios y gente que traya el dicho don Diego de Almagro / fue por los esquadrones y gente de su real para animarlos a dezirles cosas con que procurasen a / nymo diciendo que su Magestad les gratificaría lo que cada uno hiziese y mirasen lo 
que en ello les yba sus bi / das y como vieron que la gente también anymo les ponía el dicho licenciado y con tan buena voluntad querían / salir determinaron de encontrarse como luego lo hizieron y el dicho licenciado Vaca de Castro como dize en las / otras preguntas antes desta se quedó en la vanguardia ${ }^{20}$ con treinta y siete lanzas poco más o menos e / ansí comenzó la dicha vatalla hasta que fue ansí de noche y al tiempo que pareció ser necesario y que la va / talla estaua en el mayor herbor arremetió el dicho licenciado Vaca de Castro con las dichas treinta e < siete $>$ / [tachado: una] lanzas como muy baleroso y esforzado gobernador y luego se reconoció la vitoria dellos a los otros / ya de noche y saue este testigo que al dicho tiempo que arremetió le mataron dos a García de Montaluo y / al capitán Ximénez e a otros hirieron los quales yvan con él y luego incontinente que se / reconoció la vitoria el dicho licenciado remedió la gente y mandó dar alarma para dos ban / deras que abían quedado altas se rendiesen de las del dicho don Diego y este testigo fue en avisarlo al / dicho licenciado Vaca de Castro el qual dio luego alarma y se rebolbieron sobre ello y luego huyeron / y esto dixo que vio porque se halló presente a todo ello y vio como el dicho licenciado Vaca de Castro / lo hizo balerosamente como tal cauallero el qual hera dino de grandes mercedes y ansí se pensaba en to / do el real que por aquello y por los seruicios que hasta allí avía hecho a su Magestad pensaua que se hiziera / grandes mercedes y esto pasó como la pregunta dize e declara. Francisco Bezerra dixo que saue lo contenido / en la dicha pregunta porque este testigo anduvo con el dicho licenciado por los esquadrones hablando a la gente //

/ 96 v. / de guerra palabras con que los animaua y esforzaua dándoles a entender el gran seruicio que a su Magestad hazían y / otras palabras con que les dio gran ánimo y contentamiento segund que la gente mostarua [sic] después quel dicho licenciado les a / uía hablado y saue que luego fueron acometer a los enemigos por la horden que la dicha pregunta lo dize y es / te testigo fue en la dicha retaguarda con el dicho licenciado Vaca de Castro con las dichas treinta y siete lanzas con las I quales el dicho licenciado entró a la vatalla a tiempo que fue mucho provecho y a la entrada le mataron de los que con / él yvan García de Montalbo e al capitán Ximenez e hirieron a Francisco de Godoy y a este testigo y a Merlo / secretario del dicho gobernador y a otros más y después de reconocer la vitoria por el dicho gobernador este que depone viniendo / herido topó al dicho gobernador que andaua mandando que se regrese la gente y mandó tocar alarma y bio como en / bió a socorrer y estorbar que no matasen al Sanmillán contenido en la dicha pregunta y todos los / demás quél pudo y esto saue porque se halló presente todo lo que dicho tiene. Rodrigo Salguero / dixo que llegando cerca de los enemigos que estauan esperando al dicho licenciado, el dicho licen / ciado Vaca de Castro habló a toda la gente por sus esquadrones palabras / que puso ánimo e contentamiento a la gente que llevaua consigo en especial en / lo mucho que entendieron que servían a su Magestad con el qual llegaron y acometieron a los / contrarios y se mezcló la vatalla y estando el dicho licenciado con la dicha gente que con él / avía quedado al tiempo que le pareció que avía necesidad entró en la vatalla y hizo muy / grande fruto e luego como el dicho licenciado y la dicha gente entró se reconoció vitoria y que saue / que en la dicha vatalla le mataron de los que con él entraron a García de Montaluo e al capitán / Ximenez y le hirieron a otros muy heridos especialmente a vn onbre que se dezia Merlo que / a este piensa este testigo que los contrarios lo dexaron por muerto segund las heridas tenía / e a Francisco Vezerra e a otros muchos de la dicha gente que entró con el dicho Vaca de Castro que los / nombres no se acuerda y que luego yncontinente que la vitoria se reconoció, el dicho licenciado remedió lo / que pudo para que no

\footnotetext{
${ }^{20}$ Probable error del testigo, los demás indican todos que se trata de la "retaguardia".
} 
matasen más gente e defendió algunos y que oyó dezir que defendió a / Sanmillán y a otras personas y que estando la gente deshordenada por temor que los contrarios / no se rehiziesen y por tener su gente buen recaudo dio alarma anduvo juntando la gente / por donde aunque los contrarios rebolbieran no tuvieran miedo ninguno de hazer contra ellos e / questo es lo que saue desta pregunta. Cristóval de Barrientos dixo que lo que saue es que estando el / un [sic] exército cerca del otro hordenadas sus azes para dar la vatalla el dicho licenciado Vaca de / Castro vido este testigo que anduvo desquadra en esquadra y bandera en bandera animan / do la gente y diziéndoles palabras muy buenas y animosas declarándoles la merced que Dios les a / vía hecho en tenellos en seruicio de su Magestad y su obidiencia prometiéndoles en nombre de su Magestad abiendo / vitoria grandes premios y quando su Magestad sería seruido y ellos aprovechados en auer vitoria con / tra el dicho don Diego de Almagro y su gente y que esto hecho se dio la vatalla que duraría vna / ora hasta reconocerse la vitoria por parte de su Magestad y que este testigo vido algunos de / los que se quedaron en retaguarda con el dicho licenciado Vaca de Castro muertos e / heridos otros. A las setenta e dos preguntas Gonzalo de Obregón dixo / que es verdad que todos los dichos capitanes y gente lo hizieron como buenos caualle / ros soldados y pelearon muy valerosamente con gran deseo de seruir a su / Magestad toda aquella noche estuvieron con sus banderas en mucha guar / da e con toda horden le ovedezían al dicho Vaca de Castro como a / tal capitán general e porque también lo avían hecho e de allí / del canpo se fueron aquella noche a unas questas a hazer las tien / das y toldos aunque la noche hazia muy recia y en todo dixo este testigo //

/ 97 r. / lo hazía el dicho licenciado Vaca de Castro como buen gobernador porque convenía / ansí para seruir a su Magestad. Francisco de Cáceres dixo que saue que todos / los dichos capitanes caualleros e gentiles onbres que se hallaron en la / dicha vatalla lo hizieron muy bien y pelearon animosamente con gran de / seo de seruir a su Magestad como buenos y leales seruidores y tuvieron toda / ovidiencia e acatamiento al dicho licenciado como tiene dicho en las preguntas / antes desta se juntaron luego con sus banderas y esquadrones / e ansí estuvieron toda la noche no obstante que estauan cerca / los toldos e tiendas de los contrarios y quel dicho licenciado se vbo en / todo lo que hizo e trauajó como buen capitán general e que saue / lo que dicho tiene porque lo vido y se halló presente a ello. A las seten / ta e tres preguntas fray Esteuan Tellez dixo que lo que desta pregunta / saue es queste testigo como dicho tiene en las preguntas antes desta fue y / anduvo con el dicho licenciado Vaca de Castro desde los términos de la ciudad de / San Miguel que es en Piura hasta el día de la vatalla y que en todo el dicho / tiempo que con él anduvo vido que dicho licenciado Vaca de Castro trauajó mucho co / mo bueno y leal seruidor de su Magestad en todas las cosas que fueron necesarias / ansí para la dicha guerra como para probeymiento de otras cosas e / vido que con su grande industria e trauajo y buenas pláticas e ra / zonamiento que hazía apellido e ajuntó mucha gente al seruicio de su Magestad / e vbo dineros para las cosas necesarias de la dicha guerra e hizo / e proveyó arcabuzes e picas y otras municiones necesarias para la / dicha guerra como dicho tiene por razón de lo susodicho y con ayuda de / los cauallos e gentiles onbres que de buena voluntad sirbieron / a su Magestad en la dicha vatalla el dicho licenciado Vaca de Castro vbo la vitoria / e ronpimiento contra el dicho don Diego de Almagro e con buen razonamiento / el dicho licenciado Vaca de Castro hizo a la dicha gente el día de la vatalla la / dicha gente quedó muy contenta y con buena voluntad de seruir a / su Magestad como después pareció e que cree e tiene por cierto este testigo por / las causas e razones que dichas tiene en las preguntas antes desta que si / el dicho licenciado Vaca de Castro no tuviera la buena deligencia y solicitud / e maña que tubo en todo lo que dicho es y faltar a su persona quel dicho / don Diego de Almagro se apoderara en la tierra que 
le acudieron / e se juntaran con él y no auía persona que le tuviera en la tierra respeto / y voluntad para poder hazer ninguna cosa de lo que el dicho Vaca de Cas / tro hizo por venir como vino en nonbre de su Magestad y con voz suya y porque algunos //

/ 97 v. / de los caualleros que en la tierra avía a la dicha sazón tenían buena / voluntad de seruir a su Magestad entre ellos avía algunos que tenían distin / ciones e cada uno le parecía que se quería seguir por su cabeza y a esta / causa fue necesaria la venida y buena deligencia quel dicho licenciado Vaca / de Castro tubo en lo susodicho y ansímismo cree y tiene por cierto que si el / dicho don Diego de Almagro siguiendo su mal propósito se apoderara en la / tierra después de apoderado con dificultad su Magestad tornara a re / cobrar la dicha tierra de poder del dicho don Diego e su gente y questo saue / por el conocimiento que de la dicha tierra tiene y es muy público y notorio. El comendador Juan Xácome dixo que lo que desta pregunta saue es que / desde la entrada de Quito fasta el bencimiento de la vatalla que el dicho / licenciado hizo trauajo y hizo desde que llegó a Quito fasta el día del / ronpimiento tubo muy buena horden y maña para auer dineros y caudi / llear gente e hazerla e juntarla y en auer cauallos y comprar e / hazer armas, pólbora e arcabuzes, picas y munición y trauaxó tanto / en el probeymiento e regimiento durante y en lo que habló el día que / se dio la vatalla e ronpimiento della quando robó la vitoria con a / yuda de los caualleros e gentiles onbres seruidores de su Magestad que / avía llevado que si el dicho licenciado no hiziera las dichas probidencias o / faltara la persona del dicho licenciado como persona prencipal no se jun / tara la dicha gente que se juntó con él ni oviera quien resistiera al / dicho don Diego y se perdiera todo y se apoderara de todo el dicho don Diego / de manera que con gran dificultad se pudiera cobrar la tierra y esto saue / desta pregunta y ansí es público y notorio. A la setenta e qua / tro preguntas Francisco Pérez clérigo dixo este testigo que lo que della saue / es que después de dada la vatalla el dicho don Diego de Almagro fue / huyendo hasta dos leguas de la dicha ciudad del Cuzco donde este testigo re / sidía con siete onbres que sauido por los de la ciudad del Cuzco que / venían huyendo de la dicha vatalla fueron de la ciudad del Cuzco / en nombre de su Magestad a mano armada a prender al dicho don Diego de Almagro / e a los que con él yvan y este testigo fue a los ber y vio que fueron pre / sos y los truxeron a esta ciudad del Cuzco y los pusieron en la cárcel / a buen recaudo hasta en tanto quel dicho licenciado viniese a probeer lo / que avía de hazer en ello y el dicho licenciado vino después a la dicha ciudad / del Cuzco e hizo proceso contra ellos e después por el dicho licenciado de la Gama / juez de comisión y teniente del dicho licenciado Vaca de Castro fueron sen / tenciados e condenados a muerte e le executó la sentencia en la dicha ciudad del //

/ 98 r. / Cuzco e de los que con él yban al tiempo que le prendieron y quel pro / pósito del dicho don Diego fue de tomar algunas armas e recaudos / porque venían destrozados y desbaratados por tornarse a juntar / con Mango Ynga que hera yndio y señor de la tierra e que si con él se jun / taran se hizieran muy grandes daños e guerras porque todos los des / baratados de la guerra se fueran con los susodichos don Diego de Al / magro e Mango Ynca e de necesidad oviera muchos daños e desaso / siegos en la tierra e muertes y no pudiera ser menos si se hallaran / e juntaran porque heran partes para ello y ansí es cierto y aberigua / do e nunca se sosegara la tierra como después de muerto el dicho / don Diego se sosegó y pacificó e andaban en paz y que estando preso el / dicho don Diego en la dicha ciudad del Cuzco se procuró de soltar y tenía pos / tas aparejadas en ciertos tanbos camino de donde estaua el dicho / Manco Ynga y como el dicho licenciado Vaca de Castro lo supo lo remedió lue / go y lo puso en otra cárcel a buen recaudo y puso deligencia en / tomar como tomó 
las dichas postas y questo saue de la pregunta. / Sancho Tofino dixo que lo que saue que este testigo estaua en la dicha / ciudad del Cuzco al tienpo que llegaron huyendo que se avían escapado / de la vatalla el dicho don Diego y Diego Méndez su capitán y otras cier / tas personas y viendo esto el regimiento y vezinos de la ciudad del Cuzco y / este testigo con ellos fueron a la casa del dicho Diego Méndez el qual se / huyó de su casa donde estaua y allí supieron por otro español que / avía venido con ellos cómo el dicho don Diego quedaua en Xaqui / xaguana ques quatro leguas del Cuzco y yendo allá encontraron / a otros españoles que avían venido con el dicho don Diego que hera uno / que se dezía Verrío e otros y el dicho regimiento y los vezinos los prendieron / y llevaron al Cuzco y este testigo fue en guarda dellos juntamente / con un regidor del Cuzco que se dezía Altamirano e allí se supo de / cierto donde estaua el dicho don Diego y fue allá un alcalde que se llamaba Antón / Ruiz de Guebara con otros españoles y rendieron al dicho don Diego / e a otros que con él estauan y los truxeron al Cuzco y este testigo le vido / preso en el Cuzco e quando llegó el dicho capitán Garcilaso de la Vega ya / estaua preso el dicho don Diego y los otros que con él estauan y / se los entregaron al dicho Garcilaso de la Vega el qual los puso a las / casas de Hernando Pizarro y a otras partes para que allí estobiesen / presos y este testigo los vido como dicho tiene presos porque los belava / muchas noches y esto que dicho tiene saue y vido desta pregunta y ansy //

/ 98 v. / fue público y notorio. A las treinta e cinco preguntas Cristóval de $\mathrm{Ba} /$ rrientos dixo que este testigo vido cómo de la dicha villa de Guamanga el dicho licenciado despa / chó para los pueblos del Perú haziéndoles sauer la vitoria que nuestro Señor les / avía dado contra don Diego e su gente para que estobiesen quietos e / pacíficos en justicia e vido este testigo como el dicho licenciado despachó al / capitán Vergara para poblar los Bracamoros y lo bido hazer y probeer / otras cosas necesarias. Francisco de Cáceres dixo que saue que estando el / dicho licenciado en la villa de Guamanga enbió a la ciudad de los Reyes / e a otros pueblos mensajeros para que diesen la nueba como el Rey / estaua en la tierra e que todos estubiesen en paz e en justicia ansímis / mo probeyó de allí al capitán Vergara a la conquista de los Bracamoros / e ansimismo hizo y probeyó todo lo que más convenía para la paz / e sosiego de la gobernación y esto que dicho tiene lo saue porque lo vi / do e se halló presente. A las setenta e seis preguntas Nicolás García / dixo que saue este testigo y vido cómo el dicho licenciado enbió al capitán / Pedro de Puelles a la probincia de Guánuco a poblar a la ciudad de / León e a los vezinos de los Chachapoyas que estauan diferentes / sobre los pleitos que avían tenido sobre sus yndios en vida / del marqués don Francisco Pizarro e los aberiguó y quedaron quie / tos en sus repartimientos lo que no hera de antes. Cristóval de Ba / rrientos dixo que este testigo saue cómo el dicho licenciado hizo poblar la / provincia de Guánuco, la ciudad de León e hizo repartimientos y / nombramientos de vezinos concertó e dio medio entre los vezinos de / Levanto e los que pretendían tener yndios en la dicha provin / cia, ciudad de León y esto saue este testigo porque lo vido e se halló / presente a ello quando se despachó e probeyó en el tanbo de / Vilcas e que en hazerse lo susodicho fue gran seruicio de su Magestad / e bien de la tierra porque escusaron muchos daños e muertos e / robos que yndios hazían a cristianos porque andaua un capi / tán que se dezía Yllatopa alzado en aquella provincia con gen / te e hazía mucho mal a los cristianos y con poblarse se sosegó / e pacificó toda aquella tierra e se prendió el dicho capitán / e se hizo amigo e quedaron las dichas ciudades de León y Lebanto / e vezinos dellas en pacificación e paz que hasta allí no / tenían. A las ochenta preguntas Hernán Mexía dixo que saue e / vido que al tiempo quel dicho licenciado Vaca de Castro entró en las / dichas provincias del Perú no estauan descubiertas más tierras // 
/ 99 r. / en la cordillera que la pregunta dize más de las que en ella se declaran / e que después que el dicho licenciado Vaca de Castro entró en las provin / cias del Perú por su buena yndustria y solicitud que vbo a seruir a / su Magestad despachó los capitanes que la pregunta dize para que des / cubriesen e conquistasen las demás tierras contenidas e declara / das en esta pregunta y fue público y notorio que los susodichos por / razón de lo quel dicho licenciado les dixo descubrieron y conquistaron / las dichas tierras que dicho tiene y que estauan por descubrir en / lo qual el dicho licenciado Vaca de Castro hizo gran seruicio a su Magestad e mul / tiplicó sus quintos y rentas reales mucho más de lo que esta / van antes y al tiempo quel dicho licenciado Vaca de Castro entrase en las dichas / probincias e que esto saue desta pregunta. Francisco de Cáceres dixo / que saue que en los dichos Reynos y probincias del Perú al / tiempo que el dicho licenciado la recobró e pacificó estaua descubierta la / cordillera de la costa de la mar desde Puerto Viejo hasta don / de está hecha la ciudad de Santiago que es en Chile por la sierra es / taua descubierto desde la ciudad de Quito otra cordilera has / ta las Charcas y villa de Plata y quel dicho licenciado por hazer / seruicio a su Magestad y porque la gente que no tenía yndios en la dicha / provincia hera mucha y no se podía sustentar en la probincia / syn que la destruyeran y oviera cada día ynconbinientes tra / vajosos de remediar probeya capitanes que fuesen a entradas / y este testigo vido probeer al capitán Vergara para los Bracamoros / e al capitán Juan Porcel a Chiquimayo y al capitán Juan Pérez / de Guebara para Moyobanba y al capitán Pedro de Puelles pa / ra poblar a Guánuco e conquistar Rupa Rupa e a Diego / de Rojas e a Felipe Gutiérrez hazia el estrecho e que saue lo que / dicho tiene porque vido probeer los dichos capitanes para las / partes e probincias que tiene dicho e yr con gente y prouisiones / para ello e yr nonbrados en nonbre de su Magestad y esto dize e / saue desta pregunta. A las ochenta e nueve preguntas Rodrigo / Salguero dixo que saue quel dicho licenciado hizo todo lo contenido en la pregunta / porque este testigo vio y oyó dezir que con Paulo no auía podido ninguna / persona antes del licenciado Vaca de Castro que se tornase cristiano y que / este testigo le rogó muchas vezes al dicho Paulo que se tornase cristiano / e que a frayles y a clérigos y a personas que con él tratauan le vio//

/ 99 v. / este testigo quel dicho licenciado les dezía que ynportunasen al dicho Paulo / que se volbiese cristiano que si fuese necesario le prometiesen dádibas / e que él se las daría porque se bolbiese cristiano e que tratado desto el / dicho Paulo dixo que quería ser cristiano e que este testigo se halló presente / a verlos bautizar a él e a dos mugeres suyas e que de allí adelante / le vio tener un clérigo consigo para que le administraua [sic] en la / fee y le bio hazer una yglesia e dezir cada día misa en ella y que este / testigo le parece que fue muy buena obra de buena caridad e hizo / muy gran fruto e también hizo lo contenido en la pregunta que unos / criados de Vaca de Castro se hizieron religiosos y a manera de ermitaños / e frailes por otras partes y clérigos por otras para conbertir a / los dichos yndios e mostrarles la doctrina cristiana y que le parece a / este testigo que avía más de quatro mil indios que sauían Pater Noster / e Ave María y que se avían tornado cristianos la mayor parte de a / questos yndios y questo saue desta pregunta. Gonzalo de Obregón / dixo que saue quel dicho licenciado en el tiempo ya dicho que llegó e después / que retuvo puso mucha deligencia en todo bien de fe y en la con / versión de los yndios naturales e se hizieron muchas cosas en / su tiempo dinas de memoria especialmente se tornó cristiano Pau / lo Ynga señor de yndios más principal y le hizo que deprendiese / la doctrina cristiana y para aprenderla tubo en su casa un clérigo / bizcayno el dicho Paulo Ynga se bautizó con su muger e yndios e se puso por nombre don Cristóval e en ella perseveró y perse / vera contino oyendo misa e haciendo aquello que cristianos hazían y en su casa tenía una hermita para mejor usar de la / fe y saue este testigo que en 
tornarse cristiano el dicho Paulo Ynga / con las palabras quel dicho licenciado le dezía fue causa que ansimismo / se tornasen cristianos muchos de los dichos yndios y oyó dezir que / avía gastado el dicho licenciado Vaca de Castro muchos dineros en su / vautismo e ansimismo saue que tres criados del dicho licenciado / dexaron el ábito seglar y pusieron esquela de doctrina por el co / legio y enseñaron a muchos yndios la doctrina cristiana y se tor / naron muchos cristianos e demás desto auía otras escuelas / que hizo poner el dicho licenciado especialmente puso al provincial e / regente en la horden de Santo Domingo los quales ponían las dichas //

/ 100 r. / esquelas y en el Cuzco salían de las esquelas < los indios > a visitar las yglesias / e sacramento con cruzes y cantando la doctrina cristiana y saue que la / seguían y por muchas partes se dibulgaba y lo oyó dezir a los dichos / yndios en muchas partes en su lengua e castellana lo qual no a / vía antes que fuese el dicho licenciado Vaca de Castro y saue an / simismo que se mandó que los hijos de principales caciques fuesen a / la esquela a deprender la dicha doctrina y este testigo los topó que yvan / a la dicha esquela a deprender la doctrina por manera que quedó en / la tierra e provincia muchos yndios cristianos quando se vino / el dicho licenciado Vaca de Castro lo qual fue gran seruicio de Dios / e de su Magestad la buena yndustria y esto saue desta pregunta. / A las noventa e ocho preguntas Francisco de Cáceres dixo que saue / que luego que cesó la dicha necesidad y se pacificó la tierra el dicho licenciado / hizo hordenanzas en remedio y livertad de los yndios na / turales y buena gobernación por las quales se remedió las / cargas, cadenas, colleras y cepos y el pasar los yndios de / una parte a otra y se proveyó e dio horden como no obiese / valdíos por la tierra comiendo sobre los yndios y que no fue / sen rancheados ni tomados bienes suyos e que por lo su / sodicho cesaron los dichos daños y los dichos yndios recibieron li / vertad, provecho y contentamiento segund que parece por las dichas / hordenanzas las quales este testigo vido y leyó muchas vezes co / mo lo tiene dicho en esta pregunta y que esto saue porque lo vido / ansí como lo tiene dicho en esta pregunta. Gonzalo de Obregón / dixo que es verdad que luego que las dichas hordenanzas se hi / zieron cesó la dicha necesidad y se pacificó la tierra e luego el / dicho licenciado en execución de un capítulo de su ynstrución hizo hor / denanzas en remedio de lo susodicho en livertad de los yndios natu / rales y buena gobernación por lo qual se remedió las cargas, cadenas y colleras como parecerá por las dichas hordenanzas a / las quales se remite y proveyó ansimismo que toda la gente / valdía andubiese por los caminos reales de suerte que de / todo ello venía gran provecho a los dichos yndios porque les co / mían sus haziendas los tales y por esto dize que es verdad / que luego cesó la necesidad y se pacificó la dicha tierra y esto saue desta pregunta. //

/ 100 v. / A las ciento y una preguntas el comendador Juan Xácome dixo queste / testigo vido en el dicho tiempo contenido en la dicha pregunta los caminos / pacíficos y la tierra quieta e sosegada e avía en ella justicia / e razón entre los vezinos de la dicha provincia del Perú e que des / pués de la venida del dicho licenciado Vaca de Castro a auido muchas / alteraciones e muertes y robos e sin justicias e a sucedi / do mucho mal e alboroto lo qual no avía en el tiempo que residía / e fue gobernador en las dichas provincias el dicho licenciado Vaca de / Castro y esto lo saue este testigo porque siendo el dicho licenciado Vaca de / Castro gobernador se halló en las dichas provincias y estaua / en ellas hasta que puede auer doze días que desenbarcó en el / puerto de las Mullas desta ciudad de Sevilla y esto saue de / esta pregunta e dello es público y notorio. Gonzalo de / Obregón dixo que la saue como en ella se contiene, fue preguntado / a este testigo como lo saue dixo que porque al tiempo que pasaua / lo susodicho este testigo estaua con el dicho Vaca de Castro y vía / como en la dicha ciudad del Cuzco se hazía después que entró en / la dicha tierra y ciudad muchas 
casas porque los yndios que an / dauan destraídos e huidos se recogían a sus naturales y que / todos los caminos estauan muy poblados por tal manera / en poco más del año que la pregunta dize estubo el dicho licenciado / se hizieron en el Cuzco e sus arrabales mucho número de casas / e saue que se senbraba la dicha tierra donde muchos años avía / que no se senbraua y como se poblaua la tierra y saue este testigo que / los dichos yndios bibían e yvan en gran riqueza y pros / peridad, seguridad e contentamiento por el buen tratamiento que el / dicho Vaca de Castro les hazía e ansimismo saue que desde / la ciudad de Quito hasta las Charcas que puede aver setecien / tas leguas poco más o menos por los caminos reales avía / muchos pueblos muy despoblados antes quel dicho licenciado Vaca de / Castro fuese a la gobernación por el mal tratamiento que a los / españoles les hazían e avían hecho e que después que el / dicho licenciado fue a la gobernación este testigo andubo la mayor parte / del dicho camino y saue que estaua poblado e que se yvan / los indios muy contentos e que poblaban sus pueblos por yntercesión //

/ 101 r. / de la buena gobernación quel dicho licenciado Vaca de Castro les hazía e / que ansí seguramente podía yr un español solo desde Quito / a las dichas Charcas desocupadamente sin contradición alguna / lo que no hazían antes quel dicho Vaca de Castro fuese y gobernase / e por esta razón saue la dicha pregunta. A las ciento y dos pregun / tas Gonzalo de Obregón dixo que saue este testigo quel dicho licenciado Vaca / de Castro quando fue a la dicha provincia halló que andaban / las hijas de Guaynacaba señor que avía sido de aquella tierra / que fue estimado e adorado de los yndios por dios y tornado / dellas cristianas y casó la una con un español Bautista Armero / e le dio yndios y procuró que se buscase a la hija de Tabalipa / niña y la hizo poner en su casa y desposada e que la casó que / fue con un español que se llamaua Pedro de León cristiano el / qual tenía yndios y sauía que otra hija de Guaynacaba / se casó en aquel tiempo mesmo con un vezino que se llamaba Vi / llacastín y todas las tornó cristianas y las bautizó e / amostró la doctrina cristiana a su costa el dicho licenciado porque tenía / en su casa un clérigo que las enseñaba e hazía lo que buen gobernador / avía de hazer y esto saue desta pregunta. Martín de Sancho Hernández dixo / ques verdad lo que la pregunta dize porque este testigo vio / que casó a las hijas de Guaynacaba que andaban perdidas y / a la hija de Tabalipa la buscó e hallada la hizo bestir e / poner en casa de una de las dos hijas de Guaynacaba que se casó / primero y desde supo la doctrina cristiana la hizo bautizar / e la casó con español que tenía yndios e que ansimismo metió / en su casa a dos hijos de Tabalipa e otros de algunos vezinos / e tenía clérigos que los enseñavan a leer y escriuir y la fe y / que esto saue de la pregunta porque lo vido. A las ciento y cinco preguntas / Juan de Herrera dixo que saue y vido que al tiempo quel dicho licenciado / Vaca de Castro se quería venir del Cuzco para acá para España / salían los yndios y caciques señores principales por los cami / nos llorando e haziendo gran sentimiento porque se venía el / dicho Vaca de Castro diziendo que les trataua mejor que su señor / Guaynacaba e que por qué el apo grande de Castilla lo quitaua / que lo tenían como a padre y que enbiaran a otro que los tratase / mal e desto tenían miedo los dichos yndios e le dezían al dicho Vaca //

/ 101 v. / de Castro que les hiziese quilcas que quiere dezir cartas a / su Magestad y que no se viniese él y esto saue desta pregunta porque / lo vido como dicho tiene y aun hasta oy lloran los dichos yndios / e hacen taquis de lloro al dicho Vaca de Castro porque faltó en la / tierra. Frai Juan Bautista dixo que la saue porque lo vido en la / ciudad de los Reyes en los señores yndios que allí estauan que / hazían gran sentimiento por su ausencia del dicho licenciado y lo mismo oyó / dezir que hazían atrás los dichos yndios hazia el Cuzco. Luis de / Carrizales dixo que la saue como en ella 
se contiene porqueste / testigo lo vido los grandes llantos que los yndios hazían por su / venida. Nicolás García dixo ques verdad que los yndios hizieron / muy gran sentimiento al tiempo que se quiso partir el dicho licenciado y les bi / do este testigo llorar diziendo que era su padre. A las ciento y / setenta y seis preguntas el comendador Juan Xácome dixo / que saue y vio quel dicho licenciado Vaca de Castro tubo grandes o / cupaciones después que se hizo justicia del dicho don Diego de $\mathrm{Al} /$ magro en provisiones de tenientes y justicias y en el gobierno / general e en otras cosas complideras a la gobernación de las / dichas provincias y pueblos e cabildos dellas. Juan de Herrera dixo que la saue como en ella se contiene porque ansí lo / vido este testigo ser y pasar como la dicha pregunta lo dize y nunca / a visto este testigo mejor horden de gobierno e justicia que las que / el dicho licenciado tubo después de muerto el dicho Diego de Almagro. A las ciento y setenta e siete preguntas Francisco Pérez / clérigo dixo este testigo que lo que della saue que este testigo saue que / demás de las dichas ocupaciones quel dicho licenciado Vaca de Castro / tubo en la gobernación cumplió muchas cosas de las que / llevaua en la dicha ynstrución y cédulas en especial saue / este testigo que reformó los repartimientos que pareció ser e / cesibos y número de yndios questo fue cosa ardua e dificultosa / e aún peligró de su persona porque no le estaua bien a los que / lo quitaua y reformaba e quel dicho licenciado en ello se dio buena ma / ña e vbo hefeto por manera que quedaron pocos repartimientos / por reformar e que entendió en señalar límytes para los o / bispados lo qual hizo con buen acuerdo e retamente y que saue y / vio quel dicho licenciado Vaca de Castro truxo pilotos para verificar el sytio //

/ 102 r. / e grados en que estaua el Cuzco para declarar sobre la tomada la / altura e grados del río de Santiago que se dize Tenunpulla e que ansy / mismo saue quel dicho licenciado mandó que qualquiera persona pudiese / rescatar sin licencia en general y que secrestó los bienes del dicho marqués / don Francisco Pizarro hasta que se pagasen lo que debía de deudas a su Magestad e / a otras personas y aún a este testigo se le pagó como dicho tiene una deuda / que le debía el dicho marqués Pizarro en que perdió la terzia parte della / e que ansimismo saue quel dicho licenciado puso gran cuydado e deligencia / en la conbersión de los indios haziendo yglesias templos en la dicha / ciudad del Cuzco y fuera en las probincias de los mismos caciques pro / veyese que oviese escuelas donde fuesen los caciques y sus hijos a / aprender la doctrina cristiana e que los yndios e yndias que / seruían a los españoles fuesen a las yglesias donde deprendiesen / la doctrina cristiana en cierto tiempo como de antes se hazía y vio quel / dicho licenciado probeyó que algunos españoles se casasen y estubie / sen en seruicio de Dios e hizo casar muchos por su yndustria e yn / tercesión e mandó y hordenó que no sacasen yndios de la provincia / en el remedio de los yndios a otras partes de que no oviese valdíos / ni rancheadores ni quien les hiziese daño, mandó que los dichos yndios li / bres no se hechasen a las minas eceto los que fuesen de su voluntad / e que mandó y probeyó que los yndios de la syerra no fuesen a / seruir a la ciudad de los Reyes y llanos por el peligro que en ello les / subcedía y mandó que no obiese juegos excesiuos con grandes penas / e que tanbién dio el dicho licenciado Vaca de Castro e hizo bolber ciertos / yndios heredades que les tenían tomadas por fuerza algunos cristia / nos para que pudiesen senbrar haziéndoles en ello justicia e / ansimismo proveyó y mandó como obiese buen recaudo en el / almofarifazgo de las mercadurías que hasta allí no se avía / hecho ni hazía ninguno y que mandó apregonar las cédulas y / provisiones e hordenanzas para que viniese a noticia e todos e / queste testigo se halló presente al tienpo que se pregonaron en la dicha ciudad / del Cuzco e se mandó lo que dicho tiene hizo otras cosas to / cantes e concernientes al seruicio de Dios e de su Magestad y a la / muy buena 
gobernación de las probincias y como muy buen gobernador / e seruidor de su Magestad y ansí fue y es público y notorio y pública //

/ $102 \mathrm{v}$. / es e fama entre las personas que dello tienen noticia como es / te testigo e que esto es lo que saue desta pregunta. Gonzalo de Obregón / dixo que lo que desta pregunta saue es que demás de lo que dicho tiene / no ostante las ocupaciones que tenía el dicho licenciado se acuerda este testigo / que hizo las cosas siguientes que moderó y reformó los repartimientos / que pareció ser excesivos en número de yndios e que sobre esto vbo / murmuración como dicho tiene quel dicho licenciado se dio tan / buena maña que pasó con ello por manera que quedaron poco / por reformar e saue este testigo que señaló los límites de los / obispados e fue público en el Cuzco que tomó el altura en / los grados que estaua el Cuzco y que tomó ynformación sobre ello / tocante a la hazienda de su Magestad e saue que todos rescataban en / general libremente como dicho tiene y saue que puso el dicho licenciado Vaca / de Castro gran deligencia en la conbersión de los yndios y en hazer / yglesias y monasterios e dar sitios conbinientes para que se hiziesen / otros y probeyó como dicho tiene que se oviese escuela don / de fuesen a deprender la doctrina los caciques principales e / sus hijos e que los yndios e yndias que serbían a los españoles / que fuesen a ellas y saue que hizo casar españoles e ansimis / mo saue que proveyó como no se sacasen yndios de las probin / cias e saue ansimismo que hizo hordenanzas sobre el cargar / de los yndios e ansimismo de que no obiese valdíos ni ran / cheadores como dicho tiene y saue e oyó dezir y fue público quel / dicho licenciado Vaca de Castro probeyó que los yndios no fuesen / a la ciudad de los Reyes ni llanos e saue que proybió los juegos / excesibos con grandes penas que como dicho tienen senbraban / los yndios heredades que avía mucho tiempo que no se senbra / van y es todo lo que saue desta pregunta e quel dicho licenciado / hizo todo aquello que pudo para la gobernación de la tierra y es / to responde a esta pregunta. A las docientas y setenta e / dos preguntas Martín de Sancho Hernández dixo queste testigo es / taua en la tierra al tienpo que llegó a ella el dicho treslado de hor / denanzas antes que Blasco Núñez fuese el qual dio desasosiego / entre la gente de aquella tierra que se trataua de ynbiar a / su Magestad mensajeros para que la revocasen y les hiziese merced por / que dezían que su Magestad avía sido engañado para hazerlas y que heran //

/ 103 r. / muy rezias e se trataua de enbiar mucho dinero del seruicio y que la ciu / dad de los Reyes enbió a tratar esto con la del Cuzco a don Antonio / de Ribera e a Alonso Palomino y este testigo fue en aquella sazón en / su compañía desde la ciudad de los Reyes hasta el Cuzco e que saue / este testigo que estando el dicho licenciado a la sazón en el Cuzco con valor tra / tó como la gente se sosegase y lo pacificó todo dándoles res / puestas agradables y mostrándoles buen rostro y con esto que / dó la tierra tan pacífica como de antes lo estaua e ansí lo estubo / y en toda quietud e sosiego hasta que Blasco Núñez entró en aquella / probincia y por la execución que hazía de las hordenanzas comenzaron / a alterarse e a venirse la gente huyendo de temor de su execución / e cosas que hazía e que este testigo saue que la tierra estaua como Cas / tilla antes que fuese el dicho Blasco Núñez y ansí lo estobiera has / ta agora si Vaca de Castro la gobernara porque él la tenía en toda su / jeción y hera amado e obedecido. Gaspar de Cuellar dixo que este testigo vio / el traslado sinple de las dichas hordenanzas en la ciudad de los / Reyes y vio a muchos vezinos conquistadores quexarse dellas / e supo que se ynbiaban al Cuzco y por toda la tierra muchas ve / zes oyó dezir a regidores y personas principales de la ciudad de / los Reyes como querían enbiar procuradores a su Magestad sobre ello / e que la sirbirían con la cantidad de pesos de oro en la pregunta con / tenía e aun en más e que este testigo vio reciuir al dicho Blasco Nú / ñez Vela por virrey en la ciudad de los 
Reyes e que al tiempo quel dicho / Vaca de Castro dexó la gobernación todo el Reyno estaua en quie / tud e pacificación esperando la suplicación de las dichas hor / denanzas e con ella ynbiar sus procuradores e hazer seruicio a su Magestad de más / cantidad de lo en la pregunta contenido. Juan de Herrera dixo que / nunca este testigo vio el traslado de las dichas hordenanzas mas de / avello oydo dezir a muchas personas de la tierra andaban muy / apasionadas y enojadas diziendo que aquel galardón les daba / su Magestad e se trataba de enbiar procuradores por la tierra a suplicar a su Magestad / de las dichas hordenanzas e juntamente con esto seruir a su Magestad con can / tidad de dineros y este testigo vido quel dicho Vaca de Castro lo andaba / apaciguando llamando a los vezinos e diziéndoles no tubiesen / pasyón ninguna quel escribiría a su Magestad sobre ello y quando el dicho Blasco Núñez //

/ 103 v. / Vela llegó aquellas provincias estauan muy pacíficas y todas en paz / e sosiego e con mucho contentamiento y esto es ansí muy público y notorio. / A las ducientas y setenta y tres preguntas Martín de Sancho Hernández / dixo este testigo que siempre vio e oyó dezir al dicho Vaca de Castro / ansí estando en el Cuzco después que fue el dicho traslado como por / el camino viniendo a la ciudad de los Reyes muchas cosas en / provecho de las hordenanzas e que heran muy justas y las podía / su Magestad hazer e que hera razón que se obedeciesen y que ansí el pecho / por tierra avía de obedecerlas e yr a dexar el cargo de gobernador e / seruir a su Magestad como siempre lo hizo e dezía a los que venían con / él que todos hiziesen lo mismo porque heran obligados a seruir / al Rey e que hera trayción no hacello e que este testigo sienpre vio / e conoció del dicho Vaca de Castro muy gran voluntad de que se obe / deciese lo que el Rey mandaua e que se executase las dichas hor / denanzas y que ansí lo dezía muchas vezes e questo saue desta pregunta. / Fray Pero de Carrió dixo que lo que della saue es que este testigo vio co / mo dicho tiene que en la dicha ciudad del Cuzco el dicho licenciado se dio / tan buena maña que los sosegó y pacificó de la alteración que tenía / por las dichas hordenanzas y no solamente allí pero este testigo fue con él / hasta el tanbo de Xaquijaguana y por el camino en todo tiempo bio / quel dicho licenciado Vaca de Castro dixo e habló muchas cosas y pa/ labras en justificación de las dichas hordenanzas para que mejor / se obedeciesen e cumpliesen lo que su Magestad mandase para tener la tie / rra pacífica y esto saue desta pregunta. Don Luis Barba dixo / que la saue como en ella se contiene porque ansí lo vio ser y pasar / como la pregunta lo dize. A las docientas y setenta y quatro / preguntas don Luis Barba dixo que la saue como en ella se contie / ne porque ansí lo vio ser y pasar como la pregunta lo dize. Fray Juan Bautista dixo que la saue como en ella se contiene por / que este testigo lo oyó de la boca del dicho licenciado hablando muchas vezes / sobre las dichas hordenanzas con caualleros faboreciendo y jus / tificando las dichas hordenanzas y estas palabras dixo después / que dexó el cargo e sienpre faboreció el mandamiento de su Magestad y es / to es público en aquella tierra. A las docientas y setenta y siete / preguntas don Luis Barba dixo que la saue como en ella se contiene //

/ 104 r. / porque este testigo le vido enbiar al dicho Serna y le vido como le habló / el dicho Vaca de Castro al dicho Serna y le dio ciertas cartas para el virey / en las quales se contenían lo contenido en esta pregunta e que esto vido / e fue muy público e notorio. Luis de Carrizales dixo que la save / como en ella se contiene porque este testigo se halló presente a todo ello / y fue público y notorio. Martín de Sancho Hernández dixo que save la / pregunta como en ella se contiene, preguntado como la saue dixo / que porque este testigo vio quel dicho licenciado Vaca de Castro en sabiendo que he / ra desenbarcado en Tunbez Blasco Núñez luego le ynbió a Gerónimo de / la Serna su 
mayordomo y este testigo lo vio yr de parte de Vaca de Castro con el / recaudo que la pregunta dize y le vio bolber y por esto lo saue. A / las docientas y setenta e ocho preguntas Luis de Carrizales dixo / que la saue con en ella se contiene porque este testigo se halló presente / a lo contenido en la pregunta. Alonso de Argüello dixo que lo que de / lla saue es que este dicho licenciado escribió al cavildo del Cuzco la carta con / tenida en la dicha pregunta y questo que lo saue porque lo vio y la lle / vó este testigo y la dio al dicho García de Montalvo theniente y luego / se juntaron en cabildo y la leyeron e trataron de poner por obra / de enbiar los dichos mensajeros. A las dozientas y ochenta e dos / preguntas don Luis Barba dixo que lo que este testigo de esta pregunta saue es / que este testigo vido estando en la ciudad de Lima con el dicho licenciado Vaca / de Castro que todos los vecinos de la ciudad de Lima y el cabildo / della fueron a tomar consejo con el dicho Vaca de Castro so / bre si recibirían al visorrey o no porque todos querían supli / car de las hordenanzas y no consentir que las cumpliese ni exe / cutase e que se lo querían salir a defender con gente armada y el / dicho Vaca de Castro como los vido con la dicha opinión les aconse / jó y persuadió y mandó que no se pusiesen en el dicho propósito / que dello tenían porque dello su Magestad no sería seruido y resulta / rían grandes daños a la tierra y gente della e habló allí al licenciado / Niño que hera procurador de la dicha ciudad y al licenciado León que hera acessor [?] / en la dicha ciudad y les dixo que aconsejasen a la dicha ciudad que no se / pusiesen en lo susodicho porque resultarían los dichos yncon / vinientes y daños que dichos tiene e por [tachado: que] razón de lo quel dicho / licenciado Vaca de Castro les dixo y mandó los susodichos se a //

/ 104 v. / placaron e no pusieron por obra lo que tenían en propósito y luego / el dicho licenciado Vaca de Castro por remediar los dichos ynconbinientes / y porque el dicho virrey Blasco Núñez fuese apoderado en la tierra e / la gente della no fuese parte para le enojar scriuió luego al dicho virrey / Blasco Núñez diziéndole que se diese priesa a venir a la dicha ciudad / de Lima porque era cosa que convenía al servicio de su magestad y a la execución de su / real justicia e < luego > dende a quatro o cinco días después que fue es / crita la dicha carta por el dicho licenciado vino el dicho virrey a la dicha ciudad / de Lima donde por las causas e razones que el dicho licenciado Vaca / de Castro avía dicho a la dicha ciudad fue reciuido el dicho virrey por la / dicha ciudad y vezinos della quieta e pacíficamente con regocijo y sin alteración / alguna e questo saue y vido desta pregunta. García de Contreras dixo que / saue y vido este testigo que la ciudad de los Reyes estaua alborotada / e determinados a no salir a reciuir al dicho Blasco Núñez Vela / sy no admitiese la suplicación de las hordenanzas y sobreseyese / la execución hasta que su magestad proveyese lo que fuese servido y quel / dicho licenciado Vaca de Castro vido que lo apaciguó y tubo artes y / mañas como saliesen a reciuir al dicho Blasco Núñez y este testigo vido / como salió toda la ciudad a le reciuir y le metieron con palio el qual / llevaban los oficiales de su magestad. Fray Juan Bautista dixo / que lo que saue desta pregunta es que vido como en la ciudad de los / Reyes tenían hordenado de hazerle al dicho Blasco Núñez ciertos / requerimientos y para ello yva el licenciado Rodrigo Niño procurador de la ciudad de los / Reyes y este testigo vido los dichos requerimientos los quales hizo el licenciado / Martel y los leyó allí este testigo e que después el dicho licenciado Vaca de Cas / tro habló a muchos vezinos de la dicha ciudad y les dio manera como se / recibiese el dicho Blasco Núñez por gobernador e virrey sin contradición / e ansí vido que se hizo en la dicha ciudad porque fue notorio y lo vido / e lo demás desta pregunta no lo saue. A las docientas y noventa / e tres preguntas Alonso de Arguello dixo que vio quel dicho Gonzalo / Pizarro puso capitán y arcabuceros en el nabío donde estaua / el dicho licenciado para que le guardasen e que lo demás contenido / en la dicha pregunta que lo cree y tiene por cierto este testigo porque mu / chos amigos del dicho 
licenciado le dezían que aunque fuese nadando / se saliese de aquel navío porque su vida no estaba segura / que esto saue e cree de esta pregunta. Martín de Sancho Hernández / dixo que estando el dicho licenciado en el puerto de Lima antes que llegase //

/ 105 r. / Gonzalo Pizarro a la dicha ciudad enbió capitán e arcabuzeros que guardasen al dicho Vaca de Castro en el navío donde estaua y lo que / se creya y este testigo tiene por cierto fue que lo querían matar e ansy / lo hiziera sino que se alzó con el navío e dexó a Pizarro la mar / sin navío y en alzándose avía muy gran estruendo en Lima y mandava / Pizarro salir gente de a cauallo e arcabuzeros a la mar y este día / a la noche dio tormento Pizarro a dos criados de Vaca de Castro di / siendo que ellos sabían aquel secreto y se avía de bolber a la tierra / e avía un ruydo muy grande y esto oyó este testigo. A las docientas / e noventa e quatro preguntas Alonso Melen [dez] dixo que este testigo oyó / dezir ansí al doctor Texeda quel dicho licenciado Vaca de Castro no auía que / rido dar parecer para que se recibiese por gobernador el dicho Gonzalo Pi / zarro sino que antes le avía puesto el dicho licenciado Vaca de Castro cier / to exenplo para que no se hiziese el qual aunque el dicho doctor / lo dixo a este testigo no se acuerda del ni de otra cosa desta pregunta. / Alonso de Arguello dixo que lo que desta pregunta saue es que es / tando este testigo con el dicho licenciado en el dicho navío e después de llegado / a media legua de Lima el dicho Gonzalo Pizarro fue al puerto el doc / tor Texada y de tierra enbió a dezir al dicho licenciado que viniese / a le hablar y que luego como lo supo dixo este testigo que creya quel dicho / doctor venía a pedirle parecer para lo contenido en la dicha pre / gunta e que si a esto venía no auía de dar tal parecer aunque / le matasen ni hazer tal deservicio a su magestad y quel dicho licenciado saltó / en tierra y se andubo solo con el dicho Texada un buen rato e des / pués de despedido el dicho licenciado dixo a este testigo que lo que antes / le auía dicho hera lo que quería el dicho Texada y que él le auía res / pondido quél no daría tal parecer y otras cosas cerca desto que al ser / vicio de su magestad cumplía que a este testigo no se le acuerda al presente y que / otro día bio este testigo después que recibieron por gobernador en Lima al dicho / Gonzalo Pizarro o el mismo día que le recibieron no se acuerda qual / destos fue vino un scriuano al dicho navío a lo contenido en la dicha / pregunta y tanpoco el dicho licenciado quiso dar el dicho parecer y / que esto vido e saue de la dicha pregunta. A las docientas y noven / ta e seis preguntas fray Juan Bautista dixo que lo que saue de / esta pregunta es que vido llevar artillería e aparejos para ar / tillar el dicho navío donde estaua preso el dicho licenciado y gente e / marinos a él para el hefeto que la pregunta dize e saue que no //

/ 105 v. / avía más de aquel navío en la ribera y que saue quel dicho licenciado / se hizo a la vela con el dicho navío para venirse a Panamá e que en / hazello se puso a peligro de la vida en ello porque si le asieran los sol / dados de Gonzalo Pizarro pudiera ser que alguno dellos se desbergonzara a / lo matar. Martín de Sancho Hernández dixo que dize lo que dicho tiene en la / pregunta antes dicha e que fue hecho de servidor lo que Vaca de / Castro hizo en salirse con el navío e dexar a Pizarro sin él e que se de / zía que Pizarro le temía acá a Vaca de Castro porque avía de bol / ver a ganar la tierra al rey que esto dize a esta pregunta. Alonso de Ar / guello dixo que la saue como en ella se contiene porque este testigo lo vido y se halló presente quando pasó lo contenido en dicha / pregunta en el dicho navío con el dicho licenciado. A las docientas y / noventa e ocho preguntas Diego de Hontiberos dixo que lo que desta / pregunta saue es que quando el dicho licenciado Vaca de Castro llegó a la ciu / dad de Panamá a lo contenido en la dicha pregunta vido este testigo / como hizo juntar a todos los regidores y él con ellos juntos en / traron en cabildo porque este testigo se halló al dicho tienpo en / la dicha ciudad de Panamá pero lo que en el dicho 
cabildo acor / daron este testigo no lo saue. El canónigo Vidal dixo que saue la pre / gunta como en ella se contiene porque al tiempo quel dicho / licenciado Vaca de Castro llegó a Panamá que venía de veni / da para España este testigo estaua en la dicha ciudad de Panamá / e vido quel dicho licenciado dio quenta al cabildo y oficiales / de la dicha ciudad de Panamá de lo que pasaua e que se dezía que / el dicho Gonzalo Pizarro avía de enbiar gente a ocupar la / dicha ciudad e después subcedió estando este testigo en la dicha / ciudad que enbió a la dicha ciudad el dicho Gonzalo Pizarro un / capitán a manera de paz e hizo cierta gente e después de / hecha comenzó a hazer molestias en la dicha ciudad de ma / nera que la justicia ni nadie no se lo pudo defender e que el / dicho Vaca de Castro dexó a la dicha ciudad y para defensa della / el navío en que vino con los tiros y todo lo demás e que o / yó dezir este testigo a la sazón a personas de quien no tiene no / ticia que avía enbiado a avisar de los susodichos al cabildo / e oficiales del Nombre de Dios e que estas dichas cosas e / otras que el dicho licenciado hazía e hizo hera todo a buen / fin e propósito como leal servidor de su magestad. //

/ 106 r. / A las docientos noventa e nuebe preguntas Diego de Hontiberos dixo / que lo que desta pregunta saue es que estando este testigo en la ciudad / de Panamá por el tiempo contenido en esta pregunta llegó a la dicha / ciudad de Panamá el dicho Hernando Vachicao capitán del / dicho Gonzalo Pizarro el qual venía por mandado de el / dicho Gonzalo Pizarro a prender o matar al dicho licenciado Va / ca de Castro el qual hera ya partido e estaua en el Nombre de / Dios que se avía ydo por alguna sospecha que de lo susodicho / tenía e tiene este testigo por cierto que si allí lo hallara lo / maltratara. Francisco de Torres dixo que saue este testigo quel dicho / Gonzalo Pizarro enbió a Vachicao en un navío a Panamá pero / que no saue para qué y que esto saue porque lo vido. Cristóbal de $\mathrm{Ba} /$ rrientos dixo que este testigo vido en la ciudad de Panamá a Va / chicao, capitán de Hernando [sic] Pizarro pedir al cabildo e ynportunalles / que le diesen al dicho licenciado e haziéndoles muchas amenazas por / que no se lo dauan. A las trecientas preguntas Alonso de Arguello di / xo que lo que della saue que estando los navíos en el dicho puerto / de Guarua los soldados que avían sido en la prisión del Virrey / saquearon lo que el dicho licenciado tenía en el navío en que avía venido / desde Lima hasta allí e de oro y plata salvó una taza y unos / saleros e un tenedorcillo de plata y que esto le parece a este testigo que / lo rescató y se lo pagaron después en Lima a los que se lo dieron / e después que llegó al puerto de Lima en el navío visto que no tenía / platos en que comer le llevó este testigo al navío ciertos platonzillos / de plata e escudillas y otras cosillas de servicio y que no sacó / más barra de oro ni plata consigo en el dicho navío del Perú e / que si lo sacara este testigo lo viera e supiera por venir / con él e ver todo lo que él traxo en sus caxas e fuera dellas / e questo saue desta pregunta. Fray Juan Bautista dixo que / lo que saue desta pregunta es que los soldados que fueron al / puerto de Guarua saquearon todo lo que avía en el navío del dicho / licenciado y que esto fue notorio e que lo demás desta pregun / ta ansí lo oyó dezir / a sus criados que allá quedaron. A la tercera pregunta aña / dida Alonso de Arguello dixo que bio que estando el dicho Vaca //

/ 106 v. / de Castro en el puerto de Guarua a la sazón que traxeron allí / al dicho Blasco Núñez Vela para lo enbarcar e hechar de la / tierra antes que lo enbarcasen le dixo el dicho Blasco Núñez / al dicho licenciado en presencia de este testigo e de otras personas / e con juramento que hizo dixo al dicho Vaca de Castro / que le perdonasen que no le tenía culpa en lo que con él / se avía hecho así en lo de la prisión como en lo demás / porque los oydores avían sido la causa dello e quellos se / lo avían hecho hazer y esto saue e que lo demás contenido / en la pregunta se refiere a lo que dicho 
tiene en las pregun / tas antes desta del ynterrogatorio primero e que esto / saue deste caso y es la verdad e parece que después de / pasado el término probatorio por parte del dicho / licenciado Vaca de Castro fue pedida publicación de / testigos e que se denegase al dicho fiscal cierta pro / rrogación que pedía. Y visto por los del dicho nuestro / Consejo juntamente con lo que contra ello fue dicho e a / legado por el dicho nuestro fiscal dieron dos autos en / vista e en grado de revista en que en efecto mandaron / hazer publicación de las probanzas en el dicho pley / to hechas sin embargo de la prorrogación del tér / mino pedida e demandada por el dicho fiscal e / que las probanzas que presentase el dicho fis / cal en el dicho pleito hasta la sentencia difinitiba / se viesen juntamente con el dicho proceso e le / fuesen ávidas por traydas e presentadas / en tiempo e en forma e parece por el / dicho nuestro fiscal se presentaron después / de los dichos autos otras probanzas por su / parte hechas una dentro del dicho término / provatorio dixeron e alegaron de su / derecho e el dicho pleito fue avido por / concluso. E estando el dicho //

/ 107 r. / licenciado Vaca de Castro presentó dos acusaciones quel fiscal / de su magestad del Perú puso contra don Diego de Almagro y sus se / cazes e ciertas < cartas > mesibas del dicho don Diego de Almagro y de / sus capitanes para el dicho licenciado Vaca de Castro y otras del / dicho Vaca de Castro para el dicho don Diego y para los dichos sus ca / pitanes y una carta de seguro dada por el dicho licenciado Vaca de / Castro para los susodichos y una fe de los scriuanos de lo que pasó / el día de la vatalla y un parlamento que hizo el dicho don Diego a / los dichos sus capitanes y secazes del tenor siguiente: En el valle / de Xauxa deste reyno de la Nueba Castilla provincia del / Perú diez e seis días del mes de agosto año del nacimiento / de Nuestro Salvador Ihesus Christo de mil e quinientos y quarenta y dos años / antel Ilustre señor el licenciado Cristóval Vaca de Castro cauallero de la / horden de Santiago y del Consejo Real de su magestad gobernador y capitán / general en estos reynos de la Nueva Castilla y Nuebo Toledo por el / enperador nuestro señor en presencia de mí Pero López escriuano de su magestad / e de la audiencia y juzgado de su señoría en los dichos Reynos pare / ció presente el licenciado García de León fiscal de su magestad y presentó / el escripto siguiente: Ylustre y muy magnífico señor el licenciado García de León / promutor fiscal de la justicia por su magestad y como uno del pueblo / como mexor puedo y aya lugar de derecho denuncio y acuso criminal / mente ante vuestra señoría a don Diego de Almagro hijo del adelan / tado don Diego de Almagro ya difunto y a Juan de Herrada y Alon / so de Porras y a Diego Flores y a Pedro de Sanmillán y a Juan Rodríguez Ba / rragán y a Gerónimo de Almagro y Antón de Almagro y a Francisco / de la Fuente y a Juan de Guzmán y a Bartolomé de Arbolanche e / a Coronedo y a Martín Begaso y a Martín de Bilbao e a Francisco / Núñez e a Cabezas y Santiago de Pontejos comendador de / San Juan e a Sosa cavallerizo del marqués y a Baltasar / Gómez e a Narbaez difunto e a Domingo Ruiz de Du / rango clérigo e a Ramirillo de Baldes e a García de / Albarado e a Francisco de Chabes difunto e a / García Ramírez e a Pedro de Mendoza e a Fran / cisco Pérez e a Martín Carrillo e a Velázquez / e a Herencia e a Diego de Mella e a Alonso de Saabedra //

/ 107 v. / e a Juan Muñoz, el capitán, e a Muñoz el cantor e a / Diego Méndez e a Martel e al bachiller Enríquez ya de / funto y a Juan Tello e a Pero López de Ayala y a Juan de Ma / zariegos y Antón de Ribera y a Pero Barba e a Loaysa e / a Poblete e Sevillano e Alonso Valles e Cansino e / Andrés Hernández e a su hermano e a Pereyra e a Pantoja / e Navarro el de la pedrada y Santiago el de la cuchi / llada en el pescuezo y a Cristóval de Sotelo e a Rengifo e a / don Baltasar Peraza e a Coronado el manco y a Cristóval Ca / rrillo e a los dos hermanos Francisco de Verrío e Juan / de 
Verrío e a Diego de Hozes e a Juan Gutiérrez Mala / ver e a Marchena y a Picón y a Bielma e a Rocha e a / Francisco López e Alonso García Zamarrilla y a Pineda / paje del adelantado e a Juan Vázquez de Osuna e a / Pantoja huesped de Hordoñez e a Hordoñez y a Piña e / a Lugones difunto e a Cornejo y a Quadra criado de Die / go Méndez difunto y a Pedro Riquelme e a Ribe / ra difunto y a Peralta y a Pedro de Oñate y a Pedro / de Candia y Antón Pérez, herrero, y Antón de Agüero / e a Reynaga e a Juan Sánchez Copin e a Juan de / Almagro y a Martín de Oribe y a Francisco Núñez de / las piernas gordas e a Vela, jugador, y Carreño, por / tugués, e a Rodrigo Martínez e a su hermano e a / Aguirre el tuerto e a Juanes, sastre, e a Xuarez e a / Moriana e a Ramírez e a Salzedo e a Juan Balsa e / Diego Pérez e a Criado e Andrés Hernández e a Enri / quez e a Segura, criado de Ramírez, e a Cárdenas / e a Marticote e a otro Moriana e a Juan Gómez e / Albornoz e Antón de León e a todos los demás que / se hallaron y parecieron culpados en los delitos cri / mines de que adelante se hará mynción e digo que / un día del mes de junio y los demás días del dicho mes / y en los días de todos los meses siguientes del año / próximo pasado de quinientos e quarenta e un / años en los días del todos los meses del año presente //

/ 108 r. / fasta oy día reynando en estos reynos la sacra cesárea cathólica magestad del enperador rey don Car / los nuestro señor etcétera premisas las otras solenidades / de derecho los susodichos reos por mi acusados pos / puesto el temor de Dios y el servicio de su magestad e / en desacato de su justicia real con ánimos diabólicos e / ynfernales abiendo primero mucho tienpo antes entre / sí acordado, consultado e determinado ni más ni menos / que adelante lo hicieron, cometieron y perpetuaron conti / nuando y perpetuando los delitos siguientes primeramen / te en la ciudad de los Reyes se juntaron todos los susodichos / por mi acusados, unánimes y conformes para lo que hizie / ron e concertaron entre sy como por la obra lo pusieron de / matar al marqués don Francisco Pizarro gobernador destos / reynos e adelantado mayor en ellos e a Francisco Mar / tín su hermano y al capitán Francisco de Chabes y a todos los / que con el dicho gobernador hallasen y a qualesquier que / se lo defendiesen y a muchos vezinos de la dicha ciudad / e de alzarse después con estos reinos e de matar / a todos los que se lo ynpidiesen y estorbasen e / ansimismo de hazer e cometer todos los delitos crí / menes que de ynfra se hará minción y ansí deter / minado e concertado lo pusieron por la obra en / veinte y seys días del mes de junio un domingo en / medio del día aviendo puesto primero por espías / al dicho Domingo Ruiz e al dicho Ramirillo de Baldes / los quales los avisaron quando el dicho marqués / e los que con él estauan, estauan más descuydados e / sin pensamiento de la dicha trayción siendo avisados / de los susodichos Domingo Ruiz e Ramirillo que aquel / hera el tienpo conbenible para lo que avían de / terminado de hazer por estar como estaua el dicho / marqués tan descuydado se puso a una bentana / de las casas de su morada del dicho don Diego de Almagro //

/ 108 v. / el dicho Juan Sánchez Copin porque de allí se podía bien / ver de las demás casas de do salieron los susodichos de / linquentes e hizo como entre ellos estaua concertado una / señal con un paño blanco y luego salieron de las dichas casas / del dicho don Diego de Almagro e desde a poco de las del dicho / García de Albarado e de casa de Diego Martínez de Mercado e / de casa de Juan Alonso de Badajoz e de casa de Alonso Díaz / e de las casas de Hordoñez mercader e de las casas do / moraba el dicho Diego Méndez e de la casa de Montenegro e / de otras casas de la dicha ciudad todos los susodichos ar / mados de muchas armas ofensibas e defensibas ar / cabuzes e vallestas armadas, lanzas e a / labardas, espadas, cotas, coracinas, adargas e rodelas e / otros muchos géneros de armas y muchos de los suso / dichos ansí armados a cauallo e dándose fabor e ayuda / los unos a 
los otros y los otros a los otros y fueron / a las casas do bibía el dicho marqués y las quebranta / ron dentro el dicho Juan Derrada y Martín de Bilbao / e Martín de Laso y Juan Rodríguez Barragán e Picón / e Juan de Guzmán y Antón de Almagro e Gerónimo de / Almagro y Narbaez y Porras y Francisco de la Fuen / te y Santiago de Contreras y Pedro de Sanmillán e / Bartolomé de Arbolancha y Francisco Coronado e / Sosa el cauallerizo del marqués y Valtasar Gómez e / Juan Diente y Navarro el de la pedrada y Enríquez / y García Ramírez y a la entrada de la sala del dicho mar / qués llevando sus espadas desenbaynadas en las / manos y las demás armas susodichas no les hazien / do ni diziendo el dicho capitán Francisco de Cha / ves cosa de que mal ni daño debiesen de recebir antes / saliendo a ellos a salua fee diziéndoles qués esto / señores qué alteración es esta cata que os perdéys / en llegando a ellos a trayción por detrás le dieron tres / estocadas de que le pasaron el cuerpo de parte a //

/ 109 r. / parte aviéndole dado primero una cuchillada en la / cabeza de que le aturdieron e otras muchas cuchilladas / de que le cortaron cuero e carne de que le salió tanta san / gre que luego murió naturalmente y luego yncontinente / ni más ni menos dieron tantas cuchilladas y estocadas / e lanzadas a Francisco Mendo y a Pedro sus criados que / tras él yvan que les cortaron cuero e carne y les salió / tanta sangre que luego murieron naturalmente de / las dichas heridas y prosiguiendo su dañado e comenzado / propósito entraron más dentro en la cámara del re / traymiento donde estaua el dicho marqués salvo e / seguro sin hazer ni decir cosa porque mal ni daño obiese / de reciuir y todos juntos arremetieron a la cámara del / dicho retraimiento y la quebrantaron y por fuerza en / traron dentro y los unos asieron por los brazos e / piernas al dicho marqués y los otros arremetieron a él / y le dieron tantas cuchilladas y lanzadas y puñaladas / e estocadas que le pasaron el cuerpo por muchas par / tes y le cortaron cuero e carne y le salió tanta sangre / que luego murió naturalmente e al tienpo que el dicho / gobernador cayó en el suelo y quería espirar teniendo / una cruz que hizo con la mano puesta en la voca pidien / do confisión de sus pecados, el dicho Juan Rodríguez / Barragán como crudelísimo e ynfernal traydor a / viendo sido criado y mayordomo del dicho marqués / le dio en la boca y rostro sobre la dicha cruz con una / alcarraza llena de agua que tomó y se la quebrantó / enzima diziendo al ynfierno al ynfierno os / yreys a confesar del qual golpe ansí por ser gran / de la dicha alcarraza como con mucha fuerza dado como / por la mucha agua que dentro tenía el dicho marqués lue / go acauó de espirar después de lo qual ni más ni menos / que al dicho marqués arremetieron al dicho Francisco / Martín de Alcántara e abiéndole dado algunas heridas //

/ 109 v. / primero le dieron tantas cuchilladas, estocadas y lanzadas / de que le pasaron e cortaron todo el cuerpo e rostro y cabeza / e le salió tanta sangre que luego murió naturalmente / e ni más ni menos arremetieron a Juan de Bargas hijo / de Gómez de Tordoya e a García Descandón e Francis / co Gaytán que allí estauan a los quales dieron tantas / cuchilladas y lanzadas y estocadas e otras heridas / mortales por todos los cuerpos e cabezas de los qua / les les cortaron cuero e carne y les salió tanta sangre / que luego todos murieron naturalmente e luego arre / metieron a Gonzalo Hernández e a Juan de Ver / gara alguazil y a don Gómez de Luna que allí se ha / llaron a los quales dieron tantas cuchilladas y es / tocadas de que los dichos Vergara e / Gonzalo Hernández quedaron mortalmente heridos / en el suelo e llegaron a punto de muerte de las dichas / heridas creyendo los dichos creminosos e deliquen / tes avellos muerto los dexaron lo qual si no / creyeran los acabaran de matar e antes que a / cabasen de hazer e cometer los dichos delitos estan / do matando al dicho marqués e a los susodichos muer / tos vino al dicho don Diego de Almagro e García de / Albarado 
con muchos de los susodichos delinquen / tes por una parte y el dicho Francisco de Chabes / con otros muchos por otras e defendiendo por / fuerza de armas que ningund vezino ni otra per / sona socorriesen al dicho marqués vinieron a / las dichas sus casas do lo avían muerto los suso / dichos traydores a los quales dieron fabor e ayu / da para acabar de hazer e cometer los dichos delitos / e luego todos juntos dándose fabor e ayuda los / unos a los otros y los otros a los otros saquearon / toda la casa del dicho marqués al qual tomaron e roba / ron e llebaron todo el oro y plata e piedras preciosas //

/ 110 r. / joyas e tapicería e alhajas, cauallos, bestias, esclavos, / e todo lo demás quel dicho marqués tenía y poseya en / la dicha su casa sin dexar cosa alguna en ella que valdría / e podía valer cien mil pesos de oro o más. Yten después / de lo susodicho añadiendo delito a delito y culpa a cul / pa fueron a las casas de la morada del dicho Fran / cisco Martín de Alcántara y ansimismo la saquea / ron e robaron todo el oro e plata, joyas e pie / dras de casa e cauallos e armas y esclavos y todo / lo demás quel dicho Francisco Martín tenía y poseya / lo qual podía valer quinze mil pesos de oro y más. / Yten fueron ansimismo a las casas de Antonio Picado / secretario del dicho marqués y las saquearon y le robaron / e tomaron y llevaron todo el oro y plata y piedras / preciosas esmeraldas, cauallos, mulas y otras bes / tias, ropas de bestir, preseas e joyas e todo lo de / más que el dicho secretario tenía y poseya lo qual / podía valer sesenta mil pesos de oro y más. Y / ten después de lo susodicho añidiendo delito a / delito, culpa a culpa los susodichos criminosos hi / zieron cárcel pribada y prendieron en ella con gran / des y graves prisiones al doctor Juan Blazquez / theniente que a la sazón hera del dicho gobernador e le / quitaron la bara que traya y le privaron de la jure / dición que tenía y exercía y prendieron ansimismo / en la dicha cárcel a Alonso Palomino y a Juan de / Barrios alcaldes que a la sazón heran de la jus / ticia de la ciudad y les quitaron las baras que / trayan e les privaron de la jurisdición que te / nyan y exercían. Yten añadiendo delito a de / lito, culpa a culpa prendieron en la dicha cárcel / a todos los regidores de la dicha ciudad y tenién / dolos ansí presos con temores que les pusieron / e amenazas que les hizieron poniéndoles las espadas //

/ 110 v. / desenbainadas a los pechos les conpelieron por fuerza a / que hiziesen, eligiesen y nonbrasen e recibiesen al dicho / don Diego de Almagro por gobernador destos reynos / sin tener el dicho don Diego de Almagro probisión po / der ni facultad de su magestad pa ello y ansimismo les / conpelieron e forzaron a que recibiesen e tobiesen / al dicho Cristóval de Sotelo por su lugarteniente del dicho don / Diego de Almagro y al dicho Pedro de Oñate por su algua / zil mayor e de toda la gobernación e hirieron e con / pelieron a los dichos regidores que nonbrasen y eligie / sen por alcaldes hordinarios de la dicha ciudad a / los dichos Martín Carrillo y Francisco Pérez los qua / les dichos don Diego de Almagro e su theniente y Cristó / val de Sotelo e los dichos alcaldes y el dicho su al / guazil mayor usaron de la dicha juresdición tiránica / mente en la dicha ciudad por tienpo y espacio de / siete meses poco más o menos sin el dicho poder co / misión e facultad de su magestad ni más ni me / nos como si la tobieran haziendo muchos agrabios / a muchas personas diziendo muchas ynjurias / berbales e autuales y a otros muchos matando e / atormentando y afrontando, quitando, despo / seyendo ynjustamente de sus yndios e hazien / das a otras muchas. Yten después de auer tiraniza / do la dicha ciudad y la juresdición della los dichos fa / cinorosos añidiendo delito a delito, culpa a culpa an / dubieron todas las casas de la dicha ciudad e las / quebrantaron y tomaron e robaron por fuerza a / todos los vezinos, estantes e abitantes todas las / armas e cauallos y otras bestias que tenían e po / seyan e usaron dellas contra su voluntad e se las / llevaron que serían 
en cantidad de docientos cauallos / poco más o menos sin las otras bestias que podían / valer cient mil castellanos y las dichas armas e //

/ 111 r. / lo demás veinte mil pesos de oro y más e dexaron los / vezinos de la dicha ciudad sin armas ofensibas e de / fensibas algunas para que pudiesen anparar e de / fender de los naturales de la tierra e de quien los qui / siese matar e ofender. Yten después de muerto el dicho / marqués andubieron buscando al dicho su se / cretario Antonio Picado hasta que le hallaron en / casa del thesorero Alonso Riquelme y allí le prendieron / diziéndole muchas ynjurias y ansí preso le metieron / en una cárcel tenebrosa y le tomaron por fuerza / todas las scripturas suyas e del dicho marqués pú / blicas y pribadas, probisiones e ynstruciones de su / magestad publicas y secretas y teniéndole preso / le dieron grabes e ásperos tormentos hasta que le / hizieron decir lo que ellos quisieron e luego le conde / naron a muerte y la executaron llebándole por las ca / lles públicamente con voz de pregonero hasta la pico / ta y allí le cortaron la cabeza. Yten antes que los / dichos criminosos matasen al dicho marqués al tien / po que determinaron e concertaron de matar jun / tamente a vuestra señoría siendo como es del / Consejo Real de su magestad e biniendo como venía / a poner en justicia esta tierra por poder mejor / alzarse con estos dichos reynos e cometer e per / petrar mas a su salvo las tiranías, trayciones / e delitos que an cometido e que no obiese quien / se los resistiese ni ynpidiese y para efetuar / e cometer esta dicha traición fue el dicho Juan Balsa / con otros treinta de a cauallo los susodichos delin / quentes a la ciudad de Truxillo que hera el camino por / do vuestra señoría avía de venir para que llegando / a la dicha ciudad de Truxillo vuestra señoría lo pu / diese matar y en matándolo enbiasen una posta / que tenían puesta a esta ciudad de los Reyes para //

/ 111 v. / que avisase al dicho Juan Derrada para que él e los / que le mataron matasen al dicho marqués e ansí obiese / efeto su ynorme propósito e yntención y visto / que vuestra señoría se tardaua e ya se andaba sonando / la diabólica trayción que querían cometer antes que / el dicho marqués la supiese y se pudiese remediar / le mataron como dicho es e concertaron e determina / ron ansimismo de yr a buscar a vuestra señoría como / lo pusieron por la obra y matalle como lo hizie / ron si pudieran y para hefetuar lo susodicho en sa / viendo que supieron que vuestra señoría avía apor / tado al puerto de la Buenaventura donde vuestra / señoría aportó con el dicho propósito y mala yn / tención hizieron junta de gente de muchos de los dichos / delinquentes e de otros que conbocaron y llama / ron los quales serían hasta ciento y cinquenta on / bres poco más o menos e hizose e hizieron capi / tán de la dicha gente al dicho García de Albarado e / alcalde mayor al dicho Juan Rodríguez Barragán e / capitán de arcabuceros al dicho Marticote e algua / zil al dicho Velázquez e todos armados a manera de / gente de guerra con cotas e coracinas, adargas e / lanzas y espadas e arcabuzes, vallestas e / otros muchos géneros de armas ofensibas e / defensibas y los más dellos a cauallo se me / tieron secretamente porque vuestra señoría no los sin / tiese por podello tomar seguro y más a su salvo en / el dicho galeón grande y fueron en demanda de la / ciudad de San Miguel do pensaban que ya llegaría / vuestra señoría para efectuar el dicho propósito e / yntención y matar a vuestra señoría por mejor po / der alzarse con estos dichos reynos e hazer / e cometer los delitos e trayciones que an cometi / do y perpetrado e yendo de camino principalmente //

/ 112 r. / a lo que dicho tengo determinaron y concertaron / de hazer como lo hizieron de matar e robar a to / dos los que no fuesen de la dicha opinión e desenbar / caron en el puerto de Santa que es 
en estos dichos rey / nos junto a la dicha ciudad de Truxillo y saltaron en / tierra con las dichas armas y cauallos y viniendo por el / camino real salvos e seguros Alonso de Cabrera e A / lonso de Bozmediano e Antonio de Villegas y Pe / dro Barroso y Francisco de Cárdenas e Antonio de Cá / ceres y otros diez o doze onbres a obedecer e dar / fabor e ayuda a vuestra señoría como gobernador / destos reynos caualleros en sus cauallos sin / hazer ni dezir cosa porque mal ni daño debiesen / reciuir los dichos delinquentes fueron corriendo / tras ellos y los tomaron y prendieron a todos / e los tomaron e robaron por fuerza todo el oro / e plata que trayan que sería en cantidad de diez / mil pesos de oro y más e toda la ropa e joyas / e cauallos que tenían e trayan lo qual podía va / ler quarenta mil pesos de oro y más. Yten tobie / ron y llevaron presos en muy grandes y grabes pri / siones de grillos e cadenas esposas a los susodichos / Alonso de Cabrera e Alonso de Vozmediano a / Villegas e a Barroso y Cáceres en cadenas ansí pre / sos los llevaron a la dicha ciudad de Truxillo y los / metieron en cárceles escuras e grabes con las / dichas prisiones y guardas que les pusieron. Yten al / tienpo que entraron en la dicha ciudad de Truxillo / a uno que los regidores della avían reciuido / por gobernador al dicho don Diego de Almagro por / las cartas y poder que les enbió los susodichos de / linquentes e entrando tomaron todas las calles / de la dicha ciudad alborotándola toda e repartieron / toda la dicha gente por todas las dichas calles e pren / dieron todos los dichos regidores de la dicha ciudad y ansí //

/ 112 v. / presos de nuebo les hizieron que recibiesen por gober / nador al dicho don Diego de Almagro y por su lugarte / niente a [en blanco en el original] de Villafranca. Yten después de lo suso / dicho añidiendo delito a delito, culpa a culpa los / dichos criminosos entraron e quebrantaron todas las / casas de los vezinos e moradores de la dicha ciudad e / los tomaron e robaron e llevaron contra su volun / tad todas las armas e cauallos e otras vestias que / tenían e poseyan que serían quarenta cauallos po / co más o menos que podrían valer quinze mil pesos / de oro y más las dichas armas y las otras bestias / diez mil. Yten añidiendo delito a delito e culpa / a culpa tomaron e robaron a Diego de Mora the / sorero que a la sazón hera de su magestad todo el / oro y plata de sus quintos reales que estaban en / poder del dicho Diego de Mora que podrían ser en can / tidad de onze mil pesos de oro y más. Yten toma / ron y robaron contra la voluntad de sus dueños / mucha cantidad de oro y plata y hazienda de to / dos los difuntos menores e ausentes. Yten / añidiendo delito a delito, culpa a culpa el dicho / García de Albarado y el dicho Juan Rodríguez Barragán / dieron muy grabísimos tormentos al dicho Alonso / de Vozmediano para hazelle decir lo quellos que / rían y porque no lo quería decir se los dieron tan / recios y grabes que el dicho Alonso de Vozmediano / quedó tollido de brazos y piernas que nunca más / los pudo menear hasta que murió. Yten dexaron / preso en la dicha ciudad de Truxillo al dicho Pedro / Varroso e ansí presos como estauan los suso / dichos Alonso de Cabrera e Alonso de Vozmediano e / Villegas e Cáceres en cadenas los metieron en el dicho / galeón con gente de guardia y ansí presos los enbia / ron al puerto de Payta y toda la demás gente / con el dicho capitán García de Albarado y fueron por //

/ 113 r. / tierra en busca de vuestra señoría con el susodicho propó / syto camino de la dicha ciudad de San Miguel do lo pen / saron hallar destruyendo e alborotando toda la tie / rra por donde yban haziendo alzar e rebelar los / caciques e yndios que estauan de paz e robando e / salteando todos los que topauan por los caminos. Yten / llegados que fueron los dichos delinquentes a la dicha ciudad / de San Miguel entraron por fuerza y con mano armada / en la dicha ciudad e hizieron reciuir por gobernador della / al dicho don Diego de Almagro y por su lugarteniente a / Diego de Santiago vezino de la dicha ciudad el qual quiso, / aceptó y usó de la juredición de la dicha ciudad tirá / 
nicamente en nombre del dicho don Diego de Almagro muchos / días como amigo e secaz suyo. Yten los dichos delin / quentes entraron e quebrantaron todas las casas / de la dicha ciudad contra la voluntad de sus dueños y / les tomaron y robaron por fuerza todos los caua / llos e armas e otras bestias que tenían y poseyan / que serían veinte e cinco cauallos e casi otras tan / tas yeguas y mulas y mancarrones los quales / podían valer veinte mil pesos de oro poco más o / menos. Yten tomaron e robaron todo el oro e / plata de difuntos e menores que avían en la dicha / ciudad que sería en cantidad de seis mil pesos de / oro poco más o menos. Yten agrabando los dichos / delitos e haziéndolos más ynormes el dicho Juan Ro / dríguez Barragán e el dicho García de Albarado en / biaron al dicho Velázquez su alguacil e al dicho Sosa / e al dicho Juan del Valle e al dicho Cansino e a / otros muchos de los dichos criminosos para que / truxesen presos a los dichos Alonso de Cabrera e / Alonso de Vozmediano e a Villegas para los matar / como los mataron los quales alguacil y los demás fue / ron al dicho puerto de Payta donde los susodichos estaban //

/ $113 \mathrm{v}$. / presos en el dicho galeón y por fuerza tomaron las / armas e adereços de cauallos que avía en el dicho / puerto e en los navíos que en él estauan e otras / cosas e truxeron a los dichos Alonso de Cabrera e / Vozmediano y Villegas presos a la dicha ciudad de / San Miguel y en llegando el dicho García de Albarado / y el dicho Juan Rodríguez Barragán los condenaron / a pena de muerte y los mandaron e hizieron sacar / en medio de la plaza de la dicha ciudad al pie de la / picota con voz de pregonero delante que los ynfa / maba de alborotadores y traidores y el dicho Velázquez / por mandado de los susodichos Juan Rodríguez Barra / gán y García de Albarado los ahogó e cortó e hizo / cortar las cabezas al pie de la picota que está en la pla / za en medio de la dicha ciudad. Yten los dichos García de / Albarado e Juan Rodríguez Barragán prendieron e / tobieron preso a mí el dicho licenciado con determinación / de matarme en una cárcel graue e escura con gente / de guarda e con muchas prisiones de grillos e cade / nas porque dixe a los regidores de la dicha ciudad / que no podía criar ni hazer ni reciuir gober / nador sin probisión, poder y facultad de su / magestad e que hera mal caso hazer otra co / sa e porque dixe que la jurisdicción del gober / nador pasado quedaua en sus tenientes has / ta que su magestad proveyese y porque a / visaua e aconsejaua a todos que sirbiesen a / su magestad e se apartasen de semejantes deli / tos porque en ello le serbirían mucho a lo qual / susodichos me acomulaban que avía avisado a vuestra / señoría de lo que en la tierra pasaba por lo qual vuestra / señoría no avía benido ni ellos lo avían podido to / mar por lo qual me tubieron para matar y estubieron de / terminados de lo hazer e hizieron proceso contra mí e me //

/ 114 r. / ynfamaron de alborotador e traydor y por poder a / segurar a vuestra señoría no me mataron allí e me traxeron / preso a la ciudad de los Reyes donde estaua el dicho don / Diego de Almagro el qual me matara si no me escapara / e huyera de sus manos. Yten visto que no podían auer / a las manos a vuestra señoría para le matar y efectuar / su dañado propósito y que vuestra señoría no pasaua de la probincia de Quito ansí por esto como por la priesa quel / dicho don Diego de Almagro les daua para que le socorriese / porque los vezinos del Cuzco venían a dar fabor e / ayuda a vuestra señoría para matarlos y estorbarles el / paso y se bolbieron por el camino que avían venido / por tierra destruyendo todas las probincias y pue / blos y por do pasauan forzando e cargando a todos / los naturales de toda la tierra de los robos e hur / tos que avían hecho y truxeron cargados cantidad / de mil yndios quando llegaron a esta ciudad de los / Reyes donde estaua el dicho don Diego de Almagro. Y / ten dieron muy grabes tormentos a Juan de Villa / lobos e a Francisco Rodríguez, criado del licencia / do de la Gama, porque dixesen lo que no avían he / cho y 
lo quellos querían y porque no lo dixeron se / los dieron tan grabes que quedaron tollidos de / las piernas y brazos que no los pudieron menear / ni mandar ni aprobecharse dellos en cosa ninguna. Y / ten que el dicho Francisco de Chabes y el dicho bachiller / Enríquez se querían reduzir al servicio de su ma / gestad y dar fabor e ayuda a vuestra señoría quan / do llegase los mandó prender el dicho don Diego de Al / magro e Juan Derrada y el dicho Cristóval de Sotelo / e los enbiaron a un navío y los mandaron matar / e para ello enbiaron al dicho Juan Balsa e al dicho / Arbolancha para que lo hiziesen con otros muchos //

/ 114 v. / de los dichos delinquentes y el dicho Juan Balsa y el dicho / Arbolancha ahogaron el dicho Francisco de Chabes e / al dicho bachiller Enríquez e les cortaron las cabezas. / Yten añidiendo delito a delito e culpa a culpa al / zaron bandera y estandarte e hizieron junta de gente a / pregonando guerra sin licencia, poder ni facultad de su / magestad alborotando e alterando todos estos rey / nos contra el pro y pacificación dellos con propósito de / oprimir e destryr e matar los vezinos y vasa / llos de su magestad que estaban e moraban en la / ciudad del Cuzco y en los Charcas, Arequipa y Goamanga que / no querían obedecer al dicho don Diego por gobernador / ni ser de su propósito e yntinción e con propósito / de destruir e robar de camino todas las dichas / ciudad y villas y los vezinos dellas como lo an / hecho e hazen. Yten para lo susodicho tomaron / e robaron ansí de los nabíos como de la dicha ciu / dad todos los tiros de bronze que en ella avía. De bronze y hierro y el dicho Pedro de Candia fun / dió otros más para lo susodicho e hizo muy / gran cantidad de pólbora para ellos y la afinó / e concertó y apuntó los dichos tiros y se ensaya / va como lo avían de hazer e los esforzaba / e animaba diciendo déxame a mí que yo les abri / ré los esquadrones a aquellos traidores del Cuzco. / Yten para faborecer, animar, ayudar los susodichos / delinquentes el dicho Antón Pérez herrero hizo fra / gua e apuntó mucha cantidad de arcabuzes / e agora los haze y fragua para ello e dio, daba / e da mucha yndustria, fabor e ayuda a los / susodichos delinquentes para ofender e de / fenderse de vuestra señoría e de su magestad. Yten / antes que se partiesen prendieron con gran //

/ 115 r. / crueldad e ynumanidad a quatro hijos pequeños del / dicho marqués quel mayor dellos podía ser de ocho / años poco más o menos y prendieron ansimismo la / muger del dicho Francisco Martín y los metieron en / un nabío para los enbarcar por la mar adelante don / de no pareciesen con propósito e yntención que mu / riesen y pereciesen en una ysla despoblada donde / los mandauan hechar lo qual oviera hefeto si el / maestre del nabío que los llebaua no obiera mise / ricordia e hiziera lo que le mandauan. Yten el dicho / don Diego de Almagro y el dicho Juan de Herrada e / Cristóval de Sotelo e los demás delinquentes sus a / liados prendieron a Alonso Pérez Desquibel e / a Manjarres e a Ruy López e a don Gómez de Luna / e a Martín de Salas y a Juan Despinosa e a o / tros muchos y los metieron en un nabío que en / biavan [a] Arequipa con propósito y yntención de / los matar lo qual hizieran y efetuaran los su / sodichos si no se alzaran e huyeran con el dicho nabío / en que los avían metido presos. Yten hecha / la dicha junta de gente y alzada la dicha bandera / con el dicho propósito e yntención de matar a los / dichos vezinos del Cuzco, Charcas e Arequipa e / e Guamanga hizieron y nonbraron por capitanes / de la dicha junta de gente de la de cauallo a Gar / cía de Albarado e a Cristóval de Sotelo e a Diego de / Hozes e a Juan Tello e hizieron capitanes de la / ynfantería, arcabuzeros y piqueros a los dichos / Francisco Núñez e Cárdenas y Marticote e de la ar / tillería al dicho Pedro de Candia e hizieron sar / gentos de la dicha gente a los dichos Xuarez e Moriana / e puesta la dicha gente en la dicha horden e de la dicha / manera deduxeron la dicha yntención y ánimo de matar // 
/ 115 v. / a los vezinos del Cuzco que no heran de su propósito e / voluntad e atos tan propincos que si los dichos vezi / nos de la dicha ciudad y villas y su capitán los quales ve / nían a dar fabor e ayuda a vuestra señoría e a hebitar / las dichas tiranías no vinieran por otra parte y camino / los dichos facinerosos los mataran e efetuaran y / executaran la dicha su voluntad e yntención con la / qual yntención siguieron a los dichos vezinos que ve / nían a seruir a su magestad por el dicho camino que ve / nían hasta que vieron que a su salvo e a trayción no / los pudieron aver a las manos con las espías, en / gaños e asechanzas que les tenían puestas por lo qual / los dichos criminosos se bolbieron del dicho camino hazia / la dicha ciudad del Cuzco e las demás villas por do a / vían venido el dicho capitán e la dicha gente en ser / vicio de su magestad e de vuestra señoría e repartieron / la dicha su junta de gente e capitanías por los cami / nos en gran daño e perjuizio de toda la tierra e / de los naturales della y vecinos e a todos quantos / toparon en los dichos caminos los saltearon e ro / baron especialmente el dicho García de Albarado que / yva por los llanos camino de Arequipa robó a /muchas personas, muchos cauallos y armas e oro e / plata e ropa en cantidad de cien mil pesos de oro / e mas todo lo qual repartieron entre la gente que / con él yva e mucha parte della tomó para sí e a / otras muchas personas salteó e robó y pren / dio. Yten el dicho Francisco Pezes con veinte arca / buzeros y vallesteros que consigo llevó fue a la / dicha villa de Arequipa e hizo por fuerza reciuir / por gobernador al dicho don Diego de Almagro e por / su lugarteniente a Juan de la Torre e después tomó / e prendió a Cornejo al qual so grabes penas le mandó//

/ 116 r. / declarar qué bienes tenía de los vecinos que avían ydo / con el capitán Peraluarez Holguín so cuya bandera ve / nyan los dichos seruidores de su magestad diciendo que / por ello heran traidores e los tenían perdidos y porque / el dicho Cornejo no lo quiso dezir lo prendió en una cár / cel grabe y escura y estubo allí cinco días y mandó / que no le diesen de comer ni beber todo el dicho tienpo / diziendo que juraría a Dios que no avía de comer ni / beber hasta que lo aclarase e le diese quatro mil / pesos de oro que tenía el Obispo de Plasencia e / nunca le quiso soltar hasta que le dio dos mil pesos / después de lo qual lo tornó otra vez a prender por / que declarase de quien tenía más dineros y ansí le to / bo preso hasta que le dio tres mil pesos de otras per / zonas que con el dicho Peraluarez Holguín avían be / nido e le hizo jurar en un ara que otros bienes al / gunos ni ningunos no tenía y por esto lo soltó. Yten to / mó e robó él e la dicha gente que consigo llevaua to / dos los cauallos e armas que en la dicha villa a / vía lo qual podía valer ocho mil pesos y más / e hizo otros muchos ynsultos, trayciones e delitos / muy graues. Yten después de ydo el dicho Francisco Pezes vino el dicho García de Albarado con cinquenta / de a cauallo a la dicha villa de Arequipa y en entran / do cabó e haró el monesterio de Santo Domingo do / le dixeron que estaua enterrado el oro e plata de / los dichos vezinos que venían a seruir a su magestad / e sacó, tomó e robó sesenta mil pesos de oro en / oro y plata poco más o menos que en el dicho mo / nesterio estauan enterrados y escondidos. Yten / el dicho García de Albarado prendió a Francisco / de Montenegro y llevándole preso a la ciudad del / Cuzco el dicho Montenegro temiendo la muerte e te / niendo lugar de huyr se bolbió a la dicha villa de //

/ 116v. / Arequipa huyendo e el dicho García de Albarado bolbió / tras él y lo prendió e luego aquella noche lo ahorcó en su / casa e ansí ahorcado e muerto lo sacó por la mañana en / la plaza e lo hizo poner en un palo porque todos lo / viesen. Yten el dicho Diego Méndez con diez o doze de ca / uallo fue a la villa de Plata en los Charcas e hizo / por fuerza que fuese reciuido por su gobernador en ella / el dicho don Diego de Almagro y tomó e robó todas las / armas e cauallos que en ella halló que podían valer / diez mil pesos poco más o menos e de allí fue a las mi / nas de Porco 
y tomó e robó veinte mil marcos de / plata blanca y más. Yten estando vuestra señoría re / ciuido por gobernador por probisión real de su magestad / en la dicha ciudad del Cuzco el dicho Cristóval de Sotelo / fue con mucha gente de la dicha junta de gente a la dicha ciu / dad e tomó las baras que estauan puestas por / vuestra señoría a los alcaldes que a la sazón heran e al / licenciado de la Gama su lugarteniente y ronpió la dicha / provisión real e hizo reciuir por gobernador al / dicho don Diego de Almagro e a él por su lugartheniente la qual juresdición la a usado y exercido y la usa / y exerce fasta oy en día y tiene la dicha bara por el dicho / don Diego de Almagro no reconosciendo ni queriendo / reconocer superioridad a su magestad ni queriéndole / tener por señor natural como son obligados. Yten / los dichos criminosos en las dichas ciudades y villas / que an llegado, an tomado e robado contra la volun / tad de los tesoreros de su magestad todo el oro y plata / de sus quintos e rentas reales que serán en canti / dad de cien mil pesos de oro y más sin lo que arriba / he dicho. Yten an ynpedido que todas las minas de / oro y plata de todas las ciudades e villas / no se labren ni puedan labrar más de lo quellos sa / can para sí en lo qual an hecho perder y pierde su magestad //

/ 117 r. / de lo que podría auer de sus quintos reales can / tidad de más de quinientos mil pesos de oro. Yten hacen perder a todos los señores de las dichas minas / diez tanto de lo susodicho y más todo lo que los suso / dichos les toman e roban e llevan para sí. Yten añi / diendo culpa a culpa e delito a delito no quieren ni / quisieron obedecer las probisiones e cartas reales / de su magestad ni quieren reconocer ni reconocen su / juredición real se alzan e an alzado con su tierra usur / pando su juredición. Yten el dicho don Diego de Almagro y el / dicho Cristóval de Sotelo prendieron en la dicha ciudad del Cuzco / a Pedro del Barco y le tobieron preso porque les / diese los dineros que él tenía y porque no se los quiso / dar ni decir donde los tenía le dieron muy rezios tor / mentos e lo sacaron a la plaza a haorcar e tenién / dole al pie de la horca con la aflición de la muerte di / xo a vozes válgame Dios y el rey y respondieron / los susodichos o todos los más delinquentes por mí a / cusados que allí estauan que no ay otro rey si / no don Diego de Almagro ni aquí no conozemos otro rey si / no él y él a de ser gobernador a pesar del rey en es / ta tierra e de quantos ay en ella e si el dicho Pedro / del Barco no diera los dineros que tenía le ahorcaran. / Yten el dicho Juan Balsa y el dicho don Diego de Al / magro e los demás prendieron en Guamanga a / [en blanco en el original] porque quiso huir dellos y venir a seruir a / su magestad le dieron tan recios y grabes tormentos / que quedó tollido de piernas y brazos e lo ahor / caran si no fuera por muchas personas que le ro / garon e ynportunaron al dicho don Diego de Almagro. / Yten el dicho don Diego de Almagro e los susodichos / sus tenientes e capitanes usurpando la jure / dición real y usando della como de suya propia / an repartido e reparten entre sí las personas que //

/ $117 \mathrm{v}$. / que quieren todos los caciques e yndios de todas las dichas / ciudades y villas y ellos y aquellos a quien los en / comiendan los destruyen e los roban e an robado e / les llevan e an llevado tributos que los dichos yndios / no pueden dar e para sacárselos les an dado e dan gra / vísimos tormentos de los quales an muerto muchos de / llos e oy día los matan por sacárselos. Yten para / hazer e cometer y perpetrar todos los susodichos / delitos de suso memorados luego que mataron al dicho / marqués los dichos criminosos hizieron consulta e con / sejeros della al dicho Cristóval de Sotelo e al dicho Juan / Derrada e Juan Balsa e García de Albarado e Rodrigo / de Salzedo e Antón de León todos los quales teniendo / tiranizadas las dichas ciudades y villas e la juredición / dellas entraban cada día en consulta e pensa / van e consultaban e determinaban primero / en ella los susodichos delitos e otros mayores / e más ynormes y grabes que efetuaran si pu / dieran especialmente consultaron que con los dichos / nabíos que tenían detenidos yr a Panamá e al / 
Nonbre de Dios e robar y matar todos quantos / en las dichas ciudades avían e de su opinión no / fuesen e después tomar los nabíos que obiese / en la mar del norte e yr a dar la obidiencia e va / sallaje que debían a sus majestades al rey de Francia / que a la sazón se sonaba que tenía diferencias con / su magestad e ansimismo consultaron e franc al qual determinaron ansimismo de darle / el señorío de todos los dichos reinos y ser sus vasallos e / quitarlos a su magestad e negarlo y no tenerlo por señor. / Yten para que se executase e obiesen efeto todas las //

/ 118 r. / dichas trayciones e delitos ansí los que cometieron como / los que pensauan cometer pusieron por capitán / general al dicho Juan de Herrada prencipal autor / de todo lo susodicho y matador del dicho marqués el qual / usó de la dicha capitanía e hizo e adrezó toda la dicha / junta de gente con el dicho propósito e yntención. Yten / perpretado e cometido e cometen e perpetran o / tros muchos e ynormes e grabes delitos oy en día / dinos de punición e castigo especialmente en los / susodichos los dichos facinorosos an cometido e co / metieron crimen lege magestatis y son traydores por / averse rebelado e lebantado contra su magestad / e hecho junta de gente contra el pro e pacificación e en / daño de toda esta tierra e de los naturales e ve / zinos della, son reos del mismo crimen por aver pen / sado e determinado de quitar el señorío destos / reynos a su magestad e darlos al rey estraño / e hazerse sus vasallos, son reos del mismo crimen / por aver muerto a trayción al dicho marqués siendo / como hera señor de título gobernador e adelantado / destos reynos por su magestad, son reos ansimis / mo del dicho crimen por aver tenido voluntad deduzida / a acto tan propinco y que no quedó por ellos de matar / a vuestra señoría siendo como es del Consejo Real de / su magestad y gobernador destos reinos por pro / bisión real, son reos ansimismo por auer exer / cido e adbertido de la juredición de las dichas / ciudades e villas sin comisión, poder e facul / tad de su magestad especialmente aviéndola como / la an tiranizado e ynpedido e usurpado, son reos / ansímismo del dicho crimen por auer tomado, roba / do e hurtado los quintos e rentas reales, son reos an / simismo del dicho crimen e an incurrido e caydo en cri / men perduliones por aver alzado bandera y estandarte / contra lo que vuestra señoría trae por su magestad como Ca //

/ 118 v. / pitán general destos Reynos y contra lo que trayan / en nombre de su magestad el dicho capitán e caualleros e / vezinos de la dicha ciudad del Cuzco e las demás villas, / son reos ansimismo del dicho crimen por auer hecho jun / ta de gente e apregonado guerra contra los dichos ca / ualleros e vasallos de su magestad sin licencia al / borotando y alterando toda la tierra y contra el pro e / pacificación della, son ansimismo omicidos matadores / e alebosos por auer muerto los susodichos que mataron / e por aver atormentado los que atormentaron, to / llido y mancado sin proceder culpa ni causa justa, son / robadores e ladrones manifiestos y notorios por lo / que an hurtado, tomado e robado, son salteadores / por los caminos porque an salteado, son reos e cul / pados en todos los delitos y crímenes de suso me / morados e relatados por lo qual los susodichos crí / menes e facionorosos, an caydo e yncurrido, cayeron / e yncurrieron en grandísimas y grabísimas penas / establecidas en derecho contra los semejantes las / quales se deben executar en sus personas e bienes e / por ellas deven ser castigados, punidos y escarmen / tados, por tanto pido e suplico a vuestra señoría que sien / do tanta parte verdadera que baste para fundar / mi yntención condene a los susodichos reos por / mí acusados a las mayores y más grabes penas que / por fuero e por derecho hallare establecidas con / tra los que tales e semejantes delitos cometen las / quales penas vuestra señoría mande executar y execute / en sus personas e bienes declarándolos y dándolos / por traydores públicos y notorios a ellos y a sus hijos / e decendientes declarando ansimismo auer perdido / todos sus bienes desde el día que pensaron y andubieron / en las dichas trayciones ansí los 
que precedieron y so / jure como aquellos de que ay necesidad de oficio de juez / que para ello ynploro y el oficio de vuestra señoría que a //

/ 119 r. / biendo por proscritos todos los dichos bienes y aplicándo / los a la cámara y fisco de su magestad y haciendo car / go dellos a su thesorero e dando e executando en / los susodichos traydores muertes ebiltadas [?] y orrendas se / gún que la ynormidad de los dichos delitos requiere e de / rribando sus casas por el suelo executando en ellos / todas las demás penas porque a ellos sea castigo / e a otros en exenplo y para que aya efeto todo lo / susodicho e se executen las dichas penas en los dichos / crímenes pues que todos los dichos delitos y crímenes / que an cometido y perpetrado son tan notorios por la / ebidencia del hecho que no tienen necesidad de prueba / e los susodichos facionorosos delinquentes están av / sentes en la dicha ciudad del Cuzco y apoderados della con / gran fuerza de la gente de armas que llevaron e otra / que an ayuntado, cometiendo y perpetrando otros ta / les e tan grandes delitos como los que an cometido e / perpetrado e al presente no pueden ser auidos como es / notorio ni es seguro el acesso a ellos para los citar e / llamar por estar como están rebelados e alzados / e a vuestra señoría le consta pido e suplico e si nece / sario es requiero a vuestra señoría las vezes que de / derecho puedo e debo so las protestaciones que con / bienen hazer que hago vuestra señoría haga en todo e / por todo como por mí le es pedido e demandado y pro / ceda contra los susodichos por mí acusados como / contra criminosos e reos de crímenes notorios / pues lo son mandado juntar y llamar e conbocar / toda la gente e armas que se pudiere auer en este / reyno para yr contra ellos y prendellos executan / do las dichas penas en sus personas e bienes y para / obrar y ebitar e resistir los grandes daños e altera / ciones e inquietudes, delitos e alebes y trayciones que / en estos dichos reynos hazen cometen y ponen y ansimis / mo para pacificar estos dichos reynos y reducillos e //

/ 119 v. / bolbellos a su prístino estado e al yugo de su magestad so / bre todo lo qual pido justicia por aquella vía e for / ma que más de derecho lugar aya y protesto las costas o / trosi hago la misma denunciación y acusación contra / todos aquellos que se an juntado antes e después / acá con el dicho don Diego de Almagro e contra todos a / quellos que al tienpo y después de la muerte del marqués / que no salieron en fabor de la justicia de su magestad e / contradezir todos los susodichos e sus ecesos e de / litos como heran obligados por derecho y leyes de / partida y pido contra todos e qualesquier dellos / todo lo susodicho e conplimiento de justicia y en lo / necesario el oficio de vuestra señoría ynploro y ansimis / mo pido e suplico a vuestra señoría que si en algo de / lo susodicho o dependiente dello fuere necesario / alguna solenidad, auto o prueba que vuestra señoría de / su oficio lo haga el qual para ello y para todo lo / demás ynploro en lo necesario y juro a Dios e a / esta cruz + questa acusación no la pongo de mali / cia sino que es cierta y verdadera la qual pongo con / protestación que hago de añadir e acrecentar y men / guar e quitar lo que me pareciere y viere que conbiene / al seruicio de su magestad y a la execución de su jus / ticia y si en ella ay necesidad de ynscrición me yns / cribo y obligo a la pena del talión el licenciado de León. / Estando en este real de su magestad que al presente es / tá asentado junto a la villa de San Juan de la Fron / tera en ocho días del mes de setienbre año del Señor de / mil y quinientos y quarenta e dos años ante el muy ylustre / señor licenciado Vaca de Castro cauallero de la horden de San / tiago del Consejo Real de sus majestades, gobernador e capitán / general en estos reynos y probincias de la Nueva Cas / tilla y Toledo llamado Perú etcétera por sus majestades / y en presencia de mí Francisco Paez escriuano de sus majestades e de / los testigos de yuso scriptos pareció presente el licenciado // 
/ 120 r. / de León promotor fiscal de sus majestades e dixo que ya su se / ñoría sabía y es, hera notorio como después que don Diego de / Almagro y sus secazes mataron al marqués don Francisco $\mathrm{Pi} /$ zarro gobernador destos reynos hizieron junta general e al / zaron bandera contra su magestad e con tiranía y biolencia / an usurpado estos reynos y la justicia de su magestad e hecho / reciuir al dicho don Diego por fuerza de armas por gobernador / en ellos y tomando e robando los quintos reales e ren / tas de su magestad e dineros de difuntos e otros de de / pósitos e saqueado casas e muerto onbres sin culpa e / robando otros en los caminos y continuando su lebantamiento / contra el seruicio de su magestad siendo sus vasallos no / ovedecieron el dicho don Diego ni sus capitanes ni secazes / la prouisión de su magestad que su señoría tenía y tiene de / gobernador destos reynos sabiendo que por ella a / vía sido reciuido por tal en Quito e Piura y en Truxillo / y en la ciudad de los Reyes después que de allí salieron / y estando por ella reciuido en la ciudad del Cuzco antes / quel dicho don Diego y sus secazes llegasen y constándo / les y siendo notorio quitaron al licenciado de la Gama / teniente del dicho señor gobernador e las otras jus / ticias que en su nonbre estaban puestas lebantándo / se con la dicha ciudad contra su magestad e el dicho señor / gobernador en su nonbre y que para mexor se defender / e continuar el dicho su lebantamiento hizieron con / juración en el Cuzco el dicho don Diego y los dichos sus ca / pitanes e con parlamento quel dicho don Diego les / hizo con pregón y en un cadahalso que hizieron pa / ra ello persuadiéndolos a que le jurasen por gober / nador e que le tubiesen por tal y por superior e / le defendiesen contra toda persona hasta morir / por él e ansí lo juraron los capitanes y soldados e / gente de guerra en un altar que tenían puesto para ello / sobre cruz, ara y misal y evangelios y el dicho don Diego / de se lo pagar e repartir con ellos los repartimientos //

/ 120 v. / e provechos destos reynos y hizo y cometió otros / delitos muchos pues en su acusación que demás de ser / notorios, públicos y evidentes en estos reynos los / tienen probados por tales e demás de lo susodicho / hizieron mucha artillería y munición para defender / y executar su voluntad el lebantamiento y para lo / poner en execución el dicho don Diego y sus capitanes e / secazes permaneciendo en las dichas sus tiranías le / bantamiento e trayciones an venido hasta el tanbo de / Vilcas que es deste dicho asiento e real diez leguas como / están con mucho alboroto e juntas de gentes e a / punto de guerra de donde el dicho don Diego y los dichos / capitanes enbiaron cartas firmadas de sus nonbres / al dicho señor gobernador con Lope de Ydiaquez su / mensajero y en los dichos despachos y cartas que es / cribieron parece que todavía quieren perseverar / en su lebantamiento y trayciones e deslealtad con / mucha desbergüenza y poco acatamiento e deseruicio / e menosprecio de su magestad e de su real jus / ticia lo qual ansimismo parece por las cartas que / antes avían traydo el licenciado de la Gama y el ju / rado Gonzalo Fernández sus mensajeros de lo qual / todo que dicho es acusación, probanza e cartas hago / presentación e que demás de lo susodicho queriendo el / dicho señor gobernador usar con el dicho don Diego y sus / capitanes y secazes de benibolencia e piedad / queriéndolos reduzir al seruicio de su magestad por / bien les enbió perdones de la ciudad de los Reyes / e porque más viniese a noticia de todos se fueron / por los tanbos e lugares públicos hasta la ciudad / del Cuzco excebtando a solamente los que fueron / en la muerte del dicho marqués e después de venido / el dicho Lope de Ydiaquez les enbió Alonso García vezino / de Guamanga por ser conoscido dellos e aver perdido //

/ 121 r. / su amistad con cartas al dicho don Diego y a los dichos / sus capitanes y a otros muchos particulares dando a / entender los daños e el lebantamiento en que an / dauan persuadiéndolos para que se viniesen para él / en seruicio de su magestad y les perdonaba y en todo / les haría justicia 
enbiándoles escrituras de perdo / nes para los más conbencer y luego que llegó el / dicho mensajero al dicho tanbo de Bilcas a do estaua el dicho / don Diego y los dichos sus capitanes e secazes le ahorca / ron sin esperar respuesta de las cartas que avía en / viado con el dicho Lope Ydiáquez por do constaba / ebidentemente quel dicho don Diego e los dichos sus ca / pitanes y secazes estar pertinaces en su delito e rebelión / e se debe proceder con brevedad contra ellos hasta los con / denar como tales y tan grabes delitos evidentes / notorios sin guardar orden de derecho ni figura de juicio / e porque proceder contra los susodichos como contra / ausentes y por tan largos términos como disponen / las leyes e derecho de los reynos de su magestad no / a lugar por estar los dichos deliquentes en el dicho tanbo / de Vilcas presentes y por ser sus delitos tan notorios / e ebidentes y permanentes en que no se requiere guar / dar horden de derecho en que se deben pronunciar / sus delitos por notorios y condenarlos en las pe / nas por él pedidas y porque de los dichos sus delitos / e probanzas con esta averse lebantado el dicho don / Diego y los dichos sus capitanes contra su rey en es / te reyno y en tal caso está dispuesto por ley de / la partida que los susodichos que tal lebantamien / to an hecho son traydores ansí por lo que hacen como / porque la dicha ley les obliga a que no sigan al dicho / don Diego y vengan a fauor de su rey a contra de / zir el tal lebantamiento sin ser llamados so pena / de traydores y que cayan la dicha pena quel dicho principal //

/ 121 v. / don Diego deue aver e ansí todos los susodichos an cay / do en la pena de la dicha ley por ende dixo que pedía e / pidió al dicho señor gobernador declare el dicho don Diego / e los dichos sus capitanes aver cometido los susodi / chos delitos y por notorios como los son e aver he / cho el dicho lebantamiento e perseberar en él declara / do a todos los susodichos aver caydo e yncurrido en / las penas de la dicha ley e de las otras de los reynos / de su magestad condenándoles en las penas esta / blezidas en las dichas leyes mandándolas executar / contra sus personas e bienes como contra rebel / des y verdaderas contumazes y hallados y to / mados en el ynfragante delito susodicho e deli / tos e ser públicos y notorios sin más amones / taciones pues lo qual consta y es notorio por es / tar como están con tanta gente de guerra e auer pre / so a Gómez de Rojas mensajero del dicho señor gober / nador en el Cuzco y en el tanbo de Vilcas ahorcado / al dicho mensajero Alonso García pues esto les haze / ser auidos por presentes para la declaración e con / denación susodicha y luego sin otra dilación ni auto / ni apercebimiento proceda contra los susodichos / a execución de las dichas penas con todo rigor po / derosamente pues la calidad de los dichos negocios e / de los delitos que los susodichos an cometido e la des / lealtad e desberguenza en que permanecen no da lugar / a otra cosa e ansí conbiene al seruicio de su magestad y bien público destos sus reynos pues es / notorio los muchos ynconbinientes e daños e des / trymientos destos reynos que de no lo hazer podría / subzeder en tan gran deseruicio de su magestad e da / ño destos reynos lo qual dixo que pedía en la mijor / forma que podía e de derecho debía con todas las / ynstancias y protestaciones necesarias dixo que de nuebo //

/ 122 r. / acusaua criminalmente como mexor podía al dicho don / Diego y a los dichos sus capitanes y secazes declarados en / la dicha su acusación e ynterrogatorio y probanzas de / los dichos delitos y lebantamiento e espresados en es / te dicho pedimento que en él son contenidos y declarados / en la dicha su acusación con las solenidades que de derecho / hera obligado e sobre todo pidió serle hecho entero con / plimiento de justicia e ynploró el ylustre oficio del / dicho señor gobernador siendo presentes por testigos / Diego Maldonado e Gómez de Tordoya y García de Mon / talbo e Alonso de Origuela e Diego de Balmaceda cria / dos del dicho señor gobernador, el licenciado León. El te / nor de las dichas cartas quel dicho Lope de Ydiaquez tra / xo son las 
siguientes y van primero los sobrescritos / de cada una: Al muy magnífico señor licenciado Va / ca de Castro, Presidente de Panamá e del Consejo de su Magestad, muy magnífico señor a me alterado en tanta ma / nera la nueba que he oydo que a no firmármela per / sona de vista no la pudiera ymaginar que vuestra merced / viniendo por ministro de su magestad a poner paz e / justicia en esta su tierra se faborece de los que la / an alborotado cosa nunca oyda ni dina en verdad de / ser creyda de una tanta persona y tan calificada pues / por concurrir en ella la que faltaua en otras muchas e / de mucho tomo segund por acá se a publicado fue he / lexida la de vuestra merced para la presidencia de Pana / má y para enmendar agrabios y paréceme da calor a / los que Pizarros cometieron en daño de mi padre pues sien / do ellos los que en estas partes los senbraron biene vuestra / merced no a desarraigarlos pero a que no se pierda la simiente / pues con los que hasta aquí an ayudado a sustentar / los se a vuestra merced conjurado contra mí e contra los que / me ayudan a defender causa tan justificada y mer / ced tan benemérita y como su magestad hizo a mi padre //

/ 122 v. / desta gobernación del Nuebo Toledo pues tan señalados ser / vicios y por ellos fue seruido gozase yo della después / de sus días como príncipe muy agradescido con el licen / ciado Antonio de la Gama y jurado Gonzalo Hernández / que tengo por nueva cierta están día ha con vuestra merced / escreuí en su crehencia y llevaron cierta ynstrución / mía y capítulos para platicarlos con vuestra merced e / por no ser cierto si la mala voluntad de los que aconpa / ñan a vuestra merced abrá sido alguna parte para que mis / justificaciones no sean oydas ni dado lugar a que las / digan de la mía a vuestra mercd los mensajeros llevan a / gora los mismos Lope de Ydiaquez que movido solo por / el celo que tiene al seruicio de su magestad condolién / dose de los grandes trauajos y muertes que resciben / los yndios reconociendo el gran daño que podría sub / ceder en esta su tierra y si vuestra merced persebera en el / propósito que me an certificado trae y por estar libre / de pasión como lo sauen bien todos los que lo conocen / a determinado tomar este trauaxo sin podérselo / yo escusar por ser muy peligroso en la coyuntura que / a él se ofrece por estar los yndios de la tierra de / guerra y no perdonar la vida a ningún cristiano e / dizen ellos y lo certifican que por mandado de vuestra / merced y que ansí lo enbía dezir de parte de vuestra merced / Maldonado a un criado suyo que se dize Juan Depinos / que está en sus pueblos que lo ha de efetuar y Palo / mino y otros vezinos de Guamanga los ynsisten / tanbien a ello y ansia an sido causa de matar ocho o / diez cristianos que algunos dellos se yban a España / a sus casas con lo que tenían y junto con esto les an / tomado sus haziendas y no obstante todos estos / temores se an dispuesto a sacrificar la suya en / pasos tan meritorios él es persona que sabe bien //

/ 123 r. / lo acaescido en estas partes después que se descubrieron / e lo que an cometido en ellas Pizarro y lo que contra mi pa / dre y los que se siguían se a hecho y mi yntención por / que se la he declarado y conoce mi justicia e dará de mi / parte mis justificaciones como quien saue quan jus / tas las tengo para que me sea guardada y por auer enbia / do lo que enbío con los que digo y no tener respuesta de / vuestra merced ni dellos de aquello y esperalla con tanta / voluntad por sauer la que en este caso muebe a vuestra merced / a estar con mis henemigos y porque el portador supli / rá a lo demás diziendo verdad que por ser dotado / de virtud como es puede vuestra merced ser cierto en na / da se apartará del camino della no me alargaré yo / más de lo que aquí diré remitiéndome en todo a su / relación que es que sabiendo la venida de vuestra merced / en mi perjuizio con mano armada con mis henemigos / e por mexor dezir de su magestad estando de la / misma manera no para deseruir a vuestra merced sino pa / ra dalle fabor contra quien no obedeciese sus man / 
damientos como al presente lo haría siendo necesario / teniéndome ser vuestra merced danificado de los que me / parece faboreciese salí del Cuzco para le yr a buscar / llegado él aquí supe lo que digo que no poco me he escan / dalizado por tanto, sepa vuestra merced que yo tengo pro / visión patente de su magestad en que hizo merced desta / gobernación a mi padre y otra para que la tenga la per / sona a quien él la dexase e dexola a mi su hijo como / parece por la cláusula de su testamento que vuestra merced / abrá visto si lo abrá tenido por bien que todo re / caudo lleuaron el licenciado y el jurado y digo que / los que me siguen y yo somos seruidores y vasa / llos de su magestad y por tales nos tenemos y / peleamos vaxo de su ynperial estandarte defendien / do esta merced hasta tanto que su magestad yn //

/ 123 v. / formado de la muerte que dieron tan abatida a mi pa / dre y a muchos de los que le seguían e de los grandes a / grauios que a él e a ellos se les hizieron y como le mata / ron Pizarros por robarle lo que hera suyo para sobor / nar a los que por bien tubieron en menosprecio de su prín / cipe ser particioneros de sus bienes porque no biniesen a / oydos de su magestad, ynsultos tan abominables / enbíe a mandar lo que más conbenga a su seruicio que / en caso que yo sepa que en manera de su voluntad que / no tenga yo esta gobernación en su nonbre la de por / ne [sic] juntamente con las armas y los que conmigo es / tán e yo yremos pecho por tierra sin dilación alguna / a justificarnos ante su cesareo acatamiento y / en caso que vuestra merced no se oviese juntado o se aparta / de mis henemigos sería con el mismo obedecido por / mí y no haziéndolo ansí certifico a vuestra merced quellos / e yo yremos como ymos a defender los límites / desta gobernación y ofenderemos a todos los que nos / lo quisieren usurpar y ansí abierto a vuestra merced / vea el daño que se puede recrecer y lo pisense bien y / el deseruicio tan grande que se haze a Dios y a su ma / gestad y no consienta que los nublados que están / congelados se derramen poniendo en más miseria a / los vasallos de su magestad y naturales desta míse / ra tierra de la que en lo pasado an padecido que / no es pequeña ni que dure la guerra sino que depues / tas las armas se esté vuestra merced en esa goberna / ción de la Nueva Castilla dexándome a mí en esta de / que su magestad me ha hecho merced mandando que los / caminos se abran y los yndios biban en paz y se / sepa la voluntad de su magestad en todo por / que aquella obedeciere yo y esto requiero a vuestra / merced una e dos e tres vezes y quantas de dere / cho puedo e devo de parte de Dios e de su magestad //

/ 124 r. / e que las muertes e daños que se recrecieren en la tie / rra y naturales della que no es poca lástima / verlos y pérdidas de quintos reales por durar vuestra / merced y los que le siguen en esta pertinancia cargue so / bre vuestra merced y sobre ellos y no sobre mí ni sobre los que / me siguen pues con mano armada y con fabor de mis enemigos me biene vuestra merced a matar a mí y a ellos por / defender yo la tierra de su magestad que me dio en / protection no queriendo poner paz pues vino por tal / ministro e no de la guerra y ansí digo que no queriendo / dar corte en estos escándalos se atribuyrá vuestra merced / ser causa dellos y no biniéndome a buscar procuraré / de dilatar esta cosa todo el tienpo que lo pudiere ha / zer e no fuere constriñido a ofender por de / fenderme hasta sauer lo que su magestad fuere / seruido de mandar probeer al despacho que llevó / de mi parte Gerónimo Zurbano que tengo por cierto ser ya / en esta tierra con él e haziendo vuestra merced lo con / trario no me partiré del canpo hasta que una de las / partes quede en él venzida e a Dios suplico me / oya en esto como en lo pasado porque pueda / poner toda la tierra en deboción de su magestad e / restaurando sus quintos e haziendas que tan / robadas an sido en lo pasado e de cada día espe / ran ser más por los alborotadores que del Cuzco / salieron trayendo el ynga natural señor 
destas / partes a su deboción pues ellos an sido causa / que no aya venido a ella por mi mano días ha y / espero verná puesto porque aunque es yndio / reconoce las trayciones y maldades de Pizarros / e de sus secazes y la justicia e razón que yo ten / go y los que me siguen y ansí ba él delante de / mí a hazer la guerra a esos deseruidores de su ma / gestad y hará la de beras y a vuestra merced ansimismo //

/ $124 \mathrm{v}$. / por auerse juntado con ellos si no muda propósito aun / que tengo por cierto si a estado y está en su libre poder / nunca el de vuestra merced aver sido ynclinado a hazerme / agrauio, guarde y prospere Nuestro Señor la muy magnífica / persona y estado de vuestra merced. De Vilcas quatro de se / tienbre de mil y quinientos e quarenta e dos años / a seruicio de vuestra merced Don Diego de Almagro. Al Ylustre / señor licenciado Vaca de Castro, presidente de la Real / Audiencia de Panamá e juez de agrabios e del Con / sejo de su magestad. Ylustre señor aun el trueno de / la justicia que viene vuestra señoría a hefetuar en es / tas partes no lo hemos oydo y el relámpago de la / sin justicia que nos desea hazer ha días que nos tie / ne ciegos ni vuestra señoría hera justo nos tubiese por / seruidores y vasallos de su magestad ni nosotros / nos persuadiríamos serlo si pasásemos con silen / cio lo que oymos y no adbirtiésemos a vuestra señoría / de lo que nos parece ser seruicio de Dios e de su magestad / que vien confiados quedamos si vuestra señoría to / ma el parecer de nuestros henemigos en nada darán / corte para que la paz se anteponga a la guerra pues / Dios la amó y en su nombre la ama el gobernador / don Diego de Almagro como temeroso dél e del seruicio / de su rey y nosotros la deseamos por ber su jus / ticia e deseo tan ynclinado a todo bien pues se / ofrece mensajero que dara entera relación a vuestra / señoría de nuestras voluntades remitiéndonos a él en / lo demás dezimos e suplicamos a vuestra señoría / pues su magestad no puede ser seruido con la gue / rra y muerte de onbres y esta no poderse escusar / viniendo vuestra señoría en compañía de nuestros enemi / gos que a la ora se aparte dellos y se ponga de por / medio y atienda a dar algún corte de concordia hasta / tanto que su magestad ynformado de lo pasado e de //

/ 125 r. / la justicia que el gobernador tiene provea lo que fuere / su seruicio pues hasta agora los que le ayudamos a / sustentar e ayudaremos hasta morir es la merced / que su magestad hizo a su padre y a él en su nombre desta / gobernación del Nuevo Toledo certificando a vuestra se / ñoría si perseberare en venir contra ella con mano ar / nada nos hallará en sus límites defendiéndola a / todos los del mando en tanto que su magestad y que se / pamos manera de su cesarea voluntad no mandare / el contrario hasta que los de una parte queden / venzidos por tanto sabiendo vuestra señoría nuestras / yntenciones y nuestra justicia e el adrezo que tenemos / de artillería y munición, amigos, armas y lo demás / e muy buenas voluntades para ofender a / mucho número de gente le suplicamos otra e muchas / vezes de algún buen medio de paz y esto reque / rimos todos unánimes y conformes de parte de / Dios e de su magestad a vuestra señoría con el acata / miento que debemos e somos obligados, don / de no protestamos que todos los daños y menos / cabos y muertes de onbres y pérdida de la tierra y / naturales della e de los quintos e haziendas / reales sean a cargo de vuestra señoría e de los que en su / compañía vienen como personas que no desean / paz por sus propios yntereses posponiendo pues le requerimos con tienpo con e / lla y lo que vuestra señoría hera obligado a pedir, pe / dimos nosotros biendo a vuestra señoría tan metido / en la guerra como nos dizen contra súbdito de / su magestad siendo enbiado a mantenerlos en con / cordia e porque podría ser que Peraluarez e / Tordoya e los apasionados que de acá fueron / en su compañía y vuestra señoría los a acogido en la // 
/ 125 v. / suya pongan en plática a vuestra señoría que vengan con / tra el gobernador e contra los que le seguimos dándo / le a entender que la gente que le faborece oydo el non / bre del rey unos se yrán a vuestra señoría y otros se yrán / a Chile de manera que podrá ganar la vitoria e sea / gran señor sin abenturar nada a esto respondemos / que el gobernador y los que con él estamos tenemos / la voz de su magestad e deseamos mas su ser / vicio que nuestras propias vidas e ansí fabore / cemos sus reales prouisiones certificando a / vuestra señoría que la ora que sepamos su mobimiento / contra el gobernador hiremos con los ánimos hostiga / dos de los malos tratamientos que hemos reciuido / e de los que esperamos de vuestra señoría reciuir si no / nos defendemos a pelear pues a tomado la pro / terción de nuestros henemigos y con tanto rigor / viene en nuestro daño procurando dar la muerte / a los que no la desean acabar y con esto nos parece / cunplimos con Dios y con nuestro rey para que en / ningund tienpo dexemos de ser tenidos por muy / verdaderos súbditos y vasallos suyos e teme / rosos de su onra como fieles seruidores y por / desearlo ser de vuestra señoría nos abríamos de encare / cer la merced que se nos haría en que vuestra señoría lo / mirase bien y fuese medianero y no parcial certe / ficando a vuestra señoría faborecer causa la más / ynjusta del mundo y no queriéndose reconocer es / peramos que mostrara Dios su justicia como en lo pa / sado y por quedar confiados verá vuestra señoría / lo que suplicamos ser lo mexor no nos alargamos a / más, guarde y prospere Nuestro Señor la ylustre / persona y estado de vuestra señoría, de Vilcas quatro / de septiembre de mil e quinientos y quarenta / e dos años de vuestra ylustre señoría muy ciertos seruidores //

/ 126 r. / que sus manos vesan Juan Balsa, Diego de Hozes, Diego Men / dez, Juan Tello, Cárdenas, Martín de Viluao, Pedro de / Candia, Martincote, Juan Gutiérrez Maraber, Juan de / Olea, Pedro de Oñate, Juan Pérez e ansí fecho el dicho / pedimento por el dicho licenciado León promutor / fiscal y presentadas las dichas cartas que de suso van / encorporadas. Luego el señor licenciado Vaca de / Castro gobernador dixo que no obstante que podría / proceder contra el dicho don Diego y capitanes y seca / zes conforme a lo pedido por el dicho promutor fiscal / por ser ansí como en su pedimento se contiene e / ser notorios los dichos don Diego y capitanes e seca / zes aver cometido los dichos delitos e lebantamientos / que todavía por ser vasallos de su magestad e es / cusar la vatalla que le venían a dar e riesgo y muer / tes que podrían recrecer e atraer a los susodichos / al seruicio de su magestad y para más les conben / cer mandaba e mandó dar su carta e probisión pa / ra el dicho don Diego y otra para los dichos sus capi / tanes y para toda la gente e secazes en que / se les declare los delitos y lebantamientos en / que andan contra su magestad y bien destos reynos / e amonestándoles a que se aparten del dicho le / bantamiento e delitos e se vengan al seruicio de / su magestad declarándoles ser traydores lo con / trario haziendo inserta la dicha ley de partida que / los declara por tales dándoles término en for / ma para ello con apercebimiento que no viniendo / en el dicho término sean desde agora citados e / llamados perentoriamente para declarar los dichos / delitos que an cometido por notorios y aver yn / currido en la pena de la dicha ley de traydores con / denados por tales e a muerte conforme a la dicha ley //

/ 126 v. / e otras de los reynos de su magestad que hablan e dispo / nen en los dichos casos e delitos e que por no auer segu / ra llegada a los susodichos don Diego y capitanes e / gente de personas y escriuanos mandaua se entregase / la dicha probisión al dicho Lope de Ydiaquez por ser / su mensajero y al fator Diego de Mercado por ser fator / de su magestad y amigos de los susodichos antes de / los dichos lebantamientos que con el dicho Lope de Ydiaquez / fuese e ansimismo demás de la dicha probisión / llevasen las cartas que escribía al dicho don Diego e / otra a los dichos 
capitanes de palabras veníbolas e / persuasibas para que mexor biniesen al seruicio / de su magestad y que para que si alguno buen concierto / quisiesen tomar mandaua y mandó dar su carta / e cartas de seguros para las personas que el dicho / don Diego y sus capitanes quisiesen enbiar y man / daua y mandó que las dichas probisiones cartas e / seguros se entregasen al dicho Lope de Ydiaquez / e fator Diego de Mercado por ante mí el dicho Fran / cisco Paez e ansimismo por ante Pero López / escriuano de su juzgado e que quedase traslado / e registro en el proceso de todo e firmado del / dicho señor gobernador e de los dichos escriuanos e / que mandaua y mandó a los dichos Lope de Ydia / quez y fator Mercado que fuesen al dicho tanbo / de Vilcas que es diez leguas del asiento deste / real e diesen las dichas cartas y probisión de / seguro al dicho don Diego y capitanes públicamente / e lo dibulgasen entre toda la dicha gente de mane / ra que pudiese venir a noticia de todos y lo fir / mó de su nonbre siendo presentes por testigos los / dichos Diego Maldonado y Gómez de Tordoya y García / de Montalvo e Alonso de Origuela estantes en el //

/ 127 r. / dicho real y para lo susodicho les hazía e criaba escriuanos, escri / tores y nuncios, testigos los dichos el licenciado Vaca de Castro / e después de lo susodicho en la dicha villa de San Juan de la Fron / tera nueve días del mes de septiembre del dicho año en / presencia de mí el dicho Francisco Paez e de Pero López escriuanos / de sus majestades, su señoría el dicho señor gobernador dio / y entregó al dicho Lope de Ydiaquez una carta para el dicho don / Diego de Almagro con una probisión sobre lo susodicho / e ansimismo otra carta para los susodichos que se llaman / sus capitanes con otra probisión de la misma manera su / thenor de las quales dichas cartas y probisión que fue / ron duplicadas firmadas del dicho señor gobernador e re / frendadas de nosotros anbos a dos los dichos escriuanos es / este que se sigue: Al muy magnífico señor don Diego de Alma / gro. Magnífico señor las cartas que vuestra merced me / dio Ydiaquez me forzaron a enviar la probisión que va / con esta mas no obstante esto que es hazer lo que mi oficio / me obliga digo que en viniendo vuestra merced ante mi per / sona que se entienda en su derecho yo le daré su justicia e / trataremos de conciertos por donde se sirba nuestro Se / ñor Dios e su magestad e aya más pacificación en la / tierra e vuestra merced y esos caualleros se remedien e / aquí enbío seguro para la persona que con su poder / quisiere enbiar e mire vuestra merced quan sin propósi / to es lo que se funda su carta pues saue que la pro / visión de su padre para poder nombrar quien goberna / e otra quel marqués tenía del mismo tenor / cesa por la que su magestad fue seruido que a mí se / diese como muchas vezes le tengo escripto y le es no / torio y venir conmigo estos caualleros no es ynpe / dimiento para dexar de hazer justicia quando dellos / se pidiere que las justicias no deven desecharlos / que viene en su acompañamiento e ansí se hará a / Vuestra merced y a los que de allá quisieren venir y más cier / ta los ternán para seguir su justicia que ausentes //

/ 127 v. / mayormente que yo no sé que venga conmigo onbre de nonbre / de Pizarro Nuestro Señor la magnífica persona de vuestra merced / guarde. De San Juan de la Frontera ocho día de setiembre / de mil y quinientos y quarenta e dos años a seruicio de vuestra / merced el licenciado Vaca de Castro. Francisco Paez, Pero / López escriuano de su magestad. A los magníficos señores Juan / Balsa e Diego de Hozes e Diego Méndez e Juan Tello e / Martín de Bilbao e Cárdenas e Pedro de Candia y Martico / te e Juan Gutiérrez Maraber e Juan de Olea y Pedro de / Oñate y Juan Pérez, magníficos señores reciuí la carta / de vuestras mercedes y bien creo yo que no obstante lo / que en ella dizen an de venir a seruir $[\mathrm{sic}]^{21}$ a seruir a su magestad / en acompañamiento mío porque creo

\footnotetext{
${ }^{21}$ Repetido en el original.
} 
que sus firmas / son más para agradar que no para executar y para / que mexor pueda hazer lo que digo y vean la obli / gación que tienen de derecho para ello y las penas que / en contrario se les ponen enbío la probisión que va / con esta vuestras mercedes las bean y lo que les va en ello / que en mí siempre hallarán padre para todo su bien / e como por otras les tengo advertido la probisión / que tenía el adelantado don Diego de Almagro para / nonbrar quien gobernase, entendía fasta que otra co / sa su magestad probeseye y ansí lo dixo el adelantado / en su nonbre y nonbramiento e agora lo a probeido en / enbiarme a mí no se deven fundar sobre cosa tan des / viada de la verdad e justicia y fidelidad que / deven a su rey ni tan poco en venir los que vienen / en mi acompañamiento porque aquí estarán más cer / ca para hazer justicia dellos si la tubieren qualquier / de vuestras mercedes. Nuestro Señor las magníficas per / zonas de vuestras mercedes guarde de San Juan de la / Frontera, ocho de setiembre de mil y quinientos e / quarenta e dos años a seruicio de vuestras mercedes, el / licenciado Vaca de Castro. Francisco Paez, Pero López //

/ 128 r. / escriuano de su magestad. El seguro para las personas que / don Diego y los que le seguían quisiesen enbiar el licenciado / Cristóval Vaca de Castro cauallero de la horden de Santiago / del Consejo Real de sus majestades, gobernador y capi / tán general en estos reynos y probincias de la Nueva / Castilla e Nuebo Reyno de Toledo, llamado Perú, etcétera / por sus majestades. Por quanto por don Diego de Alma / gro e los capitanes que con él estaban me fue enbia / do un mensagero con ciertas cartas el qual no trae poder / ni facultad de su parte para tratar en las cosas de la / pacificación e sosiego destos reynos e de las alte / raciones que en ellos a abido e ay e porque yo deseo / se entienda en ello e se trate de algunos buenos medios / que convengan al seruicio de Dios Nuestro Señor e de su ma / gestad e bien de la tierra por ebitar que no aya / ronpimiento e acordado de enbiar seguro para que / syn temor algunas personas con poder de los suso / dichos pudiesen venir a entender en lo susodicho por / ende acatando lo susodicho en nombre de su mages / tad tomó debaxo de su seguro anparo e defen / dimiento real para que puedan venir ante mí por / parte de los susodichos don Diego y capitanes con su / poder a tratar e estar en este real de su magestad / entendiendo en lo susodicho y boluer a la conpañía / del dicho don Diego libremente sin que por mí ni por otra / persona alguna les sea hecho ynpedimento, agra / vio ni otro mal tratamiento alguno no enbargante qua / lesquier delitos que ayan cometido en que se ayan / hallado hasta agora y mando al maestre de campo / e capitanes e otras personas de gente de guerra / deste real de su magestad que guarden y cumplan lo / contenido en esta mi probisión en contra ello no vayan / ni pasen por manera alguna so pena de muerte e per / dimiento de todos sus bienes para la cámara y fisco //

/ 128 v. / de su magestad a cada uno que lo contrario hiziere y pro / meto e doy mi palabra como cauallero de les guardar es / te seguro que no les será quebrantado a los susodichos / de lo qual di esta mi probisión firmada de mi nonbre e / refrendada de los escriuanos yuso escriptos que es fecha en / la villa de San Juan de la Frontera a ocho días del mes / de setienbre de mil e quinientos e quarenta e dos años / el licenciado Vaca de Castro, por mandado de su señoría, / Francisco de Paez. Traslado que se enbía de la probisión / a los susodichos ynserta la ley de la partida el licencia / do Vaca de Castro cauallero de la horden de Santiago del / Consejo Real de sus magestades, capitán general en estos / reynos y probincias de la Nueva Castilla y Nuebo Reyno de Toledo llamado Perú, etcétera por sus magestades para ello tengo su tenor de lo qual es este que se / sygue: El Rey. Por quanto nos enbiamos a uos el / licenciado Vaca de Castro de nuestro Consejo, cauallero de / la horden de Santiago a las probincias del Perú a / entender en algunas cosas tocantes a nuestro seruicio / y execución de la nuestra justicia y podría ser que / durante el tiempo que vos en las 
dichas probincias / residiésedes por ser cosa natural y porque el marqués / don Francisco Pizarro nuestro gobernador de la pro / bincia de la Nueva Castilla es hombre de hedad acaecie / se fallecer, en tal caso por la confianza que de / vuestras letras, retitud e fidilidad tenemos es nuestra / voluntad que vos el dicho licenciado Vaca de Castro / tengays por nos la nuestra justicia e gobernación de / la dicha probincia de la Nueva Castilla e de la probincia del / Nuebo Toledo cuya gobernación teníamos encomendada / al mariscal don Diego de Almagro, difunto entre tanto e / hasta tanto que nos ynformados mandamos probeer lo que / a nuestro seruicio y buen estado de las dichas provincias con //

/ 129 r. / venga por ende por la presente queremos y mandamos que / en caso que quando vos el dicho licenciado Vaca de Cas / tro llegaredes a las dichas provincias del Perú el dicho / marqués don Francisco Pizarro sea fallescido o fa / llezca en el tiempo que vos en ellos residieredes que / entre tanto como dicho es mandaremos probeer lo que / fueremos seruidos vos el dicho licenciado Vaca de Castro / goberneys y tengáis en justicias las dichas probincias / de la nueva Castilla y Toledo e hagáis las otras / cosas quel dicho marqués don Francisco Pizarro y el dicho / adelantado don Diego de Almagro hazian y podían e / debían hazer por virtud de los poderes e ynstru / ciones que de nos tenían que por la presente vos damos / el mismo poder y facultad quellos tenían y tienen / por virtud de las dichas nuestras probisiones, poderes / ynstruciones para todo lo tocante a las dichas go / vernaciones y execución de la nuestra justicia como / oy si a vos fueran dirigidas y enderezadas con todas / sus incidencias e dependencias, anecidades y cone / xidades e mandamos a los concejos, justicias, re / gidores, caualleros, escuderos, oficiales y ombres / buenos de todas las ciudades, villas y lugares de / las dichas provincias de la nueva Castilla y Toledo / e a qualesquier capitanes y gente de guerra que / en ellas estobieren e allá fueren que durante el / tiempo que como dicho es nos mandamos proveerlo / que a nuestro seruicio convenga que en el dicho caso / de fallecimiento del dicho marqués don Francis / co Pizarro vos ayan e tengan por nuestro gobernador / e justicia de las dichas provincias e usen con vos / en el dicho oficio y en todos los casos a él anejos / e concernientes fecha en Madrid a nueve de se / tienbre de mil e quinientos y quarenta años, / frater García Cardenalis Yspalensis por mandado //

/ 129 v. / de su Magestad. El gobernador en su nombre Juan de Sámano / hago sauer a vos don Diego de Almagro hijo < del mariscal don Diego de Almagro > y a vos Juan / de Balsa e Diego de Hozes e Diego Méndez e Juan / Tello e Martín de Bilbao e Cárdenas e Pedro de / Candia e Marticote e Juan Gutiérrez Maraber e Juan / de Olea y Pedro de Oñate e Juan Pérez que os llamays e / dezis sus capitanes y a vos Pedro de Sanmillán e Juan / Rodríguez Barragán e Gerónimo de Almagro e Antón de / Almagro y Francisco de la Fuente e Juan de Guzmán e / Bartolomé de Arbolanche e Coronado e Martín de Jaso / e Martín Carrillo e Cabezas e Santiago de Pontejos, co / mendador de San Juan e Sosa cauallerizo del marqués y Valtasar Gómez e Ramirillo de Baldes e Ramírez / y Pedro de Mendoza y Francisco Peces y Velázquez e / Herencia e Diego Damián e Alonso de Saabedra e / Juan Muñoz el capitán e a Muñoz el cantor y Martel / y Juan Tello y Pero López de Ayala y Juan de Ma / zariegos e Antonio de Ribera y Pedro Barba e Po / blete el sevillano e Alonso Valles e Cansino e / su hermano de Andrés Hernández e a Pereyra e a / Diego Pantoja e a Nabarro el de la pedrada e a San / tiago e a Rengifo e a don Baltasar de Peraza e / a Coronado el manco e a Cristóval Carrillo y a Fran / cisco e Juan de Berrio hermanos e a Marchena e / a Biedma e a Rocha y Francisco López y Pineda / paje del adelantado y Juan Váquez de Osuna / e a Pantoja huésped de Hordoñes e a Hordoñez / e Pina e a Cornejo e a Pedro Riquelme e a Peralta / e Antón 
Pérez herrero e a Pedro de Heredia e a / Arias e Alonso Díaz el herrador e Juan Bartelomé / e Antonio de Agüero e Arrinaga e Juan Sanz Copin / e Juan de Almagro y Martín de Uribe y Francis / co Núñez de las piernas gordas e a Palomares / e Avila jugador e a Carreño portugués e a Rodrigo //

/ 130 r. / Núñez e a su hermano e Aguirre el tuerto e a / Juanes sastre e a Suarez e a Moriana e a Ramírez e a / Salzedo e a Diego Pérez e a Pero López de Ayala e a Criado / e Andrés Fernández e a Enríquez y a Segura, / criado de Ramírez e a Cárdenas e a otro Moriana / e a Juan Gómez e Albornoz e Antón de León e a todos / los otros sus aliados y personas que andays en / compañía del dicho don Diego de Almagro y a cada uno / e qualquier de vos e bien saueis como después / de aver por parte de vos el dicho don Diego muer / to al marqués don Francisco Pizarro adelantado / mayor y gobernador y capitán general en estos dichos / reynos y probincias por sus majestades vos el su / sodicho con gran deslealtad e desacato de la cesarea / e católica magestad hezistes juntas de la dicha / gente e alzates vanderas contra vuestro rey e / señor natural tomando y ocupando estos sus rey / nos con gran tiranía e violencia y usurpando la / jurisdicción real haziendo os nonbrar e recibir / vos el dicho don Diego de Almagro por gobernador dellos / por fuerza de armas y puesto tenientes ansí en la / probincia de Lima y Truxillo y San Miguel e después / en la probincia del Cuzco y Nuebo Reyno de To / ledo estando yo reciuido en ella por virtud de los / dichos poderes y probisiones que de su magestad / tengo y quitando los tenientes que por mí estauan / puestos y ansimismo para mejor hazer el dicho / alzamiento y ocupación tomastes las armas y los / cauallos de los vezinos de los dichos pueblos que / estauan en seruicio de su magestad y tomas / tes y robastes los quintos reales de su mages / tad y bienes de los difuntos e otros depósitos / e saqueando casas e robando los que yban //

/ $130 \mathrm{v}$. / por los caminos matando los onbres sin culpa e hecho o / tras tiranías y fuerzas e delitos grabísimos como des / leal a vuestro rey y que aunque por mi parte ha sido / exortado y amonestado y a vos el dicho don Diego que / depusiésedes la dicha gobernación que con tiranía a / víades usurpado e derramásedes los dichos ayun / tamientos de gente de guerra y apartados della no / lo avíades querido hazer ni cumplir antes sienpre / aveys permanecido y perseberado en la dicha des / lealtad e guerra y tiranizando y usurpando es / tos reynos e haziendo y cometiendo otros mu / chos e muy grandes delitos en deseruicio de su magestad / e daño unibersal de la república destos reynos se / gund que todo es muy público y notorio en ellos tal que / no requieren probanza e yo como tal gobernador / verdadero destos dichos reynos y probincias por / su magestad viendo la dicha vuestra pertinacia he benido / en persona con los caualleros e seruidores de / su magestad destos dichos reynos a poner remedio / en los dichos lebantamientos y estorbar e obiar los / dichos delitos e tiranías e daños e ynconbinientes / que dello se sigue e porque quando tales lebantamientos / se hazen en qualquier reyno no solamente es pro / yvido que ningunos sigan a los tales pero todos / son obligados a yr luego a lo vedar muy cruelmente / e a se poner a lo remediar e acudir para ello a la / parte del rey sin ser llamados con sus personas / e bienes e aberes sin esperar mandamiento del rey / so pena de traydores segund parece e se dispone / por la ley tercera título diez e nuebe de la segunda / partida que sobre lo susodicho habla la qual por / que no puedan pretender ynorancia ba aquí yncor / porada de berbo ad berbun su thenor de la qual es / este que se sigue: Reyno es llamado la tierra que a //

/ 131 r. / rey por señor y él a otrosi nombre rey por los hechos / que ha de hazer < en ella > manteniéndola en justicia e con derecho / e por ende dixeron los sabios antiguos que son / como 
alma e cuerpo que mangueran si se an de $\operatorname{partidos}^{22} /$ el ayuntamiento les haze ser una cosa e aunque el / pueblo guardase al rey en todas cosas sobredichas si al / rey ${ }^{23}$ no guardase de los males que y podrían venir no / sería la guarda cumplida y la primera guarda destas / que le conbiene hazer es quando alguno se alza con el / reyno para bollecer y hazer otro daño ca a tal hecho / como este deven todos venir lo más ayna que pudie / ren por muchas razones. Primeramente guardar el / rey su señor de daño e de bergüenza que nace del / tal lebantamiento como este caen la guerra que le viene / de los enemigos de fuera non amara villa ningu / na porque no an con el deudo de naturaleza nin de / señorío ${ }^{24}$ mas de la que se lebanta de los suyos mismos / desta guisa nasce mayor deshonra como en querer / se los vasallos ygualarse con el señor y contender / con él argulladamente y con soberbia y es otrosy / mayor peligro porque tal levantamiento como este / siempre se mueve con gran falsedad señaladamente / por hazer engaño y mal y por esto dixeron los sabios / antiguos que en el mundo no ay mayor pestilencia que / reciuir onbre daño de aquel en que se fía ni más / peligrosa guerra que de los enemigos de que onbre non se / guarda que non son conocidos mostrándoseles amigos / ansí como de suso diximos y al rey biene otrosi / gran daño porque le nace guerra de los suyos mes / mos que les ha ansí como hijos y criados y biene otro / si de partimiento de la tierra de aquellos que la deben / ayuntar e destruymiento de aquellos que la deven / guardar porque sauen la manera de hazer y < mal > más / que los otros que no son ende naturales y por ende / es ansí como la pozoña que si luego que es dada //

/ 131 v. / non acorren al onbre vale derechamente al corazón e / matalo y por eso los antiguos llamaron at al guerra ${ }^{25} \mathrm{co} / \mathrm{mo}$ esta lid de dentro del cuerpo y sin todo esto biene / gran daño porque se le be tan gran blasmo no tan / solamente a los que lo hazen mas aun a todos los de la / tierra si luego que lo sauen no muestran que les pesa / yendo luego al lecho ${ }^{26}$ y vedándolo muy cruelmente por / que tan gran henemiga como esta no se encienda ni el rey / reciua por ende mengua en su poder ni en su onra ni / otrosi al rey ${ }^{27}$ pueda ende venir gran daño ni des / truymiento ni que los malos atrebiéndose tomasen / en exenplo para hazer otro tal y por eso debe ser / luego amatado de manera que [tachado: no] solamente no sal / ga ende fumo porque pueda ennegrecer la fama bue / na de la tierra y por ende por todas las razones de / ven todos venir luego que la supieren a tal hueste non / atendiendo a mandado del rey que a tal lebanta / miento como este por tan estraña cosa lo tubieron / los antiguos que mandaron que ninguno no se escu / sase por onra del linage ni por pribanza que o / viese con el rey ni por preuilegio que tubiese del rey / ni por ser de orden si no fuese home encerrado si no / los que fincasen dezir las oras que todos biniesen / ende para ayudar con sus manos y con sus conpañas / e con sus aberes a tan gran saber ovieron de la ver / $\mathrm{dad}^{28}$ que

\footnotetext{
22 Según Las Siete Partidas del rey don Alfonso el Sabio cotejadas con varios códices antiguos, Real Academia de la Historia, Madrid, 1807 (tomo II, páginas 181-182), el texto es como sigue: "son como alma et cuerpo que maguer sean en sí departidos, el ayuntamiento les face seer una cosa”.

${ }^{23}$ Ibidem: "si el regno no guardase de los males".

${ }^{24}$ Ibidem: "ca en la guerra que le viene de los enemigos de fuera non ha maravilla ninguna, porque no han con él debdo de naturaleza ni de señorío".

${ }^{25}$ Ibidem: "at al guerra".

${ }^{26}$ Ibidem: "hecho".

27 Ibidem: "reyno".

${ }^{28}$ Ibidem: "e con sus haberes. Et tan gran sabor hobieron de lo vedar".
} 
mandaron que si todo leal falleciese las / mugeres viniesen a destruyr tal hecho como este ca / pues el mal y el daño tañe a todos no tubieron por / bien ni por derecho que ninguno no se pudiese escusar / que todos no biniesen a desarraygallo onde los que / tal lebantamiento como este hazen son traydores y / deven morir por ello y perder todo quanto obieren. / Otrosi los que a tal hueste como esta no quisieren / venir o se fuesen della sin mandado porque se / meja que les non pesa de tal hecho devan aver tal pena //

/ 132 r. / como dicho es ca derecho conoscido es que los hazedores de / tal hecho como este y sus aconsejadores de tal mal / ygualmente son penaderos pero non caherían en pena los / que no pudiesen venir mostrando escusa derecha ansí como a / quellos que son de menos edad de catorze años y mayor de se / senta o enfermos o heridos de manera que no pudiesen / venir y si fuesen enbargados por muy grandes niebes o de / grandes ríos que no pudiesen pasar por ninguna cosa mas / de la hueste no sería ninguno escusado para venirse della / si no fuese enfermo o cegado de tan grabemente que / no pudiese tomar armas. Pero a lo que dize de suso / de los viejos que deven ser escusados no se entiende de / aquellos que [tachado: no] fuesen tan sabidores que pudiesen / ayudar por su seso a los de la hueste que a una de / las cosas del mundo en que más son menester estas dos co / sas es en hecho de armas y por esta razón los antiguos ha / zían engaños y maestrías para llevar consigo en las hues / tes los viejos que no podían caualgar para ayudarse de / su seso e de su consejo y aunque por disposición de la dicha / ley que de suso va yncorporada se podría declarar y pronun / ciar a vos los susodichos aver yncurrido en las dichas / penas en ella contenida y proceder a execución dellas / por aberos juntado en dicho lebantamiento y no auerlo / contradicho ni aver benido a lo contradezir y estorbar / en mi compañía y estandarte real pero para más os con / vencer y a mayor abundamiento di esta mi probisión / en la dicha razón lo qual os enbío con Lope de Ydia / quez vuestro mensajero para que venga a vuestra noticia por / que por los delitos y fuerzas que vos los susodichos / hazeys y cometéis continuamente no se permite o / tra notificación lo qual dicha mi probisión yo man / do dar y entregar cerrado e sellado al dicho vuestro / mensagero en respuesta de lo que por vuestra parte / vino a negociar porque conste aver benido a / vuestra noticia y dello no podays pretender ynorancia //

/ 132 v. / por la qual vos exortó e amonestó y mandó a vos los / susodichos y cada uno de vos como tal gobernador / en nonbre de su magestad que luego derrameys la dicha / gente de guerra que ansí teneys junta y los aparejos / armas y aparatos della e depongáis la dicha gober / nación y vos el dicho don Diego no podáis llamar ni / llameys más gobernador e dentro de seis días / primeros siguientes que corran e se quenten desde / el domingo que se contarán diez días deste pre / sente mes ynclusibe que es término conpetente por / estar vosotros en el asiento de Vilcas tan cerca / deste real de su magestad porque los otros / dos días de la hecha desta quedan para que el dicho / vuestor mensajero lleve la dicha probisión a vuestro poder / los quales vos doy e asigno por tres plazos / e términos perentorios acauados vengays / e parezcáis ante mí sin el dicho ayuntamiento e / armas y aparatos de guerra devaxo del estándar / te real de su magestad so cuya protección como / tal gobernador yo ando para seruir a su magestad / conforme a la dicha ley suso yncorporada y a los / que por virtud della soys obligados con apercibi / miento que vos hago que haziéndolo y cunplién / dolo ansí hazeys bien y lo que soys obligados en / otra manera lo contrario haziendo y no biniendo / como dicho es a obidiencia de su magestad el dicho tér / mino pasado sin vos más citar ni llamar ni oyr ni a / tender sobre ello declararé vuestros delitos susodichos / por notorios e auer yncurrido en las dichas penas en / la dicha ley contenidas y en las demás en que por los / reynos de sus 
magestades por lo susodicho aver caydo / e yncurrido y procederé a execución dellas con todo rigor como la calidad del caso lo requiere //

/ 133 r. / e conviene al seruicio de su magestad y bien y pacificación / destos reynos e república dellos que por la presente / en quanto es necesario vos cito llamo y enplazo pe / rentoriamente para todos los autos e deligencias e / cosas que para execución e cunplimiento de lo suso / dicho se obieren de hazer y oyré ansimismo al promutor / fiscal de su magestad a cuyo pedimento de la presente / en todo lo que sobre ello quisiere dezir e alegar e so / bre todo haré e determinaré lo que hallare por jus / ticia sin vos más citar ni llamar sobre ello como dicho es / de lo qual di esta mi probisión firmada de mi nombre / e refrendada del escriuano yuso scripto que es fecha / en la villa de San Juan de la Frontera ocho días / del mes de septiembre de mil y quinientos y qua / renta e dos años el licenciado Vaca de Castro. Por / mandado de su señoría Pero López escriuano de su / magestad Francisco Paez las quales dichas cartas / para el dicho don Diego y los que se llaman sus capi / tanes y las dichas probisiones que con cada una / dellas yvan se abrieron y mostraron las dichas / cartas al dicho Lope de Ydiaquez su mensagero e se / le entregaron para que los diese a los dichos don Die / go y sus secazes el qual las reciuió y prometió / de dar e notificar a los susodichos siendo / presentes por testigos el secretario Sebastián / Sanz de Merlo y Miguel Luis estantes en la dicha / villa e después de lo susodicho en este dicho día e / mes y año susodichos su señoría el dicho señor gober / nador en presencia de nosotros los dichos escriuanos dio / e entregó otro tal despacho como el susodicho al fator / Diego de Mercado duplicado para que los llevase jun / tamente con el dicho Lope de Ydiaquez a los dichos don Diego / e sus secazes y les fueron mostradas las cartas que / llevaua con las dichas probisiones como dicho es el qual //

/ 133 v. / las reciuió e llevó en su poder y prometió de las dar / y noteficar a los susodichos en sus manos a lo qual fue / ron presentes por testigos el dicho secretario Sebastián Sanz / de Merlo y el dicho Miguel Luis paje de su señoría y nosotros / los dichos Pero López y Francisco Paez escriuanos de sus ma / gestades susodichos que al hazer y escriuir y entregar / de las dichas cartas y probisiones que se entregaron a los / dichos Lope de Ydiáquez y fator Diego Mercado con los / dichos testigos fuymos presentes como dicho es y damos fe / que las dichas cartas y probisiones que ansí se entregaron / a los susodichos son otro tanto a la letra de como de suso / va declarado y por ende hizimos aquí nuestros signos / a tal en testimonio de verdad Pero López escriuano de / su magestad Francisco Paez e después de lo susodicho / en la dicha villa de San Juan de la Frontera en martes / doze días del mes de setienbre del dicho año de mil e / quinientos y quarenta e dos años ante su señoría del / dicho señor gobernador y en presencia de mí el dicho Fran / cisco Paez escriuano susodicho e de los testigos de yuso / escritos parecieron presentes los dichos Lope de Ydiáquez / e fator Diego de Mercado mensageros susodichos / e dixeron quellos avían dado y entregado a los dichos / don Diego y los que se dezían sus capitanes las dichas / cartas que avían lleuado de su señoría y las pro / bisiones que con ellas yvan el domingo pasado que se / contaron diez días deste presente mes de setienbre / e las avían visto, leydo y entendido y en res / puesta dellas les avían enviado ciertas cartas que / trayan las quales avían dado y entregado a / su señoría su tenor de las quales es este que se / sygue: Al my magnífico señor el Presidente Va / ca de Castro del Consejo de su magestad la carta / de vuestra merced que me traxeron Lope de Ydiáquez / e Diego de Mercado reciuí y vi lo que de su parte / me dixeron y lo que vuetra merced pide que enbíe al // 
/ 134 r. / capitán Juan Balsa e dar asiento en lo que convenía al / seruicio de Dios e de su magestad yo digo que enbiaré / a él o al capitán Rodrigo de Salzedo con lo que de mi parte / se pidiere y con poder para que viniendo vuestra merced en / ello se concluya pero temo el cumplimiento de lo que se con / cluyere que no se me guardara esto dígolo porque los men / sageros de vuestra merced llegaron quando se ahorcaba / una espía que vuestra merced ynbió para que hiziese el / daño que pudiese en este real y vi las cartas que tra / xo y las di a quien venían y aunque de vuestra merced se es / pere que cumplirá su palabra dándola como cauallero / que es y persona nuevamente venida de aquella bue / va [sic] tierra son tantos los que con voluntad da / nada andan cerca de vuestra merced que temo ser en / gañado e se quiera dilatar conmigo para rehazer / se vuestra merced y los que están en su compañía e / viéndose vuestra merced poderoso no quiera esperar / lo que su magestad será serbido enbiar a mandar / ni cumplir lo capitulado y el daño postrero sería / peor que el primero con que mi padre fue traído / a la muerte con tantos juramentos y pleitos me / najes como don Francisco Pizarro e sus her / manos y esos caualleros que con vuestra merced / andan hizieron y ninguno se cumplió ansí que / para yr allá una de las personas que digo de / mi parte vuestra merced por seguridad della me / enbié para que esté conmigo en tanto que se / concluye al capitán Alonso de Albarado e / al capitán Peralvarez y porque Lope de Ydiáquez / dirá lo demás que yo podría aquí dezir no me / alargo. Guarde Nuestro Señor la muy magnífica / persona de vuestra merced de Vilcas a onze de / setienbre de mil y quinientos y quarenta / e dos años a seruicio de vuestra merced don Diego de / Almagro al ilustre señor el presidente Vaca de Castro //

/ 134 v. / del Consejo de su Magestad. Ilustre señor recibimos la carta de / vuestra señoría que nos dio Lope de Ydiáquez y en verdad / sy vuestra señoría piensa que hemos de dexar al goberna / dor don Diego de Almagro por lo que nos scriuió en cu / ya compañía servimos a su magestad por yr a la de vuestra / señoría se engaña muy de veras y bien es que vuestra seño / ría crea ser nuestra carta escripta por bien parecer / e no para hefetuarse lo que en ella dezimos y por / que vuestra señoría esté certificado que ansí lo cun / pliremos juramos a Dios y por vida de su magestad / de hazerlo que seruimos a vuestra señoría si no se to / ma con el gobernador tal asiento qual convenga / al seruicio de Dios y de su magestad paz y tran / quilidad de la tierra e haziendo esto vuestra señoría / todos seremos seruidores. Guarde Nuestro Señor la ylustre persona de vuestra señoría de Vilcas onze / de setienbre de mil y quinientos y quarenta e / dos años de vuestra ylustre señoría muy ciertos ser / vidores que sus manos vesan Juan Balsa, Diego / de Hozes, Cárdenas, Diego Méndez, Martín de Bilbao, Juan Gutiérrez Maraver, Marticote, Juan Tello, Juan / de Olea, Pedro de Candia, Pedro de Oñate, Juan Pérez. E ansí entregadas e dadas las dichas cartas / del dicho don Diego e de los dichos sus aliados y ca / pitanes al dicho señor gobernador por los dichos / Lope de Ydiáquez y fator Diego de Mercado luego / su señoría para mayor claridad de sus justifi / caciones e de las exortaciones y apercibimientos / que a los susodichos se avían hecho para que vinie / sen al seruicio de su magestad tomó e reciuió ju / ramento en forma devida de derecho de los dichos / Lope de Ydiáquez y fator Diego de Mercado sobre / una señal de cruz tal como esta cruz so cargo / del qual les mandó que declarasen si es verdad / que avían dado y entregado a los dichos don Diego //

/ 135 r. / e sus capitanes e aliados y secazes las dichas sus car / tas mesibas y probisiones de exortación y apercebi / miento que les auía sido entregadas por su señoría los qua / les anbos dixeron que hera verdad quellos de su propia / mano avían dado y entregado a los dichos don Diego de Al / magro y a los que se dezían sus capitanes y aliados las / dichas cartas y probisiones y despachos que de suso se / haze minción el domingo pasado que se contaron diez / días deste 
presente mes los quales las avían visto y en / tendido y se avían leído públicamente las dichas cartas / ante muchos de los susodichos que están en deseruicio / de su magestad e que demás de las dichas cartas e des / pachos les dieron y manifestaron y le es público y noto / rio como el dicho señor gobernador estaua en esta villa / en este exército real de su magestad e que hera gobernador / destos reynos en anbas gobernaciones y el buen celo e / voluntad e deseo que tenía de hebitar que no oviese ron / pimiento de vatalla sino entender en todos buenos me / dios de paz y que les sería padre como se lo scribía y fue / sen ciertos que lo cunpliría y que les convenía mucho en / tender en ello porque de manera se perdían e que / enviasen persona con poder que entendiese en lo su / sodicho pues trayan y lleuaban seguro en blanco para ello / y otras muchas palabras y buenas consideraciones / persuadiéndolos a que viniesen al seruicio de su magestad / e se entendiese en algunos buenos medios para escusar / la vatalla e ronpimiento quellos querían hazer / contra el estandarte real y el dicho señor gobernador / e los seruidores de su magestad y que no obstante lo su / sodicho les avían dado las dichas cartas en respues / ta de las otras cartas y probisiones que avían lleuado / e que después de dadas muchos de los susodichos di / xeron públicamente que no querían ni avían de tomar / medios ningunos ni querían sino guerra e abello por / rencuentro de vatalla y que al rey que allí viniese / en persona le darían la vatalla porque la tierra hera //

/ 135 v. / suya y ellos la avían ganado y conquistado sino se ha / zía lo quellos querían y que no enviase el dicho señor / gobernador otro mensagero sino que lo matarían e que / porque ellos les afeaban aquellos malos miramientos e / desacatos que les dezían e les dezían el gran desacata / miento e deslealtad que en lo susodicho cometían los qui / sieron matar e se vieron en mucho peligro e riesgo / e que continuando en sus deslealtad e tiranía publi / cauan e hera notorio que partían del dicho asiento de Vil / cas con las dichas juntas de gente y aparatos de guerra / para donde estaua el dicho señor gobernador e los / seruidores de su magestad a procurar de los destruyr / e desbaratar e que de lo contenido en las dichas pro / visiones e cartas no avían pretendido ynorancia el / dicho don Diego y capitanes porque después de avér / selas entregado se las mostraron ellos mismos / las dichas cartas e que hera público quel dicho don Diego / e sus secazes avían ahorcado a un Alonso Gar / cía que avía lleuado a los susodichos ciertas cartas / e perdones del dicho señor gobernador e que esta es / la verdad so cargo del juramento que hizieron e / lo firmaron de sus nonbres siendo presentes / por testigos el capitán Rodrido Docanpo e Miguel / Luis paje de su señoría Diego de Mercado, Ydiáquez. Pasó ante mí Francisco Paez. E después de lo suso / dicho en el dicho real de su magestad estando en el a / siento de Chupas que es dos leguas de la dicha villa de San Juan / de la Frontera en sáuado diez días del dicho mes de setien / bre del dicho año ante su señoría el dicho señor gober / nador y en presencia de mí el dicho Francisco Paez / escriuano y los testigos de yuso escriptos pareció presente / el dicho licenciado León promutor fiscal de su / magestad e dixo que ya su señoría saue y le es no / torio y público como los dichos Lope Ydiáquez e / fator Diego de Mercado dieron y entregaron las dichas //

/ 136 r. / probisiones y amonestaciones que su señoría enbió / con ellos al dicho don Diego e sus secazes y capitanes e / le consta como los reciuieron por las cartas que a / ello respondieron e los dichos de los dichos mensa / geros de que hazía e hizo presentación que es lo que / de suso va yncorporado por manera que no podían / pretender ynorancia de las dichas probisiones / como por sus cartas e dichos de los dichos mensageros consta y que no solamente no las quisieron / ni an querido conplir ni venir a la obediencia e ser / uicio de su magestad pero continuando en la dicha / su tiranía e desbergüenza y gran desacatamiento / avían respondido y con juramento dicho que no / 
avían de tomar medios ningunos ni venir a / seruir a su magestad como en las dichas probisiones / se les mandaua y amonestaua sino que avían / de dar vatalla y venían contra el dicho señor go / bernador y el estandarte real con las dichas jun / tas de gente y aparatos de guerra para le desbara / tar y matar y apoderarse de todos estos reynos / continuando sus trayciones y tiranías e desle / altad y estauan ya poco más de una legua deste real / de su magestad y ansimismo hera pasado el tér / mino en que les mandó que derramasen la dicha / gente de guerra y viniesen al seruicio de su ma / gestad y no avían venido por ende que él los / acusaua la rebeldía y como mexor de derecho o / viese su lugar pedía e suplicaua a su señoría man / dase hazer en todo como por él estaua pedido e / suplicado declarándolos y pronunciándolos por / tales traydores a su magestad e condenándoles a / pena de muerte y en las otras establecidas por / leyes e premáticas de los reynos y señoríos de / su magestad por su sentencia difinitiba pues aunque //

/ 136 v. / por la mucha notoriedad de los muchos delitos / no avía necesidad de más probanza estaua aberi / guado y probado contra ellos ni avía necesidad de / proceder por otra vía judicial segund que todo he / ra notorio y por tal lo allegaua y les acusaua de los / dichos delitos notorios e de la rebeldía y perti / nancia dellos como se contenía en la primera acu / sación que les auía puesto en el pedimiento por él / fecho junto a la dicha villa de Guamanga de que de / suso en este proceso se haze minción y que por es / tar todo en el estado en que estaua como hera notorio / sin más dilación pues la calidad y estado de los / dichos negocios no dauan a ello lugar mandase pro / ceder y procediese con todo rigor poderosamente / a execución de las dichas penas en que los susodichos / avían yncurrido pues heran tomados ynfra / gante delito pues de no lo hazer se siguía tan nota / ble daño e destruyción destos reynos e de los va / sallos e seruidores de su magestad en tan gran des / seruicio suyo e que a mayor cumplimiento hazía / e hizo presentación del proceso que se avía hecho / ante mi el dicho escriuano susodicho contra espías de / los susodichos e pedía a su señoría le mandase poner / e acomular con este proceso lo qual todo dixo que / pedía e suplicaua a su señoría por la mejor for / ma e manera que a su derecho conviniese y pidió / sobre todo serle hecho entero cumplimiento de jus / ticia y en lo necesario ynploro el oficio ylustre de / su señoría y los firmó de su nombre siendo presentes / por testigos el capitán Rodrigo Docanpo e An / tonio de Quiñones camarero de su señoría e Alonso / de Origuela, el licenciado León. Y luego su señoría del / dicho señor gobernador dixo que lo oye y abiéndose este / pleito por concluso y mandaua y mandó a mí el //

/ 137 r. / dicho Francisco Paez que juntase e acumulase el dicho / proceso que el dicho fiscal presentaua con este y que él / lo verá e determinará sobre todo lo que hallare por / justicia. Testigos los susodichos, el licenciado Vaca / de Castro. Visto por mí el licenciado Vaca / de Castro cauallero de la horden de Santiago, del Con / sejo real de sus majestades, gobernador e capitán / general en estos reynos y probinicias de la Nue / va Castilla y Toledo, llamado Perú etcétera por sus ma / gestades los delitos e crímenes públicos y notorios / que an cometido don Diego de Almagro, hijo del maris / cal Diego de Almagro difunto e Juan de Herrada / e Pedro de Porras, difuntos, y Pedro de Sanmillán / e Juan Rodríguez Barragán y Gerónimo de Alma / gro e Antón de Almagro y Francisco de la Fuen / te e Juan de Guzmán y Bartolomé de Arbolancha e / Coronado e Martín Dejaso y Martín de Bilbao y Fran / cisco Núñez e Cabezas e Santiago de Pontejos, comen / dador de San Juan e Sosa cauallerizo del marqués / e Baltasar Gómez y Narbaez, difunto e Diego / Ruiz de Durango, clérigo y Ramiro de Baldes / e García de Albarado y Francisco de Chabes, difuntos, e Ramírez y Pedro de Mendoza y Francisco Pezes / e Martín Carrillo y Velázquez y Herencia e Diego 
de / Ávila e Alonso de Saabedra e Juan Muñoz el capi / tán y Muñoz el cantor e Diego Méndez y Mar / tel y el bachiller Enríquez, difunto, e Juan Tello / e Juan de Mazariegos e Antón de Ribera y Pedro / Barba y Loaysa y Poblete y el sevillano y Alonso Va / lles e Cansino y su hermano de Andrés Hernández e / Pereyra y Pantoja y Nauarro el de la pedrada y San / tiago el de la cuchillada en el pescuezo y Cristóval de / Sotelo, difunto, y Rengifo y don Baltasar de Peraza e / Coronado el manco y Cristóval Carrilo y los dos herma / nos Juan de Verrío y Francisco de Berrío e Diego de Hozes //

/ 137 v. / e Juan Gutiérrez Maraver y Marchena y Picón y Bielma / e Rocha y Francisco López y Pineda, paje del Adelantado / e Juan Vázquez de Osuna y Pantoja huésped y Hor / dóñez e Hordóñez y Pura y Lugones, difunto y Cornejo e / Quadra criado de Diego Méndez, difunto, y Pedro Riquel / me y Ribera, difunto, y Peralta y Pedro de Oñate y / Pedro de Candia y Antón Pérez herrero e Pedro de Here / dia e Alonso Diez, el herrador, e Juan Bartolomé y An / tonio de Agüero y Arrinaga y Juan Sánchez Copin e Juan / de Almagro y Martín de Oribe y Francisco Martínez de / las piernas gordas y Palomares e Ábila, jugador, e / Carreño, portugués, e Rodrigo Martínez y su hermano / e Aguirre el tuerto y Juan el sastre y Suárez y Moria / na, Cárdenas y Marticote e otro Moriana y Juan / Gómez e Albornoz e Antón de León y Pedro de Zárate / e Alonso Diez, sastre, e a todos los otros aliados / e secazes del dicho don Diego de Almagro y personas que / andan y están en su compañía que he aquí por espresados / en matar como mataron sobre acuerdo librado al mar / qués don Francisco Pizarro, adelantado e gobernador / e justicia mayor en estos reynos por su magestad e / hazerse reciuir por fuerza de armas el dicho don Die / go por gobernador destos reynos y alza[r] vanderas / contra la cesárea y católica magestad e hizieron jun / tas de gente con tiranía para apoderarse destos reynos / como lo hizo y ocupó las ciudades de los Reyes y Truxillo / e San Miguel e después la villa de Guamanga e / ciudad del Cuzco y villas de Charcas y Arequipa e se a / poderó y usurpó toda la justicia real e abiéndome / puesto su magestad en la gobernación del Nuevo / Reyno de Toledo como lo tenía el mariscal don Diego de / Almagro, difunto, no an obedecido las probisiones de / su magestad ni reciuido a mí en su lugar antes quitó / el teniente que estaua puesto en mi nombre en //

/ 138 r. / la ciudad del Cuzco y tomaron e robaron las rentas / e quintos reales de su magestad y los bienes de los di / funtos e otros depósitos de personas particulares que / avía en las dichas ciudades y villas y saquearon el / dicho don Diego y sus secazes y aliados las casas del dicho / marqués y de otros y tomaron todas las armas y cauallos / de los vezinos y seruidores de su magestad y mataron jun / tamente con el dicho marqués a Francisco Martín su herma / no y al capitán Francisco de Chaves y a otros e robaron por / los caminos y de las yglesias y monesterios mucho oro e / plata y armas y cauallos y mataron sin culpa publica / mente so color de justicia al secretario Antonio Picado e An / tonio de Origuela e Alonso Cabrera e a Villegas e a Voz / mediano y a Montenegro y a otras personas e an hecho / otros muchos delitos y tiranías e ynsultus y como / an desovedecido mis mandamientos y probisiones / e como perseberando en los dichos sus delitos e tira / nías an salido con las dichas juntas de gente a punto / de guerra con banderas y estendidas contra mí y / estandarte real de su magestad e contra los / caualleros y gentiles hombres que van devaxo de la / pacificación destos reynos para pelear contra / nosotros y nos espunar [sic] y desbaratar y apoderar / se destos reynos y como se an estendido a tanto / sus delitos que an tenido acordado e determinado / no solamente de tomar e ocupar estos reynos pe / ro los de Tierra Firme, Panamá y Nonbre de Dios e defen / dello todo a su magestad en todo tienpo e como los suso / dichos se juntan y ponen con el 
dicho don Diego para ha / zer mal e deseruicio a su rey y procurar que sea des / apoderado del reyno y procurar que la tierra no / obedezca al rey e se alcen contra él en tan grandí / simo daño y destruyción del pro común al della e //

/ 138 v. / como an hecho pregones públicos e juramentos para se de / fender a su magestad de que an hecho gran daño a su ma / gestad e a la tierra e ansimismo an dicho muchas pala / bras feas en gran desacatamiento de su ynperial / persona y como no obstante todo lo susodicho querién / dolos tratar como a vasallos de su magestad les en / bié mis probisiones y amonestaciones para que derra / masen la dicha gente de guerra y aparatos della y vi / niesen a favorecer contra su lebantamiento e al / teración destos reynos al estandarte real e a mí / en nonbre de su magestad y a los dichos caualleros e / gentiles onbres que andan en su seruicio y como luego / determinadamente respondieron que avían de / continuar su dañado propósito e dar vatalla co / mo parece por sus cartas y dichos de los mensajeros / que les fueron por mí enviados con las dichas pro / bisiones e bienen ya de presente desta parte del a / siento de Vilcas donde les / fueron dadas las dichas / amonestaciones continuando su mal propósito / y están tan cerca del real de su magestad e según / que todo lo susodicho es muy público y notorio e / como por la mucha notoriedad dello no ay nece / sidad de otras más probanza e aberiguación alguna / e ansí lo pronunció e declaró y visto todo lo de / más que sobre ello se debía ber y mirar atenta / la calidad de todo lo susodicho y el estado en que es / tá fallo que devo de declarar e declaro a los / dichos don Diego e los susodichos sus aliados e se / cazes aver cometido los dichos delitos y auer yncu / rrido en delitos e crimen de lege magestatis y trayción / contra la sacra, cesárea cathólica magestad y per / duliones e contra el estado y pro comunal y bien / de la cosa pública destos reynos y ansy pronuncio //

/ 139 r. / e declaro a todos los susodichos por tales tray / dores en consequencia de lo qual devo condenar / e condeno al dicho don Diego e a todos los susodichos / e a cada uno dellos en pena de muerte natural / la qual les sea dada y executada en esta / manera que a do quiera que sean ávidos se / an presos a las colas de dos cauallos e otras / bestias arrastrados públicamente con voz / de pregonero que manifieste sus delitos por / las calles de los pueblos e asientos donde pu / dieren ser ávidos e llevados a las picotas / públicas e sean hechos quartos e puestos / los dichos quartos en palos por los caminos / públicos y ansimesmo les condeno en per / dimiento e confiscación de todos sus bienes / aplicados para la cámara y fisco de sus / majestades e mando que sean derrocadas / sus casas que tuvieren en estas provincias / e puestos en ellas mármoles de piedra con / letreros e que declaren los dichos delitos e que / los susodichos e sus hijos nascidos después de la / dicha trayción sean ynfames para sienpre / e no puedan aver honra de cauallería ni dinidad / ni de otra honra ni oficio público ni los / tales sus hijos puedan heredar a ningún pa / riente que ayan ni otro estraño que los establez / can por herederos ni puedan aver las / mandas que les fueren hechas e sean priva / dos e ynábiles de todo ello para en todo / tienpo como hijos de tales traydores a / su magestad e ansí lo pronunció e mandó / por esta mi sentencia difinitiba juzgando en / estos scritos e por ellos, el licenciado Vaca / de Castro. Dada y pronunciada fue esta sentencia //

/ 139 v. / por su señoría el dicho señor gobernador en el real de su magestad / que está en el asiento de Chupas cerca de la villa de Guamanga / en diez e seis días del mes de setienbre de mil y quinien / tos y quarenta e dos años en presencia de mi Francisco Paez / su secretario y escriuano de sus majestades siendo presentes / por testigos Peralvarez Holguín, capitán e maestre de / canpo del real de su magestad y Peranzures y Gómez / de Albarado e Rodrigo Docanpo y Alonso de Albarado / e 
Nuño de Castro e Juan Velez de Guevara y Pedro de / Vergara, capitanes del dicho real y otros muchos e an / si dada y pronunciada la dicha sentencia que suso ba / encorporada. Luego el dicho señor goberna / dor en nombre de su magestad dixo que mandaua / e mandó a todos los capitanes caualleros e / gentiles hombres e soldados que están en este / canpo de su magestad devaxo de su estandarte / real que executen la dicha sentencia en los susodichos / e en cada uno dellos e si se defendieren que los / maten como a malos traydores y delinquentes e / otrosi digo que vista la gran lealtad e / fidelidad e grande ánimo e voluntad con / que los dichos capitanes caualleros y gen / tiles hombres e sodados que están en / este real de su magestad se an juntado / a serbir a su magestad en la pacificación / e restauración destos dichos reynos que esta / van tiranizados e usurpados por los susodi / chos con el dicho señor gobernador devaxo del / estandarte real e lo mucho que an tra / vajado e gastado e perdido que demás e / aliende de las mercedes que merezen que su / magestad les haga e él en su nonbre les / dava e dio canpo franco contra los di / chos don Diego de Almagro y sus secazes para //

/ 140 r. / que todo lo que ovieren e tomaren sea / suyo e lo firmó de su nombre siendo pre / sentes por testigos los susodichos el licenciado / Vaca de Castro e luego yncontinente en el / dicho real en el dicho sáuado diez e seys / días del dicho mes de setienbre del dicho año / ante su señoría del dicho señor gobernador e / capitán general y en presencia de mí el dicho / Francisco Paez secretario e escriuano de / su magestad presentes los capitanes ca / ualleros e gentiles onbres del dicho real de / su magestad se pregonó públicamente por / voz de Niculás pregonero público acostunbra / do la dicha sentencia e autos segund que están / firmados del dicho señor gobernador por / tres vezes en tres esquadrones ca / be el estandarte real e donde estaua / la dicha gente e algunos dellos lo pidieron por / testimonio a lo qual fueron presentes / por testigos los dichos capitanes e otros / muchos. Pasó ante mí Francisco Paez. E / después de lo susodicho en el dicho día sáua / do diez e seis días del mes de setienbre / del dicho año en presencia de mí el dicho / Francisco Paez su señoría el dicho señor gober / nador e capitán general porque fue yn / formado que el dicho don Diego e sus secazes / continuando su mal pensamiento / venía ya muy cerca del real de su mages / tad a punto de guerra para lo destruyr / e desbaratar, mandó yr ciertos caua / lleros que fuesen a descubrir e correr / el canpo entre los quales fueron //

/ 140 v. / Hernando Bachicao e otros los quales dende a / poco bolbieron e dixeron al dicho señor go / bernador como el dicho don Diego y sus se / cazes venían marchando muy cerca hazia / el dicho real de su magestad e que avía / hablado con los corredores del canpo que por / parte del dicho don Diego andauan en el / canpo diziéndoles que viniesen e se re / duxesen al seruicio de su magestad los / quales avían dicho e respondido muchas / palabras feas e desonestas contra el / dicho señor gobernador e contra su mages / tad que acá le avía enbiado e que bibiese / el rey don Diego de Almagro e que presto se / rían todos destruydos e desbaratados por el / dicho don Diego e sus secazes e el dicho señor go / bernador mandó a mí el dicho escriuano que / se lo diese ansí por testimonio a lo qual / fueron presentes por testigos el capi / tán Rodrigo Docanpo e Gómez de Ro / xas e el capitán Alonso de Albarado / e otros muchos e después de lo susodicho / en el dicho asiento en este dicho día e / mes e año susodicho el dicho señor gober / nador dixo que mandaua e mandó a / nosotros los dichos Pero López y Fran / cisco Paez escriuanos de sus magestades / que diésemos por fe e testimonio todo / lo demás que pasase en execución de / la dicha sentencia que por él se dio contra / los susodichos en conplimiento de lo qual / damos por fe que visto por su señoría / del dicho señor gobernador lo susodicho // 
/ 141 r. / porque le pareció no estar en buen asien / to el real de su magestad para la bía / e propósitos que los susodichos tenían / mandó al capitán Nuño de Castro que con / ciertos gentiles onbres arcabuzeros de / su compañía fuese a tomar unas lomas / que estauan junto al dicho real e a es / torbar que el dicho don Diego e sus secazes / no asentasen el dicho su real allí e / para seguridad e guarda dellos mandó an / sy mismo al capitán Peranzures que con / la gente de cauallo de su compañía le fuese a ha / zer espaldas e a le faborecer e ayu / dar a lo susodicho los quales luego fue / ron a ello e luego yncontinente el dicho / señor gobernador armado en blanco con el / estandarte real de su magestad mandó a to / dos los capitanes caualleros e gentiles on / bres que con él estauan que dexando en / aquel asiento sus haziendas e tiendas / como estaua armado le siguiesen con sus / armas e cauallos a la ligera e él con ellos / fueron hasta ponerse encima de las di / chas lomas e yendo por la ladera dellas / el dicho señor gobernador concertó los / esquadrones de los dichos caualleros e gen / te de guerra e tomo para sí para socorrer / a la mayor necesidad obra de treynta e / cinco lanzas e caualleros e luego los visitó / por todos los esquadrones e los habló es / forzándolos e animándolos al seruicio de / su magestad e a que hiziese en él lo que debían //

/ 141 v. / con muy buenos razonamientos a / legría e animándolos e que en execución / de la sentencia que contra los susodichos te / nía dada los procurasen de desbaratar en ben / cer ofreciéndoles en nombre de su ma / gestad la satisfación e premio de sus tra / vaxos, seruicios e lealtad e hecho lo su / sodicho puesta la gente en la dicha horden mos / trando alegría e contentamiento e con es / fuerzo e valor comenzó a marchar con / la dicha gente e llegando los dichos caualleros / e gentiles onbres que yvan en conpa / ñía del dicho señor gobernador devaxo / del estandarte real de su magestad a la / asomada de unas lomas a donde se be / yan los reales uno a otro los dichos don / Diego e sus secazes parecía aver para / do e tener asentado real de las dichas / juntas de gente que con él venían a obra de / quarto de legua de donde yvan luego como lle / garon a vista los unos de los otros comen / zaron a disparar mucha artillería de tiros / gruesos que trayan contra el dicho señor gober / nador e los seruidores de su magestad / que con él estauan e vaxo el real de / su magestad por un vallecillo hazia donde / estauan los dichos don Diego e sus secazes / e allí se comenzó la vatalla donde pareció / que estando los seruidores de su magestad / en algún riesgo en ella por la mucha pu / janza de artillería, arcabuzes, armas e / cauallos que los contrarios trayan el //

/ 142 r. / dicho señor gobernador con la quadrilla e caualle / ros que consigo traya entró a los fabore / cer e remediar e fue Dios seruido que luego / se conoció la vitoria contra los dichos deseruidores / de su magestad e les fue ganada el artillería e / tomadas algunas de las banderas y estandar / tes que trayan y fueron desbaratadas co / mo por ello pareció en lo qual murieron y salie / ron heridos algunos seruidores de su magestad / e de los dichos contrarios que seguían al dicho don / Diego e otros dellos se prendieron luego ynfra / gante delito entre otros Pedro de Sanmillán / e Martín Carrillo e Melchor Velázquez e / Francisco Coronado el alto e Juan Navarro el / de la pedrada e Juan de Cárdenas capitán de / el dicho don Diego que fueron matadores del dicho / marqués don Francisco Pizarro de los quales se / hizo justicia e fueron arrastrados e hechos / quartos en el mismo asiento donde se dio la / vatalla e ansimismo fueron en seguimien / to de los que se avían desbaratado en la / dicha vatalla e fueron presos en la dicha / villa de Guamanga Pedro de Oñate e Diego de / Hozes e Juan Tello e Francisco Peces e Mar / ticote capitanes e Bartolomé de Arbolanche / e Rodrigo Barragán e Francisco de Saldibar / e Vasileo griego e Santiago el de la cuchillada / en el pescuezo e Martel e Mendo de Quesada / e Antón Noguerón que fueron en la 
muerte / del dicho marqués e los dichos capitanes los que / firmaron las cartas contenidas en este proceso / de los quales se hizo justicia por la forma suso //

/ 142 v. / dicha ecepto del dicho Juan Tello que solamente fue / degollado e ansimismo se prendieron otros muchos / y están presos para hazer dellos lo que convenga al / seruicio de su magestad segund que más largamente / se contiene en los autos y procesos que contra al / gunos de los susodichos se hizieron que nos refe / rimos en fe de lo qual lo firmamos de nuestros / nombres Pero López escriuano de su magestad, Fran / cisco Paez. Pregón mandado por don Diego de Al / magro, pusose en este proceso por mandado del dicho señor / gobernador. Señores capitanes, caualleros, gentiles / onbres, amigos y hermanos míos han vuestras mercedes de / sauer que la disciplina e arte militar hallada por el / gobernador de la república y freno de tiranos e / xercitada con guerras e desensiones suele ser causa / de la perpetua tranquilidad de los reynos donde / se mueven y pues en el Libítico se lee que mandó Dios / al pueblo judaico persiguiendo a vuestros enemigos / en tal manera que delante a vuestros pies los hagays / caer en las vatallas fueron las tales permitidas / por él para castigo de los ynobidientes desasosega / dores de repúblicas abatimiento de tiranos, / paz y tranquilidad del mundo y pues esto es ansí / muy justa es la guerra questá movida contra tan / to deseruidor de Dios e de su magestad e que el / capitán Peralvarez que los rige esté de voluntad / ynclinada a tiranizar claramente se a visto / pues no aviendo razón a que traxese así junta / de onbres vino a esta ciudad a desasosegar los / vezinos e avitantes della e Muño a los de las / Charcas, Arequipa y Guamanga a hazer el mismo / lebantamiento alzando bandera con título de ser / uidor de su magestad y su fundamento principal fue hazer //

/ 143 r. / comunidad la tierra para hazerse señor della por auer lo que no es justo tenga ni merece / y si sus locos pensamientos avían de ser remunerados en ygualdad con los tan crudos seruicios / del adelantado mi señor y padre a vuestras mercedes dexó que lo juzguen e desto dan claro testimonio / las probisiones de su magestad pues le hizo merced prometiéndoselas mayores desta gober / nación con negociar Hernando Pizarro lo contrario avaxando sus seruicios hasta el suelo me / nospreciando su persona e hablando mal della ante su cesáreo acatamiento y pues / ansí es justo título tiene de tirano y que lo[s] que con él van le tengan de alborotadores públicos pues / por sus particulares yntereses y por repartir entre sí el oro de su magestad de sus quintos / propusieron su seruicio en tanto daño de su real hazienda y pérdida de la tierra abiéndose / escrito a todos que estubiesen en sus casas e serían mantenidos en justicia y no les sería / hecho agrabio pues el que mató a mi padre quería matar a mí hera muerto, e dél solo es / peraua yo la venganza y no dellos y que solo su magestad hera el juez desta causa y él me / avía de justificar como mi rey e señor natural pues declaró Dios en ella su divina / justicia y permitió que diez o doze onbres vastasen estando el marqués entre to / dos sus amigos con el trono e triunfo de su señoría a darle muerte en que fuese ansí abatido el que / con una soberbia luziferina y con tan crecidos desagradecimientos pagó deuda tan crecida como debía a / mi padre por los grandes travaxos que pasó e gastos que hizo de su hazienda e de la de / sus amigos con tan sobrada deligencia por ponerle en el estado y señorío que tubo no queriendo / reconocer amistad a quien tan verdadera se la tenía ofrecida pudiendo él mandar / la tierra quiso antes poner a su amigo para que llevase el fruto de todo pues tan públicos / son los seruicios que hizo a su magestad en el descubrimiento destas partes para el beneficio y acrecentamiento / de Pizarro e ansí los ynbió con sus dineros a negociar para anbos la gobernación y con los / mismos desenpeños a él e a sus hermanos a la buelta que bolbió de Castilla que no pocas / heran las deudas que trayan y en esto se le debían dobladas gracias pues no teniéndolos bus / caua 
e se enpeñaua él por desenpeñar a ellos biendo que nayde se lo quería prestar / no me alargaré a más de dezir algo en suma para que los que no lo sauen sepan el pago que / dieron a mi padre aviendo él hecho por ellos lo que hizo, porque si todo se obiese de re / latar sería gastar mucho tiempo en lo que tan sabido se está y aunque Pizarro negoció / para sí solo la gobernación pasó por ello por no poner falta en su conpañero / ni ser por intereses oydos y luego lo puso en horden el armada y le enbió al / descubrimiento e dende a poco tiempo no sabiendo nueba dél fue < con más nabíos, armas y gente a buscar e de > aquel viaje le quebraron / los yndios un hojo y bueltos anbos desbaratados sin sauer el uno del otro acerca de / Panamá e Pizarro con boluntad de no bolber más a la empresa de nuebo mi padre bus / có entre sus amigos dineros e como si no obiera perdido nada puso otra armada en hor / den e contra su voluntad le tornó a enbiar con ella e dende a pocos días salió tras él / con más nabios e gente de socorro e hállose en Caxamalca que a no llegar a tal tiempo / los yndios matauan al gobernador y los de su compañía porque heran muy pocos e de allí con mu / cha cantidad de dineros queriendo a Hernando Pizarro tanto y más que a su hermano le despachó / a la corte y él le prometió de negociarle la gobernación después de los límites / de la de su hermano y ofreciéndole de hazer relación de todos sus seruicios a su magestad y llegado / antes hizo relaciones muy falsas y mentirosas por donde se colige que siempre / tuvo voluntad de pagar con desagradecimiento el bien que le hazían y de allí vino a esta //

/ 143 v. / ciudad e la pobló e bolbió a Quito a hechar de la tierra al adelantado / don Pedro de Albarado e por contemplación de su magestad y por no ser cobdicioso de / más que de la honra no quiso romper con él si no pagándole la costa de su armada / se bolbiese a Guatemala dexando la gente en la tierra y para en todo corroborar / el amistad dejando a su conpañero pacífico gobernador de una tan riquísima tierra siendo / la mitad della e de lo ganado suyo quiso igualar [a] Alexandro en el conquistar / como en el ánimo descubriendo otro nuebo mundo cumpliendo la corona real de / su magestad e ansí tomó nuebos trauajos en la demanda de Chile quando fuera razón / tomar descanso de los pasados y entendiendo en lo que digo los Pizarros entendían / en caluniarle aviendo enbiado a pedir quien les partiese los límites de sus / gobernaciones porque viniendo en ausencia de mi padre le haría tanto que señalasen / esta ciudad dentro de la sentencia si no pudiese con dádibas con temores e ansí vino el / Obispo de Panamá e después de muy bien visto hallaua que entraba en la de mi padre y / biendo el gobernador que estaua determinado de pronunciarlo ansí lo amenazó de suerte que no o / sándose declarar se bolbió e luego despacharon a Peranzures a que pidiese a su magestad / que por quanto el adelantado hera ydo a descubrir y podría ser bolbiese sin hallar / tierra donde poblar e se quisiese meter en la que no hera suya / y desto se podría recrecer algunos escándalos fuese seruido de dar una cédula en que mandase por ella / que cada una de las partes se estubiese quedo donde le fuese presentada hasta que los limi / tes fuesen partidos e su magestad ynbiase persona a ello por qualquier Obispo de Panamá no se auía determinado y esta se enbió a pedir con muy gran cautela y fue para que / sabiéndose la buelta de mi padre les saliesen con ella a reciuir a esos despoblados ha / ziéndole bolber o no pasar adelante que bien confiados estauan ellos que en nada avía de ser / contra el mandamiento de su magestad aunque obiese sido alcanzado y pedido con la mala yntención como / lo hera él que digo y ya que presumieron questa cédula sería avida enbiaron a Zauallos a que / pidiese a su Magestad la gobernación de mi padre para Hernando Pizarro diziendo que tenía por / nueva cierta de yndios que hera muerto él y los que llevaba consigo que avía / enbiado dos nabíos a buscalle condoliéndose mucho de su muerte porque con estas cau / telas fingiendo verdadera amistad su magestad le diese lo que pedía que quanto mi padre / trauajó por hazerles bien otro tanto se desbeló el gobernador e sus hermanos / en hazerle mal por abarcarlo 
todo para sy gozando del sudor axeno e biendo / Dios quan mal le pagaba quiso que conociese todo el mundo las malas voluntades / que contra la suya tan buena le zizañaban y ansí se lo escribieron al camino quando / yvan e con todo esto nunca quiso que faltase por él el amistad que avía prometido / e juntamente con estas cartas fueron los despachos de su magestad desta gober / nación en que le mandaua viniese en su nombre a gobernarla pues bien la merecía e / ansí bolbió con determinación de llegado aquí enbiar capitanes a que hi / ziesen a su magestad el seruicio que él deseaba halló que el ynga avía quitado el cerco / que tenía puesto en esta ciudad porque si su tornada no fuera, los yndios mataban / a todos los que aquí estaban y a Hernando Pizarro que hera teniente de su hermano / e aunque sus valedores digan el contrario ello fue ansí verdad. Venido a platicar / por Hernando Pizarro presentándole las probisiones de su magestad firmadas //

/ 144 r. / e selladas de su real mano e sello desta gobernación pidiéndo / le por merced las obedeciese e después de muchos cumplimientos que con él / tuvo reconoció que le quería defender la ciudad por armas y ansí $\mathrm{u} /$ na noche porque no obiese muertes de onbres que solo uno mataron los del / galpón prendió mi padre a Hernando Pizarro como es público e quitado el / de en medio los del cabildo unánimes y conformes le recibieron / por governador con que diese la probanza que esta ciudad cae en los límites desta / gobernación e ansí la dio bastantísima de pilotos, personas fidedinas / e de sana conciencia y hecho esto llevando consigo a Hernando Pi / zarro se fue con su conpañero a uer para dar horden en que no obiese / alteraciones ni muertes de onbres porque no fuese su magestad desser / uido rogándoselo y pidiéndoselo por merced de parte de Dios e del rey / e que fuesen buenos cristianos y lo escribiesen ansí a la corte / y esperasen el mandado de su magestad yn formándole de todo porque aquel / sería obedecido y el gobernador se estubiese en Lima y mi padre se re / tirase a esta ciudad e como esto se hiziese soltaría a Hernando Pizarro e / ansí se juntaron el gobernador y mi padre e Hernando y Gonzalo Pizarro e juraron los / capítulos de la paz e hermandad como buenos y fieles cristianos con / ceremonias muy solenes ynponiendo sobre quien lo quebrantase mal / diciones que bien se ha visto si le alcanzaron y espero en Dios alcanza / ran a los dos que quedan e hecho esto fue suelto Hernando Pizarro / e a esta coyuntura llegó Peranzures con la cédula de su magestad que fue / Dios servido viniese a tiempo que se hallase mi padre en Lima y Xauxa e / aunque pudiera estarse donde le tomó la voz della quiso cumplir lo que / avía prometido e ansí se retiró a esta ciudad y aun la tinta de lo / que avía jurado e firmado no estaba bien enjuta y la voluntad de / quebrantárselo hera muy vieja e ansí comenzó el gobernador a hazer gente e / vinieron con ella Hernando y Gonzalo Pizarro a esta ciudad a dar la vatalla / a mi padre por guardar Dios el castigo a Hernando Pizarro a tiempo que / más lo sintiese le quiso dar la vitoria y prendióle y con malos tratamientos / que muchos se hizieron después de benzidos muchos de vuestras mercedes son testigos / pues pasaron por ellos y no teniendo respeto Hernando Pizarro a que mi pa / dre cumplió muchas vezes sus necesidades y a las obras dél reciuidas / estando ya la pluma de la carne del amigo le mató por tomarle su gober / nación e robarle su hazienda e de sus amigos teniendo por cierto que muerto él no / avía quien le pudiese matar y usaría libremente de todo. No él [sic] quiso / perdonar la vida enbiándole a su magestad a que mandase justificarle antes //

/ 144 v. / de onbre pribado se hizo de hecho justicia mandándole sacar medio muer / to a esta plaza con una soga a la garganta e como sayón sediendo / de sus bienes le hizo cortar la cabeza vuestras mercedes bean si muerte execu / tada con tanta crueldad e con tanta razón fuera justo la oviera yo como / buen hijo muchos días a vengado, sufrime creyendo que su magestad man / dara como rey 
justiciero que es que fuera castigado por como el / cardenal presidente de las Yndias tuviese el deudo de Hernando Pizarro / por más principal que la onra de su magestad tenía tanta vigilancia / en que no supiesen los agravios e ynjusticias que acá se hazían que / syn autoridad de nuestro rey entre conpadres estando a ello presente Hernando / Pizarro se justificó su causa como él quiso y estando Dios harto / de sus maldades y satisfecho de nuestra paciencia viendo que en la tierra no avía justicia enbió la suya del cielo con la qual me hizo vengado / del todo e ansí que tornando al propósito después que Hernando Pi / zarro ovo muerto a mi padre fue por toda esa tierra del Collao e / Charcas robando a los caciques e yndios matando y quemando a los que no le davan el oro y plata que tenían y sacándoles todas sus obe / jas, comida e ropa de que avía gran carestía por las guerras pasadas enbiándolo a rescatar todo a esta ciudad hizo dello / gran cantidad de oro y plata como es notorio y biendo los yndios / ser robados syn ninguna piedad reconocieron que aquel no hera / señor sino ladrón e ansí se lebantaron contra él donde por esta cau / sa murieron en el Desaguadero, muerte tan arrebatada algunos de / su conpañía que bien pareció vigilia de la fiesta que les ha venido / e por esto dezía Hernando Pizarro e los que con él fueron que avían / conquistado la tierra e ansí la dio a los que vinieron con él a matar / onbres quitándolo a los que lo avían seruido y descubierto y la mere / zía pensando que poblándola de sus valedores e teniendo de su parte / al Cardenal e a los del Consejo estarían siempre a su deboción no a / cordándose que al que de nada le dio ser le podía volver a lo primero / vuelto aquí con mucha suma de oro y plata se fue a la corte a dar / quenta al Cardenal diziéndole el recurso que le quedaba de las minas / de plata e la cantidad que sacaría dellas en todo año para le enchir / aquella codicia frailesca e conciencia de teólogo para no poder / en la vida auer justicia ni hazérnosla de nuestros agrabios aviendo / ynterese tan crecido syno ser desto agraviados como ellos publi / cavan. Venía un licenciado despachado de dicho Cardenal sólo a sustentar //

/ 145 r. / la causa de Pizarros como se parece por la copia de los capítulos que traya / e por las cartas quel secretario Cobos e Cardenal e algunos de los del Consejo / escreuían de cada día al gobernador e que a todos alcanzaba en el soborno que se / hallaron en casa del marqués quando le mataron y están aquí e / podrán las ver cada uno que quisiere quando le pareciere porque se / satisfaga más por entero viendo las traiciones que en daño de / la honra de su magestad e de la justicia de mi padre e de todos vuestras mercedes / y mía e de lo nuestro se cometiron tan disolutamente e a la clara / siendo el principal tramador della el Cardenal por las causas / dichas por tanto vean vuestras mercedes si defiendo buena causa e lo que digo / de los capítulos e cartas no es por color arnada [sic] sino por decir verdad a / me parecido dezir lo contenido en esta escritura para que los que / no sauen porque yo tomado las armas contratando de seruicio de Dios / e del rey y enemigos de todos que sustentan lo malo que Pizarros / hizieron lo sepan y aunque soy cierto no auer necesidad de exorta / ciones para traer a vuestras mercedes a la sustentación de causa tan justi / ficada todavía he querido que vean mi justicia para que con más en / teras voluntades ayuden a defenderla e se obliguen de nuebo a lo que / tan obligados están por lo pasado pues a mí en nombre de su magestad queda de grati / ficar tan señalados seruicios como le harán en esta empresa y porque por espirien / cia se ha visto e cada día se ve muy necesaria la unión y conformidad en / tre las personas que tienen cargo de gente e la gobiernan para que aunque sean muchos / los que mandan y los mandados seamos todos una cosa en lo que toca a la susten / tación de lo que tenemos en la mano pues romanos tanto fueron señores / de lo mucho que conquistaron quanto se gobernaron con una voluntad / enderazada a la sustentación del menor de su república e como entre / ellos reynaron disensiones y enbidias particulares no bastó su / gran poder para que se dexase de venir a deboción 
de sus enemigos e / porque por el consiguiente podamos atraer a la nuestra a los nuestros dándoles ley / en que biban es muy conviniente esto y bueno que aya entre nosotros mu / cha conformidad faboreciéndonos como buenos amigos y hermanos mirando / cada uno e teniendo delante los ojos el bien y amor del próximo e / quitando e desarraygando las malas voluntades, chismerías, enbidias y par / lerías que no traen otro fruto sino desasosegar al que las trata y estar mal con / quien por ventura no se lo merece perdiéndonos sin ver enemigos y para / que en una voluntad nos gobernemos conviene que todos vuestras mercedes nombrados en el / principio deste parlamento juren de mantener y guardar los capítulos que de / lante se dirán y lo contenido en ellos y yo juraré lo mismo y otros que tocan / a cunplir a mí en beneficio de todos vuestras mercedes y en su utilidad y provecho conju / rándonos juntamente como buenos hermanos e jurando cada uno por sí e todos por //

/ $145 \mathrm{v}$. / uno de cunplirlos como en ellos se contiene para que seamos tenidos / donde se supiere por ombres de razón a que la anteponemos en todas / nuestras cosas a nuestros apetitos y voluntades por seruicio de Dios e de / su magestad pues dexado esto aparte somos tenudos a tener por pren / cipal cunple tanto a la sustentación, paz descanso e quietud / de todos en general quanto al primero capítulo digo ques muy público e / notorio que su magestad por sus reales probisiones las quales se an leydo / muchas vezes en esta plaza a voz de pregonero hizo merced al adelan / tado don Diego de Almagro mi padre desta gobernación del Nuebo / Toledo de ques es la cabeza esta ciudad del Cuzco por sus muchos e señalados seruicios y para que al tiempo de su fin e muerte pudiese dexar a / la persona que le pareciere la dicha gobernación para que la tubiese / como tal gobernador en nombre de su magestad e ansímismo nonbró a mí en / su testamento para que gozase de las mercedes a él hechas como su hijo na / tural y no auer tomado posesión hasta pocos días a dello fueron / causa el marqués e sus hermanos que nunca la quisieron ove / decer como an hecho todos los demás mandamientos de su magestad que no ha / zían a su causa y en provecho de sus intereses pensando quedarse / con la gobernación y pues yo soy avido e tenido por virtud de las / dichas provisiones por gobernador e reciuido por todos / los cavildos de la gobernación en nonbre de su magestad an de jurar / vuestras mercedes de me tener por tal gobernador e que cunplirán e o / vedecerán mis mandamientos como son obligados e deben allá los súbditos y vasallos de su magestad e que en ninguna cosa harán / lo contrario. Yten por parecerme cosa muy necesaria para a / certar en el seruicio de su magestad en sustentación e conserba / ción de todos tener quien me conseje bien y fielmente porque / por mi poca espiriencia podría herrar en el camino de la / razón no por desear yo yr fuera della y por probeer este yn / conbiniente e nonbrado y nonbro para que juntamente sus / tenten conmigo e me aconsejen en todas y qualesquier cosas / ansí que toquen a la guerra como a lo demás y lo que convenga / en todo hazerse sin reserbar ninguna a que siendo como son / personas de calidad que tienen méritos, suficiencia y espiri / encia para todo lo que digo me a parecido nonbrarlos entre todos / no porque los que de vuestras mercedes quedan aya falta de personas que / tienen las calidades dichas y más para se les poder encargar lo / mismo y cosa más dura pero por no poder caber la suerte de pocos //

/ 146 r. / a muchos e yo llegado los que digo y an vuestras mercedes de jurar de guardar / e ovedecer lo que por mí y por ellos fuere acordado, hordenado e man / dado de los quales e de cada uno dellos tomaré aquí en presencia de vuestras / mercedes juramento solene en forma que me aconsejaran en Dios y en sus / conciencias lo que alcanzaren convenir al seruicio de Dios e de su magestad e mío / bien e acrecentamiento de todos en general e que por amor, temor, enemis / tad de ser el uno más 
quel otro en el mandar no me dirán e aconse / jarán sino lo que se les alcanzaré convenir al bien e sustentación suyo / e de todos. Yten por quanto yo despaché a su magestad persona propia / con mis cartas en el punto que fue muerto el marqués haziéndole / sauer su muerte y todo lo pasado y dándole quenta de los grandes agra / vios recibidos y tan obexecidos [sic] para que mandase prober con jus / ticia y presto lo que más conviniese a su seruicio diciendo en mis cartas / como yo quedaua como su gobernador en tanto asistiendo a la susten / tación e pacificación de la tierra e de sus rentas, quintos, hazien / da diziendo los engaños y maldades quel presidente y cardenal con / algunos de los del su Consejo en menosprecio de su cesárea honra / por los sobornos de Pizarros disimulaban negando a su magestad la / verdad porque no mandase prober de justicia por tanto que an / de jurar vuestras mercedes que hasta en tanto que su magestad ynformado de la verdad / de todo lo subcedido ynbie a mandar lo que fuere seruido se haga en la / probisión desta gobernación que yo en su nombre y por sus probisio / nes poseo me seguirán e serbirán en nonbre de su magestad sustentando mi / persona defendiéndola, faboreciéndola ayudándome contra todas e / qualesquier personas de qualquier estado e condición, calidad que / sean que contra mí quisieren venir y tomaren armas para me dañar e / contradezir la causa que todos sustentamos e aunque se declaren / en esta escritura hasta que como dicho tengo se sepa la voluntad de / su magestad ynformado de toda la verdad e que con todas sus / fuerzas la sustentarán e defenderán e a mí con ella hasta / la muerte. Yten tenemos de jurar e prometer como buenos cristia / nos de nos amar e querer como hermanos para que sea una voluntad la / de todos pues como tales nos conjuramos y juntamos para esto / e de tal manera nos confederamos que ni en dicho ni en hecho ni / consentimiento no seremos unos contra otros e si alguno oviere / y por tercera persona que otro anda en tratos de mala desistión [sic] / e perjudiciales en deseruicio del gobernador e de lo que conbiene a todos //

/ 146 v. / o aya dicho palabras escandalosas y para al / terar voluntades que las tales son muy odiosas en / todo tiempo para que sean castigadas como conbiene las / venga a declarar de que las oyere o viniere a su no / ticia dentro de un día natural ante mí so pena de / perjuro e fementido e de ser castigado si por otra al / guna arte se alcanzare a sauer que alguno lo supo y no lo / declaró dentro del dicho día y esto a de durar todo el tiempo / que durare la guerra contra nuestros enemigos pues guardán / dose ansí no se dará lugar a cosa malhecha ni dicha don / de se junta tanta conformidad y hermandad. Yten por / que vivan todos vuestras mercedes con confianza de ser re / munerados de sus trauajos e seruicios pues sirben a su / magestad e a mí en su nombre ayudando a poner en su obidien / cia los alteradores desta tierra es justo saquen el fruto / dellos que es razón y para que más confiados estén que / ay de que digo que juraré agora primero que todos de / guardar todo lo aquí capitulado e que no he dado a / persona ninguna cédula de yndios de repartimiento ni / la daré a ninguno sino que salidos que seamos desta ciu / dad en demanda de nuestros enemigos para los echar / de la tierra e castigarlos conforme a sus deméritos que / darán todos los yndios en mi cabeza los quales pro / meto e juro como cauallero de los dar e repartir syn / quedar ninguno sin hazer ecebción de personas más de / conformarme con lo que cada uno sirbiere e con las / calidades de sus personas remunerándolos a to / dos e que no miraré antigüedad porque esto es la bi / ña de Dios que el que sirbiere agora que es la postrera / ora del día para venir al descanso que deseamos / será remunerado sirbiendo bien e con voluntad / tan bien como el que madrugó e para los que / no oviere yndios que darles y no quisieren per / seberar acá serán gratificados con dineros para / que se puedan yr a España o a donde por bien / tubieren o a los demás que tubieren otra voluntad // 
/ 147 r. / se les dará armas y cauallos y todo lo que obieren menester pa / ra que con el capitán que se les dará muy a su contento vayan a / descubrir que se tiene noticia que ay mucha tierra e muy rica e / prometo de lo cumplir de manera que nayde tenga causa justa / de se quexar ni dar por mal enpleado el tiempo que gastare en / seguirme y todos roguemos a Dios nos de gracia para que / guardemos y cunplamos lo que aquí juramos de manera que sea / en su seruicio amén. E yo Diego Descalante scriuano público e / del Consejo desta ciudad del Cuzco doy fe que en treynta de abril / del año de mil y quinientos y quarenta e dos años estando / don Diego de Almagro en esta ciudad del Cuzco con mucha gente de / guerra teniendo la ciudad y justicia della más por fuerza que / por voluntad aviéndose hecho reciuir por gobernador / diziendo ser suya la gobernación del Nuevo Reyno de / Toledo ante sus capitanes e gente de guerra él y ellos / en unas tierras de Gonzalo Pizarro que son junto a / esta ciudad hizieron un alarde de toda la gente y en pre / sencia de todos estando yo el dicho escriuano mirando lo que / hazían bi e oy apregonar los autos y capítulos atrás / contenidos por su mandado siendo scriuano dello Gas / par de Rojas ante quien pasaua y por pregonero Hernan / do de Benalcazar a lo qual se hallaron muchas gentes / presentes demás de las que seguían al dicho don Diego e / yo después de apregonado saqué este treslado de los / dichos capítulos a hefeto de avisar a su magestad o al / ylustre señor licenciado Vaca de Castro su presidente / de la audiencia real de Panamá dello e doy fe que ba ver / dadero y paso y lo firmé aquí de mi nombre Diego de / Escalante. Después de lo qual los del dicho nuestro Consejo / Real de las Yndias aviendo visto el proceso del dicho / pleito dieron y pronunciaron en el sentencia difinitiba / su thenor de la qual es este que se sigue: Visto por nos / los del Consejo Real de las Yndias de su magestad e pro / ceso criminal que es entre el licenciado Villalobos fiscal / de su magestad acusador de la una parte y el licenciado / Vaca de Castro gobernador que fue de las provincias del //

/ 147 v. / Perú reo acusado de la otra sobre las causas y capítu / los en el proceso del dicho pleito contenidos fallamos / atentos los autos y méritos deste processo que devemos / pronunciar y pronunciamos en la forma siguiente: que en quan / to al primer capítulo en que el fiscal acusa al dicho licenciado / Vaca de Castro diziendo que no pudiendo lleuar cargados los / yndios e debiendo castigar a los que hiziesen lo contrario los / lleuó cargados como bestias más de ciento dellos con sus ropa / e hazienda más de trecientas leguas sin darles cosa alguna / de que recibieron gran daño e muchos muerte que por / la culpa que resulta del dicho capítulo por el exceso que / ubo en el cargar de los dichos yndios y en no pagarles su tra / vaxo ni mandarlo pagar a otros que los cargaron devemos / condenar e condenamos al dicho licenciado Vaca de Cas / tro en docientos ducados aplicados la tercia parte dellos / para la cámara y fisco de su magestad y la otra tercia parte / para los religiosos que pasan a Yndias y la otra / tercia parte para los estrados deste Real Consejo e / más le condenamos en otros seyscientos ducados para los / yndios que ansí fueron cargados o sus herederos en / pago de lo que merecieron por su trauajo y en defeto / dellos por no ser abidos mandamos que se / gasten en un ospital en la dicha probincia reserbando / como reserbamos su derecho a saluo al dicho licenciado / Vaca de Castro para que si viere que le cunple pueda pe / dir los dichos seicientos ducados a su magestad o a otra / persona que fuere obligado a pagarlos. E otrosi, en / quanto al segundo capítulo de la dicha acusación en que / es acusado diziendo que deviendo poner en cabeza de / su magestad todos los yndios que vacasen no lo hizo an / tes los puso en su cabeza y él e sus criados lleuaron los / frutos dellos en quantía de más de cien mil caste / llanos que heran los yndios siguientes: los del mar / qués Pizarro y sus hijos que heran las ciudades de Tru / xillo e los Reyes y otros en la ciudad del Cuzco e / los que tenían Diego Méndez y Pedro de Oñate // 
/ 148 r. / e Juan Vázquez de Osuna e don Diego de Almagro y Hernando Pizarro / y en Arequipa otros muchos y la probincia de los Carangas con co / lor que heran de Diego de Aller y otros muchos en las Charcas / y en Guánuco y Chachapoyas y los de Juan de Baldibiesso e / los del Obispo del Cuzco lo qual todo pide el fiscal al dicho / licenciado Vaca de Castro que lo restituya a su magestad que por / lo que deste capítulo resulta que le devemos de condenar / e condenamos en tres mil ochocientos castellanos que el dicho / licenciado Vaca de Castro confiesa que por su mandado se co / braron y están a su cargo y los pagaron ciertas personas a / quien don Diego de Almagro sin tener poder para ello avía enco / mendado yndios en recompensa de lo que gozaron dellos más le / condenamos en treze mil castellanos que lleuó e cobró de los / yndios que fueron del marqués don Francisco Pizarro / en las probincias del Cuzco y Collao y en otros dos mil cas / tellanos que leuó de tributos de los yndios que dizen de / Guarua en la probincia de la ciudad de los Reyes que tan / bien fueron del dicho marqués y en otros veynte e ocho / mil castellanos que los dichos yndios de las probincias del / Cuzco y Collao que puso en su cabeza le sacaron de las / minas y los reciuió Gerónimo de la Serna su criado en / su nonbre segund que en la dicha su confisión se contiene / de las quales dichas sumas de castellanos en este capítu / lo contenidas e que ansí va condenado se le an de des / contar al dicho licenciado Vaca de Castro lo que parece / que se le debe de su salario contándole al respeto de diez / mil ducados por año de más de los cinco mil ducados que / él se tenía y esto por el tienpo que hizo y usó oficio de / gobernador de las dichas probincias del Perú que fue / desde que en la ciudad de Quito comenzó a aparexar la / guerra contra don Diego de Almagro hasta que le fue no / teficada la prouisión de gobernador que llebaua Blas / co Núñez Vela que subcedió en la gobernación porque / estos diez mil ducados de más de los cinco mil duca / dos que se tenía le señalamos de salario por año / por el tiempo que usó el dicho oficio de gobernador //

/ 148 v. / e por el más tiempo se le quente el salario a razón de / cinco mil ducados que tenía de salario por su probisión / los quales se le paguen conforme a ella. Otrosy le con / denamos en todo lo que más pareciere que cobró y se a / provechó de los yndios que como dicho es puso en su ca / beza para liquidación de lo qual mandamos se haga / más aberiguación y que se de cédula real de su magestad diri / gida al presidente e oidores de las probincias del Perú / en que se les mande que la hagan con toda deligencia. O / trosí, en quanto al tercero capítulo en que el dicho licen / ciado es acusado diziendo que estando proybido por / hordenanzas que ninguno pudiese vender en la tie / rra carnero ni obeja ni cordero sino fuese el obligado / que lo hazía guardar a todos y ponía estanco en ello y / en el mayz proybiendo que nadie lo contratase / sino él solo y un criado suyo en su nonbre que se / llama Gaspar Gil en lo qual ynteresó otros cien / mil castellanos los quales es obligado a restituir / a su magestad que por la culpa que deste capítulo re / sulta contra el dicho licenciado Vaca de Castro le deve / mos condenar e condenamos en quinientos ducados / aplicados para la cámara y para pasaje de reli / giosos a las Yndias y para estrados por yguales / partes e reservamos la demás pena para el / fin desta nuestra sentencia. Otrosí, en quanto al quarto / capítulo en que es acusado diziendo que estando en / la ciudad de los Reyes para yr a la probincia de Xau / xa recibió de los oficiales de su magestad en ropa pa / ra la gente quantía de sesenta mil ducados y retubo / en su poder mucha parte dellos sin lo pagar a los / soldados y puso tienda dellos en los Reyes y en el / Cuzco por dos criados suyos que se llamaban Mexía / e Gudiel en lo qual ynteresó más de otros cinquenta / mil castellanos y es obligado a lo restituir a su magestad / que le devemos absolber y absolbemos de lo que es a / cusado en este capítulo y le damos por libre e quito dello. // 
/ 149 r. / Otrosí, en quanto al quinto capítulo en que es acusado diziendo / que hizo dar al capitán Peranzures de la hazienda de su magestad / cinco mil castallanos quando venía a estas partes y es obligado / a los bolver que le debemos absolber e absolbemos de lo / en el dicho < quinto > capítulo contenido reserbando como reserbamos / su derecho a salbo al fiscal de su magestad para que no se pu / diendo cobrar del dicho Peranzures ni de sus fiadores lo pue / da pedir si viere que le cunple al dicho licenciado Vaca / de Castro si y en quanto de derecho aya lugar. Otrosí, en / quanto al sesto capítulo en que es acusado diziendo que / estando probeydo que no se hechasen yndios a las minas / e aviéndolo él de mandar ansí que se guardase no / lo hizo antes mandó echar mucha cantidad de yndios / a las minas specialmente a las minas de la probincia de / Carabaya e a otras muchas minas y murieron mu / chos yndios y sacaron más de cinquenta mil castellanos / e no pagó los jornales yncurrió en las penas en / que caen los que los hechan a las minas y pidese que / sea condenado en lo que sacó y en los jornales y en la / pena de la ley que por la culpa que deste capítulo / de acusación resulta contra él le devemos con / denar e condenamos en tres mil castellanos de pena / los dos mil dellos para hazer un ospital en a / quella comarca de tierra de donde fueron hechados / los yndios a las minas y los otros mil es para los di / chos yndios que ansí fueron hechados a minas e / sus herederos y en caso que no se hallen se junten con / los otros dos mil e se gasten en el dicho ospital y en / quanto a lo que el dicho licenciado se aprobechó de lo que / sacaron de las minas lo remitimos al segundo ca / pítulo donde le condenamos por ello y por la / más culpa que de este capítulo resulta remiti / mos la más pena para el fin desta nuestra sentencia. / Otrosí, en quanto al sétimo capítulo en que es / acusado diziendo que tomó de la hazienda de su magestad //

/ 149 v. / más de ciento e cinquenta mil castellanos y no a dado / quenta dellos que devemos condenar e condenamos / al dicho licenciado Vaca de Castro a que de todo lo que entró / en su poder de la hazienda de su magestad e de otra / persona en su nonbre de quenta con pago dello y en quan / to a la que por sus libranzas se dio a otras personas y no / entró en su poder mandamos que aquellos que lo reci / bieron den quenta con pago dello y en caso que aquellos / o alguno dellos no diere quenta o no se pudiere cobrar dellos / o de alguno dellos en qualquier manera el alcance que / se les hiziere se reserba su derecho a salvo al fiscal de / su magestad para lo pedir y si quando e como e donde vie / re que le cumple y en quanto a la quenta que parece a / verse tomado a Diego Mexía por Pedro de Avendaño / teniente de contador de la ciudad de los Reyes por / Juan de Cáceres contador mandamos que los oficiales / de su magestad que residen en la ciudad de los $\operatorname{Re} /$ yes tornen a reber la dicha quenta para que si en ella / oviere alguna falta pogan recaudo en la hazien / da de su magestad. Otrosí, en quanto al otabo ca / pítulo en que es acusado diziendo que por defraudar / el patrimonio real no manifestó lo que sacó de / las minas ni lo que obo de los réditos de los yndios / por no pagar el quinto que sería más de cinquenta mil / castellanos y para mejor desfraudarle el dicho quinto / hizo que un platero hiziese dos marcas y las tubo / en su casa y poder más de quatro días aunque los / oficiales de su magestad le requirieron que no / avía de auer más de una marca y que la metiese / en el arca no lo quiso hazer antes la tubo en su poder / e después que hubo hecho lo que quiso y marcado el / oro hizo llamar a los oficiales y al platero e re / machar la una e metió las otras en el arca e se pre / sume aver marcado su oro en los dichos días e aber come / tido el dicho delito por aver cometido otros que devemos //

/ 150 r. / absolber e absolbemos al dicho licenciado de lo contenido / en el dicho capítulo de acusación y le damos por libre / e quito dello. Otrosí, en quanto al noveno capítulo / en que es acusado diziendo que enbió de las probincias / del Perú a estos reynos más de ducientos mil caste / 
llanos a escondidamente con muchas personas en es / pecial con Alonso de Villalobos e Diego de Aller los / quales dize que después de traydo se bolbieron al Pe / rú y con fray Francisco Martínez y el capitán Peran / zures y Francisco Vezerra y Juan de Carranza y Fran / cisco de Ruyloba su criado el qual diz que traya más de / sesenta mil castellanos y se juntó con el licenciado / en Cuba e de allí los juntó con lo que traya e a / todas las personas con quien enbió el oro diz que los man / dó que no lo registrasen en su nonbre syno en / él dellos y ansí se hizo por encubrirlo todo lo qual / diz que a perdido con el quatro tanto conforme a las / hordenanzas que por la culpa que deste capítulo re / sulta contra el dicho licenciado Vaca de Castro le debe / mos condenar e condenamos en quatro mil ducados / de pena repartidos en tres partes según de suso. $\mathrm{O} /$ trosí, en quanto al dézimo capítulo en que es acu / sado diciendo que estando proybido por horde / nanzas que ningún oro ni piedras ni plata ni otras / cosas que vinieren de las Yndias se desenbarque / sino en Sevilla y se manifieste todo ante los ofi / ciales, fletó una carabela en la ysla de Cuba e / la enbió a Portugal con mucha cantidad de oro / con un criado suyo que se llamaua Arguello e lo / ascondió en Portugal y ansimismo el dicho licencia / do viniendo de la dicha ysla de Cuba en conserva / con la flota se derrotó a la ysla de los Azores / con toda su hazienda e de ay a Portugal donde lo //

/ 150 v. / ascondió sin traerlo a Sevilla e yncurrió en perdimien / to de todo ello con el quatro tanto que le devemos / asolber e asolbemos de lo contenido en este capí / tulo de acusación y le damos por libre y quito dello. / Otrosí, en quanto al onzeno capítulo en que es a / cusado diziendo que no enbargante que en Tierra Fir / me se le notificó una probisión real para que fue / se a hazer residencia no lo hizo ni enbió persona con / poder antes se bino huyendo continuando su derro / ta se vino a la ysla de los Azores y no publicamen / te sino por lugares e caminos escondidos que le / devemos asolber e asolbemos y damos por / libre desto con que se guarde lo questá probeydo / cerca dellos por cédulas e probisiones reales. / Otrosí, en quanto al dozeno capítulo en que es / acusado diziendo que no cumplió las cédulas / reales que le fueron dadas cerca del buen tratamiento / de los yndios y que no los consintiese cargar ni he / char a las minas y tasa de los tributos lo qual diz / que hizo por su propio ynterese por cargar él los yn / dios e heharlos a las minas y llevarles los / tributos que llebó que quanto a este capítulo / le devemos poner y ponemos culpa por lo que del / resulta. Otrosí, en quanto al trezeno capítulo / en que es acusado diziendo que aviéndole sido / mandado por real cédula e ynstrución que tobiese / especial cuydado de la hazienda real y tomase / las quantas della no lo hizo antes tomó y ocupó / mucha de la hazienda y aunque le fue notificada / la cédula en Tierra Firme no bolbió a hazer re / sidencia ni enbió ni se ocupó tanpoco en las otras / cosas que le fueron encomendadas que le deve / mos absolber e absolbemos de lo contenido en este //

/ 151 r. / capítulo y le damos por libre y quito dello. Otrosí, en / quanto al catorzeno capítulo en que es acusado dizien / do que debiéndose ocupar en cumplir las probisiones / e ynstruciones se ocupó en cosas suyas particula / res en el grangear de las minas y cobrar para sy los / tributos de su magestad y en rescatar con los yndios y / en el trato de vender por sí solo e por sus criados / todos los mantenimientos y ropa y con esto diz que / dexó de cobrar para la cámara los bienes de los / culpados en la muerte de don Francisco Pizarro y en / biar al Consejo los autos y sentencias dello para que / acá se cobraran los bienes de los tales culpados en lo / qual diz que a reciuido la cámara de daño más de docien / tos mil castellanos pídese que sea condenado en / ello y que a su costa se hagan las deligencias que le / devemos absolber e absolbemos de lo en este capítu / lo contenido y le damos por libre y quito dello. Otro / sí, en quanto al quinze capítulo en que es acusado / diziendo 
que aviendo de hazer sus autos e deli / gencias con don Diego de Almagro y sus secazes pa / ra que reduxesen al seruicio de su magestad no lo hizo / antes al tiempo del ronper la vatalla se apartó / con quarenta de a cauallo escogidos para guarda de su / persona e se puso detrás de un cerro y aunque / se agrabiaua la gente por sacalles a aquellos caua / llos escogidos y le dixeron que no lo hiziese y por e / llo estuvo a punto de perderse la vatalla que le / devemos absolber y absolbemos de todo en es / te capítulo contenido e le damos por libre e quito / dello. Otrosí, en quanto al capítulo diez e seys / en que es acusado que dilató la prisión a don Diego / de Almagro cinco o seis meses por gozar de los frutos / de sus yndios y estubo a punto de soltarse teniendo / puestas postas para yrse a Mango Ynga que es //

/ 151 v. / taua alzado e tornará rehacerse y lo mismo hizo / con Diego Mendez dilatándole la prisión por gozar / de sus yndios hasta que se fue que hera uno de los / más culpados que por lo que deste capítulo resulta / quanto a lo que toca a Diego Mendez le devemos po / ner culpa e reserbar como reserbamos la pena / para el fin desta sentencia. Otrosí, en quanto al / capítulo diez e siete en que es acusado diziendo que / sabiendo que su magestad enbiaba visorrey y abdien / cia con hordenanzas que no se encomendasen yndios / e que ningún gobernador tubiese encomienda de / yndios después de sabidas las hordenanzas dio mu / chas encomiendas de yndios a personas que no a / vían sido conquistadores ni seruido a su magestad sino / que heran sus criados, amigos y parientes y personas / de quien esperaba fabor e ynterese de dineros que / por lo que deste capítulo resulta contra el dicho / licenciado Vaca de Castro le debemos condenar e / condenamos en mil ducados aplicados segund / desuso e le devemos poner y ponemos culpa grabe y reserbamos la más pena que por ello merece / para el fin desta nuestra sentencia. Otrosí, en quanto / al capítulo diez e ocho en que es acusado que a / reciuido presentes en mucha cantidad de dinero/ oro, plata e joyas e otras cosas por dar repar / timientos, gobernaciones y capitanías e otros o / ficios y por disimular con otros culpados e por / que no quitase yndios a otros y por otras causas / lo qual fue más de cien mil castellanos e de lo de / vido a su magestad a tomado más de ciento y cinquenta / mil castellanos que en lo que toca a unas fuentes / de plata y una copa con sobrecopa doradas que el / fiscal pretende que un Diego de Mora dio al dicho licen / ciado Vaca de Castro devemos mandar y mandamos //

/ 152 r. / que se haga más aberiguación de la questá hecha para que / vista se haga lo que sea justicia y en quanto pretende el dicho / fiscal probar cerca deste capítulo quel dicho licenciado / enbió a un Orihuela a ranchear los yndios de Ysasa / ga en el Collao el qual diz que sacó del dicho rancho va / lor de ocho mil castellanos que por la culpa que deste capítu / lo resulta devemos condenar e condenamos al dicho / licenciado Vaca de Castro en docientos ducados de pena / aplicados como en los capítulos antes deste e re / serbamos la más pena para en fin desta sentencia. Otrosí, / en quanto al capítulo diez y nueve en quel dicho licen / ciado Vaca de Castro es acusado diciendo que sabiendo / del visorrey e audiencia que yva e de las hordenanzas / hizo juntar los pueblos del Perú e los persuadió que / no ovedeciesen las hordenanzas y a esta causa se levantó / la tierra e subcedieron las disensiones pasadas e / desseruicios de su magestad en lo qual diz que su magestad / a perdido más de un millón y es obligado a lo pagar que / le debemos absolber e adsolbemos de lo en este capítulo contenido e de la acusación criminal sobre es / to hecha e le damos por libre e quito della. Otrosí, / en quanto al veinte capítulo en que es acusado dizien / do que como onbre culpado en las tomas de la hazien / da real de su magestad y de particulares y en otras culpas / enuiaba dádibas de oro e de otras cosas a los / del Consejo de las Yndias e a sus mugeres e a otras per / sonas faborecidas e por dar color a sus delitos e / ynbió poder para recusar a los del Consejo e oydores / 
de la audiencia de quien no estubiese seguro que / le avían de favorecer que por lo que deste capítulo / resulta devemos poner y ponemos culpa al dicho / licenciado Vaca de Castro e reserbamos la pena / para en fin desta nuestra sentencia. Otrosí, en quanto / al capítulo veynte e uno en que es acusado diziendo / que por ser más aprovechado de la hazienda de su magestad //

/ 152 v. / e de los repartimientos de yndios e porque su magestad no fue / se avisado de sus culpas y excesos tubo mucho tiempo / detenidos los nabíos en los puertos de que su magestad / fue muy deseruido e los tratantes e maestros da / nificados en más de cien mil castellanos de oro en / lo qual se pide sea condenado que por lo de este capí / tulo resulta, devemos poner y ponemos cul / pa al dicho licenciado e reservamos para el fin / desta nuestra sentencia la más pena y en quanto al daño e / ynterese que dello pudo venir a la hazienda de su ma / gestad mandamos que se haga más aberiguación e / condenamos al dicho licenciado en todo lo que pare / ciere averle venido de daño y en quanto al daño / e ynterese de los tratantes e maestres les reser / vamos su derecho a saluo para que lo pidan ser / como vieren que les conbiene. Otrosí, por la culpa / que resulta contra el dicho licenciado Vaca de Cas / tro del terzero desto diez e seis, diez e siete y diez / e ocho e veinte y veinte y un capítulos desta / acusación lo devemos condenar e condenamos en / suspensión de su ofico e de tener cargos e o / ficios de justicia por tiempo y espacio de seys a / ños cunplidos primeros siguientes. Otrosí, en / quanto a la reconbención hecha por parte del dicho / licenciado Vaca de Castro contra el dicho fiscal en que / se pide treinta e nueve mil e novecientos / e noventa e nueve castellanos e quatro tomines / de oro que dize que alcanza a su magestad en la dacta / quentas en lo que gastó e reduzir e ga / nar el Perú conforme a una carta quenta fir / mada de su nonbre del dicho licenciado Vaca de Castro / en este proceso presentada en la qual se haze / cargo de lo que dize auer reciuido en el Perú de la ha / zienda de su magestad e de los yndios e des / pués da sus descargos por partidas menudas //

/ 153 r. / de los gastos que dize que hizo en seruicio de su magestad an / sí en comprar armas y cauallos para la gente como / en otras gratificaciones que hazía a la gente y en / comprar municiones e herraje e nabíos e otros / gastos de la guerra como en pagar salarios a los de / la guarda e a los menestriles que siruieron en la gue / rra e a otras muchas personas contenidas en la dicha / su quenta e tanbien lo que dio a los dueños de los / nabíos por la detenencia que hizo dellos e las deu / das que al presente dize que se deve que devemos / mandar y mandamos quel presidente e oydores de las / probincias de la audiencia y chancillería que reside / en la ciudad de los Reyes e con ellos juntamente los ofi / ciales de la hazienda de su magestad que allí residen hagan e / reciban la quenta que zerca de lo contenido en este capí / tulo de reconbención el dicho licenciado Vaca de Castro / o quien su poder obiere quisieren dar llamando prime / ramente la parte del fiscal de su magestad para verla / dar e hallarse presente e oyéndole zerca della e con que / no le reciban ni pasen en quenta lo que dize auer gastado / en los salarios de los de su guarda ni lo que obiere gas / tado en otros qualesquier gastos de su casa y au / toridad de su persona a tanto que para esto se le da / competente salario como arriba en el segundo capí / tulo de la acusación del fiscal se contiene e ansí he / cha la dicha quenta los dichos presidente e oydores / e oficiales la enbien a este Consejo con sus pare / ceres zerca della para que vista se haga e deter / mine en ella lo que sea justizia. Otrosí, en quanto / el dicho licenciado reconbiene ansimismo al dicho / fiscal en cinco mil ducados que dize que su magestad / le deue del salario de juez e también le reconbiene / en el salario de gobernador de la gobernación de / la Nueva Castilla y Nuebo Toledo de dos años / e ocho meses que dize que fue gobernador el qual salario // 
/ 153 v. / diz que a de ser conforme al que se daua a los gober / nadores don Francisco Pizarro e don Diego de Almagro / que quanto a esto nos devemos remitir e remiti / mos al dicho segundo capítulo de la dicha acusación que / por el fiscal le fue puesta donde está determinado / vastantemente cerca desto e por esta nuestra sentencia / difinitiba ansí lo pronunciamos e mandamos con / costas. El marqués, el licenciado Gregorio López, el licen / ciado Tello de Sandoual, el dotor Ribadeneyra, el licenciado / Bribiesca, la qual dicha sentencia fue dada y pronun / ciada por los del dicho nuestro Consejo en la villa de / Valladolid a diez e nuebe días del mes de abril del / año pasado de mil e quinientos e cinquenta e quatro / y en veinte y un días del dicho mes e año se notificó / al dicho licenciado Agreda nuestro fiscal en el dicho Consejo / e a Juan de Oribe procurador del dicho licenciado Va / ca de Castro del nuestro Consejo y parece que a treynta / días del dicho mes de abril del dicho año el dicho Juan / de Oribe en nonbre del dicho licenciado Vaca de / Castro presentó una petición en el dicho nuestro Consejo / de las Yndias en que dixo que la dicha sentencia en / quanto hera o podía ser en favor del dicho su parte / hera buena justa e derechamente dada y él la con / sentía, pero en todo aquello que hera contra el dicho / su parte él suplicaua della e hablando con devi / do acatamiento hera ninguna y do [?] alguna muy / ynjusta e agrabiada contra el dicho su parte e / de rebocar porque deviendo dar por libre en / todo al dicho su parte le avían condenado e por / que aviendo seruido señaladamente en los más / capítulos y mereciendo por ello gratificación / e merced e siendo justos y permitidos y en libre / facultad de lo hazer se avían pronunciado por / notales condenando en ellos al dicho su parte y por //

/ 154 r. / que aunque fueran los dichos capítulos de culpa, que no / heran, no se avían cometido en el oficio y le avían con / denado como de culpas cometidas en él estando libre e / sin culpa e aviéndonos hecho grandes y señalados seruicios / en los dichos reynos del Perú, siendo gobernador dellos en / recobrarlos de poder de don Diego de Almagro e sus secazes / que después de auer muerto al marqués don Francisco Pi / zarro nuestro gobernador los tenía tiranizados e ocupados / poniendo justicia de su mano y robando nuestros quintos / reales y poniendo nueva marca al oro creciéndole / en quintales para su probecho y robando bienes de di / funtos, depósitos de monesterios e armas e cauallos / e haziendo gente de guerra y artillería para se defender / de nos e del dicho licnciado Vaca de Castro nuestro gobernador / e hallando el dicho su parte aquellos reynos del / Perú sin dineros algunos de nuestra hazienda real ni / cauallos ni armas ni aun hierro para las hazer ni gente / acaudillada la hizo a caudillo y juntó el dicho su parte / e procuró de hazer armas, arcabuzes, pólbora e / munición e auer cauallos e hazer sillas y los otros / aparejos necesarios, todo gran trauajo y exatima [sic] / deligencia suya que subcedió hazer los hierros de picas / en la ciudad de Quito y trecientas y cinquenta leguas / de allí las hastas y ansí por el consiguiente las otras / cosas semejantes hasta venir el dicho don Diego y su gente / a romper la que el dicho su parte llebaua en nuestro / seruicio no se queriendo nunca reduzir por diligencias / que se avían hecho por el dicho licenciado Vaca de Castro / en el qual dicho ronpimiento y vatalla el dicho su parte / ovo vitoria e recobró y subjetó los dichos reynos / del Perú y castigó los dichos nuestros vasallos desa / catados al qual seruicio siendo tan grande e se / ñalado no se avía tenido ninguna consideración en / la dicha sentencia antes avía sido muy agrabiado / e maltratado en prisión larga y en dilatársela de //

/ 154 v. / terminación del dicho pleito cinco años e más después que / fue visto lo qual no hera justo hazerse con persona que / tanto avía seruido a nuestra corona real con tanto peligro / e trauajos e porque aviéndonos hecho el dicho su parte gran / seruicio en el buen cobro e recaudo que avía dado 
de nuestra / hazienda real en hazer la dicha guerra e gente para ella / e auer armas y cauallos e todas las otras cosas nece / sarias para venir a subjetar los contrarios con solos / cinquenta e tantos mil castellanos que avía buscado / prestados e devía la mayor parte dellos que gastó des / de la dicha ciudad de Quito hasta deshazer la gente de gue / rra en el Cuzco y enbiarlas a entradas e descubrimientos / e ensanchar la tierra e con otros cinquenta mil que se a / vían gastado por los nuestros oficiales en la ciudad de / los Reyes siendo en tienpo que avían gran carestía en / aquella tierra a falta de todas las dichas cosas avien / do gastado e tan poca cosa como avía hecho Blasco / Núñez Vela trecientos mil castellanos quel dicho su parte / tenía juntos para nos lo enbiar y el Obispo de Palencia / otros quinientos o seiscientos mil razón y justicia / obligaua a que fuera gratificado e remunerado y no / agrabiado e porque siendo lo susodicho y muchos de / los dichos capítulos determinados anexos al oficio que / tubo en la dicha guerra de nuestro capitán general que no en / traban ni podían entrar ni regularse conforme a / capítulos de corregidores e de residencia por los / necesitar el tiempo de guerra e oficio e bastando para / esta justificación y probanza dezir que conbino lo / avían juzgado e determinado como de residen / cia e juez hordinario e que demás de lo que siruió el / dicho su parte en el dicho oficio siruió mucho en el de / gobernador poniendo los dichos reynos en subjeción / pacificación y justicia y los yndios naturales en / livertad e bien de fe con muchas escuelas derra / madas que tenía puestas en la tierra e abiendo re //

/ 155 r. / hedeficado las yglesias parrochiales de los pueblos e hecho / se en su tienpo la catedral de los Reyes y comenzádose / la del Cuzco e hecho tenplos de monesterios e dado sitios a o / tros y hecho pueblos de nuebo como fue el que dizen de / León e de Guánuco y comenzado otro que se hizo después / entre Quito e San Miguel e dado horden para hazerse / otro entre el Cuzco e las Charcas que después se hizo / e demás desto avía administrado en todo bien e / cumplidamente justicia y hecho otros seruicios y buen gobierno / tales que merecían mucha gratificación y que para lo susodicho / e para que en todo se deviera dar al dicho su parte por libre / bastaua hallar como halló los dichos reynos del Perú tira / nizados y en tanto discrimen y rebelión y las gentes / tan yndómitas e aparejadas para hazer qualquier / alteración y para le matar a tan asentos sin aver / justicia asentada en aquellos reynos ni la conozer / ni temer y acostunbrados a daños, robos e / muertes de yndios que obligaua y necesitaua al dicho su / parte a disimular con lo uno y pasar con lo otro / aunque en hazerse ansí se pasasen los derechos e / lo mandado y probeydo y que hallándolos del dicho / nuestro Consejo Real de Yndias juez linpio al dicho / su parte de ynterese ynjusto de tomar ni reciuir cohecho / ni otra cosa semejante obligaua ansimismo a / tener consideración a esto mayormente siendo los / dichos capítulos arbitrarios y que demás de las ra / zones susodichas que hazían la dicha sentencia yn / justa se mostraua lo mismo por cada capítulo / tomado de por sí aunque no concurrieran todas / las dichas causas sobredichas porque en el primer capí / tulo en que avían condenado al dicho su parte en / ochocientos ducados diziendo que abía avido exeso / en el cargar de los yndios y no pagarles su trauajo / esto hera fuera de lo que por el proceso y probanzas //

/ 155 v. / parecía e ansimismo de términos de derecho porque en el / cargar yndios en el Perú con cargas moderadas no hera artí / culo proybido lo qual de más de ser ansí constaua por la yns / trución que se dio al dicho su parte en que se le cometió que diese / cerca desto la horden que le pareciese y hasta hazerse por / ley e ordenar lo contrario no se hazía proybición alguna an / tes hera cosa usada y acostunbrada de cargarse los / yndios en tienpo de señor yndio que los tenía antes del dicho / su parte en ansí estauan en uso e costunbre de se cargar / sin les dar por ello cosa alguna de 
tienpo ynmemorial / antes del dicho Vaca de Castro lo qual bastaua para ser / justo y lícito el cargarse y escusaba toda pena por / derechos vulgares e que aunque espresamente esto / viera proybido de no se hazer ni cargar siendo cosa tan / necesaria para remedio del daño que a la sazón a / vía en aquella tierra de estar tiranizada e ocupada por / el dicho don Diego de Almagro y para la recobrar de / su poder que los dichos yndios ayudaban a llevar / las armas y lo necesario a la gente de guerra quel dicho / su parte acaudillaua desde la ciudad de Quito ade / lante sin lo qual no se podía hazer ni efetuar e / por no auer bestias de carga en todos aquellos rey / nos a la sazón podía el dicho su parte por ser cosa en / que se permitía pasar las leyes y el mandamiento aun / que fuera hecho en contrario aunque jurara de lo / cumplir y para escusar tan gran daño como el / susodicho en que estaua la tierra bien se permitía este / menor daño aunque estobiera proybida y los yndios / como vasallos nuestros heran obligados por ley de par / tida de acudir a seruir contra el dicho don Diego y su / gente que estauan lebantados con aquellos reynos / contra nuestro seruicio y pues no podían ni heran partes / para pelear justo hera e obligatorio que sirbie / sen en lo susodicho para que tenían abilidad y costunbre //

/ 156 r. / e que viendo esto los yndios generalmente de su volun / tad yban e se ofrecían a seruir en lo susodicho y porque / en hazerse así avía redundado gran utilidad, pro / vecho a los dichos yndios porque constó que de su parte / ayudaron e avía podido acaudillar la gente de guerra / e pelear e vencer con lo qual se avían librado los dichos / yndios de las grandes tiranías, robos e muertes que re / cibían del dicho don Diego y su gente lo qual solo bastaua / de por si además de todo lo susodicho para quel dicho su / parte fuese dado por libre y se pronunciase auer en esto / bien seruido y que lo que en el dicho capítulo dezía / de llevar el dicho su parte muchos yndios cargados hera / contra lo que estaua probado en el proceso donde estaba / verificado ser muy pocos por llevar el dicho su parte / sus cosas en hazémilas que tenía que metió consigo en la / tierra y ansimismo hera contra lo probado dezir que / el dicho su parte no les pagaua estando probado con testigos / contestes lo contrario y que para la gente de guerra los pagase / ni su parte tenían dineros de nuestra hazienda real para ellos / ni los avía en la tierra a la sazón ni la gente de guerra / que yba a seruir y pelear tenía con que ni el dicho su / parte hera parte para se lo hazer pagar que antes / clamauan porque a ellos les pagase el dicho su parte / e les diese dineros para armas y cauallos y lo necesa / rio por lo qual e otra cosas semejantes se avía visto / su parte entre ellos en peligro de muerte y pues por esto / le hera necesario sufrir que no diesen como no querían / dar carta de pago de lo que les daba y callar quanto más / le fuera peligroso y áspero y aparejó de deshazer / la dicha gente y no se recobrar la tierra ni hazerse / el hefeto que se hizo apremiarlos a que pagasen / no teniendo como no tenían con que ya que fuera a / la sazón parte para ello y que para lo susodicho no se to / maba ni cargaba excesibo número de yndios sino lo necesario //

/ 156 v. / ynescusable y porque a no hazerse lo susodicho no sola / mente no se recobrara la tierra y quedara perdida más / hérale necesario al dicho su parte huyr della e dexalla al / dicho don Diego de Almagro y lo mismo de ayudar los yndios / con llevar las dichas cargas y fardaje en tienpo de gue / rra se avía usado e hecho en tienpo de los gobernadores / antes del dicho Vaca de Castro y los que después dél / fueron Blasco Núñez Vela y el licenciado de la Gasca, O / bispo de Palencia las quales razones no solamente / hazía justo e sin culpa alguna lo que en el dicho capítulo / se condenaua mas hera gran seruicio que se avía hecho / a Dios Nuestro Señor y a nos en segurarse con esto la pacificación / e bien de fe y cesar los ynsultos que se hazían e / recobrarse aquellos reynos e subjetar y castigar / vasallos que no avían sido tan desacatados y poner / la dicha tierra con 
subjeción y pacificación lo qual bas / taua para que no solamente se diese por libre al dicho / su parte mas que se declarara auer hecho señalado ser / uicio mayormente concurriendo como estaua probado / en que el dicho su parte probeya que los yndios no pa / sasen con las dichas cargas mas que de un tanbo a otro / y en la deligencia que ponía discurriendo al galope / por el fardaje que lleuaban los yndios no permitien / do que fuesen como solían antes que fuese a a / quella tierra con cadenas ni colleras ni se les hiziese mal / tratamiento y en que si alguno no se hallase bueno se / fuese tanto que en cierto despoblado donde a / vía falta de agua el dicho su parte enbió criados suyos / con tanto socorro de aguas y frutas yendo y viniendo / en esta deligencia se mataron dos cauallos que metió en la dicha tierra / e no consintió que llevasen los yndios como hasta allí se ha / zía artillería ni cosa pesada conprando con dineros presta / dos mulas de carga que a gran trauaxo se pudieron aver / para lleuar la dicha artillería y por estas causas yban los //

/ 157 r. / yndios bien tratados e sin daño e luego que pasó la dicha nece / sidad dio hordenanzas que hizo en como los indios nin / gún daño recibiesen con carga ni otras bexaciones acostun / bradas a lo qual si se obiera respeto no se pudiera ha / zer ni hiziera la dicha condenación y demás desto la re / serbación que se hazía en el dicho capítulo de la dicha sentencia / mostraua ser justo e seruicio todo lo susodicho e seguirse / dello ser injusta la dicha condenación y reserbación porque / pidiendo al dicho su parte el físco él auía de ser condenado / a que pagase y no su parte en caso que fuera justo e / ansí pedía se hiziese y en quanto en el segundo capítulo conde / naron al dicho su parte a que volviese cien mil pesos de / oro en el dicho capítulo contenidos de yndios que su parte / avía encomendado y puesto en su cabeza mandándole / descontar de los dichos pesos de oro la quantía que se / señalaua por salario en el dicho capítulo hera ansimis / mo ynjusto e agrauiado e de enmendar y revocar / porque el dicho su parte se avía podido encomendar los / yndios de que se hazía la dicha condenación por las / causas y razones siguientes: la una porque esto hera / costumbre usada e guardada después que las Yn / dias se descubrieron de poder poner los gobernadores / yndios en sus cabezas e hazían e hizieron suyos / los tributos que dauan los dichos yndios que se enco / mendauan sin que fuesen obligados a quenta alguna / más que a dar el quinto dellos y ansí no se hallaría a / verse pedido en tienpo alguno para la qual costun / bre vastaban dos autos como se avía hecho e usa / do en el Perú antes quel dicho su parte fuese por / gobernador e ansí lo avían usado e hecho los go / bernadores e adelantado don Diego de Al / magro e marqués don Francisco Pizarro / en sus tienpos la qual costunbre usso y / exercicio fue sabido por nos e se yno / vaua por tienpo y por llevar de los dichos gobernadores //

/ 157 v. / de las Yndias e del Perú el quinto de todo lo que / les dauan y rentauan los indios que ansí se avían encomen / dado y tenían en sus cabezas y por otras causas traídas y pro / vadas la dicha costunbre avía dado derecho al dicho, su / parte para que pudiese hazer lo mismo como gobernador / e que a los dichos gobernadores se les avían dado car / gos sin salarios porque podían poner en sus cabezas / yndios para sustentar las dichas cargas a su voluntad / e dispusición sin distinción de número ni cantidad / de repartimientos de indios, ni de cantidad de tri / butos e probechos dellos como hazían los dichos / gobernadores en las dichas gobernaciones en el Pe / rú e por darse como se auía dado, dio al dicho su parte / el mismo oficio sin salario se seguía dársele con / poder de hazer lo mesmo y gozar e lleuar lo que / sus antepasados hizieron y llevaron y para se poder / como ellos encomendar y poner yndios en su cabeza / y esto estaua ansí determinado de derecho mayor / mente diciendo en la provisión que se dio de gobernador / al dicho su parte con las mesmas facultades, gracias / e preeminencias, salarios e derechos que los gober / nadores pasados del Perú de que se 
seguía claramente / aver podido el dicho su parte encomendarse los dichos / yndios y ponerlos en su cabeza e hazerlos tributos / syn tener obligación a paga ni quita, ni razón alguna / y en mandarse lo contrario en la dicha sentencia he / ra tal qual dicha tenía lo qual avía lugar aunque el dicho / su parte se encomendara sesenta mil yndios como tu / vieron y se encomendaron los dichos gobernadores pasados / del Perú quanto más moderándose el dicho su parte en / poner en su cabeza, en gran parte menos número e / cantidad de yndios que fueron solamente / los necesarios y conbinientes a la sustentación del / oficio e cargo que estaua muy claro y ebidente //

/ 158 r. / quel dicho licenciado Vaca de Castro no podía sutentar / se en el dicho oficio de gobernador ni la tierra en / pacífica posesión sino que hera necesario dexarla / a no hazer lo susodicho porque no le aviendo dado salario / ni aviendo en la caxa real dineros para ello por ser de / próximo robados por el dicho don Diego de Almagro ni / llevar el dicho su parte poder ni facultad para los to / mar ni gastar en esto aunque los obiera de necesario / se seguía lo susodicho lo qual e auer sido menester to / do lo que se ubo de los dichos yndios para cumplir / lo susodicho bastaua para no se hazer cerca desto ni pro / nunciarse lo que se auía pronunciada en la dicha sentencia / e que aunque lo susodicho cesara se auía de quitar / e mucha de la cantidad de la dicha sentencia en que / su parte hera condenado en este capítulo por las cau / sas e razones contenidas en su confisión que estaua / probada la qual avía lugar ansímismo en lo que / se condenaua de los yndios que avían sido del mar / qués como en los demás y porque en caso que se pu / diera hazer condenación, que no podía, no se daua ni se / ñalaua al dicho su parte la cantidad en salario que le / hera necesaria y conviniente para cumplir con el dicho / oficio y sustentación del porque probado estaba / en el proceso que con cinco mil ducados que se le a / vían dado de salario con el oficio de juez ni con ocho tan / to más se podía sustentar en el oficio de gober / nador e no se podía auer consideración a lo que se le / señaló de salario y llevó Blasco Nuñez Vela por / que lo avía abcetado como persona que no sabía la / tierra ni lo que hera necesario para sustentar el oficio / e cargo que llevaua más antes se auía de aver con / sideración en esto a la información de testigos y pro / banza que enbió luego que llegó a la ciudad de los Reyes / el dicho virrey Blasco Nuñez de Vela con dichos, e declara / ciones de los oficiales de nuestra Hazienda Real //

/ 158 v. / e otras personas que tenían noticia de lo que hera menes / ter para sustentación del dicho cargo y oficio e por / que de necesario pues el oficio hera todo uno en / tienpo de qualquier gobernador e las necesidades pa / ra sustentarle por ygual como hera notorio y con es / taua por la dicha ynformación y probanza lo mismo / de necesidad se avía de señalar al dicho su parte e quan / do a esto no se obiera respeto ni consideración avía / se de señalar al dicho su parte tanto como hubo me / nester gastar e gastó el licenciado Gasca, Obispo de $\mathrm{Pa} /$ lencia que agora es de nuestros quintos reales por no lle / var señalado salario para ello sino que se le diese / e gastase lo que obiese menester para sustentarse / en el dicho cargo y no poder por las nuebas hordenanzas poner yndios en su cabeza a lo qual se deviera / de aver respeto por yr el dicho licenciado Gasca / y estar en el dicho oficio en tienpo de semejante alte / ración de tierra como fue y estubo el dicho su parte / aunque fue tienpo de más careza que obligaba / a mayor gasto que valía a la sazón una arroba / de vino sobre cinquenta castellanos y ansí to / das las otras cosas ni tanpoco se podía aver res / peto al salario que se avía señalado al virrey don / Antonio de Mendoza por aver ydo en tienpo de paz / en que se podía sufrir el cargo con mucho menos gasto / al qual tanpoco les bastaua ni podía sustentar / en el dicho oficio con veinte y cinco mil ducados que / se le avían señalado sin se lo crecer o poner mucho / de su casa como él nos lo scribiría o ynbiaria yn / formación dello por manera que por 
ebidencia no / toria parecía ser cosa ynjusta e muy agraviada se / ñalar a su parte para la sustentación del dicho oficio / e cargo quinze mil ducados en especial siendo casi / todo el tiempo que gobernó de guerra e alteración / como fue el dicho licenciado Gasca e demás careza e //

/ 159 r. / siendo los cinco mil de los quinze de salario que le fue se / ñalado de juez para en cosas particulares que avía de aver / como salario distinto del salario y oficio de goberna / dor aviendo de aver según derecho anvos salarios / con que quedaua más ynjusto e sin se poder sufrir / el dicho salario porque dar en diez mil ducados por / manera que la constitución del dicho salario no hera bas / tante ni equivalente aunque él pudiera condenar en / lo que ubo de los yndios que se encomendó que no po / día e que tanpoco podía venir en la dicha condenación / lo que su parte dezía que vbo de los yndios que avían / sido del marqués don Francisco Pizarro en la probin / cia del Cuzco y Collas por se los encomendar y poner / en su caueza ni para sustentación del cargo como les / hera necesario hasta la parte que de los yndios que / se encomendó que avían vacado por muerte de Peralua / rez y Castro y Oñate pudieron auer dineros, oro de mi / nas con que acudieron para en pago de sus tributos / a su voluntad porque luego auía dexado [lo] que a / vía sido del dicho marqués como estaua probado por / manera que siendo esto indios de la misma naturaleza / que los otros que avía tenido casi el tiempo ade / lante que gobernó auía hecho suyos los tributos de / llos y le pertenecían por las causas y razones su / sodichas y porque constando a los del nuestro Consejo que / lo que toca a los indios que fueron del dicho marqués / estaua pedido a su parte en la ciudad de los Reyes / e ante el dotor Durango alcalde de nuestra casa e Corte / y executado por ello no podían venir en condenación / contra su parte aunque cesara todo lo susodicho ma / yormente teniendo probado el dicho su parte auer / gastado esta quantía y mucha más en la guerra / contra el dicho don Diego que se le avía de tomar en quenta conforme a una nuestra cédula //

/ 159 v. / que tenía presentada a lo menos hasta que sobre toda / la carta quenta por su parte presentada oviese justa de / terminación no podía hazerse condenación en ello y tan / poco se podían poner con los yndios que avían sido del / dicho marqués los yndios de Guarua ni venir en condena / ción lo que dellos se vbo porque avían sido del dicho don / Diego de Almagro quel dicho su parte se encomendó des / pués de la merte de Peraluarez que los tenía para sus / tentar el cargo ni tanpoco se podía su parte condenar en los / tres mil e ochocientos pesos por ser de la mesma natura / e condición que se ubo de los dichos yndios que su parte / encomendó por resultar e ser de los tributos dellos co / mo auía dicho en su confisión e ansí estaua probado / e se colegía de las palabras de la dicha sentencia y por / que se avían puesto en la dicha sentencia tres mil e ochocien / tos no estando ansí probado ni declarado por su parte / ni haziendo probanza alguna la confisión que su parte a / vía hecho de ser más de tres mil e ochocientos queda / dos mil e ochocientos antes se auía de estar a los dos / mil e ochocientos en fauor de su parte en caso que / se pudiera hazer condenación e fuera deudor e / por concurrir con ser ansí probanza de testigos / del fiscal e porque aunque todo lo dicho cerca / destos tres mil y ochocientos castellanos cesara / que no cesaua no podía ser condenado en ellos el / dicho su parte para los pagar debiéndolos del cargo / condicional quel dicho su parte se auía hecho dellos / en caso que fuese obligado por ser la dicha confi / syón e cargo con calidad de averlo gastado en / nuestro seruicio y teniéndolo ansy probado con testigos de / vista fidedinos contestes y en quanto por la / dicha sentencia y capítulo condenaron al dicho su / parte en lo que más pareciese auer él cobrado u otro en / su nonbre por los dichos yndios que se encomendó hera // 
/ 160 r. / ansímismo muy injusto agrabiado e de rebocar por / que deviendo de declarar no auer venido a poder de su / parte más suma de la que dicha e declarado tenía en su con / fisión no se auía hecho ni declarado y porque no avien / do probanza del fiscal cerca desto que concluyese en / cosa alguna en contrario antes constando como cons / taba bien mirado la probanza del dicho fiscal con / formar más con la dicha declaración y confisión / de su parte no auía razón alguna probada ni por / ninguna vía que vastase para hazer la dicha conde / nación y que no se pudieron mover a ello los del / nuestro Consejo por la encomienda que su parte se hizo / en sí de los dichos yndios en la ciudad de Quito por / que si los puso no hera para se aprovechar dellos desde / luego por estar lexos de allí muchas leguas y distan / cia de tierra y apoderado el dicho don Diego y su gen / te robándolos y saqueándolos y los avían puesto / en su cabeza por dos hefetos conbinientes al / nuestro seruicio: el uno publicando que para los re / partir a los que viniesen a nuestro seruicio contra el / dicho don Diego que hera el mayor aviso que se podía / tener para acaudillar gente porque por este res / peto avían seruido todos en la dicha guerra más / que por dineros y ansí parescía por el poco e vaxo / gasto que su parte auía hecho en la dicha guerra con / tra el dicho don Diego como todo constaua por el pro / cesso y por poder su parte llegado al Cuzco en cu / ya provincia estaban los yndios vacos aver / alguna suma de los tributos del medio tiempo / para pagar las deudas hechas hasta allí en / sustentación del dicho oficio lo qual podía hazer / por su propio derecho segund las causas e ra / zones sobredichas como podía en los demás / yndios con que se avía quedado repartido estos //

/ 160 v. / e porque menos se avían podido mover los del nuestro Conse / jo a hazer la dicha condenación a su parte de lo que más / pareciese auer cobrado de los dichos yndios sobre fun / damento de estar vacos los repartimientos que en el / dicho capítulo se referían porque los de Hernando / Pizarro los poseya y tenya criados en ellos que / llevasen sus aprovechamientos y en esto no abía / tocado el dicho su parte y ansí estaua probado / e lo mismo en los Carangas porque heran de Diego / de Aller en quien se avía encomendado en la ciudad de / Quito luego que su parte entró en la dicha tierra por / lo que avía seruido y venir por mensajero a darnos / noticia de la muerte del dicho marqués e alzamiento / del dicho don Diego y estado de la tierra e ansí es / taua probado y no auer yndios vacos en Guánuco / e Chachapoyas como el fiscal en su capítulo que / ría decir y porque por evidente probanza cons / taua que los yndios que avía vacos desde la / ciudad de Quito al Cuzco heran ciertos indios en / San Miguel se avían dado a Grijeda y los que en / aquella probincia avía tenido el dicho marqués / e no otros e que estos se avían dado por el dicho / su parte a los hijos del dicho marqués sin quedar / en su poder cosa alguna y que los demás que a / vía vacos en aquel tiempo estaua en la comarca / del Cuzco de ay adelante y que destos no podría lle / var su parte tributos y provechos ansí por estar / de próximo saqueados y robados por el dicho / don Diego y su gente como repartirlos luego / que el dicho licenciado Vaca de Castro llegó al Cuzco e / cebto los pocos yndios de Chuquiago que fueron / del dicho marqués contenidos en este capítul que / tenía hasta que la parte de indios con que se quedó / repartidos los demás puso en su cabeza que avían //

/ 161 r. / sido de Peraluarez y Castillo y Oñate pudieron yr a las mi / nas por manera que siendo ansí como hera y se colegía / del proceso y probanzas se debía declarar y no ser su / parte obligado a cosa alguna desto y en caso que lo fue / ra que negaua solamente a lo que se cobró declarado / en su confisión de los que avían gozado los yndios / por encomienda del dicho don Diego e tenerlo esto / gastado en caso que fuera obligado en la guerra con / tra el dicho don Diego como tenía probado por las quales / razones el dicho capítulo y sentencia hera qual dicho te / nía e se devía rebocar y pronunciar en favor de su / parte e hazer segund de suso tenía dicho y en quanto / por el tercero 
capítulo de la dicha sentencia declara / ron resultar culpa contra su parte de lo contenido / en el tercero capítulo de la dicha acusación del fiscal / la cual culpa reserbaron para el postrer capítu / lo de la sentencia e que hizieron condenación a su parte / e más le condenaron en quinientos ducados aplicados / en cierta forma hera ansimismo ynjusto e a / grabiado e de revocar porque para se poder / hazer lo contenido en la dicha sentencia hera necesario / que los testigos del fiscal concluyesen en todo lo /contenido en el dicho capítulo de la dicha acusación / que su parte obiese puesto estanco en la ciudad del / Cuzco que ninguno contratase y que lo hiziese sola / mente Gaspar Gil contenido en el dicho capítulo de la / dicha acusación por mandado del dicho su parte y para / él y en que oviese hordenanza que nayde pudiese / vender ovejas y la vendiese el dicho Gaspar Gil con / permisión del dicho su parte y para él mandar do / la guardar con otros en lo qual no concluyan ni podía / concluir los dichos testigos ni avía de ser del dicho / Vaca de Castro cosa alguna si la vendiese el dicho Gas / par Gil y no obstante esto se avía pronunciado lo //

/ 161 v. / contrario en el dicho capítulo de la dicha sentencia y los del / nuestro Consejo no se pudieron mover a hazer la dicha conde / nación como hicieron por los dichos de los testigos del fiscal / por no hazer ni prueba alguna porque contra las per / sonas de los que algo quisieron dezir en contrario estaua / probado que antes e al tienpo que dixeron sus dichos heran enemigos capitales del dicho su parte y partes for / males contra él y ser esto ansí cosa sabida e notoria / hera a los del nuestro Consejo porque sabían que el uno a / vía venido desde el Perú a hazer el daño que pudiese / al dicho su parte e ansí lo avía procurado en Consejo / e con nos en Flandes e les constaua ser yntimo a / migo de Gonzalo Pizarro que estaua lebantado en el / Perú contra nuestro seruicio y su secaz en el dicho leban / tamiento e su alguazil y por esto avía sido conde / nado e hecho quartos e ser el dicho Gonzalo Pizarro / enemigo capital del dicho su parte y tenerle para / matarle en el Perú si no se saliera del navío en / que le tenía y estar ansí probado y el otro que he / ra el fator Diego de Mercado les constaua y pa / rescía por el proceso que avía denunciado de su / parte en la chancillería que reside en Panamá e / le avía acusado de lo contenido en el dicho capítu / lo e otras semejantes cosas y esta denunciación / avía venido al nuestro Consejo y estaba puesta en el / proceso y ansí por consiguiente de los demás tes / tigos del fiscal de manera que no avía de su par / te provanza alguna que bastase para pronunciar / lo en el dicho capítulo contenido e que lo contrario de / todo lo contenido en el dicho capítulo tercero capítulo de la / dicha acusación estaua vastantemente probado / con muchas más y mayor número de testigos fi / dedinos y contestes e mayores de toda excención / que ni heran tachados por el fiscal ni padecían objeto / alguno e ansí se le avía de dar entera fe en quanto //

/ 162 r. / dezían e deponían que luego que el dicho su parte entró en el Cuzco / e avían alzado contra todo bedamiento ynpiditibo de contratar / en los trianguez libremente en la dicha ciudad y dio libertad / general para que todos contratasen libremente sin ynpe / dimiento alguno e que ansí se avía hecho e pasado todo el / tienpo que el dicho Vaca de Castro estubo en el Cuzco e dezían / que el dicho su parte no tenía que contratar por sí ni por otro / ni lo hazía ni podía por no tener qué e daua sufizientes ra / zones dello que concluyan de afirmativa y depusición / de verdad e que antes conprauan cosas de carnicerías pa / ra el gasto de su casa e otras cosas ebidentemente es / clusibas del dicho capítulo del fiscal y estando esto an / sí probado e concurriendo demás desto la presunción / de derecho que su parte tenía por sí y que no se presu / mía mandado quanto más en lícita estorsión e contra / tación no se podía ni devía pronunicar lo que los / del nuestro Consejo avían determinado e sentenciado en el / dicho capítulo y final y porque con la dicha probanza con / 
formaua y contestaua otra probanza de su parte hecha / en Panamá que no se avía visto por no ser en bía hor / dinaria aviendo en ella muchos testigos ratifica / dos y porque aunque fuera ansí como el fiscal dezía / que oviera hordenanza o vedamiento de no bender obeja / esto sería para que no saliese de la dicha ciudad del / Cuzco a diversas partes y no para que entre los de la ciu / dad no se pudiese hazer pues entre ellos cesaua la cau / sa de la hordenanza y vedamiento de no menosca / barse el ganado para probisión de la dicha ciudad ni / tanpoco para otro y dar un ganado por otro por / que ansimismo en este caso no solamente cesaua la cau / sa de la hordenanza mas ni hablaua ni disponía en este / caso ni tanpoco en que cada vezino en su casa no pu / diese matar ovejas para su mantenimiento no procedería ni habla / ría la tal hordenanza porque cesaua en tal caso / la causa de la dicha hordenanza por tener como te / nían a la sazón vezinos del Cuzco repartimien / tos de yndios que dauan ganado en tributo y ser lo //

/ 162 v. / necesario venderlo ansí y contratar para las otras co / sas que les heran necesarias e sus bibienda lo qual se / hazía en la dicha ciudad del Cuzco libremente por todos / e desta manera se usava lo susodicho por lo qual aun / que fuese ansí que Gaspar Gil u otro qualquier vezino / lo hiziese no caería en pena y aunque se pasara de la / dicha hordenanza por el dicho Vaca de Castro que negava / no se podía ni debía condenar a más de la pena con / tenida en la tal hordenanza ni vedamiento si lo obie / ra e aunque el dicho Gaspar Gil o otra qualquier / persona hiziera o pasara en el vender en qualquier / manera contra qualquier hordenanza y probisión / no caya su parte en pena alguna no le siendo denun / ciado e requerido para ello pues no se presumía / en el dicho su parte ciencia en lo tal ni en cosas semejan / tes mayormente estando en tan grandes ocupacio / nes como a la sazón el dicho su parte tenía en paci / ficar aquellos tan grandes reynos por las quales / razones la condenación contenida en la dicha sentencia / hera tal qual dicha tenía y en quanto por el quinto / capítulo de la dicha sentencia se avía reserbado / el derecho a salvo al fiscal sobre los cinco mil / castellanos contenidos en el dicho capítulo contra / el dicho su parte no los pudiendo cobrar de Peranzu / res se avía hecho ansimismo notorio agravio al / dicho su parte e se debía dar por libre de la dicha / reserbación y en quanto por el sesto capítulo / de la dicha acusación se avía pronunciado resul / tar en lo contra su parte y en el prostrero se hizo / condenación y más le condenaron en tres mil ducados / aplicados en cierta forma hera ansimismo yn / justo e agrabiado e de rebocar e se debía de dar / del todo por libre al dicho su parte e declarar / aver en este artículo hecho servicio a nos e buen / gobierno lo qual se devía hazer porque no obs / tante lo que cerca del no yr los yndios a minas se avía //

/ 163 r. / puesto en general en la ynstrución dada al dicho su / parte quando fue a aquellos reynos, halló luego que / llegó a la ciudad del Cuzco después de la vitoria que / se ubo del dicho don Diego de Almagro una cédula nuestra / dada e concedida por el mismo tiempo a los vecinos / de aquella ciudad e reynos para que pudiesen echar / yndios a minas yendo los yndios de su voluntad / para pagar sus tributos lo qual se auía dispuesto / así por otra provisión limitado la general que en ella se / dezía sobre no ir los yndios a minas y estante lo / susodicho especialmente se probeya que no se entendía qui / tado ni revocado por lo generalmente probeido como / estaua de derecho dispuesto y aunque en lo generalmen / te probeydo se dixera e mandara guardar no obstante / otra qualquier provisión no se podía ynputar culpa a / su parte que lo permitiese y porque estante lo susodicho / de cédula y provisión claro estaua que en la dicha per / misión que su parte auía hecho conforme a ellas no se / podía decir auer cometido dolo y este cesando co / mo aquí hera notorio que cesaua no se seguía culpa / contra su parte ni menos condenación como se auía / hecho en el dicho capítulo e 
sentencia y vastaua / para lo susodicho ser costumbre en aquellos reynos / de enbiar los yndios a minas para en pago de sus tributos ya verse ansí usado e usar a la sazón después que aquellos reynos no se descubrieron / e ganaron e que estando probado en el proceso co / mo queriendo su parte hordenar y prober como / no fuesen yndios a minas subcedió alteración e / manera de motín contra el dicho su parte por lo suso / dicho que quería hazer y prober diciendo que les avía / de guardar la dicha cédula y provisión de que estauan / en uso e costumbre y que desta manera no te / nían que comer por estar robados e saqueados los / indios por el dicho don Diego y su gente y aun gastado //

/ 163 v. / lo que tenían en seruicio nuestro en andar con su parte e se / hallar con él en la guerra contra el dicho don Diego y en armas / e cauallos e otros aparejos y gastos y no tener otra cosa / alguna que les dar los yndios que tenían de tributos para / les poder sustentar por estar ansímismo robados e / saqueados del dicho don Diego e sus secaces lo qual hera de / tal manera que si el dicho su parte porfiara en que no / fueran yndios a minas ni permitiera usar de la dicha / cédula e provisión le mataran e subcediera alteración / en nuestro deseruicio e daño común de la tierra e de los / mismos yndios y en mayor daño suyo que ir a las minas / por tal manera que le avía sido forzado al dicho su parte / pasar por ello y estando esto ansí probado cunpli / damente por legítima escusa bastaua a su parte aun / que precisamente fuera mandado y estubiera pro / beydo que no fueran yndios a minas no solamente / para no le poder ynputar culpa como se auía hecho, mas / para lo pronunciar por seruicio e buen gobierno / e porque se debiera tener consideración al seruicio / que su parte avía hecho en las limitaciones que puso / e hordenó a la dicha cédula y provisión para que los / indios no recibiesen daño en yr a las dichas minas, / que le reciuerán e grande si así como se disponía en la dicha / cédula e provisión se guardara e que con las dichas hor / denanzas y limitaciones que por ellas se pusieron a la dicha / cédula e provisión recibían en yr a las minas pro / vecho los yndios y no daño pues constaua auer horde / nado como se entendiese y supiese de los yndios que que / rían yr e yban a las minas de su voluntad para pa / gar sus tributos y porque con la cobdicia que los yn / dios tenían de yr a las minas de oro por lo que se les / quedaua de lo que sacauan e yendo todos les hera / muy dañoso y perjudicial avía hordenado que no / pudiesen yr a las minas más de la quinta parte de / yndios de repartimiento que cada un vezino tuviese //

/ 164 r. / e que no entrasen en esto mujeres ni mochachos que fuesen de / cierta parte y no más lexos que no fuesen ni biniesen cargados / e le hiziesen casas en que estubiesen en las minas e que / tuviesen cunplido bastimento y que cogiesen primero sus / panes e saliesen a senbrar e que tuviesen clérigo que los / doctrinase y enseñase las fiesta, la dotrina cristia / na e que no hallándose bien se pudiesen salir e que o / viese alcaldes e beedor general para la execución de / esto e bien e seguridad de los indios y ansí se guar / daua e cumplía sin que recibiesen ni pudiesen reci / bir daño alguno por manera que si se considerara lo suso / dicho bierase que hallándose el dicho su parte en tanto discri / men y peligro de vida y alteración y estando tan generales / la dicha cédula y provisión y costumbre de enbiar cada / uno sus yndios a minas e muy lexos de sus casas / e que llevasen e se probeyesen ellos de comida e / andar en ellas syn ningund beneficio de los sobredichos / hasta en tanto quel dicho su parte subjetase los vezinos / de la tierra avía conbenido e seydole necesario / pasar por lo susodicho que hera tan en probecho de los / yndios y en ello auía hecho seruicio de calidad e buen / gobierno y vastante para le hazer nuestro e no conde / nación y que mandándose a su parte en la ynstrución / e probisión que le fue dada que tasase los tributos / que avían de dar los yndios a aquellos en quien es / taban encomendados y los tenían en sus cabezas y no / se pudiendo 
esto hazer como a los yndios convenía / ni con la retitud necesaria hasta que se contasen / los yndios que avía en cada repartimiento y en / comienda y sauer qué cogía y tenía cada cacique en / su reparetimiento para que dello pagase el / tributo en el entretanto podía hazer el dicho su parte / lo susodicho en lugar de tasación de tributos y por / que bien considerado lo susodicho se hallaría que no / se podía dar ni tasar a los indios más vaxo tributo //

/ 164 v. / ni más provecho de los yndios pues en cinco años / no les salía a dar ni daban otra cosa sino lo que en los / quatro meses o cinco sacavan de minas y holgaban qua / tro años y medio en que avían de yr las otras quatro / partes e de esta manera cesava lo que los yndios te / nían por más grave que hera dar de sus casas cosa alguna / e con conocer en quatro años y medio dueño e / conplir con el poco tienpo que yban a las minas con / forme a las dichas hordenanzas e de su voluntad por / cinco años y medio y en aquel sacar para sy lo que to / mavan e ascondían que lo tenían por tan gran ganan / cia que los que yvan una vez querían yr adelante / mayormente con darles en las Yndias cosa, comida / e quien los yndustriase e ansí cometiendo co / mo se avía cometido al dicho su parte la tasación / de tributos su determinación y parecer basta / va para no le poder ynputar culpa de poner por / tasación e yr los yndios a minas con las dichas / modificaciones y calidades aunque cesara to / do lo susodicho que lo hazía justo servicio e buen / gobierno y ansí estaba probado con gran número / de testigos e porque yendo como yvan los dichos / yndios de su voluntad a minas como estava probado / solo esto bastava para excluir todo género de / culpa pues heran libres para lo hazer e ansí / se avía declarado después acá por otra probisión / e permisión y si los del nuestro Consejo se movieron / a cargar culpa a su parte e hazer la dicha conde / nación por yr a las minas parte de los yndios con / que se que no [sic] para sustentar el cargo que heran parte / de los ynidios que tenían los capitanes Peralvarez / e Castro e Oñate contenidos en el dicho capítulo segundo / hera ansimismo ynjusto e agrabiado contra su parte / porque de encomendárselos se avía seguido justificación / de yr los dichos yndios a minas como los demás con las dichas cali //

/ 165 r. / dades por las razones y fundamentos sobredichos que / avían lugar y procedían en este caso porque permitiéndo / se a los que tubiesen yndios en sus cabezas y en en / comienda y el yr a las minas los tales yndios siendo de / su voluntad para pagar sus tributos por el consiguiente / se entendía permitir a su parte pues los podía tener / e poseer como los otros y porque por esta costum / bre en aquellos reynos después que se descubrieron e / ganaron yr los yndios a minas sin yntervenir ninguna / de las dichas calidades y modeficaciones en probecho / de los dichos yndios y la misma costumbre avían tenido / después que las Yndias se descubrieron los dichos / gobernadores pasados antes de su parte de yr los yn / dios que los dichos gobernadores tenían en sus cabezas / para sustentar el cargo a las minas sin yntervenir / tanpoco ninguna de las dichas calidades y modefi / caciones susodichas en probecho de los dichos yndios / la qual dicha costumbre aunque fuera mala escusa / va al dicho su parte de culpa e condenación pues lo / podía hazer como los gobernadores pasados quan / to más concurriendo las dichas hordenanzas en pro / becho e seguridad de los dichos yndios e redunda tan / en su probecho como dicho hera y porque yr los dichos / yndios a las dichas minas hera cumplir con la dicha / tasación que debían de tributo y en cumplimiento / della que bastava y porque hera necesario por / precisa necesidad yr los dichos yndios a minas / que el dicho su parte se encomendó para que pudiese / sustentar el cargo de gobernador la tierra en paci / ficación e justicia porque el dicho su parte no tenía de / otra parte donde poder aver con qué ni en las nuestras / arcas lo avía y ya que lo obiera el dicho su parte / no la podía tomar por no llevar poder para ello ni los / tenía de sus casas ni otra parte de que lo poder // 
/ 165 v. / dar como estaba dicho y probado en el proceso e ansí / la causa porque fueron a las dichas minas los dichos yndios / hera en servicio nuestro y bien del reyno y de los yndios y / en libertad e seguridad de los grandes daños que hasta / allí recivían de lo qual e del remedio quel dicho su parte / avía puesto constava por el proceso y parecía por / las dichas hordenanzas que para esto avía hecho pues se avía / convertido el yr los dichos yndios a minas y lo que sacaron / e aprobecho dellos mismos no avía porque resultase / culpa contra el dicho su parte ni condenación ni aplicación / para nos ni para los dichos yndios mayormente es / tando como estaba probado aver gastado su parte lo que / ubo de los dichos yndios en probecho común dellos pues con / esto se libertaron cargas, cepos y colleras en que los / solían traer antes que su parte fuese aquella tierra / de una parte a otra muriéndose por los caminos fue / ra de sus tierras e de los robos e tomas que se les / hazían e de los valdíos que andavan por la tierra an / tes que su parte fuese a ella derramados en qua / drilla robándoles lo que tenían e ganados y las mu / geres e hijas que les parecía[n] y fueron puestas en / seguridad de todo e bien de fe según estaba proba / do cumplidamente y que estando probado aver gastado / su parte todo lo que ubo de los dichos yndios en lo susodicho / e sustentar el cargo en nuestro servicio en que ganó mucho a / nuestra hazienda real que a no lo hazer ansí el dicho su parte / y poner los dichos yndios en su cabeza para sustentar / el dicho cargo hera necesario salir de nuestra hazienda real / que avía sido gran servicio pues por no lo hazer así / el Obispo de Palencia gastava en cada un año como le / sería necesario de nuestra real hazienda cinquanta mil cas / tellanos lo qual vastava para dar lo que su parte hizo / cerca desto por buen servicio y en gran probecho de la dicha real / hazienda e no dar culpa e condenar al dicho su parte mayor //

/ 166 r. / mente no quedando nada dello en su poder mas gastándolo / todo en nuestro servicio y vien de los dichos yndios y abiéndolo / hecho el dicho su parte con buena fe como de los [sic] susodicho se colegía / y estando bastantemente probado en el proceso e porque / de las causas y razones dichas e traídas en el sobredicho / segundo capítulo de la dicha suplicación y por las aquí dichas / e alegadas constava aver tenido el dicho su parte título / e razón e justicia para poner los dichos yndios en su ca / veza a lo menos no se podía negar aver tenido buena fe en / ello de que se seguía averla tenido ansímismo en el yr de / los dichos yndios a minas y lleuar lo que de aquello diesen pa / ra paga y cumplimiento de tributos la qual buena fe hazía / en caso que lo demás cesase que no cesava no aver delito / ni casi para se pronunciar como se avía pronunciado y porque / estando como estaba probado con mucho número de testigos a / ver ydo los dichos yndios a las dichas minas de su propia volun / tad e contra la de su parte por el probecho que se les seguía no / avía razón ni justicia para condenar al dicho su parte / por ello pues los dichos yndios heran libres para hazer a / su voluntad e ansí se avía después declarado por cédula / e probisión que lo hiziesen y pudiesen hazer y los del / nuestro Consejo no se avían podido mover a dar culpa e / condenar a su parte por lo que algunos de los testigos / del fiscal quisieron dezir que a los yndios se seguía / daño y mal tratamiento por estar probada la enemis / tad capital y no aver estado en las dichas minas ni a / ver visto lo que deponían e ansí no hazía fe / ni prueba y por aver mucho más número de testigos / fidedinos y contestes que no padecían tachas ni les / avían sido puestas que deponían de vista de ojos / e de verdad en todo lo contrario e que siendo justo / el yr los dichos yndios a minas y permitido aunque / después se les syguiera algún daño no hera en culpa su parte / quanto más yendo como yvan de su propia y libre volun / tad por las quales razones y cada una dellas lo contrario //

/ 166 v. / en el dicho capítulo que se avía declarado y pronunciado con / tra el dicho su parte de culpa e condenación hera tal qual dicho / tenía e se debía rebocar e asolver al dicho su parte e dar / 
le por libre de todo lo por el dicho fiscal pedido e acu / sado cerca de lo en este capítulo contenido y ansí lo pedía / e suplicava y en quanto al sétimo capítulo en el / qual los del nuestro Consejo avían condenado a su parte / a que diese quenta con pago de lo que entró en su poder / o de otras personas en su nonbre de nuestra hazienda real / hera ynjusto e agrabiado e de enmendar e rebocar / porque constando por el proceso probanzas e con / fisión de su parte e quenta por él presentada ser todo / lo que de la hazienda real entró en su poder quinze / mil e docientos y quarenta castellanos en que en / travan los dos mil e ochocientos pesos que se cobra / ron de los que se gozaron yndios sin título contenidos en / en el segundo capítulo de la dicha acusación avíase / de declarar ser está la suma que entró en poder de su / parte pues estava cierta e aberiguada y que con to / das las excesisimas deligencias hechas por todo el / Perú libros y oficiales no se avía hallado aver en / trado ni venido a poder de su parte otra cosa alguna / más y en no se aver declarado así se avía hecho agravio / a su parte e teniendo probado ansimismo la quenta, / paga e gasto de todo el dicho cargo averlo gastado en nuestro / servicio en la guerra que se tubo contra el dicho don Diego / de Almagro con testigos contestes e de vista que hera / probanza que vastaba mayormente aviéndose per / dido a su parte los libros y razón dello en el saco e / robo que estava probado aversele hecho por los alte / rados e lebantados contra nuestro servicio e ser muertos / aquellos por cuya mano pasó el dicho recibo e gasto e / averse perdido las haciendas, libros, recaudos con / quanto tenían por ser muertos e robados en las / dichas alteraciones pasadas en el Perú e teniendo así //

/ 167 r. / mismo robado por hebidencias del hecho que subcedió el dicho / levantamiento de don Diego y gasto que fue necesa / rio hazerse para el remedio y la carestía que avía en a / quellos reynos junta la dicha suma del dicho cargo e gasto / e dificultad que avía en la probanza en partidas tan / por menudo y en tan lejos partes y falta de libros por / lo que dicho hera que hazía de por sí vastante probanza del / dicho gasto quanto más concurriendo lo mucho más que / gastó Blasco Núñez Vela en cosas de menos gasto y efeto / e lo mucho que gastó el Obispo de Palencia que aunque se / juntase con el dicho gasto e con lo que más gastó su parte / que alcanzaba y lo que gastaron los nuestros oficiales en / la ciudad de los Reyes que hera cinco vezes más hazía / el gasto del dicho su parte verdadero y sin dubda e aver / hecho oficio de buen servidor en el buen cobro del por / gasto que en lo susodicho se avía fecho e que ansí se / deviera pronunciar por los del nuestro Consejo y no re / mitirlo a nueba quenta, pleito y probanzas contra / la hordenanza que disponía que lo líquido se declarase / así e no se remitiese a quentas y hera contra una / nuestra cédula en que se mandava que se tomase en quenta / al dicho su parte lo que obiese gastado en la dicha guerra / contra el dicho don Diego e ansí lo mandado en el dicho capítu / lo hera tal qual dicho tenía e devía rebocar e decla / rarse el cargo que se hazía a su parte el sobredicho e te / nerlo pagado e cumplido en el gasto susodicho e darle / de todo por libre e así lo pedía e suplicava e en / quanto por el nono capítulo de la dicha sentencia conde / naron al dicho su parte en quatro mil ducados aplicados / en cierta forma hera ynjusto y agrabiado contra / su parte e de rebocar porque no avía ni resultaba / del proceso causa vastante para ello y porque no a / vía ley ni hordenanza por que se pudiese venir condena / ción de quien enbiava oro y plata del Perú por regis / trar y porque no se pudieron mover los del nuestro Consejo //

/ 167 v. / por cierta cédula e hordenanza quel fiscal presentaba por / que aquella nunca se avía publicado en el Perú para poder / venir a noticia de su parte como se requería y constase por ser / penal y porque no hablava con aquellos cuya hera la hazien / da e lo enbiavan sino con los que lo trayan ni se podía de es / tender más y porque sobre esto conforme a ello estaba / pleito pendiente 
entre el fiscal y Francisco Bezerra que he / ra uno de los dichos mensajeros e que trayan la dicha suma / porque dezía el fiscal que la traya por registrar y hasta que / con aquel se determinase no se podía venir a la dicha condenación / que se avía fecho en este capítulo y la dicha hordenanza no / avía lugar sino en lo que viniese a Sevilla o a estos rey / nos por registrar ni en lo que entrase registrado agora / fuese en qualquier parte o lugar de qualesquier puertos / e yslas que ay antes de venir a estos reynos subjetos a nos / e así y así se avía usado e guardado por manera que aun / que del Perú saliese qualquier suma por registrar se le re / gistraban en qualquier de las otras partes sobredichas de / manera que entrase por Sevilla registrado venía libre la / dicha suma y lo mismo hera si la tal suma perdía en el / camino o por el que lo traya a lo qual si se obiera considera / ción no se hiziera la dicha condenación porque no constava que / de verdad la suma que salió del Perú enviada por el dicho / su parte no aver entrado por Sevilla ni venido a estos reynos / por registrar sino diez mil castellanos poco más o me / nos que traxeron Diego de Aller y Villalobos y Francisco / Martínez nonbrados en el capítulo e sentencia porque lo / que traya[n] Bezerra e Carranza no avía venido a estos / reynos sino solamente ciertas cosas de oro que se de / positaron en poder de Gaspar Ochoa que podían valer / quinientos ducados porque de lo que más trayan parte / avían dexado en el Perú en la ciudad de los Reyes / e parte en Panamá en poder de nuestros oficiales por / el comendador mayor Cobos y parte secrestado que / enbiaron a Sevilla los dichos oficiales registrado $\mathrm{e} / /$

/ 168 r. / parte perdieron ellos que dezían avérseles hurtado en lo / demás avían entregado a Peranzures por poder que tenía de / el dicho su parte y lo que estos entregaron al dicho capitán Pe / ranzures quel traya lo avía dexado en Panamá en poder de Lu / ys Sánchez Dalvo que solamente traya consigo al dicho su parte / a estos reynos siete mil castellanos poco más o menos / y esto agora los traxese registrados o no vastaua que se / resgistraron en la ciudad de Santo Domingo y vinieron re / gistrados a estos reynos a la Casa de la Contratación de / Sevilla e dos mil y tantos castellanos auía entregado / al dicho Luis Sánchez Dalvo a los oficiales de Tierra Fir / me que enbiaron registrados ansímismo y sacado de / lo que más queda en poder del dicho Luis Sánchez Dalvo o / cho mil castellanos que pagó por libranzas de su parte / en Panamá en paga e cumplimiento de deudas, entero / seruicio hecho de todo lo demás que abía entregado el / dicho Luis Sánchez Dalvo a Francisco de Ruyloba contenido / en el dicho capítulo de sentencia solamente vinieron a es / tos reynos ocho mil castellanos que avía dado a / un Cristóval Muñoz vezino de Sevilla a los quales no se / podía tener consideración contra su parte por quel / dicho Cristóval Muñoz avía sido preso y condenado en / cierta pena por lo auer traído sin registrar por / manera que constando como constaua por lo susodicho que / estaua ansí aberiguado en el proceso que de toda la dicha / suma quel dicho su parte enbió, no avía venido por re / gistrar a Sevilla sino los dichos nuebe o diez mil cas / tellanos e las dichas cosas de oro, graue cosa e injusta / hera condenar al dicho su parte en los dichos quatro mil cas / tellanos y la dicha cédula o provisión que el fiscal a / puntaba ni otro qualquiera que sobre esto hablase por / parecer que hera hecha mas adterior en que para exe / cución condenatoria no se auía guardado y si alguna vez / se auía hecho alguna condenación hera en muy poca quan / tía por ser cosa grabe que aviendo pagado los quintos //

/ 168 v. / reales a nos de lo que se trae a estos reynos per / diese la parte cuya es por traer su hazienda como qui / siese y ansí se auía hecho con el dicho Cristóval Muñoz / e otros y las tales proybiciones no podían a / ver lugar si no hera concurriendo aprehensión personal / en el paso de las tales sumas y que no estaua pro / vado aver mudado el dicho su parte que se traxese / por registrar y 
ansí lo confesaua el fiscal que / su parte mandaua que se registrase públicamente / e aunque en secreto dezía que mandaua lo contrario / y esto no lo probaua si algunos testigos algo quisie / ran decir no obrauan hefeto alguno por ser en su / exoneración e descargo y antes parecía lo contrario / porque constaua su parte auía dado poder al dicho / Peranzures para que cobrase en Sevilla la suma que / los susodichos trayan por las quales razones e ca / da una dellas el dicho capítulo de condenación hera / injusto e agrauiado contra su parte e se debía / revocar y en quanto por el doze capítulo se auía / puesto culpa a su parte y hecho condenación en el / último capítulo hera ninguno injusto e agrauiado / e de rebocar por quel dicho su parte avía cunplido / las provisiones reales quanto lo hera posible / e a onbre umano y a lo ynposible no hera obligado / e aquellas de que se hazía minción en el dicho capítulo / cerca del buen tratamiento de los yndios avía cunpli / do perfetamente porque a su parecer le avía sido / remitido como parecerá por el capítulo de su ynstru / ción presentado por el fiscal e por hordenanzas a / vía hecho y probeido los quales se guardaban y atento el / tiempo en que las hizo y qual estaua la tierra como si a / más pasara no se obedeciera y obiera alteración y escándalo que dauan muy justificadas las dichas hordenanzas / e la moderación que en ellas tubo tanto que hera de / tener en estimación poderlas hazer guardar //

/ $169 \mathrm{r} /$ e cunplir y estando lo susodicho probado por las dichas / hordenanzas y por testigos y por el escándalo que / subcedió en tiempo de Blasco Núñez por querer pasar / a mas y conestando desto a los del nuestro Consejo no de / vieran cargar a su parte la dicha culpa y porque no so / lamente se avía probeydo lo que tocava al buen tratamiento / de los yndios y en no cargar mas se avían puesto en más / livertad que tenían en tiempo que heran de yndios / e siendo ansí como hera notorio bien se abría cumplido / con lo quel dicho su parte devía cerca del dicho artículo / que en quanto a lo que se le avía encargado cerca del yr / los yndios a minas por lo dicho en el sesto capítulo / conestaba del buen cumplimiento y probisión hecha / por el dicho su parte y pues por lo allí dicho se satisfa / zía a la culpa que se ponía al dicho su parte no se podía / poner en este y quedaba ansimismo satisfecho / y que en quanto al tasar los tributos de los dichos yndios / se podía muy menos por esto cargar la dicha culpa por / que su parte no tenía obligación ni facultad para los / tasar de por sí por yr como yva allí remitido al / Obispo del Cuzco juntamente e siendo como hera muerto / el dicho obispo no avía quedado en su parte poder ni obli / gación para lo hazer y que por su parte se avía hecho per / fetamente la obligación, ynteligencia y probención / necesaria sin la qual no se podían tasar los tributos / que hera contarse los yndios que avía en los repar / timientos y encomiendas de cada uno y que se supie / se en que linage y natura de bienes podía pagar / cada repartimiento y cacicado sus tributos y al / tiempo en que se feneció y acabó y en que teniendo / su parte poder y obligación para ello se pudiera pasar / a la tasación de tributo y avía llegado Blasco Núñez / Vela e dexado su parte el cargo y ansí por esto no se le / podía ynputar la culpa del dicho capítulo y de poner //

/ 169 v. / la tierra e pacificación no avía sazón ni tiempo ni facul / tad ni poder para hazer en aquel tiempo cosa alguna ni me / nos las que tocaban en vezinos y estantes que yvan con el / dicho licenciado Vaca de Castro en la dicha guerra porque se siguie / ra entre ellos tal alteración e desgracia que o mataran al / dicho su parte o se fueran al dicho don Diego ni sucediera es / cándalo dello y porque en el poco tiempo que después / estubo su parte en la dicha gobernación avían tenido $\tan /$ tas e tan grandes ocupaciones en poner como puso aque / llos reynos en horden, justicia, subjeción y pacificación y / en otras cosas ynportantísimas y necesarias a nuestro ser / vicio que ansí por esto como por la brevedad del tienpo hera / ynposible de toda ynposibilidad pasar a más en el / entretanto ansí por no tener su parte poder para la dicha / tasación por probisión particular como 
por la difi / cultad y brevedad del poco tiempo y ocupaciones so / bredichas avía hecho por tasación la horden que dio con / tenida e declarada en el sesto capítulo sobredicho y es / tando todo esto probado e aberiguado en el proceso / no se podía ni devía cargar al dicho su parte la dicha cul / pa y por aver de más desto conplido su parte lo / que hera mandado como lo dezían sus testigos se avía / de declarar aver bien cumplido y serviso cerca de lo su / sodicho e de lo que le fue encomendado y en no se hazer / ansí hera su parte agrabiado e la sentencia cerca de / esto dada ynjusta e se devía rebocar y en quanto / al diez y siete capítulo en que en efeto avían de / clarado ser su parte en culpa en lo quel fiscal dezía / averse detenido Diego Méndez en la cárcel por gozar / de sus yndios hasta que se fuese hera ynjusto e de / rebocar porque en quanto ansí se avía dilatado o no / el determinar el pleito del dicho Diego Méndez su / parte hera ni podía ser en culpa alguna por no / ser juez de la causa que lo hera el licenciado Antonio //

/ 170 r. / de la Gama teniente general en aquellos reynos y si al / gund efeto en el proceder o dilatar avía avido, que / negava, contra él avía de tener el fiscal recurso antes / que contra su parte en especial siendo tan rico e a / bonado y que tenía repartimiento de yndios en a / quella tierra y porque el dicho licenciado de la Gama se / mobería por muchas causas y por reformar e / ligitimar bien en el proceso que contra el dicho Diego / Méndez hazía para lo qual avía muchas causas / que movían a los juezes de que en el proceso no se ha / zían a vezes ni convenía hazerse en entera relación e que la dilación que se avía tenido en determinar / el pleito de su parte abiendo los términos como en el / de publicación e otros hazía justo lo susodicho e de / las causas que tenía el dicho licenciado de la Gama el / dicho su parte no avía tenido noticia particular mas / de que en general mandava muy contino al dicho licenciado / de la Gama que despachase aquel negocio y en todo su / parte avía hecho [lo] que devía y en quanto a la decla / ración si la vbo o no en el despacho del dicho negocio el / dicho su parte no hera en culpa alguna y porque de sol / tarse el dicho Diego Méndez no se podía cargar culpa / al dicho su parte por no ser juez de la causa y porque sin / ser juez avía puesto gran deligencia en la guarda de / el dicho Diego Méndez porque demás de la que avía del / carcelero hordinario había puesto ciertas per / zonas de confianza e calidad en guarda del dicho Diego / Méndez e subcedió a esta sazón que se quitó los grillos / cierta noche y por cierto agujero se salió y luego a la ora / que se supo hizo su parte exsatísimas deligencias en pro / curar por todo el Reyno de aver al dicho Diego Méndez / enviando por todas bías personas para ello e / a los puertos de mar para que no se pudiese sa / lir de la tierra y azotó al carcelero públicamente //

/ 170 v. / las guardas sin tener culpa se huyeron y que lo que se de / zía en el dicho capítulo ques de tener al dicho Diego Méndez / mucho tiempo en la cárcel por sentencia hera por gozar / su parte de sus yndios falso fundamento sobre / que no se podía fundar la dicha condenación porque el dicho / Diego Mendez desde el día que cometió el delito en jun / tarse con don Diego de Almagro y sustentar su leban / tamiento avía perdido los yndios y ansí por bacos se avía entrado en ellos el capitán Castro e dellos le / avía hecho el dicho su parte probisión e después por / muerte del dicho capitán Castro se los avía encomenda / do el dicho su parte y ansí no se podía seguir la causa / quel fiscal en el dicho capítulo dezía y porque hera no / torio que aunque el dicho Diego Mendez tubiera los yn / dios en su cabeza como los tenía antes del delito más / le inportava a su parte para los gozar libremente / que se hiziera luego justicia del dicho Diego Mendez e que / tanpoco se pudieron mover los del nuestro Consejo por / cierta carta que su parte scriuió al secretario Saa / bedra porque aquel hera caso diverso carta de cun / plimiento y sin efeto y porque por ello antes parecía / que se devía hazer justicia del dicho Diego Mendez que / no soltarle por manera que estante lo susodicho y 
pro / vado en el proceso no avía de que echar culpa al dicho / su parte antes avía de ser dado por libre cerca de lo / en este capítulo contenido y ansí se devía hazer re / bocando lo cerca desto declarado y sentenciado y en / quanto al dézimo séptimo capítulo en que avían con / denado al dicho su parte en mil ducados declarando / resultar culpa grabe de que se avía hecho / condenación en el último capítulo hera muy yn / justo e agrabiado contra su parte e de rebo / car por lo que resulta de lo arriba dicho e alegado / e porque el dicho su parte avía tenido poder y facultad //

/ 171 r. / como gobernador que a la sazón hera de dar los dichos yndios / e no se le avía quitado la facultad ni hecho ynpedimento que / se dixo en el Cuzco treslado de hordenazas que se avían hecho / en España por ser treslado sinple que su parte no leyó que su / parte no avía de ser gobernador y juez, que avía de mober / se que se dixese del dicho treslado para dexar de hazer lo que / devaxo de su oficio se contenía que hera repartir yndios con / forme a lo que avían hecho los gobernadores pasados en el / Perú y en todas las Yndias donde no avía sido spresamente ve / dado y estando ansí savido y probeydo por nos y porque el dar / los pocos yndios que su parte dio después que salió del / Cuzco no hera nobedad sino continuar el repartimiento que / tenía encomendado en reformación de la tierra y ansí los yn / dios que dio heran ciertas demasías que se quitaron a Her / nando Pizarro los quales avía dado legítimamente a per / zonas que avían servido y lo merecían e haziendo su par / te bien su oficio y a esto no ynpidía que viniendo de camino / para los Reyes después de pasados de Guamanga se dixe / ra que venía virrey ni aunque se dixera que hera llegado e se supiera de cierto porque por esto no espirava el poder / que su parte tenía hasta que le fuese noteficadas las pro / visiones que llevava e que después que adelante le fueron / noteficadas no se hallaría aver dado ni repartido yndio ninguno / e que los dichos yndios avía dado e repartido el dicho su parte sin / aver ni pretender ynterese alguno como avía hecho e tra / tado lo que en aquella tierra avía administrado e que si el dicho su parte no quedara con los yndios que tenía para susten / tar el cargo dexados aquellos no tenía qué comer ni con qué / vivir hasta que dexase el cargo e se avía detenido algu / nos días sin lo repartir hasta que la gente a quien avía / prometido yndios porque peleasen contra el dicho don Diego pareciéndoles quel dicho su parte yba a la ciudad de los Reyes para venir a Castilla acudieron con demasiado yn / pitu al dicho su parte para que le diese los dichos yndios / que tenía en su cabeza para sustentar el cargo des / hordenándose en palabras y atrebimientos y ayuntamientos //

/ 171 v. / entre sí de matar al dicho su parte y hazer alteración sino / le diese los yndios aunque no quisiese de que se le siguió / justo temor de perder la vida e peligro de su persona e de / ser apremiado para ello que le hera forzado, conpelido por el / dicho peligro que se tenía de cierto que le subcediera de muerte / y coation personal para se librar e sosegar la alteración / que se representaua de quitar de sí los dichos yndios e los / dar e repartir por lo qual aunque se auía cunplido / con pocos heran tales que avía cesado el dicho peligro e al / teración y no se pudieron mover los del nuestro Consejo a lo / que determinaron en este capítulo por los testigos que en esto dixeron contra su parte en especial en la proban / za hecha contra él en el Cuzco e los Reyes de que no avía da / do treslado ni hecho publicación por ser personas los que / allí dixeron delinquentes e aver cometido crímen leges / magestatis contra nuestro servicio e bien público de aque / llos reynos e por esto heran ynfames demás de ser enemigos capitales de su parte e yntimos amigos, fa / miliares, hermanos y parientes de enemigos públicos su / yos e no hazían al caso sus dichos por las quales / razones e cada una dellas estaua su parte escusado / de toda culpa y constaua del agrabio e ynjusticia / del dicho capítulo para que se debiese revocar e dar / a su parte por libre y en quanto al 
diez e ocho capítulos / de la dicha acusación dixo que todo lo que hera o podía / ser en favor de su parte hera buena e justamente dada / e pronunciada pero en quanto hera o podía ser / contra él hera ninguna especialmente en quanto / por él se avía mandado que cerca de ciertas fuentes quel / fiscal pretendía aver dado a su parte Diego Mora vezino / de la ciudad de Truxillo se hiziese más aberiguación estan / do bastantemente privado e aberiguado en lo que dixeron / los testigos presentados por el dicho fiscal junto aver su parte / mandado hazer las dichas fuentes por su dinero e pa / sado al dicho Diego de Mora realmente y con efeto todo //

/ 172 r. / el valor e costa y hechura dello e que deviendo de dar / por libre a su parte cerca de lo quel fiscal pretendía / aver el dicho su parte enbiado a ranchear los yndios que de / zía de Ysasaga por un Alonso de Origuela le avían con / denado en ducientos ducados y en culpa en el final ca / pítulo lo qual hera ynjusto e agraviado contra su parte / e de rebocar por lo general que estava dicho e alegado / e porque su parte no hera persona que avía de enbiar / a ranchear yndios algunos porque ynbiar a ranche / ar es ynbiar a robar e por una vía ni por otra el / dicho su parte no avía enbiado a yndios de Ysasaga por / que nunca los tubo en la tierra en tiempo de su parte / y el dicho Alonso de Origuela avía ydo a cobrar tribu / tos justos e devidos por los yndios que se dezían $\mathrm{Ca} /$ rangas que por muerte de Antonio de Origuela último te / nedor su parte los avía encomendado y probeído al dicho / Diego de Aller en la ciudad de Quito por lo que avía servido / e venir por mensagero a nos ynbiado por su parte para / que supiésemos la muerte del dicho marqués y alzamiento / de don Diego y estado de la tierra como hera razón e ha / zerse por el dicho su parte en gratificación de su travajo / como se acostunbrava hazer en Yndias yr los gobernadores con / lo que avían enbiado e ynbiavan por mensageros a nos / y en proveer su parte en el remedio de su hazienda du / rante su hazienda [sic] y que se cobrasen los tributos de los yn / dios justo que solían dar sin que recibiesen agravio / avía hecho oficio de buen juez en que se pagase la deu / da y de buen gobernador y servidor nuestro e que no recibie / se daño el dicho Diego de Aller por aver venido en nuestro ser / vicio e deviendo como debían los dichos yndios dos años / poco más o menos de tributos aver y cobrar dellos en lo / quellos podían y solían ocho mil castellanos de valor / siendo como heran de los ricos y principales repar/ timientos del Perú en lo qual los dichos yndios antes avían //

/ 172 v. / sido muy aprobechados que recibiesen en cosa alguna / fuerza ni agrabio ni vejación e siendo ansí notorio e / averiguado y el justo principio y medio y no avía por / qué condenar a su parte e la dicha condenación se debía re / bocar declarando por libre de todo lo susodicho y en quanto / en el veinte capítulo de la dicha sentencia se avía puesto / culpa al dicho licenciado Vaca de Castro y condenación / en el capítulo final hera ynjusta y agrabiada co / mo en todo lo demás porque el dar poder su parte / general para recusar cualquier juezes no hera ar / tículo proyvido mas permitido por todo derecho / porque estando como estaba tres mil leguas de España / justa causa tenía de probeer a la seguridad de su / justicia y por qué estatuyda esta pena a quien / pone recusación sin causa y ansí sin pena se puede / dar poder y no lo poner y no hera ni quedaba cosa de / culpa e que por la ynstrución y capítulo que el / fiscal presentaba no parecía se seguía que su parte es / criviese que se hiziese en estos reynos ningún servicio a / las mugeres de los del nuestro Consejo para corrución de / buena administración de justicia ni tal se podía pre / sumir mayormente no teniendo su parte pleito pendien / te a la sazón en el nuestro Consejo ni en otro tribunal y quel / efeto de lo contenido en el capítulo de la dicha yns / trución aunque fuera en caso proyvido lo que en e / lla se dezía no se podía dezir culpa perficionada / no aviendo efeto mayormente viniendo a volun / tad e determinación agena e aquella determinán / dose en que no se hiziese ni efetuase como 
no se avía / hecho ni efetuado cosa de lo en el capítulo contenido / quanto más que de los afetos sin efetos no se seguía / culpa por la qual se devía rebocar la dicha sentencia / en este artículo e dar por libre al dicho su parte y en / quanto por el veinte y un capítulo que habla de los //

/ 173 r. / navíos que fueron detenidos en el puerto de los Re / yes se dava por culpado el dicho su parte con condena / ción en el final capítulo e se avía dicho ansímismo / que en quanto al daño e ynterese que dello avía / venido a nuestra hazienda real se hiziese más aberigua / ción e condenación en lo que pareciese aver venido / de daño y en quanto al ynterese de los tratantes re / serbaron su derecho a salvo contra su parte hera ninguna / e agraviada e de rebocar porque deviendo de de / clarar aver hecho servicio de ganar la mar de poder del / don Diego de Almagro y tomarle los nabíos que te / nía en el puerto sin lo qual no se ganara la tierra de su / poder porque con esto recogiera consigo todos los / pasajeros aquella tierra fueran en el medio tiempo e / armas, cauallos y otros aparejos y probeyera de enbiar / a Panamá con que pudiera traer más gentes y aparejos / por la qual por ninguna vía el dicho Vaca de Castro fue / ra parte para recobrar della tierra y a gran travajo / después se entrara se avía hecho e declarado en la dicha sen / tencia lo contrario y que demás de lo susodicho que hera / servicio y necesario tener su parte los nabíos en el puerto / lo hazía e ansímismo justo lo siguiente que a la sa / zón e tiempo que estubieron en el puerto concurría / ser necesario a la guerra contra el dicho don Diego de Alma / gro y recobrar la tierra tenerlo su parte en el puer / to para recoger los dichos pasajeros e armas e / cauallos y aparejos para la guerra que a la tierra / vinieron al medio tiempo porque como en la tierra a / vía poca gente que no tubiese don Diego y dificulto / sa de acaudillar avía ansimismo defeto de armas / e tiros de cauallos y otros aparejos y con tener el dicho / Vaca de Castro los dichos nabíos en el puerto pudo / recoger como avía hecho estas personas y cosas //

/ 173 v. / que avía sido grande ayuda para acrescentar su real e / poder y auer vitoria lo qual se probava por aver estado / con todo ello tan dubda la vitoria de la vatalla como he / ra notorio y por dezir como dezían los testigos en las pro / banzas deste dicho pleito que una de las más pequeñas / probidencias que su parte avía hecho para las dichas vatallas / que faltara no se ubiera vitoria e se perdiera la tierra / de que se seguía ser en servicio nuestro y necesario para la dicha / guerra de tener los dichos nabíos pues a no lo hazer e / faltando las dichas probidencias se perdiera la vitoria / e también estava aberiguado tenerse por cierto que por ser / casi todos los dueños de los dichos nabíos y marineros afi / cionados al dicho don Diego si se soltaran del puerto y no es / tubieran con buena guarda se fueran para él hazia la / vanda del Cuzco e subcedieran los daños susodichos / ansimismo hera necesario y buena probidencia fue / tener seguridad con esto el dicho su parte para si fuera / venzido el dicho don Diego tener en que se recoger con / la gente que le quedara para yr con los nabíos a Pana / má e Nicaragua a recoger de presto gente e apa / rejos con que volver a servirnos contra el dicho don Diego / por carta e amenazada la ciudad de los Reyes por / que avía reciuido a su parte por gobernador de bolber / sobre ellos y hera necesario para recoger en tal caso / los vezinos tratantes con sus hijos y mugeres e ha / ziendas en los dichos nabíos lo qual bastava para hazer / justa e bien probeyda su detenencia y que en hazer / el dicho su parte en lo susodicho no solamente los tratantes / no avían perdido mas avían reciuido probecho porque por / ninguna vía si el dicho don Diego estobiera apoderado co / mo estaua en la tierra y su parte no le benciera y la / pacificara ellos no podían continuar sus tratos / sino perderlos y ser cada día robados y saqueados / ni los osaran enbiar por mercadurías ni los de Panamá // 
/ 174 r. / enbiárselas y con ser tan grande y necesaria ayuda de / tenerse los dichos nabíos para se recobrar y pacificar / la tierra avían sido en esto muy aprobechados e / deviéndose pronunciar el detener los dichos nabíos por / necesario para la guerra y vien de los tratantes e de / viéndose mandar a su parte la satisfación que / cerca desto avía hecho a los dueños de los dichos nabíos / se avía pronunciado en todo lo contrario y que aunque / todo lo susodicho cesara, que no cesaua, hera notorio e se / siguía claro de las probanzas que su parte no auía reciui / do probecho ni ynterese alguno de la detenencia de los / dichos navíos sino a nos y bien de los tratantes y a la dicha tie / rra e que avía hecho la dicha detenencia con justa / razón e buena fe la qual escluya todo delito e / culpa para que no se le deviera cargar a su parte / como se avía hecho e que ynterese de ynterese no se seguía / de derecho y en declarar en todo lo contrario la dicha sen / tencia hera qual dicha tenía e se debía rebocar e dar / a su parte por libre y mandar que se le tomase cue[n]ta / e se le hiziese pago de lo que avía dado en satisfación / a los dueños de los dichos nabíos guardando cerca desto / la cédula por nos dada que estaua por su parte presentada / en que se le mandaua tomar en quenta lo gastado en / la guerra contra el dicho don Diego como hera justo e / se debía hazer e pronunciar lo mismo en lo del poco / tiempo que los nabíos estuvieron en el puerto después de / avida la vitoria por llegar a la sazón carta de los / oydores que residían en Panamá en que dezían a / su parte que pusiese recaudo en los puertos por / que tenían nueva cierta de una carabela que avía lle / gado que avían enbocado diez nabíos de franceses / por el estrecho de Magallanes, concurrió a la sa / zón venir aviso al dicho Vaca de Castro de la puerta / de Arequipa que salían por lengua de yndios que venían //

/ 174 v. / nabíos por la parte de Chile y hasta sauer verdad conbino / a nuestro seruicio y bien y pacificación de la tierra y seguridad / della detenerse los dichos navíos e ansí los hiziera qual / quiera que gobernara que tubiera capacidad y cuidado de / tener su provincia segura y en condenar en los deste tienpo / con lo demás al dicho su parte hera agrabio e de rebocar / como se debía hazer y en quanto en el fin de la dicha sentencia / por donde reservaron las culpas que se cargaron al dicho / su parte por los sobredichos capítulos de la sentencia le / condenaron en seis años de suspensión de su oficio e de / administrar cargos y oficios de justicia hera ninguna e muy / injusta e agrauiada e de revocar por todas las razo / nes de nulidad e agrauio e ynjusticia arriua dichas e / alegadas en cada uno de los dichos capítulos en que se / auía cargado culpa al dicho su parte porque por ellas que / daua escluyda toda la culpa e ansí cesaua la dicha con / denación y porque bastaua al dicho su parte para esto tener / como tenía en cada uno de los dichos capítulos buena fe, / costumbre, causa o necesidad precisa y convenir a nuestro ser / vicio e bien de la tierra las quales causas y qualquiera / dellas se escusauan de culpa e que en caso que alguna ovie / ra que negaua bastaban las causas generales al principio / de la dicha suplicación refiridas e rebocar para que / deviese rebocar la dicha condenación e dar por libre a su parte / como estaua dicho y alegado e pedido e suplicado y en quanto / remitieron al presidente e oydores de la Chancillería que / reside en la ciudad de los Reyes de las provincias del / Perú para que ante ellos e los nuestros oficiales que allí re / siden se hiziese quenta de lo en la reconvención contenido / e que no se le tomase en quenta el salario de la gente de / su guarda e que después se enbiasen las dichas quentas con / el parecer de los dichos presidentes y oidores del nuestro con / sejo para pronunciar sobre ello hera muy injusto / e agrauiado e de revocar porque debiendo pro //

/ 175 r. / nunciar cerca desto la dicha reconbención por bien proba / da e condenar en toda ella al dicho nuestro fiscal no se avía he / cho ni declarado ansí en caso que alguna duda ubiera en el caso / 
e berificación de la dicha reconbención se avía de mandar / hazer la quenta y birificación en esta nuestra corte donde esta / va el dicho su parte y nuestro fiscal e las probanzas que avía cerca / desto e mandádose como se avía mandado en la dicha sentencia quel / dicho su parte diese quenta con pago en esta corte de lo que se ha / zía cargo de hazienda de necesario y consecutibamente pe / día que se hiziese lo mismo en lo por su parte reconbenido / e pareciese aver gastado en nuestro servicio y en no se hazer / ansí hera agrabio e desygualdad de justicia y no avía / preuilegio de físco ni otro derecho que tal pudiese justi / ficar y que constando evidentemente por probanzas del / proceso ser los dichos oficiales enemigos capitales como / demás de deponerlo los testigos ansí se probaua por / las cartas que nos scribieron contra su parte no se po / día ni devía mandar que ante ellos se hiziese la quenta / ni asistiesen allá y estando acá las probanzas como / otros testigos muchos que hazían la dicha reconbención / e muertos muchos testigos de los que estauan presenta / dos por ninguna vía se podían hazer las quentas en el / Perú sin llevar todo el proceso y atento esto y las dis / tancia del camino y peligros dél y la dilación que trayan / consigo < todas quantas avía sin fenecimiento y las otras > cosas que cerca deste artículo concurrían por / ygual hera lo que se avía mandado en la dicha sentencia / que dar por libre al fiscal e quitar a su parte derecho e justicia / e que perdiese toda la dicha hazienda gastada en nuestro / servicio e quedase con las deudas que devía dello a / personas particulares e que su parte no tenía más / que probar ni averiguar cerca del alcance que ha / zía en sus quentas y pedía por reconbención y por es / to no avía lugar remisión sino determinación y en mandar / como se avía mandado que no se tomase en quenta a su parte //

/ 175 v. / el gasto e salario de la guerra y otras cosas que tubo he / ra contra razón e justicia y contra una nuestra carta que / mandaua que se tomase en cuenta lo gastado en la gue / rra contra el dicho don Diego por la cual y por otra carta que / escrevimos al dicho su parte desde Monzón y por la que / ansímismo screuimos quando fue el dicho Blasco Nuñez / parecía que todo lo gastado en la dicha guerra hera en / nuestro seruicio y lo que se auía determinado hera quitarlo / todo a su parte contra la probanza evidente que avía / de testigos de ser necesario tener la dicha guarda el tiempo de / la dicha guerra para guarda de su persona porque a no la / traer corría peligro y faltando él ni se hizieran las / cosas que heran necesarias para recobrar la tierra ni se / recobraua ni después de la vitoria se subjetara en / pacificación e justicia e ser esto ansy se probaua / por evidencia notoria de los subcesos que subcedieron / en el Perú a los gobernadores dél por no tener la dicha guar / da como su parte tubo que al marqués don Francisco / Pizarro por no la tener le mataron y a Blasco Núñez Vela / por lo mismo le prendieron e le hecharon de la tierra que / sy la tubieran con vos no subcediera lo que subcedió e / por este hefeto avía perdido nuestra hazienda real en cada / alteración de las susodichas dos millones de oro de donde / se colegía quan en nuestro servicio avía sido tener su parte la / dicha guarda y el gasto que con ella se avía hecho porque / por la tener no subcedió otro semejante subceso e avía / estado la tierra el tiempo que su parte gobernó en pacificación / e justicia lo qual hera ynjusto e agrabiado lo que contra / su parte en esto estaua determinado e que aun no se / avía tenido consideración a lo que antes estaua seña / lado al marqués Francisco Pizarro para la guarda / de su persona en tiempo de paz porque si a esto se tubie / ra consideración no se podía quitar al dicho su parte e / atenta la guerra que tubo por justo y moderado gasto //

/ 176 r. / lícito e devido se tubiera lo que su parte gastó e dava / por gastado en la dicha guerra y el salario a que se refe / ría el dicho capítulo ni vastaua para suplir esto ni para sus / tentación de la tierra parte que avía menester el dicho su / parte como estaua dicho en el segundo capítulo de la dicha / suplicación por las quales razones lo que se avía de / terminado cerca de la dicha 
reconbención hera tal qual / dicho tenía e se devía condenar el dicho nuestro fiscal en / todo lo de la dicha reconbención haciendo a su parte / justicia sobre todo como tenía pedido e suplicado y en / quanto por el final capítulo de la dicha sentencia se avía re / sumido el salario que a su parte se devía del oficio / de juez desde el tiempo que se hizo a la vela hasta que / bolbió a esta corte donde partió y el que ansimismo le / pertenecía y avía de auer de gobernador conforme a / como lo tenían los gobernadores pasados en los quinze / mil ducados que se le señalauan por todo la dicha sen / tencia hera ynjusta e muy agrabiada porque el salario / que se le avía señalado de juez hera distinto del oficio / de gobernador y para cosas que requerían comisión e / ansímismo lo que en lugar de salario tenían los gober / nadores pasados de ayuda de costa hera de oficio di / verso del de juez y por aver hecho su parte anbos oficios / se le avían de dar anbos salarios por derechos claros / e en pronunciarse lo contrario hera agrabiada contra / su parte e porque el salario de los quinze mil ducados / a que se refería el capítulo de la dicha sentencia no hera / equivalente para sustentar en el oficio quanto más / para satisfación y cunplimiento de paga de los dichos / salarios devidos como más largamente estaua dicho / e declarado en el dicho segundo capítulo por el qual lo / que en el dicho capítulo se avía determinado contra / su parte se devía como ynjusto rebocar e mandar e / pagar al dicho su parte los dichos salarios enteramente //

/ $176 \mathrm{v}$. / e condenar al dicho fiscal a que an sido lo hiziese e cum / pliese e ansí pedía por las quales razones e cada / una dellas dichas en general e particular en cada uno de / los dichos capítulos nos suplicaua que en todo lo susodicho / que la dicha sentencia hera o podía ser contra el dicho su parte la / mandásemos rebocar e asolbiésemos e diésemos por / libre e quito al dicho su parte de todo lo contra el pedido sen / tenciado e determinado condenando al dicho nuestro fiscal / en todo lo por el dicho su parte pedido e reconbenido y en el / dicho alcance de quentas e salarios declarando no se poder / aver hecho ni hazer al dicho su parte cargo alguno de las co / sas que fueron necesarias y convinientes hazerse en la gue / rra contra el dicho don Diego de Almagro e recobrarse de / su poder aquellos reynos y los tener e subjetar en / pacificación y justicia y en nuestro servicio mandando ha / zer e haziendo en todo al dicho su parte cumplimiento de / justicia por aquella vía y forma que más le conbiniese / e que se ofrecía alegar lo alegado y no probado e lo / nuevamente alegado de la qual dicha petición e supli / cación fue mandado dar treslado al dicho nuestro fiscal y es / tando en este estado Juan de Oribe en nonbre del dicho / licenciado Vaca de Castro del nuestro Consejo por otra pe / tición que presentó dixo que pues por la dicha sentencia el / dicho su parte estaua dado por libre de todo lo acusado / en delitos y lo más consistía en hazienda e con lo / que el dicho su parte tenía probado en su reconbención an / tes alcanzaba nos suplicaua le mandásemos alzar la / carcelería que le estaua puesta libremente o con fian / zas de la haz lo qual visto por los del nuestro Consejo Real / de las Yndias probeyeron que dando fianzas de cient / mil pesos de oro de estar a derecho e pagar lo juzgado hasta esta / cantidad descontando dellos todo lo que le estaua se / crestado ansí en España como en las Yndias y los diez mil / ducados que se le acreçentauan de salario por el tiempo dicho en //

/ 177 r. / la sentencia y el salario de los cinco mil ducados que corrió / desde la noteficación de la probisión de Blasco Núñez / Vela hasta que tornó en España se le alzaría la carcele / ría después de lo qual el licenciado Agreda nuestro fiscal / por una petición que presentó en onze días del mes de mayo / del dicho año pasado de mil y quinientos y cinquenta y quatro / dixo que la dicha sentencia en el dicho pleito dada en lo que hera / o podía ser en favor de nuestra cámara y fisco hera buena / justa e derechamente dada e della no avía lugar suplicación / ni otro remedio alguno ni se avía 
suplicado ni en tiempo ni en / forma y hera pasada en cosa juzgada y por tal pedía se / pronunciase e caso que esto cesase, que no cesaua, se a / vía de confirmar o de los mismos autos dar otra tal sin / envargo de lo que en contrario estaua dicho y alegado pero / en quanto hera o podía ser en perjuizio de nuestra cámara / e fisco y que en no auer condenado a la dicha parte con / traria en mayores cantidades y penas y costas hera / de enmendar suplir y reformar y él ansí lo pedía e / para ello sy necesario hera suplicaua de la dicha sentencia / quanto a lo susodicho por vía de restitución e como me / xor oviese lugar de derecho lo qual pedía se le concediese / e que no avía lugar la reconbención que la parte contra / ria hazía e ansí se avía de declarar contra lo qual / Juan de Oribe en nombre del dicho licenciado Vaca de Cas / tro por otra petición que presentó dixo que la dicha su / plicación no se podía ni devía recibir ni admitir por / no ser puesta por parte ni en forma ni como se requería de / derecho y hera fuera de tiempo estatuydo por leyes destos / nuestros reynos y ansí en quanto al dicho fiscal la dicha sen / tencia hera pasada en cosa juzgada e menos avía lugar / de ynterponerse la dicha suplicación por vía de res / titución ni otro remedio alguno contra el transcurso / del tiempo porque no le pertenecía ni podía per / tenecer de derecho por pasarsele el término en que podía supli[car] //

/ 177 v. / mayormente en este caso en que atenta la acusación / e natura del negocio y calidades de los artículos sentenciados / e determinados por la dicha sentencia estaua escluso el fis / co de todo auxilio de restitución ni otro recurso ni / remedio alguno por lo qual la dicha suplicación por sí ni por / la dicha vía de restitución ni por otra manera no avía lugar / e se devía repeler del proceso e declarar no auer / lugar y estar la dicha sentencia pasada en cosa juzgada / quanto al fisco e ansí pedía y suplicaua se hiziese / e determinase e se diese al dicho su parte en los artículos / determinados en su favor carta executoria dello e / ante todas cosas pedía sobre esto debido pronunciamiento / e quando se reciuiese a prueba se determinase lo suso / dicho porque el dicho su parte supiese sobre qué artículos / avía de hazer su probanza sobre lo qual por las dichas / partes fueron dichas e alegadas otras muchas razones / cada una dellas en guarda de su derecho fasta tanto / que concluyeron y fue avido el dicho pleito por concluso / e visto por los del dicho nuestro Consejo dieron e pronun / ciaron en él un auto del tenor siguiente: [Al margen: Auto] Los señores del / Consejo Real de las Yndias de su magestad aviendo visto el / proceso entre partes de la una el licenciado Agreda / fiscal en el dicho Consejo e de la otra el licenciado Vaca / de Castro del Consejo Real en Valladolid a catorze días del / mes de agosto de mil e quinientos y cinquenta e quatro / años dixeron que debían recibir e recibieron a la parte / del dicho licenciado Vaca de Castro a la prueba de lo por él / dicho y alegado y no probado en la primera ystancia para / que lo pruebe por scripturas o confisión de parte y no en / otra manera e de lo nuevamente alegado por aquella / vía de prueba que obiere lugar de derecho e a la otra / parte de lo contrario si quisiere salbo jure yn per / tinenciun ed no admitendorun con plazo e término de / cinquenta días primeros siguientes y en quanto a la restitución //

/ 178 r. / pedida por parte del dicho fiscal en la petición de suplica / ción declararon que no avía ni ubo lugar e se la devían de / negar e denegaron el qual dicho auto se notificó a las / dichas partes y el dicho licenciado Agreda nuestro fiscal por una / petición que presentó en el dicho nuestro Consejo dixo que / suplicaua del dicho auto en lo que hera en perjuizio de nuestro fisco / e hablando con devido acatamiento se devía rebocar / porque ante todas cosas se avía de determinar e declarar / si el término de los diez días avía corrido y no para poder / suplicar y el dicho artículo hera el principal y perjudicial e / que ante todas cosas se avía de determinar e declarar / e por qué leyes e 
hordenanzas de las dichas chancillerías rea / les de Valladolid y Granada estaua determinado el dicho artículo / e punto y que en qualquier causas cebiles o criminales / pidiendo el fiscal el proceso al tiempo que se le notifi / can las sentencias e autos como él lo avía hecho no le corría / tiempo ni término alguno para poder suplicar has / ta que real e verdaderamente el testimonio de la causa / le enbiase y entregase el proceso y el dicho fiscal no he / ra obligado a enbiar por el proceso ni hazer otra de / ligencia alguna las quales dichas leyes e hordenanzas / heran usadas e guardadas en las dichas chancillerías / sin que se obiese visto ni hecho lo contrario e aquellas / mismas se avían de guardar en el dicho nuestro Consejo Real de / las Yndias por estar ansí mandado y que la preminencia / dada e concedida a nuestro fisco real no se avía de que / brantar mayormente en tan alto e supremo tribunal / donde el fisco hera de mayor dinidad y preheminencia / e que cesando todo lo susodicho, que no cesaua, la resti / titución por él pedida se avía de conceder porque en / todas las causas cebiles y criminales en los autos / e cosas judiciales para suplicar y alegar lo que no / estaua alegado se avía de dar y conceder la dicha res / titución según derecho a todas las personas que tenía //

/ 178 v. / beneficio de restitución e que en las causas criminales / solamente se denegaba la dicha restitución quando se pedía / para probar después de hecha públicamente por la pre / sunción y temor de sobornación donde ya el remedio / e abción estaua prescrito y hera hordenado solamen / te a venganza lo qual no perjudicaua ni se aplicaua / a este caso donde el fisco no se ofrecía a probar ni / menos la abción estaua perenta ni extinta e donde pre / tendía un millón al ynterese como tenía pedido / e avía e podía aver condenación pecuniaria en / caso que no oviese lugar la pena hordinaria del / delito y que en todas las causas se podía suplicar / pasados los diez días por vía de restitución probado / el engaño e lesión segund la más regurosa y estrecha / opinión porque la dubda que se avía tenido y tenía he / ra si bastaua el transcurso de los diez días sin otra / probanza de lesión y puesto que obiese opiniones la / que se tenía por estilo y costumbre general hera que por / pasar los diez días se tenía por probada la lesión sin / hazer otros nuebos pleitos y probanzas en el dicho ar / tículo e sobre si avía la dicha lesión o no porque sería / hazer los pleitos ynmortales y heran cosas que se abe / riguaban quando los negocios se veyan en difinitiba e / que en caso que por parte de nuestro fisco se obiese de probar / la dicha lesión y no vastase auerse pasado los dichos diez / días parecía e se probaua la dicha lesión por el mismo proce / so y probanzas hechas en el dicho artículo en el cargo diez e / nueve así por testigos como por scripturas, conjeturas y presunciones / porque en semejantes casos se avían de tener por probanzas bas / tante y si no fuese para pena hordinaria al menos para extrahor / dinaria y para condenar a la parte qontraria en los daños y menoscabos que / por la dicha razón y culpa avíamos reciuido en las pro / bincias del Perú en especial que más de lo contenido en / el dicho cargo resultaua culpa contra la parte contraria por //

/ 179 r. / no aver hecho de su parte todo lo que podía hazer en nuestro servicio / para remediar y sosegar el dicho delito de rebelión ro / gando y persuadiendo a los pueblos la verdad y el /servicio nuestro y juntándose con el visorrey Blasco / Núñez Vela y con todos los servidores que tenían / nuestra voz en las dichas probincias y absoltarse en se / mejantes tienpos e dexar de servirnos avía sido / gran favor y ánimo a los contrarios y gran cargo / e culpa de la parte contraria que hera persona tan / principal en las dichas probincias a quien se tenía mu / cho respeto y para sosegar semejantes rebeliones / y escándalos no avía excusación ni causa ligítima / que pudiese escusar la parte contraria de culpa e / cargo en lo susodicho pues en semejantes tienpos y en de / litos de rebelión hechos contra nuestra persona real nuestros / vasallos sin ser llamados ni requeridos 
pospuesto / todo temor de personas, bienes y hazienda avían / de yr a servirnos y qualquier culpa y negligencia de / qualquier calidad que fuese se tenía por delito graue / especial en personas calificadas e de oficio como / lo hera la parte contraria y para el dicho hefeto e / para que fuese condenado por las dichas causas y cul / pas en las mayores penas cebiles e creminales en que / avía yncurrido lo qual si necesario hera dezía e pedía / de nuevo se avían de mandar ver las dichas probanzas / y scripturas que avía cerca de lo susodicho porque por / ellas pareciera ser verdad lo que estaua dicho y que a / vía lesión e causa legítima para conceder la dicha / restitución en caso que fuese necesario y que / pues la parte contraria tenía suplicado diziendo que / avía sido condenado por culpado no lo siendo en / causa criminal para la suplicación hera común por ser / la causa yndibida y que no pretendiendo probar ni di / latar como no pretendía nuestro fisco salvo que de los mis //

/ 179 v. / mos autos y procesos se determinase la dicha causa e / culpa no tenía de que se agrabiar la dicha parte contraria / pues dello no reciuía perjuizio por ende que nos supli / caua mandásemos ante todas cosas declarar aver a / vido lugar la dicha suplicación por razón de la dicha prehe / minencia de nuestro fisco y pedía ante todas cosas pronuncia / miento cerca de lo susodicho e csando esto que no cesaua / mandásemos reciuir la dicha suplicación por vía de res / titución o como mejor obiese lugar de derecho condenan / do a la parte contraria según tenía pedido y en la dicha / petición se contenía lo qual pedía e dezía de nuebo / con protestación que no le corriese tiempo ni término / para pedir restitución contra la sentencia principal / ni para dezir ni alegar lo que más a nuestro servicio conbi / niese de la qual dicha petición fue mandado dar treslado / al dicho licenciado Vaca de Castro el qual concluyó sin / embargo della negando lo perjudicial y por los del / dicho nuestro Consejo fue avido el dicho pleito por concluso / en el dicho artículo y visto dieron y pronunciaron / en el otro auto del tenor siguiente: Los señores del Consejo / Real de las Yndias de su magestad aviendo visto este / proceso entre partes de la una el licenciado Agreda / fiscal en este dicho Consejo e de la otra el licenciado Va / ca de Castro en Valladolid a diez e ocho días del mes de / setiembre de mil y quinientos y cinquenta e quatro años di / xeron que sin embargo de la suplicación interpuesta / por el dicho fiscal devían confirmar e confirma / ron en grado de reuista el auto y mandamiento por / los dichos señores dado e pronunciado a catorze días del mes agosto próximo pasado deste dicho año / y en grado de revista ansí lo pronunciaron e man / daron, el qual dicho auto se notificó a las dichas partes / e el dicho licenciado Agreda nuestro fiscal por una petición / que presentó dixo que los dichos autos heran e se avían //

/ 180 r. / de entender solamente quanto a lo criminal y no quanto a / yntereses y daños y condenación pecuniaria que estaua / pedida contra la parte contraria y nos pedía y suplicaua / para ebitar dubdas ansí lo mandásemos e declará / semos y estar denegada la dicha restitución solamente / quanto a lo criminal declarando aver lugar la dicha res / titución e reciuirse la dicha suplicación quanto a los dichos / daños e yntereses e condenaciones pecuniarias que se / pedía y él ansí lo pedía y ante todas cosas devido / pronunciamiento cerca de lo susodicho y para ello si ne / cesario hera en lo que avía lugar de derecho suplicaua del / dicho auto últimamente dado y ansimismo nos pedía / e suplicaua mandásemos declarar que los dichos autos / especial el de revista heran e se entendían sin perjui / zio de la nueba acusación por él puesta contra la parte / contraria pues hera artículo diferente de la qual dicha / petición fue mandado dar treslado al dicho licenciado / Vaca de Castro el qual por otra petición que presentó / replicó contra ello alegando de su derecho e suplicándonos / mandásemos denegar lo en contrario pedido e declarar / no aver lugar y concluso el dicho negocio 
en el dicho ar / tículo visto por los del dicho nuestro Consejo dieron e / pronunciaron en el otro auto del tenor siguiente: En la villa / de Valladolid a diez e siete días del mes de dizienbre de mil / e quinientos e cinquenta e quatro años los señores del Con / sejo Real de las Yndias de su magestad aviendo visto el / proceso de pleito del licenciado Agreda fiscal de su magestad / en el dicho Consejo con el licenciado Vaca de Castro del / Consejo Real y los pedimentos hechos por el dicho fiscal en / la petición por él presentada a veinte e dos días del mes / de setiembre próximo pasado en que en efeto pide / que se declare que la restitución que le está denegada en / la suplicación del negocio prencipal sea e se entienda / tan solamente en quanto a lo creminal y no quanto / a lo cevil de los daños e ynteres y condenaciones pecu //

/ $180 \mathrm{v}$. / niarias e que se declare asimismo que los autos dados / sobre el denegamiento de la dicha restitución especial el / de revista son e se entienden sin perjuizio de la nueva / acusación por él puesta contra el dicho licenciado Vaca de / Castro segund que en la dicha petición [testado: más largo] se contiene mandaron / que los dichos autos de vista e revista sobre el denegamiento / de la dicha restitución sean guardados cunplidos y executa / dos sin embargo de lo dicho e alegado por el dicho fiscal / en la dicha su petición e sin otra declaración alguna la / qual le devían denegar e denegaron el qual dicho auto / se notificó a las dichas partes y el dicho licenciado Agreda / nuestro fiscal suplicó dél por una petición que presentó / dixo e alegó ciertas razones suplicándonos man / dásemos revocar el dicho auto e hazer en todo lo / que tenía pedido e suplicado de lo qual fue man / dado dar treslado al dicho licenciado Vaca de Castro / e por otra petición que Juan de Oribe en su nombre / presentó dixo que la dicha suplicación no avía lugar / ni se devía admitir por no auer como no avía grado e / que sin embargo de lo en ella contenido concluya e por / los del dicho nuestro Consejo fue avido el dicho pleito por / concluso en el dicho artículo y visto dieron y pro / nunciaron en el otro auto del tenor siguiente: Los señores / del Consejo Real de las Yndias de su magestad aviendo vis / to el proceso entre partes de la una el licenciado A / greda fiscal en el dicho Consejo e de la otra el licen / ciado Vaca de Castro del Consejo Real sobre las de / claraciones pedidas por el dicho fiscal en Valladolid a / veinte e cinco días del mes de henero de mil e quinientos / cinquenta e cinco años dixeron que sin embargo de la / suplicación ynterpuesta por el dicho fiscal devían / confirmar e confirmaron en grado de revista el auto / e mandamiento por los dichos señores dado a diez e siete días / del mes de dizienbre próximo pasado del año de / cinquenta e quatro en grado de revista ansí lo pronunciaron //

/ 181 r. / e mandaron el qual dicho auto se noteficó a las dichas partes / e por parte del dicho licenciado Vaca de Castro se presenta / ron algunas scripturas y entre ellas un testimonio signado / de scriuano público y una carta por nos scripta al / dicho Vaca de Castro < y una nuestra cédula dirigida al dicho Vaca de Castro > el tenor de lo qual es como se sigue: [Al margen: Testimonio] En la villa de San Lúcar de Barrameda biernes cinco días / del mes de noviembre año del nascimiento de Nuestro Salvador / Jesu Cristo de mil y quinientos y quarenta años. Es / tando en la ribera de la mar della en presencia de mí / Pero Fernández scriuano de su magestad y escriuano público del / número de la dicha villa por el duque mi señor pareció / presente el magnífico señor licenciado Cristóval Vaca de Cas / tro del Consejo de su magestad e dixo que por quanto él / se parte para las Yndias por mandado de su magestad a en / tender en ciertos negocios que conbiene a su servicio e / por juez de residencia de las probincias del Perú en / la nao nonbrada Sant Antonio de ques capitán Cosme / Parfan vezino de Sevilla y porque él se enbarca luego / de presente para seguir su biage que por ende que pedía e / pidió a mí el dicho escriuano se lo diese por testimonio para lo / 
presentar donde convenga y yo el dicho escriuano de pedimento / del dicho señor licenciado doy fe que lo bide en mi presencia / enbarcar en un barco con su gente y fue a la dicha nao la qual y / va saliendo de viaje a la vela y el dicho señor licenciado se en / tró dentro y la dicha nao se fue de viaje con él de lo qual di / este testimonio signado con mi signo que es fecho y pasó / en el dicho día mes e año sobredicho a lo qual fueron pre / sentes por testigos Pedro Serrano regidor e Juan de Her / mosilla piloto y el capitán Gonzalo Gómez Despinosa e / Hernando Blas visitadores de las naos de las Yndias, vezinos / de la ciudad de Sevilla e en testimonio yo el dicho escriuano / público fize aquí mi syno y so testigo. El Rey, licen / ciado Vaca de Castro del nuestro Consejo cauallero de la hor / den de Santiago gobernador de las probincias del Pe / rú ya sabeys como desde Monzón ocho de agosto del año pasado //

/ 181 v. / de mil e quinientos y quarenta e dos os mandé screuir que se a / vían reciuido unas cartas que hasta entonces nos auíades scrito / con Diego de Aller vuestro criado y os encargamos mucho que ansí en la / execución de la nuestra justicia e administración della como en el / cumplimiento de todas las otras cosas que os están cometidas / e vos viésedes que convenía a servicio de Dios y nuestro y buen / recaudo de nuestra hazienda y paz y quietud desa tierra las / hiziésedes y probeyésedes como de vos lo confiamos y por / la priesa con que entonces os mandé screuir no se os respondió / particularmente a vuestras cartas e después no se a hecho a / causa de aver estado como abreys sauido enbarazado el nuestro Con / sejo de las Yndias e resultar de vuestras cartas algunas cosas / que para la probisión dellas conbiene platicarse en el Consejo / y ansí por no se auer podido platicar en ello hasta agora no se os / responde en esta particularmente ni se os ynbian los despa / chos en los quales yo he mandado que se entienda y despachen / con toda la breuedad y ansí se hará visto que después que / mandamos probeer la nuestra audiencia y chancillería real de / Panamá se descubrieron a las probincias y que las per / zonas que en ella residen hacen grandes costas e gastos / en yr a seguir sus causas e pedir justicia a la dicha au / diencia por lo que toca al bien y alibio de los naturales y / estantes en esa tierra avemos acordado de poner en ella una / nuestra audiencia y chancillería real porque no la a de aver / en Panamá que aya un presidente y quatro oydores e que resida en la ciudad de los Reyes en el despacho de la / qual y en elegir personas quales conbienen para ella se en / tiende con deligencia y se despachará brevemente y porque / podría ser que entretanto que acá se entiende en buscar / persona que tenga las calidades necesarias para ser pre / sydente de la dicha audiencia los oydores que para ella se an de / probeer se partiesen para esa probincia avemos acordado / que llegados ellos en tanto que va la persona que a de yr / de presidente de la dicha audiencia vos presidays en ella / e ansí se vos ynbiará para ello el despacho que convenga por //

/ 182 r. / seruicio nuestro en tanto que la dicha nuestra audiencia llega vos en / tendays y probeays las cosas que os tenemos cometidas con el / cuydado e diligencia que de vos confiamos y sienpre nos a / viseys del estado de esas partes muy particularmente de Al / calá de Henares a primero de marzo de mil y quinientos y quaren / ta e tres años, yo el rey por mandado de su magestad Juan de Sa / mano. El Rey, licenciado Vaca de Castro del nuestro Consejo Caballero / de la Horden de Santiago nuestro gobernador de la provincia del / Perú sabed que nos mandamos dar e dimos una nuestra cédula / dirigida a vos y al marqués don Francisco Pizarro nuestro gobernador / que fue desa probincia difunto firmada del muy Reverendo Cardenal / Arzobispo de Sevilla nuestro gobernador que a la sazón hera de las / nuestras Yndias del tenor siguiente: El Rey, Marqués don Francisco / Pizarrro nuestro gobernador de la probincia del Perú y licenciado / Vaca de Castro del nuestro 
Consejo bien sabeys como por más / provisiones e ynstruciones vos está mandado que hagáis la / reformación y moderación de los repartimientos de / indios desa probincia e agora el licenciado Juan Villalo / bos nuestro procurador fiscal en el nuestro Consejo Real de las / Yndias me a hecho relación que algunas personas que tie / nen repartimientos de yndios en esa probincia a fin de / fraudar lo que por nos está mandado y que no se refor / men los repartimientos que ellos tienen an procurado / probisiones nuestras para que no se les quiten los yndios que / les están encomendados sin que primero sean oydos y que si / se les ovieren quitado se los buelvan y que las tales / probisiones para más efeto / de que sin causa justa no se les quitasen ni remobiéndose los / dichos yndios y que tanbien se an dado a otros licencia pa / ra estar ausentes algún tiempo y durante las dichas li / cencias se an mandado que no les sean quitados los yndios / que tubieren encomendados y que para hazer la dicha reformación de lo que / tenían demasiado no se podía aprobechar de las dichas licencias porque //

/ 182 v. / serían de mexor condición los ausentes que los presentes y que por / que cesasen fraudes que con color de las dichas probisiones / e cédulas se podrían hazer para ynpedir la dicha reforma / ción que me suplicase mandase que la dicha reformación no ce / sase ni se ynpidiese ni ynpidiese ni defiriese por ninguna de las / dichas nuestras cédulas y probisiones que hasta aquí emos da / do e de aquí adelante diéremos en favor de los que sí an / estado y estubieron ausentes desa tierra y que sin embargo / dellas cunpliésedes y efectuásedes la dicha reformación o / como la mi merced fuese lo qual visto por los del nuestro Conse / jo Real de las Yndias fue acordado que devía mandar dar es / ta mi cédula para vos e yo tóbelo por bien porque vos mando / que veais lo susodicho y sin embargo de qualesquier nuestras / probisiones que ayamos dado y diéremos para que no se / quiten los yndios a los que los tobieren encomendados sin que / primero sean oydos e de qualesquier cédulas deligencia / que ansimismo ayamos dado a algunas personas para venir / a estos reynos y estar en ellos cunplais y efetueys lo / que por nos vos está mandado cerca de la dicha reformación / la nuestra yntención y voluntad es que por razón de las dichas / nuestras probisiones e cédulas no se ynpida ni defiera el ha / zer de la dicha moderación y reformación como dicho es y / en lo demás mandamos que se guarden y cumplan las / dichas nuestras cédulas y probisiones como en ellas se contie / ne. Fecho en la villa de Talavera a quinze días del mes de / abril de mil e quinientos e quarenta y un años, Frater García / Cardenalis Yspalensis por mandado de su magestad el gober / nador en su nombre Juan de Sámano. E agora el dicho licenciado Vi / llalobos nuestro fiscal nos suplicó bos mandásemos que vie / sedes la dicha nuestra cédula suso encorporada y si como por vos / solo fuera dirigida la guardásedes y cunpliésedes como / en ella se contiene e yo tóbelo por bien porque vos man / do que veais la dicha nuestra cédula que de suso va yncorporada / e como si para vos solo fuera dirigida la guardeys y cunplais / como en ella se contiene fecha en la villa de Valladolid a //

/ 183 r. / catorze días del mes de mayo de mil e quinientos y quaren / ta e dos años. Yo el Rey por mandado de su magestad Juan de Sámano señala / da del dotor Beltrán y Obispo de Lugo y Bernal Velázquez / corregida. E parece que dentro del término probatorio / que fue dado por el dicho licenciado Vaca de Castro se hizie / ron ciertas probanzas e las presentó en el dicho nuestro Consejo / Real de las Yndias en las quales entre otras cosas articuló / dos preguntas de su ynterrogatorio para probar el tiempo / que fue gobernador en las dichas probincias del Perú e co / menzó a entender y probeer lo necesario para la guerra / contra el dicho don Diego de Almagro hasta que le fue note / ficada la probisión que lleguó de gobernador Blasco / Nuñez Vela y el día en que se 
embarcó e hizo a la vela / en el puerto de San Lúcar de Barrameda para yr a las / dichas probincias su tenor de las quales dichas dos pre / guntas e de lo que a ellas respondieron algunos de los / testigos es este que se sigue : Yten si sauen en quel / dicho Vaca de Castro se hizo a la vela para el Perú en / San Lúcar a cinco días del mes de nobiembre del año / pasado de mil e quinientos y quarenta años y que fue / reciuido por gobernador e comenzó a entender y se / probeer en lo necesario para la guerra contra don Diego / en el mes de agosto del año siguiente de mil y quinientos / e cuarenta y uno e que dexó el cargo a Blasco Nu / ñez Vela luego que se le notificó su probisión en el / mes de mayo del año de quarenta e quatro. Fray Pedro / de Ulloa dixo que no saue este testigo en qué tienpo / se hizo a la vela para el Perú el dicho Vaca de Castro / ni tanpoco se acuerda en qué tienpo comenzó la guerra / contra el dicho don Diego de Almagro e que saue que por / el verano de mil e quinientos e quarenta e quatro por / el mes de mayo e junio del dexó el dicho cargo el dicho / Vaca de Castro al dicho Blasco Nuñez Vela porque este / testigo salió de la dicha ciudad de los Reyes a reciuir //

/ 183 v. / al dicho Blasco Nuñez Vela e fue onze leguas de allí a / reciuirlo y quando bolbió con el dicho Blasco Nuñez Vela / que lo salió a reciuir el dicho Vaca de Castro hasta una / legua de la ciudad de los Reyes luego dexó el cargo el dicho Vaca de Castro. Alonso Sánchez de Canales dixo que no / saue este testigo en qué tiempo se hizo a la vela el / dicho Vaca de Castro en San Lúcar pero que vido que fue re / ciuido por gobernador en los dichos reynos del Perú e co / menzó a entender en probeer lo necesario para la gue / rra contra don Diego de Almagro en el mes de agosto del año / de mil e quinientos e quarenta e uno o poquito antes e después / e questo es lo que saue desta pregunta. Fray Ysidro / de San Bizente dixo que la saue como en ella se contiene / porque este testigo salió del Puerto de San Lúcar de / Barrameda para yr a los dichos reynos del Perú con / doze frayles de su horden en la mesma flota en que / fue el dicho Vaca de Castro y estubo en los dichos reynos / del Perú quando el dicho Vaca de Castro entró en ellos / e fue reciuido por gobernador y comenzó a entender en las cosas de la guerra contra don Diego de Almagro / e también se halló presente al tienpo quel dicho Vaca de Castro dexó el cargo de gobernador al dicho Blasco Nu / ñez Vela. Sebastián de Merlo dixo que este testigo / se halló en la ciudad de Quito de los reynos del / Perú al tienpo quel dicho Vaca de Castro fue reciuido / por gobernador dellos y al tiempo que comenzó en ella / a probeer las cosas de guerra aunque antes de / Popayán las auía comenzado a probeer en que hera / por el tienpo que la pregunta dize y que ansímismo / se halló presente al tiempo que Vaca de Castro dexó / el cargo de gobernador que fue en Guadacheri repartimiento / deste testigo viniendo desde el Cuzco a la ciudad de / los Reyes por un treslado de la probisión del dicho / virrey Blasco Nuñez Vela quel cabildo de la ciudad de //

/ 184 r. / los Reyes le enbió a noteficar e que tanbién fue por / el tiempo que la pregunta dize e que ansímismo oyó / dezir públicamente en la dicha ciudad de Panamá estando / este dicho testigo en ella quel dicho Vaca de Castro auía en / varcado en San Lúcar de Barrameda par los dichos rey / nos del Perú por el tiempo que la pregunta dize. Simón de / Cabezuela dixo que este tetigo se enbarcó el día e mes e / año en la pregunta contenido para las Yndias en la flo / ta en que yva el dicho Vaca de Vaca de Castro y a lo queste testigo / se acuerda fue reciuido por gobernador por el tiempo con / tenido en la dicha pregunta poco más o menos e luego co / menzó a entender en las cosas necesarias para la gue / rra y le parece que dexó el cargo a Blasco Nuñez Vela por el / tiempo contenido en la pregunta poco más o menos y esto saue de / esta dicha pregunta. Pedro de Valdés dixo que no la saue / más de que saue que dexó el cargo a Blasco Nuñez Vela / luego que se le notificó la 
provisión que llebaua por el / tiempo contenido en la dicha pregunta e ansí es público e / notorio. Diego de Aguilera dixo queste dicho testigo no sa / ve el tiempo que dicho Vaca de Castro se enbarcó en España / para yr a las Yndias y que cree a lo que se acuerda que / fue reciuido en el Perú por gobernador en el tienpo con / tenido en la pregunta e que también dexó el oficio a / Blasco Nuñez a lo que se acuerda por el tiempo contenido en la pregunta. Juan Velazquez dixo que no saue en qué / tienpo el dicho licenciado Vaca de Castro se hizo a la / vela en el puerto de San Lúcar más de que saue e vido / que fue reciuido por gobernador en la ciudad de Quito / que es en el Perú por el tiempo que la pregunta dize / e desde allí comenzó a se probeer de lo necesario para / la guerra contra don Diego de Almagro que fue por el mes de / agosto de mil y quinientos y quarenta y uno e que o / tra cosa de lo contenido en la dicha pregunta no saue más / de que luego que fue recibido por gobernador en la dicha ciu / dad de Quito lo recibieron en todos los otros //

/ 184 v. / pueblos del dicho reyno del Perú. Cristóval de Barrientos dixo / que lo que saue este testigo desta pregunta es que a lo que se / acuerda que fue reciuido por gobernador el dicho Vaca de Castro en el Perú e comenzó a entender e probeer e hazer / lo necesario para la guerra contra don Diego de Almagro en el / año de mil e quinientos y quarenta y un años contenido en / la pregunta y que a lo que se acuerda que fue por el mes / de agosto del dicho año contenido en la dicha pregunta poco / más o menos e que ansímismo tiene por cierto a lo que / se acuerda que dexó el cargo a Blasco Nuñez por el año de / mil e quinientos e quarenta e quatro años contenido en la / pregunta por el mes de mayo. Francisco de Vezerra dixo / que lo que saue desta pregunta es quel dicho Vaca de Cas / tro fue a las probincias del Perú e comenzó a / hazer exercito contra don Diego de Almagro el mes / de agosto del año que la pregunta dize de mil e quinientos / e quarenta e uno porque este dicho testigo a la sazón quel dicho / Vaca de Castro enpezó a hazer lo susodicho estaua en la / tierra e se fue a juntar con él al camino e que por / esto lo saue. Yten si sauen que ansímismo se le re / creció al dicho Vaca de Castro por lo que sirbió a su magestad / en fauor de Blasco Nuñez e contradición de Gonzalo / Pizarro que fue por su parte robado e saquea / do lo que tenía en el puerto de Guarua y en el Cuzco / e se le siguió por esto perdida en quanto tenían / que valía treinta mil castellanos y a pasar como / pasó en la prisión que se le hizo el dicho Gonzalo Pizarro / peligro de la vida y le matara sy no subcediera la / necesidad que se pudo hallar en el navío en que estaua / e le tenía rendiendo maestre y marineros digan lo / que sauen. García de Montalvo dixo quel dicho Gonzalo / Pizarro hera enemigo capital del dicho Vaca de Castro / por palabras y obras del dicho Gonzalo Pizarro / que después lo fue mayor por la contradición quel dicho / Vaca de Castro hizo a su lebantamiento en fabor del virrey //

/ 185 r. / Blasco Nuñez Vela y que vió este dicho testigo que luego quel dicho / Gonzalo Pizarro vino alzado al Cuzco él y los que con él / yvan tomaron la hazienda que allí tenía el dicho Vaca de / Castro que valía muchos millares de pesos de oro como a / su contrario y enemigo e seruidor de su magestad y que ansímis / mo este testigo oyó dezir por público y notorio que / los del nabío que le volbieron preso al puerto en la / ciudad de los Reyes desde Guarua que fueron los que / llevaron presos [sic] a Blasco Nuñez de Vela tomaron y saque / aron al dicho Vaca de Castro quanto tenían en el dicho nabío sin le dexar salvo una taza e un salero pequeño e una / cuchara e una cama de ropa en que durmiese lo qual / saue este dicho testigo por ser ansí público y notorio e / ver quando el dicho Vaca de Castro y este testigo se sali / eron con el nabío en que estaua el dicho Vaca de Castro que / solamente llevaua la dicha cama de ropa y unos pla / tillos y otras cosillas y ser notorio que los susodichos / se lo avían saqueado en el puerto de Guarua y que saue / y vió que si el dicho Vaca de 
Castro y este testigo no se sa / lieran con el dicho nabío en que el dicho Gonzalo Pizarro le / tenía preso le matara e ansí lo entendió este dicho testigo / e fue público y notorio y cosa conocida a la dicha sazón. / Diego de Aguilera dixo que este testigo saue quel dicho Vaca / de Cstro corrió muy gran riesgo de la vida en la prisión / que lo tubo Gonzalo Pizarro y que ansímismo oyó decir / que le avían robado mucha suma de hazienda e / esto responde a la pregunta. Gomez de Rojas dixo / que lo que saue es quel dicho Vaca de Castro estaba preso / en un nabío en el puerto de la ciudad de los Reyes / e Gonzalo Pizarro le tenía puesto al capitán Al / mendras por guarda e que al tiempo quel dicho Vaca / de Castro se hulló con el nabío ubo gran alboroto en Lima e Gonzalo Pizarro hizo dar tormento a ciertos criados / suyos al dicho Vaca de Castro y queste testigo oyó / decir a Gonzalo Diez capitán del dicho Gonzalo [Pizarro] //

/ 185 v. / que si Vaca de Castro no se huyera que antes de seis días le / hiziera matar Gonzalo Pizarro porque estaua concertado / e questo es lo que saue desta pregunta y vió y oyó decir / estando en aquella tierra. / Juan de Guzmán dixo que saue / que estando el dicho licenciado Vaca de Castro en el puerto de Guarua le saquearon y robaron por ser como hera ser / vidor del rey e le fue hecho el dicho robo por parte de los / oydores de Gonzalo Pizarro y ques este testigo no saue la / cantidad del robo que le fue hecho más de que oyó dezir / públicamente que avía sido mucho lo que avía / robado y que se tubo por cosa muy cierta que si el dicho licenciado / Vaca de Castro no se alzara como se alzó con el dicho galeón los que faborecían al dicho Gonzalo Pizarro lo mataran e / que esto es público e notorio y pública voz y fama e / que esto lo que saue desta pregunta. Francisco de las / Valsas dixo que lo que saue desta pregunta es que / después de preso Blasco Nuñez Vela y venido Gonzalo / Pizarro a la ciudad de los Reyes e aviéndose huydo / el dicho Vaca de Castro en el nabío donde estaua preso / oyó este testigo al dicho Gonzalo Pizarro tratar e decir / mal de la persona y casa del dicho Vaca der Castro diziendo / que le avía sido enemigo y mostrando estar muy a / pasionado con él e segund lo que este testigo colegió y en / tendió de las palabras del dicho Gonzalo Pizarro tie / ne por muy cierto que si el dicho Gonzalo Pizarro pudie / ra aver al dicho Vaca de Castro después que se huyó / que lo pasara mal el dicho Vaca de Castro. Fray Ysidro / de San Bizente dixo que lo que desta pregunta saue es que / quando el dicho visorey Blasco Nuñez Vela entró / en la dicha ciudad de los Reyes vido este testigo quel dicho / Vaca de Castro le salió a reciuir e le recibió muy bien / e umilmente e después de reciuido el dicho visorey / vido este dicho testigo que algunas personas llamándole / [...] al dicho Vaca de Castro como antes le solían llamar / [...] gobernador el dicho Vaca de Castro no lo consentía //

/ 186 r. / diciendo el dicho Vaca de Castro a los que se lo llamaban que a / quel hera título que an daua con el oficio de gobernador e / quél ya no lo hera que no quería que se lo llamasen porque / a lo que su magestad proveya él e todos hera razón que se / ovedeciese e avaxase la cabeza como a mandamiento / de su rey e que luego dende a pocos días el dicho visorey / enbió al Arzobispo de la dicha ciudad de los Reyes y a este / testigo con él a la ciudad del Cuzco hablar con Gonzalo Pi / zarro para que se subjetase y no hiziese alboroto y le / bantamiento e que después bolbieron de la dicha / jornada a la dicha ciudad de lo Reyes ya auía pasado / lo demás contenido en esta pregunta y por esto no sa / ve más de lo en ella contenido. Diego Mexía dixo que publi / co y notorio fue en la dicha ciudad de los Reyes quel dicho Gonzalo Pizarro quería mal al dicho Vaca de Castro / por la contradición que le hizo en favor del dicho visorey / Blasco Nuñez Vela y que le auía robado y saqueado él e / sus secazes todo lo que tenía en el Cuzco y en el puerto / de Guarua donde tubo preso al dicho Vaca de Castro e que ansímismo saue este testigo quel dicho Vaca de Castro / pasó 
muy gran trabajo en la prisión que tubo en un / nabío en el puerto de la dicha ciudad de los Reyes por / mandado del dicho Gonzalo Pizarro y que por la mayor parte / de la gente de la dicha ciudad de los Reyes se tenía enten / dido y se platicaua ansí que si el dicho Vaca de Castro no se alzara en el nabío donde estaua preso e se fue / ra con él quel dicho Gonzalo Pizarro le matara. Pedro / de Valdés dixo que cuando el dicho Gonzalo Pizarro esta / va en el Cuzco vió este testigo cómo la gente que con él es / tavan tomaron todo lo que hallaron del dicho Vaca de / Castro oro y plata e tapicería e otras cosas e que / después vió este testigo muchas cosas de las del / dicho Vaca de Castro en poder de soldados e otras gen / tes y que es verdad quel dicho Vaca de Castro como seruidor //

/ 186 v. / de su magestad se bió en gran peligro en el nabío donde estaua / preso e cada día se pensaua quel dicho Gonzalo Pizarro / lo avía de matar por le tener por contrario y enemigo ca / pital si no se saliera como se salió del dicho nabío en que / como dicho estaua e después de pasado el dicho termino probatorio de pedimento del dicho licenciado Vaca de Castro / los del dicho nuestro Consejo mandaron hazer publicación de / las probanzas en el dicho pleito hechas e que se diese tres / lado dellas a las partes para alegar de su derecho y parece / quel dicho licenciado Agreda nuestro fiscal por una petición / que presentó dixo que en el dicho término probatorio no se a / vía hecho probanza por parte de nuestra cámara y fisco / en lo qual hera leso e danificado y le competía bene / ficio de restitución para hazer probanza por los mis / mos artículos e derechamente contrarios la qual pedía / se le concediese y visto por los del dicho nuestro Consejo jun / tamente con lo que contra ello fue dicho y alegado por el / dicho licenciado Vaca de Castro dieron un auto en que man / daron quel dicho pleito se lleuase ante ellos en difinitiba / e que de la vista dél resultaría lo que de justicia se / deviese hacer. Y estando en este estado Juan de Oribe en / nombre del dicho licenciado Vaca de Castro por una peti / ción que presentó dixo que para que conestase cómo por / lo quel dicho su parte ubo en el Perú de los yndios que / fueron del dicho marqués don Francisco Pizarro tenía he / cha obligación a sus hijos por el contrario de doze mil pe / sos de oro y estaua dado a executar por ellos ante el dotor / Durango alcalde de nuestra casa e corte por doña Francisca / Pizarro hija que se dezía ser del dicho marqués y toda / vía pendía el dicho pleito hazía presentación de un testi / monio signado de Diego de Hermosa escriuano de la audiencia / del dicho nuestro alcalde en el cual estaua yncorporada la dicha / obligación suplicándonos lo mandásemos auer por / prersentado e que se pusiese en el proceso del dicho pleito //

/ 187 r. / para descargo del segundo y séptimo cargos el tenor del qual / dicho testimonio y obligación es este que se sigue : En la villa de / Valladolid a veinte y seis días del mes de junio de mil e quinientos / e cinquenta e cinco años ante el muy magnífico señor dotor Durango / del Consejo de su Magestad alcalde de la su casa e corte por ante mí / Diego de Hermosa escriuano de su magestad del juzgado del dicho señor alcalde. / Antonio Baca en nombre del licenciado Vaca de Castro del Consejo de / su Magestad presentó una petición del tenor siguiente: Muy magnífico señor Antonio Baca en nombre del licenciado Vaca de Castro del Consejo / de su Magestad digo que por mi parte tiene necesidad de una fe de litis / pendencia del pleito que contra mi parte trata doña Francisca Piza / rro ante vuestra merced sinada en manera que haga fe para la presentar / en un pleito que trata mi parte con el fiscal del Real Consejo de / Yndias en el dicho Consejo a vuestra merced pido y suplico me la mande / dar para el dicho hefeto y para ello etcétera. E ansí presentada la dicha / petición suso encorporada e por el dicho señor alcalde vista / dixo que mandaba e mandó dar a la parte del dicho licenciado / Vaca de Castro la fe de litis pendencia que pide en for / ma 
citada la parte para ello la qual dicha petición y lo su / sodicho a ella probeydo por el dicho señor alcalde se notificó / al licenciado Agreda fiscal de su magestad en el su Real Consejo de / Yndias segund parece por la notificación que está a las espal / das de la dicha petición firmada de Cristóval Péres escriuano del tenor siguiente : En Valladolid a veinte seis días del mes de junio de mil e quinientos y cinquenta e cinco años yo el escriuano yuso escrito ley y notefique la petición desta otra parte / con el auto en ella probeydo por el señor dotor Durango / alcalde de su magestad como en ella se contiene e declara al / licenciado Agreda fiscal en el Consejo Real de las Yndias / en su persona el qual dixo que lo oya siendo pre / sentes por testigos Pero Perez Carrillo y Martín de Azere cria / dos del dicho licenciado Agreda e yo que fuy presente / y en fe dello lo firmé de mi nombre, Cristóval Perez. / Y en complimiento de lo mandado por el dicho señor alcalde / yo Diego de Hermoza escriuano de su magestad e de la audiencia / e juzgado del dicho señor alcalde doy fe y verdadero testimonio a //

/ 187 v. / todos los señores que la presente vieren como en la villa de Ma / drid a catorze días del mes de marzo de mil y quin ientos y cinquenta / e tres años Pero Hernández en nombre de doña Francisca / Pizarro muger de Hernando Pizarro hija y heredera que dize ser / del marqués don Francisco Pizarro e con su poder de que hizo / presentación y dio execución ante el dicho señor alcalde e / por ante mí el dicho escriuano contra la persona e bienes del dicho licenciado / Vaca de Castro del Consejo de su Magestad por quantía de doze mil / pesos de oro contenidos en una escriptura pública de obli / gación que presentó del tenor siguiente: Sepan quantos esta / carta de obligación vieren como yo el licenciado Cristóval Vaca de Castro cauallero de la Horden de Santiago del Consejo Real de su Magestad otorgo y conozco a los menores hijos del marqués / don Francisco Pizarro e al señor Gonzalo Pizarro su tu / tor e curador en su nombre e digo que por quanto por / parte de los dichos menores me an sido movidos algunos / pleitos pidiéndome e demandándome quantías de pe / sos de oro y a muchos criados míos segund que más larga / mente se contiene en las dichas demandas que sobre ello están puestas e de los pleitos que de todo lo susodicho / e de cada una cosa dello está pendiente ansí en la audiencia real de su magestad como ante qualesquier / justicias hordinarias e porque se me dé fin e quito de todas ellas e de todo el derecho e abción e título / e recurso que sobrello se me pueda pedir e deman / dar como a los dichos mis criados y por tanto por ra / zón de todos ellos por esta presente carta otorgo e / prometo e me obligo de dar e pagar a los dichos meno / res e a quien por ellos lo oviere de auer doze mil pe / sos de buen oro de quatrocientos y cinquenta maravedís cada pe / so los quales dichos doze mil pesos de oro prometo y me obligo / de dar e pagar por razón de todo aquello que de las ha / ziendas de lo dichos menores yo e abido e cobrado e otro / por mí mandado de manera que por razón de lo susodicho / yo soy libre e quito e los dichos mis criados e de aquí ade //

/ 188 r. / lante en ningund tiempo para siempre jamás no me pueda ser / pedido ni demandado a mí ni a otro por mí ni a Gaspar Gil mi / criado ni a otro mi criado alguno ansí de las demandas que / oy día estén puestas como otras qualesquier que se les pue / da pedir en qualquier manera cosa alguna todos los quales / dichos pleitos en el estado en que están y los que se quisieren yn / tentar se entienda que ningunos y de ningund efeto e valor / por las causas susodichas y por ello prometo y me obligo / de dar los dichos doze mil pesos de oro en qualesquier parte / e lugares que me sean pedidos e demandados desde oy día / questa carta es fecha y otorgada en un año cunplido / primero siguiente so pena del doblo e la pena pagada / o no que todavía pagaré los dichos doze mil pesos / de oro entendiéndose no poder ser detenydo en estos / reynos e de sacarme a paz e a saluo de 
qualesquier / pleitos e demandas e abción que por razón de lo suso / dicho por parte de los dichos menores o de otra qualquier per / sona me ser pedido e demandado cosa alguna de lo que / yo ove e lleue de los dichos indios e haciendas del / dicho marqués para lo qual ansí tener e guardar e / cunplir e aver por firme como dicho es por esta carta / doy e otorgo poder cunplido a todos e qualesquier /alcaldes e juezes e justicias de qualquier fuero / e juredición que sean al fuero e juredición de los qua / les e de cada uno dellos me someto con la dicha my persona / e bienes muebles e rayzes e renuncio mi propio fuero / juredición e domicilio y la ley sid conbenerid de juredi / cione oniun judicun para que sin yo ni otro por mí ser / llamado a juyzio ni oydo ni vencido sobre esta dicha razón / me puedan prender e prendan y fagan y manden hazer / entrega y execución en mí y en todos mis bienes muebles / e raízes do quier que los hallaren e los yo aya e ten / ga e los bendan e rematen luego sin ningún plazo que sea / de alargamiento porque de los maravedís que valieren vos entreguen e / fagan pago destos dichos doze mil pesos deste dicho [sic] devda //

/ 188 v. / e de la dicha pena del doblo sy en ella cayere y todas las otras / costas e omisiones e daños e menoscauos que sobre ello / se vos recrecieren bien ansí e a tan conplidamente como si / todo lo susodicho fuese en cosa juzgada e pasada en pleito / por demanda o por respuesta o fuere sobre ello dada / sentencia difinitiua y la sentencia fuese consentida e pasada / en cosa juzgada renuncio toda execución e suplicación / e todas cartas e mercedes y preuilegios de rey o reyna o de / otros señores o señoras ganadas e por ganar e toda bue / na razón y execución e defendiesen y por mí ponga e / alegue a todas e qualesquier franquezas e libertades y e / senciones e preheminencias ansí por cauallería de la Horden / de Santiago e sea del Consejo de su Magestad de que pueda ayudar / e aprobechar que non vala en esta razón y renuncio la ley / del derecho en que diz que general renunciación non vala e / para lo cunplir e auer por firme obligo mi persona e bie / nes muebles e raízes avidos o por auer e consiento que / deste contrato se pueda sacar un treslado o dos o más / el uno pagando los demás sean en sí ningunos. Fecha / carta en el tanbo questá junto al puerto de la ciudad de / los Reyes de la Nueva Castilla probincia del Perú a / onze días del mes de otubre año del nacimiento de Nuestro / Salvador Jesu Cristo de mil e quinientos e quarenta e / quatro años. Testigos que fueron presentes Francisco de / Herrera e Simón de Alzete e Miguel de Robles estantes / e residentes en el dicho tanbo y vezinos y estantes en la dicha / ciudad. Y el dicho señor licenciado Vaca de Castro lo firmó / de su nonbre en el registro desta carta al qual yo el es / criuano yuso scripto doy fe que conozco va testado do de / zía por parte e do dezía siguiente va entre renglones ${ }^{29}$ : / o diz vía no en pezca e más va entre renglones o diz / cosa alguna vala e yo Juan Franco scriuano de sus majestades y / su notario público en la su corte y reynos e señoríos / lo screuí segund que ante mí pasó y fize aquí mi signo / a tal en testimonio de verdad Juan Franco scriuano de su magestad //

/ 189 r. / yo Diego Gutiérrez scriuano de su magestad y público del cauildo / desta ciudad de los Reyes doy fe quel dicho Juan Franco de / quien esta scriptura está synada y firmada en el tiempo que pa / rece que pasó e se otorgó antes estaua en esta dicha ciudad e / usaua del oficio de scriuano de su magestad y que a las scripturas y / autos que ante él como a tal scriuano pasa se le a dado e da ente / ra fe e crédito de la qual di la presente fecha en los Reyes / a diez e ocho días del mes de marzo año de mil e quinientos e / cinquenta e dos va testado do dezía de mí. E por ende en / testimonio de verdad fize aquí mi sygno a tal Diego Gutiérrez / scriuano público e del cauildo la

\footnotetext{
${ }^{29}$ Notas de salva.
} 
qual dicha obligación suso / encorporada y poder presentado por el dicho Pero Hernández / e pedimiento por el hecho visto por el dicho señor alcalde / mandó dar su mandamiento executorio por la dicha quan / tía de los dichos doze mil pesos de oro contenidos en la / dicha obligación por virtud de la qual el alguazil Bar / tolomé de Santiago hizo la dicha execución en la per / sona del dicho Vaca de Castro y en cierta cama de canpo e / otros bienes muebles suyos en voz y en nombre de todos / los otros bienes que se hallasen del dicho licenciado Vaca / de Castro e hecha la dicha execución se dieron los prego / nes a los dichos bienes y el dicho licenciado por mandamiento / del dicho señor alcalde fue citado en forma para el re / mate después de lo qual Antonio Vaca a nombre del / licenciado Vaca de Castro e con su poder de que hizo pre / sentación se opuso a la dicha execución diziendo quel dicho / Vaca de Castro su parte no devía cosa alguna a la dicha / doña Francisca Pizarro e que la dicha obligación por virtud / de que se auía hecho la dicha execución la avía hecho el / dicho licenciado con justa causa de temor y miedo con temor / y miedo que cayera en qualquier constante varón estan / do preso en un nabío con guarda de arcabuzeros por Gon / zalo Pizarro que a la sazón estaba alzado en los reynos / del Perú contra el seruicio de su magestad por lo qual y por o / tras causas que alegó en la dicha opusición por su pe / tición que presentó pidió al dicho señor alcalde mandase //

/ 189 v. / reponer y rebocar e dar por ninguno el dicho mandamiento / executorio y execución hecha al dicho licenciado Vaca de Cas / tro e todo lo demás contra él hecho e autuado por / virtud de la dicha obligación la qual dicha petición de opusición / el dicho señor alcalde mandó dar treslado a la parte de / la dicha doña Francisca Pizarro e reciuió a las partes a prue / va con diez días de la ley la parte de la dicha doña Fran / cisca Pizarro e aviéndole sido noteficado e dado treslado / de la dicha petición presentada por parte del dicho licenciado / Vaca de Castro respondió a ella e presentó una petición / ante el dicho señor alcalde del tenor siguiente: Muy magnífico / Juan Alonso de Senabria en nombre de doña Fran / cisca Pizarro muger de Hernando Pizarro e hija y here / dera del marqués don Francisco Pizarro respondiendo / a una petición e opusición hecha por el licenciado / Vaca de Castro del Consejo de su Magestad a una execución / hecha en sus bienes a pedimiento de mi parte por doze / mil pesos de oro cuyo tenor auido aquí por repeti / do digo que vuestra merced deve mandar yr por la execución / adelante e mandar hazer trance e remate en los / bienes executados e en todos los otros bienes del dicho / licenciado Vaca de Castro e hazer pago a la dicha mi parte / del prencipal y costas sin enbargo de lo contenido en / la dicha opusición por lo siguiente: lo primero por no / ser presentada por parte e por todo lo demás que general / mente se suele dezir e alegar que la aquí por espresado, lo / otro porque ante vuestra merced obligación que consigo trae / aparexada execución e la deuda es pura y líquida y el / término es pasado muchos días ha, lo otro porque la / dicha obligación se hizo a la dicha mi parte por causas jus / tas e aun fue en muy gran probecho e utilidad del / dicho licenciado Vaca de Castro e a su pedimiento e con / gran ynportunación suya e quando la hizo no obo fuer / za ni opresión alguna antes hizo con entera voluntad / e syn aver miedo ni fuerza, lo otro porque en caso quel dicho / licenciado Vaca de Castro estubiera preso al tienpo que la otorgó //

/ 190 r. / hera por otras causas e por sus culpas y exesos y por / mandado de Blasco Núñez Vela visorrey de la probincia del / Perú, lo otro porque niego quel dicho Gonzalo Pizarro hizie / se fuerza ni pusiese temor alguno al dicho licenciado Vaca / de Castro para que hiziese la dicha obligación antes al dicho / licenciado Vaca de Castro hizo ynportunar con sus amigos / al dicho Gonzalo Pizarro para que la dicha scritura de obli / gación no quisiese quel dicho licenciado Vaca de Castro 
fuese / pedido en su residencia en estos reynos de España e / a su pedimiento e ruego lo tubo por bien el dicho Gon / zalo Pizarro, la otra porque el dicho licenciado Vaca de Cas / tro se puso en su cabeza los yndios de la dicha mi parte / no lo pudiendo hazer conforme a derecho e los tributos / e aprovechamientos dellos se lleuó en cantidad de más / de cinquenta mil castellanos e antes quel dicho Gonzalo / Pizarro partiese de la ciudad del Cuzco el dicho licenciado Va / ca de Castro entendió que se le auía de tomar residencia / por el visorrey e audiencia real que a la sazón resydía / en la ciudad de los Reyes envió a rogar muchas vezes a / don Antonio de Ribera tutor e curador de la dicha mi parte / que no le pidiese lo que ansí avía lleuado de los dichos yndios / que a él le pertenecían que él haría una scriptura de obligación / para los dichos doze mil pesos y el dicho don Antonio no / quiso venir en ello por parecelle poca cantidad para / lo mucho quel dicho licenciado Vaca de Castro se auía a / probechado de los dichos yndios, lo otro porque niego / quel dicho licenciado Vaca de Castro estubiese preso / por mandado del dicho Gonzalo Pizarro porque nunca / tal estubo sino por mandado de Blasco Núñez vuestro visorrey / e como está dicho el qual entendiendo que convenía al vuestro / real seruicio y al bien y pacificación de la tierra le mandó / prender en la ciudad de los Reyes y le mandó lleuar a la / mar porque en un nabío le tubiesen preso e a buen re / cado donde estubo muchos días preso en tienpo del dicho [...] / visorrey de su prisión del dicho visorrey en tienpo de los $[\ldots] / /$

/ 190 v. / y en este estado le halló el dicho Gonzalo Pizarro quando entró / en la dicha ciudad de los Reyes y en ello no ynobó cosa alguna / al qual nunca hizo fuerza ni daño al dicho licenciado Vaca de / Castro ni le tomó cosa alguna de sus bienes, lo otro por / que las encomiendas que tenían los hijos del dicho marqués / heran por título particular del dicho marqués como gober / nador e por ley no hera proyvido encomendar a los / hijos naturales de los conquistadores antes es cosa muy / usada specialmente que esto fue con espresa ciencia e / sauiduría de su magestad e de los señores del su Consejo e los / hijos heran ligitimados que sin espresa encomienda / podían subceder en los yndios, lo otro porque la dicha / obligación se hizo por causas justas aunque confor / me a derecho por leyes destos reynos en qualquier / manera que uno quiera obligar a otro queda obligado aun / que no aya causa y en esta la ubo muy vastante como está / dicho, lo otro porque todas las execiones que ponen no son / de las quel derecho y leyes destos reynos se requieren se / pongan para ynpedir la execución del contrato guaren / tigio e ansí no se a de admitir en este juizio executibo / lo otro porque la obligación es pura e no condicional, / lo otro porque la restitución que pide no a lugar ni le / conpete ni ay de qué ni la pide en tienpo ni en forma ni con la / solenidad que se requiere ni menos a lugar los pedimientos / que haze ni toca ni a ello no a lugar en este juizio de mi parte / por ende a vuestra merced pido e suplico que sin enbargo de lo / contenido en la dicha petición y opusición mande proce / der por la execución adelante mandado hazer tranze / e remate y pago a mi parte de prencipal e costas / e pido justicia para lo qual etcétera Otrosí hago presentación / de las probanzas por mi parte hechas sobre este mismo / pleito y con el mismo licenciado Vaca de Castro por probi / sión de su magestad las quales mi parte tiene presentadas / en el Consejo Real de Yndias suplico a vuestra merced las a / [ya?] por presentadas e mande al secretario del Consejo de las //

/ 191 r. / Yndias me de un treslado dellas citada la parte. Otrosí, hago / presentación deste ynterrogatorio y presentó por testigos a los contenidos / en este memorial, pido y suplico a vuestra merced los mande to / mar sus dichos por el interrogatorio. Otrosí, pido y suplico a / vuestra merced mande quel dicho licenciado Vaca de Castro jure de calunia / e responda a los artículos del dicho ynterrogatorio las quales / le pongo por pusyciones y en este dicho término de los dichos diez / días 
de la ley con que las dichas partes fueron reciuidas a prueva / e después de pasados anbas las dichas partes hizieron probanza / e presentaron scripturas sobre la verificación de las quales / la dicha doña Francisca Pizarro y el dicho licenciado Vaca de Cas / tro y a sus hijos que a este pleito se opusieron diziendo y pre / tendiendo que avían de ser preferidos e primero pagados de la / suma que doña María de Quiñones su madre lleuó en dote a casamiento / con el dicho licenciado Vaca de Castro e sobre otras causas e ra / zones en el proceso del dicho pleito contenidas las dichas par / tes fueron reciuidas a prueba con término de ciento e / veinte días y en este estado está el dicho pleito segund más / largo parece por el proceso del que originalmente pa / sa y queda ante mí y en mi poder a que me refiero. En fe de / todo lo qual de pedimiento del dicho licenciado Vaca de Cas / tro e de mandamiento del dicho señor alcalde doy fe de / todo lo susodicho y fize este mi signo a tal va testado. / O diz con y entre $\operatorname{con}^{30}$, en testimonio de verdad Diego de / Hermosa de la qual dicha petición y testimonio y obligación / fue mandado dar treslado al dicho nuestro fiscal el qual re / plicó contra ello e concluso el dicho pleito visto por los / del dicho nuestro Consejo Real de las Yndias dieron y pronun / ciaron en el sentencia difinitiba en grado de revista el tenor / de la qual es este que se sigue: [Al margen: Sentencia] En el pleito que es entre el / licenciado Agreda fiscal en este Consejo Real de las Yndias de la / una parte y el licenciado Cristóval Vaca de Castro del Consejo Real / e Juan Ortiz de Oribe su procurador en su nombre de la otra / fallamos que en los capítulos de la sentencia difinitiua po [...] / los del Consejo Real de las Yndias dada y pronunciada de $[\ldots] / /$

/ 191 v. / por parte del dicho licenciado Vaca de Castro fue suplicado deve / mos pronunciar e declarar en la forma y manera siguiente que / en quanto al primer capítulo de la dicha sentencia que trata sobre el / cargar los yndios en el qual estaua condenado el dicho licenciado / Vaca de Castro en docientos ducados aplicados por tercios pa / ra la cámara y estrados reales y pasajes de religiosos y en otros seys / cientos ducados para los yndios segund que en la dicha sentencia más / largo se contiene que atentas las nuebas probanzas ante nos he / chas e presentadas en este grado de suplicación la dicha sentencia es de / enmendar y para la enmendar la devemos rebocar e / rebocamos e haziendo justicia absolbemos e damos por libre / e quito al dicho licenciado Vaca de Castro de lo contenido en el dicho / capítulo. Otrosí, en quanto al segundo capítulo que trata de los / yndios quel dicho licenciado puso en su cabeza e de / sus criados debiéndolos poner en la de su magestad en el qual el dicho / licenciado está condenado en tres mil e ochocientos castellanos / que confesó por su mandado se cobraron y están a su cargo que / los dieron las personas a quien don Diego de Almagro encomendó / yndios y en treze mil castellanos que cobró de los yndios que / fueron del marqués don Francisco Pizarro en el Cuzco y Collao y en o / tros dos mil castellanos de los tributos de los yndios de Guarua / y en otros veinte e ocho mil castellanos que los yndios del Cuzco / e Collao que puso en su cabeza sacaron de las minas según que / en su confisión se contiene de las quales dichas sumas de cas / tellanos se a de descontar lo que pareciere que se le deue de su sala / rio contándole a respeto de diez mil ducados por año de más / de los cinco mil ducados quel dicho licenciado tenía y esto por el / tiempo que hizo y usó oficio de gobernador de las probincias / del Perú que fue desde que en la ciudad de Quito comenzó a / aparejar la guerra contra el dicho don Diego de Almagro hasta / que le fue noteficada la probisión de gobernador que llevaua / Blasco Núñez Vela porque estos diez mil ducados de más de los / cinco mil que él se tenía se le señala de

\footnotetext{
${ }^{30}$ Notas de salva.
} 
salario por año por el / [tiempo] que usó el dicho oficio de gobernador y por el más tiempo / [...] a de contar el salario a razón de los dichos cinco mil ducados //

/ 192 r. / conforme a su probisión e demás de lo susodicho está ansí / mismo condenado en todo lo demás que pareciere que cobró e / se aprovechó de los yndios que como dicho es puso en su cabeza / sobre lo qual está mandado hazer más aberiguación según / que en el dicho capítulo y sentencia más largo se contiene que de / vemos confirmar e confirmamos la dicha nuestra sentencia en grado / de revista con estas declaraciones que en quanto a los treze / mil castellanos del dicho marqués Pizarro devemos man / dar e mandamos que su magestad y el dicho fiscal en su nonbre / den fianzas legas, llanas e abonadas al dicho licenciado Va / ca de Castro para que en caso que fuere venzido e condenado / por todas ynstancias por doña Francisca Pizarro en el / pleito que tratan sobre la obligación de los dichos tributos / de que resultaron los dichos castellanos pagará su magestad por / ella condenación que contra él fuere hecha hasta en la dicha / cantidad e con que los diez mil ducados de salario en cada / de un año de oficio de gobernador sean e se entiendan a / razón cada un año de veinte e quatro mil ducados por / el tiempo que como dicho es fue gobernador e con que en quan / to al último deste capítulo e sentencia está mandado hazer / más aberiguación mandamos que no se haga porque en quan / to a esto rebocamos la dicha nuestra sentencia. Otrosí, en quan / to al tercero capítulo que trata del estanco de la venta de / las cosas de probisión en el qual está condenado el dicho licenciado / en quinientos ducados aplicados en tercios y la demás pena re / mitida a la final segund que en el dicho capítulo e sentencia más / largo se contiene que atentas las dichas nuebas probanzas / la dicha sentencia es de enmendar y para la enmendar la devemos / rebocar e rebocamos e haziendo justicia que devemos / de absolber e absolbemos al dicho licenciado Vaca de Cas / tro de lo contenido en el dicho capítulo dámosle por libre / e quito dello. Otrosí, en quanto al quinto capítulo que tra / ta de los cinco mil castellanos que se dieron al capitán Pe / ranzures en el qual está absuelto el dicho licenciado Vaca de //

/ 192 v. / Castro e reserbado su derecho al fiscal para que no pudiéndose co / brar los dichos castellanos de oro del dicho Peranzures e de sus fiadores / pueda pedir al dicho licenciado cerca dellos lo que viere que le con / biene que devemos confirmar e confirmamos en grado de revis / ta la dicha nuestra sentencia. Otrosí, en quanto al sesto capítulo que trata / sobre aver hechado yndios a las minas e decla / radas en el dicho capítulo auer sacado muchas cantidades / e que diz que se hizieron malos tratamientos a los yndios en el / qual está condenado el dicho licenciado en tres mil castellanos de pe / na aplicados en cierta forma e la demás culpa está remitida a / la dicha sentencia final segund que en el dicho capítulo y sentencia más / largo se contiene que atentas las dichas nuebas probanzas la dicha / sentencia es de enmendar e para la enmendar la devemos rebo / car e rebocamos e haciendo justicia absolbemos al dicho licen / ciado Vaca de Castro de lo contenido en el dicho capítulo dámosle / por libre e quito dél. Otrosí, en quanto al séptimo capítulo so / bre que diz que tomó el dicho licenciado de la hazienda de su magestad / más de ciento cinquenta mil castellanos y no a dado quenta / dellos que en quanto en este capítulo está condenado el dicho licenciado / aquí de todo lo que entró en su poder de la hazienda de su magestad / o de otra persona en su nonbre de quenta con pago dello que / atentas las dichas nuebas probanzas devemos rebocar / la dicha nuestra sentencia en quanto a lo susodicho damos por libre e / quito al dicho licenciado de la dicha condenación pero en quanto / a lo que por sus libranzas se dio a otras personas y no / entró en su poder que está mandado que aquellos que lo re / cibieron den quenta con pago dello y en caso que aquellos / o alguno dellos no dieren quenta o no se pudiere cobrar / dellos o de alguno dellos en 
qualquier manera el alcance / que se les hiziere se reserba su derecho a saluo al dicho fis / cal para lo pedir si e quando e como viere que le cunple que / devemos confirmar e confirmamos en grado de / revista la dicha nuestra sentencia pero en quanto a la quenta que / parece aver tomado a Diego Mexía por Pedro de A / vendaño theniente de contador y por los otros oficiales está //

/ 193 r. / mandado que los oficiales de su magestad que residen en / la ciudad de los Reyes tornen a ver la dicha quenta para que / si en ella oviere alguna falta pongan recaudo en la hazien / da de su magestad devemos rebocar e rebocamos la dicha nuestra sentencia / en quanto a lo susodicho. Otrosí, en quanto al nono capítulo / sobre que diz que enbió el dicho licenciado Vaca de Castro / a estos reynos de lo que ovo por vía e maneras ylícitas / más de ducientos mil castellanos ascondidamente special / con las personas contenidas en el dicho capítulo y que les mandó / que no registrasen en su nonbre sino en el de los que trayan / en el qual capítulo está condenado en quatro mil ducados / aplicados por tercias segund que en el dicho capítulo e cargo / más largo se contiene que atentas las dichas nuebas probanzas / la dicha nuestra sentencia es de enmendar y para la enmendar la devemos / rebocar e rebocamos y haziendo justicia asolbemos al dicho / licenciado Vaca de Castro de lo contenido en el dicho capítulo / dámosle por libre y quito dél. Otrosí, en quanto al doze / capítulo sobre que diz que no cumplió las cédulas reales / que le fueron dadas cerca del buen tratamiento de los yndios / e que no los consintiese cargar ni echar a las minas y ta / sar los tributos en el qual se le puso culpa al dicho licenciado / Vaca de Castro según que en el dicho capítulo y sentencia más largo se contiene / que atentas las dichas nuebas probanzas devemos rebocar / e rebocamos la dicha sentencia y absolbemos al dicho licenciado de lo contenido / en el dicho capítulo dámosle por libre y quito dél. Otrosí, en / quanto al diez e seis capítulo sobre la dilación en la prisión / de don Diego de Almagro e Diego Méndez en el qual está pues / ta culpa al dicho licenciado por lo que tocaba a lo del dicho Diego / Méndez y la demás pena reserbada para la dicha sentencia / final segund que en el dicho capítulo y sentencia más largo se contiene / que atentas las dichas nuebas probanzas devemos re /bocar la dicha nuestra sentencia y absolbemos al dicho licenciado Vaca de / Castro de lo contenido en dicho capítulo dámosle por libre y quito [dél] / Otrosí, en quanto al diez y siete capítulo en que se trata que [...] //

/ 193 v. / sabiendo el dicho licenciado que su magestad enbiaba virrey y audiencia con / hordenanzas que no se encomendasen yndios y que ningún / gobernador tubiese encomienda de yndios dio muchas en / comiendas después de savidas las dichas hordenanzas / a personas que no lo merecían, sus amigos e parientes e / de quien esperaba favor e ynterese en el qual fue con / denado en mil ducados y le fue puesta culpa graue e / la demás pena remitida a la final segund que en el dicho / capítulo y sentencia más largo se contiene que atentas las dichas / nuebas probanzas la dicha sentencia es de enmendar y para la / enmendar la devemos rebocar e rebocamos e haziendo / justicia absolbemos al dicho licenciado Vaca de Castro de lo contenido / en el dicho capítulo dámosle por libre y quito. Otrosí, en quanto / al diez e ocho capítulo sobre que avía reciuido presentes en / mucha cantidad de dineros, oro y plata e joyas por / dar regimientos, gobernaciones, capitanías e por disimular / con otros y por otras causas en cantidad de más de / cinco mil castellanos que en quanto en la sentencia deste capítulo / está mandado hazer más aberiguación cerca de las fuen / tes de plata y copa y sobrecopa doradas de un Diego de Mora / que devemos rebocar la dicha nuestra sentencia e absolbemos al / dicho licenciado Vaca de Castro de lo tocante a lo susodicho dámosle / por libre y quito dello, pero en quanto por la dicha nuestra sentencia / condenamos al dicho licenciado Vaca de Castro en docientos du / cados aplicados por tercios e la demás pena está 
remitida a / la dicha sentencia final por lo quel dicho fiscal pretendía del ran / cho que diz que hizo un Origuela en los yndios de Ysasaga / que atentas las dichas nuebas probanzas la dicha sentencia es de / enmendar e la devemos rebocar e rebocamos e ha / ziendo justicia por lo que resulta de lo susodicho contra el / dicho licenciado Vaca de Castro le ponemos culpa. Otrosí, en / quanto al veynte capítulo en que se trata como onbre / culpado en las tomas de hazienda de su magestad y en otras / [...] enbiaua dádibas de oro e otras cosas a las personas / en el dicho capítulo contenidas y enbiaba poder para recusar lo dél contenido e //

/ 194 r. / oydores de las audiencias en el qual fue puesta culpa al dicho / licenciado e reserbada la demás pena para la dicha sentencia final / segund que en el dicho capítulo y sentencia más largo se contiene que a / tentas las dichas nuebas probanzas la dicha sentencia es de enmendar / e la devemos rebocar e rebocamos e haziendo justicia absol / bemos al dicho licenciado Vaca de Castro de lo contenido en el dicho capítulo / dámosle por libre e quito dél. Otrosí, en quanto al veynte y un / capítulo en el que se trata de la tenencia de los nabíos en lo qual / diz que su magestad fue deseruido e los tratantes y maestres danifi / cados en más cantidad de cien mil castellanos de oro en el qual / capítulo fue puesta culpa al dicho licenciado Vaca de Castro e reser / vada la demás pena para la dicha sentencia final y quanto a los daños / e yntereses que dello pudo venir a la hazienda de su magestad estando / que se haga más aberiguación y está condenado el dicho licenciado en / todo lo que pareciere aver venido de daño y en quanto al daño / e ynterese de los tratantes y maestres les está reserbado su derecho / a saluo para que lo pidan si como vieren que les conviene segund / que en el dicho capítulo y sentencia más largo se contiene que aten / tas las nuebas probanzas la dicha nuestra sentencia es de en / mendar e para la enmendar la devemos rebocar e rebo / camos e haziendo justicia absolbemos al dicho licenciado Vaca / de Castro de lo contenido en el dicho capítulo dámosle por libre e quito / dél. Otrosí, en quanto al capítulo final de la dicha nuestra sentencia / por las culpas de los capítulos terzero, sesto, diez e seis / diez e siete, diez e ocho, veynte y veynte y uno está conde / nado el dicho licenciado Vaca de Castro en suspensión de su / oficio y de tener cargo e oficio de justicia por tienpo y espacio / de seis años cunplidos primeros siguientes atentas / las dichas nuevas probanzas ante nos hechas y presentadas / la dicha nuestra sentencia es de enmendar y para la en / mendar la devemos rebocar e rebocamos e hazien / do justicia absolbemos al dicho licenciado Vaca de / Castro de la dicha condenación por libre e / quito della. Otrosí, en quanto a la reconben [ción] / hecha por parte del dicho licenciado Vaca de Castro //

/ 194 v. / contra el dicho fiscal en que le pide treinta e / nueve mil e novecientos e noventa nueve / castellanos e quatro tomines de oro que dize que al / canza a su magestad en la data de sus quentas en / lo que gastó en reduzir e ganar el Perú y en / otras cosas contenidas en la dicha reconben / ción en la qual está mandada que el presidente e / oydores de la abdiencia e chancillería que reside en / la ciudad de los Reyes e con ellos juntamente los o / ficiales de la hazienda de su magestad hagan e reciban / la quenta que cerca de lo contenido en este capítulo / de reconbención el dicho licenciado o quien su poder / oviere quisieren dar llamada primeramente la parte / del dicho fiscal para verla dar e hacerse presente e / oyéndole cerca dello con que no se le recibiesen en quenta / las cosas e gastos contenidas en la dicha nuestra sentencia y hecha / la dicha quenta la enbiasen a este dicho Consejo con sus pare / ceres para probeer lo que fuese justicia segund que en el / dicho capítulo de reconbención e sentencia del más larga / mente se contiene que devemos de rebocar e rebocamos / la dicha nuestra sentencia e haziendo justicia devemos absolber / e absolvemos al dicho fiscal de la dicha reconbención / dámosle por libre e quito della. Otrosí, en quanto a la / otra reconbención de 
los cinco mil ducados de juez y en lo / que ansimismo reconbiene sobre el salario de gober / nador de las gobernaciones de la Nueva Castilla e Nuevo To / ledo de dos años e ocho meses que dize que fue gober / nador el qual salario dize que a de ser conforme a lo / que se dava a los gobernadores don Francisco Pizarro e don Diego / de Almagro en el qual capítulo está por nos remtido todo esto al segundo / capítulo de este dicho pleito donde está determinado bastantemente cerca desto / según que en el dicho capítulo de reconbención y sentencia dél más largo se contiene que deve / [mos?] confirmar e confirmamos en grado de revista la dicha nuestra sentencia en este dicho capítulo / [...] de reconvención. Otrosí, en quanto a la nueva reconbención puesta / [...] por el dicho licenciado Vaca de Castro contra el dicho fiscal después la dicha nuestra //

/ 195 r. / sentencia en que le pide otros cinco mil castellanos de gastos que por a / verse perdido sus libros dize no se acordar dellos al tiempo que escri / vió la quenta segund que en la dicha < nueva > reconbención más largo se contiene / fallamos quel dicho licenciado no probó la dicha su reconbención / dámosla por no provada por ende devemos absolber e absol / bemos al dicho fiscal de lo en ella contenido dámosle por libre / e quito della. Otrosí, en quanto por la dicha nuestra sentencia condenamos al dicho licenciado en las costas de la primera ynstancia / la rebocamos e absolbemos al dicho licenciado Vaca de Castro / de la dicha condenación de costas dámosle por libre e quito della y por esta / nuestra sentencia difinitiua en grado de revista ansí lo pronunciamos / e mandamos sin costas. Licenciado Tello de Sandobal. Licenciado / Bribiesca. Licenciado don Juan Sarmiento. El dotor Vázquez. Licenciado Villagómez. La qual dicha sentencia fue dada y pronunciada por los del / dicho nuestro Consejo en esta villa de Valladolid a veynte e tres días del mes de / mayo de mil e quinientos y cinquenta y seis años. E agora Juan / de Oribe en nombre del dicho licenciado Vaca de Castro del nuestro Consejo nos suplicó / le mandásemos dar nuestra carta executoria de las dichas sentencias dadas en vista / e en grado de revista o como la nuestra merced fuese lo qual visto por los del dicho / nuestro Consejo Real de las Yndias fue acordado que devíamos mandar dar esta / nuestra carta executoria para vos en la dicha razón y nos tobimoslo por bien / por la qual vos mandamos a todos e a cada uno de vos segund dicho es que / veays las dichas sentencias que ansí por los del dicho nuestro Consejo Real de / las Yndias fueron dadas y pronunciadas en vista y en grado de revista que de / suso van yncorporadas y las guardéis, cumpláis y executéis e hagáis / guardar, cumplir y executar en todo y por todo según y como en ellas / se contiene y contra el tenor y forma dellas no vais ni paséis / ni consintáis yr ni pasar en tiempo alguno ni por al / guna manera e los unos ni los otros non [fag]ades / nin fagan ende al so pena de la nuestra merced e [de?] diez / [mil?] maravedís para la nuestra cámara a cada [uno] / que lo contrario hiziere so la qual dicha pena manda[mos] / a qualquier scriuano público que para esto [fuere llama?] do que de [...] vos la mostrare testimonio signado con su sino [para que nos?] //

/ 195 v. / sepamos como se cunple nuestro mandado. Dada en la villa de Valladolid a treze / días del mes de hebrero de mil y quinientos y cinquenta y ocho años. Va escripto entre ren / glones ${ }^{31}$ : o diz crecida, porque fue ynformado, se recobró y ganó la vitoria, avía / el dicho don Diego, Vaca de Castro, dichos, 1, aquella provincia, y cumpliese, a, como / nos lo alcanzaron, y lo vio como dicho tiene y pasó ansí, a unas partes, en blanco, / y esquadrones, este testigo saue que, con, los yndios, las, lo, luego, diz, cartas, del / mariscal don Diego de Almagro, en ella, con más nauíos que armó y gente a buscar / e de, quinto, todas quantas avía su fenecimiento y las otras, más largo, y una /

\footnotetext{
${ }^{31}$ Notas de salva.
} 
nuestra cédula dirigida al dicho Vaca de Castro, nueva y he mendado o diz, a la resi, a, / para, a, lesi, San Miguel, eros, pa, sen, Diego, e, persona, boluer, de, st, Núñez, juris / te, guarda, p, y sobre raido o diz, y el, por mandado de su magestad Joan, el Príncipe, / licenciado, veni, testigo, pendencia, lado, ocho, 1, ll, y eron, Toledo, por mandado del dicho su parte / y ara, el, denar, rimi, por mandado de su magestad Joan, dicha nuestra, de costas dámosle / y en la margen o diz, deste, evo, a lo mesmo, siete, vala, va testado o dezía, q, o, se / lo, a, una, lo, ni, de, re, no vala.

\section{La Princesa}

Yo Francisco de Ledesma secretario de su cathólica magestad la fize / screvyr por el mandado de su alteza $[\ldots]$ en su nombre /

Johan de Luyando [rubricado] Por chanciller / Juan de Angu[...] [rubricado]

Licenciado Tello de Sandoval [rubricado] Licenciado Vriviesca [rubricado] Licenciado don Juan Sarmiento [rubricado] El doctor Velázquez [rubricado]

[Executoria] de las sentencias dadas en el negocio del fiscal con el licenciado Cristóval Va / ca de Castro del Consejo de vuestra Magestad y vuestro gobernador y capitán general que fue de las provincias del Perú.

Transcripción de: $\quad$ Álvaro M. Espinoza de la Borda

Deysi A. Zambrano Flores

NOTA: Los primeros cuarentinueve folios presentan una numeración arábiga, en tanto que el resto, números romanos. Optamos por los primeros para que haya uniformidad.

Se ha preferido usar la zeta o ce en vez de la cedilla.

En casos en los que una misma palabra presenta más de una forma de escritura se ha tendido a uniformizar.

Se ha desarrollado tanto abreviaturas como siglas. 